\title{
Governing Africa's Forests in a Globalized World
}





\section{Governing Africa's Forests in a Globalized World}

Edited by Laura A. German, Alain Karsenty and Anne-Marie Tiani 
First published by Earthscan in the UK and USA in 2010

Copyright $@$ C Center for International Forestry Research, 2010

This publication is co-funded by the European Union. The contents of this publication are the sole responsibility of CIFOR and can in no way be taken to reflect the views of the European Union or other donors.

\section{All rights reserved}

ISBN: 978-1-84407-756-4

Typeset by Domex e-Data Pvt. Ltd.

Cover design by Susanne Harris

For a full list of publications please contact:

\section{Earthscan}

Dunstan House

14a St Cross St

London, EC1N 8XA, UK

Tel: $+44(0) 2078411930$

Fax: +44 (0) 2072421474

Email: earthinfo@earthscan.co.uk

\section{Web: www.earthscan.co.uk}

22883 Quicksilver Drive, Sterling, VA 20166-2012, USA

Earthscan publishes in association with the International Institute for Environment and Development

A catalogue record for this book is available from the British Library

Library of Congress Cataloging-in-Publication Data

Governing Africa's forests in a globalized world / edited by Laura A. German, Alain Karsenty, and Anne-Marie Tiani.

p. $\mathrm{cm}$.

Includes bibliographical references and index.

ISBN 978-1-84407-756-4 (hardback)

1. Forest policy-Africa. 2. Forest management-Africa. 3. Decentralization in government-Africa.

4. Globalization-Africa. I. German, Laura A. II. Karsenty, Alain. III. Tiani, Anne-Marie.

SD659.G58 2009

333.75096-dc22

2009010565

At Earthscan we strive to minimize our environmental impacts and carbon footprint through reducing waste, recycling and offsetting our $\mathrm{CO}_{2}$ emissions, including those created through publication of this book. For more details of our environmental policy, see www.earthscan.co.uk.

This book was printed in the UK by CPI Antony

Rowe. The paper used is FSC certified. 


\section{Contents}

List of Figures, Tables and Boxes xiii

List of Contributors xvii

Foreword by Pam Yako and Bruno Oberle xxi

Acknowledgements $\quad x x i i$

List of Acronyms and Abbreviations $\quad x x v$

Chapter 1 Forest Governance and Decentralization in Africa: Linking

Local, Regional and Global Dialogues

Laura A. German, Carol J. Pierce Colfer, Edmund Barrow,

Christian Küchli, Jürgen Blaser and Wahjudi Wardojo

Introduction

Roots of the conversation $\quad 2$

Cross-cutting themes $\quad 7$

$\begin{array}{lr}\text { Chapters in this volume } & 17\end{array}$

$\begin{array}{ll}\text { Conclusions } & 20\end{array}$

\section{Part I Governing Africa's Forests in a Globalized World: Framing the Dialogue}

Chapter 2 Forestry and Democratic Decentralization in Sub-Saharan Africa:

A Rough Review

Jesse C. Ribot

Introduction

Forestry decentralization in historical context 33

Obstacles to decentralization implementation 35

Decentralization and outcomes $\quad 38$

Factors influencing decentralization, forestry decentralization $\begin{array}{ll}\text { and its outcomes } & 41\end{array}$

What have we learned? 44

Conclusions: Forestry can shape local democracy 47

Chapter 3 Elusive Meanings: Decentralization, Conservation and Local

$\begin{array}{ll}\text { Democracy } & \mathbf{5 6}\end{array}$

Mariteuw Chimère Diaw

Introduction $\quad 56$

Decentralization and conservation: Short histories $\quad 57$

Decentralization, conservation and local governance 60 
Environmental decentralizations and the movement to reform the state

Decentralization, parks and conservation

Local upsurges in environmental governance

Blood rights, civil rights and democracy: A conversation on local governance

Politics, conservation and democracy

Space-taking, space-making and space-granting: Alternative paths for local democratic governance

Conclusions

Chapter 4 The New Economic 'Great Game' in Africa and the Future of Governance Reforms in the Forest Sector

Alain Karsenty

Introduction 79

The new 'great game' in Africa

A new orientation for trade flows and a new geopolitical hand

Impact upon sectoral and environmental governance

Reforms that falter over the nature of the state ... and 'communities' 85

Administrations swayed by private interests 86

Uneven results of community forestry in Cameroon 88

$\begin{array}{ll}\text { Fresh funding to fight deforestation and forest degradation } & 91\end{array}$

On generating income from conservation: 'Conservation rents' 94

Conclusions

\section{Part II Decentralized Forest Management: Forms and Outcomes}

Chapter 5 Forest Sector Reforms, Livelihoods and Sustainability in Western Uganda

Pamela Jagger

Introduction

Literature review

Uganda's forest-sector governance reform: Process and implementation

Methods

Results 
Chapter 6 Hidden Harvest: Unlocking the Economic Potential of

Community-Based Forest Management in Tanzania

Tom Blomley, Hadija Ramadhani, Yassin Mkwizu and Andreas

Böhringer

Introduction

Context: Participatory forest management and decentralization

Implementation progress to date

The contribution of community-based forest management

(CBFM) to village-level income

Challenges to enhancing local benefits from CBFM in Tanzania

From policy to practice: Putting the benefits of sustainable

forest management in the hands of villagers

Conclusions

Chapter 7 Gendered Representation and Participation in Decentralized Forest Management: Case Studies from Cameroon and Senegal

Solange Bandiaky and Anne-Marie Tiani

Introduction

The sites

Gender, decentralization and resource management:

An overview

Causes and implications of women's marginalization

Economic and ecological implications of women's low

representation

Conclusions and recommendations

Chapter 8 Forest Revenue Decentralization and Profits Redistribution in the

Democratic Republic of Congo

Sébastien Malele Mbala and Alain Karsenty

Introduction

Forests in the national context of the DRC

$\begin{array}{ll}\text { The position of forests in the national economy } & 161\end{array}$

$\begin{array}{ll}\text { The economic and fiscal reform } & 162\end{array}$

$\begin{array}{lr}\text { The state of the forest industry } & 163\end{array}$

$\begin{array}{ll}\text { Important innovations in the forest code } & 166\end{array}$

$\begin{array}{ll}\text { The forest area fee (FAF) } & 166\end{array}$

Allocation of the forest area fee and other forestry taxes $\quad 166$

$\begin{array}{ll}\text { The political stakes of transfers } & 168\end{array}$

$\begin{array}{lr}\text { Recommendations } & 170\end{array}$

$\begin{array}{ll}\text { Conclusions } & 171\end{array}$ 
Chapter 9 Governance of Decentralized Forest Revenue in Central Africa: For Better or for Worse?

Patrice Bigombé Logo

Introduction

The configuration of systems for transferring revenue from timber and wildlife operations to local government and communities

The governance logic of decentralized forest revenue

Chapter 10 Local Government and Forest Resource Governance in Mali: Taxation and Decentralized Management of Forest Resources in Siby Rural Commune

Bréhima Kassibo

Introduction

Background: Decentralization in Mali

Siby rural commune

Donor strategies and government policy

Implementation of the reform: The domestic energy strategy

Rural fuelwood markets

Stakeholder dynamics: The strategic groups

Consequences of the changes to the reform

Conclusions and recommendations

Box C Governance of Multi-stakeholder Forest Landscapes and Ecosystem Services: The Case of Tree-Water Interactions in South Africa

Chapter 11 Decentralization Outcomes in the Context of Political Uncertainty in Zimbabwe: A Comparative Assessment of Co-Management and CAMPFIRE and Implications for Policy Everisto Mapedza

Introduction

Background

Community-based natural resource management (CBNRM)

in Zimbabwe

Research methods

Assessing the social, institutional and ecological effects of political uncertainty 
Chapter 12 Bridging the Gap between Environmental Decision-Makers in Madagascar

Nadia Rabesahala Horning

Introduction

Background: Historical antecedents to Malagasy biodiversity

conservation

Biodiversity as a global commons

Methods

Community-level dynamics: The link between rules and conservation outcomes

National-level dynamics: The link between aid and policy outcomes

What we learn from the two-level analysis

The GELOSE experiment (1999-present)

Policy implications

Conclusions

\section{Part III International Trade, Finance and Forest-Sector Governance Reforms}

Chapter 13 Trends in Ghana's International Timber Trade: Implications

for Local Livelihoods and Sustainable Forest Management

J. Henry Owusu

Introduction

Methodology

Structural adjustment, the forest sector and the timber trade

The Ghanaian economy and the forest sector

Implications of the reforms

Conclusions and policy recommendations

Chapter 14 Forestry Governance and Trade Transformations: Experiences from Tanzania and Implications for Sustainable Development

Simon Milledge

Introduction

Opportunities abound: Tanzania, transformations and

timber trade

Recipe for opportunity

A trio of timber trade transformations

Realities reverberate: Forest governance and sustainable

development 
$\begin{array}{lr}\text { Impediments to good governance } & 288\end{array}$

$\begin{array}{ll}\text { Discussion and recommendations } & 291\end{array}$

$\begin{array}{ll}\text { Conclusions } & 296\end{array}$

Chapter 15 The Africa Forest Law Enforcement and Governance (AFLEG) and Forest Law Enforcement, Governance and Trade (FLEGT) Processes and the Challenges of Forest Governance in African Tropical Timber-Exporting Countries

James K. Gasana and Jean-Marie Samyn

Introduction

Background

AFLEG and FLEGT processes: A brief introduction

Differences and possible synergies between AFLEG and FLEGT 305

Main achievements of AFLEG and FLEGT 306

$\begin{array}{ll}\text { Initiatives at the national level } & 307\end{array}$

$\begin{array}{ll}\text { The challenges ahead } & 307\end{array}$

$\begin{array}{ll}\text { Conclusions } & 313\end{array}$

Chapter 16 Free, Prior and Informed Consent: Implications for Sustainable Forest Management in the Congo Basin

Luke Freeman, Jerome Lewis and Sophie Borreill-Freeman with Christoph

Wiedmer, Jane Carter, Nicole Clot and Belmond Tchoumba

Introduction

Background

$\begin{array}{ll}\text { The indigenous forest peoples } & 320\end{array}$

$\begin{array}{lr}\text { Forest exploitation } & 320\end{array}$

Free, prior and informed consent (FPIC) 322

$\begin{array}{ll}\text { The rights of indigenous peoples } & 323\end{array}$

Methodology 323

Preliminary findings $\quad 325$

FPIC and sustainable forest management $\quad 331$

Chapter 17 On the Nature of Intergenerational and Social Networks in the African Forest Sector: The Case of Chinese, Lebanese, Indian and Italian Business Networks

Jean-Marc Roda

Introduction

Background $\quad 336$

$\begin{array}{ll}\text { Questions and approach } & 337\end{array}$

Methodology and conceptual framework 338

Findings and discussion: A new economy for African timber? 339 
Structural similarities among Chinese, Syro-Lebanese, Indian and Italian business networks

Implications for forest governance in Africa

Conclusions

Chapter 18 Climate Change: What Are Its Implications for Forest Governance?

Carmenza Robledo, Jürgen Blaser and Sarah Byrne

Introduction

The role of forests and forestry in climate change

Forestry activities in the Kyoto Protocol until 2012

Key issues related to governance and climate change in the forest sector

Conclusions

\section{Part IV Conclusions}

Chapter 19 Forest Governance and Decentralization in Africa: Issues and Emerging Trends

Doris Capistrano

Decentralization, democratization and governance reform

Decentralization: Diverse forms, contested meanings

Livelihood and sustainability impacts, revenue and

benefit-sharing

Trade and international influences on local governance

Conclusions 



\section{List of Figures, Tables and Boxes}

\section{FIGURES}

3.1 $\quad$ Rough evolution of protected areas (1872-2003) $\quad 59$

$\begin{array}{lll}3.2 & \text { Selected cases of environmental decentralization } & 62\end{array}$

3.3 Decentralization schemes in park management 64

3.4 Cases of self-initiated popular environmental movements 66

3.5 A representation of the continuum between civil rights and blood rights 69

4.1 The Great Game: A clash between the Russian bear, the British lion

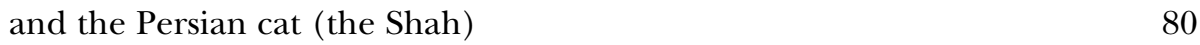

4.2 Evolution of trade between Africa, China and India 82

4.3 The top five African timber suppliers to China 83

4.4 Asian foreign direct investments (FDIs) in sub-Saharan Africa, 2004-2005 (US\$ million)

4.5 Statistical relationship between vertical integration (self-management) of a sample area of community forests in Cameroon and distance to timber markets

4.6 Diagram of possible payment for deforestation reduction in comparison to past reference period ('historical baseline')

4.7 Diagram of possible payment for avoided deforestation with reference scenario ('projected baseline'), including an 'adjustment factor' to accommodate development requirements

5.1 Map of villages included in the study

6.1 Mean annual changes in basal area in 13 forests under different management and ownership regimes

6.2 (a) Regional poverty rankings; and (b) area of unreserved forest per square kilometre by region

9.1 Distribution of wildlife resource development committee (COVAREF) funds in eastern Cameroon

C.1 Accumulated daily stream-flow data $(\mathrm{mm})$ for Cathedral Peak catchments IV (control) and II (treated), between 1950 and 1987

C.2 Stream-flow gauging weir used to assess the impacts of catchment afforestation with Pinus radiata on stream flow

12.1 Evolution of financial contributions to the National Environmental Action Plan (NEAP)

12.2 National and local conditions for resource conservation 247

13.1 Volume of lumber and other wood products exported, 1973-2006 262

13.2 Formal and informal sectors of the African economy 269

13.3 Pre-Economic Recovery Programme (ERP) linkages between Ghana's formal and informal wood-processing sectors and associated markets 
13.4 Post-ERP linkages between Ghana's formal and informal wood-processing sectors and associated markets

14.1 Diagram illustrating the gross value chain for hardwood logs from Tanzania (2005)

14.2 'Timber trade bribery index' (ranging from 0-100) during the main stages of the timber trade chain for both legally and illegally sourced products

14.3 Geographic variation in forest area, revenue targets and staffing capacity 293

17.1 International trade of tropical logs in 1997: Major fluxes 336

17.2 International trade of tropical logs in 2003: Major fluxes

\section{TABLES}

1.1 Regional summary: Who owns Africa's forests? 13

4.1 Forest Stewardship Council (FSC)-certified forests in Africa 85

4.22007 data on community forests in Cameroon $\quad 89$

4.3 Data on deforestation in developing countries $\quad 94$

5.1 Reform mechanisms for catalysing favourable livelihood outcomes $\quad 107$

5.2 Difference-in-difference estimates of forest income and share of income from forests (pooled Tobit regression results) 111

$5.3 \quad$ Indicators of change in forest cover between 2002 and $2007 \quad 115$

$5.4 \quad$ Indicators of change in forest quality between 2002 and $2007 \quad 116$

5.A1 Descriptive statistics for variables used in regression analysis 124

6.1 A summary of differences in joint forest management (JFM) and $\begin{array}{lr}\text { community-based forest management (CBFM) } & 129\end{array}$

6.2 Current coverage of CBFM across mainland Tanzania 130

6.3 Estimates of adoption and spread of CBFM in Tanzania from 1999 to the present

6.4 Selected areas of forest under village management and their revenue generation potential

8.1 New forest revenue system relative to the preceding one 164

8.2 Income based on land allocation fee (in US\$) 164

8.3 Declared timber harvests between 2002 and $2006 \quad 165$

8.4 Wood exports and their total values between 2002 and $2006 \quad 165$

8.5 Forest revenue for fiscal years 2005 and $2006 \quad 167$

10.1 Decree No 95-422/P-RM Setting Tax Rates on Wood Harvesting and Distribution of Revenues

10.2 Decree No 98-402/P-RM of 17 December 1998 Setting the Distribution of Revenues from Taxes on Wood Harvesting

11.1 Decentralization arrangements and outcomes in Southern African: Case studies

11.2 Selected indicators assessing the pre-2000 and post-2000 co-management and CAMPFIRE resource management regimes 
12.1 Characteristics of surveyed communities: Demographics and isolation 238

12.2 Extent of deforestation around southern forests

14.1 Comparison of timber export volumes $\left(\mathrm{m}^{3}\right)$ from Tanzania (2003-2005)

288

14.2 Some reported examples of self-dealing, nepotism and cronyism in the timber trade

16.1 Forest estate in the Congo Basin

17.1 Variables used in field research to study industrial actors and their behaviour

17.2 Attributes of environmental behaviour for the 23 largest companies with forest concessions in Cameroon (February 2006)

18.1 Mitigation options and forest management practices

19.1 Forest area under management by communities and indigenous groups (A) and under concessions (B) in heavily forested countries of Africa (million hectares)

\section{BOXES}

1.1 Principles and guidelines for implementation of decentralization derived from the Interlaken workshop

1.2 Major issues identified in the Asia-Pacific region during the Yogyakarta Workshop on Forest Governance and Decentralization

1.3 Some definitions

1.4 Forest tenure and tenure reforms in Africa

2.1 Definitions

5.1 Early lessons from the implementation of decentralization reforms in Kenya and Uganda

6.1 Kilwa District, Eastern Tanzania

C Governance of multi-stakeholder forest landscapes and ecosystem services: The case of tree-water interactions in South Africa

C.1 Policy-oriented research for forests and water in South Africa

C.2 The regulation of water-use impacts of forestry in South Africa: Appraisal of the development of policy and governance

11.1 Forest decentralization experiences from Southern Africa

12.1 Decentralized forest resource management in the highlands of Madagascar: The cases of Arivonimamo and Merikanjaka

15.1 Lessons learned from the Africa Forest Law Enforcement and Governance (AFLEG) process

16.1 The definition of free, prior and informed consent (FPIC) 322

16.2 Forest Stewardship Council (FSC) criteria 2 and 3

18.1 Governance of forest income from community forest exploitation in Cameroon

19.1 General recommendations from the Durban Workshop on Forest Governance and Decentralization in Africa 



\section{List of Contributors}

\section{CHAPTERS}

Solange Bandiaky is the programme coordinator for Africa at the Rights and Resources Initiative Secretariat in Washington, DC, US.

Edmund Barrow is the Africa regional coordinator for the Livelihoods and Landscapes Strategy of the World Conservation Union's (IUCN's) Forest Conservation Programme, and is based in Nairobi, Kenya.

Patrice Bigombé Logo is a political scientist, lecturer and researcher at the Group for Administrative, Political and Social Science Research (GRAPS), University of Yaoundé II, and director of the Centre for Research and Action for Sustainable Development in Central Africa (CERAD) in Yaoundé, Cameroon.

Jürgen Blaser is the head of the Forest/Environment Team and deputy director of Intercooperation, the Swiss Foundation for Development and International Cooperation in Bern, Switzerland.

Tom Blomley is an independent consultant based in the UK working on forestry and natural resource governance issues, mostly in Africa.

Andreas Böhringer is with the Forestry and Beekeeping Division of the Ministry of Natural Resources and Tourism in Dar es Salaam, Tanzania.

Sophie Borreill-Freeman is affiliated with the environment and development laboratory Pôle de Recherche pour l'Organisation et la Diffusion de l'Information Géographique (PRODIG) at the Centre National de la Recherche Scientifique (CNRS) in Paris and is a consultant with Anthroscape Ltd, UK.

Sarah Byrne is with the Swiss Foundation for Development and International Cooperation (Intercooperation) in Kathmandu, Nepal.

Doris Capistrano is a senior fellow at the Southeast Asian Regional Centre for Graduate Study and Research in Agriculture (SEARCA) in Los Baños, the Philippines.

Jane Carter is with the Swiss Foundation for Development and International Cooperation (Intercooperation), in Bern, Switzerland. 
Nicole Clot is with the Swiss Foundation for Development and International Cooperation (Intercooperation), in Bern, Switzerland.

Carol J. Pierce Colfer is an anthropologist and senior associate with the Forests and Governance Programme at the Center for International Forestry Research (CIFOR) in Bogor, Indonesia.

Mariteuw Chimère Diaw is an economic anthropologist and interim director of the African Model Forest Network Initiative (AMFI) in Yaoundé, Cameroon.

Luke Freeman is a lecturer and researcher in the Department of Anthropology, University College London, and a director of Anthroscape Consultancy Ltd in London, UK.

James K. Gasana is with the Swiss Foundation for Development and International Cooperation (Intercooperation) in Bern, Switzerland.

Laura A. German is an anthropologist and senior scientist with the Forests and Governance Programme at the Center for International Forestry Research in Bogor, Indonesia.

Nadia Rabesahala Horning teaches political science at Middlebury College in Vermont, USA.

Pamela Jagger is an assistant professor of environmental policy in the Department of Public Policy at the University of North Carolina at Chapel Hill, USA.

Alain Karsenty is social scientist with the Centre de Coopération Internationale en Recherche Agronomique pour le Développement (CIRAD) in Montpellier, France.

Bréhima Kassibo is an anthropologist and director of research at the Institut des Sciences Humaines (ISH) in Bamako, Mali.

Christian Küchli is a forester with the Federal Office of the Environment in Bern, Switzerland.

Jerome Lewis is a lecturer and researcher in the Department of Anthropology, University College London, and a director of Anthroscape Consultancy Ltd in London, UK.

Everisto Mapedza is a social and institutional scientist at the International Water Management Institute in Addis Ababa, Ethiopia.

Sébastien Malele Mbala is director of forest inventory and planning, Ministry of Environment, Nature Conservation and Tourism in the Democratic Republic of Congo. 
Simon Milledge is the deputy director of TRAFFIC East/Southern Africa, based in Dar es Salaam, Tanzania.

Yassin Mkwizu is working with the IUCN Tanzania office as the coordinator of their Forest Governance Project, based in Dar es Salaam, Tanzania.

J. Henry Owusu is a development geographer and associate professor at the University of Northern Iowa, Cedar Falls, Iowa, US.

Hadija Ramadhani is with the Forestry and Beekeeping Division of the Ministry of Natural Resources and Tourism in Dar es Salaam, Tanzania.

Jesse C. Ribot is an associate professor in the Department of Geography and the School of Earth, Society and Environment at the University of Illinois at UrbanaChampaign, US.

Carmenza Robledo is with the Swiss Foundation for Development and International Cooperation (Intercooperation) in Bern, Switzerland.

Jean-Marc Roda is an economist and Researcher at the Centre de Coopération Internationale en Recherche Agronomique pour le Développement (CIRAD), seconded to the Forest Research Institute of Malaysia (FRIM) in Kuala Lumpur, Malaysia.

Jean-Marie Samyn is with the Swiss Foundation for Development and International Cooperation (Intercooperation) in Bern, Switzerland.

Belmond Tchoumba is international coordinator of the Forest and Biodiversity Programme at Friends of the Earth.

Anne-Marie Tiani is a social ecologist with the African Model Forest Network Initiative (AMFI) in Yaoundé, Cameroon.

Wahjudi Wardojo is special staff to the minister on forest security, Ministry of Forestry, Jakarta, Indonesia.

Christoph Wiedmer works with the Society for Threatened Peoples, Switzerland.

\section{BOXES}

Krister Andersson is with the Kennedy School of Government, Harvard University, US.

Joseph Bahati is a staff member in the Faculty of Forestry and Nature Conservation, Makerere University, in Kampala, Uganda. 
Abwoli Banana is a professor of forestry at the Faculty of Forestry and Nature Conservation, Makerere University, Kampala, Uganda.

Joseph Tsana Enama is coordinator of Groupe de Recherche et d'Accompagnement des Initiatives de Développement (GRAID), based in Yaoundé, Cameroon.

Laura A. German is an anthropologist and senior scientist with the Forests and Governance Programme at the Center for International Forestry Research in Bogor, Indonesia.

Mark B. Gush is a scientist with the Council for Strategic and Industrial Research (CSIR) in Pietermaritzburg, South Africa.

Annette Kolff is the delegate of Intercooperation in Antananarivo, Madagascar.

Fred Kruger is with Fred Kruger and Associates in Pretoria, South Africa.

Frank Matose is a senior lecturer at the Department of Sociology, University of Cape Town, South Africa.

Anicet Minsoum'a Bodo is an official with the Ministry of Forests and Fauna, Yaoundé, Cameroon.

Esther Mwangi is with the Sustainability Science Program at the Kennedy School of Government, Harvard University, US.

Paul Ongugo is with the Kenya Forestry Research Institute in Nairobi, Kenya.

Estelle Raharinaivosoa is director of the Sahan'Asa Hampandrosoana ny Ambanivohitra (SAHA) Programme funded by the Swiss Development Cooperation (SDC) in Antananarivo, Madagascar.

Aimee Randrianarisoa is the local economy coordinator for the SAHA Programme in Antananarivo, Madagascar. 
Foreword

Forests are global and national. The whole world benefits from their rich biological diversity and entire nations are provided with their diverse services, including food, water and carbon sequestration. All nations suffer from uncontrolled forest destruction, because as we know today, deforestation and other land-use changes are currently responsible for about one fifth of annual greenhouse gas emissions. At the same time, forests are profoundly local. Each one is unique and forest use depends heavily upon specific environmental, social and economic contexts. People with formal forest management responsibilities are more successful in their endeavours if they tailor their efforts to local conditions. It is also almost impossible to maintain forests long without local support. Decentralized forest governance is part of the solution for most of the critical issues related to sustainable forest management, like avoiding forest fires or enhancing forest rehabilitation. Forests owned by local communities often suffer less from illegal logging, and enhancing local rights and responsibilities can support the economic and ecological benefits of forests managed for multiple uses and users under the right conditions.

In 2004, the Interlaken Workshop on Forest Governance in Federal Systems, organized as a country-led initiative in support of the United Nations Forum on Forests (UNFF), provided decision-makers and other key stakeholders the opportunity to share global experiences with decentralization in the broader context of governance reform. Participants of the Interlaken meeting recognized the importance of appropriate sharing of decision-making authority and responsibility for forest management between different levels of government. Other lessons included the need for more effective enforcement of accountability at all levels of government and appropriate and strong linkages with local forest users, other sectors and civil society. The Interlaken workshop was succeeded by the Yogyakarta Workshop on Forest Governance and Decentralization in Asia and the Pacific, held in 2006 in Yogyakarta, Indonesia, to explore how the lessons from Interlaken are manifest at regional level and to expand and deepen the dialogue.

The Workshop on Forest Governance and Decentralization in Africa, held in Durban, South Africa, in April 2008 was part of the same initiative to promote regional dialogue about these issues. The Durban workshop, organized by the governments of South Africa and Switzerland in support of the UNFF, was conceived as a means to extend the dialogue to the African continent, to take stock of challenges faced in implementing lessons and recommendations from previous workshops, and to synthesize Africa's unique experiences in forest governance and decentralization. This workshop explored a broader set of governance challenges and opportunities associated with increased trade, investment and financial flows into and out of Africa, which add a layer of complexity to the implementation of decentralization and governance reforms. These issues and challenges are likely to take even greater 
significance in the context of current discussions on reducing emissions from deforestation and forest degradation in the international climate change debate.

The Durban workshop brought together 187 participants from 34 African countries and 11 participants from outside the continent, collectively representing diverse government and non-governmental organizations and the private sector. Participants shared experiences and explored opportunities to generate concrete gains from governance reforms and decentralized forest management against the backdrop of both global trends and local contexts. Participants identified several issues in need of attention and offered recommendations for the consideration of participant countries and the UNFF.

The outcome was a lively and interesting discussion about key challenges, opportunities and lessons learned, the results of which are reflected in an official United Nations report. ${ }^{1}$ Given the urgent need to find the right balance between local, regional, national and global governance of forests, through this book we hope to share with a wider audience some of the background information, experiences and conclusions that grew out of the Durban workshop.

As the co-sponsors of this initiative, we would also like to give a special word of thanks to the Center for International Forestry Research (CIFOR) and Intercooperation, which have provided much of the technical and administrative support for this initiative, and to the Secretariat of the United Nations Forum on Forests, the International Tropical Timber Organization (ITTO), and the governments of the UK, Norway, Germany, the US and Finland, who provided valuable technical and financial support for the initiative. Our thanks also go to Laura German, Alain Karsenty and Anne-Marie Tiani for editing the present volume.

Pam Yako

Director-General

Department of Water Affairs and Forestry, South Africa

Bruno Oberle

Director

Federal Office for the Environment of Switzerland (FOEN)

August 2009

\section{NOTE}




\section{Acknowledgements}

While each chapter has its own set of acknowledgements based on particular contributions, a number of institutions and individuals must be acknowledged for the role that they played in facilitating the evolution of the volume as a whole. The governments of Switzerland and Indonesia have jointly initiated the process of reflection on forest governance and decentralization as inter-sessional initiatives of the United Nations Forum on Forests and the Asia Forest Partnership. Thanks to the cooperation of these two countries, the present workshop is the third event to follow the global workshop on forest decentralization in Interlaken, Switzerland in 2004, and the regional workshop for Asia in Jogjakarta in 2006. Our biggest debt of gratitude goes to Christian Küchli from the Swiss Federal Office of Environment, an avid proponent of devolving forest management to local communities who has been instrumental in conceptualizing, financing and steering the workshops that gave rise to this volume and others proceeding it. Doris Capistrano and Carol Pierce Colfer of the Center for International Forestry Research (CIFOR), Jürgen Blaser of Intercooperation and Pak Wahjudi Wardojo of the Indonesian Ministry of Forestry have all been staunch supporters, providing intellectual and strategic leadership to these efforts from their inception. The Department of Water Affairs and Forestry of South Africa (DWAF, now the Department of Agriculture, Forestry and Fisheries or DAFF) and the Federal Office for the Environment of Switzerland (FOEN) worked tirelessly to coordinate and host the Workshop on Forest Governance and Decentralization in Africa, where these chapters originated, in addition to providing financial support. We would like to acknowledge the generous financial support provided by other governments and organizations, including Switzerland - FOEN, the Swiss Development Cooperation (SDC) and the Swiss State Secretariat for Economic Affairs (SECO); the UK - Department for International Development (DfID); Norway Ministry of Foreign Affairs; Germany - German Technical Cooperation (Deutsche Gesellschaft für Technische Zusammenarbeit, or GTZ); Finland - Ministry for Foreign Affairs; the US - US Forest Service; and the International Tropical Timber Organization (ITTO). We are also grateful to the European Union for co-financing the production of this volume. We would also like to thank CIFOR and Intercooperation for providing intellectual leadership and logistical support to the workshop from which this volume emerged.

While it is impossible to identify all of the individuals who have contributed to the workshop and the production of this volume, we would like to single out a few people whose contributions were instrumental to both. The workshop would not have been a success without the tireless work of our hosts and other members of the Steering Committee, including Thea Carroll, Motsamai Nkosi, Sipho Masuki, Renny Madula and Moshibudi Rampedi (DWAF); Christian Küchli (FOEN); Doris Capistrano, Carol Pierce Colfer and Laura German (CIFOR); Jürgen Blaser, Jean-Marie Samyn, James Gasana and Claudia Greco (Intercooperation); Barbara Tavora-Jainchill (UNFF); and 
Gill Slaughter, Kerry Firmani and Lucille Harisunker (Turners Conferences and Conventions). Many of these individuals provided essential technical contributions to the workshop's thematic focus, the selection of authors and the schedule of events. Additional thanks also go out to Carol Pierce Colfer, whose extensive experience on decentralization, conference organization and editorial tasks proved invaluable in getting through the various hurdles associated with workshop organization and book production.

We are also grateful to our field trip hosts Steven Ngubane, Mark Gush, James Perkins, Chris Davel, Carl van Loggerenberg, Keith Cooper, Vusi Dladla, Nomusa Zwane, Jacqui Shuttleworth and communities visited for their instrumental role in deepening participants' understanding of how key workshop themes play out in South Africa. Theme working groups also deserve mention for their efforts to track the dialogue from presentations, group discussions and field trips to ensure the main threads of conversation and lessons were duly captured. These volunteers included the following:

- 'Decentralized Forest Management and Livelihoods': Abwoli Banana, Carol Pierce Colfer, Aimee Randrianarisoa, Jesse Ribot and Jean-Marie Samyn.

- 'Conservation, Sustainable Forest Management and Forest Governance': Mariteuw Chimère Diaw, Renny Madula, Robert Nasi, Enos Shumba and Anne-Marie Tiani.

- 'International Trade, Finance and Forest-Sector Governance Reform': James Gasana, Alain Karsenty, Simon Milledge, Steven Ngubane and Jürgen Blaser

The chapters in this book were all reviewed on a volunteer basis by two or more independent reviewers who are experts in their fields. While we are unable to name them due to the 'blind review' process, we would like to express our sincere thanks for their efforts to enhance the quality and accuracy of this volume. We would also like to thank our two translators, Tilly Gaillard and Harriett Coleman, who have made chapters from Francophone authors accessible to an Anglophone audience.

At CIFOR, we are grateful for the tireless efforts and able administrative coordination provided by Dina Hubudin and for the financial support provided by Hari Sukmara and Suci Ningsih. Michael Hailu, Nia Sabarniati, Gideon Suharyanto, Rahayu Koesnadi and Florence Munoh all provided much-needed assistance at key stages of workshop organization and book production. We are also grateful for the technical inputs of Ganga Ram Dahal, Henri-Nöel Bouda, René Oyono and Daniel Tiveau, each of whom provided important contributions at early stages of planning to assist in the development of workshop themes that can most effectively speak to the African experience of forest governance and decentralization. Finally, we would like to express our gratitude to Camille Bramall, Tim Hardwick, Claire Lamont and Rob West of Earthscan for embracing this most recent of CIFOR's contributions to the Earthscan Forest Library, and for their patient support in coordinating the final stages of production. Those of us involved in the production of this book hope that the experience and insights reflected herein will contribute to improving the process of devolution of powers to African citizens and to leveraging natural resources for the benefit of all. 


\section{List of Acronyms and Abbreviations}

$\begin{array}{ll}\text { AEC } & \text { African Economic Community } \\ \text { AFF } & \text { annual forestry fee } \\ \text { AFLEG } & \text { Africa Forest Law Enforcement and Governance } \\ \text { AFR } & \text { annual forest revenues } \\ \text { AMADER } & \text { Malian Agency for the Development of Household Energy and } \\ & \text { Rural Electrification } \\ \text { AMFI } & \text { African Model Forest Network Initiative } \\ \text { ANAE } & \text { Agence Nationale d'Actions Environmentales } \\ \text { ANGAP } & \text { Agence Nationale pour la Gestion des Aires Protégées (now } \\ & \text { Madagascar National Parks) } \\ \text { A/R } & \text { afforestation and reforestation } \\ \text { ASEAN } & \text { Association of Southeast Asian Nations } \\ \text { ATEM } & \text { alternate tenure and enterprise model } \\ \text { ATP/RN-POP } & \text { Thematic Action Programme/Natural Resources and Populations } \\ \text { AWG-KP } & \text { Ad Hoc Working Group on Further Commitments for Annex I } \\ \text { AWG-LCA } & \text { Parties under the Kyoto Protocol } \\ \text { Ad Hoc Working Group on Long-Term Cooperative Action under } \\ \text { CA } & \text { the Convention } \\ \text { CAMPFIRE } & \text { CAMPFIRE Association } \\ \text { Communal Areas Management Programme for Indigenous } \\ \text { CAR } & \text { Resources } \\ \text { CASS } & \text { Collective Action and Property Rights Initiative } \\ \text { CBC } & \text { Central African Republic } \\ \text { CBD } & \text { Centre for Applied Social Sciences } \\ \text { CBFM } & \text { Center for Biodiversity Conservation (American Museum of } \\ \text { CBFP } & \text { Natural History) } \\ \text { CBNRM } & \text { Convention on Biological Diversity } \\ \text { CBO } & \text { community-based forest management } \\ \text { CCG } & \text { Congo Basin Forest Partnership } \\ \text { CCL } & \text { community-based natural resource management } \\ \text { CDD } & \text { community-based organization } \\ \text { CDM } & \text { CAMPFIRE Collaborative Group } \\ \text { CEB } & \text { Fuelwood Unit (Cellule Combustible Ligneux) } \\ \text { CED } & \text { community-driven development } \\ \text { CEFDHAC } & \text { Clean Development Mechanism } \\ \text { CER } & \begin{array}{l}\text { Comestic Equatoriale des Bois } \\ \text { Conference on Central African Moist Forest Ecosystems }\end{array} \\ \text { certified emission reduction }\end{array}$


CERAD

CF

CFMA

CFR

CGRF

CIB

CIDA

CIFOR

CIRAD

CITES

CMA

$\mathrm{CO}_{2}$

COBAs

COMIFAC

COMODE

COP

COSEF

COVAREF

CSIR

CWM

2D

3D

DAE

DBM

DD

DEF

DfID

DFO

DFS

DGF

DID

DNPWM

DRC

DUAT

DWAF

EAC

ECOWAS

EITI

ERP

ESAP

EU
Centre for Research and Action for Sustainable Development in Central Africa community forestry

collaborative forest management agreement

Central Forest Reserve

Forestry Licence Fee Management Committee

Congolaise Industrielle du Bois

Canadian International Development Agency

Center for International Forestry Research

French Agricultural Research Centre for International

Development

Convention on International Trade in Endangered Species of

Wild Fauna and Flora

catchment management agency

carbon dioxide

Communautés Locales de Base

Central African Forest Commission

Conseil Malgache des ONG pour le Développement et l'Environnement

Conference of the Parties

Senegalese Council of Women

wildlife resource development committee

Council for Scientific and Industrial Research

community wildlife management

two dimensional

three dimensional

decentralized administrative entity

district board of management

Land Division of the Ministry of Agriculture

Waters and Forests Division of the Ministry of Agriculture

UK Department for International Development

district forest officer

District Forestry Service

Direction de la Gestion Forestière

difference-in-difference

Department of National Parks and Wildlife Management

Democratic Republic of Congo

Direito de Uso e Aproveitamento da Terra (commonly translated from Portuguese as 'right of use and benefit')

Department of Water Affairs and Forestry of South Africa

East African Community

Economic Community of West African States

Extractive Industry Transparency Initiative

Economic Recovery Programme

Economic Structural Adjustment Programme

European Union 


\begin{tabular}{|c|c|}
\hline FAF & forest area fee \\
\hline FAO & United Nations Food and Agriculture Organization \\
\hline FBD & $\begin{array}{l}\text { Forest and Beekeeping Division, Ministry of Natural Resources } \\
\text { and Tourism, Tanzania }\end{array}$ \\
\hline FCPF & Forest Carbon Partnership Facility \\
\hline FCZ & Forestry Commission of Zimbabwe \\
\hline FDI & foreign direct investment \\
\hline FERN & Forests and European Union Resource Network \\
\hline FID & Forestry Inspection Division \\
\hline FLEG & forest law enforcement and governance \\
\hline FLEGT & Forest Law Enforcement, Governance and Trade process \\
\hline FMU & forest management unit \\
\hline FOB & free on board \\
\hline FOB & freight on board \\
\hline FOEN & Federal Office for the Environment of Switzerland \\
\hline FOMOD & Dja and Mpomo Model Forest \\
\hline FPIC & free, prior and informed consent \\
\hline FPU & Forest Protection Unit \\
\hline FRIM & Forest Research Institute of Malaysia \\
\hline FRP & Forestry Research Programme \\
\hline FSC & Forest Stewardship Council \\
\hline FSUP & Forest Sector Umbrella Programme \\
\hline FTM & National Geographic Institute \\
\hline FWP & Forest and Wildlife Policy \\
\hline G8 & $\begin{array}{l}\text { Group of Eight industrialized nations (Germany, Canada, US, } \\
\text { France, Italy, Japan, UK and Russia) }\end{array}$ \\
\hline GDP & gross domestic product \\
\hline GHG & greenhouse gas \\
\hline GIC & common initiative group \\
\hline GIE & economic interest group \\
\hline GIS & geographic information systems \\
\hline GPS & global positioning system \\
\hline GRAID & $\begin{array}{l}\text { Recherche et d'Accompagnement des Initiatives de } \\
\text { Développement }\end{array}$ \\
\hline GRAPS & $\begin{array}{l}\text { Group for Administrative, Political and Social Science Research } \\
\text { (Groupe de Recherches Administratives, Politiques et Sociales) }\end{array}$ \\
\hline GTZ & $\begin{array}{l}\text { Deutsche Gesellschaft für Technische Zusammenarbeit (German } \\
\text { Technical Cooperation) }\end{array}$ \\
\hline HIPC & Heavily Indebted Poor Countries Initiative \\
\hline IAD & Institutional Analysis and Development \\
\hline ICDP & integrated conservation and development project \\
\hline IDA & International Development Association \\
\hline IFI & international financial institution \\
\hline IFIA & Inter-African Forest Industry Association \\
\hline IFM & independent forest monitoring \\
\hline
\end{tabular}


IIED

IMF

IO

IPA

IPCC

IRD

ISH

ITTO

IUCN

JFM

LAAC

LDC

LULUCF

MDC

MDG

MNRT

NCA

NEP

NEAP

NEPAD

NFA

NFF

NFP

NGO

NRM

NSF

NTFP

OFIDA

ONE

PAC

PAR

PES

PFM

PNDC

RC

$\mathrm{RC}$

RDC

REDD

REPAR

RIL

RMC

RMNP

RRI
International Institute for Environment and Development

International Monetary Fund

independent observer

indigenous protected area

Intergovernmental Panel on Climate Change

integrated rural development

Institut des Sciences Humaines

International Tropical Timber Organization

World Conservation Union (formerly International Union for the Conservation of Nature)

joint forest management

Licence Assessment Advisory Committee

least developed country

land use, land-use change and forestry

Movement for Democratic Change

Millennium Development Goal

Ministry of Natural Resources and Tourism

National Constitutional Assembly

National Environment Plan

National Environmental Action Plan

New Partnership for Africa's Development

National Forestry Authority

National Forest Fund

National Forest Programme

non-governmental organization

natural resource management

National Science Foundation

non-timber forest product

Customs Service

Office Nationale pour l'Environnement

problem animal control

problem animal reporter

payments for environmental services

participatory forest management

Provisional National Defence Council of Ghana

Republic of Congo

rural community

rural district council

reducing emissions from deforestation and degradation

Regional Network of Parliamentarians

reduced impact logging

resource management committee

Rwenzori Mountains National Park

Rights and Resources Initiative 


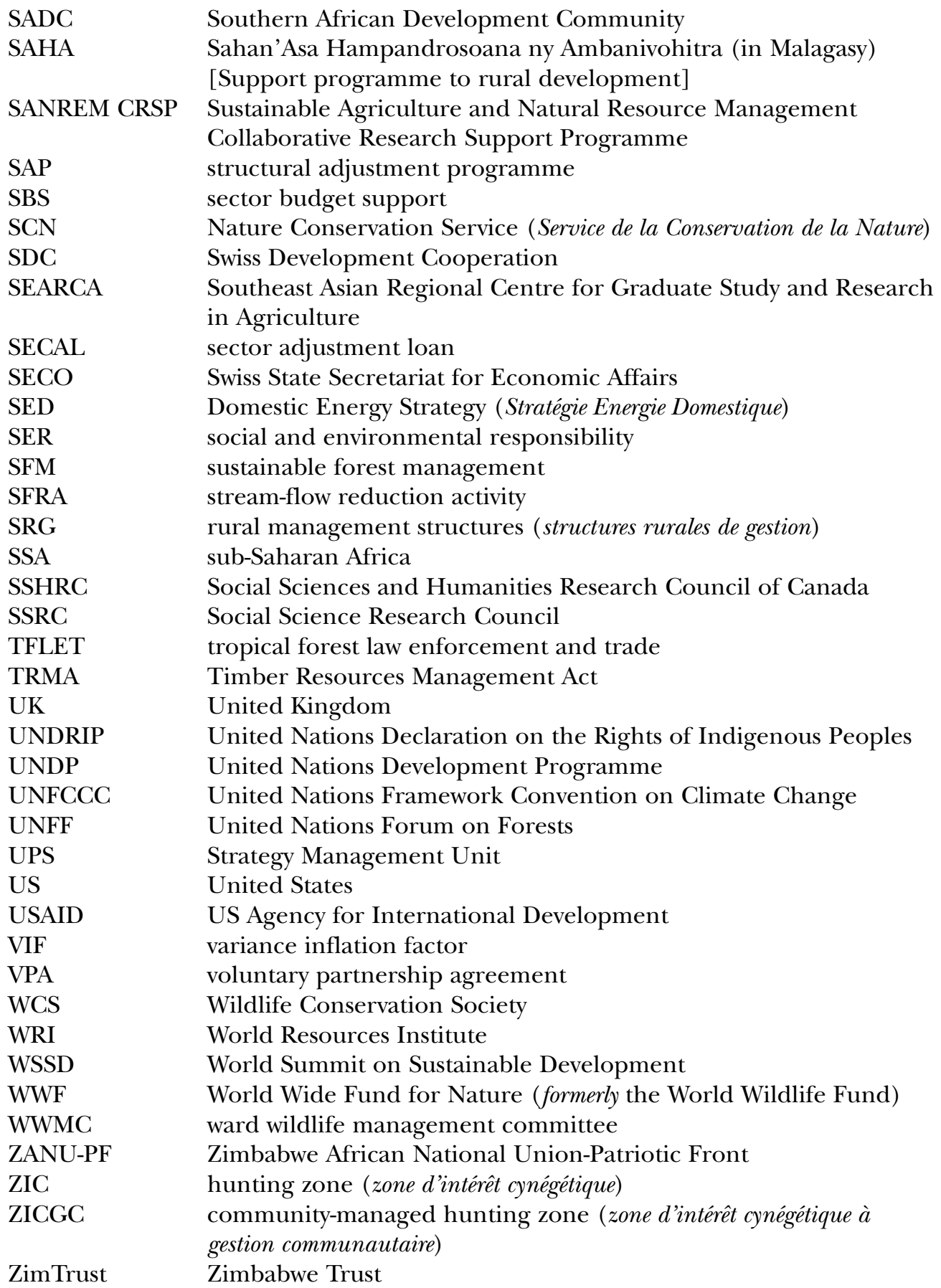





\title{
Forest Governance and Decentralization in Africa: Linking Local, Regional and Global Dialogues
}

\author{
Laura A. German, Carol J. Pierce Colfer, Edmund Barrow, \\ Christian Küchli, Jürgen Blaser and Wahjudi Wardojo
}

\section{INTRODUCTION}

The decade of the 1990s saw the rebirth of democracy in some parts of Africa, and with it the initiation of different governance reform initiatives, notably processes of administrative and political decentralization. Many countries embarked on decentralization in response to demands for better management of natural resources, including forests, and for more equitable sharing of benefits derived from them. Forest governance reform and decentralization in countries in sub-Saharan Africa (SSA) have taken various forms and are proceeding at different paces and stages of implementation.

A host of organizations, initiatives and policy instruments suggest an ongoing commitment to the principles and strategies of democratic decentralization in Africa. Meetings of the African Union, the Partnership for Municipal Development, Africities, Réseau Réussir la Decentralization, Permanent Interstate Committee for Drought Control in the Sahel, Conference on Ecosystems of the Dense and Wet Forests of Central Africa and regional authorities such as La Commission des Forêts d'Afrique Centrale (COMIFAC); the Southern African Development Community (SADC); the East African Community (EAC) and the Economic Community of West African States (ECOWAS) continue to reaffirm commitment to improved governance and to actively address the challenges of decentralized natural resource management.

While these initiatives and accompanying reforms have created real opportunities, putting democratic decentralization into practice for more sustainable forest management, equitable distribution of benefits remains a major challenge. Gains are often undermined by the dearth of mechanisms to track progress and exchange lessons to inform action and by the absence of a framework to value and capitalize on forest resources under decentralized management. Inadequate technical competencies and 
lack of funding and incentives constrain effective implementation on the ground. Protected area conservation and landscape management approaches premised on large-scale, state-managed, command-and-control practices, commonly employed in Africa, also often run counter to decentralized resource governance.

Increased trade, investment and financial flows into and out of Africa also add a layer of complexity to the implementation and effectiveness of decentralization and governance reforms. These issues and challenges are likely to take even greater significance in the context of current discussions on reducing emissions from deforestation and degradation (REDD) in the international climate change debate.

The Workshop on Forest Governance and Decentralization in Africa, held in Durban, South Africa, on 8-11 April 2008, was conceived as a means to extend the dialogue to the African continent, to take stock of challenges faced in implementing lessons and recommendations from previous workshops, and to synthesize Africa's unique experiences in forest governance and decentralization. The workshop brought together local and regional stakeholders, policy-makers and international experts with the overall objectives to:

- Distil and share lessons learned from experiences of African countries, including from regional initiatives, in their implementation of decentralization and broader governance reforms in the forest sector.

- Foster shared understanding of concepts and key trends and sharing of lessons and workable approaches, especially as they relate to poverty reduction and sustainable forest management, including forest conservation.

- Strengthen cooperation and enhance partnerships among countries and key stakeholders in addressing common challenges.

- Recommend approaches for strengthening policies, institutions and practices of decentralized forest governance systems to reduce the gap between theory and practice.

As an initiative in support of the United Nations Forum on Forests, the workshop also sought to identify the features of more promising systems of forest governance, and to support African decision-makers at diverse levels to better leverage governance transitions for the benefit of forest communities and society at large. This volume, derived from formal presentations by researchers and practitioners, field visits and group work, is a product of this exchange and of the ongoing reflection on how to bring social justice into the process of governing locally important resources that are, at the same time, of global interest.

\section{ROOTS OF THE CONVERSATION}

This book adds a new chapter in a body of experience and literature that tries to keep up with the fast-moving global policy changes related to decentralization and forests. Here we highlight some of the central discussions and related writings that have characterized the debates about decentralization and devolution. 
Much of the earliest effort to document and share decentralization experience occurred in Asia. An important 1999 workshop in the Philippines served as a vehicle to start an international conversation on the topic, and, indeed, served as a spur for the 'conversational thread' of which this book forms a part. Decentralization and Devolution of Forest Management in Asia and the Pacific (Enters et al, 2000) reports the results of the Philippines workshop and broached many of the issues that have recurred in subsequent studies. At that stage, as today, real devolution or decentralization was hard to find. The group clarified the difference between the two concepts and developed a typology of approaches to decentralization and devolution. For these and later authors, decentralization referred to transferring power to lower levels in a government bureaucracy, whereas devolution encompassed broader transfers of power within and outside of government. They also identified some enabling factors to effective decentralization and devolution, such as trust among stakeholders, effective checks and balances, and monitoring of performance. A higher degree of scepticism regarding the ability of communities to manage forests sustainably is more apparent in the early dialogue than now.

Their work was followed by in-depth studies of three Asian countries - China, India, and Indonesia (Edmunds and Wollenberg 2003). These authors looked at the issue more broadly, focusing on devolution rather than decentralization. One of the interesting and surprising findings coming out of Edmunds and Wollenberg's work was the degree to which decentralization actually resulted in a decrease in local people's rights to resources that they had considered their own (see Contreras, 2003; Sarin et al, 2003). This restriction in rights occurred through increased involvement of, and management by, government in people's daily affairs activities that once followed local norms and went largely unnoticed by government.

The topic of devolution was also taken up in southern Africa in a project comparing 14 case studies in 8 countries (Shackleton et al, 2001). These cases focused on the following topics:

- the degree to which laws and policy devolved decision-making and benefit flows to local communities;

- the power and legitimacy of local community institutions and their networks (with non-governmental organizations (NGOs), donors, the private sector and local government); and

- internal relationships and differentiations within local communities.

As with subsequent studies, these authors found large differences among cases in terms of the impacts of devolution policies, with some very positive results and others unlikely to result in good long-term resource management.

During the early 2000s, two global workshops of significance took place. The first, the Workshop on Decentralization and the Environment, took place in Bellagio, Italy, in 2002 with the goal of consolidating findings from research on decentralization and natural resources globally (Ribot and Larson, 2005). The workshop assessed the extent to which central governments have actually decentralized, the relations between the decentralized entities and local people, and the effects on people and 
their environment (Larson and Ribot, 2005). As with the other experiences summarized here, significant problems emerged during implementation, with concepts more difficult to implement than anticipated and aspirations not fully met by realities on the ground.

The second global conference on the subject was the Interlaken Workshop on Decentralization, Federal Systems of Forestry and National Forest Programmes, which took place in April 2004. This workshop was designed to provide an update on previous workshops, offer an opportunity for sharing international experiences, and feed directly into discussions at the United Nations Forum on Forests. The Interlaken workshop, with funding and encouragement from Swiss and Indonesian governments, was also global in scope, bringing together some 160 people from 51 countries and addressing the following 6 themes (Blaser et al, 2005):

1 allocation of roles and responsibilities and coordination across levels and sectors;

2 maintenance of ecosystem functions, sustaining forest productivity, and application of knowledge and technology;

3 regulatory frameworks, policies and equitable benefit-sharing;

4 financial incentives, and promotion of investment and private-sector partnerships;

5 participation, conflict and multi-stakeholder processes; and

6 capacity-building, information and technical support.

One inescapable conclusion coming out of all these meetings was the uniqueness of each site and the importance of the historical and socio-political context in determining the outcome of decentralization experiments. Presentations from researchers and practitioners, group work and field trips to Swiss forests enabled the generation of a set of principles considered important for effective and equitable implementation of decentralization policies (see Box 1.1).

Given the large variation globally, the Interlaken organizers determined to address decentralization on a regional basis. They wanted to see if clearer patterns and lessons could emerge from country groupings that were geographically closer. The continuing policy attention to decentralization also meant that there remained a need to understand how this governance experiment was evolving over time. Thus, a follow-on international workshop for the Asia-Pacific region was held in Indonesia. In the Yogyakarta Workshop on Forest Governance and Decentralization in Asia and the Pacific, organized under the auspices of the Asia Forest Partnership, a specific attempt was made to ensure that areas that were inadequately addressed and/or identified in earlier workshops were given attention (Colfer et al, 2008). Attempts were made to accommodate the interests of different partners. The Asia Forest Partnership, for example, stressed illegal logging, forest fires and forest rehabilitation as central concerns needing attention, while the Indonesian government was interested in exploring differing roles, responsibilities and rights in decentralization, and the financial implications of such changes - based on their own serious challenges in these realms. The controversial topics of equity, corruption, land tenure and land-use planning were brought in by the Center for International Forestry Research (CIFOR). Box 1.2 reproduces the Asian/Pacific concerns for comparison with the findings from Africa. 


\section{Box 1.1 Principles and guidelines for implementation of decentralization derived from the Interlaken workshop}

- Establish a clear legal and policy framework with a clear allocation of roles, responsibilities and resources, as well as clarity and consistency regarding strategy and implementation.

- Decentralization of powers and responsibilities to districts and municipalities should not proceed arbitrarily, but according to a clear set of rules and conditions.

- Decentralization requires accountability at all levels and corresponding multiple accountability mechanisms; elections alone are insufficient.

- Decentralization should recognize, work with and strengthen representative democratic institutions at all levels.

- Decentralization in the forest sector should not be implemented in isolation from a general national forestry strategy such as national forest programmes.

- Decentralized forest management should be based not only on controls, but also incentives; rules that cannot be enforced should not be made.

- Decentralization and the implementation of national forest programmes should include monitoring and evaluation with clear, specific variables and indicators.

- Rights and responsibilities must be accompanied by adequate resources and capacity building.

- Decentralization should be based on transparent horizontal and vertical information flows and dialogue, including across sectors.

- Decentralization should benefit from, as well as enhance, social capital, increasing coordination and trust among different levels and sectors.

- Local peoples must have a voice, and decentralization should take into account livelihoods, ways of life and improving the economic well-being of these peoples, as well as address inequities such as those relating to gender. Efforts must be made to raise and include the voices of special groups such as women, youth and indigenous peoples.

Source: Capistrano and Colfer (2005)

Capistrano and Colfer (2005) summarize more general lessons learned from the global experiences reported in the Interlaken and Yogyakarta workshops. First, decentralization occurs within a particular historical, cultural, economic and political context, which exerts meaningful influences on decentralization practices and outcomes. Second, governance systems were shown to be characterized by a neverending tension, and oscillation or balancing act, between centralizing and decentralizing tendencies - an observation confirmed by Ribot (2003; see also Chapter 2 in this volume), Oyono (2004) and Wily (2003) for the African context. Decentralization was also observed to take time, sometimes a long time, requiring attention to capacity-building, people's participation in decision-making and flexibility 


\section{Box 1.2 Major issues identified in the Asia-Pacific region during the Yogyakarta Workshop on Forest Governance and Decentralization}

- In most Asian countries, the involvement of women in the development process is largely ignored; decision-making and benefit-sharing in forestry are controlled by local elites. Gender mainstreaming and capacity-building are needed to improve women's participation.

- Government officials feel accountable to higher authorities but not to communities. Performance evaluations should consider officials' contributions to local empowerment.

- Decentralization in the forest sector is constrained by funding and capacity gaps, insufficient transfer of authority, and unclear roles and responsibilities at various levels.

- Lack of trust between government and communities and within the government bureaucratic layers contributes to a low level of commitment to decentralization. For government, it is important that transfer of responsibility and accountability accompany transfer of authority.

- Laws and regulations are highly inconsistent and frequently changing. A clear legal framework is necessary to ensure that decentralization arrangements are sound and enduring.

- In most cases in Asia, ethnic minority communities are marginalized and lack rights to their land. Equity in benefit-sharing is not always addressed and is often left unclear.

- Logging bans are not observed in practice, and illegal logging is highly linked to corruption in most Asian countries. The solution lies beyond intervention in the forest sector.

- In many cases, customary institutions are good mechanisms for managing forests. Institutional restructuring could help to improve implementation of decentralization.

- Decentralization presents both threats (decentralization of corruption) and opportunities (grassroots control and empowerment). In some countries, it has led to concrete advances in infrastructure development, education and healthcare.

- Better governance in forestry requires greater transparency through the establishment of new laws and increased media scrutiny.

- Decentralization takes time, and there are no short-cuts. Negative impacts are often intensified in the early years and subside as implementation is improved. Gradual implementation, with monitoring of processes and outcomes, is needed.

Source: Capistrano (2008)

to adapt to changing circumstances in time and space (Küchli and Blaser, 2005; Küchli, 2008). This lesson is also reflected in the African literature, which exposes the need to evaluate decentralization performance not only by focusing on outcomes, but 
on the extent to which it has actually been put into practice (Oyono, 2004; see also Chapter 2 in this volume). Capistrano and Colfer (2005) also highlight that effective decentralization requires both upward and downward accountability, and proactive efforts to avoid elite capture of benefits and rights. In the African context, one of the main reasons for reluctance to devolve natural resource management is concern over the ability and incentive of local communities to protect forest ecosystem services arguably requiring some upward accountability by forest users to the wider society (Ribot, 2002b). And limited downward accountability and elite capture continue to be two of the main concerns expressed about local bodies charged with receipt of powers whether grassroots organizations or local administrative structures (Ribot, 2002a; Bigombé Logo, 2003; Brockington, 2007), and analysts argue for greater attention to the institutions receiving decentralized powers (Ouedraogo, 2003).

Capistrano and Colfer (2005) argue that decentralization works best when there are reinforcing societal pressures from both the 'top' and the 'bottom,' an argument echoed in African case studies illustrating the need for strong local organizational arrangements to demand greater accountability from sub-national administrative bodies and elites (Oyono et al, 2006). These authors also observe that successful decentralization requires secure tenure and access to forest resources, financial means and authority at lower levels, commercial rights and market access, and sensitivity to cultural traditions and local knowledge. Similar observations on the importance of tenure security (Shackleton et al, 2002; Katila, 2008), financial means (Lund, 2007), market access (see Chapter 4 in this volume) and sensitivity to customary rights, traditions and knowledge (see Chapter 3 in this volume; Etongou, 2003) have been made for Africa. Finally, decentralization in the forest sector seems to be intimately linked to such processes in other sectors. While evidence suggests this is also true for Africa, one can observe that effective devolution and decentralization in forestry and natural resource management may be a vehicle for improving local governance more broadly (see Chapter 2 in this volume; Wily and Dewees, 2001). As such, local actors are not only at the mercy of broader structural conditions, but may exhibit a large degree of agency in shaping how these broader forces play out locally.

The Workshop on Forest Governance and Decentralization in Africa, a countryled initiative in support of the United Nations Forum on Forests by South Africa and Switzerland, was an effort to carry this global dialogue forward while also exploring new themes emerging out of Africa's unique experiences with forest governance and decentralization and this unique moment in history. The next section gives a general overview of the core themes that structured the dialogue and this volume.

\section{GROSS-GUTTING THEMES}

\section{Decentralized forest management and livelihoods}

The core theme of this book is decentralized forest management in Africa and its effect on local livelihoods. Decentralization has a long history in Africa and worldwide, but gained much momentum over the last two decades. Governments have decentralized 
for a host of reasons. The most prominent rationale is enhanced administrative efficiency. By placing decisions within the local sphere, it is argued that decisionmaking will be faster and more responsive to local needs, transaction costs will be reduced by making decisions locally, and service delivery will be improved through better matching of supply and demand. Another argument is the strengthening of democratic institutions and procedural and distributional equity through increased public participation and enhanced downward accountability. More critical reviews suggest that decentralization is simply a means for central governments to transfer their fiscal and administrative burdens to decentralized actors (Nsibambi, 1998).

Decentralization can assume multiple forms (see Box 1.3). Of the two main types administrative and democratic decentralization - the former is argued to be the 'weaker' form due to stronger lines of accountability towards central government ministries delegating authority and supervising decentralized administrative bodies (Ribot, 2003; Ribot and Larson, 2005). Democratic decentralization, on the other hand, aims to increase public participation in decision-making, leading to strong downward accountability to local constituencies - presumed to enhance many of the stated benefits of decentralization.

The move towards decentralized government parallels similar shifts in the forest sector. A marked shift in forest management authority away from central governments to decentralized administrative units (district councils, village councils, communes,

\section{Box 1.3 Some definitions}

Decentralization refers to any action taken by a central government to formally cede powers to actors and institutions at lower levels in a political-administrative and territorial hierarchy. This is not to be confused with privatization, which is the transfer of powers to non-state entities (individuals, corporations, NGOs). A few key types of decentralization may be noted:

- democratic or political decentralization, or the transfer of powers and resources to 'authorities' representative of and downwardly accountable to local populations;

- administrative decentralization or de-concentration, which concerns transfers of power to local branches of the central state, whose primary responsibility is to the central government;

- fiscal decentralization, which refers to the transfer of fiscal resources and powers for revenue generation, and may be a feature of either democratic or administrative decentralization.

Devolution is often used synonymously with administration decentralization; but in the forestry literature it has been used to encompass transfers of powers to local elected governments, NGOs, customary authorities and private actors.

Source: Smith (1985); Agrawal and Ribot (1999); Manor (1999); Colfer and Capistrano (2005) 
rural councils, local government councils), community-based organizations (forestuser groups, natural resource management committees, community trusts, village action groups and terroir villagois) or customary authorities (e.g. chiefs) has occurred both across Africa and worldwide (Mandondo, 2000; Wollenberg and Kartodihardjo, 2002; Kaimowitz et al, 2003; see Chapter 11 in this volume). These shifts take many forms, from community-based forest management, participatory forest management, community forestry and joint forest management to district or council forests and the redistribution of forestry tax revenues (Bigombe Logo, 2003; Blomley, 2006; Oyono et al, 2006; see Chapters 10 and 11 in this volume).

One of the central themes in this volume is the extent to which decentralization policies have been put into practice. The weak representative decision-making processes that are characteristic of many developing countries have undermined the translation of decentralization theory into practice - making ideal cases hard to find (Agrawal and Ribot, 1999; Larson, 2003; Ribot et al, 2006). Authors in this volume and elsewhere (e.g. Edmunds and Wollenberg, 2004; Ribot and Larson, 2005) highlight that natural resources are at once critical for local livelihoods and provide significant wealth for governments and national elites. Weak governance creates opportunities for local elites and vested interest groups to manipulate the opportunities created by decentralization for their own benefit (Tacconi, 2007). Thus, decentralization may challenge traditional power relations and face 'push-back' from bureaucrats and elites fearing loss of privileges (see Chapter 10 in this volume). Resistance by powerful groups also can be seen in the value of resources targeted for decentralized management; it has often been argued that the most degraded forests and low-value resources are decentralized, while central states retain control over the most valuable resources (Blomley and Ramadani, 2006; Oyono et al, 2006). It can also be seen in the proliferation of complex regulations, heavy fees and taxation, selective application of laws to different actors and the slow pace of implementation, among others. In many countries, the state uses various means to exert control over decentralized forest management, including complex management plans, restrictions on the use of certain resources through the use of permits, retaining the ability to revoke agreements, or placing perverse incentives (taxes, permits) for rural people to engage with the market. Resistance can also manifest itself outside the law in the form of corruption, patronage and lack of transparency. Conflicts of interest faced by government officials wishing to retain previously enjoyed forest rents are a key constraint in implementation (see Chapter 6 in this volume).

Another major theme running through this book and the wider literature on decentralized forest management is the governance mechanisms that characterize decentralized forest management in different contexts, and the nature of powers and resources being decentralized. The 'actors, powers and accountability' framework by Agrawal and Ribot (1999) provides a powerful framework for evaluating decentralization forms and processes. The question of actors focuses on who receives powers in decentralization and who represents local people - whether elected authorities, customary authorities, local management committees or private actors. Powers encompass both the ability to make and carry out meaningful decisions concerning the resource and the economic value of the resource itself. Forest tenure reforms towards increased local management and control are a major form of power 
transfer sweeping the the tropics (White and Martin, 2002). Accountability, on the other hand, refers to both the obligation to provide information and explanations concerning decisions and actions, and the ability to enforce rules and apply sanctions (Brinkerhoff, 2001, cited by Ribot, 2003). Accountability may be either upward or downward, the latter being the essence of more democratic institutions. Examples are rife of both unaccountable and upwardly accountable local institutions such as the misappropriation of funds intended for local communities by municipal and administrative authorities and the use of decentralized forest management as a means to shift management costs to local communities (Oyono, 2005; Brockington, 2007). Yet other examples exist to illustrate the potential of decentralized forest management when real powers are devolved to the local level (Lund, 2007).

Another major theme is the impact of decentralized forest management on local livelihoods. Each of the above factors - decentralization policies, the degree to which these policies have been put into practice and governance mechanisms - have helped to shape highly variable livelihood outcomes both within and between countries that have enacted reforms (Edmunds and Wollenberg, 2004; Colfer and Capistrano, 2005; see Chapters 5 and 6 in this volume). Yet livelihood benefits are also mediated by a host of contextual factors - among these the wider governance context (see Chapters 6 and 11); levels of education, legal literacy and empowerment; traditional roles; gender; local institutional capacity for governing the resource base and finances; and levels of poverty - affecting the ability of households to channel increased rights to forest resources into wealth generation. Emerging themes centre on the nature of incentive structures and their role in shaping behaviour (largely outside legally mandated spheres), the challenges of effective representation, and the need for checks and balances that can help to translate policy intentions into field realities.

\section{Forest tenure}

Forest tenure is one major form that power transfers can take. While touched on only peripherally in many of the chapters of this volume, it is emphasized here given its cross-cutting importance to all the themes of the volume. Secure rights are often needed to derive meaningful livelihood benefits from forests, to provide incentives for investing in long-term returns from forest management, and to secure local benefits capture from expanding commercial interests. Yet much of the global forest estate is characterized by insecurity over property rights - with property rights to forests often contested, overlapping or unenforced (White and Martin, 2002; Sunderlin et al, 2008).

Property rights or tenure refer to systems of rights and institutions that govern access to and use of land and other natural resources (Maxwell and Wiebe, 1998), including forests. Globally, four main forms of property rights are recognized, as defined by the holders of rights: public property, private property, communal property (governed by common property regimes) and open access (where rights are unspecified or not held by anybody) (Feeny et al, 1990). In Africa, only the first two are widely recognized, with the third officially recognized in some countries:

1 Public or state property is property that is held in trust by the government on behalf of the people, and for which the state reserves the rights of adjudication of land 
use and management. Forms of public property common in Africa include urban and protected areas, reserved lands for national security, and other lands for public utilities.

2 Private property is recognized in all countries, and can include leasehold land, adjudicated for a determined period (99 years or less) for specific uses; freehold land, where the holder enjoys perpetual rights; and privately owned/registered communal land (with rights held collectively).

3 Communal property is property held under customary law, with varying levels of formal recognition and treatment within reform processes in different African countries (Wily, 2003).

In addition to classifications of forest tenure by rights holders, it may be analysed as a 'bundle of rights' (Bruce, 1993). For common property resources, these include the rights of access, withdrawal, management, exclusion and alienation (Schlager and Ostrom, 1992). Some authors further differentiate these different aspects of 'breadth' of rights with two other important dimensions: duration (the time over which rights are held) and assurance (the ability of individuals to exercise their rights) (Place and Swallow, 1993). The concept of a bundle of rights acknowledges that individuals may hold some form of rights, while not holding others. In Africa, for example, local communities are often given rights to access forest areas and withdraw forest products for their own consumption; but certain rights to transfer forest products to others through sale are restricted through absolute prohibition (common for jointly managed protected areas) or taxation. In forestry, assessing which rights in the bundle are held by whom is complex, as it is often necessary to differentiate between rights to land versus forest, as well as to diverse forest products (timber and non-timber forest products). With new markets for forest ecosystem services emerging, this web of rights becomes ever more complex, extending rights to biodiversity conservation, watershed protection and carbon sequestration to national and global communities. Further complexities emerge due to overlap and contradictions between formal and customary, de jure (legally recognized) and de facto (practised) rights.

The relevance of tenure security to forest governance lies in its role in shaping the set of incentives in forest management. History has shown how periods of shifting or insecure tenure have led to widespread overexploitation and destruction of forests (Bekele, 2003). Conversely, tenure security is known to be a necessary - albeit insufficient - condition for sustainable forest management. Strong tenure security coupled with other enabling conditions (market access, forest value, effectiveness of local institutions) can enable local forest users to invest in long term over immediate returns from forests. When systems of rights are unclear or unenforced, open-access regimes may result that quickly lead to resource degradation. While traditionally associated with communal property (Hardin, 1968), open-access situations may also exist with public or private property due to poor enforcement of rights to exclude others. Research has shown that when governed by a common property regime consisting of locally formulated collective choice rules to regulate access and use among a self-governing group of local users, communal property can be managed sustainably (Ostrom, 1990). For both state and communal property, institutions capable of translating a system of rights into a set of practices for ensuring sustainable 
forest management are fundamental. It is important to note that these institutions may be 'hybrids' linking different holders of rights (the state, local communities, individuals), irrespective of ownership (German and Keeler, forthcoming). Box 1.4 provides an overview of forest tenure and tenure reforms in Africa.

\section{Box 1.4 Forest tenure and tenure reforms in Africa}

\section{Edmund Barrow}

Forest tenure in Africa has witnessed multiple transformations throughout the centuries as a function of historical uses, the effects of colonization and land alienation, and the impacts of post-independence policy changes (Platteau, 1996; Diaw, 2005; Oyono, 2007). Customary rights over land and forests were largely expunged, and customary occupants considered 'illegal squatters' on their own land. In forestry, formal rights have historically focused on valuable resources such as timber. Rights to timber were alienated from communities; but colonial administrations often allowed community access for less valuable forest resources through permits. These historical complexities are compounded by a situation of legal pluralism, in which customary and statutory norms and systems overlap and create a system of competing claims over resources within a web of recognized and unrecognized rights. In Cameroon, for example, the 'national domain' is considered by the state as 'vacant' and therefore available for private appropriation - despite its status as customary territory (Bigombé Logo, 2007).

Table 1.1 summarizes ownership patterns in Africa based on United Nations Food and Agriculture Organization (FAO) data (FAO, 2003, 2005) and other data sets (Kamugisha, 2007; Nhantumbo, 2007; Oyono, 2007; Savadogo, 2007). But the 'official' status of forest rights (for Central, French West and Eastern Africa) obscures customary rights and recent gains in local access and control (reflected in Southern Africa; Nhantumbo, 2007)). For Southern Africa the sources and assumptions are well explained (Nhantumbo, 2007), ${ }^{1}$ and include a combination of assessment means including FAO data; a greater understanding of de facto ownership (especially of lower value forests) by communities; the extent of decentralization of rights to forest management (not necessarily the same as forest ownership); forests that are potentially available to communities (though might not actually be); and the extent to which local government forests are multipurpose and reserved for communities.

$A$ recent wave of forest tenure reforms has strengthened local rights to forest resources in the process of devolving forest management functions. In some cases, there has been an attempt to integrate customary and statutory laws within new land and forestry policies while adopting contemporary concepts of equity (Selebalo, 2001; Wily and Mbaya, 2001). While decentralization policies strengthen local use rights over forests and wildlife on paper, the state has often been reluctant to relinquish control over valuable resources - making it difficult to move beyond rhetoric. In addition to retaining control over high-value forests, costly permits and detailed management plans have made it difficult for communities to benefit from high-value forest products. There are also problems with marginalization and elite capture, as seen in fast-track mechanisms to accelerate land allocation to the private sector without similar 
mechanisms for local communities. Opportunities to support growing demands for community ownership and use rights and to harmonize decentralized forest management with land laws (as in Tanzania and Mozambique) are hindered by communities' inability to negotiate and defend such rights. Civil society, though not strong in many parts of Africa, has begun to advocate for formal recognition of customary rights and the transfer of substantive rights for natural resource access and control (including revenues accruing from their exploitation). In several countries in Africa, networks have mobilized to defend community and minority rights to forests and related benefits. However, the strength of civil society relative to the state varies greatly, with greater decentralization where it is strong (e.g. eastern and southern Africa).

Table 1.1 Regional summary: Who owns Africa's forests?

\begin{tabular}{|c|c|c|c|c|c|}
\hline $\begin{array}{l}\text { Forest type (millions } \\
\text { of hectares) }\end{array}$ & $\begin{array}{l}\text { Central } \\
\text { Africa }\end{array}$ & $\begin{array}{c}\text { French } \\
\text { West Africa }^{3}\end{array}$ & $\begin{array}{l}\text { Eastern } \\
\text { Africa }^{4}\end{array}$ & $\begin{array}{l}\text { Southern } \\
\text { Africa }^{5}\end{array}$ & Totals \\
\hline $\begin{array}{l}\text { Public (administered } \\
\text { by government) }\end{array}$ & $\begin{array}{l}1368.28 \\
(99.96 \%)\end{array}$ & $\begin{array}{l}41.95 \\
(97.6 \%)\end{array}$ & $\begin{array}{l}127.39 \\
(96.8 \%)\end{array}$ & $\begin{array}{l}76.23 \\
(36.0 \%)\end{array}$ & $\begin{array}{l}613.85 \\
(81.3 \%)\end{array}$ \\
\hline $\begin{array}{l}\text { Public (reserved for } \\
\text { community and } \\
\text { indigenous use) }\end{array}$ & $\begin{array}{l}0.62 \\
(0.04 \%)\end{array}$ & $\begin{array}{c}0.76 \\
(1.8 \%)\end{array}$ & $\begin{array}{c}1.624 \\
(1.2 \%)\end{array}$ & $\begin{array}{l}121.31 \\
(57.3 \%)\end{array}$ & $\begin{array}{l}124.31 \\
(16.5 \%)\end{array}$ \\
\hline $\begin{array}{l}\text { Private (community and } \\
\text { indigenous people) }\end{array}$ & 0 & 0 & 0 & $\begin{array}{c}3.59 \\
(1.7 \%)\end{array}$ & $\begin{array}{c}3.59 \\
(0.5 \%)\end{array}$ \\
\hline $\begin{array}{l}\text { Private (individual and } \\
\text { companies) }\end{array}$ & 0 & $\begin{array}{c}0.25 \\
(0.6 \%)\end{array}$ & $\begin{array}{c}2.62 \\
(2.0 \%)\end{array}$ & $\begin{array}{l}10.43 \\
(4.9 \%)\end{array}$ & $\begin{array}{l}13.30 \\
(1.7 \%)\end{array}$ \\
\hline Totals & 1368.90 & 42.96 & 131.64 & 211.56 & 755.06 \\
\hline
\end{tabular}

Notes:

1 Burundi, Cameroon, Central African Republic, Democratic Republic of Congo, Equatorial Guinea, Gabon, Republic of Congo, Rwanda.

2 Burkina Faso, Mali, Senegal, Togo, Côte d'Ivoire, Mauritania, Niger. 3 Sudan, Djibouti, Somalia, Somaliland, Ethiopia, Kenya, Uganda, Tanzania.

4 Angola, Botswana, Namibia, Zimbabwe, Zambia, Malawi, Mozambique, South Africa, Lesotho, Swaziland.

Source: FOSA (2003); FAO (2005); Kamugisha-Ruhombe (2007); Nhantumbo (2007); Oyono (2007); Savadogo (2007); Sunderlin et al (2008)

Does security of tenure over forest resources translate into improved well-being for communities dependent upon forest resources and often living under extreme poverty? The answer is clearly not yet. In addition to state control limiting local incentives to invest, the tendency to devolve low-value resources and lack of support systems for value addition and marketing, have often hindered the translation of tenure reforms into concrete gains for local livelihoods. 


\section{Conservation, sustainable forest management and forest governance}

One of the key themes explored in this book is the relationship between decentralized governance or community-based natural resource management (CBNRM) and environmental sustainability. Based on the assumed causal link between increased local ownership and control over forests and the incentive to invest in sustained returns, the literature has perhaps over-theorized a positive linkage between decentralization and sustainable natural resource management. This narrative has been propagated in academic and practitioner circles alike without adequate scrutiny. As pointed out by Tacconi (2007), even where democratic decentralization has been put into practice, there is no reason to assume this relationship will hold true. A host of authors in this volume and elsewhere have shown how decentralization and community-based forest management can result in either sustainable forest management or deforestation (Agrawal and Chhatre, 2006; see Chapters 5 and 6 in this volume). In some locations, increasing local control over forests has resulted in increased logging contracts or agricultural conversion as a means of increasing tax revenues or deriving greater value from land (Kaimowitz et al, 1998; Casson and Obidzinski, 2002; Ribot, 2002a; Larson, 2005).

This is not to say that centralized state control over natural resources is any more likely to ensure sustainable forest management. Forest governance models predicated on strong central government control may result in unsustainable practices due either to incentive structures favouring the maximization of resource rents or inadequate capacity to enforce rules of exclusion (Banana et al, 2007; see Chapter 5). Restricting access to customary rights-holders merely drives unsustainable harvesting due to active protest against rules of exclusion or to the incentive structures set up when government controls are lacking; de facto open-access situations are created (Katerere, 2000; Mudekwe, 2005). Often, resource access to local communities is restricted while permits for outside actors are increased.

Clearly, democratic and administrative decentralization needs to be supplemented with other policies and practices to ensure conservation or sustainable forest management. The literature posits what some of these conditions might entail. Tacconi (2007) suggests that devolution to local communities in the form of CBNRM or democratic decentralization can only work if the benefits from forests are higher than those from other land uses, creating a utilitarian incentive to conserve forests. This suggests that efforts should be made to decentralize resources with meaningful economic value or to support activities enabling meaningful value addition. It also suggests that in the absence of such value, communities should not be expected to conserve forests on their own accord. According to Ribot (2002), a set of 'minimum environmental standards' is often required due to the livelihood orientation of local resource users. Thus, substantial powers may be devolved to local communities, provided this minimum set of standards is met. The government's role then becomes one of monitoring the extent to which these conditions are met and ensuring compliance.

Other authors suggest that of equal importance to tenure security are the institutional arrangements for putting rules into use (German, 2008). In a study by Banana et al (2007) across nine forests in Mpigi District of Uganda, local compliance 
with timber and firewood harvesting rules was observed in areas where there was either strict enforcement of rules by the forest owner, or where there was strong cooperation between local communities and forest owners for forest protection. They conclude that sustainable forest management may be more a function of the institutional arrangement governing that forest than a specific distribution of powers and authority between different levels of government and local user groups. Similarly, Tacconi (2007) suggests that both financial incentives and monitoring and evaluation mechanisms are needed to complement the current decentralization model. Others suggest that effective representation of women and marginalized groups could enhance sustainability through the value placed on non-timber forest products (NTFPs) and multiple use values (see Chapter 7).

Another key theme in this book is the issue of how to reconcile local livelihood priorities with environmental services of national or global concern. According to Sayer et al (2008, p1), 'processes of governance and rights reform are revealing underlying tensions between the needs to husband the local values of forests versus the need to conserve the so-called public goods values that accrue to society at large'. Reconciling these trade-offs will be a major challenge for resource managers and governments in the coming decades. There are three fundamental approaches to reconciling local rights and benefits with the stewardship of public goods values of forests:

1 the establishment of protected areas with rights awarded to local users in ways that are consistent with conservation values;

2 recognition of local ownership and use rights, but with certain restrictions or easements on these rights to ensure public goods values are maintained (Sayer et al, 2008);

3 involving local resource users as beneficiaries for incentive-based payments for ecosystem services (watershed protection, avoided deforestation, etc).

While conservation organizations and governments have shown a preference towards the first, the promise of the latter two is becoming increasingly recognized worldwide.

South Africa's experience in water management illustrates how a resource of national concern and requiring management across sub-national and national political boundaries does not easily lend itself to decentralized systems of management. Different administrative functions - from the funding of research to guide policymaking to the establishment of regulatory frameworks and the governance of crosssectoral water allocations - are required at different levels of a political-administrative hierarchy. Here, the principle of subsidiarity comes in - namely, that decisions be made at the lowest possible level of the political-administrative hierarchy. The crucial role of effective public institutions in securing critical ecosystem functions also becomes clear. Chapter 11 illustrates the pitfalls of grounding forest management in strong government oversight in the absence of local incentive structures and legitimacy: during lapses of government oversight, rapid loss of forest cover and ecosystem services can occur even where local organizations for sustainable forest management are strong. Ultimately, the most resilient organizations for sustainable forest management will be those that provide sufficient incentives to local communities, where the goals and minimum conditions of forest management are clear, and where there are strong institutional arrangements at multiple levels to put rules into practice. 


\section{International trade, finance and forest-sector governance reform}

The forest sector is more embedded in the global economy than ever. Africa's natural resources are gaining in global importance as one of the 'last frontiers' for exploitation by global actors. The recent food and fuel crises are placing new pressures over vast tracts of forest and other land, land which is often considered 'underutilized' by national governments despite their critical role in supporting local livelihoods. This trend is, in part, due to rapid growth in emerging economies such as China, with economic growth increasing demand for energy, water, food and forest products (Toyne et al, 2002; White et al, 2007). With domestic sourcing falling far short of demand and restrictive policies on logging, China has become the world's largest importer of timber - with forest product imports to China increasing threefold and $\log$ imports fivefold from 1997 to 2004 (Mackenzie, 2006). The impact of this demand on Africa's forests is already being felt and is likely to continue apace (Toyne et al, 2002; Mackenzie, 2006; White et al, 2006). In addition to these direct linkages, emerging economic powers are likely to have a profound influence on the performance of global economic and financial systems (White et al, 2007). With the influence of the World Bank and European markets eroding, so too could their political influence around issues of transparency and improved governance (Karsenty, this volume). With looser standards for information sharing and transparency, this expansion of players and practices will make it more difficult to identify and influence markets and business practice. Markets for environmental services of global interest such as the growing market in carbon credits, while presenting a new window of opportunity for capturing value from standing forests, must contend with other competing land uses.

These economic trends are occurring in the context of shifts in social and political systems related to forest tenure reforms, decentralization and declining authority of central governments, expansion in telecommunications and information access, and the rising influence of informal networks (Roda, this volume; White et al, 2006). Increased demand for forest products in the context of tenure reforms and decentralized decision-making could create unprecedented economic opportunities for forest-dependent communities. However, increasing 'stakes' over forest resources and land will also create new levels and types of challenges for forest governance. As stated before, elite capture by powerful economic interests in contexts of weak and shifting governance constitutes one of the main challenges. Furthermore, poor track records of regulatory reforms, entrenched industrial interests, economies of scale, and diminished roles and responsibilities of national governments represent substantial challenges for making this a reality.

Chapter 4 of this volume and Sunderlin et al (2008) raise concerns that the promising royalties under the new REDD mechanism for avoided deforestation could create incentives for states to create 'conservation rents' at the expense of local communities. If powerful elite networks, multinational companies and migrant ethnic groups have been more effective in capturing Africa's economic opportunities in the past (Bonacich, 1973; UNSC, 2002), it is imperative that we take a new look at the characteristics of governance reforms required to enable these opportunities to be harnessed for the benefit of local communities and African societies. Certainly, the 
central state has a role to play in regulating industry to ensure that social and environmental standards are adhered to and to assist resource-poor households to participate in emerging markets and to access benefit flows. A core challenge in the decades ahead is to support a transition from weak governance and historical patterns of corruption and patronage to enabling governments to act in the public interest.

\section{CHAPTERS IN THIS VOLUME}

This volume is divided into three major sections. Part I provides an overview of the key themes in this volume. Part II explores key themes associated with decentralization processes and outcomes, including a look at the extent to which democratic decentralization has been implemented, livelihood outcomes of decentralization reforms, and lessons learned in efforts to use decentralization as a means of achieving both rural livelihood and environmental objectives. Part III takes a look at some of the broader global drivers of trends in the sector, including major shifts in policies and industrial organization, the emergence of carbon as a global forest commodity, and some of the initiatives and challenges of harvesting valuable forest resources for meaningful local and national development in the context of expanding global trade.

Part I has three chapters that help to frame the volume as a whole. Chapter 2, by Jesse C. Ribot, sets a foundation for discussions about decentralization by clarifying concepts, providing a brief historical overview of past decentralizations in Africa, highlighting some of the obstacles to implementing democratic decentralization in practice, and distilling lessons on decentralization processes and outcomes. He argues that democratic decentralization reforms rarely take place, in forestry or any other sector, making it difficult to understand the conditions under which democratic decentralization improves equity and efficiency or alleviates poverty. He finishes by outlining opportunities for legislating and implementing democratic decentralization, and an approach to promoting democratic environmental governance. Chapter 3 is by Mariteuw Chimère Diaw, who analyses the disconnect between the dominant forms of political expression and social change found in the decentralization and conservation arenas, and the highly resilient customary institutions and informal networks that have been on the receiving end of these projects. He argues that governance systems and reforms favouring 'crafted institutions' and rendering customary institutions invisible have been the cause of many governance challenges due to the unanticipated complexities of local reality as well as active resistance to dominant discourses and practices. He sees these disconnects manifested in the tendency of power to evolve outside the reach of formal institutional structures and processes, and in the resulting elite capture and uncertainty of outcomes from standardized reforms (see also Diaw, 1998). Diaw introduces the concept of 'space-taking' as a metaphor for the unanticipated expressions of local agency, arguing that decentralization would be better served by creating or granting space for local agency and deliberative process (with space for negotiation for weaker voices) as opposed to over-defining how local actors should organize. The last chapter in this section (Chapter 4) is from Alain Karsenty, who 
expands the forest governance dialogue to the international realm, emphasizing the emergence of a new global architecture for trade in forestry products. He introduces the concept of the 'grand game' to refer to strategic rivalries between powers seeking control over geographic areas or prime resources, and explores two 'grand games' playing out in Africa at the moment. First, the emerging economies such as China are generating a new rivalry in Africa for high-stake access to natural resources (and, to a lesser extent, markets), and eroding the influence of the World Bank and other Western interests - with potential risks to ongoing governance reforms. The second is the positioning of actors around access to future income from conservation linked to international efforts to combat climate change.

Part II has eight chapters that focus on core themes which have characterized the literature and practice on forest decentralization and sustainable forest management in Africa and globally. The first of these themes is the relationship between decentralized forest management and local livelihoods. Chapter 5 by Pamela Jagger illustrates why Uganda is at the forefront of governance reforms in the region (Ndegwa, 2002) in terms of the proportion of forests managed by decentralized local governments, and explores the extent to which this has led to gains in local livelihoods and sustainable forest management. Tom Blomley and colleagues explore a similar set of issues in Chapter 6, but focusing on livelihood outcomes from community-based forest management in Tanzania. He explores why a progressive policy ensuring that almost all forest management benefits are captured at the community or forest-user group level has not led to the anticipated economic returns for local communities. Factors considered include the quality of the resource transferred to communities, governance failures at diverse levels and broader discourses on environmental destruction. In Chapter 7, Solange Bandiaky and Anne-Marie Tiani explore local impacts through the lens of gender and equity, exploring the extent to which decentralized forest management actually delivers its theorized benefits in terms of equity and improved representation of marginalized groups.

The next set of chapters explores the challenges of fostering local livelihood benefits from the decentralization of forest rents (fiscal decentralization). In Chapter 8, Sébastien Malele Mbala and Alain Karsenty explore the attempts and pitfalls of establishing fiscal decentralization policies in the Democratic Republic of Congo, where a long period of political unrest has created a governance vacuum in vast forest areas. They highlight the challenges of governing natural resource wealth in countries composed of sub-jurisdictions with highly heterogeneous resource endowments. Chapter 9 by Patrice Bigombé Logo explores factors hindering effective livelihood outcomes from fiscal decentralization in Cameroon, including the extent to which elite capture by local government officials and upward accountability have shaped livelihood gains from the substantial flows of forest revenues to municipalities and local communities. Chapter 10 by Bréhima Kassibo similarly illustrates the various ways in which elite interests (in this case, traders and public servants) can shape both ongoing reforms and flows of resource rents, and in turn local incentives for sustainable harvest. A common theme running through these chapters is the role of political interests in capturing opportunities or positions of privilege in contexts of weak or shifting governance and limited checks and balances. 
Another core theme in this section is the relationship between decentralized forest management and environmental sustainability. The contrasting findings in Chapters 5 and 6 , which show that both negative and positive environmental outcomes may result, are given partial explanation in Chapters 11 (by Everisto Mapedza) and 12 (by Nadia Rabesahala Horning). Mapedza explores the role of political uncertainty in the capacity to sustain gains in equity and sustainability achieved under two of Zimbabwe's CBNRM initiatives hailed as a success internationally. He explores the role of the broader governance context in shaping the implementation of, and outcomes from, decentralized natural resource management, and touches on paradigmatic themes for the integrated conservation and development debate. Among these is the role of incentive-based (as opposed to regulatory) systems for sustainable forest management to enhance resilience in times of political and economic uncertainty; how to align conservation with local livelihood interests (e.g. via transfer of resources with meaningful economic value); and the role of effective public institutions in complementing local efforts to secure critical ecosystem functions. Horning's chapter then makes an ambitious attempt to distil a set of limited and specific conditions under which conservation is possible. The role of certain conditions and their interaction - among these the interests of individual users, how these interests relate to interests of other users, and rule enforcement capabilities - are explored. The chapter echoes a core theme in the decentralization literature - namely, that rules alone are insufficient for ensuring the outcomes that these rules are designed to achieve.

Part III has six chapters that go beyond decentralization to broader forest governance issues, with a focus on key trends in globalized trade and investment, how these trends are affecting local forest users, and attempts to strengthen forest governance in the context of increased demand for forest products and services. Chapter 13 by J. Henry Owusu explores the long-term consequences of Ghana's free market-based economic recovery programme of the 1980s on both the environment and forest communities. Hailed as a success internationally, this chapter highlights the consequences of accountability to international financial actors - which dramatically transformed the traditional relationships between the formal and informal sectors of the wood industry - on jobs and local livelihoods. Chapter 14 by Simon Milledge demonstrates how the 'golden opportunity' provided by the recent rapid growth of Tanzanian indigenous hardwood exports has led to less than satisfactory results for equitable and broad-based benefits. He explores how uncertainties created around national governance reforms interact with global market forces to shape a set of perverse incentives and governance shortfalls in the sector. Chapter 15 by James K. Gasana and Jean-Marie Samyn summarizes the state of play on the continent for international cooperation in forest law enforcement and governance (FLEG), aimed at curtailing illegal logging and illegal timber trade and fostering trade in sustainably sourced timber. The authors explore the extent to which increased awareness and a host of commitments at diverse levels have led to anticipated outcomes, and the extent to which adaptive learning on FLEG implementation and complementary governance instruments are necessary to consolidate the potential gains from FLEG initiatives in addressing the age-old problems of illegal logging. Luke Freeman and colleagues (Chapter 16) explore the potentials and limitations of a market-based instrument for 
enhancing local livelihood benefits from international timber trade - namely, Forest Stewardship Council (FSC) certification. These authors explore the promise and pitfalls of the FSC requirement of free, prior and informed consent by exploring how pygmy hunter-gatherers are consulted and involved in the management of forest concessions in the Congo Basin.

The last two chapters of Part III focus on emerging trends in the forest sector that are compounding the challenges to forest governance on the continent. Chapter 17 by Jean-Marc Roda explores a major shift in the pattern of industrial organization in the extraction and trade of tropical timbers that emerged during the mid 1990s. He highlights the properties that confer competitive advantages to this mode of organization, the ethnic networks that have managed to capture these opportunities, and their adeptness in exploiting governance shortfalls. ${ }^{1}$ The chapter suggests that more creative governance instruments are required to ensure sustainability and equitable benefits capture from the forest sector. Chapter 18 by Carmenza Robledo and colleagues explores the emergence of carbon trading in the forest sector. They explore the degree to which high transaction costs and complex requirements represent insurmountable barriers to equitable benefits capture, and the emerging governance issues associated with carbon credits as a new international forestry commodity. They explore the key issues that must be looked at in the public and private sectors and for civil society in order to ensure good governance of forest resources in the context of climate change, illustrating the new layer of complexity brought in by new opportunities for deriving meaningful economic returns for society. Each of these chapters reiterates the challenges of harnessing valuable forest resources for meaningful local and national development in the context of expanding global demand for forest products and services. The concluding chapter (Chapter 19) by Doris Capistrano in Part IV pulls together the various strands of conversation and evidence from the chapters in this volume and the wider conversation initiated in Durban and in earlier workshops.

\section{CONCLUSIONS}

The forest sector faces unique challenges of governance related to the often competing demands for government revenue, local livelihood values and the provision of public goods in the form of forest ecosystem services. In this regard, challenges of equity and sustainability are paramount. Age-old challenges of forest governance on the continent are likely to increase exponentially as new public and private actors seek to secure privileged access over land and resources that are increasingly limited worldwide. This book is part of a larger project to keep a finger on the forest governance and decentralization pulse; to continue to share experiences across countries; and explore emerging themes in forest governance and decentralization in major world regions. More importantly, it represents an effort to clarify what has been learned from decentralization in the past and to highlight emerging challenges to come in order to better prepare African communities, leaders and civil society for the challenges and opportunities on the road ahead. 


\section{NOTE}

1 As well as to align themselves to the rule of law in cases where governance is strong.

\section{REFERENCES}

Adams, M. and R. Palmer (2007) Independent Review of Land Issues - Eastern and Southern Africa, SARPN, Pretoria

Agrawal, A. and A. Chhatre (2006) 'Explaining success on the commons: Community forest governance in the Indian Himalaya', World Development, vol 34, no 1, pp149-166

Agrawal, A. and J. C. Ribot (1999) 'Accountability in decentralization: A framework with South Asian and African cases', Journal of Developing Areas, vol 33, summer, pp473-502

Banana, A. Y., N. D. Vogt, J. Bahati and W. Gombya-Ssembajjwe (2007) 'Decentralized governance and ecological health: Why local institutions fail to moderate deforestation in Mpigi District of Uganda', Scientific Research and Essay, vol 2, no 10, pp434-445

Bekele, M. (2003) Forest Property Rights, the Role of the State and Institutional Exigency: The Ethiopian Experience, PhD thesis, Swedish University of Agricultural Sciences, Uppsala, Sweden

Bigombé Logo, P. (2003) The Decentralized Forestry Taxation System in Cameroon: Local Management and State Logic, Environmental Governance in Africa Working Paper no 10, WRI, Washington, DC

Bigombé Logo, P. (2007) 'Les régimes de tenure forestière et leurs incidences sur la gestion des forêts et la lutte contre la pauvreté au Cameroun.' Final Draft Report for the FAO, GRAPS, Yaoundé, Cameroon

Blaser, J., C. Küchli, C. J. Pierce Colfer and D. Capistrano (2005) 'Introduction', in C. J. P. Colfer and D. Capistrano (eds) The Politics of Decentralization: Forests, Power and People, Earthscan/CIFOR, London, p9

Blomley, T. and H. Ramadhani (2006) 'Going to scale with participatory forest management: Early lessons from Tanzania', International Forestry Review, vol 8, no 1, pp93-100

Bonacich, E. (1973) 'A theory of middleman minorities', American Sociological Review, vol 38, no 5, pp583-594

Brinkerhoff, D. (2001) Taking Account of Accountability: A Conceptual Overview and Strategic Options, Draft report for the Implementing Policy Change Project, Phase 2, Center for Democracy and Governance, USAID, Washington, DC, ABT Associates, Inc

Brockington, D. (2007) 'Forests, community conservation, and local government performance: The village forest reserves of Tanzania', Society and Natural Resources, vol 20, pp835-848

Bruce, J. W. (1999) Legal Bases for the Management of Forest Resources as Common Property, Community Forestry Note 14, FAO, Rome

Capistrano, D. (2008) 'Decentralization and Forest Governance in Asia and the Pacific: Trends, Lessons and Continuing Challenges', in C. J. P. Colfer, G. R. Dahal and D. Capistrano (eds) Lessons in Forest Decentralization: Money, Justice and the Quest for Good Governance, Earthscan/CIFOR, London

Capistrano, D. and C. J. Pierce Colfer (2005) 'Decentralization: Issues, lessons and reflections', in C. J. P. Colfer and D. Capistrano (eds) The Politics of Decentralization: Forests, Power and People, Earthscan, London, pp296-313 
Casson, A. and K. Obidzinski (2002) 'From new order to regional autonomy: Shifting dynamics of illegal logging in Kalimantan, Indonesia', World Development, vol 30, no 12, pp2133-2151

Colfer, C. J. P. and D. Capistrano (2005) The Politics of Decentralization: Forests, Power and People, Earthscan, London

Colfer, C. J. P., G. Ram Dahal and D. Capistrano (eds) (2008) Lessons in Forest Decentralization: Money, Justice and the Quest for Good Governance in Asia-Pacific, Earthscan/CIFOR, London

Contreras, A. P. (2003) 'Creating space for local forest management: The case of the Philippines', in D. Edmunds and E. Wollenberg (eds) Local Forest Management, Earthscan, London

Diaw, M. C. (1998) 'Anthropological institutions and forest management: What institutional framework for community-based forest management in Cameroon?', Proceedings of the Workshop on Community-Based Forest Management in Cameroon, WWF, Yaoundé

Diaw, M. C. (2005) 'Embedded Tenure Institutions: African Attempts to Reform Local Forest Policies', in S. Kant and R. A. Berry (eds) Sustainable Institutions and Natural Resources: Institutions for Sustainable Forest Management, The Netherlands, Springer, pp43-83

Edmunds, D. and E. Wollenberg (eds) (2003) Local Forest Management, Earthscan, London

Enters, T., P. B. Durst and M. Victor (eds) (2000) Decentralization and Devolution of Forest Management in Asia and the Pacific, vol RECOFT, Report no 18 and RAP Publication 2000/1, RECOFTC and FAO/RAP, Bangkok, Thailand

Etongou, P. (2003) Decentralization Viewed from Inside: The Implementation of Community Forests in East Cameroon, Environmental Governance in Africa Working Papers no 12, WRI, Washington, DC

FAO (United Nations Food and Agriculture Organization) (2003) Forestry Outlook Study for Africa: Sub-Regional Report for West Africa, African Development Bank, European Commission and FAO, Rome

FAO (2005) State of the World's Forests 2005, FAO, Rome

Feeny, D., F. Berkes, B. J. McCay and J. M. Acheson (2004) 'The tragedy of the commons:

Twenty-two years later', Human Ecology, vol 18, no 1, pp1-19

FOSA (2003) Étude prospective du secteur forestier en Afrique, Rapport du Benin, FOSA, African

Development Bank, European Commission and FAO

Hardin, G. (1968) 'The tragedy of the commons', Science, vol 162, pp1243-1248

German, L. and A. Keeler (forthcoming) 'Hybrid institutions: Applications of common property theory beyond discrete tenure regimes', International Journal of the Commons

Goldman Sachs Group (2003) Dreaming with the BRICs: The Path to 2050, Global Economics Paper no 99, New York

Kaimowitz, D., C. Vallejos, P. B. Pacheco and R. Lopez (1998) 'Municipal governments and forest management in lowland Bolivia', Journal of Environment and Development, vol 7, no 1, pp45-59

Kaimowitz, D., A. Faune and R. Mendoza (2003) Your Biosphere is My Backyard: The Story of Bosawas in Nicaragua, CIFOR Working Papers no 23, CIFOR, Bogor, Indonesia

Kamugisha-Ruhombe, J. (2007) The Status of Forests in Eastern Africa: A Contribution to the Listening, Learning and Sharing Launch of RRI and IUCN, IUCN, Nairobi

Kamugisha-Ruhombe, J. (2007) The Status of Forests in Eastern Africa: A Contribution to the Listening, Learning and Sharing Launch of RRI, Kampala, Rights and Resources Initiative and IUCN, Washington, DC

Kandola, F. (2001) Land Reform in the Regional Context: Malawi Experiences in SARP Network, Regional Conference for Land Reform and Poverty Alleviation in Southern Africa, Pretoria 
Katila, P. (2008) Devolution of Forest-related Rights: Comparative Analyses of Six Developing Countries, Tropical Forestry Reports no 33, Viikki Tropical Resources Institute, University of Helsinki, Helsinki

Küchli, C. (2008) 'From decentralization to governance: Recurring issues', in C. J. P. Colfer, G. Ram Dahal and D. Capistrano (eds) Lessons in Forest Decentralization: Money, Justice and the Quest for Good Governance in Asia-Pacific, Earthscan/CIFOR, London

Küchli, C. and J. Blaser (2005) 'Forests and decentralization in Switzerland: A sampling', in C. J. P. Colfer and D. Capistrano (eds) The Politics of Decentralization: Forests, Power and People, Earthscan/CIFOR, London, pp1-9

Larson, A. M. (2003) 'Decentralisation and forest management in Latin America: Towards a working model', Public Administration and Development, vol 23, no 3, pp211-226

Larson, A. M. (2005) 'Democratic decentralization in the forestry sector: Lessons learned from Africa, Asia and Latin America', in C. J. P. Colfer and D. Capistrano (eds) The Politics of Decentralization: Forests, Power and People, Earthscan, London, pp32-62

Larson, A. M. and J. C. Ribot (2005) 'Democratic decentralization through a natural resource lens: An Introduction', in: J. C. Ribot and A. M. Larson (eds) Democratic Decentralization through a Natural Resource Lens: Cases from Africa, Asia and Latin America, Routledge, London, pp1-25

Lund, J. F. (2007) Is Small Beautiful? Village Level Taxation of Natural Resources in Tanzania, Public Administration and Development, www.interscience, wiley.com

Mackenzie, C. (2006) Forest Governance in Zambézia, Mozambique: Chinese Take-Away!, Forum das ONGs da Zambezia (FONGZA), Quelimane

Mandondo, A. (2000) Situating Zimbabwe's Natural Resource Governance Systems in History, CIFOR Occasional Papers no 32, CIFOR, Bogor, Indonesia

Manor, J. (1999) The Political Economy of Democratic Decentralization, World Bank, Washington, DC

Maxwell, D. and K. Wiebe (1998) Land Tenure and Food Security: A Review of Concepts, Evidence and Methods, University of Wisconsin Research Paper no 129, Land Tenure Center, Madison, WI

Mendelsohn, J. and S. el Obeid (2005) Forests and Woodlands of Namibia, Government of Finland and Government of Namibia, Sing Cheong Printing, Hong Kong

Milledge, S., I. Gelvas and A. Ahrends (2007) Forestry, Governance and National Development: Lessons Learned from a Logging Boom in Southern Tanzania, TRAFFIC, Tanzania Ministry of Forestry and Tourism, and Tanzania Development Partners Group, Dar es Salaam, Tanzania

Minula, M. A. (2007) Política Nacional de Forestas, Fauna Selvagem and Áreas de Proteçção, Documento de Discussão, Maputo

Nhantumbo, I. (2007) Forest Tenure in Southern Africa: A Contribution to the Listening, Learning and Sharing Lunch of RRI, Nairobi, Rights and Resources Initiative and the World Conservation Union (IUCN), Washington, DC

Nsibambi, A. (ed) (1998) Decentralisation and Civil Society in Uganda: The Quest for Good Governance, Fountain Publishers, Kampala

Ostrom, E. (1990) Governing the Commons: The Evolution of Institutions for Collective Action, Cambridge University Press, Cambridge

Ostrom, E. (1999) Self-Governance and Forest Resources, CIFOR Occasional Paper no 20, CIFOR, Bogor, Indonesia

Ouedraogo, H. M. (2003) 'Decentralization and local governance: Experiences from Francophone West Africa', Public Administration and Development, vol 23, pp97-103 
Oyono, P. R. (2007) Understanding Forest Tenure in Central Africa: Transitions or Hidden Status Quo in the Dawn of the New Century? A Contribution to the Listening, Learning and Sharing Lunch of RRI, Yaoundé, Rights and Resources Initiative and the World Conservation Union (IUCN), Washington, DC

Oyono, P. R. (2004) 'One step forward, two steps back? Paradoxes of natural resources management decentralisation in Cameroon', Journal of Modern African Studies, vol 42, no 1, pp91-111

Oyono, P. R. (2005) 'The foundations of the conflit de langage over land and forests in southern Cameroon', African Study Monographs, vol 26, no 3, pp115-144

Oyono, P. R., J. C. Ribot and A. M. Larson (2006) Green and Black Gold in Rural Cameroon: Natural Resources for Local Governance, Justice and Sustainability, Environmental Governance in Africa Working Papers no 22, WRI and CIFOR, Washington, DC and Bogor

Place, F. and B. Swallow (2002) 'Assessing the relationship between property rights and technology adoption in smallholder agriculture: Issues and empirical methods', in R. Meinzen-Dick, A. Knox, F. Place and B. Swallow (eds) Innovation in Natural Resource Management: The Role of Property Rights and Collective Action in Developing Countries, Johns Hopkins University Press/IFPRI, Baltimore and London, pp45-72

Platteau, J.-P. (1996) 'The Evolutionary Theory of Land Rights as applied to Sub-Saharan Africa: A Critical Assessment', Development and Change, vol 27, pp29-96

Ribot, J. C. (2002a) African Decentralization: Local Actors, Power and Accountability, Democracy, Governance and Human Rights Paper, World Resources Institute, Washington, DC

Ribot, J. C. (2002b) Democratic Decentralization of Natural Resources: Institutionalizing Popular Participation, WRI, Washington, DC

Ribot, J. C. (2003) African Decentralization: Actors, Powers and Accountability, Democracy, Governance and Human Rights Papers no 8, UNRISD, Geneva

Ribot, J. C. and A. Larson (2005) Democratic Decentralization through a Natural Resource Lens, Routledge, London and New York

Ribot, J. C., A. Agrawal and A. M. Larson (2006) 'Recentralizing while decentralizing: How national governments re-appropriate forest resources', World Development, vol 34, no 11, pp1864-1886

Sarin, M., N. M. Singh, N. Sundar and R. K. Bhogal (2003) 'Devolution as a threat to democratic decision-making in forestry? Findings from three states in India', in D. Edmunds and E. Wollenberg (eds) Local Forest Management, Earthscan, London

Savadogo, M. (2007) Regional Situation Analysis for West Africa French Speaking Countries: A Contribution to the Listening, Learning and Sharing Launch of RRI, Ouagadougou, Rights and Resources Initiative and the World Conservation Union (IUCN), Washington, DC

Sayer, J., J. McNeely, S. Maginnis, I. Boedhihartono, G. Shepherd and B. Fisher (2008) Local Rights and Tenure for Forests: Opportunity or Threat for Conservation?, Rights and Resources Initiative, Washington, DC

Schlager, E. and E. Ostrom (1992) 'Property-rights regimes and natural resources: A conceptual analysis', Land Economics, vol 68, no 3, pp249-262

Selebalo, Q. C. (2003) 'Land reform and poverty alleviation: Lesotho's experience during the last two decades'. Paper presented at the Regional Conference for Land Reform and Poverty Alleviation in Southern Africa. Pretoria, Southern Africa Regional Poverty Network

Shackleton, S. and B. M. Campbell, with M. Cocks, G. Kajembe, E. Kapungwe, D. Kayambazinthu, B. Jones, S. Matela, G. Monela, A. Mosimane, N. Nemarundwe, N. Ntale, 
N. Rozemeijer, C. Steenkamp, B. Sithole, J. Urh, and C. van der Jagt (2001) Devolution in Natural Resource Management: Institutional Arrangements and Power Shifts (a Synthesis of Case Studies from Southern Africa), CIFOR and CSIR, Bogor, Indonesia

Shackleton, S., B. Campbell, E. Wollenberg and D. Edmunds (2002) Devolution and CommunityBased Natural Resource Management: Creating Space for Local People to Participate and Benefit?, ODI Natural Resource Perspectives no 76, London

Smith, B. C. (1985) Decentralization: The Territorial Dimension of the State, George Allen, London Sunderlin, W. D., J. Hatcher and M. Liddle (2008) From Exclusion to Ownership? Challenges and Opportunities in Advancing Forest Tenure Reform, Rights and Resources Initiative, Washington, DC

Tacconi, L. (2007) 'Decentralization, forests and livelihoods: Theory and narrative', Global Environmental Change, vol 17, pp338-348

Toyne, P., C. O'Brien and R. Nelson (2002) The Timber Imprint of the G8 and China: Making the Case for Green Procurement by Government, WWF, Gland, Switzerland

UNSC (2002) Final Report of the Panel of Experts on the Illegal Exploitation of Natural Resources and Other Forms of Wealth of the Democratic Republic of Congo, UNSC, New York

White, A. and L. Martin (2002) Who Owns the World's Forests? Forest Tenure and Public Forests in Transition, Forest Trends, Washington, DC

White, A., X. Sun, K. Canby, J. Xu, C. Barr, E. Katsigris, G. Bull, C. Cossalter and S. Nilsson (2006) China and the Global Market for Forest Products: Transforming Trade to Benefit Forests and Livelihoods, Forest Trends, Washington, DC

White, A., A. Khare and A. Molnar (2007) 'Transitions in forest tenure and governance: Drivers, projected patterns and implications', Paper prepared as a background document for the Blue Skies Meeting on Illegal Logging and Associated Trade: Exploring Options, 24 January 2007

Wily, L. A. (2003) Governance and Land Relations: A Review of Decentralisation of Land Administration and Management in Africa, IIED, London

Wily, L. A. and P. A. Dewees (2001) From Users to Custodians: Changing Relations between People and the State in Forest Management in Tanzania, World Bank Policy Research Paper no 2569, World Bank, Washington, DC

Wily, L. A. and S. Mbaya (2001) 'Land, People and Forests in eastern and southern Africa at the beginning of the 21st century: The impact of relations on the role of communities in forest future', Nairobi, NRI and IUCN

Wollenberg, E. and H. Kartodihardjo (2002) 'Devolution and Indonesia's new forestry law', in C. J. P. Colfer and I. A. P. Resosudarmo (eds) Which Way Forward? People, Forests and Policymaking in Indonesia, Resources for the Future, Washington, DC 



\section{PART I}

Governing Africa's Forests in a Globalized

World: Framing the Dialogue 

Chapter 2

\title{
Forestry and Democratic Decentralization in Sub-Saharan Africa: A Rough Review
}

\author{
Jesse C. Ribot
}

\section{INTRODUCTION}

Democracy is the accountability of leaders to their people. Different institutions in the local arena are accountable to local people in different ways. Which institutions, authorities or categories of person represent - are accountable and responsive to 'local' people in forestry? Who is receiving authority or powers to manage forests under a given reform or project? The choice of local institutional interlocutors by intervening agencies - central governments, donors, large non-governmental organizations (NGOs) or international development agents - is important. Working through different kinds of local institutions - private, public, representative, administrative, civic - might have different kinds of equity, efficiency and democracy outcomes (Woolcock and Prichett, 2005; Ribot, 2006; Ribot et al, 2008).

The choice of local actors by intervening agents reflects something about what these agents are trying to accomplish - e.g. democratic processes, thickening of civil society or privatization. Some aim to strengthen public institutions (line ministries or elected local governments), others root for so-called civil society (NGOs, communitybased organizations (CBOs) and some indigenous authorities), and yet others champion private institutions (corporations or individuals, and some indigenous authorities). They may be motivated by an anti-government neo-liberal stance with a polar view of bad corrupt government and good civil society/private sector. Their choices may reflect a general uninformed conformity to the trends of development concerning good governance, bad government, let's go private, let's downsize the state and build up the third sector, let's try local government via decentralization. The choices by intervening agencies may also just reflect expedience in implementing forest management interventions - practitioners or development agents may choose the quickest or cheapest interlocutor for establishing a management plan, a 
participatory process, a forest plantation, a protected area or some other measurable success to bring home to their parent agency. Together the mix of drivers and the institutional choices being made bring us to the confused amalgam of the present plurality of local institutions.

Decentralization (see Box 2.1) is a particular type of institutional choice. It is a set of legal reforms that result in the transfer of powers from central government to lower levels of government - that is, to local administrative offices or to local elected government. Community-based natural resource management (CBNRM) is a form of intervention that usually engages communities in projects through participatory processes, committees, user groups, chiefs, NGOs, private corporations or private individuals. These are not formally decentralization since most of these local bodies are not within government or are usually not receiving rights and powers in CBNRM processes. CBNRM is a big topic in itself - it is a means of intervention that, despite all of its shortcomings, remains very popular (Blaikie, 2006). This chapter is dedicated to examining one form of intervention that most African governments claim to be undertaking and that forestry services claim to be involved with - democratic decentralization, or transfers of powers to elected local governments. While a transfer to a local line ministry is a form of decentralization (called de-concentration), few CBNRM advocates would consider it CBNRM. Yet, democratic decentralization, where local representative authorities receive powers in the name of local citizens, can be counted among the many manifestations of CBNRM. This is the form of CBNRM at the focus of this chapter.

The distinction between CBNRM and democratic decentralization of natural resource management (NRM) is that the latter is specifically about including whole populations - all citizens - in NRM decision-making based on representative authority (see Alden Wily, undated; Ribot, 2002). Like the World Bank's communitydriven development (CDD) interventions, however, CBNRM practitioners define community for each intervention - the user group, the 'stakeholders', the people near the forest, the fishers. Furthermore, they define the mode of representation of that 'community' as their project is implemented - through appointed committees, elected committees, stakeholder fora, participatory processes, 'customary' chiefs, project personnel, etc. Often, CBNRM bodies represent only a subsection of a population. Democratic decentralization, however, involves transfers to ostensibly representative elected local government under whose authority 'community' is defined as 'the citizens' - those who live in the jurisdiction. This breadth of representation matters, as theory tells us, because broad-based citizen inclusion in decision-making can increase efficiency and equity as well as natural resource management outcomes (Agrawal and Ribot, 1999). Being representative of a whole population ostensibly makes a decision-making process more likely to achieve more equitable and effective implementation. Local government as a form of institution is also both scalable to cover whole national territories and is sustainable in so far as it is a permanently legislated form of local governance. These latter advantages also make local government a solid infrastructure for sustainable and widespread participation, distinct from CBNRM because, as part of government, it does not collapse when project funding runs out. 


\section{Box 2.1 Definitions}

Decentralization is any act by which a central government formally cedes powers to actors and institutions at lower levels in a political-administrative and territorial hierarchy. Decentralization is typically divided into democratic decentralization and deconcentration.

Democratic decentralization (often also called political decentralization or devolution) occurs when powers and resources are transferred to authorities typically, elected local governments - that are representative of, and accountable to, local populations. Democratic decentralization aims to increase public participation in local decision-making. Democratic decentralization is an institutionalized form of the participatory approach. Of the two primary forms of decentralization, democratic decentralization is considered the stronger and the one from which theory indicates that the greatest benefits can be derived.

Deconcentration (also known as administrative decentralization) concerns transfers of power to local branches of the central state, such as prefectures, administrations or local technical line ministries. These upwardly accountable local bodies are appointed administrative extensions of the central state. While some downward accountability may be built into their functions, their primary responsibility is to central government. Deconcentration is considered the weaker form of decentralization because downward accountability is not as well established as it is in the democratic or political form of decentralization.

Institutional choice is the identification by intervening agencies of the locus of decentralized authority, the local partner with whom intervening agencies work, and therefore to whom they transfer powers or provide support.

Recognition is the acknowledgement of another person, culture or institution. The choice of local authorities or organizations by the government or by international agencies is a form of acknowledgement or recognition. Local institutions are recognized through the transfer of powers, partnering in projects, engagement by contracts or via participation in dialogue and decision-making. As an analytic concept, recognition helps us to focus on the effects of the transfer of powers to, and backing of, select local institutions.

Democratic representation occurs when a leader is responsive to the needs and aspirations of her or his population. When the population can sanction the leader so as to hold the leader accountable, then the representation can be considered democratic.

Citizenship is the ability to be politically engaged and shape the fate of the polity in which one is involved. Citizenship in a liberal democracy is often associated with entitlement to certain civil, social and political rights, irrespective of one's identity and interests.

Public domain consists of the resources and decisions under public control that are the basis for public decision-making. The public domain is a domain of powers that citizens may be able to influence. It defines the space of representative democracy.

Subsidiarity is the idea that the best level for policy and procedural decisions is the most local possible level at which decisions are not likely to produce negative effects for higher scales of economic, social or political-administrative organization. 
Articulation is the functional joining of two parts so that they can work together in a mutually supportive manner. An example of political articulation is when local and national governments become interdependent so that they must work together due to shared interests - as when local government can garner votes for central actors and central actors can provide resources for local government.

Source: Føllesdal (1998); Rocher and Rouillard (1998); Isin and Turner (2002); Sparke (2004); Ribot (2004, 2007); Chhatre (2008)

Democratic decentralization is predicated on the transfer of forestry management and use decisions to broadly representative local bodies. Forest sector democratic decentralizations are predicated on the existence of broadly representative local government; hence, they must take place in the context of larger efforts to build local government (Alden Wily, undated). One of the first obstacles to democratic decentralization in forestry, as in any other sector, is the failure of central governments to establish local governments that are empowered and accountable to the local population. A second is the failure of line ministries to work with local governments even when they are established and accountable. But decentralized as well as community-based forestry have faced many other obstacles and disappointments. Case studies and comparative research indicate that democratic decentralization and CBNRM do little for conservation and that conservation may not be good for local livelihoods (Blaikie, 2006; Tacconi et al, 2006).

During the last decade a body of research on forestry and decentralization - the forms that it is taking and its effects - has emerged. The first line of research concerns the conditions under which forestry decentralization takes place. Why has it taken place? Why does it usually not take place: what are the reasons and means for resistance and recentralization? A second line of research has addressed the conditions under which forestry decentralization affects the quality of forest management. When does it lead to degradation or deforestation? When does it lead to conservation? A third area of research concerns the conditions under which forestry decentralization results in improved livelihoods. When does decentralization increase local income or improve access to subsistence goods? When does deforestation or conservation (under decentralized management) lead to improved livelihoods? Another area that is not addressed directly in the literature, and which is taken up in this chapter, is the relation between decentralization in forestry and the formation of local democracy. When do local forestry interventions support local democracy?

Despite obstacles and limitations, there are at least three sets of values that decentralization theorists and practitioners believe that democratic decentralization can promote: better use and conservation of environmental services; improved rural livelihoods; and local enfranchisement. These values are shared with CBNRM and will be explored in this chapter. Some theorists and many practitioners of CBNRM believe that the three are interlinked; but as of yet, these inter-linkages remain 
hypothetical - or at least highly contingent on yet-to-be-understood conditions. Nevertheless, all three values are worth pursuing - and there will be trade-offs and positive reinforcements among them. This chapter explores what we know about these relations and then tries to disaggregate these three objectives in order to explore some minimum requirements for achieving each separately and/or together. The chapter explores some of the problems and outcomes associated with reforms that have been called 'decentralization' in the forest sector, and outlines some possible ways forward.

\section{FORESTRY DECENTRALIZATION IN HISTORICAL CONTEXT}

The history of local government across Africa is one of territorial management, control and integration (Buell, 1928; Mamdani, 1996). Introduction of local government has long roots in the management of subjects and the extraction of wealth under colonial rule. Colonial powers ventured to transfer the administrative management of the rural world to 'customary' authorities under what the British called 'indirect rule' and French called 'association'. The Portuguese followed similar policies. Colonizers used local customary authorities as administrators for the central state in what was a locally rooted de-concentration. At independence during the middle of the last century, Africa's fledgling new nations chose to recentralize control in order to consolidate power and only later re-launched decentralization in the 1970s. While there were rumblings about local democracy during the colonial period, it was not until the $1980 \mathrm{~s}$ that decentralization discourse adopted the widespread enfranchising language of democracy. Rather than managing subjects, decentralization took a turn towards the production of democracy and the consequent transformation of subjects into citizens.

This shift in discourse has been followed in many nations through new laws introducing or strengthening elected local authorities. In parallel to these political-administrative reforms, forestry services and forestry practitioners have also shifted both their language and practice first towards greater participation and then towards 'decentralization'. Like the general administration of colonial Africa, forestry services also had a long history of subjugating rural Africans. Foresters were the vanguard of rural colonization between 1910 and 1916, ${ }^{1}$ being the first to accompany the colonial military into Africa's interior. Foresters have always followed the discourse and the administrative conventions of their times. They also followed the practices of their times - which was usually to continue to control and manage the rural world for extractive purposes ${ }^{2}$ even when the discourse turned to participation and later enfranchisement at the end of the 20th century. ${ }^{3}$

Decentralization reforms across Africa reached the new century with a mix of hope and frustration. Like the promise of democratization stirred by the fall of the Berlin Wall, at the dawn of the new century local empowerment and enfranchisement are incipient at best. Many reforms had been put in place, but little substantive change 
was visible on the ground (see Kulipossa, 2004; Ribot, 2004; Ribot and Oyono, 2005). In addition, new monkey wrenches began jumping into the gears of change. Customary chiefs began to reemerge and challenge democratic decentralization with great force (van Rouveroy van Nieuwaal et al, 1999; Geschiere and Boone, 2003; Ntsebeza, 2002, 2005). While donors pushed ever harder for decentralization, central governments began to master the art of recentralizing while decentralizing - making everyone happy in the political sphere of state and donors while delivering few new benefits to local governments or local people (Ribot et al, 2006).

Dubois (1997) identifies three phases in forestry management in Africa: a technocratic colonial-style era; a 'participatory' period beginning in the 1980s; and a negotiation-based 'stakeholder' era introduced during the late 1990s. The latter two eras overlap with the onset of decentralization reforms across the continent. In recent decades, Dubois observed a move from an ability to participate in others' projects to an ability to negotiate with some significant leverage. While the negotiated interventions may be neither democratic nor decentralized, they are a move towards greater community control. By 2000, Alden Wily (undated) describes forestry programmes in Africa as evolving from a set of revenue- or benefit-sharing efforts towards real power-sharing. This is a shift where villages go from having access to forests for use or are allowed to share some income to a situation where local communities become resource managers themselves. This shift changes the relation between communities and forest services. In the latter case the forest service gives up some of its authority and transfers it to the community.

Alden Wily (undated) describes an evolution within the transfer of management from the forest service to communities, where at first transfers are to user groups interested parties in forestry - and later to multipurpose elected governments. She cites the case of Tanzania as the vanguard in this truly democratic and decentralized form of forest management. In this context 'community-level managers may operate and also be held accountable to their constituencies' (Alden Wily, undated, p17). In Tanzania, this is made possible by the existence of democratic local government structures. She concludes by observing that 'Where devolved governance is poorly developed, empowerment of local forest management in new legislation is demonstrably constrained' (Alden Wily, undated, p18).

As Alden Wily (undated) observes, for there to be decentralized forestry, there needs to be decentralized government institutions. Forestry law and practice reflects a microcosm of the broader political-administrative reforms in which it is located although the sector often resists those reforms, it at least takes on the discourse. While line ministries, such as environment, health, education or agriculture, can deconcentrate on their own, they cannot engage in democratic decentralization if the broader democratic decentralization has not been undertaken by the nation. Democratic decentralization of forestry requires the prior establishment of elected local authorities. We arrive at the end of the first decade of the new century with a clear discourse on democratic decentralization and embracing this discourse in forestry. But we find the new century as fraught as the old with the failure to translate progressive discourse into law and law into practice. In the next section we examine some of the recurring obstacles in the path of decentralization as practice. 


\section{OBSTACLES TO DECENTRALIZATION IMPLEMENTATION}

New local elected governments popping up across Africa face many constraints. Organic and electoral laws make elected officials upwardly accountable to parties and budget arrangements make them accountable to line ministries and the legislature. They are given little discretion and can hardly be said to be representative institutions. Further, most development agencies and forestry line ministries choose, even where there are elected local authorities, to work through participatory, stakeholder or CBNRM approaches.

Forestry line ministries in many decentralization efforts have created or strengthened their local offices; but forestry, by and large, has not gone through a democratic decentralization. Lund and Wardell (2006, p1896) observe a move towards user groups rather than representative authorities in Ghana. Mozambique's 1999 Forest and Wildlife Law creates 'fragile' elected committees at the local level despite there being elected local governments (Salomão and Matose, 2007). In most cases, where local governments were involved, their main role was to sign off on management plans laid down by forest services or to carry out prescribed forest management activities - a kind of new era corvée. Only in a few cases were there significant decision-making powers or revenues devolved to elected local authorities as in Uganda, Senegal and Tanzania (Ribot, 2003; Oyono, 2004a; Brockington, 2007; Alden Wily, undated).

Dozens of studies conducted on forestry and other natural resource decentralization reforms in Africa by the World Resources Institute (WRI) from 2000 to 2007 show progress in implementation and outcomes as well as retrenching through recentralization of powers over environmental services (further developed in the section on 'Factors influencing decentralization, forestry decentralization and its outcomes'). ${ }^{4}$ The most striking finding is that, even in the cases declared great successes, democratic decentralization of forest and other natural resource management either transfer too little power to be meaningful or transfer those powers to non-representative local authorities (Ribot, 2004; Ribot et al, 2007). Neither powers without representation nor representation without powers constitute decentralization. We do not expect improved equity, efficiency or democracy from either of these configurations. In short, democratic decentralization of natural resources of any sort is rare, making it very difficult to study. Nevertheless, there is progress in forestry decentralization despite the pulling back of each advance.

For example, under Mali's, Senegal's, Tanzania's and Uganda's progressive decentralizations, democratically elected local governments have been established as recipients of decentralized powers (Ribot, 2008; Alden Wily, undated). In Mali, however, the Forestry Department refuses to transfer powers to elected local government despite requirements of the new forestry laws. ${ }^{5}$ Similarly, in Uganda, powers transferred to local institutions are limited by required restrictive management plans and by limiting which forests are considered 'local' (Namara, 2001; Bazaara, 2006; Muhereza, 2006). Uganda's 2001 Forestry law does not specify guidelines for selecting powers that will be 
transferred, nor the levels of local government that will receive them (ROU, 2001). ${ }^{6}$ In Senegal, the 1998 Forestry Code gives rural councils powers to decide if and when their forests will be cut and the right to make and execute management plans; but the Forest Service has not allowed them to exercise any of the rights that they were given in law (Larson and Ribot, 2007). In these cases the laws give local authorities the right to manage natural resources; but they are subject to restrictive requirements imposed by central forestry agencies. Further, in Mali and Uganda many forests previously in the public domain are being privatized in the name of decentralization (Ribot, 1999; Muhereza, 2001). Privatization is taking public resources away from democratic institutions and transferring them to customary (which are self-regulating, self-serving or often non-sanctionable) and other private bodies, a move that neither supports nor follows the logic of democratic decentralization.

Management plans seem to be the most common means for forest departments to recentralize any autonomy that might be implied by the transfer of rights to manage. The participatory and current 'decentralized' forestry periods have both been accompanied by a proliferation of micro-management plans. Forest services, with the help of donors, required village, user or project committees or their elected rural authorities to elaborate complex management plans before they would have the right to break even one small branch. These plans have tended to be overly complex and highly expensive to elaborate. The trend in the past four or five years has been to speak of 'simplified' management plans. But the practice has changed little. Management plans are one of the main factors enabling continued line-ministry control, and preventing rural populations from using the resources around them unless they agree to labours of forest management (Ribot, 1995, 2004; Etoungou, 2001; Graziani and Burnham, 2002; Latif, 2002, p67; Oyono, 2004a, 2004b, 2004c; Wardell and Lund, 2006, p1894; Salomão and Matose, 2007, p15). Like participatory approaches in forestry, many management planning requirements were introduced much earlier in the colonial period and just reworked with each new forestry era. Indeed, local participation in the elaboration of management plans in some places has been less frequent during recent years than during colonial times (Wardell and Lund, 2006, pp1894-1896). ${ }^{7}$ Licensing and permitting are also frequently used to exclude local people from commercially valuable resources (Salomão and Matose, 2007, pp14-15; Ribot, 2008).

Leaving important decisions over the allocation of valuable resources to ministerial decrees or administrative order is one of the many techniques for recentralizing environmental legislation. This means is used in Mali, Cameroon, Senegal, Guinea, Burkina Faso, South Africa, Zimbabwe and elsewhere. In Mali, for example, decentralization is called for by the constitution, while decentralization of powers over natural resources is called for in environmental legislation, such as the Forestry Code. But, within the 1996 Forestry Code, the powers to be devolved are left to be specified by decree of the minister responsible for forests. The procedures to resolve disputes over forestry matters will be specified by order of the state-appointed governor of each region. Hence, decentralization in the environmental sector is ultimately reserved as a discretionary matter for the ministry responsible for forests and its administrative staff. In this manner, what appears to be a constitutional guarantee is transformed into executive branch discretion (Ribot, 2004). Similarly, in Senegal, decentralization laws transfer forest management powers to elected rural 
councils and the forestry laws then reiterate this transfer; but, in practice, the Forest Service does not allow elected councils to make decisions (Ribot, 2008). The organization of forestry production is left to ministerial decrees ( $R d S, 1998)$.

There are many other means that foresters use to recapture control of 'decentralized' forestry (see Ribot and Oyono, 2005; Ribot et al, 2006). Rent-seeking by foresters is common. The systems of control and management lend themselves to negotiation of access (Oyono, 2005; Blundo, 2006; Wardell and Lund, 2006, p1898). Selective implementation and non-implementation are also used as a means of central control and of rent-seeking for officials and front-line agents (Wardell and Lund, 2006; Larson and Ribot, 2007). Conditional transfers of funds or powers by higherlevel agencies make recipients upwardly accountable - since they can lose the transfers if they do not do as they are told (Conyers, 2003).

Obfuscation is another problem blocking democratic decentralization in forestry. One of the confusing factors in current forestry discourse is that everything is being called 'decentralization'. So, without careful reading it is difficult to distinguish participatory approaches from co-management from democratic decentralization. The confusion adds to an institutional amalgam, an analytic nightmare in which no policy or project called 'decentralized' can be taken at face value, but must be analysed according to its substantive elements - its transfer of discretionary powers and empowerment of local actors downwardly accountable to the population (see Agrawal and Ribot, 1999).

In recent years, privatization seems to be gaining on decentralization. The discourse on decentralized forestry and natural resource management has been moving away from enfranchisement (giving citizens representation and control) and towards incorporation (engagement of 'forest-dependent' people with markets). Most forestry projects today emphasize helping local people to produce for the market. The emphasis is on building 'community-based enterprises'. 'Decentralized' forest management is less about producing citizenship and enfranchising people. Such attempts to get Africans to produce for the market are also not at all new (Mamdani, 1996). Colonial foresters were preoccupied with getting Africans to produce for the market (Geschiere, 1993, p154; Ribot, 1999) - to supply the goods, not to reap the profits. Today, villagers are being harnessed to markets as suppliers of primary or specialty forest products - usually remunerated with subsistence incomes.

In most instances where CBNRM or decentralized forestry programmes allow rural people to produce for the market, economic activity is restricted to non-timber forest products (NTFPs) or some stumpage fees on timber (e.g. Delnooz, 1999; Oyono, 2004b; Salomão and Matose, 2007). I am not aware of any instances where timber concessions - that are not already cut over - are transferred to local government. This is of note since timber concessions are widespread and there are almost always people living in the areas being cut. But forestry services and projects seem unlikely to ever allow local people to become major operators or shareholders in timber concessions or traders further upstream. Usually, they have to make do with marketing marginal (e.g. non-lucrative) NTFPs. When will rural populations be able to engage in production, transformation, marketing and export, or will they always be limited to primary production? Will development agencies give them the loans they need to buy equipment and rent trucks to sell in the cities, or will they be stuck selling raw materials to the next merchant who comes along? What will this new market era 
look like? What will the role of environmentalists and other development professionals be in enabling (or disabling) local people to enter and profit from the lucrative trade in timber and wildlife?

The sections below examine some of the data available on the relation between decentralization and environment, livelihoods and democracy outcomes.

\section{DECENTRALIZATION AND OUTCOMES}

Even under constrained circumstances of incomplete decentralization, successful outcomes have been observed in forestry decentralizations (see Ribot, 2004). In Uganda, Muhereza (2006) observed in Rakai District that the Forest Department gave the district council the right to auction off impounded illegal timber and keep 40 per cent of the revenues. This increase in income reflected the increased power of decentralized bodies. In Cameroon, revenues have increased for rural communities in community forestry zones (Oyono and Efoua, 2006; Oyono and Nzuzi, 2006). Increased revenues can result in positive outcomes when invested in local well-being (Ribot, 2003, 2004; Oyono, 2004a; Brockington, 2007; Alden Wily, undated). The links, however, between forestry decentralization, ecological sustainability, livelihoods and local democratization are more complex. While theories give us some indications of why we should expect some institutional arrangements to lead to positive outcomes, the ensemble of contradictory assumptions and experiences indicate that while theory is needed to guide interventions, so is iterative context-based observation. This section outlines some of the findings of recent research on:

- measured effects of CBNRM, which indicate some effects that local or decentralized management may have;

- outcomes of decentralization discourse and laws - that is, whether decentralization is being established in practice;

- links between decentralization, where established, and improved forest management; and

- links between decentralization and livelihood outcomes.

This section is entitled decentralization and outcomes since most case studies fail to establish a causal link between the two.

\section{Community-based natural resource management (CBNRM) insights for decentralization}

CBNRM is much broader than decentralization. It can include decentralization as one of the forms that it takes. But, as a form of local resource management, CBNRM can provide decentralization advocates and theorists with insights about important variables for successfully working locally. In an analysis of 69 case studies of forestry CBNRM (17 per cent of which are from Africa), Pagdee et al (2006, p40) found that 
40 cases were classified as successes and 29 as failures. As measures for success the cases used efficiency (90 per cent), ecological sustainability ( 87 per cent) and equity (65 per cent). The study finds that secure forest tenure followed by clear boundaries were the most frequently cited variables explaining success. The other high-ranking variables are effective institutional arrangements and community interests or incentives (Pagdee et al, 2006, p49). They found that tenure security was closely associated with the transfer of authority (which they define as reallocation budgets) to local communities (Pagdee et al, 2006, pp42, 48). They conclude that central governments' transfer of responsibilities is insufficient to generate success if they remain reluctant to transfer 'management authority' to local institutions (Pagdee et al, 2006, p48). They find that 'Clear ownership is positively associated with both local responsibility and authority. However, tenure security shows an association only with local authority. If decentralization involves only local responsibility, user tenure can remain insecure' (Pagdee et al, 2006, p51).

In short, the CBNRM experience indicates that decentralizing will be more effective for NRM where substantive management authority is transferred, tenure is secure due to the establishment of significant local authority, and incentives to manage forests sustainably are in place. The link that they show between authority and tenure security is important. It tells us what we already know - that without enforcement (via some authority), tenure is not an effective right and is therefore not secure. The remainder of this section examines research on decentralization writ large and decentralization in the forest sector concerning the link between decentralization and outcomes. First we need to understand the degree to which decentralization is being implemented and then what, when implemented, its forest management and livelihood outcomes are.

\section{Decentralization: Is it being established?}

Andersson and Gibson (2004, p3) argue that most studies:

- fail to assess the specific powers transferred to local authorities that would be critical for determining outcomes;

- ignore other policies affecting the local arena that may swamp the conservation effects of decentralization; and

- do not establish the causal links between institutional arrangements and forest outcomes.

Ribot (2003, 2004) observes that most forestry decentralization reforms that have been studied do not result in the conditions that theorists would call 'decentralization' hence, there is little reason to believe that they would result in the positive outcomes that theory predicts. The fact that decentralizations are not really being implemented indicates that it would be difficult to establish any causal links between decentralization and outcomes. ${ }^{8}$ Similar observations leads Tacconi et al (2006, p15) to ask whether local democratic governance is possible. Non-implementation of CBNRM and forestry decentralization is widespread (Nemarundwe, 2004, p285). 


\section{Decentralization: Does it lead to improved forest management?}

Existing research indicates that decentralized forest management, where it has ostensibly taken place, is not clearly better than central forest management for improving the quality or sustainability of forest management. Indeed, Andersson and Gibson (2004, p20) find no relation between local governance in any form and total deforestation. They show that 'decentralized forest governance is not inherently superior to centralized governance systems'. But it can work. They argue that outcomes are determined by many factors and "performance of any system depends on how human institutions at multiple levels interact with a myriad of exogenous factors' (Andersson and Gibson, 2004, p20). Tacconi et al (2006, p2) agree that 'it is impossible to state a priori whether decentralization will lead to sustainable forest management... In fact, under certain conditions, decentralization might contribute to deforestation, or at least might not reduce it.' They attribute the assumption of improvement to a literature that 'pays little attention to the economic and financial benefits that may drive public and private sector decisions' ${ }^{9}$

It is often assumed that when people profit from forests, they will conserve them. French West African forester Aubréville (1939, pp487-488) wrote: 'The day ... that all African forest formations will have an immediately realizable economic value, I am convinced that all of the difficulties that we encounter in ensuring their protection will straighten out. This is why I believe that the future and even the existence of African forests are inseparable from the possibilities for their exploitation.' He goes on: 'Also am I - a bit paradoxically in the eyes of some - obliged to stand up against the opinion of all who to safeguard the forest do not want to use its wood (here at least, where it still exists, is quite vast).' While this is an old assumption and is often repeated, Tacconi et al (2006) argue that it is difficult to support the assumption that engaging local people in forest commerce is of benefit on the grounds that engagement in profit from forests will result in better conservation and less deforestation. ${ }^{10}$

\section{Decentralization: Does it improve local livelihoods?}

The direct consequences of decentralized management of forests on local livelihoods are evident in some studies. Where local people gain access to forest products, to tax revenues or to commercial forestry opportunities, as in Uganda's, Tanzania's, Senegal's and Cameroon's forest-sector decentralizations, income may go up and local people can benefit (Ribot, 2003; Oyono, 2004a; Brockington, 2007; Alden Wily, undated).

There are some theories that say decentralization is good for forests and that improved forest management can improve local livelihoods. But we do not know under what circumstances maintaining forests is good for local livelihoods. Tacconi et al (2006, p2) present data indicating that alternative land uses (e.g. for agriculture) can produce greater income. Certainly, without allowing rural people access to the most lucrative aspects of forestry (timber and wildlife), it is unlikely that the forests will compete against other land uses. Forests are usually less able to support livelihoods than are alternative land uses - such as agriculture - and it makes sense that agricultural conversion is the leading cause of tropical deforestation (Tacconi et al, 2006, p5). Tacconi et al's arguments indicate that we need to delink livelihood arguments from forestry arguments, recognizing that forests are not always good for local livelihoods. 


\section{FACTORS INFLUENCING DECENTRALIZATION, FORESTRY DECENTRALIZATION AND ITS OUTCOMES}

This section examines some contextual factors that influence decentralization and decentralized forestry outcomes more generally. The relation between decentralized forestry and environmental or livelihood outcomes is shaped by a multilayered political economy. The vertical division of powers between central and local shapes the degrees of freedom of local institutions (see Mawhood, 1983; Føllesdal, 1998; Rocher and Rouillard, 1998; Manor, 1999). The horizontal distribution of functions and powers among different kinds of institutions in the local arena is also usually influenced by higher-level intervening agencies and can shape local decisions and outcomes (Ribot et al, 2008). The degree to which local populations can influence these higher-level authorities reflects the degree to which the society is democratic. This 'articulation' (or interdependence) between lower- and higher-level institutions and local populations also shapes how higher authorities choose local institutions and the vertical and horizontal distribution of powers that they hold (see Chhatre, 2007, on the concept of 'articulation'). The choices made by central actors, in turn, influence the degree to which elected local authorities are empowered and the degree to which the public space of discretion is kept open so that there is a space for democratic interaction. These choices also shape the degree to which powers are transferred to private bodies or customary authorities, enclosing the public domain through privatization and desecularization of public powers. Intervening agencies in forestry often choose nondemocratic local authorities as their partners (Ribot et al, 2008). Forest services also typically choose to devolve select powers: they hold onto lucrative opportunities while devolving subsistence values and the burdens of management (Ribot, 2004). Blaikie (2006, p1950) modulates up another level arguing that CBNRM is shaped by interfaces involving national politics between administrations, policy elites, and IFIs [international financial institutions] and bilateral aid agencies)' (see also Ferguson, 1996).

Further, these higher-level institutions shape the accountability of local institutions. By the laws that they put in place (structuring elections or establishing accessible courts) or by the implementation or lack of implementation of those very policies, they can enhance accountability of local government to the local population, to the central state or to nobody. Furthermore, these higher-level institutions can shape citizen engagement with local government or with central government via civic education, telling people they have rights and how to exercise them (if, indeed, there are any rights) and instructing leaders on their roles and responsibilities. In addition, they shape the rules of forest and land use that determine economic incentives for management. For example, if conversion to agriculture is forbidden as a precondition for local control of the forests, incentives may re-link forests and livelihoods - if the management requirements do not swamp the benefits. The result is very different from devolving total discretion. Rules of use matter. The market or use value of forests cannot save forests from destruction - and the fickle nature of markets may mean that today forests are safe, but tomorrow prices go up and cutting begins. Standards and rules set at a higher level are needed (see Ribot, 2004). There is no inherent reason to believe that local people will not sell off or convert forests if those are the most 
lucrative options. There are, however, good reasons to believe that collective local decisions can differ from individual local decisions or outsider decisions - in so far as collective decisions are more likely to internalize externalities and produce broader community support. ${ }^{11}$

Some case studies also suggest that local governments will perform well in some domains only if forced to by central government. Crook and Sverrisson (2001) have argued that local government will serve the poor if mandated to do so by central authorities. If not, they are not likely to serve the interests of poor and marginal populations. Bandiaky (2008a) has shown that interventions in local government from above or interventions by local government are likely to exacerbate local gender inequalities if not mandated to take affirmative actions to ensure greater gender representation - making certain that women are present in decision-making processes and ensuring that there are mechanisms by which women's issues are better represented in decisions. As Goetz and Hassim (2003, pp20-21, cited in Bandiaky, $2008 \mathrm{~b}, \mathrm{p} 22)$ argue, it is simplistic and misleading to think that the transfer of power to local actors will solve gender inequality problems. Hence, there are many roles that central authorities can and should play in ensuring that even local democratic institutions address the needs and aspirations of all local people.

The form of decentralization is also reshaped in implementation. In Zimbabwe, Nemarundwe (2004) describes how existing social stratifications influence who participates in committees and decision-making, and how local people use the ambiguous relation between customary and formal authorities to bring their own problems to those authorities who likely to be more accommodating. This is very much a case of what von Benda Beckmann (1981) calls 'forum shopping'. Bandiaky (2007) shows how decentralized forestry follows the contours of existing inequalities of local social hierarchies, transforming the intended equity outcomes into reinforced inequalities (see also Mandondo and Kozanayi, 2006; Bazaara, 2006; Feyissa, 2006, who come to similar conclusions in Zimbabwe, Uganda and Ethiopia). Assembe Mvondo (2006, pp687-668) also notes that decentralization to multi-ethnic villages resulted in reproduction or reinforcement of existing social stratifications, with the Baka minority having little access to justice. But in a community made up solely of Baka, access to the benefits of decentralization is more equitable. He concludes that 'the decentralization of forest resources management does not bring actual horizontal equity to all local populations'. Furthermore, local people maintain access to resources in numerous ways. They continue to manipulate the authorities around them and negotiate continued access either through reciprocal relations or payments (Nemarundwe, 2004; Blaikie, 2006). Such negotiated access, as Nemarundwe (2004, p289) points out, is 'influenced by factors such as descent, social stratification, character of the person involved, and longevity of residence in the area', among many other factors (see Ribot and Peluso, 2003).

Differences between those wishing for conservation and those bearing the costs also reshape motives for implementation. Higher-level institutions may want conservation for higher-level values, such as biodiversity, carbon storage or watershed regulation; yet the costs of all of these are usually born at the local level. Devolving responsibility for values that do not accrue to local people who bear the cost of conservation measures is not likely to lead to success unless complemented by a 
transfer of funds so that local people have incentive to provide these services (Tacconi et al, 2006, p6). Conservation is often viewed as something that local people will do for the returns they will gain. ${ }^{12}$ But those returns are public, while the efforts of local people are private. There is no more reason to believe that a village should pay for a bridge so that a national highway can cross a river near them than to believe that they should pay for forest management in support of national or global benefits from conservation. Work in natural resources seems to be viewed by higher-level actors as if it were not labour and does not need remuneration, while work on a highway would never be expected without pay - except during the times of corvée labour under colonial regimes. Again, a set of higher-level perceptions and assumptions are shaping incentives for forest conservation. The assumption that rural people will work free for a public good - with some notion of long-term payoffs - justifies a tax in labour that is part of what keeps rural people poor.

One other way that higher-level institutions have consistently shaped the scope of local institutions is through the maintenance of central control over 'decentralized' authorities. Many mechanisms have been used (and some recent examples discussed earlier in this chapter). These include the dependence upon central government for funds (earmarked or conditionally transferred), staff and administrative controls, forms of oversight and tutelle; executive personnel deployed locally; imposition of 'expert' advice; discourses of lack of local capacity; transfers of burdens with retained central control of benefits, etc. (Nemarundwe, 2004, pp287-288; Ribot and Oyono, 2005; Ribot et al, 2006; Wardell and Lund, 2006, p1894). ${ }^{13}$ As Wardell and Lund (2006) show, 'contemporary decentralization is accompanied by increasing central government and line ministerial control, hollowing out local people's participation and control'. The strengthening of central government and line ministries 'has provided the Forest Department [in Ghana] with the means of off-setting local people's ability to enjoy the rights with which they have been enfranchised' (Wardell and Lund, 2006, p1899). 'Access should not be prevented, but kept illegal in order for various rents to be extracted' (Wardell and Lund, 2006, p1900).

Assembe Mvondo (2006, p687) observes within Cameroon's autocratic national context that 'decentralization of forests in Cameroon brought about a kind of reproduction, or transposition, of hegemonic political behaviour from the national to the local level'. He partly attributes this to a decentralization law (1994) that does not clearly specify how different social groups should be represented in local forestry institutions or give guidance on the sharing of forest benefits. Larson and Ribot (2007) and Ribot and Oyono (2005) show the multiple ways in which decentralization reforms are resisted by central actors threatened by their own loss of powers, embedded in their own cultures and beliefs about the forms and necessities of environmental management, faced with lucrative rent-seeking opportunities, under pressure to keep up production, etc. Governments are not giving much up. They have used decentralization as a strategy to shed burdens and responsibilities without devolving real powers or lucrative opportunities to the local arena (e.g. Nemarundwe, 2004, p287).

Lastly, history matters deeply. In Mozambique, local people are reluctant to engage with authorities or with rules given the long history of authoritarian rule. They believe that personalized relationships and informal rules matter more than codified rules or formal processes (Salomão and Matose, 2007, p16). This is also found in Latin America. 
In Brazil, due to a history of patron-client relations, local people elect local mayors and councils dominated by elite landowners who mostly belong to opposition parties (Toni, 2007). In Guatemala, the state has engaged in a long history of integrationist policies, depriving indigenous peoples of their rights. The history of integrationist nationbuilding in Guatemala is today an obstacle to indigenous people's participation in forestry management with democratic local government. That history has fostered a healthy mistrust of government, which has, in turn, affected their ability to take advantage of new local government institutions (Larson, 2007). Salomão and Matose (2007, p17) argue that trust is a key element for implementation of land and resource legislation. But, of course, that trust must be merited.

\section{WHAT HAVE WE LEARNED?}

Based on the studies reviewed, we can theorize or at least make some general statements about the democracy, livelihoods and ecological outcomes of decentralized forestry. First, ecological, livelihood and democracy objectives are not always mutually reinforcing - under some circumstances they may be at odds. Second, ecological improvements for local people (linked to local livelihoods) may look very different from ecological improvements for a more distant or higher-scale aggregate of populations (linked to watershed, biodiversity or global change). The use of the landscape for livelihoods by the poor may also be at odds with the profit and revenue interests of local elites, national commercial interests and national governments. Each set of objectives must be taken separately and the relation among them must be negotiated in a specific context.

There are several questions that need to be asked if we are to balance these competing and converging objectives in a way that supports sustainability, rural livelihoods and democratization. What are the minimum requirements for guaranteeing ecological sustainability (in whatever form the environment may take), local livelihoods and local democracy? This section goes over each briefly to point out some areas that we still need to think through and some contradictions that immediately emerge:

- Ecology. What is needed to optimize (conserve or transform) the ecology for local values and for higher-scale values? We already know that to produce different values from a landscape, rules are essential and enforcement is essential. When local people agree to the rules, enforcement is easier. When local people are involved with enforcement they are more likely to engage in the objectives that the rules were designed to achieve (Agrawal, 2005). In the rare instances where central government is willing to enforce the rules, elites will get away with fewer abuses.

It appears that some higher-scale agreement is needed on the environmental values that must be protected to benefit society at large and to fulfil higher-scale social needs. Additionally, some negotiation at the local level is needed to simultaneously protect local values or compensate local people for limits that higher-scale needs place on local-level values. Any solutions must attend to the fact 
that most burdens of conservation are born at the local level while the benefits are manifest at higher scales. Conservation or even use for higher-scale or distant actors must reflect basic needs, such as health, welfare or subsistence, of distant and local societies - mere profit or economic growth do not always justify extraction. Is carbon storage a necessity? Is watershed regulation a necessity? Is timber extraction for national use a necessity? Is timber extraction for export and foreign exchange necessary? If so, what must be given back to make it palatable to local people? Are rural livelihoods needed (people could be moved to cities)? What is the social and political-economic cost of any of these decisions?

- Livelihoods. What must be done to guarantee livelihoods for local people or for higher-scale economic and use values from forests? Similarly to ecology, guarantees for what are perceived to be necessary aspects of production and reproduction of individuals, households, communities and nations must be assessed. What is more important: revenue from the timber trade or subsistence values of local people? When should forest use for poor people be supported, and when should alternative income activities be sought? These questions are not easy to answer. Should elites get rich or forest villagers get rich when there is wealth in the forests? Clearly, most national governments value timber more than subsistence values and elite wealth over enriching those who are currently politically, economically and socially marginal. Clearly, the market and policy processes that produce marginality while enriching others are not processes that governments or elites want to halt. Clearly, deep structural changes will be needed if the rural poor and forest dependent populations are to be safe from the vagaries of markets and of elite-driven policy processes. These changes would be painful to the rich and powerful and to the liberal free-trade, free-market profiteers. They are not likely to happen.

- Local and legislative democracy. What are the conditions necessary to promote democratization in and for the local arena? To guarantee local democracy, the criteria are a bit easier. Local democracy is about accountability of leaders to their people. Local leaders in democracy are representative - which means responsive to local needs and downwardly accountable (Manin et al, 1999). To be responsive they must have discretionary powers that are relevant and significant to the problems faced by the people they ostensibly represent. To be accountable there must be multiple mechanisms of accountability (means of positively and negatively sanctioning leaders) - among which elections (with open candidature and universal suffrage) are one important, but insufficient, means. Democratization may broaden the political base so that the majority, at least, is better cared for. But, like any political system, it needs the multiple pressures from social movements and organized civil society to keep from veering off into elite self-service. Hence, procedural rights that enable people to organize, protest, march, engage in civil disobedience and to generally voice their grievances and aspirations while sanctioning their leaders are also essential.

The just and sustainable balancing of ecological and livelihoods aspirations of local and higher levels of social organization requires some means to seriously negotiate between central and local values - and among an array of local values. Local 
representative authority is one node of negotiation - such representatives could speak on behalf of local needs and aspirations to higher-scale actors. They can mediate the relation between the local population and outside interests. Local representation, however, is not enough. The laws that define the powers of local representative authorities are hammered out in national legislatures and in line ministries - forestry departments and environmental ministries in the case of forestry. Rural representation in legislatures across Africa is weak. Deputies and members of parliaments rarely introduce legislature on behalf of the rural poor or in protection of their rights to natural resources (Veit, 2008). Strong legislative representation would be necessary to establish powers in decentralized venues to make local government a viable locus for such negotiation. The power of local government representatives, however, is also still wildly insufficient to engage in negotiations to leverage greater power from above.

We know from previous studies that there are many ecological and livelihood decisions in forestry that can be devolved to local authorities without negative ecological or livelihood consequences - hence, there is plenty of room in forestry to support local democracy. For example, once it is determined at a higher scale that a certain forest can be cut for timber and the necessary techniques for cutting have been specified, the decision as to whether it should be cut, how much should be cut, when it should be cut, who should have the right to cut and who should profit from the cutting can all be decisions made at the local level. These latter allocation decisions cannot be said to threaten the ecology (at least not more than allowing outsiders to cut the same amount of timber already deemed exploitable by outside agents). Bazaara (2006) notes that forest services often devolve burdens of management without devolving lucrative opportunities. He argues that they do so by conflating technical decisions of management and use (which should often be taken at a higher scale) with political decisions of allocation (which can be devolved). Hence, we know that forestry could be more supportive of the construction of local democratic authorities without negative trade-offs on the ecological front. The trade-offs here are on the political front between national elites, local elites and democratic processes.

Clearly, context matters. Olivier de Sardan (2004, p3) outlines three contextual factors that will shape the outcomes of democratic decentralization. Socio-political aspects will include the role of local aristocracies who claim legitimacy from the precolonial era, lineage-based societies and heterogeneous villages. Differences will be expected among different socio-economic contexts, such as agro-pastoral, intensive agricultural and livestock economies. Furthermore, these different contexts will have different fiscal potentials. Some will easily generate revenues while others will have no sources. Differences will also be expected between different socio-cultural contexts that may be homogenous or heterogeneous and which may exhibit different degrees of internal conflict or cohesion. Olivier de Sardan (2004) is setting up a research observatory to examine how uniform policies can adapt - officially or unofficially - to these diverse situations. But his approach to enhancing implementation through research on the match between policy and context is still awaiting the implementation of decentralization in Niger. Constant research and feedback are needed to inform the negotiation processes and deliberations among local people and between local people, local elites and national elites. 
Raik and Decker (2007) argue that decentralized forestry falls short in so far as it is too narrowly focused on the forest sector. ${ }^{14}$ Forests are usually neither people's dominant economic nor cultural base. People spend their time worrying about farming, business, health, education, welfare, infrastructure, social cohesion, family, etc. In an evaluation of World Bank community-driven development projects, Ribot (2005) found that when communities were given a menu of options to invest in, natural resource management was rarely a top priority. The irony of Raik and Decker's (2007) observation is that the development trend of 30 years ago - integrated rural development (IRD) - was all about the need to integrate across all household needs. IRD ran into problems because it was top down and too complex. Ribot (2001) has argued that well-structured decentralization is the new form of integrated rural development, but this time integrated through representative authority rather than through planners or sectoral imperatives. Democratic decentralization is one means of reintegrating priorities, allowing local representative authorities to place forests and NRM among other needs and aspirations of their communities.

\section{CONCLUSIONS: FORESTRY CAN SHAPE LOCAL DEMOGRACY}

Because there are few reasons ${ }^{15}$ to trust that local people, local representative authorities or central commercial interests will not want to transform forests into agricultural fields or use them one way or another to produce cash, there is a need for rules that protect some agreed-upon ecological values. A minimum standards approach (see Ribot, 2004) to forestry is consistent with maximizing local public discretionary power. If truly minimum rules of use can be set that are aimed at protecting essential ecological functions (for all scales) and protecting livelihood and economic values (for all scales), then the remainder of decisions over forest management and use should be at the discretion of local representatives. Of course, protecting ecological and income values must also be considered in the light of protecting other values - such as democracy and human rights (Petrasek, et al, 2002; Kulipossa, 2004). Balancing these objectives is not an easy constrained optimization.

To arrive at minimum technical standards first requires sophisticated representative engagement from the rural world. It will also require sophisticated engagement by experts who are able to stand up to 'forestry' experts and other 'environmental' experts so as to prevent them from using science-based arguments to impose rules and regulations that are not merited by ecological necessity. It will also require a significant presence of voices for human rights and local democracy to ensure that local values are protected from the unequal leverage of higher-scale decision makers and commercial interests. Most critically, it will require that the costs of protecting extra-local values are borne by external actors - not those who depend upon the resources and have been systematically and continuously pushed to the margins of the broader economy that they are located in but do not benefit from. If local people are expected to engage in any way in conservation or carbon storage 
activities, they should be paid a living wage (not a subsistence wage) sufficient to motivate them to engage in these external projects and to give them the means to pursue alternative livelihoods for themselves and their children.

The hammering out of a minimum set of rules of forest management and use does not resolve the contradictions among different kinds and scales of objectives. Resolving these tensions is a political process. Where do these different objectives converge or conflict? When does decentralization of forest management strengthen or weaken livelihoods, democracy or human rights? Clearly, from the above discussions, we do not yet know. But setting priorities and determining which values take precedence is a decision that can be engaged in - politically. When are different parties willing to give up democracy for conservation or livelihoods? When are different actors willing to give up livelihoods for conservation or democracy? When is society willing to give up conservation for livelihoods or democracy?

Whatever political decisions are made, foresters have two opportunities to contribute to local democracy. First, by helping to define a realm of local discretion over forests and forest products, they help to define the local public domain - the set of powers over which democratic decision-making is exercised. Foresters can help to establish this domain by transferring sufficient and meaningful discretionary powers to local democratic institutions. Second, by choosing to locate these public powers with democratic authorities, forestry agencies, professionals, donors and NGOs are choosing democracy. In the process, foresters will help to produce a public domain in which local people can engage and develop as citizens. Forestry and the great material wealth that it represents have the power to support fledgling democratic institutions across Africa.

Discretion and representation are the infrastructure of democratic environmental governance. Environmentalists, foresters and democracy advocates need to collaborate to execute 'environmental governance infrastructure assessments' to ensure that these elements are in place. They need to begin looking to see whether powers that can be devolved to local authorities are being devolved and whether they are being devolved to local authorities who, in the long run, are likely to support just, equitable, representative social processes in the local arena. Such assessments could be used to evaluate the basic infrastructure of local representation - that is, the responsiveness and accountability of local government and forestry institutions.

\section{NOTES}

1 Foresters were often the first professionals to accompany the military into Africa's interior during the early colonial period.

2 In the colonial period it was one of management. Today it is one of participation and is moving towards representation. Stating the goal of France's mission, French forester Bertin (1919, p305) writes: 'We engage ourselves, in effect, to know all the exploitable species, neglected to the present, and that should have been used for the profit of industry' (italics in original). Bertin also wants to train the 'natives' (using the term dressage) in order to get the most from their labour. Bertin (1919, p308) states: 
The final goal toward which we must move is to cede to the natives for the most part forestry work, and the organization of small interested local businesses where collectives and black villages monitor by themselves their work and automatically augment their efficiency. But one must at least teach the blacks to use tools and engines, quite rustic without doubt, but allowing nonetheless to improve the yield of human labor.

3 Senegal instituted a 'participatory' forestry code in 1993; Ghana in the late 1980s (Ribot, 1995; Wardell and Lund, 2006, p1894). Participatory forestry laws swept the continent by the mid 1990s. Many were then later revised as participation gave way to decentralization.

4 See WRI working papers at http://www.wri.org/publications/2284.

5 Pers comm, Yaya Tamboura, National Director, Direction National de la Conservation de la Nature, Bamako, Mali, November 2000, and meetings with forestry officials in Mali in March 2002.

6 I do not have an update of the final law. I resigned in 2001 from a forestry bill review board when my request to remove forced labour from the law was ignored.

7 In 1919 the Minister of Colonies established 'Councils of Notables' to give 'natives' in the rural areas an opportunity to participate in or be consulted concerning administration. According to the minister, the aim was the 'formulation of an élite which will later be able to cooperate more closely and in a more personal manner in the economic and financial life of the colony' (cited in Buell, 1928, p999). From 1936 the colonial French West African government required that the people be consulted through the medium of village chiefs about the choice of a canton chief. Proposed canton chiefs then had to be approved and appointed by the administration (Cowan, 1958, p177). Indeed, Indirect Rule was described as a form of enfranchising participation:

The basic aim of Indirect Rule is the development of an African society able to participate in the life of the modern world as a community in its own right. In territories where it is followed government does not accept the encouragement of European enterprises as a duty, but judges its value in the light of the contribution which it can make to African development. The other aspect of Indirect Rule - the preservation of African institutions where the needs of the Africans themselves do not call for their modification - is almost a natural corolary of this attitude towards European penetration. (liberal anthropologist Lucy Mair, 1936, p12-14)

8 See also Wily (2003, pi) who observes a lack of implementation in land administration decentralizations.

9 Misconceptions in analyses are multiple. Tacconi et al (2006, p3) argue that studies fail to question the core assumptions of decentralization advocates that:

- democratic decentralization is an institutionalized and scaled-up form of CBNRM;

- people will engage in conservation due to the benefits that will follow (Hailey, 1938, pp985-987, who also observed that 'conservation' forests are not advancing because they are insufficiently remunerative and Africans do not understand their value); and

- benefit-driven conservation will lead to less deforestation. 
The first failure they observe, however, is definitional. No amount of research will resolve it. It is not an assumption - rather an 'if-then' statement: if there is institutionalized representation in the form of democratic decentralization and the representative authorities hold management responsibilities over natural resources, then it is an institutionalized form of CBNRM. As for the latter two assumptions, the authors show that these hold only under certain circumstances due to the presence of multiple intervening variables. Agrawal and Chhatre (2005, p164) add, based on an analysis of 90 cases in India: 'variations in how the same factors operate and should be operationalized in different micro-contexts should make us pessimistic about the possibility of a universal theory of the commons'.

10 The is it logical to economists. If the growth rate of a forest is lower than returns elsewhere, why not cut down the total forest stock now and invest the capital in a fund that has a return greater than the forest growth rate? Why not cut it down and invest in hotels?

11 There is reason to believe that incentives do differ under collective management due to the internalization of externalities in decisions such that those who might want to cut the trees down may be challenged by those who want to continuously use the bark, leaves and fruits or others who see them as aesthetically pleasing or as having functions for soil conservation or for wind protection. But if the price of the timber is high enough, we still do not have any reason to believe that the other actors in the collective decision cannot be paid off for the loss of these ongoing functions of the tree.

12 As Wily (undated, p5) describes the trend during the late 1990s: 'Local populations have been presented as being legitimate forest users, whose cooperation may be secured in exchange for their subsistence needs being considered, an approach greatly encouraged by the current donor-led focus upon sustainable rural livelihoods.'

13 'The trend towards decentralization and devolution of forest management responsibilities to the local governments could not be effective due to low capacity of the sector at all levels', cited in the Country Report-Ethiopia (Bekele, 2001).

14 Note, however, that 'decentralized' forestry in Madagascar described by Raik and Decker (2007) is not decentralized - rather, it is a contractual relation between the Forest Service and a registered local NGO. This is more closely akin to co-management approaches.

15 The idea of internalizing externalities in decisions does imply that local collective decisions will differ from individual or commercial decisions taken without community input. But if the values are high enough, there is plenty of reason to believe a community will act just like a corporation in transforming a forest into other kinds of uses or values. There is also reason to believe that deriving more subsistence value from a forest may change the relation of a population to the forest. But when commercial values are high, when alternative incomegenerating opportunities are abundant, or during very hard times, there is little to prevent even those who use the forest for subsistence or income from damaging it.

\section{REFERENCES}

Agrawal, A. (2005) Environmentality: Technologies of Government and the Making of Subjects, Duke University Press, Durham, UK

Agrawal, A. and A. Chhatre (2006) 'Explaining success on the commons: Community forest governance in the Indian Himalaya', World Development, vol 34, no 1, pp149-166 
Agrawal, A. and J. C. Ribot (1999) 'Accountability in decentralization: A framework with South Asian and African cases', Journal of Developing Areas, vol 33, pp473-502

Alden Wily, L. (2003) Governance and Land Relations: A Review of Decentralisation of Land Administration and Management in Africa, IIED, London

Alden Wily, L. (undated; circa 2000) Making Woodland Management More Democratic: Cases from Eastern and Southern Africa, Mimeo

Andersson, K. P. and C. C. Gibson (2004) 'Decentralization reforms: Help or hindrance to forest conservation?', Draft paper presented at the Conference on the International Association of Common Property (IASCP), Oaxaca, Mexico, 9-13 August 2004, Mimeo

Assembe Mvondo, S. (2006) 'Decentralized forest resources and access of minorities to environmental justice: An analysis of the case of the Baka in southern Cameroon', International Journal of Environmental Studies, vol 63, no 5, pp681-689

Aubréville, A. (1939) 'L'utilisation totale des bois tropicaux de l'Ouest Africain', Revue des Eaux et Forêts, June, pp485-495, 599-608

Bandiaky, S. (2008a) Engendering Exclusion in Senegal's Democratic Decentralization: Subordinating Women through Participatory Natural Resource Management, PhD thesis, Clark University, pp1-271

Bandiaky, S. (2008b) 'Gender inequality in Malidino Biodiversity Reserve, Senegal: Political parties and the "village approach", Conservation and Society, vol 6, no 1, pp62-73

Bandiaky, S. (2007) Engendering Exclusion in Senegal's Democratic Decentralization: Subordinating Women through Participatory Natural Resource Management, Representation, Equity and Environment Working Paper no 31, WRI, Washington, DC

Bazaara, N. (2006) 'Subjecting nature to central authority: The struggle over public goods in the formation of citizenship', African Development, vol 31, pp19-36

Bekele, M. (2001) Country Report - Ethiopia, FAO Corporate Document Repository, www.fao.org/docrep/004/ab582e/AB582E00.HTM, accessed 1October 2008

Benda-Beckmann, K. von (1981) 'Forum shopping and shopping forums: Dispute processing in a Minangkabau village', Journal of Legal Pluralism, vol 19, pp117-159

Bertin, A. (1919) La Question Forestière Coloniale: Mission d'Études Forestières Envoyée dans les Colonies Française par les Ministères de la Guerre, de l'Armement et des Colonies, Émile Larose, LibraireÉditeu, Paris

Blaikie, P. (2006) 'Is small really beautiful? Community-based natural resource management in Malawi and Botswana', World Development, vol 34, no 11, pp1942-1957

Blundo, G. (2006) 'Dealing with the local state: The informal privatization of street-level bureaucracies in Senegal', Development and Change, vol 37, no 4, pp799-819

Brockington, D. (2007) 'Forests, community conservation and local government performance: The village forest reserves of Tanzania', Society and Natural Resources, vol 20, pp835-848

Buell, R. L. (1928) The Native Problem in Africa I and II, MacMillan, New York, NY

Chhatre, A. (2007) Accountability in Decentralization and the Democratic Context: Theory and Evidence from India, Representation, Equity and Environment Working Papers no 23, WRI, Washington, DC

Chhatre, Ashwini (2008) 'Political Articulation and Accountability in Decentralization: Theory and Evidence from India', Conservation and Society, vol 6, no 1, pp12-23

Conyers, D. (2003) Whose Elephants Are They? Decentralization of Control over Wildlife Management through the CAMPFIRE Programme in Binga District, Zimbabwe, Environmental Governance in Africa Working Paper no 4, WRI, Washington, DC 
Cowan, L. G. (1958) Local Government in West Africa, Columbia University Press, New York, NY

Crook, R. C. and A. S. Sverrisson (2001) Decentralization and Poverty-Alleviation in Developing Countries: A Comparative Analysis, or is West Bengal Unique?, Institute of Development Studies Working Paper no 130, IDS, Brighton, UK

Delnooz, P. (1999) Gestion des ressources forestières: La communauté, l'état et le marché: Étude de projets d'aménagement au Burkina Faso, PhD thesis, Fondation Universitaire Luxembourgeoise, Louvain-la-Neuve, France

Dubois, O. (1997) 'Preface', in L. A. Wily (ed) Villagers as Forest Managers and Governments 'Learning to Let Go', IIED Forestry and Land Use Program Working Paper no 9, IIED, London

Etoungou, P. (2001) 'L'impense des forêts communautaires: Décentralisation à l'est du Cameroun', Programme on Decentralization and the Environment draft paper (June), Yaoundé, Cameroon, Mimeo

Ferguson, J. (1996) The Anti-Politics Machine: Development, Depolitization and Bureaucratic Power in Lesotho, Cambridge University Press, Cambridge

Feyissa, D. (2006) 'Decentralization as ethnic closure, with special reference to a declining negotiated access to natural resources in Western Ethiopia', Africa Development, vol 31, no 2, pp243-260

Føllesdal, A. (1998) 'Survey article: Subsidiarity', Journal of Political Philosophy, vol 6, no 2, pp190-218

Geschiere, P. (1993) 'Chiefs and colonial rule in Cameroon: Inventing chieftaincy, French and British style', Africa, vol 63, no 2, pp151-175

Geschiere, P. and C. Boone (2003) Crisis of Citizenship: New Modes in the Struggles over Belonging and Exclusion in Africa and Elsewhere, Research concept sketch for SSRC-programme (November), Mimeo.

Goetz, A. M. and S. Hassim (eds) (2003) No Shortcuts to Power: African Women in Politics and Policy Making, Zed Books, New York, NY

Graziani, M. and P. Burnham (2002) 'Legal pluralism in the rain forests of southeastern Cameroon', in K. Homewood (ed) Rural Resources and Local Livelihoods in Africa, James Curry, Oxford

Hailey, L. (1938) An African Survey: A Study of Problems Arising in Africa South of the Sahara, Oxford University Press, London

Isin, Engin F. and Bryan S. Turner (eds) (2002) Handbook of Citizenship Studies, Sage Publications, London

Kulipossa, F. P. (2004) 'Decentralisation and democracy in developing countries: An overview', Development in Practice, vol 14, no 6, pp768-779

Larson, A. M. (2003) Decision-Making under Decentralization: Local Governments in Natural Resource Management, Draft, December, Mimeo

Larson, A. M. (2007) Indigenous Peoples, Representation and Citizenship in Guatemalan Forestry, Representation, Equity and Environment Working Paper no 27, WRI, Washington, DC

Larson, A. M. and J. C. Ribot (2007) 'The poverty of forestry policy: Double standards on an uneven playing field', Sustainability Science, vol 2, no 2, pp189-204

Latif, M. (2002) Minutes of the World Resources Institute Conference on Decentralization and the Environment, Environmental Governance in Africa Working Paper no 18, WRI, Washington, DC

Madondo, A. and W. Kozanayi (2006) 'Demand-driven model of decentralized land-use planning and natural resource management: Experiences from Chiredzi District of Zimbabwe', Africa Development, vol 31, no 2, pp103-122

Mahwood, P. (1983) 'The place of traditional political authority in African pluralism', Civilisations, vol XXXII, no 2 - vol XXXIII, no 1, pp209-237 
Mair, L. P. (1936) Native Policies in Africa, Negro University Press, New York, NY

Mamdani, M. (1996) Citizen and Subject: Contemporary Africa and the Legacy of Late Colonialism, Princeton University Press, Princeton, NJ

Manin, P. and S. Stokes (1999) Democracy, Accountability, and Representation, Cambridge University Press, Cambridge

Manor, J. (1999) The Political Economy of Democratic Decentralization, World Bank, Washington, DC

Muhereza, F. (2001) Concept Note on the Need to Re-think the Issue of Private Forests, Kampala, Mimeo

Muhereza, F. (2006) 'Decentralizing natural resource management and the politics of institutional resource management in Uganda's forest sub-sector', Africa Development, vol 31, no 2, pp67-102

Namara, A. (2001) Whose Interests Matter? Assessment of the Operations of Local Institutions in Natural Resource Management: The Case of Bwindi Impenetrable National Park, Uganda, Draft Report to the World Resources Institute/Centre for Basic Research Program on Decentralization and the Environment, Kampala, February, Mimeo

Nemarundwe, N. (2004) Social Characters and Organisation for Access to Woodlands: Institutional Implications for Devolving Responsibilities for Resource Management to the Local Level in Chivi District, Zimbabwe, Mimeo

Ntsebeza, L. (2002) 'Decentralization and natural resource management in rural South Africa: Problems and prospects', Paper submitted to the Conference on Decentralization and the Environment, Bellagio, Italy, 18-22 February

Ntsebeza, L. (2005) 'Democratic decentralisation and traditional authority: Dilemmas of land administration in rural South Africa', in J. C. Ribot and A. Larson (eds) Decentralization of Natural Resources: Experiences in Africa, Asia and Latin America, Frank Cass, London

Olivier de Sardian, J.-P. (2004) 'Local powers awaiting decentralisation (Niger)', Paper presented at the Decentralisation in Practice: Power, Livelihoods and Cultural Meaning in West Africa Workshop, Uppsala (May), Uppsala University and IIED, Uppsala

Oyono, P. R. (2004a) Institutional Deficit, Representation, and Decentralized Forest Management in Cameroon, Environmental Governance in Africa Working Paper no 15, WRI, Washington, DC

Oyono, P. R. (2004b) 'One step forward, two steps back? Paradoxes of natural resources management decentralization in Cameroon', Journal of Modern African Studies, vol 42, no 1

Oyono, P. R. (2004c) 'Social and organizational roots of ecological uncertainties in Cameroon's forest management decentralization model', in J. C. Ribot and A. M. Larson (eds) Decentralization of Natural Resources: Experiences in Africa, Asia, and Latin America, Frank Cass, London

Oyono, P. R. (2005) 'The social and organisational roots of ecological uncertainties in Cameroon's forest management decentralization model', in J. C. Ribot and A. M. Larson (eds) Democratic Decentralization through a Natural Resource Lens, Routledge, London, pp174-191

Oyono, P. R. and S. Efoua (2006) 'Qui represente qui? Choix organisationnels, identités sociales et formation d'une elite forestière au Cameroon', Africa Development, vol 31, no 2, pp147-182

Oyono, P. R. and Francis Lelo Nzuzi (2006) 'Au sortir d'une longue "nuit" institutionelle, nouvelles transactions entre les politiques forestières et les societés rurales en RD Congo post-conflit', Africa Development, vol 31, no 2, pp183-214

Pagdee, A., Y.-S. Kim and P. J. Daugherty (2006) 'What makes community forest management successful: A meta-study from community forests throughout the world', Society and Natural Resources, vol 19, pp33-52 
Petrasek, D., F. El Tom and R. Archer (2002) Local Rule: Decentralisation and Human Rights, International Council on Human Rights Policy, Geneva

Pritchett, L. and M. Woolcock (2004) 'Solutions when the solution is the problem: Arraying the disarray in development', World Development, vol 32, no 2, pp191-212

Raik, D. B. and D. J. Decker (2007) 'A multisector framework for assessing community-based forest management: Lessons from Madagascar', Ecology and Society, vol 12, no 1, pp1-14

RdS (Republique du Senegal) (1993) Loi No 93-06 du 4 Fevrier 1993, Code Forestier de la Republique du Senegal, Ministere de l'Environnement et de la Protection de la Nature, Dakar

Ribot, J. C. (1995) 'From exclusion to participation: Turning Senegal's forestry policy around', World Development, vol 23, no 9, pp1587-1599

Ribot, J. C. (1999) 'Decentralization, participation, and accountability in Sahelian forestry: Legal instruments of political-administrative control', Africa, vol 69, no 1, pp23-65

Ribot, J. C. (2001) 'Integral local development: “Accommodating multiple interests' through entrustment and accountable representation', International Journal of Agricultural Resources, Governance and Ecology, vol 1, no 3, pp327-350

Ribot, J. C. (2002) African Decentralization: Local Actors, Powers, and Accountability, Democracy, Governance, and Human Rights Working Paper no 18, UNRISD and IDRC, Geneva

Ribot, J. C. (2003) 'Democratic decentralization of natural resources: Institutional choice and discretionary power transfers in sub-Saharan Africa', Public Administration and Development, vol 23, no 1, pp53-65

Ribot, J. C. (2004) Waiting for Democracy: The Politics of Choice in Natural Resource Decentralization. Washington: WRI.

Ribot, J. C. (2005) Steering Community Driven Development? A Desk Study of NRM Choices, Draft report to the World Bank Natural Resources Thematic Group, March, World Bank, Washington, DC

Ribot, J. C. (2006) Analyse de la filière charbon de bois au Sénégal: Recommendations, Policy Brief based on the research program Pour une gestion décentralisée et démocratique des ressources forestières au Sénégal, September, WRI, Washington, DC

Ribot, J. C. (2008) Authority Over Forests: Negotiating Democratic Decentralization in Senegal, Representation, Equity and Environment Working Paper no 36, WRI, Washington, DC

Ribot, J. C. and P. R. Oyono (2005) 'The politics of decentralization', in B. Wisner, C. Toulmin and R. Chitiga (eds) Toward a New Map of Africa, Earthscan, London

Ribot, J. C. and N. L. Peluso (2003) 'A theory of access', Rural Sociology, vol 68, pp153-181

Ribot, J. C., A. Agrawal and A. M. Larson (2006) 'Recentralizing while decentralizing: How national governments reappropriate forest resources', World Development, vol 34, no 11, pp1864-1886

Ribot, J. C., A. Chhatre and T. Lankina (2008) Institutional Choice and Recognition in the Formation and Consolidation of Local Democracy, Representation, Equity and Environment Working Paper no 35, WRI, Washington, DC

Rocher, F. and C. Rouillard (1998) 'Decentralization, subsidiarity, and neoliberalism in Canada: When the tree hides the forest', Canadian Public Policy-Analyse de Politiques, vol 24, no 2, pp233-258

ROU (Republic of Uganda) (2001) The Forestry Act: Draft for Consultation, Ministry of Water, Lands and Environment, Uganda Forests, January, Uganda

Rouveroy van Nieuwaal, E. R., B. Adriaan and R. van Dijk (eds) (1999) African Chieftaincy in a New Sociopolitical Landscape, Lit Verlag, Hamburg 
Salomão, A. and F. Matose (2007) Towards Community-Based Forest Management of Miombo Woodlands in Mozambique, May, Mimeo

Sparke, M. (2004) 'Passports into Credit Cards: On the Borders and Spaces of Neoliberal Citizenship', in J. S. Migdal (ed) Boundaries and Belonging: States and Societies in the Struggle to Shape Identities and Local Practices, Cambridge University Press, Cambridge, pp251-283

Tacconi, L., Y. Siagian, and R. Syam (2006) On the Theory of Decentralization, Forests and Livelihoods, Environmental Management and Development Occasional Papers no 9, Asia Pacific School of Economics and Governments, Australian National University, Canberra

Toni, F. (2007) Party Politics, Social Movements and Local Democracy: Institutional Choices in the Brazilian Amazon, Representation, Equity and Environment Working Paper no 32, WRI, Washington, DC

Vaughan, M. (1991) Curing Their Ills: Colonial Power and African Illness, Stanford University Press, Palo Alto, CA

Veit, P. (2008) On Whose Behalf?: Legislative Representation and the Environment in Africa, WRI, Washington, DC

Wardelle, D. A. and C. Lund (2006) 'Governing access to forests in northern Ghana: Micropolitics and the rents of non-enforcement', World Development, vol 34, no 11, pp1887-1906 
Chapter 3

\section{Elusive Meanings: Decentralization, Conservation and Local Democracy}

Mariteuw Chimère Diaw

\section{INTRODUCTION}

There is a problem with 'decentralization' and 'conservation'; both are used in various brands of the literature to mean different things, often for quite different reasons. On the ground, the realities and social processes that are referred to differ widely and are marred with layered conflicts of purposes and meanings. To ask whether decentralization can be 'a panacea for conservation' - or, to put it rhetorically, whether conservation could be 'saved' by decentralization - a question raised recurrently in the 1990s and early 2000s (e.g. Enters and Anderson, 2000; Fisher, 2000; Fisher et al, 2000; Gupte, 2006; Whyckoff-Baird et al, 2000), is, therefore, highly problematic.

This chapter starts with the idea that decentralization and conservation theories have problems of their own, related to discrepancies in the theory as well as between normative frames and local realities. Bringing the two together without addressing those gaps only complicates issues of theory and policy, particularly in tropical environments. The plurality of discourses on decentralization and conservation magnifies the problems posed by each of these interventions in the local space and hinders our capacity to draw actionable lessons from either of them. This is a problem of language as well as history and epistemology, which we briefly address in the first section of this chapter. We start by situating the 'heartland' of conservation and decentralization discourses in the context of their emergence before interrogating the main discursive forms through which they have evolved in the literature. On this basis we review a small sample of cases from Asia, Africa and Latin America to highlight key forms of decentralization and/or conservation, and conditions where they differ, contradict or coalesce with autonomous forms of local agency. 
The chapter's core theoretical contribution is brought together in the section on 'Blood rights, civil rights and democracy'. Having noted the distinct topologies - 'the actual and metaphorical constructions of space' (Brosius, 1999) - that populate the decentralization-conservation field, we identify a common node of 'problems' stemming from unanticipated complexities of local reality. We ask why and propose an interpretation emphasizing the pluralism of the post-colonial rural society and its roots in the continued coexistence of blood rights and civil rights in modern states. From this, we argue, arise major discrepancies between the dominant values and structures promoted by decentralization and conservation programmes and the still functioning, mostly invisible infrastructure of embedded institutions and local legitimating networks. We are thus far more interested in local actors as active democratic subjects and in the diverse manifestations of local agency than in the nascent controversy about what qualifies as democratic decentralization. This contribution thus strives to conceptualize the troubled link between the making, granting and taking of space in local governance and goes beyond simple electoral politics to challenge more complex concepts of deliberative democracy and social movements. In that process, we question the concept of democratic decentralization as it has been presented in the literature, and rhetorically ask about the acceptability to conservation advocates of the notion of 'democratic conservation'.

\section{DEGENTRALIZATION AND CONSERVATION: SHORT HISTORIES}

At its roots, decentralization theory is an outgrowth of political theories of the state, while modern conservation theory has foundations in $19^{\text {th }}$ century American theological romanticism and moral activism - with earlier ramifications in European philosophical thought and aestheticism. In this section, we explore the linkages of these traditions to the expansion of western forms of politics, values and countervalues in the $19^{\text {th }}$ and $20^{\text {th }}$ Centuries and try to understand how they became joined in segments of the late $20^{\text {th }}$ Century environmental discourse.

\section{A brief history of decentralization}

In his Political Economy of Decentralization, James Manor (1999) links current decentralization policies to the unravelling in the 1970s of the post-war economies and to a post-1980 movement, mostly initiated from above, 'to enhance the state's capacity for non-coercive governance'. Earlier decentralization experiences go as far back as the 1891 Brazilian constitution, the Philippines in 1901 and Sri Lanka in 1931 (Manor, 1999; Melo and Rezende, 2004). Analysing the highly centralized history of Latin America, we note that state formation was a protracted struggle between central and regional elites, with experiences of autonomy (19th-century Argentina), mass movements and near state collapse (1910-1920 Mexican revolution) (Del Río, 2004; Faletti, 2004; Selee, 2004). Latin American political history has been one of iron-clad 
centralism, strongly interpenetrated with regional elites and oligarchies until the 'democratic decentralizations' of the 1980s and 1990s.

In African British colonies (as in India), local bodies were created by the state during the 1950s but had limited powers and were ephemeral. Local governments were suppressed at independence to reinforce nationalism and allegiance to the central state. By contrast, Francophone Africa, which had a different colonial experience, thought it possible to construct the nation state by extending its reach through local governments. The first attempts at decentralization go back to the 1960s in Mali, Burkina Faso and Senegal, even though Senegal became the only country to implement this common project with the establishment of rural councils in 1972 (Vengroff and Johnston, 1987; Jacob and Blundo, 1997). By and large, these early attempts at decentralization were dominated by centralist and charismatic postures (Manor, 1999) and forms of 'decentralized despotism' (Mamdani, 1996).

The full growth of decentralization policies took place during the 1980s and 1990s. This was a global movement, closely associated with structural adjustment policies, land and fiscal reforms, and the progression of electoral democratic frames. Neoliberal thought packaged in various resurgences of modernization theory (Samoff, 1990) lent credence to views of decentralization as a political market bringing together state and citizens as buyers and sellers and a means to improve service delivery. Counter-views of decentralization as a condition for local democracy and creative politics were also developed (Mahwood, 1983, Agrawal and Ribot, 1999; Manor, 1999). Conceptually, and despite elaborated typologies (e.g. Leonard and Marshall, 1982), a very loose consensus emerged during the late 1990s around two major forms of decentralization:

1 de-concentration, or administrative decentralization, marked by the dispersal of state powers from higher to lower levels of administration;

2 devolution, when decision-making authority is transferred from central government to local groups and institutions.

\section{Natural wilderness: The 'heartland' of the modern conservation movement}

Historically, protected areas have been the hard core of nature conservation policies. The first modern parks were created in settler territories at the end of the 19th century (Adams and Hulme, 2001; Phillips, 2003). This was a time when policies could be imposed by force, without true negotiation with native peoples. The two first, emblematic national parks, Yellowstone and Yosemite, were created on native Indian land toward the end of the Indian Wars in the US at a time when the last hotbeds of resistance were being suppressed.

American theological romanticists, who saw in the imposing frontier landscapes of the American West the sublime call of a mystical transcendent nature and the awesome display of the power of God, had a determining influence on the creation of parks. However, transcendentalist writers such as Emerson and Thoreau were reformers who fought against slavery and for women's rights, who integrated 
non-Western writings in their search for universal divine inspiration, and who fully integrated humans in their vision of nature (Witherell and Dubrulle, 1995). John Muir, on the other hand, the father of the national parks, had eyes only for the greedy violation of nature by utilitarianism and European colonists. The ecological and theological vision that he expressed in splendid evocations in defence of American forests (1897) or national parks (Yosemite in 1890) left no room to indigenous history or the natural and cultural ethics of native peoples. In the wonderful tapestries of the American wilderness that make up his texts, native Americans figure not as living cultural communities but as remote reminiscences in the names of falls, cliffs, rocks or 'Indian tracks'. This dualistic and ethnocentric romanticism became a hallmark of the movement for wild nature conservancy in the 20th century.

Following the Yellowstone model, a radical exclusionary form of nature protection spread unquestioned around the world. For about a century, the number of protected areas increased slowly. During the 1960s, which Soulé and Terbogh (1999) consider 'the zenith of conservation' because of the undisputed, hard-line guns-and-fences policies of the time, there were still less than 2000 protected areas in the world. Since then, the areas under protection have grown to over 105,000 sites covering some 20 million square kilometres (Adams et al, 2004) (see Figure 3.1). During that process, the vocabulary of conservation also evolved significantly. From its early representation as landscape and scenery, nature became predominantly projected as wildlife, then as wildlife and flora, and as environment, before being repackaged as biodiversity (Wilson, 1988) during the late 20th-century conservation discourse.

Number of PAs

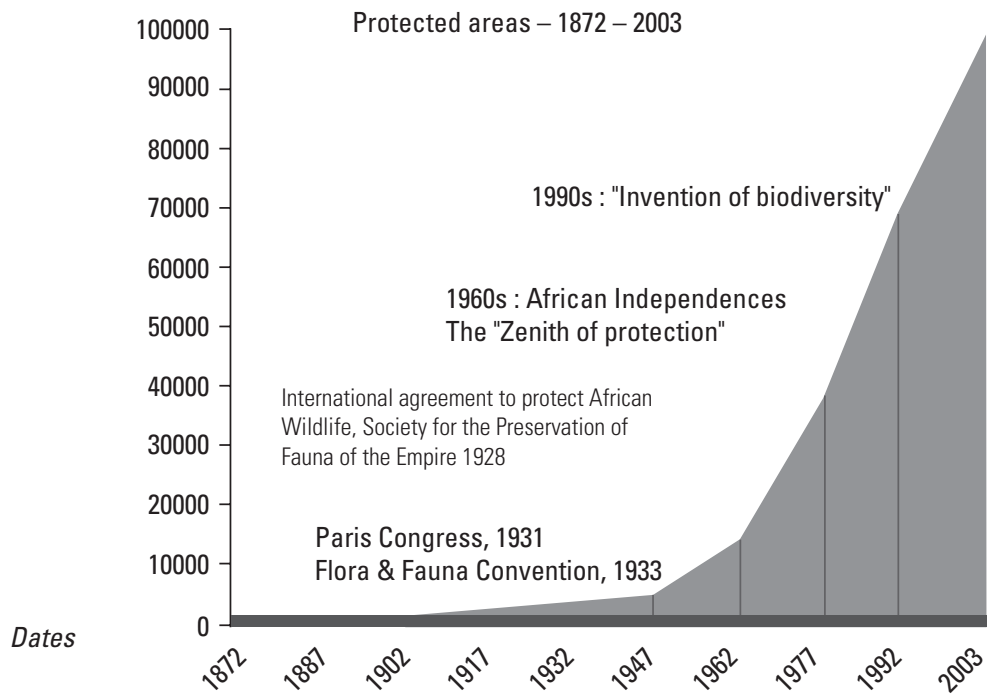

Source: various; see Phillips (2004) for a more authoritative account

Figure 3.1 Rough evolution of protected areas (1872-2003) 


\section{Conservation and decentralization}

How did decentralization and conservation come to be joined? Community-based natural resource management (CBNRM), the main junction between conservation discourse and natural resource decentralization, finds its origins in concepts of social and community forestry during the 1970s. Although now subject to conflicting findings (CIFOR, 2005; Bradshaw et al, 2007), the relationship between flooding and deforestation was unquestioned at the time; Himalayan flooding and Sahelian drought were seen as human-induced environmental catastrophes exposing the limits of command-and-control forest policies and highlighting the important role of people in sustainability. The first generation of social forestry projects took place mainly in arid and deforested environments. The shift to rainforests happened years later, on the heels of the 1980s' decentralization movement. This movement sought primarily to rationalize and democratize the exercise of state power. However, because CBNRM involved shifts of decision-making away from central government and had the aim of maintaining natural environments, the connection with decentralization was inherent. A cursory review of the literature indicates that this connection was mostly made, at first, through the language of 'sustainability', which had gained prominence with the Brundtland Report (WCED, 1987). The popularization of 'biodiversity' made this discursive connection easier and took it further. It made it easier because, in contrast to wilderness, biodiversity is everywhere - from a farmer's field to the highest forested peak; it took it further because the versatility of the concept offered a bridge between community-based initiatives in 'open' environments and attempts to open conservation to more popular participation. These attempts were gaining ground in reaction to the innumerable conflicts and forms of popular revenge on the environment generated by the policies of 'fortress conservation' (Adam and Hulme, 2001; Brockington, 2002). Thus, while biodiversity discourse was more effective in promoting conventional nature conservancy themes, it was also opening the theory and practice of conservation to increased epistemological and political pluralism. As Escobar (1998) states, biodiversity is not a stable construction. The international doctrine evolved to integrate this pluralism in the protected areas framework. A new 'governance matrix' covering all categories of protected areas was developed within the World Conservation Union (IUCN), giving credence and legitimacy to a range of governance regimes, including co-managed, private and community-conserved areas (Borrini-Feyerabend et al, 2004).

\section{DECENTRALIZATION, CONSERVATION AND LOGAL GOVERNANGE}

There seem to be two main drivers of decentralization in least developed countries (LDCs): the first is a major move to rationalize the state and respond to the political demands of societies; the second is an attempt to respond or adjust to demands for environmental justice with regard to resources, benefits, rights and land (or territories). The forms of decentralization and local governance initiatives that are 
described in the literature reflect this multiple demand for actual and symbolic space in national arenas. We distinguish six classes of local constructions that express these complex processes:

1 local governments;

2 CBNRM;

3 subsidiary and advisory bodies;

4 joint or co-managed entities;

5 integrated conservation and development projects (ICDPs), which rely mostly on class 2 and 3 instruments but can be seen as a class by itself;

6 autonomous local action initiatives.

These constructions deploy themselves differently in conservation and natural resource management (NRM) sectors; some are found in both, others are specific to conservation or NRM. The following discussion uses this typology to illustrate the distribution of cases (see Figures 3.2 to 3.4) in NRM and conservation decentralizations and to distinguish them from local autonomous initiatives or 'governance upsurges' driven from below.

\section{ENVIRONMENTAL DEGENTRALIZATIONS AND THE MOVEMENT TO REFORM THE STATE}

Sampled cases from Asia, Africa and Latin America (see Figure 3.2) highlight two types of social constructions that dominate the relationship between natural resource sectors and the movement to reform the state: local governments and CBNRM. In spite of their role in opening environmental governance to social and political pluralism, these constructions share a problem of representation, as expressed in terms of elite capture and tenure conflict.

Current criticisms of environmental decentralizations are highly focused on their 'limited', 'partial' or 'paradoxical' character (Jianchu and Ribot, 2005; Larson and Ribot, 2005; Oyono, 2005) and on the theme of elite capture in CBNRM (Bigombe, 2003; Etoungou, 2003; Resosudarmo, 2005; Blomley, 2006). This is logical. Although CBNRM does not always qualify as decentralization (see Chapter 2 in this volume), it has been a prolific and universal dimension of environmental decentralizations and a core strategy virtually everywhere. Manor's (2005) critique of the 'proliferation' of user committees reflects early views that political decentralization will facilitate the democratic transformation of the state in LDCs along the blueprint of electoral democracy. Based on known shortcomings of user committees - including the fact that they are almost never elected through secret ballots - he questions their representative and democratic credentials, highlights their vulnerability to elite manipulation and calls for an 'integration' that would put user committees under the control of elected councils. This position is different from the point repeatedly made 


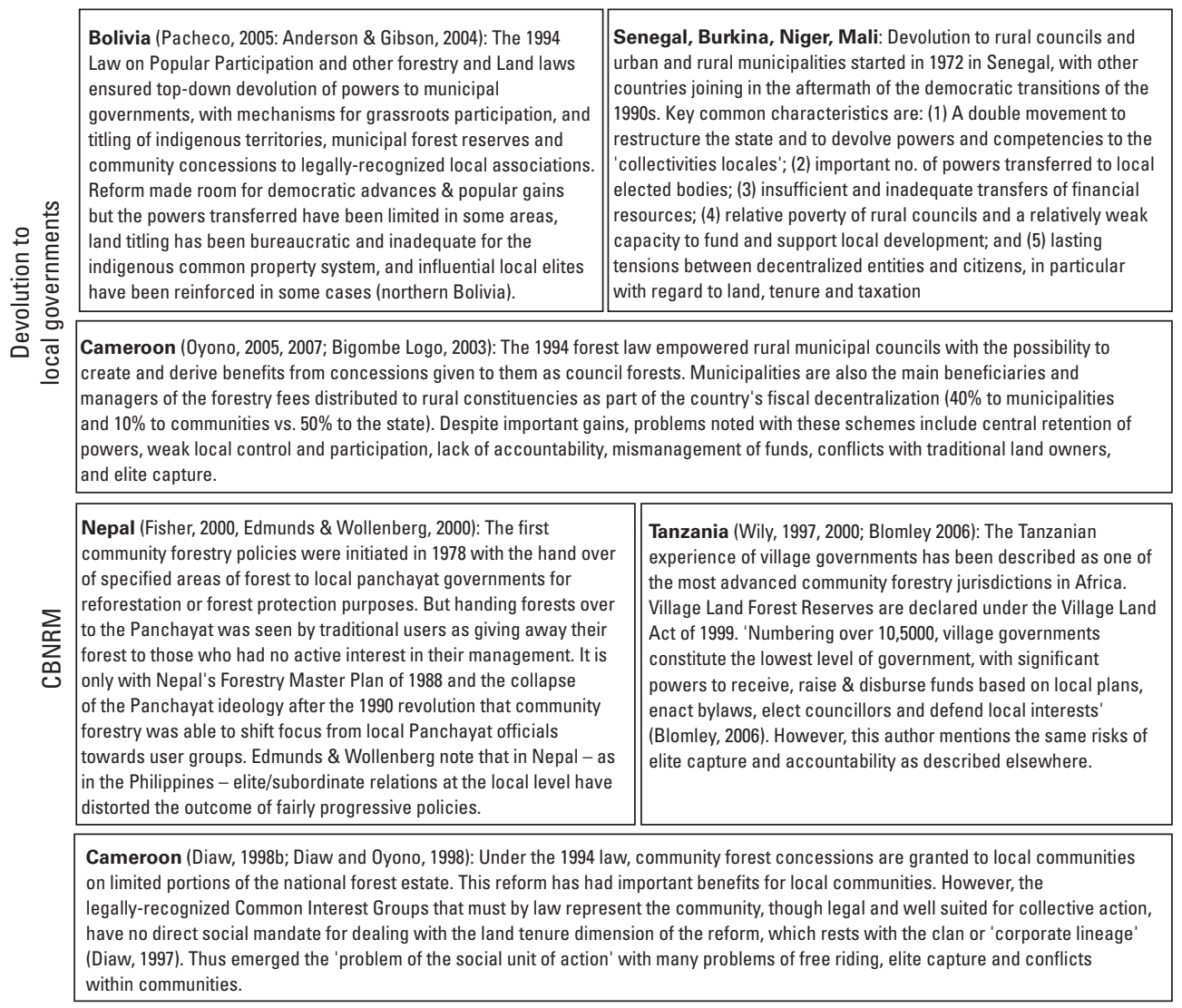

Figure 3.2 Selected cases of environmental decentralization

by Ribot and others that (real or democratic) decentralization has yet to occur in natural resource sectors. This divergence results from the emphasis placed on actors receiving decentralized powers by each author: Manor emphasizes the integrity and supremacy of local state institutions, while Ribot and others implicitly assume that democratic environmental decentralization is feasible with downwardly accountable local committees.

The case studies summarized in Figure 3.2 indicate the reality of the problems highlighted by these authors, particularly accountability and elite capture; but they also underline the strong tenure component of the problems shared by local governments and CBNRM. In West Africa, the old colonial tensions between state and customary law results in difficulties of taxing land and establishing a rural cadastre, and regular demands from elected officials to 'normalize' the local land tenure system. Attempts to establish rural land codes in Benin, Côte d'Ivoire, Guinea and 
Burkina-Faso have similar origins in dualistic land tenure and governance systems. The case of Bolivia and, to a lesser extent, Nicaragua (Larson, 2005) is almost Manor's dream come true because of the central role given to municipalities in achieving general political decentralization as well as decentralization of forest management. Nonetheless, issues of property rights (Andersson and Gibson, 2004), 'clarification of land ownership rights', titling and 'consolidation of rural property cadastre' (Pacheco, 2005) are strikingly similar to the hurdles faced by tenure policies throughout Africa. This is seen in the Cameroonian cases highlighted in Figure 3.2.

The evolution of CBNRM - including the move from panchayats to user groups in Nepal (Fisher, 2000) and through fits and starts of ejidos in Mexico (Wyckoff-Baird et al, 2000) - have been marked by problems similar to those described elsewhere: centralist retention of power, elite capture and complexity of tenure relations, among others. Overall, and despite some achievements and a reliance on a range of organizational tools, NRM decentralizations have been marked by a confluence of problems revolving around issues of representation, legitimacy, democracy and environmental justice. These issues have tended to affect all classes of decentralization instruments, including local governments.

\section{DECENTRALIZATION, PARKS AND CONSERVATION}

Local government is missing from the conservation repertoire, which exhibits an even wider range of decentralization instruments. Considering their form and rationale, we distinguish two classes:

1 CBNRM/community wildlife management (CWM) and integrated conservation and development projects (ICDPs), whose main objective is to fence off people from parks through economic incentives; and

2 subsidiary entities assuming delegated (Guatemala), advisory (Australia, Haiti) or joint management (Australia) roles in the operation of parks (see Figure 3.3).

In the latter, levels of economic and political benefits increase as one moves from delegation to joint management. Bauman and Smyth (2007) document this in their study of advisory and joint management cases in Australia. We distinguish these limited decentralization schemes, where the state delegates powers to local bodies or creates space for their participation in the management of protected areas, from CWM projects and ICDPs initiated and/or driven by conservation NGOs. In all cases, land rights and democratic decision-making stand as key governance issues, with elite capture a minor theme.

As reported in the literature and illustrated by the CAMPFIRE and COVAREF cases (see Figure 3.3), CWM generates significant benefits for communities. They remain, however, within the broad confines of the social fencing paradigm - wherein people have economic incentives to form a protective belt around parks. CBNRM and CWM projects in the periphery of parks are included in so-called second-generation 


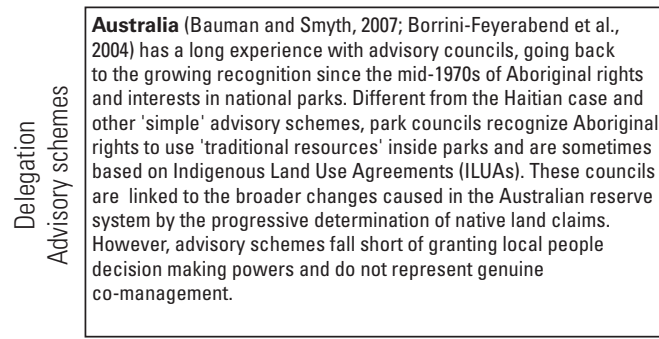

Haiti (Smucker and White, 1998): Local Consultative Councils established by the Forest and Parks Protection Project (1997) are co-management bodies operating under the authority of park managers. They drew their membership from peasant organizations and elected local government officials but became dominated by appointed MPs, bureaucrats and regional delegates of the presidency Guatemala (Whyckoff-Baird et al., 2000). The Sierra de las Minas Biosphere Reserve portrays the delegation by the Guatemalan government of reserve management authority to a national NGO, Defensores de la Naturaleza (Defenders of Nature). In administering the reserve, Defensores works with a diversity of actors, including local communities. This is a case of delegation of decision-making.

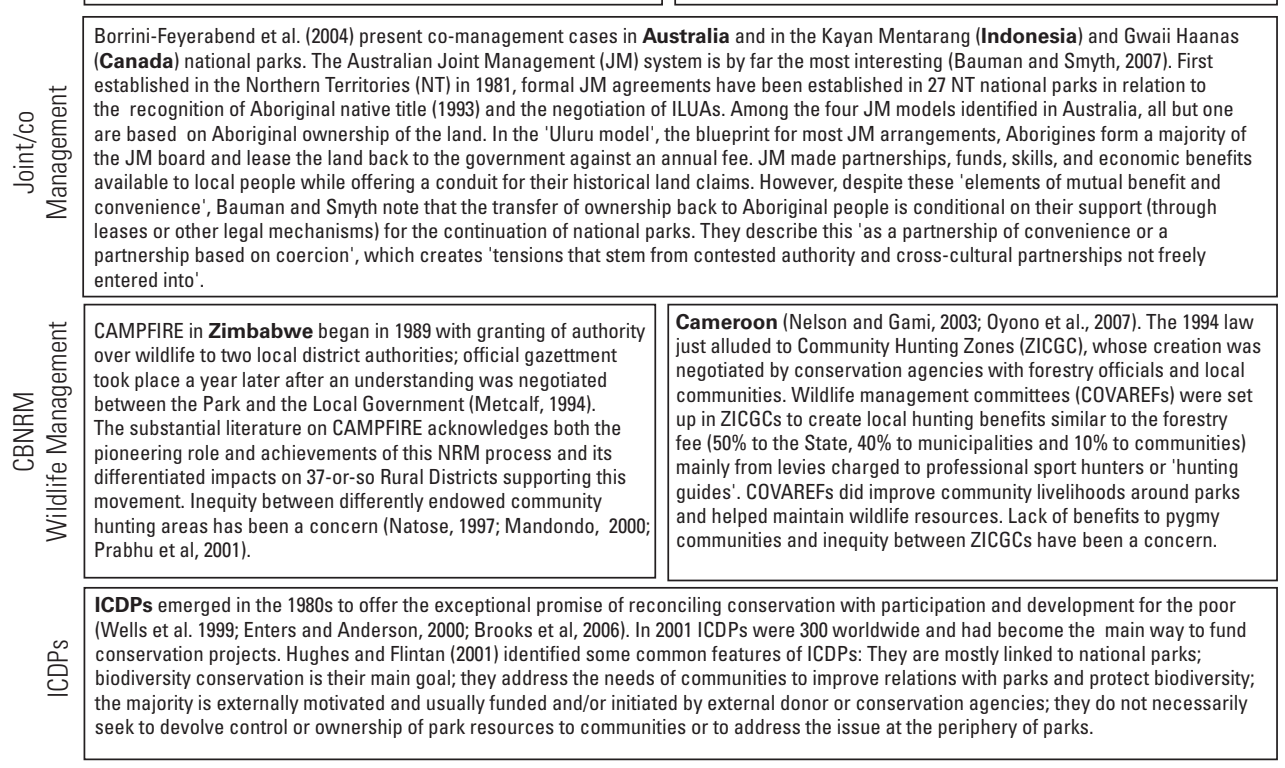

Figure 3.3 Decentralization schemes in park management

integrated conservation and development projects (Hughes and Flintan, 2001). ICDPs are considered a form of devolution in the literature (Brooks et al, 2006; Enters and Anderson, 2000), but it is difficult to see powers devolved to local government or communities in any ICDP; rather, the lack of devolution or ownership of parks resources is a common feature of ICDPs (Hugues and Flintan, 2001).

After strings of reports pointing to their 'disappointing' and 'discouraging' results (Wells et al, 1999; Enters and Anderson, 2000; Newmark and Hough, 2000), ICDPs, once the flagship of conservation projects, have become the target of a full conservationist backlash. In a series of books and articles published in the late 1990s and loaded with emotional titles on behalf of 'Nature' (Kramer et al, 1997; Brandon et al, 1998; Oates, 1999; Terbogh, 1999), leading conservation biologists criticize their failure to adequately protect biodiversity and advocate rolling back the limited participatory trends of the 1990s. At the core of some arguments is a double rejection of development and sustainability as a myth that 'the United Nations and lending 
institutions are ... continuing to propagate' (Soulé and Terbogh, 1999). These authors propose expanding the areas under 'strict protection' to form developmentfree interconnected ecosystems through entire regions and across continents (Soulé and Terbogh, 1999). For some this should be done through 'top-down' impositions, backed by the state and the military and including internationally financed 'naturekeeping forces' (van Schaik and Kramer, 1997; Rabinow, 1999; Terbogh, 1999). ${ }^{1}$

This radical return to fortress conservation fails to examine what we consider the fundamental flaw of ICDPs: their common design principle in the spatial and social separation of conservation from development rather than their 'integration' through genuine local agency. Most ICDPs are meant to be a trade-off in which people give up their land in exchange for 'development'. Whether through forced resettlement (Diaw and Tiani, in press) or social fencing in buffer zones, the main ICDP strategy has been to prevent people from accessing and using traditional park resources, which has been a structural cause of conflict and failure for both conservation and development.

The picture, thus, coming out of ICDPs but also of community-based schemes primarily aimed at keeping legitimate indigenous claimants out of national parks, is their incomplete nature. The full extent of local people's entitlements and democratic right to make decisions about their lands has been rarely recognized. Recent history shows that this can hardly last. The hard-line bio-centric critiques of ICDPs that we cited above, as well as new defensive postures justifying human displacement from protected areas (Maisels et al, 2007), are both in need of a closer look if they want conservation ideals to survive and strive in the increasingly populous and democratic world of the 21 st century.

\section{LOCAL UPSURGES IN ENVIRONMENTAL GOVERNANCE}

There is a surprisingly large and growing number of community conservation initiatives taking place outside the formal confines of decentralization laws or conservation projects. We will discuss later their significance for political theories of democratic governance. The cases selected - spanning Africa, Asia and Latin America (see Figure 3.4) - all demonstrate the capacity of local society to formulate and carry out conservation endeavours that are profoundly liberating, without necessarily resorting to the discursive and instrumental rationality of conventional forms of decentralization, conservation and electoral democracy.

Common characteristics of these cases are their emergence from local contexts and the fact that the governance design, political structure and practical orientation of NRM is in the hands of local people. In all cases, communities, diversely inspired by their leaders and elders, took steps on their own initiative to protect natural resource areas for the benefit of their communities; they also developed bylaws to adequately protect and manage these areas. The Gambian case looks the closest to classic CBNRM; it is also a rare instance of spontaneous establishment of a community forest. The attempt to 'capture' such initiatives by formal CBNRM or JFM schemes in 
India: Khotari and Pathak (2006) reviewed autonomous community conserved areas inspired by social movements in the states of Orissa, Maharashtra and Nagaland. Based on the revival of tribal cultural identity and greater control over land and resources, the late 1970s Ranapur people's conservation movement in Orissa and selfrule movement in Maharashtra share important features: a sense of impending ecological disaster following destructive pressures on forests, self-initiated forest protection and forest use regulation, and local and supra-local organizations organically linked to village clans and capable of unifying and leading the community in its search for self-governance. In Nagaland, dozens of such initiatives developed across the state in the 1990s. In the Phek District, all 80 villages of Chakesang shifting cultivators and hunter gatherers joined in 1999 to form the Chakesang Public Organization and ban destructive modes of hunting, fishing and burning. By 2005, 23 villages took the additional resolution to declare inviolate wildlife reserves. In anothe part of the state, the Council of Khonoma, a 700-year old village of traditional Anami hunters and warriors, created the Khonoma Nature Conservation and Trapogan sanctuary, following 18 years of campaigning led by a village elder.

Australia (Bauman and Smyth, 2007). There are now 22 IPAs (Indigenous Protected Areas on $\sim 20 \%$ of the landed Australian conservation state. IPAs emerged over the last 10 years partly as a result of Aboriginal land claims in the 1970s and 1980s. The first legal claim was brought against a mining company by Aboriginal people in the Dhimurru area to assert their traditional land ownership under customary law. The Federal Court denied the claim, but the Aboriginal Land Rights (NT) Act of 1976 was later passed following a Royal Commission on Aboriginal land rights. The 1992 High Court Mabo native title decision led to further recognition of indigenous ownership and laws as part of Australian common law. The Dhimurru Land Management Aboriginal Corporation was established in 1992 as part of this process by 11 clans whose lands were impacted by mining. The Chimurru IPA was declared in 2000 though traditional owners repeatedly declined in the 1990s to enter JM arrangements with the NT government. The clan groups accepted to join the PA system only after the IPA concept was developed. Dhimurru has so far been a success, with full Aboriginal control and benefits from a wide range of partnerships and opportunities.
Panama: The Study Project for the Management of the Wildlands of Kuna Yala, PEMASKY, in 1983 (Whyckoff-Baird et al., 2000; Cook, 2004; Brosius et al., 2005) aimed at establishing a 60,000-ha protected rainforest as a buffer against outside encroachments and other projected effects of the Pan-American Highway. Governed by a Kuna General Congress, the Kuna have been granted legal autonomy on their tribal lands by the Panamanian government in 1938. This autonomous conservation initiative by an indigenous people attracted heaps of funding from conservation agencies; unfortunately, the high expectations from outsiders outgrew the project's capacity, hastening its demise.

Senegal: The Areas of Community Heritage (Lariviere \& Sylla, 2003) are 'consensual indigenous initiatives' 'to protect a natural or cultural heritage site of particular interest to local people'. They can gain legal recognition by means of a convention with state services. The movement was initiated in 1987 in the Somon Laguna by an association of about 100 women organizing to restore vegetation around a natural reserve close to their village. Sixteen years later, they had established a sustainable development programme - the Natural Community Space Ker Cupaam led by a collective of 1,500 women and involving a population of 35,000 people. Similar initiatives were launched afterward in the Tengen Island, the Seseen forest, the Lake Wuy, the Dindefelo Falls and the Pincoor laguna. At the suggestion of UNESCO, the concept was disseminated in West Africa, with six francophone countries declaring their interest in adapting the concept to their national legislations.

The Gambia (Diaw, 1999, unpublished field data). The Kwashorko Community Forest in Tumani Tenda is a rare case of autonomous CBNRM. It was self-initiated by village members to fight annual bush fires before being co-opted eight years later by the official community forest programme. Unfortunately, the community did not secure clauses protective of its autonomy of decision-making. Thus, after Tumani Tenda won the First National Environmental Award, it was forced into a dispute with the National Environmental Agency that would not allow it to spend the 70,000 dalasi ( 7,000 USD) prize on an eco-tourism centre. This is different from the Maharashtra case (Khotari and Pathak, 2006) where villages co-opted by the JFM programme introduced extraordinary provisions guaranteeing the primacy of their needs and forest management rules.

Figure 3.4 Cases of selfinitiated popular environmental movements

The Gambia as in Maharashtra (Khotari and Pathak, 2006), and also by formal conservation regimes in the case of PEMASKY, points to the difficulty of balancing local autonomy with the need for external partnerships and support. The Australian cases (see Figures 3.3 and 3.4) document this question in the evolutions of joint management and indigenous protected areas (IPAs). Bauman and Smyth (2007) found that both regimes have institutional and economic advantages over conventional park management, but that IPAs are superior in allowing real indigenous ownership and better returns from external partnerships.

Overall, local governance upsurges, diversely rooted in communal and tribal identities, in indigenous land struggles (Australia, India and Panama) as in more benign environmental demands (Senegal and Gambia), demonstrate the possibility of governing the environment from below by mobilizing local institutions and politics or by transforming them. This is most strongly expressed in the central role of clans and elders in village-level institutions and supra-local federations that supported Indian popular movements and Australian land claims. This is significant. A long anthropological tradition has shown the corporate nature and political functions of 
these kin groups (Fortes and Evans-Pritchard, 1940; Fortes, 1945; Middleton and Tait, 1958; Shu, 2004) and their role in social reproduction and tenure regimes (Diaw, 1997, 2005a). Often invisible, they are the real decision-making centre in scores of tenure situations; ignoring them has been a constant source of environmental setbacks. The popular movement that we described thus had the combined advantage of social rootedness and political relevance, enabling them to be legitimate and effective players in the environmental politics of the time.

\section{BLOOD RIGHTS, CIVIL RIGHTS AND DEMOGRACY: A CONVERSATION ON LOCAL GOVERNANGE}

The question of power capture is an all-embracing theme of the decentralization literature. Kate Farrell (2004) makes the case that 'fugitive power' - the propensity of power to operate beyond the law and beyond the scope of legitimating structures - is an emergent property of political systems. This means that, given sufficient conditions, power will 'naturally' evolve out of the reach of the institutional structures that give it legitimacy and make its exercise possible (following Arendt's note that legitimacy is necessary to the exercise of power). Democracy is therefore a constant quest for recapturing power in order to improve legitimacy and governance. The key question is about the 'sufficient conditions' that make these escapades of power such a recurring characteristic of decentralization.

\section{Blood rights, civil rights and the state}

As noted by Jacob and Blundo (1997), decentralization, as 'a social project' in Africa, was from the start an attempt to break away from the dualist urban-rural dichotomy and to do away with 'multi-centricity' by concentrating local flows of resources around a unique legal entity. In the language of political sociology, a social project is a transformative project at the scale of entire societies. 'Land tenure nationalism' in Africa, during the 1960s and 1970s, was part of the broader project to 'modernize' African societies in accordance with the European model (Diaw and Njomkap, 1998). In order to build the nation state, it was considered essential to break the communal basis of land tenure systems - to 'detribalize' them, in the words of Melone (1972). In a review of the tenure profiles of 22 West African countries, Elbow et al. (1998) found that nearly 40 years after independence 64 per cent of the tenure policies did not recognize indigenous tenure or aimed for its replacement, while the remaining third were forms of passive recognition or continuation of the colonial legacy of tribal authority lands. The same study (Bruce, 1998) found that community-based tenure remained the 'de facto dominant tenure type' in almost all sub-Saharan countries. The general situation in Africa is thus one of an uneasy compromise between externally imposed statutory law and embedded tenure ${ }^{2}$ (Diaw, 2005a). This legal pluralism - the coexistence of distinct and competing legal orders - has not been recognized by decentralization and conservation policies. To understand this invisibility of customary 
institutions, one must look at the historical and epistemological conditions that produced their estrangement.

We know since Morgan (1877) that a key to understanding political systems in history is the fundamental opposition between two models of socio-political organization: the 'gentile society' (or community) and the 'political society' (or civil society). In the first, government is exerted through descent groups; in the second it is based on political citizenship and membership in a territory. The first model is founded on blood rights (jus sanguinis), the second on civil rights (or territorial rights, jus soli). These two models still coexist within the modern nation state. In North America and other 'immigration countries', citizenship derives from being born in the country; in most of the old continents, citizenship derives from being born into an existing blood line of citizens. Between the two lies a whole range of accommodations, which are the reality of modern citizenship and its actualization in plural forms of democratic expression. Thus, the nation state - a 19th-century European invention that became the template for state organization around the planet - shed blood rights as an organizing principle of the state while retaining it in the political construction of citizenship and national identity. This discrepancy is often subdued or invisible, although it can be seen in the difficulties of immigrants' children to gain citizenship in European countries or in various identity crises, civil rights movements and ethnic confrontations. Places where it is the most subdued but also the most widespread are in rural regions of the global South where blood rights are not just manifestations of ethnic identity but organizing principles of the indigenous economy and institutions. These are the places most targeted by decentralization. Figure 3.5 represents the theoretical continuum between civil and blood rights.

Decentralization is an integral part of the formation and transmutation of the nation state, which, in and of itself, is part of a broader movement to rationalize societies in line with the organizing principles of a globalized capitalist economy. This is why the role of the state and multilateral institutions in privatization and land reform programmes has been so central. In The Origins of Our Time: The Great Transformation, Karl Polanyi (1944) showed that the secret of the 19th-century liberal economy has been the 'disembedding' of the economy from society and the invention of specific market institutions around which society became organized. In contrast to pre-capitalist society (and many societies of the modern South), social relations became embedded in the market instead of the market being embedded in social relations (Polanyi Levitt, 2003). Globally, this triple movement to rationalize the state, society and the economy is largely incomplete. There has been extraordinary resilience of alternate political, social and economic forms, which the Western modernist paradigms that dominate scientific thought and political thinking in the South stubbornly refuse to see or recognize.

In preceding works (Diaw, 1998a, 2005a), we showed how this 'alterity' - this 'other way of being' - manifests itself in various economic expressions, including resilient embedded tenure regimes. This system has shown an ability to adapt to markets as well as demographic and political pressure and to support effective forms of local and supra-local governance (as we saw in the Panamanian, Australian and Indian self-rule and popular conservation movements). Its continuing existence is a primary reason for legal pluralism in the rural South. 


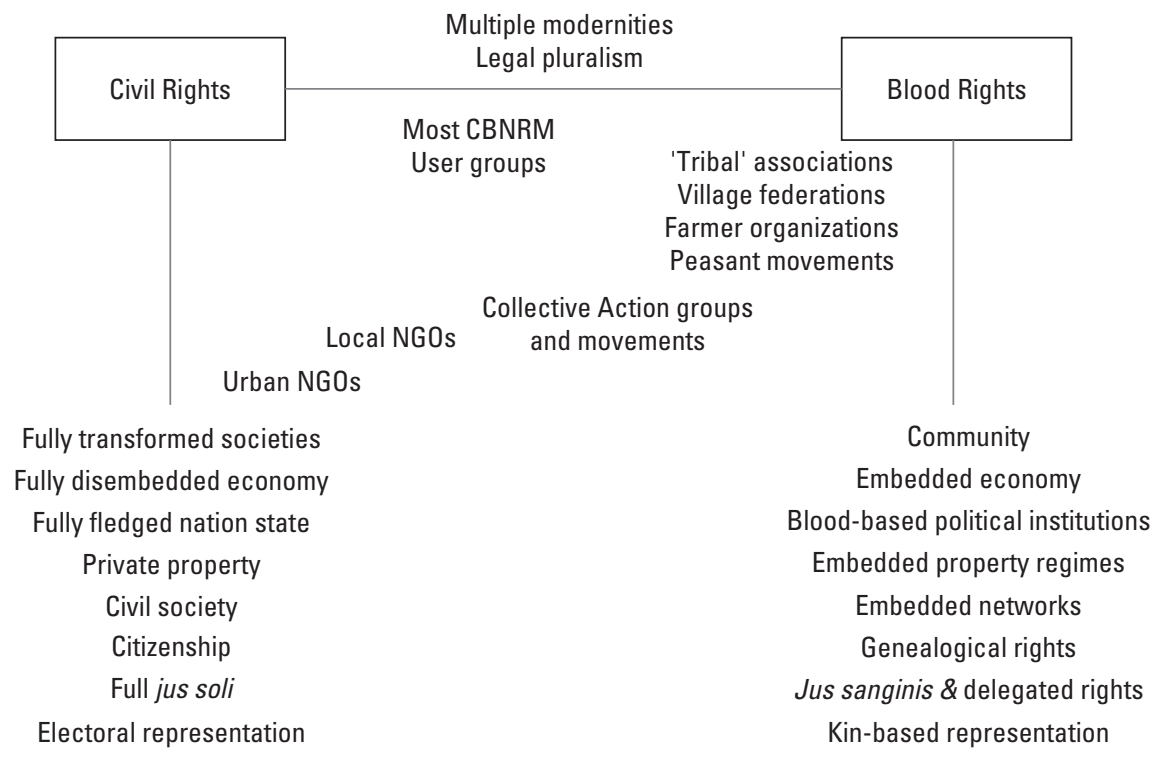

Figure 3.5 A representation of the continuum between civil rights and blood rights

\section{POLITICS, CONSERVATION AND DEMOGRACY}

Recognition of the coexistence of blood rights and civil rights in modern societies and its manifestation in various legal accommodations highlights important conditions for inclusive local governance. The first is the plural, dual or nested nature of the political sphere in many LDCs. Two sets of socio-political spheres are thus juxtaposed: a superstructure based on formal democratic institutions, private titles and civil society, and an infra-structure of embedded rights, strongest in rural areas and generating a separate regime of entitlements, representation and legitimizing networks. In many regions, the latter has been on the receiving end of development, conservation and land/environmental reform programmes; it has also been an unruly site of resistance to the meta-programme of modernization launched with colonialism more than a century ago. Democracy and local governance cannot be achieved when the legitimizing discourse and procedures of the institutional and political order are structured to make the second sphere invisible. In creating favourable conditions for fugitive power, this has been a problem for both democratic decentralization and conservation.

The concept of democratic decentralization is actually quite intriguing. Democracy is not a univocal concept or cookbook of familiar procedures to account for political preferences; electoral democracy is but one means of exercising voice in the social space. At a deeper level, democratic governance is a congruence of social 
and political entitlements including recognition, voice, legitimacy, rights and collective responsibility; though essential to democratic governance, accountability is a dimension of responsibility that does not need secret ballot to exist. Many of the conservation laws that made possible the expropriation of thousands of people without tangible evidence of benefits for nature or for people were voted by elected parliaments and carried out by representative governments; this did not necessarily make them legitimate, which is why so many of these actions spin off into new problems and social conflict. In park management, the law is often used as 'legal fencing': a discursive procedure aimed at closing off the public debate or restricting democratic deliberation (Diaw and Tiani, in press). The de-gazetting of Amboseli National Park in Kenya, an act which created an uproar within the conservation community - with accusations that the move was politically motivated to win the Masai vote in the 2005 referendum, illustrates the short-sightedness of democratic closure. That conservation expunged democracy from its discourse may reflect the fact that its 'morally superior arguments' have more to do with political influence and reasons of state than the will of the people. Democracy has been an elusive dimension of conservation, and the resulting deficit of legitimacy has made many apparent gains fragile and uncertain in the long run.

\section{SPACE-TAKING, SPACE-MAKING AND SPACE-GRANTING: ALTERNATIVE PATHS FOR LOGAL DEMOGRATIC GOVERNANGE}

In environmental governance, local groups have taken spaces on their own initiative and in ways not anticipated by governments and conservation development planners. Manor (1999) intentionally excludes voluntary grassroots movements emerging out of 'failed states' from his typology of decentralization. He accepts, however, cases of 'inadvertent decentralization' - when, as in China and Russia, policy innovations produce 'unintended decentralization of power and resources'. In our view, the former belongs to the class of unanticipated local agency driven from below. We call this space-taking as a metaphor stressing the role of citizens and communities as 'moving democratic subjects' of local governmentality.

By linking space-taking to the other twin dimensions of space-making and spacegranting, we also outline conditions for creative governance in a post-conflict society. In fact, decentralization would be better off creating and granting space for local agency rather than trying to over-define how local actors should organize. Agency is the capacity of social actors to express volition and to formulate and carry out their own social projects. For this to happen in a non-conflictive manner, it requires from the actors in power (most notably, the state, projects and corporations) a significant capacity to 'make space' for this to possibly happen or, minimally, to grant that space once it is already in the process of being taken.

The Indian case of Negaland is typical of space-making because of the state's progressive position of placing political and natural resource decision-making in the 
hands of local communities (Kothari and Pathak, 2006). In the cases of Marahashtra, Senegal, Panama, or in the Australian land claims, it was more a question of space granting; both capacities are, however, vitally important to local governance. The International Model Forest Network, which has been working in four continents since 1994 to establish landscape-scale partnerships governed by local actors themselves (Besseau et al, 2007), is yet another example of creating space around a core set of shared values, and then letting people sort out the rest for themselves. In the Cameroon model forest experience (Jum et al, 2007), it was found that such an approach could actually expand the space for decentralization by bringing together different local constructions into a locally driven collaborative agenda.

These are important discussion points for a concept of democracy that goes beyond simple electoral politics to challenge more complex concepts of deliberative democracy and social movements. Deliberative democracy, which runs deep in the writings of Rawls and Habermas (1995), is based on principles of inclusion, argumentation and deliberation in the formation of democratic decisions - and is not just about voting or electing representatives. There is, nonetheless, an implicit assumption of social homogeneity, which social movement theorists consider with suspicion on the grounds that the less powerful need to mobilize in ways and with means other than deliberation in order to have their voice heard and their interests accounted for. This streak of thinking was expressed in the decentralization literature through the works of Wollenberg et al (2001), which stand apart from the electoral accountability paradigm found in the works of Manor and Ribot. By recognizing the possible coexistence of these three paradigms (deliberation, social movements and accountability) in the materialization of multilevel pluralist governance, we posit that none of them can alone address socio-political determinations in the societies that constitute the subject of this conversation. To address not just representation or power but deeper questions of cultural identity, legal pluralism and economic alterity, a multilayered concept of governance has to be formulated. Kate Farrel (2006) advocates for an iterative deliberative process across a range of discourses and levels in order to address the 'representation gap' inherent to stakeholder consultations, citizen juries, consensus conferences and other forms of deliberative democracy. In our experience with adaptive collaborative management, we found that iteration together with interaction and negotiation of meanings has the potential to bring conflicts to levels where they can be deliberated over and transformed (Diaw et al, 2009). Our experience with the Model Forest Network further suggests the possibility of entering the local governance field in ways not anticipated by decentralization reforms but contributing to expanding their scope and democratic content.

\section{CONCLUSIONS}

Our main objective in this chapter is to highlight the need for more complex concepts of environmental governance and democracy. We started the conversation by highlighting the different historical and philosophical roots of decentralization and conservation, and concluded by pointing out their democratic deficit resulting 
from their reluctance to fully integrate the pluralism of local societies in their theoretical outlook and policy orientations. Following this thread, we described various forms of decentralization and NRM. More importantly, we distinguished decentralization from locally driven governance upsurges and showed the fertilizing nature, for both conservation and democracy, of manifestations of local agency.

At its heart, decentralization is but an extension of the historic movement of the state to penetrate and rationalize society along modernist ideals; as such, it should not be confounded with the multi-form 'taking of space' that characterizes local and trans-local governance. The move from government to governance implied by environmental decentralization cannot lead to predefined, singular social processes or environmental outcomes. A shift of perspective is thus necessary, considering that this type of governance necessarily happens at multiple scales; involves a range of actors, values and land uses; and requires social negotiation, trade-offs and enhanced capability to work cooperatively to deal with unexpected outcomes.

\section{NOTES}

1 See also the analyses of Brechin et al (2002), Wilshusen et al (2002) and Diaw (2005b).

2 By embedded tenure, we refer to an appropriation regime where private, shared, and collective rights to natural resources are nested within one another and within larger social institutions based on kinship and descent.

\section{REFERENCES}

Adams, W. and D. Hulme (2001) 'Conservation and community: Changing narratives, policies and practices in African conservation', in D. Hulme and M. Murphree (eds) African Wildlife and Livelihoods: The Promise and Performance of Community Conservation, James Currey, Oxford, pp9-23

Adams, W. M., R. Aveling, D. Brockington, B. Dickson, J. Elliott, J. Hutton, D. Roe, B. Vira, and W. Wolmer (2004) 'Biodiversity conservation and the eradication of poverty', Science, vol 306, pp1146-1149

Agrawal, A. and J. Ribot (1999) 'Accountability in decentralization: A framework with South Asian and West African cases', Journal of Developing Areas, vol 33, summer, pp473-502

Andersson, K. P. and C. C. Gibson (2004) 'Decentralization reforms: Help or hindrance to forest conservation?', Paper presented at the Conference of the International Association for the Study of Common Property (IASCP), Oaxaca, Mexico, 9-13 August 2004

Assembe, A. M. and P. R. Oyono (2004) 'An assessment of social negotiation as a tool of local management: A case study of the Dimako Council Forest, Cameroon', Scandinavian Journal of Forest Research, vol 19, supplement 4, pp1-7 
Bauman, T. and D. Smyth (2007) Outcomes of Three Case Studies in Indigenous Partnerships in Protected Area Management, Australian Institute of Aboriginal and Torres Strait Islander Studies and the Australian Collaboration, Canberra

Besseau, P., W. Alvarado, R. Calumbay, P. Daloos, R. Imperial, L. Jones, C. Jum, C. Mooney, J. Svensson, G. P. Telitsyn and L. Wagan (2007) 'The Model Forest experience in using broadbased partnerships for sustainable forest management', In Y. C. Dubé and F. Schmithüsen (eds) Cross-Sectoral Policy Developments in Forestry, FAO and CABI International, Rome, pp71-81

Bigombe, P. (2003) The Decentralized Forestry Taxation System in Cameroon: Local Management and State Logic, Environmental Governance in Africa Working Papers no 10, WRI, Washington, DC

Blomley, T. (2006) Participatory Forestry within the Local Government Reform Process in Tanzania, Gatekeepers Series no 128, IIED, London

Borrini-Feyerabend, G., A. Kothari and G. Oviedo (2004) Indigenous and Local Communities and Protected Areas: Towards Equity and Enhanced Conservation, Best Practice Protected Area Guidelines Series no 11, Cardiff University and IUCN, Cambridge and Gland

Bradshaw, C. J. A., N. S. Sodhi, K. S. H. Peh and B. W. Brook (2007) 'Global evidence that deforestation amplifies flood risk and severity in the developing world', Global Change Biology, vol 13, no 11, pp2379-2395

Brandon, K., K. H. Redford and S. E. Sanderson (1998) Parks in Peril: People, Politics and Protected Areas, Island Press, Washington, DC

Brechin, S. R., P. R. Wilshusen, C. L. Fortwangler and P. C. West (2002) 'Beyond the square wheel: Toward a more comprehensive understanding of biodiversity conservation as social and political process', Society and Natural Resources, vol 15, no 1, pp41-64

Brockington, D. (2002) 'Fortress conservation: The preservation of the Mkomazi Game Reserve, Tanzania', in African Issues, James Currey and Indiana University Press, Oxford and Bloomington

Brooks, J. S., M. A. Franzen, C. M. Holmes, M. N. Grote and M. Borgerhoff Mulder (2006) 'Testing hypotheses for the success of different conservation strategies', Conservation Biology, vol 20, no 5, pp1528-1538

Brosius, J. P. (1999) 'Analyses and interventions: Anthropological engagements with environmentalism', Current Anthropology, vol 40, no 3, pp277-309

Brosius, J. P., A. Lowenhaupt Tsing and C. Zerner (eds) (2005) Communities and Conservation: Histories and Politics of Community-Based Natural Resource Management, Alta Mira Press, Lanham, MD

Bruce, J. W. (ed) (1998) Country Profiles of Land Tenure: Africa, 1996, Land Tenure Center Research Paper no 130, Land Tenure Center, Madison, WI

CIFOR (Center for International Forestry Research) (2005) Forests and Floods: Drowning in Fiction or Thriving on Facts?, Forest Perspectives no 2, CIFOR/FAO, Bogor and Rome

Cook, H. (2004) 'The end of the road: The Darien Jungle', International Journal of Wilderness, vol 10, no 1, pp41-44

Del Río, L. S. (2004) 'Decentralization and democratic governance in Mexico', in J. S. Tulchin and A. Selee (eds) Decentralization and Democratic Governance in Latin America, Woodrow Wilson Center Report on the Americas no 2, Woodrow Wilson Center, Washington, DC, pp167-186 
Diaw, M. C. (1997) Si, Nda bot and Ayong: Shifting Cultivation, Land Use and Property Rights in Southern Cameroon, Rural Development Forestry Network Paper no 21e

Diaw, M. C. (1998a) From Sea to Forest: An Epistemology of Otherness and Institutional Resilience in Non Conventional Economic Systems, International Association for the Study of Common Property, Vancouver, BC

Diaw, M. C. (1998b) Anthropological Institutions and Forest Management: What Institutional Framework for Community-Based Forest Management in Cameroon?, Acts of the Workshop on Community-Based Forest Management in Cameroon, WWF, Yaoundé

Diaw, M. C. (2005a) 'Modern economic theory and the challenge of embedded tenure institutions: African attempts to reform local forest policies', in S. Kant and A. Berry (eds) Sustainability, Institutions and Natural Resources: Institutions for Sustainable Forest Management, Springer, Amsterdam, pp43-81

Diaw, M. C. (2005b) 'Scales in conservation theories: Another clash of civilizations?', in J. Young, A. Báldi, L. Benedetti-Cecchi, A. Bergamini, K. Hiscock, S. van den Hove, T. Koetz, E. van Ierland, A. Lányi, G. Pataki, C. Scheidegger, K. Török and A. D. Watt (eds) Landscape Scale Biodiversity Assessment: The Problem of Scaling, Report of an electronic conference, Institute of Ecology and Botany of the Hungarian Academy of Sciences, Vácrátót, Hungary, pp145-146

Diaw, M. C. (in preparation) Quelles Echelles de Gouvernance de la Biodiversité? La Globalisation du Discours Environnemental et la Construction Sociale de la Diversité

Diaw, M. C., and T. Kusumanto (2005) 'Scientists in social encounters: The case for an engaged practice of science', in C. Colfer (ed) The Equitable Forest: Diversity, Community and Resource Management, RFF Press and CIFOR, Washington, DC and Bogor, pp72-109

Diaw, M. C. and J. C. Njomkap (1998) La Terre et le Droit : Une Anthropologie Institutionnelle de la Tenure Coutumière, de la Jurisprudence et du Droit Fonciers chez les Peuples Bantous et Pygmées du Cameroun Méridional Forestier, Inades-Formation, Yaoundé

Diaw, M. C. and A. M. Tiani (in press) 'Fences in our heads: A discourse analysis of the Korup resettlement stalemate', Journal of Sustainable Forestry

Diaw, M. C., T. Aseh and R. Prabhu (2009) In search of Common Ground: Adaptive Collaborative Management in Cameroon, CIFOR, Bogor, Indonesia

Elbow, K., K. Bohrer, R. Furth, M. Hobbs, A. Knox, S. Leisz and M. Williams (1998) 'Land tenure country profiles, West Africa, 1996', in J. W. Bruce (ed) Country Profiles of Land Tenure: Africa 1996, Land Tenure Center Research Paper no 130, Land Tenure Center, Madison, WI, pp1-136

Enters, T., P. B. Durst and M. Victor (eds) (2000) Decentralization and Devolution of Forest Management in Asia and the Pacific. RECOFTC Report N.18 and RAP Publication 2000/1. Bangkok, Thailand.

Escobar, A. (1998) 'Whose knowledge, Whose nature? Biodiversity, conservation and the political ecology of social movements', Journal of Political Ecology, vol 5, pp53-82

Etoungou, P. (2003) Decentralization Viewed from Inside: The Implementation of Community Forests in East Cameroon, Environmental Governance in Africa Working Papers no 12, WRI, Washington, DC

Faletti, T. (2004) 'Federalism and decentralization in Argentina: Historical background and new intergovernmental relations', in J. S. Tulchin and A. Selee (eds) Decentralization and Democratic Governance in Latin America, Woodrow Wilson Center Report on the Americas no 2, Woodrow Wilson Center, Washington, DC, pp67-100 
Farrell, K. (2004) 'Recapturing fugitive power: Epistemology, complexity and democracy', Local Environment, vol 9, no 5, pp469-479

Fisher, R. J. (2000) 'Decentralization and devolution in forest management: A conceptual overview', in T. Enters, P. B. Durst and M. Victor (eds) Decentralization and Devolution of Forest Management in Asia and the Pacific, RECOFTC Report no 18 and RAP Publication 2000/1, Bangkok, Thailand, pp11-16

Fortes, M. (1945) The Dynamics of Clanship among the Tallensi, Oxford University Press, London Fortes, M. and E. Evans-Pritchard (eds) (1940) African Political Systems, International African Institute, London and New York

Gupte, M. (2006) 'Looking for the silver bullet: The role of communities in conservation', Paper presented at the annual meeting of the International Studies Association, Town and Country Resort and Convention Center, San Diego, CA, 22 March 2006

Habermas, J. (1995) 'Reconciliation through the public use of reason: Remarks on John Rawls's political liberalism', Journal of Philosophy, vol XCII, no 3, pp109-131

Hughes, R. and F. Flintan (2001) Integrating Conservation and Development Experience: A Review and Bibliography of the ICDP Literature, IIED, London

Jacob, J.-P. and G. Blundo (1997) Socio-anthropologie de la Décentralisation en Milieu Rural Africain, Bibliographie selective et commentée, Itinéraires, Notes et Travaux 49, IUED, Geneva

Jianchu, X. and J. C. Ribot (2005) 'Decentralisation and accountability in forest management: A case from Yunnan, southwest China', in J. C. Ribot and A. M. Larson (eds) Democratic Decentralization through a Natural Resource Lens, Routledge, London and New York, pp153-173

Jum, C., C. Diaw, J. Nguiebouri and M. Zoa (2007) 'Enhancing sustainable forest management in Cameroon through a model forest based approach', International Forestry Review, vol 9, no 4, pp892-900

Kothari, A. and N. Pathak (2006) Protected Areas, Community Based Conservation and Decentralisation: Lessons from India, Report prepared for the Ecosystems, Protected Areas, and People Project (EPP) of the IUCN World Commission on Protected Areas, IUCN Asia Regional Protected Areas Programme, IUCN, Gland

Kramer, R. E., C. P. van Schaik and J. Johnson (eds) (1997) The Last Stand: Protected Areas and the Defense of Tropical Biodiversity, Oxford University Press, New York and Oxford

Larivière, J. and S. I. Sylla (2003) Les Aires du Patrimoine Communautaire: Une Nouvelle Catégorie d'aires Protégées, Permettant aux Communautés Locales de Gérer leur Patrimoine Naturel et Culturel selon les Principes du Développement Durable, Policy Matters no 12, pp156-165

Larson, A. (2005) 'Formal decentralisation and the imperative of decentralisation "from below": A case study of natural resource management in Nicaragua', in J. C. Ribot and A. M. Larson (eds) Democratic Decentralization through a Natural Resource Lens, Routledge, New York and London, pp55-70

Larson, A. and J. C. Ribot (2005) 'Democratic decentralisation through a natural resource lens: An introduction', in J. C. Ribot and A. M. Larson (eds) Democratic Decentralization through a Natural Resource Lens, Routledge, London and New York, pp1-25

Leonard, D. and D. Marshall (eds) (1982) Institutions of Rural Development for the Poor: Decentralization and Organizational Linkages, Institute for International Studies, Berkeley, CA Mahwood, P. (1983) 'Decentralization: The concept and the practice', in P. Mahwood (eds) Local Government in the Third World, John Wiley, New York, pp1-22 
Maisels, F., T. Sunderland, B. Curran, K. von Loebenstein, J. Oates, L. Usongo, A. Dunn, S. Asaha, M. Balinga, L. Defo and P. Telfer (2007) 'Central Africa's protected areas and the purported displacement of people: A first critical review of existing data', in K. H. Redford and E. Fearn (eds) Protected Areas and Human Displacement: A Conservation Perspective, Working Paper no 29, Wildlife Conservation Society, New York, pp75-89

Mamdani, M. (1996) Citizen and Subject: Contemporary Africa and the Legacy of Late Colonialism, Princeton University Press, Princeton, NJ

Mandondo, A. (2000) Situating Zimbabwe's Natural Resource Governance Systems in History, CIFOR Occasional Paper no 32, CIFOR, Bogor

Manor, J. (1999) The Political Economy of Decentralization, World Bank, Washington, DC

Manor, J. (2005) 'User committees: A potentially damaging second wave of decentralisation?', in J. C. Ribot and A. M. Larson (eds) Democratic Decentralization through a Natural Resource Lens, Routledge, London and New York, pp192-213

Matose, F. (1997) 'Conflicts around forest reserves in Zimbabwe: What prospects for community management', in M. Leach, R. Mearns and I. Scoones (eds) Community Based Sustainable Development: Consensus or Conflict? IDS Bulletin, vol 28, no 4, pp69-78

Melo, M. and F. Rezende (2004) 'Decentralization and governance in Brazil', in J. S. Tulchin and A. Selee (eds) Decentralization and Democratic Governance in Latin America, Woodrow Wilson Center Report on the Americas no 12, Woodrow Wilson Center, Washington, DC, pp37-66

Melone, S. (1972) La Parenté et la Terre dans la Stratégie du Développement, Klinksienck, Yaoundé and Paris

Metcalfe, S. (1994) 'CAMPFIRE: Zimbabwe's Communal Areas Management Programme for Indigenous Resources' in D. Western and M. Wright (eds) and S. Strum (associate ed) Natural Connections: Perspectives in Community-Based Conservation, Island Press, Washington, DC

Middleton, J. and D. Tait (eds) (1958) Tribes without Rulers, Routledge, London

Morgan, L. H. (1971) (1877) La Société Archaïque, Anthropos, Paris

Neumann, R. P. (1995) 'Ways of seeing Africa: Colonial recasting of African society and landscape in Serengeti National Park', Ecumene, vol 2, no 2, pp149-169

Newmark, W. D. and J. L. Hough (2000) 'Conserving wildlife in Africa: Integrated conservation and development projects and beyond', BioScience, vol 50, no 7, pp585-592

Oates, J. F. (1999) Myth and Reality in the Rainforest: How Conservation Strategies Are Failing in West Africa, University of California Press, Berkeley, CA

Oyono, R. P. (2005) 'The social and organisational roots of ecological uncertainty in Cameroon's Forest Management Decentralisation Model', in J. C. Ribot and A. M. Larson (eds) Democratic Decentralization through a Natural Resource Lens, Routledge, London and New York, pp174-191

Oyono, P. R., J. C. Ribot, S. Assembe and P. Bigombé Logo (2007) Improving Decentralized Forest Management in Cameroon: Options and Opportunities from Ten Years of Experience, Governance Brief no 33, CIFOR, Bogor

Pacheco, P. (2005) 'What lies behind decentralisation? Forest, powers and actors in lowland Bolivia', in J. C. Ribot and A. M. Larson (eds) Democratic Decentralization through a Natural Resource Lens, Routledge, London and New York, pp90-109

Phillips, A. (2003) 'Turning ideas on their heads: The new paradigm for protected areas', in A. Jaireth and D. Smyth (eds) Innovative Governance: Indigenous Peoples, Local Communities and Protected Areas, Anne Books, New Delhi, pp1-27 
Phillips, A. (2004) 'The history of the International System of Protected Area Management Categories', Parks, vol 14, no 3, pp4-14

Polaniyi, K. (1944) The Origins of Our Time: The Great Transformation, Rinehart, New York, NY

Polanyi Levitt, K. (2003) The English Experience in the Life and Work of Karl Polany. Conference Proceedings, Polanyian Perspectives on Instituted Economic Processes, Development and Transformation, ESRC, Center for Research on Innovation and Competition, University of Manchester, Manchester, 23-25 October 2003

Rabinow, A. (1999) 'Nature's last bastions: Sustainable use of our tropical forests may be little more than wishful thinking', Natural History, vol 108, pp70-72

Resosudarmo, I. A. P. (2005) 'Closer to people and trees: Will decentralisation work for the people and the forest of Indonesia?', in J. C. Ribot and A. M. Larson (eds) Democratic Decentralization through a Natural Resource Lens, Routledge, London and New York, pp110-132

Samoff, J. (1990) 'Decentralization: The politics of interventionism', Development and Change, vol 21, pp513-530

Selee, A. (2004) 'Exploring the link between decentralization and democratic governance', in J. S. Tulchin and A. Selee (eds) Decentralization and Democratic Governance in Latin America, Woodrow Wilson Center Report on the Americas no 12, Woodrow Wilson Center, Washington, DC, pp3-36

Shu, P. (2004) 'Lineage making in southern China since the 1980s', 15th Biennial Conference of the Asian Studies Association of Australia, Canberra, 29 June-2 July 2004

Smucker, G. and T. A. White (1998) 'Devolution of protected area management in Haiti: Status and issues', Paper presented at the 7th Conference of the International Association for the Study of Common Property, Vancouver, 9-17 June 1998

Soulé, M. and J. Terbogh (1999) 'The policy and science of regional conservation', in M. Soulé and J. Terbogh (eds) Riding the Tiger: Tiger Conservation in Human-Dominated Landscapes, Cambridge University Press, Cambridge, pp1-17

Terbogh, J. (1999) Requiem for Nature, Island Press/Shearwater Books, Washington, DC

Van Schaik, C. P. and R. A. Kramer (1997) 'Toward a new protection paradigm', in R. E. Kramer, C. P. van Schaik and J. Johnson (eds) Last Stand: Protected Areas and the Defense of Tropical Biodiversity, Oxford University Press, New York and Oxford, pp212-230

Vengroff, R. and A. Johnston (1987) 'Decentralization and the implementation of rural development in Senegal: The role of rural councils', Public Administration and Development, vol 7, no 3, pp273-288

WCED (World Commission on Environment and Development) (1987) Our Common Future, Report of the World Commission on Environment and Development, Zed Books, London

Wells, M., S. Guggenheim, A. Khan, W. Wardojo and P. Jepson (1999) Investing in Biodiversity: A Review of Indonesia's Integrated Conservation and Development Projects, World Bank, Washington, DC

Whyckoff-Baird, B., A. Kaus, C. Christen and M. Keck (2000) Shifting the Power: Decentralization and Biodiversity Conservation, Biodiversity Support Program, Washington, DC

Wilshusen, P. R., S. R. Brechin, C. F. Fortwangler and P. C. West (2002) 'Reinventing a square wheel: Critique of a resurgent "protection paradigm" in international biodiversity conservation', Society and Natural Resources, vol 15, no 1, pp17-24

Wily, L. A. (1997) Villagers as Forest Managers and Governments 'Learning To Let Go': The Case of Duru-Haitemba and Mgora Forests in Tanzania, Forest Participation Series no 9, IIED, London

Wily, L. A. (2000) 'Forest law in Eastern and Southern Africa: Moving towards a community based forest future?', Unasylva, vol 203, www.fao.org/DOCREP/X8080E/X8080e04.htm\#PO_O 
Witherell, E. and E. Dubrulle (1995) Life and Times of Henry David Thoreau, First edition published in 1971 in J. L. Shanley (ed) Walden, Princeton University Press, Princeton, NJ; available at: http://www.library.ucsb.edu/thoreau/thoreau_life.html, accessed 30 March 2008

Wollenberg, E., E. J. Anderson and D. Edmunds (2001) 'Pluralism and the less powerful: Accommodating multiple interests in forest management', International Journal of Agricultural Resources, Governance and Ecology, vol 1, no 3/4, pp192-222 


\section{Chapter 4}

\section{The New Economic 'Great Game' in Africa and the Future of Governance Reforms in the Forest Sector}

Alain Karsenty

\section{INTRODUCTION}

A new global architecture for trade in forestry products is taking shape. Emerging economies, spearheaded by China, are buying timber, making investments and funding governments of resource-rich African countries. This trend has weakened the influence of financial institutions such as the World Bank, whose actions in the forest sector focus on policies and governance, both of which may be strongly shaped by this trend in the future. One stumbling block in World Bank-led reforms designed to promote sustainable forest management and advance governance is the malfunctioning of political institutions. Economic instruments for forest governance should be underpinned by satisfactory law enforcement and relative abnegation of personal interests by government agents. Donors and external advocates of reforms implicitly feel that governments are either potential sources of reform directed to the general good or, on the contrary, are more interested in developing personal interests that justify extensive privatization. Despite certain promising innovations such as independent observers, too little attention is being given to a different type of state construct that favours institutionalized checks and balances. And too much is being expected from community forest management as an alternative to state reforms. Substantial funding can be expected from initiatives taken under the reducing emissions from deforestation and degradation (REDD) mechanism and should, in part, pay for environmental services, thus creating new income from conservation. These 'conservation rents' will raise the stakes between and within communities; commitments that allow accountability mechanisms to develop at both national and local levels will therefore be essential to the future development of forest governance. 


\section{THE NEW 'GREAT GAME’ IN AFRICA}

During the 19th century, imperial Russia hoped to take control of the warm water ports in the Persian Gulf, but was deterred by the ambitions of a British Crown wishing to expand its zone of influence from India. The Persians found themselves in the crossfire of this rivalry, which led to the creation of Afghanistan as a buffer state. This was the 'The Great Game'l that journals of the time depicted as a clash between the Russian bear, the British lion and the Persian cat (representing the Shah) (Figure 4.1). This expression is used regularly to refer to strategic rivalries between powers seeking control over important geographic areas or prime resources.

Throughout history, Western countries and their business interests have dominated the economies of Africa; but now these countries are on the defensive. The emerging economies, with China in the lead, are now seen to be the protagonists of a new rivalry in Africa with high stakes - namely, access to natural resources and, to a lesser extent, markets.

The World Bank and other key international organizations striving to make access to natural resources more transparent through improved governance are feeling their influence eroding, and sense that changes many analysts felt were inevitable - such as devolution of forest management rights - may be called into question. The autonomy of African governments must also be factored in since they have become masters in the art of maintaining certain interests in tact while at the same time reforming the forest and mining sectors. The arrival of a giant such as China in the African political-economic game allows African states to enjoy greater autonomy, making the orientation of future change in natural resources governance even more uncertain.

Another 'Great Game' is growing out of the question of access to future income from conservation ('conservation rent') linked to international efforts to combat climate change. Forest conservation, which was left out of the Clean Development Mechanism (CDM) established under the Kyoto Protocol, has again received

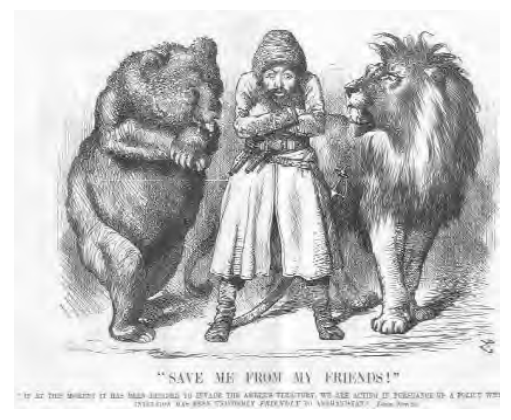

Source: The Times

Figure 4.1 The Great Game: A clash between the Russian bear, the British lion and the Persian cat (the Shah) 
attention through the Bali Declaration - which speaks of a new REDD mechanism that could generate significant financial resources for the major forest-rich countries. But the size of these financial resources will depend as much, if not more, upon the rules that will be adopted for this mechanism as upon the efforts made by these countries to reduce deforestation. The leading African forest countries (located primarily in Central Africa) have organized themselves with this in mind, and won their first points in Bali by talking about forest 'degradation', although the implications of this word were not clearly defined. This emerging game should not lose sight of its core goals namely, to reduce greenhouse gas emissions, on the one hand, and to fulfil the legitimate aspirations of the African people to rise out of poverty, on the other.

\section{A NEW ORIENTATION FOR TRADE FLOWS AND A NEW GEOPOLITICAL HAND}

During the last few years, China and, to a lesser extent, India have signed investment and trade agreements with resource-rich African countries for the exploitation of oil, gas, minerals, wood and other natural resources. Impressive monetary reserves have enabled the Chinese, more than any other country, to purchase existing companies, buy into strategic energy and mining firms, negotiate mining and forestry concessions, and - without hesitation - to build roads and other transportation infrastructure to evacuate the raw materials that fall under their concessionary agreements.

\section{The increased political influence of new international actors}

On the political side, the China-Africa Summit held in Peking in November 2006 and attended by representatives of 48 African countries shone light on the spectacular magnitude of this emerging geopolitical cooperation, marked by promises to double Chinese aid by 2009 and grant loans and credit to the African continent to the tune of US $\$ 5$ billion. An announcement was also made that on the sidelines, commercial contracts worth $\$ 1.9$ billion had been signed (Le Monde, 7 November 2006).

China is presenting itself as an alternative to European countries, which important camps of African public opinion still cast as neo-colonialist - a feeling which African heads of state quickly capitalize on to suppress external attempts to impose better governance. Chinese leaders skilfully advance the principle of non-intervention in the internal affairs of countries that receive Chinese aid. Unlike international financial institutions (IFIs), the Chinese offer certain African countries direct, condition-free financial assistance in exchange for guaranteed access to strategic resources. Countries that have raw materials sought by China (or India), and that receive substantial aid from IFIs, can thus hope to skirt the conditionalities imposed by these institutions with regard to privatization, the dismantling of public monopolies, transparency and good governance. Until now, very few authors have written about this phenomenon or analysed the effects of these new South-South alliances. The current budgetary situation of exporting countries is improving thanks to rising prices of raw materials, stimulated, among other things, by the growing demand from China and other emerging economies (see Figure 4.2). 


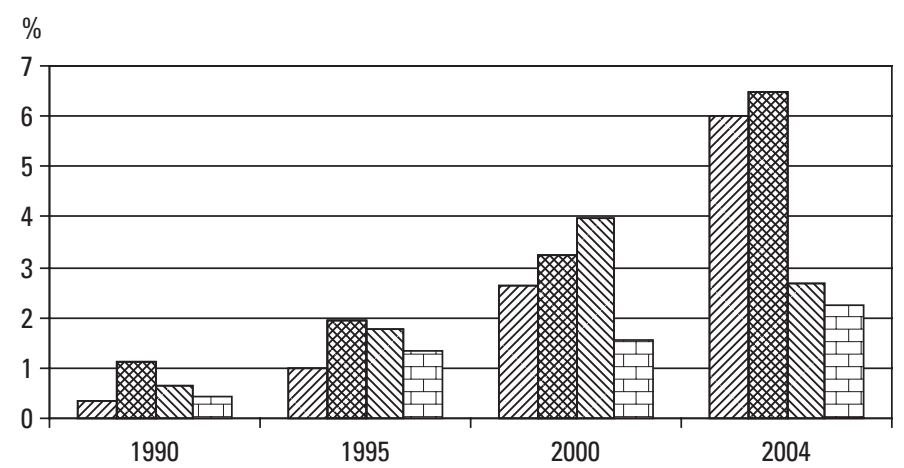

$\square$ Exports to China $\otimes$ Imports from China $\otimes$ Exports to India 由 Imports from India

Source: Goldstein et al (2006); IMF Direction of Trade Statistics

Figure 4.2 Evolution of trade between Africa, China and India

For the last two or three years, the World Bank's influence on the design of sectoral policies has been waning. This is in sharp contrast to the 1990s, when its structural adjustments and loan conditionalities enabled the Bank to dictate a common orientation towards sectoral policies adopted by several African countries, including the Cameroonian forestry reform and the Democratic Republic of Congo Mining Code. Cancellation of part of the public debt of several countries through the Heavily Indebted Poor Countries (HIPG) Initiative ${ }^{2}$ - especially that due to the World Bank and the International Monetary Fund (IMF) - helped to strengthen the autonomy of countries that produce raw materials.

\section{IMPACT UPON SECTORAL AND ENVIRONMENTAL GOVERNANGE}

The impact of growing South-South trade and direct investments by Asian firms in Africa raises important questions for the analysts of international regimes as well as for aid and cooperation agencies and non-governmental organizations (NGOs), who have counted on the application of environmental and social standards supported by private governance initiatives (e.g. certification, social and environmental responsibility (SER) initiatives, and the Extractive Industry Transparency Initiative (EITI)). These instruments, based on international standards and applied on a voluntary basis, operate through consumer awareness (stimulated by the media and international NGOs) and capacity to influence the behaviour of private companies established in the South or drawing heavily on resources from the South. Several analyses purport that these types of standards, born out of transnational arrangements linking private enterprise to civil society, enable 'governing without government' (Cashore, 2002). 
By partnering with the public sector rather than excluding it (Falkner, 2003), new forms of governance based on international social and environmental norms, companies' voluntary commitments, certification and independent verification or 'watchdog' functions have been introduced in several sectors, including forestry (Pattberg, 2005). These hint at the promise of strategies aimed at overcoming the weaknesses of public institutions. But hypotheses of this sort are being challenged by the influence of emerging economies, led by China and India, in the export figures of countries that produce raw materials and agricultural commodities, especially in Africa (see Figure 4.3). These countries are looking for large volumes at low prices, show no special interest in quality and are reluctant to pay the premiums associated with environmental and social guarantees.

The change in direction of export flows from Africa, on the one hand, and in foreign direct investment, on the other (see Figure 4.4), threatens to weaken the 'standards-based regulation' policy that had met with some success in African forestry and mining sectors. Past successes in forest governance have led to advances in Forest Stewardship Council (FSC) certification in Africa (see Table 4.1). In CongoBrazzaville, several European companies operating in the northern part of the country have obtained FSC certification (two concessions of several hundred thousand hectares each were certified in 2006 and 2007), and are in the process of preparing land management plans. However, most forestry operations in the southern part of the country are run by Chinese and Malaysian companies that, with some purported indulgence from the authorities, do not respect forest management laws generally considered as necessary and obligatory in the certification process. Furthermore, Asian companies often prefer to pay the heavy surcharges associated with breaches of law than the costs of compliance.

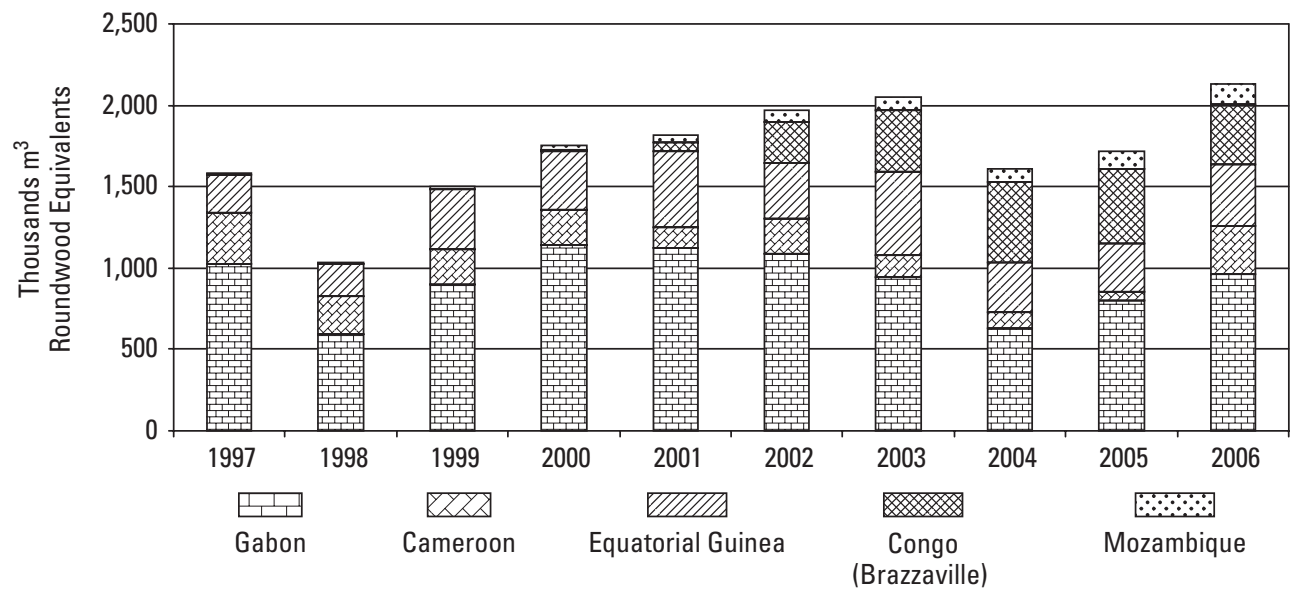

Source: White et al (2006)

Figure 4.3 The top five African timber suppliers to China 


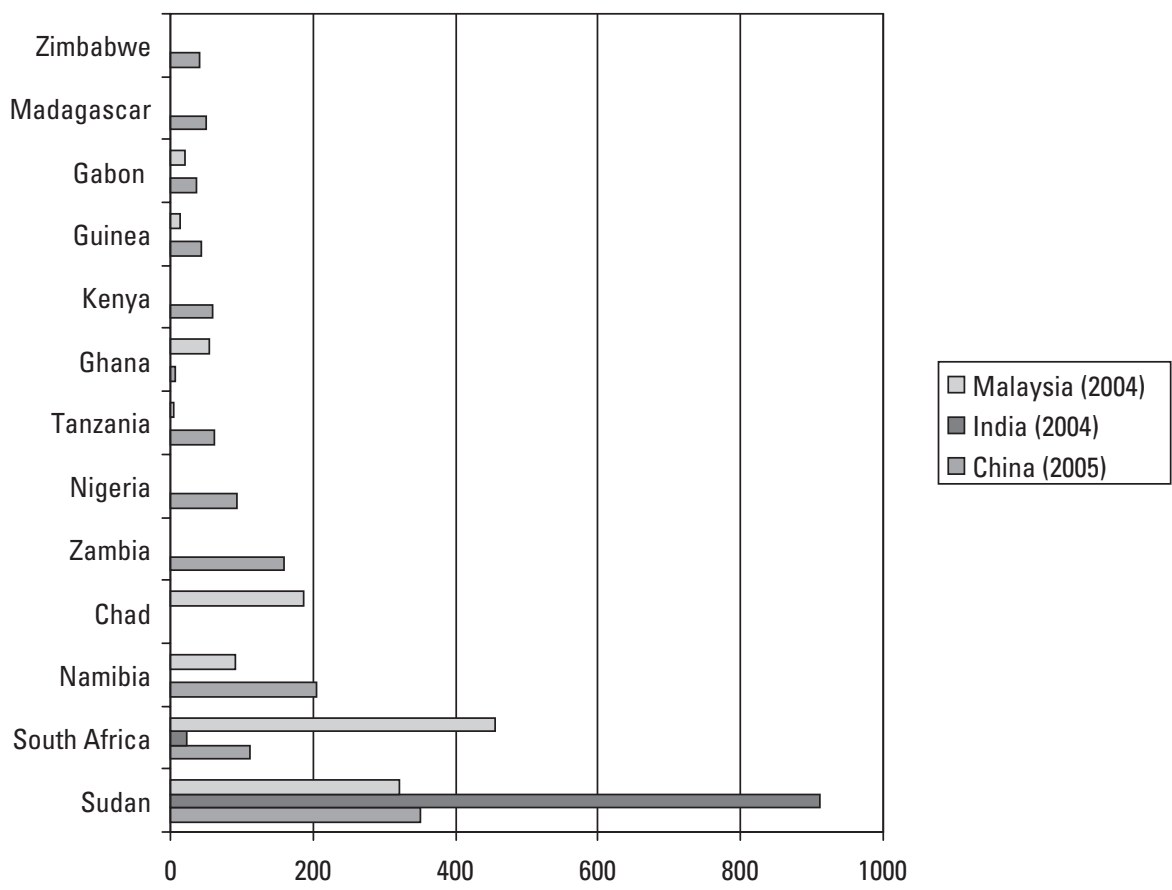

Source: UNCTAD (2007)

Figure 4.4 Asian foreign direct investments (FDIs) in sub-Saharan Africa, 2004-2005 (US\$ million)

European enterprises that see more of their business going to China and India every year might be tempted to forego the environmental and social standards earlier agreed to through forest certification or the voluntary commitments made by a certain number of large Western-based companies operating in Africa. Most of these companies are working with several markets, some of which are complementary - such as top-level niche markets in Europe and large-volume, lower-quality markets in Asia. Certification systems do not fit in well with destination-oriented production segmentation. There is also a risk to the reputation of companies that cannot afford to ignore certain markets. Another phenomenon that works in favour of certification is the significant increase in the value of shares of FSC-certified companies in the stock market. ${ }^{3}$ The Inter-African Forest Industry Association (IFIA), an association of Africa's major forest industries, has also announced its aim of having 10 million hectares of African forestlands certified by the year 2012. Yet, in some cases companies are not structured to receive international investments, and not all companies are equally concerned about protecting their reputation.

Because of these opposing trends, it is still too early to evaluate the impact of this new commercial and geopolitical situation upon the governance of natural resources, especially forests. We can hypothesize, however, that the growing competition for forestlands of high commercial value and for natural resources (e.g. mineral and petroleum products buried under forestlands) will encourage governments to 
Table 4.1 Forest Stewardship Council (FSC)-certified forests in Africa

\begin{tabular}{lllr}
\hline Country & Forest type & Tenure & \multicolumn{1}{c}{ Area (ha) } \\
\hline South Africa & & & $1,704,729$ \\
Cameroon & Natural forest & Concession & 482,110 \\
Congo & Natural forest & Concession & 748,200 \\
Kenya & Mixed & Private & 2605 \\
Morocco & Plantation & Public & 37,271 \\
Tanzania & Plantation & Private & 33,939 \\
Uganda & & & 28,500 \\
Mozambique & & & 71,061 \\
Namibia & & & 187,437 \\
Swaziland & & & 86,874 \\
Zimbabwe & & 41,574 \\
"' & Natural & Private & 47,885 \\
"' & Plantation & Private & 18,972 \\
Total & Plantation & & $3,491,157$ \\
\hline
\end{tabular}

Source: www.fsc.org, accessed September $2008^{4}$

strengthen their efforts to retain ownership and stewardship of these forests rather than satisfy the rural populations' aspirations for local control, particularly in places where the economic stakes of forestlands are high. With this in mind, we might challenge the prediction by White et al (2007, p9) that by 2020, community ownership of forests worldwide will have doubled as a result of 'less centralized government control of forest and land resources'. As will be discussed below, certain analysts also fear this centralization trend will be one of the negative effects of the REDD mechanism if it leads to the expansion of protected areas at the expense of local populations (Griffiths, 2007). With this in mind, careful attention must be given to the true goals of governments and to how states function.

\section{REFORMS THAT FALTER OVER THE NATURE OF THE STATE ... AND 'COMMUNITIES'}

Economic instruments such as fiscal incentives, voluntary certification, user-rights markets, the auction allocation system and 'payments for environmental services' (PES) are becoming standard instruments for supporting sustainable natural resource management in industrialized countries and are being used more frequently in the South (OECD, 2004). Many economists feel that these market-driven instruments are more effective than regulatory 'command-and-control' type instruments in achieving environmental goals (Cashore, 2002; Pagiola et al, 2002; Sterner, 2003). The World Bank has been very active in this field since the early 1990s, and other development cooperation organizations have encouraged African nations to adopt these instruments as a backdrop to forest taxation reforms or in efforts to enhance competition in concession allocations (Brunner and Ekoko, 2000; Karsenty, 2006). 
Another option, aside from economic instruments, is devolving managerial responsibility to communities as part of a search for an ecologically, socially and even economically more effective alternative to centralized management (Ostrom, 1990; Borrini-Feyerabend et al, 2004; White et al, 2007).

Decades of reforms and efforts to operationalize new instruments in the forest sector have produced uneven results and raise questions about the implementation of economic instruments in a context in which the state does not carry out its mission as neutral regulator working for the general interest of the population it is supposed to represent. Many observers tend to underestimate the capacity of governments - and certain non-governmental actors - to apply the famous 'requirements' of international financial institutions in a very formalized or selective manner as a means to sidestep the conditionalities that delay financial aid awards.

\section{ADMINISTRATIONS SWAYED BY PRIVATE INTERESTS}

Public institutions are supposed to create conditions propitious for achieving development goals established by political leaders. However, these institutions tend to suffer major weaknesses, such as being attracted away from their mission by private interests, insufficient coordination between various administrative structures, and lack of strategic alliances with the most dynamic components of the forest industry. For many years, the public administration of Cameroon and, indeed, many other African states, has lacked legitimacy and credibility in the eyes of the citizenry. These administrations are viewed as predatory institutions driven primarily by the search for incomegenerating opportunities. In Cameroon, for instance, where forest titles are granted through tenders, the forestry administration has no formal responsibility and is not entitled to any revenue. Over time, the administration has developed other means of control: abusive use of 'technical criteria' to oppose financial bids and disrespect for the confidentiality of bids (Karsenty et al, 2006), leading to a return of de facto discretionary allocation of forest titles and the likely associated corruption. What can be done to address a contradictory situation in which state operations are dominated by the quest for profit, while economic instruments can only function properly if the state is efficient and neutral? Should inspiration be drawn from the theories of independent authorities (Frison-Roche, 2002), whose protective and neutral status allows them to work unimpeded to regulate a public field of intervention? A number of instruments, with varying points of leverage and degrees of effectiveness, should be considered.

\section{Strengthen institutionalized checks and balances}

The first, albeit modest, step in the right direction may be the principle of independent observation, regardless of whether it is to ensure that concessions be allocated on a competitive basis (this role being entrusted to a leading figure from civil society) or to accompany forest law enforcement bodies in fighting infractions. In Cameroon and, quite recently, Congo-Brazzaville, this role of in-field forest law enforcement assessment has been assigned to Resources Extraction Monitoring, an international 
NGO, while in the Democratic Republic of Congo this responsibility could be entrusted to Global Witness. Such independent monitoring has yielded very valuable information - especially in Cameroon - for understanding the ins-and-outs of illegality, and its dynamics. However, some limitations are perceivable:

- For the independent observer (IO) in charge of monitoring the forest title allocation process, the accuracy of the work is highly dependent upon the qualities of the person having being designated IO. Furthermore, his or her reports are for limited distribution, undermining opportunities for public scrutiny.

- The organization in charge of field observations should cooperate with the forest administration in charge of control, and this cooperation can be of variable quality, limiting the investigative scope of the IO.

- The role of independent observer is to produce and disclose information. If this information is not used as a source of action and complementary investigation by the justice system, many forest crimes will remain unpunished. The information should also be used by the country's civil society and discussed in the media. This is rarely done since the detailed and quite balanced IO reports are not easy to translate into simple and straightforward messages to enable mobilization. International NGOs campaigning against industrial logging in Africa have, so far, used very little of the information published by the IOs for the very same reason.

\section{Privatization of public control functions}

Delegating control functions to private companies is also part of the arsenal used by IFIs. Privatization of this sort may seem to reflect an ideological choice by Bretton Woods institutions, ${ }^{5}$ which is sometimes the case; but as Laffont has pointed out (2000, p141), 'privatization may also be justified by the obstacles that it causes to not wellintended governments in carrying out their private agendas'. In the forest sector, where illegal logging is a critical problem, privatization is making slight inroads in control operations for timber exports, thanks to the growing role being played by security firms. The activities of these firms will probably be expanded as a result of European Union's 'legality verification' requirement for tropical timber. ${ }^{6}$ But privatization is incomplete. While these firms are responsible for checking timber at different stages along the market chain (e.g. upon entry into processing facilities and at ports of export), traditional government services, in principle, carry out the same tasks (e.g. customs officials, forestry services, etc.). Can duplication of a public service by a private service be considered a viable solution? In any case, it is a very costly option for the parties being controlled, even if their consignments are up to par. Double verification means additional taxes on exports, and a duplication of red tape and bureaucratic headaches. What alternatives are there to all-out privatization that do not supplant administrative functions?

Expanding and properly equipping control staff will not be effective unless accompanied by effective mechanisms to keep these agents out of the clutches of corruption. Although essential, increasing the salaries of civil servants will not be enough to prevent corruption, which is not limited to any particular socio-economic 
group and is especially prevalent when state agents can grant favours to or hinder wellfinanced economic agents. One solution might be to delegate certain verification duties to private companies. Another solution might be to create a special body of controllers who operate according to private-sector principles, but are employed by government and enjoy the status of civil servants - although their modus operandi, career paths and salaries are based on performance-based private-sector rules. Government agents would thus be given strong incentives to join this service, but would face the risk of being demoted into the common administrative regime if their performance was deficient (e.g. if convicted of corruption). There are no guarantees that this service would function within the law or that duplication of verifications (by civil servants not in the 'special service') would be avoided. However, this solution may be more advantageous than privatization by being more acceptable to civil servants and more efficient.

\section{UNEVEN RESULTS OF COMMUNITY FORESTRY IN CAMEROON}

Rather than acting as a lever for local development, the 'devolution of forest management' to local communities which led to the institutionalization of 'community forests' in 1994 in Cameroon had partly turned into a source of illegal gains for a certain 'elite' well connected to unscrupulous forestry officers (Bigombe Logo, 2004; Ndanyou and Majerowicz, 2004; Oyono, 2004, 2005). Part of the problem derives from the system of operating permits for Cameroonian community forests. These permits were originally meant to facilitate community forest management of forestlands exempt from the main forest taxes and to support traditional production of sawn timber according to simple 25-year management plans. Since 2003, however, these forests have been subject to uncontrolled logging, irrespective of these management plans. The zones have not been established, and the documents were not guaranteed as authentic. Partnerships were often developed with unscrupulous operators and agents to obtain bills of lading ${ }^{7}$ for sawn timber, enabling operators to strip a community forest and then declare timber from other illegally harvested forest areas as timber from the community forest. In 2005, 120,000 cubic metres of sawn timber were exported from Douala, ostensibly obtained through partnerships with community forests, although this volume was well above the amount that these forests were legally authorized to produce (Karsenty et al, 2006). Out of the 161 community forests approved by the Ministry of Forests and Wildlife in 2007, only 51 were operational, producing on average less than 10,000 cubic metres per year (see Table 4.2).

\section{Which 'communities'?}

The discrepancy between the expectations of Western observers and the actual results of community forestry in Cameroon supports the view that the concept of 'community' is a construct rather than a true reflection of rural populations. Experiences with the devolution of forest management in several countries of 
Table 4.2 2007 data on community forests in Cameroon

\begin{tabular}{lccccc}
\hline $\begin{array}{l}\text { Community } \\
\text { forests }\end{array}$ & Number & $\begin{array}{c}\text { Total } \\
\text { area } \\
\text { (ha) }\end{array}$ & $\begin{array}{c}\text { Average } \\
\text { area } \\
\text { (ha) }\end{array}$ & $\begin{array}{c}\text { Volume } \\
\text { produced } \\
\left(\mathrm{m}^{3}\right)\end{array}$ & $\begin{array}{c}\text { Annual } \\
\text { production } \\
\text { area (ha) }\end{array}$ \\
\hline $\begin{array}{l}\text { By convention } \\
\text { Simple management } \\
\text { plan and authorised }\end{array}$ & 110 & 420,713 & 3825 & & \\
logging & 51 & 195,852 & 3840 & 40,802 & 8652 \\
\hline
\end{tabular}

Source: MINEF Sub-Directorate of Community Forests, 2007

South-East Asia (Levang and Buyse, 2007) and Africa (Biesbrouck, 2002; Geschiere, 2004) show that the 'local community' does not stand out as a readily identifiable entity with well-defined contours and stable internal regulations. These uncertainties about the nature of the 'community' are often compounded by a renewed interest in the question of the identity of actors challenged to identify the rightful heirs. This is often done by playing the ethnic identity card and stigmatizing 'outsiders'. Moreover, some observers have even claimed that use of the term 'village communities' in an African context camouflages a situation in which land and resources are appropriated by family groups of various sizes and composition. From a historical viewpoint, many of the villages that observers now call 'communities' were created by colonial governments who settled people along roads in order to control them more easily.

According to French specialist of African politics J.-F. Bayart (1989), the community-based logic - in which resource appropriation and management are individualized but access to lands that support these resources is governed collectively is too often confused with holistic societies governed by collective behaviour (where the individual has no strategy outside the group). In 1993, Philippe Hugon wrote an excellent simple summary on this issue: 'the characteristic of African society is one of very strong social restrictions which limit free choice and forbid a utilitarian vision, and, at the same time, one of highly individualized economic strategies characterized by mobility, the exit option, and the great flexibility of economic practices that limit the structural effect preferred by anthropology'. The 'elite' strategies that were one of the main characteristics of the Cameroonian illegal logging crisis of the mid 2000s appear to support these claims.

All of these authors point out that the politics of resource use in Cameroon's forest-dwelling populations are not necessarily visible to the casual observer and may actually be considerably more complex than the term 'community' might suggest. First, the 'community concept' seems to be difficult to operationalize given that its two underlying assumptions - a stable, coherent entity and clear boundaries - do not readily apply to rural populations. Second, the centrifugal force of individual strategies appears to have been set aside in community forest legislation, which is primarily based on the logic of 'holistic societies', to use Bayart's terminology. It is likely that both limitations of the 'community' concept have contributed to the difficulties that community forestry has run into in countries such as Cameroon. It is 
therefore essential that the concept's limitations be recognized in policy and legislation, should community forestry become more prominent in the future.

\section{The limits to autonomy and the geographic factor}

Attempts to promote a forest management model based on local economic autonomy, which entails the transfer of rights and responsibilities, are inhibited by the high cost of economic activities in areas lacking in infrastructure and distant from markets. Ezzine de Blas and Ruiz-Pérez (2006) have shown that the probability of self-management, financially more attractive for local actors than an operating contract with a forestry company, goes down as the distance to main roads and markets goes up. Overcoming the problem of transport and marketing often requires partnering with an outside firm.

One hypothesis is that in large land-locked and sparsely populated forestry zones of Africa, small traditional businesses and community forests have difficulty creating a viable independent economic entity as long as the production of timber is the main profit generator (see Figure 4.5). Models based on the exploitation of more transportable forest resources, such as Brazil nuts in South America, may be developed in the future. Under current economic and demographic conditions, however, the industrial concessions regime still seems rational. This explains the importance of trying to regulate industrial concessions and ensure that corporate-community partnerships are sufficiently equitable.

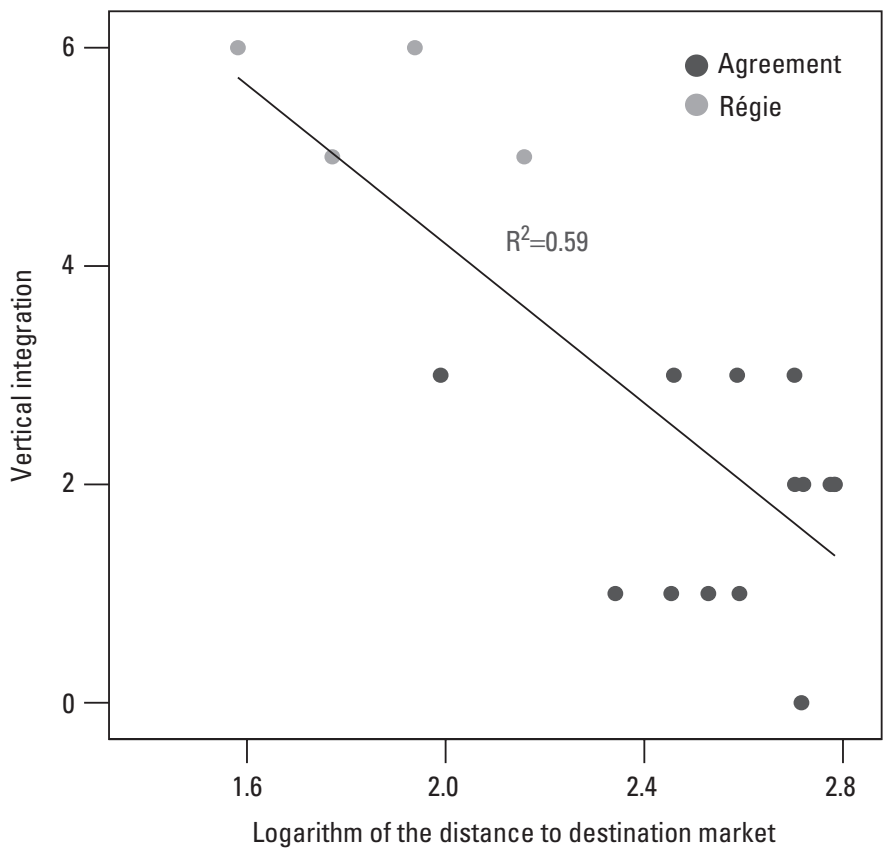

Source: Ezzine de Blas and Ruiz-Pérez (2006)

Figure 4.5 Statistical relationship between vertical integration (self-management) of a sample area of community forests in Cameroon and distance to timber markets 
The generation of some form of community management of natural resources, an option supported by many analysts, is often a way to avoid in-depth examination of state reforms - the aim being to simply circumvent the state. But this option is limited when state malfunctioning creates a situation in which any notion of general interest or public land is undermined. This option is also limited by the prevalence of bona fide relationships within 'communities' and the weak political-economic structuring of these vast landlocked territories. Finally, the new, highly prominent position of forests in international negotiations on the environment, especially negotiations on climate change, may have unexpected, and not necessarily favourable, effects on community forest management.

\section{FRESH FUNDING TO FIGHT DEFORESTATION AND FOREST DEGRADATION}

Following the decision of the 13th Conference of the Parties to the United Nations Convention on Climate Change (CoP 13) held in December 2007 in Bali, additional public funding is likely to be allocated to a portfolio of programmes designed to reduce deforestation. This should happen before 2012, when REDD is likely to be included in emissions trading schemes under the new global climate regime. Reference here is being made to a payment mechanism for developing countries that reduce their rate of deforestation (known as 'avoided deforestation'). This mechanism would be implemented in each country by comparing deforestation during the 'commitment period' with levels of deforestation during a reference period. It is presented as a win-win process since the countries of the South would receive carbon credits, or financial incentives, if they lowered their deforestation rates, but would not lose anything if they were unable to meet their goals. A number of important points need to be worked out during the post-Bali negotiations:

- $\quad$ The choice of the reference period to be used in measuring reduced deforestation. Should the level of deforestation during the commitment period (undoubtedly 2013-2017) be compared with that of a preceding period (see Figure 4.6) or should a projected 'business-as-usual's deforestation scenario be compared to the commitment period (see Figure 4.7)? In either case, there would be winners and losers: the countries that have already been heavily deforested and with low levels of remaining forest cover would undoubtedly be the winners if the period representing the past were taken into account. Conversely, the countries with a previously low deforestation rate, but where deforestation will probably be increased because of investments in roads and the expansion of farmland areas could be the losers in the first scenario. They would plead in favour of the 'business-as-usual' scenario that could include an 'adjustment factor' to accommodate development requirements - a proposal supported by the Central African Forest Commission (COMIFAC) in its negotiations. 
Deforestation (areas

deforested per yr)

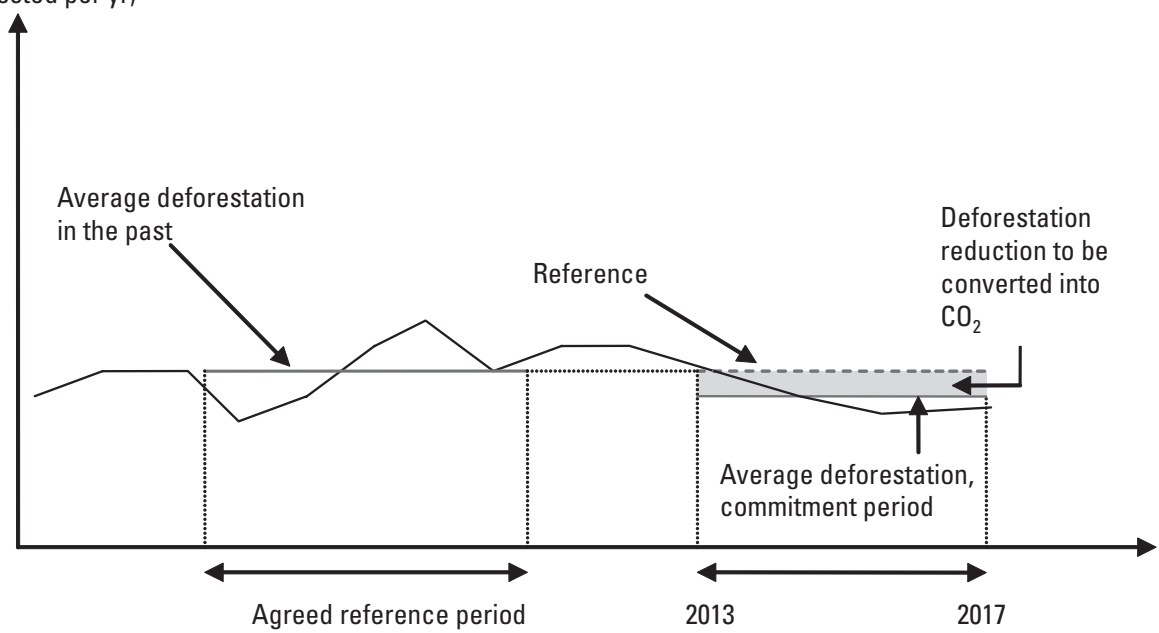

Source: Author

Figure 4.6 Diagram of possible payment for deforestation reduction in comparison to past reference period ('historical baseline')

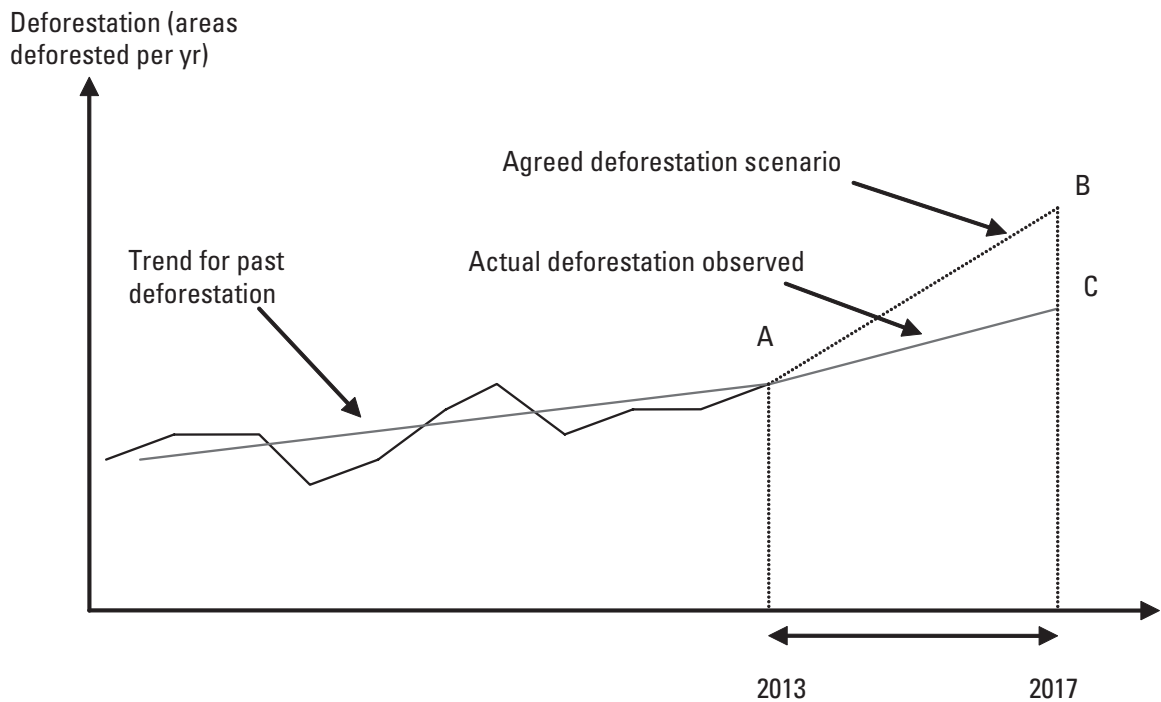

Source: Author

Note: Area ABC: 'avoided' deforestation (in relation to scenario) that could open rights to carbon credits (through the market) or payment (through a fund).

Figure 4.7 Diagram of possible payment for avoided deforestation with reference scenario ('projected baseline'), including an 'adjustment factor' to accommodate development requirements 
- Payment mechanism. Payment could be made as carbon credits that can be negotiated on the international carbon market or as specific credits which industrial countries would have committed to buy up to a certain amount. Another option is that countries having reduced their deforestation receive payments proportional to the non-emitted carbon dioxide $\left(\mathrm{CO}_{2}\right)$. In the former case, the mechanism would be integrated into the post-Kyoto agreement and will supply carbon markets. In the latter case, an international fund would have to be established to pay countries, independently of any carbon market. ${ }^{9}$

- Beneficiaries. Who would be the main beneficiaries of these carbon credits governments, local actors (communities, businesses or private land owners) or both? How would payment distribution mechanisms ensure adequate incentives (funds) flow to landowners to shift their land-use practices?

Concern was expressed about the possible detrimental effects of the various implementation mechanisms. Some highlight the fact that variations in the extent of deforestation can be traced far more to exogenous factors (changes in farm gate prices, changes in climatic conditions that affect the risk of fires, etc.) than to government actions (Pirard and Karsenty, 2009), and that large quantities of dubious (i.e. non-additional ${ }^{10}$ carbon credits could be generated, thereby destabilizing the international market for carbon credits, allowing the purchase of emission permits at low costs. Defenders of community interests fear that rapid expansion of avoided deforestation programmes might lead to tighter forest controls by the state and 'experts' who support conservation models that exclude forest peoples (Griffiths, 2007).

At the Bali meeting, in order to prepare for implementation of the REDD mechanism and strengthen the institutional capacities of the countries involved, the World Bank launched a financial instrument called the Forest Carbon Partnership Facility (FCPF). One of the goals of a 'prototype' fund of this kind is to fund new public policies and deforestation reduction programmes by providing for direct payment of people in the field who participate in deforestation reduction and other activities to enhance REDD 'readiness' in anticipation of the post-2012 global climate regime. The FCPF, together with countries such as Norway that pledged a substantial contribution (over US $\$ 500$ million in a five-year period), will funnel resources to developing countries with large forests through projects and programmes. Donor countries cannot be expected to allocate funding as financial compensation for earlier efforts to limit deforestation in regions such as the Congo Basin, for instance (see Table 4.3), where deforestation has been limited due to its limited attractiveness to large-scale agrobusiness (and low population density) rather than to 'environmental good governance'.

How the concept of (avoided) 'degradation' will be accommodated in the new climate regime is ambiguous. For countries in Central Africa, who supported mention of the word 'degradation' at CoP 13, the idea was to obtain advantages associated with the sustainable management of forest concessions. This would lead to a favourable distinction between the Congo Basin and the other tropical regions on the basis of the large amount of surface under forest management plans. ${ }^{11}$ However, there are two major arguments against the idea of compensating countries for the proportion of their forest under management plans: 
Table 4.3 Data on deforestation in developing countries

\begin{tabular}{|c|c|c|c|c|c|}
\hline Country & $\begin{array}{c}\text { Average } \\
\text { annual forest } \\
\text { loss between } \\
1990 \text { and } 2000 \\
\text { (thousand } \\
\text { hectares) }\end{array}$ & $\begin{array}{c}\text { Average } \\
\text { annual forest } \\
\text { loss between } \\
2000 \text { and } 2005 \\
\text { (thousand } \\
\text { hectares) }\end{array}$ & $\begin{array}{l}\text { Forest area } \\
\text { in } 2005 \\
\text { (thousand } \\
\text { hectares) }\end{array}$ & $\begin{array}{c}\text { Average } \\
\text { gross } \\
\text { change } \\
\text { 1990-2000 } \\
\text { (\%) }\end{array}$ & $\begin{array}{c}\text { Average } \\
\text { gross } \\
\text { change } \\
2000-2005 \\
\text { (\%) }\end{array}$ \\
\hline Brazil & 2681 & 3103 & 477,698 & -0.5 & -0.6 \\
\hline Indonesia & 1872 & 1871 & 88,495 & -1.7 & $-2.0^{*}$ \\
\hline Sudan & 589 & 589 & 67,546 & -0.8 & $-0.8^{* *}$ \\
\hline Myanmar & 466 & 466 & 32,222 & -1.3 & -1.4 \\
\hline Zambia & 445 & 445 & 42,452 & -0.9 & -1.0 \\
\hline Tanzania & 412 & 412 & 35,527 & -1.0 & -1.1 \\
\hline Nigeria & 410 & 410 & 11,089 & -2.7 & -3.3 \\
\hline $\begin{array}{l}\text { Democratic } \\
\text { Republic } \\
\text { of Congo }\end{array}$ & 532 & 319 & 133,610 & -0.4 & -0.2 \\
\hline Zimbabwe & 313 & 313 & 17,540 & -1.5 & -1.7 \\
\hline Venezuela & 288 & 288 & 47,713 & -0.6 & -0.6 \\
\hline $\begin{array}{l}\text { Other } \\
\text { countries (68) }\end{array}$ & 3257 & & & & \\
\hline
\end{tabular}

Notes: * Underestimated since partly offset by plantations.

** Thus expressed in FAO (2007).

Source: FAO (2007)

1 Since implementing a forest management plan is a legal precondition to awarding a concession, it would hardly be acceptable to offer payment to someone for respecting the law.

2 Forest management plans have not been designed to reduce $\mathrm{CO}_{2}$ emissions from logging, but to ensure renewal of the main commercial timber species; its impact on carbon is uncertain and, in any case, limited.

The most plausible idea, therefore, is that 'avoided degradation' would be measured in terms of the reduction in land area used for logging. It would also not benefit community forest systems based on timber exploitation, since this would also cause a certain amount of forest degradation.

\section{ON GENERATING INCOME FROM CONSERVATION: 'CONSERVATION RENTS'}

Besides the inevitable and necessary institution-building actions, REDD programmes will probably be used for payments for environmental services (PES) and financial compensation systems for local actors who will be requested to forego certain 
economic opportunities connected to (total or partial) deforestation. We must not underestimate a certain number of risks connected to the introduction of PES at a larger scale than in the past. These risks are illustrated by PES programmes implemented in small watersheds of Central America by companies concerned with maintaining downstream water quality. To ensure effectiveness, serious thought must be given to the question of additionalities of activities being funded - in other words, ensuring payments are not used to pay for activities that would have taken place anyway, such as compensating agents who do not have the capacity or the opportunity to deforest. However, the economists' focus on effectiveness may run up against indigenous or local peoples' claims for payment for centuries-long forest conservation practices.

PES is certainly not a panacea for sustainability, since contracts will not be spontaneously respected and monitoring large-scale programmes will be costly. The introduction of 'conservation rents' will raise the stakes both between and within communities as follows:

- Groups who hold lands that are not part of the PES programme will want to benefit from these programmes (and may increase their deforestation activities to bolster support for their demands). Reduced production of timber, agricultural produce, etc. in PES zones may - depending upon the elasticity of the offer increase profitability of these activities in zones 'bordering' the PES zones. The oft-heard argument that to reduce costs, payments should be targeted to forest areas that are really threatened does not factor in the propagation effects of such 'rights to payment' claims.

- Conflicts within 'communities', which are generally less homogeneous than we think, about who receives conservation rents are likely to emerge, generating conflict prevention and settlement costs and potentially bringing about the need for political arbitration on land distribution (e.g. genuine reforms). If this degenerates into conflicts surrounding a common identity of groups sharing lands, as occurred in Côte d'Ivoire, technical solutions will be useless.

Two opposing trends may well clash:

1 on the one hand, an effort to 'centralize' rights of access to lands and natural resources inspired by the government's interest in satisfying requests from large industrial groups for access to mining resources or to plant major industrial crops to produce agro-fuels for the world market;

2 on the other, the development of markets for ecosystem services beneficial to local communities, which will favour the de facto appropriation of these lands by local actors - since contracts are negotiated with communities responsible for the (public) zones to be protected.

In the coming years, the question of who receives conservation rents will be a critical one for the forest sector. What will be the impact upon forest governance? As potential 
beneficiaries, local living conditions are likely to improve. Will this primarily benefit the local 'elites' who cleverly captured this new income or - as most scientists working on this issue hope - will it serve as a springboard for a new community-based, sustainable development model? This is an open question. The answer lies with the African societies involved. But the scientific community also has a role to play in defining the stakes and supporting the most promising way forward. Commitment, one of the main keys to the evolution of forest governance, is required so that accountability mechanisms can develop at both national and local levels (Ribot, 2007). With regard to the structure of the state, an evolution of this sort would contribute to the emergence of institutionalized checks and balances (network of courts of auditors, parliamentary commissions with investigating powers, independent departments of justice with the capacity to act, mediators, etc.) alongside and within public institutions in order to improve governance and help to fight corruption. Although no one can guarantee that structuring institutions in this way would improve the situation, there is hope that the emerging reform-minded political and social forces in a number of African countries would activate levers that support these institutionalized checks and balances. Without powerful supporters in African civil society, the new institutional structures or forms of regulation mentioned above will not function properly, even if their various components have been formally introduced.

\section{CONCLUSIONS}

The African economy benefits and will continue to benefit from new multipurpose investment flows - including investments by China and India, the economic giants, and other emerging economies to obtain guaranteed access to agricultural lands (for agrofuels, pulpwood, rubberwood, but also food crops to be exported) and raw materials that grow increasingly scarce as their prices soar: oil, minerals and certain wood species from natural forests. This also includes investments to reduce deforestation in forestrich countries, largely through forest conservation, particularly in the Congo Basin.

There is evidence that investments from emerging economies is expanding to include farmland. As the oil crisis elevates fuel prices, agro-fuels will become more and more profitable. All eyes will be on Africa as a territory with vast stretches of land, especially forestland, that can be used to grow oil palm or other oil-yielding plants needed to run factories. Investment flows will also be used for infrastructure in areas where access to coveted resources requires road improvement or the construction of railroads. This will place additional indirect pressures on forests and will make territorial development very uneven, making current regional inequalities even worse.

These economic phenomena will affect environmental governance. States that receive the new investments (in other words, the states most endowed in increasingly strategic natural resources) are the most inclined to stay away from the demands by IFIs for transparency in access to natural resources and equality in benefits-sharing. In these countries, the tendency towards centralization and the concern for retaining centralized discretionary control over access to resources may prevail over aspirations for decentralization and local management. Conversely, in countries where natural resources 
represent lower strategic stakes, the states' difficulties in meeting the needs of local development may encourage them to transfer management and to decentralize. Here, central governments will also ' offload' certain costly responsibilities to the local level.

In the most forest-rich sub-regions, the tendency towards centralization might be further propelled by an increased demand for conservation measures as part of efforts to reduce deforestation and forest degradation through the REDD mechanism, even as efforts are deployed by the biggest economic actors to utilize these lands for industrial, forestry and agricultural production or mining. The REDD mechanism can be implemented in several ways; those that are based on payments for environmental services to local communities are likely to contribute more to strengthening the land tenure rights of local populations and can help to consolidate their control over, and benefits from, the area's resources. It is extremely important for local actors and those who advocate for their cause within civil society, together with African intellectuals, to take on this debate so that the national REDD architecture and the terms and conditions of its implementation are of benefit first and foremost to local populations. This should occur not only through direct remuneration, but through investments in sustainable agriculture and in reforms and programmes to secure land tenure and ensure the material security of rural populations.

Lastly, equity and democracy should no longer be considered merely as problems of power-sharing, for example, deciding which rights to delegate to the state and which rights devolve to local communities, but also as a problem of local management per se: which sociological and political mechanisms allow local 'elites' to monopolize various types of income from decentralization, tax paybacks or financial opportunities created by both production and conservation? The nature and functioning of the state reflect implicit collective choices and have a profound effect upon the terms and conditions of local resource management. Any political proposal on decentralization and the transfer of management stemming exclusively from the intention to bypass the state without consideration for the problem of its transformation through meaningful reforms will quickly be hindered by difficulties of local management. In many cases, these difficulties come to the fore when the elite, by taking possession of revenue, stoke up frustrations that are vented through intercommunity conflict.

\section{NOTES}

1 'Now I shall go far and far into the North, playing the Great Game' (Kim, Rudyard Kipling, 1901).

2 The Heavily Indebted Poor Countries (HIPC) Initiative is an agreement among official creditors designed to help the poorest, most heavily indebted countries to escape from unsustainable debt. It enables poor countries to focus their energies on building the policy and institutional foundation for sustainable development and poverty reduction. HIPC represents the first effort to coordinate all creditors. It includes foreign debts owed to bilateral creditors (Paris Club), multilateral creditors (international financial institutions, such as the World Bank and the IMF) and commercial creditors (London Club) (Ricksecker, 2001). 
3 Schneider (2007) showed a 300 per cent increase in the value of a major Indonesian forestry company on the stock market exclusively thanks to FSC certification. Data for Africa are not available.

4 Since the beginning of 2008, the FSC site no longer gives details on forest types or the tenure of certified areas. Table 4.1 therefore only provides this information if it is known to the author.

$5 \quad$ Signed in July 1944, the Bretton Woods Agreements established the rules for commercial and financial relations among the world's major industrial nations.

6 See http://europa.eu/scadplus/leg/fr/lvb/r12528.htm.

7 Administrative authorization to transport certain quantities of timber within the country. This bill of lading is often forged and illegally transferred.

8 In other words, what would deforestation levels be in the absence of REDD incentives (money, carbon credits)?

9 Even though such a fund could be partially resourced by the auctioning of emission permits, as suggested by the European Union.

10 Credits are non-additional if the corresponding emissions reductions would have occurred anyway in the absence of incentives (here, the REDD mechanism) due to any number of circumstances (e.g. drop in agricultural prices, changes in the rainfall periods, credit crunch, economic crises) or components of public policies implemented irrespective of REDD efforts (e.g. interest rates and monetary policy). Inaccurate baselines are another way of generating non-additional credits.

11 For information on land management in Central Africa, see Nasi et al (2006a, 2006b) and Devers and Van de Weghe (2006).

\section{REFERENCES}

Bayart, J. F. (1989) L'État en Afrique: La politique du ventre, Fayard, Paris

Biesbrouck, K. (2002) 'New perspectives on forest dynamics and the myth of "communities"', IDS Bulletin, vol 33, no 1, pp55-64

Bigombe Logo, P. (2004) Le retournement de l'État forestier: l'Endroit et l'envers des processus de gestion forestière au Cameroun, Presses de l'UCAC, Yaoundé

Borrini-Feyerabend G., M. Pimbert, M. T. Farvar, A. Kothari and Y. Renard (2004) Sharing Power: Learning by Doing in Co-Management of Natural Resources throughout the World, IIED and IUCN/CEESP/CMWG, Cenesta, Tehran

Brunner, J. and F. Ekoko (2000) 'Environmental adjustment: Cameroon case study', in F. Seymour and D. Navroz (eds) The Right Conditions: The World Bank, Structural Adjustment, and Forest Policy Reform, World Resources Institute, Washington, DC

Cashore, B. (2002) 'Legitimacy and the privatization of environmental governance: How nonstate market driven (NSMD) governance systems gain rule-making authority', International Journal of Policy, Administration and Institutions, vol 15, no 4, pp503-529

Devers, D. and J. P. Van de Weghe (eds) (2006) Les Forêts du Bassin du Congo: État des forêts 2006, Congo Basin Forest Partnership, COMIFAC/EC/USAid/Cooperation Française, Kinshasa, www.cbfp.org/documents/Les_forets_du_Bassin_du_Congo_etat_2006.pdf, accessed April 2008 
Ezzine de Blas, D. and M. Ruiz-Pérez (2006) Cameroonian Community Forests: Lessons after a Decade of Implementation, Unpublished report, WWF International, Gland, Switzerland

Falkner, R. (2003) 'Private environmental governance and international relations: Exploring the links', Global Environmental Politics, vol 3, no 2, pp72-87

FAO (2007). State of the World's Forests 2007, Food and Agriculture Organization of the United Nations, Rome

Frison-Roche, M. A. (2002) 'Pourquoi des autorités de régulation?', in Club Ulysse (ed) Le Politique Saisi par l'Economie, Economica, Paris, pp271-285

Geschiere, P. (2004) 'Ecology, belonging and xenophobia: The 1994 Forest Law and the issue of "community"', in H. England and F. Nyamnjoh (eds) Rights and the Politics of Recognition in Africa, Palgrave Macmillan Ltd, New York, NY

Goldstein, A., M. X. Chen, N. Pinaud and H. Reisein (2006) China and India: What's In It for Africa?, OECD Development Centre, Paris

Greenpeace International (2007) Carving Up the Congo, www.greenpeace.org/international/ press/reports/carving-up-the-congo-exec, accessed 6 January 2008

Griffiths, T. (2007) Seeing 'REDD'? Avoided Deforestation and the Rights of Indigenous Peoples and Local Communities. UK: Forest Peoples Programme (FPP), http://www.forestpeoples.org/ documents/ifi_igo/avoided_deforestation_red_jun07_eng.pdfReviewed

Hugon, P. (1993) 'L'Homo africanus est-il irrationnel?', in J.-L. Boutillier and Y. Goudineau (eds) Cahiers des Sciences Humaines: Trente Ans (1963-1992), Cahiers des Sciences Humaines, Paris, pp57-60

Karsenty, A. (2006) 'L'impact des Réformes dans le Secteur Forestier en Afrique Centrale', in R. Nasi, J. C. Nguinguiri and D. Ezzine de Blas (eds) Exploitation et Gestion Durable des Forêts en Afrique Centrale, L'Harmattan, Paris, pp25-60

Karsenty, A., J. M. Roda, E. Fochivé, A. Milol and M. Kuetche (2006) Audit Economique et Financier du Secteur Forestier au Cameroun, Unpublished document (first draft), Ministère de l'Économie et des Finances, Yaoundé

Laffont, J. J. (2000) 'Étapes vers un État Moderne: Une Analyse Économique', Conseil d’Analyse Économique, vol 24, pp117-149, La Documentation Française, Paris

Le Monde (2006) 'La Chine étend ses relations avec l'Afrique', Le Monde, 7 November 2006

Levang, P. and N. Buyse (2007) Droits Fonciers Doutumiers et Autonomie Régionale à Kalimantan-Est (Indonésie): Entre Enjeux de Pouvoir et Contrôle de l'Accès aux Ressources - Les frontières de la question foncière: Enchâssement social des droits et politiques publiques, VertigO (La Revue Electronique en Sciences de L'environnement), no 4, www.vertigo.uqam.ca/, accessed April 2008

Nasi, R., B. Cassagne and A. Billand, (2006a) 'Forest management in Central Africa: Where are we?', International Forestry Review, vol 1, pp14-20

Nasi, R., J. C. Nguinguiri and D. Ezzine de Blas (eds) (2006b) Exploitation et Gestion Durable des Forêts en Afrique Centrale, L'Harmattan, Paris

Ndjanyou, L. and C. H. Majerowicz (2004) Actualisation de l'Audit de la Fiscalité Décentralisée du Secteur Forestier Camerounais, MINEFI, Institutions et Développement, Yaoundé

OECD (Organisation for Economic Co-operation and Development) (2004) Le Développement Durable dans les Pays de l'OECD: Mettre au Point les Politiques Publiques, OECD, Paris

Ostrom, E. (1990) Governing the Commons: The Evolution of Institutions for Collective Action, Cambridge University Press, Cambridge

Oyono, P. R. (2004) Institutional Deficit, Representation and Decentralized Forest Management in Cameroon: Elements of Natural Resource Sociology for Social Theory and Public Sociology, 
Environmental Governance in Africa Working Papers no 15, World Resources Instititute, Washington, DC

Oyono, P. R. (2005) 'Profiling local-level outcomes of environmental decentralizations: The case of Cameroon's forests in the Congo Basin', Journal of Environment and Development, vol 14, no 2, pp1-21

Pagiola, S., J. Bishop and N. Landell-Mills (2002) Selling Forest Environmental Services: Market-Based Mechanisms for Conservation and Development, Earthscan, London and Sterling

Pattberg, P. (2005) 'What role for private rule-making in global environmental governance? Analyzing the Forest Stewardship Council (FSC)', International Environmental Agreements: Politics, Law and Economics, vol 5, no 2, pp175-189

Pirard, R. and A. Karsenty (2009) 'Should 'avoided deforestation' be rewarded?', Journal of Sustainable Forestry, vol 28, nos 3-4, pp434-455

Ribot, J. (2007) Dans l'Attente de la Démocratie: La Politique des Choix dans la Décentralisation de la Gestion des Ressources Naturelles, World Resources Institute, Washington, DC

Ricksecker, D. (2001) 'What is the HIPC Initiative?', Online paper of the University of Iowa Center for International Finance and Development, www.uiowa.edu/ifdebook/faq/faq docs/HIPC.shtml, accessed 20 January 2009

Schneider, F. (2007) Certification FSC et Gouvernance d'Entreprise en Indonésie, Mémoire Master, GEEFT, Engref/AgroParisTech, Montpellier

Sterner, T. (2003) Policy Instruments for Environmental and Natural Resource Management, World Bank, Washington, DC

UNCTAD (United Nations Conference on Trade and Development) (2007) Foreign Direct Investment Statistics, www.unctad.org/Templates/WebFlyer.asp?intItemID=4180\&lang=1, accessed April 2008

White, A., S. Xiufang, X. Jintao, K. Canby, C. Barr, E. Katisgris, G. Bull, C. Cossalter and S. Nilsson (2006) China and the Global Market for Forest Products: China-Africa Trade, Transforming Trade to Benefit Forests and Livelihoods, Forest Trends, Washington, DC

White A., A. Khare and A. Molnar (2007) Transitions in Forest Tenure and Governance: Drivers, Projected Patterns and Implications, Rights and Resources Group, Washington, DC 


\section{PART II}

Decentralized Forest Management: Forms and Outcomes 

Chapter 5

\section{Forest Sector Reforms, Livelihoods and Sustainability in Western Uganda}

Pamela Jagger

\section{INTRODUCTION}

The National Forest Plan aims to:

1 help Ugandans get more money and a better life from forests;

2 make more jobs and new ways to make money from forests;

3 make sure that the forests and trees are looked after properly. (New National Forest Plan, Popular Version; MWLE, 2003a)

Governance reforms that transfer rights and responsibilities for natural resource management to local governments or local resource users are currently under way in approximately 60 developing countries (WRI, 2003). Reforms are motivated by the failure of centralized states to provide basic infrastructure and services, high levels of corruption within centralized systems, and the desire to foster democratic institutions that take into account the needs of a diverse citizenry (Vedeld, 2003). Improved livelihoods for rural people living in or near forests and the sustainable management of forests are among the most commonly cited expected outcomes of forest-sector governance reforms (Agrawal and Ostrom, 2001; Meinzen-Dick and Knox, 2001; Fisher et al, 2005; WRI et al, 2005). However, there is a dearth of empirical data on whether such favourable reform outcomes are achieved (Bardhan, 2002) and the livelihood-environment trade-offs associated with them.

This chapter addresses the question: have favourable livelihood and forest management outcomes been achieved as a result of Uganda's 2003 forest-sector reform? The reform led to changes in the ownership and management of 85 per cent of Uganda's forested land. Although at the forefront of governance reforms in 
sub-Saharan Africa (Ndegwa, 2002), there is limited empirical evidence for how benefits associated with forests have been reoriented towards local resource users, and whether rates of forest cover and quality loss have declined.

The research employs a quasi-experimental research design comparing both preand post-reform data for a large sample of households living adjacent to three major forests in western Uganda. Outcomes for two treatment groups are considered. The first group is comprised of households living in or near privately held forests in Hoima and Kibaale districts in western Uganda (Bugoma forest site). This group has been affected by the transition from the centralized Forest Department to the decentralized District Forestry Service. The second group is households living adjacent to Budongo Central Forest Reserve (CFR), currently governed by the National Forestry Authority (Budongo forest site). A control group of households living adjacent to Rwenzori Mountains National Park (RMNP) is included in the design; forest management in RMNP was not affected by the 2003 forest-sector reform. Household income portfolio data from 2007 are compared with baseline data collected in 2003, just before the reform. Changes in forest sustainability are evaluated using household perceptions of change in forest cover and quality since the reform was implemented.

The chapter is organized as follows: the next two sections provide a brief review of the literature pertaining to livelihood and sustainability outcomes associated with forest-sector governance reform, and background information on Uganda's forestsector reform. The fourth section describes the methods used in this study. Results are reported in the fifth section. Finally, the findings of the study are summarized and policy implications presented.

\section{LITERATURE REVIEW}

Livelihood improvements are a primary rationale for natural resource-focused governance reform (Meinzen-Dick and Knox, 2001). Reforms have the potential to directly affect rural households: they may change returns to assets, including natural, physical, human, financial and social capital; and they may increase household assets (World Bank, 2008). Forest sector governance reforms are expected to allow poor people to make their assets more productive by supporting local organization and decision-making around forest use, and greater participation of local forest users in markets for forest products.

Improved property or access rights for local resource users to forests, specific forest resources and forest product markets is the most common mechanism through which returns to assets are improved (Ribot and Peluso, 2003). Having a larger and more diverse portfolio of access rights, as well as short- and long-term decision-making authority over resources, facilitates opportunities to utilize the forest in a variety of different ways, including supporting current consumption as safety nets in times of need and as pathways out of poverty. Having secure rights is an important aspect of reform implementation. Secure rights facilitate obtaining credit; reduce the risk of investment; and provide incentives to sustainably manage resources (Deininger, 
2003). Reforms often alter the organizational or administrative structure that oversee forest management. Organizations and their employees have underlying incentive structures that motivate the way in which policies are implemented. If authorities are unwilling to relinquish substantive property rights or alter power relationships to any significant degree, then reforms are, at best, partial and the opportunities for rural livelihood improvements and sustainable management are limited (Ribot, 1999; Agrawal and Ostrom, 2001).

Bardhan (2002) argues that empirical evidence as to whether decentralization reforms lead to significant changes in incomes or other measures of livelihoods are absent from the literature. However, several recent studies consider the linkage between livelihood outcomes and forest-sector governance reforms. Studies from Malawi (Jumbe and Angelsen, 2006) and Ethiopia (Jagger et al, 2005) found that devolved forest management led to increases in income from forests for rural smallholders. However, both studies found a high degree of variation across communities and households affected by the reform. Studies that examine governance reforms in cases where communities are involved in the distribution of timber concessions find that communities and households were better off after decentralization reforms (Oyono, 2005; Palmer and Engel, 2007), although again with a high degree of variation between communities and households. Communities often benefit from in-kind payments that support the development of rural infrastructure, including schools and health centres, or receive direct cash payments from small-scale timber concessions.

Political connectedness emerges as an important variable influencing reform outcomes for the poor. Recent studies from Vietnam (Sikor and Nguyen, 2007) and Indonesia (McCarthy, 2004) found that while devolution generates benefits for the local poor, local power relations and the institutions regulating access to higher value forest resources exclude the poor from benefiting. Crook and Sverrison (2001), in a cross-country study on the welfare impacts of decentralization reforms, pointed out that central government commitment to pro-poor policies and engagement with local elites to ensure unbiased implementation of reforms are important for livelihood gains. There are numerous examples of local elites, NGOs and other special interests dominating local decision-making processes regarding the assignment of rights, which may undermine outcomes for the rural poor (Ribot, 1999). A key finding from the synthesis research on the topic of decentralization is that if reforms are to have welfare-enhancing effects at the level of the rural household, attention needs to be paid to the structural inequities that emerge across the various landscapes in which reforms are implemented (WRI et al, 2005; Larson et al, 2007).

Evidence of the link between governance reforms and forest sustainability is highly variable both within and between countries, and has been explicitly addressed in relatively few studies. Several institutional factors mediate sustainability outcomes. Rules regarding forest use and the degree to which they are enforced have a significant effect on sustainability outcomes (Oyono, 2005; Banana et al, 2007). Contradictory regulations, lack of clarity regarding new forest rights associated with reforms, confusion about who controls forest resources, and an unwillingness of central government to intervene in cases of excessive forest loss are among the reasons 
that high rates of forest loss are observed under decentralization (Oyono, 2005; Andersson and Gibson, 2006).

Variation in implementation and budgetary commitment across local governments and communities is also an important determinant of ecological outcomes (Oyono, 2005; Andersson and Gibson, 2006; Banana et al, 2007). In general, a high degree of local government interest and investment in forestry is associated with lower rates of deforestation, whereas lack of forestry staff or appropriate budgetary allocations leads to higher rates of deforestation. Evidence from other sectors, including health and education, indicates that competition for scarce finances at the district level means that the environment is often a low priority for local government public service provision (Bahiigwa et al, 2005).

\section{UGANDA'S FOREST-SECTOR GOVERNANGE REFORM: PROCESS AND IMPLEMENTATION}

The Forest Sector Umbrella Programme (FSUP) initiated in 1999 was the first step in reforming the Ugandan forest sector. The goals of FSUP were twofold: to create a positive, effective and sustainable policy and institutional environment for the forest sector and, through this, to increase economic and environmental benefits from forests and trees, particularly for the poor and vulnerable (MWLE, 2004). Uganda's forest-sector governance reform was part of a larger government-wide restructuring laid out in the 1995 Constitution and the 1997 Local Government Act. The objectives of the restructuring were to downsize the public service; rationalize government functions; and improve the effectiveness and efficiency of public service provision (MWLE, 2006).

The FSUP supported a forest-sector review and the development of the Uganda Forest Policy (MWLE, 2001); the National Forest Plan (MWLE, 2002); and the National Forestry and Tree Planting Act (GOU, 2003). A major outcome of the reform process was the abolition of the centralized Forestry Department and the creation of the decentralized District Forestry Service (DFS) and the for-profit parastatal National Forestry Authority (NFA). Currently, 70 per cent of Uganda's forests are managed by decentralized local governments. An additional 15 per cent of forests within Central Forest Reserves are managed by the National Forestry Authority. The Uganda Wildlife Authority continues to manage the remaining 15 per cent of Uganda's forests and woodlands in national parks and game reserves. In addition to the development of the District Forestry Service and the National Forestry Authority, the Forestry Inspection Division (FID) was created. The FID, housed in the Ministry of Water, Lands and Environment, is responsible for policy and regulation in the forest sector, overseeing the activities of both the NFA and DFS.

During the reform process several mechanisms were identified for promoting favourable livelihood outcomes. Opportunities for achieving outcomes are different for forests on private and customary lands versus gazetted forests in Central Forest Reserves. Similarly, the incentives and constraints for achieving outcomes vary with the 
capacity of organizations charged with implementing policies, and also with the incentives and constraints of local and non-local resource users. Mechanisms identified as opportunities for catalysing favourable livelihood outcomes are summarized in Table 5.1.

While the mechanisms for achieving improved livelihoods are clearly spelled out in strategy and legislative documents that accompanied the reform, there remains very limited capacity on the part of the District Forestry Service to carry out activities such as promoting business development and facilitating tree planting. A major challenge for the District Forestry Service has been continued contestation of land tenure and security. Although provisions exist with the new Constitution (1995), Land Act (1998) and National Forestry and Tree Planting Act (2004) to clearly define tenure rights, historical land conflicts between the Buganda and Banyoro ethnic groups, and inmigration and rapid land clearing to establish de facto property rights by migrant communities from south-western and northern Uganda, have contributed to continued deforestation and forest fragmentation. The DFS has neither the mandate nor the capacity to address larger-scale issues of land tenure in rural Uganda. The National Forestry and Tree Planting Act (2004) clearly articulates provisions for establishing community forests. However, given relative land values (with agricultural land typically two to three times more valuable than forested land) and high demand for agricultural land, incentives for communities to establish community forests in the absence of a high degree of extension focused on the potential long-term benefits are weak.

The National Forestry Authority has the budgetary and human resource capacity to implement its mandate; however, attaining fiscal self-sufficiency has directed the focus of its work towards large-scale business opportunities such as plantation establishment and revenue-generating enforcement - such as the confiscation of illegally harvested timber. Significant stakeholder engagement and planning went into the development of guidelines for establishing collaborative forest management agreements (CFMAs) between the National Forestry Authority and villages adjacent to

Table 5.1 Reform mechanisms for catalysing favourable livelihood outcomes

\begin{tabular}{ll}
\hline District & Small business development in the forest sector \\
Forestry & Security of land and tree tenure \\
Service (DFS) & Use of appropriate technologies to enhance food security (e.g. improved stoves) \\
& Promoting tree planting and forest conservation for soil fertility \\
& Establishment of community forests \\
Increased access to forest resources for subsistence use, especially \\
National & wild foods, building materials and medicines \\
Forestry & Sell seed and provide technical advice to landowners who want to establish \\
Authority (NFA) & plantations \\
& Ecotourism cash or in kind contributions to communities \\
& Provisions for Collaborative Forest Management Agreements between Central \\
& Forest Reserve-adjacent communities and the NFA
\end{tabular}

Source: MWLE (2002) 
Central Forest Reserves (MWLE, 2003b). However, the process is complex and bureaucratic, and few NFA employees are effectively trained in initiating and negotiating CFMAs.

\section{METHODS}

This study employs a quasi-experimental research design called the non-equivalent comparison group design. Households in forest sites affected by the reform (i.e. treatment groups) are compared with households in a site that was not affected by the reform (control group). Data from the first and second time period are analysed as a pooled cross section.

\section{Baseline data}

The baseline data for this study were collected in late 2003 immediately prior to the implementation of the forest-sector reform. The baseline study was conducted by the Wildlife Conservation Society (WCS) (Bush et al, 2004). The objective of the study was to understand the contribution of forest products to household livelihood portfolios. The data collection involved a single household survey designed to collect information on both subsistence and cash income-generating activities over the previous 12 months.

WCS conducted surveys in four purposely selected forest sites. They had a total sample of 46 villages and 639 households. The WCS employed a multiple stage stratified random sampling process to select the villages included in the baseline study. As the focus of the study was communities adjacent to forests, the sampling was constrained to parishes (the second lowest administrative unit in the Ugandan local government structure) immediately adjacent to the forest. In order to get good spatial representation around the perimeter of each forest site, parishes were divided into 12 clusters with an equal number of parishes. From each of the 12 clusters, one parish was randomly selected. Within each selected parish a list of villages was compiled and one village was randomly selected from each parish (Bush et al, 2004). Within each village participatory rural appraisal techniques, including a wealth ranking exercise, were used to categorize each household within the village as poor, average or wealthy. From each group five households were randomly selected for the household interview (Bush et al, 2004).

\section{Follow-up data}

The nested research design of forest sites, villages and households was limited to three purposely selected forest sites from the WCS baseline survey. ${ }^{1}$ From each forest site the number of villages included in the sample was reduced from 12 to 6, largely due to financial and logistical constraints. However, the number of households surveyed in each village was increased to provide a representative sample of households within each village. Villages were randomly selected using a stratified random sampling 
method that took into consideration the distribution of the baseline survey villages by forest site and by district in order to maximize variation across the seven districts in the study ( $n=18$ villages). ${ }^{2}$ After the random selection was completed the location of each village was checked to ensure sufficient geographic distribution around each forest site. The random selection process yielded a relatively uniform distribution of villages around each of the three forest sites (see Figure 5.1). ${ }^{3}$

Thirty households were randomly selected from each village $(\mathrm{n}=521$ households). A list of households residing in each village was compiled, drawing upon information from village registers, lists provided by village leaders and information from key informants. ${ }^{4}$ Lack of household level identifiers such as household names or global positioning system (GPS) coordinates in the baseline study made it impossible to study the same households over time.

Fieldwork for the follow-up study was undertaken between October 2006 and August 2007. Each household was visited quarterly. During each visit data on the household's income portfolio, expenditures and time allocation were collected. In addition, each quarterly survey had a short section that was administered in only one quarter. Data were collected on household demographics; assets and resource use;

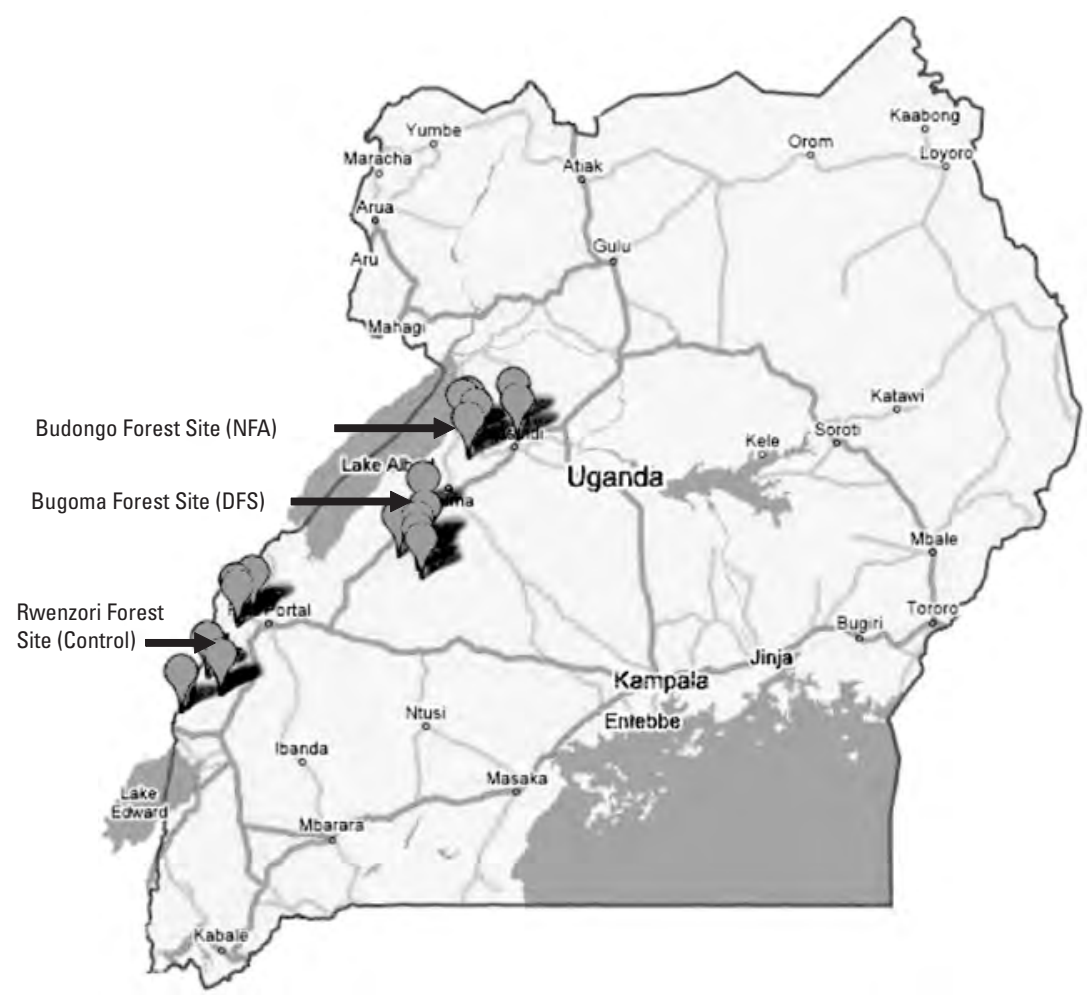

Source: Author

Figure 5.1 Map of villages included in the study 
general household welfare during the past five years; perceptions of access rights to forests, forest products and forest product markets; actual household access to forests, forest products and forest product markets; and perceptions of changes in forest cover and quality during the past five years.

\section{RESULTS}

\section{Livelihood outcomes}

The effect of the forest-sector reform on rural livelihoods is evaluated using two outcome measures: adjusted household forest income and the share of adjusted household income from forest products. ${ }^{5}$ While income is an imperfect measure of overall household welfare, it is relatively easy to measure and is a reasonable proxy for welfare (Angelsen and Wunder, 2003). In order to be able to compare incomes across households, a standardized unit of measure is required. Inter household variation in size and demographic composition are taken into account following Cavendish (2002). ${ }^{6}$

The difference-in-difference (DID) programme evaluation method is used to estimate both the group specific and time specific effect of the reform on the two livelihood outcomes (Wooldridge, 2002). ${ }^{7}$ The model is estimated with the addition of covariates that account for the possibility that the random samples within a group have systematically different characteristics in the two time periods. The coefficients of primary interest with respect to understanding the governance reform and its effect on livelihoods are treatment $d f s \times$ time (i.e. effect for households living near forests overseen by the decentralized District Forestry Service post-reform; treatment 1(T1)) and treatment nfa $x$ time (i.e. effect for households living near forests overseen by the parastatal National Forestry Authority post-reform; treatment 2(T2)). Regression results are presented in Table 5.2. ${ }^{8}$

Controlling for household and village-level characteristics, the net effect of the reform in the Bugoma forest site (i.e. democratic decentralization to local government) is relatively small. The transition from the Forestry Department to the District Forestry Service appears to have had a negligible effect on average household income from forests (i.e. an increase of 9838 Ugandan shillings or US\$5). Decomposition by income quartile reveals that the poorest households have lost a modest amount of forest income (17,469 Ugandan shillings or US\$10), whereas wealthy households have increased income from forests by an average of 55,150 Ugandan shillings or US $\$ 30$. The share of income from forests has increased 3.1 per cent for the average household. Regression results decomposed by income quartile indicate that the share of income from forests has declined for the poorest households (10.7 per cent) and increased for the wealthiest households (11.6 per cent). The decline in the share of income from forests for poor households is statistically significant at the 10 per cent level.

These findings indicate that the transition to local government control over forest management has had a limited effect on livelihoods in the treatment group. Furthermore, forest income for the poorest households has declined, while there have 


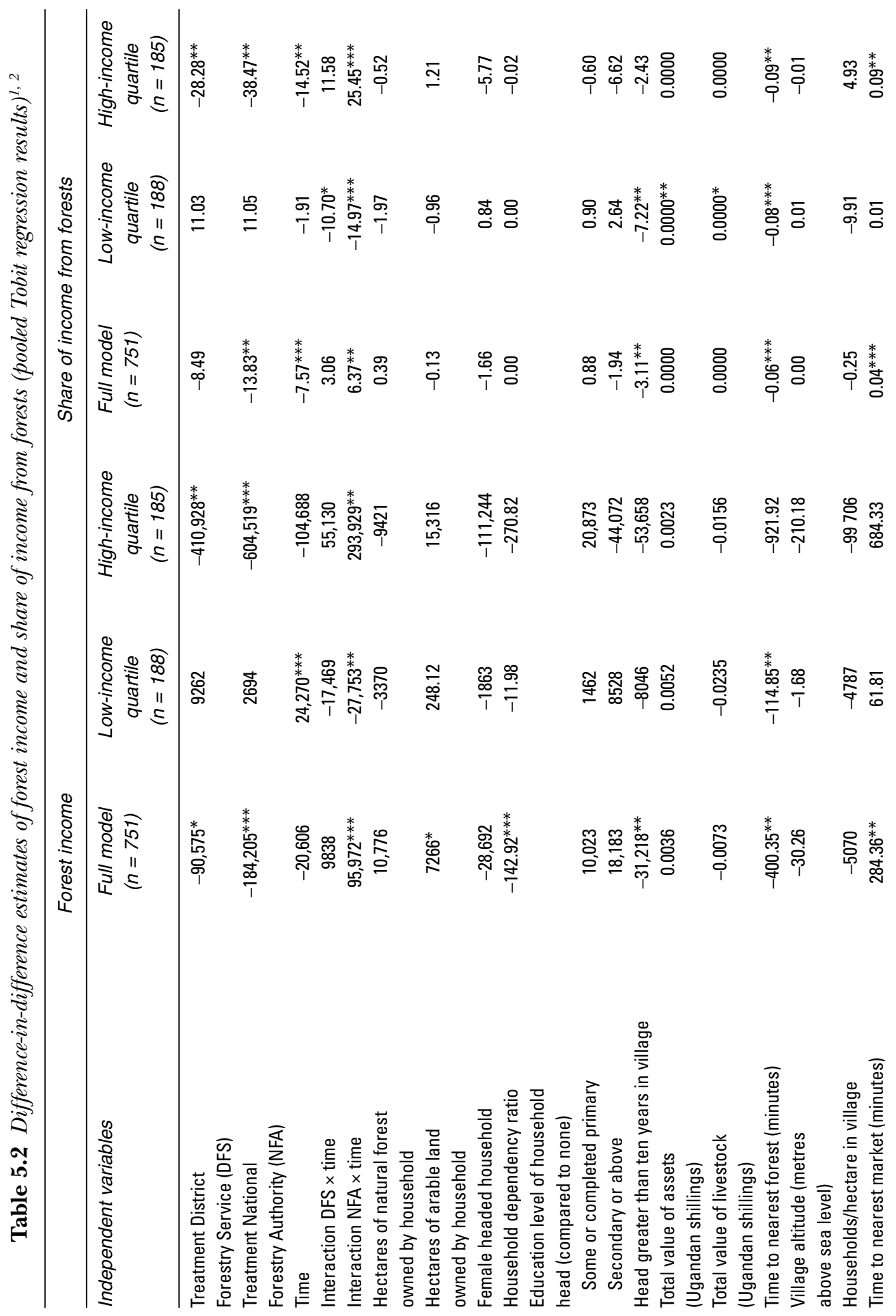




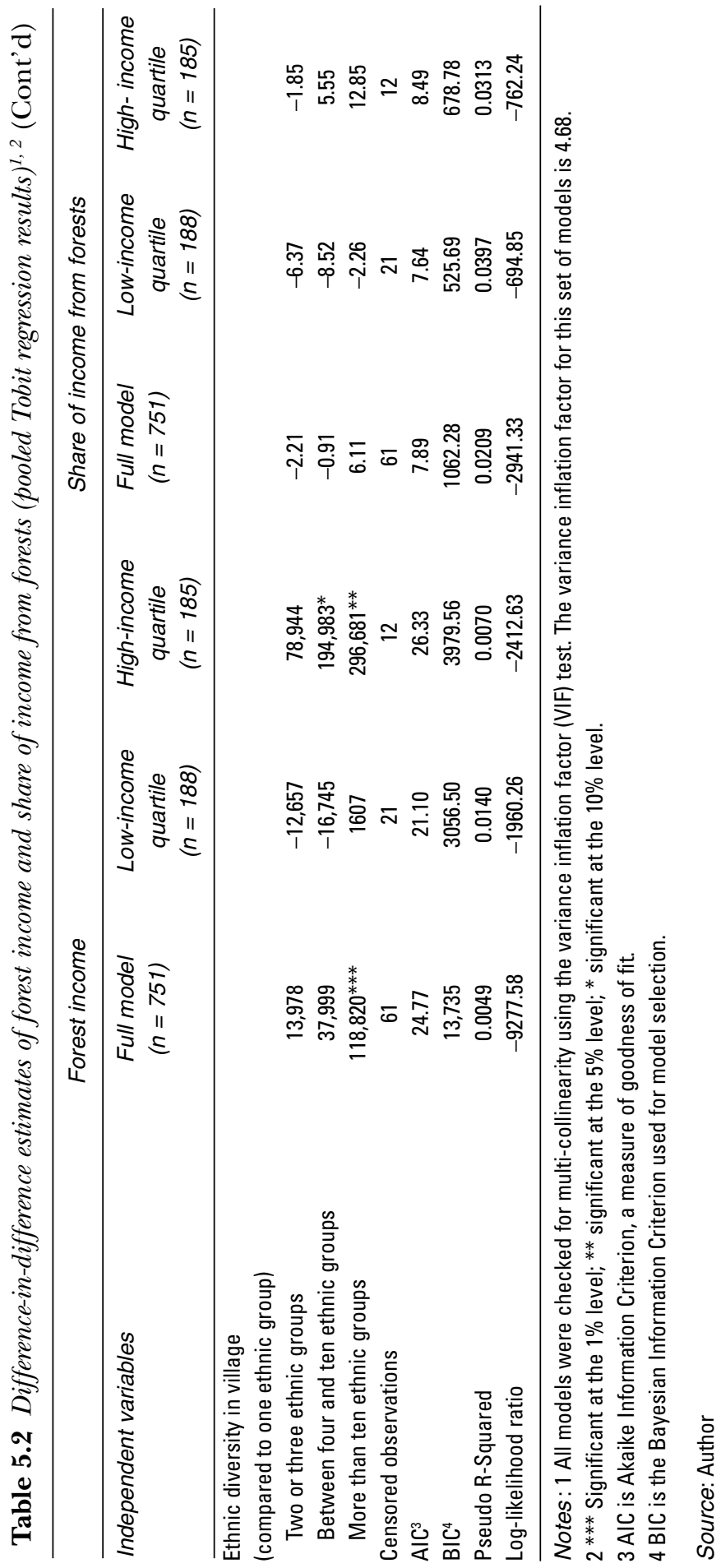


been gains in forest income for the wealthiest households. Limited capacity of district forest officers (DFOs) operating in the two districts that are included in the Bugoma forest site is a possible explanation for the lack of attention to improving rural livelihoods. DFOs in Hoima and Kibaale districts devote the majority of their time to the collection of district revenues for timber and charcoal transport. Their primary connection with local resource users is via periodic local radio programme broadcasts. The majority of forest income in the Bugoma forest site is for subsistence use; local resource users are generally excluded from accessing markets for high-value forest products. In addition, few are aware of the value of the timber that is being harvested on private and customary lands in this area. The desire to clear land for agriculture often means that landowners will invite timber harvesters to cut large trees on their land at no cost, or for a payment far below market value.

Findings for the Budongo forest site (i.e. households living adjacent to the Central Forest Reserve managed by the National Forestry Authority) suggest that the reform has had a larger effect in this area. In the Budongo forest site, the average increase in household forest income is 95,972 Ugandan shillings, or US $\$ 53$. The differential effect of the reform on forest income for the poorest and wealthiest households is striking; households in the lowest income quartile have lost an average of 27,753 Ugandan shillings, or $\$ 15$ per household, while households in the highest income quartile are estimated to have increased forest income by 293,929 Ugandan shillings, or \$162 per year. The share of income from forests has increased 6.4 per cent for the average household. Regression results decomposed by income quartile indicate that the share of income from forests has declined for the poorest households (15 per cent) and increased for the wealthiest (25 per cent). For all models, estimated coefficients for the variable treatment nfa $x$ time were significant at the 1 or 5 per cent level. The findings indicate that the forest sector reform in the Budongo forest site is strongly favouring the wealthiest households.

The extent to which wealthy households in the Budongo forest site are benefiting significantly from engagement in the timber business points to some serious flaws in the implementation of the reform. Currently there is no legal mechanism for smallholders living adjacent to Budongo Central Forest Reserve to harvest timber. As part of the transition to the National Forestry Authority, the presence of forestry officials in the Budongo forest site has significantly increased. However, based upon data collected for this study it appears that serious enforcement failures are taking place; specifically, enforcement is selective and disproportionately focused on the lowest-income households. Selective enforcement may be partially attributed to a change in the way in which forest guards are compensated. Lower pay and fewer allowances relative to management by the centralized Forest Department have created an incentive for forest guards to collude with illegal timber producers. For a complete discussion of regression results, see Jagger (2009).

\section{Forest sustainability outcomes}

Local resource users have a good overall understanding of local environmental conditions, particularly for indicators that are relatively easy to visually assess (e.g. forest cover loss, excessive soil erosion, etc.) (Gebremedhin and Swinton, 2002; Kerr and Pender, 2005). Respondents were asked to consider indicators of change in forest 
cover and quality over the past five years for each forest tenure system that their household regularly accesses (e.g. private, community, national park or central forest reserve). ${ }^{9}$

\section{Indicators of forest cover change}

In the Bugoma forest site, forest cover significantly declined for both private and community forests (see Table 5.3). Respondents in the Bugoma forest site indicated major declines in the area under forest, as well as major declines in forests that are considered closed canopy for both tenure systems. ${ }^{10}$ No major change in the occurrence of flooding, landslides or soil erosion on plots adjacent to the forest was reported. Households did indicate minor declines in water availability in forest wells and springs. Indicators of forest cover change for the Budongo forest site indicate similar trends for private and community forest. However, no significant change was observed in forest cover in the Central Forest Reserve during the past five years.

The shaded columns in Table 5.3 highlight the forest site/tenure comparisons that are central to this research. The direct comparisons are: national park (NP) in the Rwenzori forest site (control group) with privately held forest in the Bugoma forest site (T1); and national park (NP) in the Rwenzori forest site (control group) with Central Forest Reserve (CFR) in the Budongo forest site (T2). Difference of means tests show that there are significant differences in the change in the area of forest, area of forest considered closed canopy, and water availability in springs/wells in or adjacent to the forest when comparing Rwenzori with Bugoma, and also when comparing Rwenzori with Budongo.

Overall, household perceptions of change in forest cover during the past five years suggest that Rwenzori Mountains National Park is being well managed relative to private forest in the Bugoma site and the forest in the Budongo CFR. The comparison between private forest in the Bugoma forest site and forest within the national park in the Rwenzori forest site is that forest cover is rapidly declining in the Bugoma site and remaining stable or improving in the Rwenzori site. Relative to forests in Rwenzori Mountains National Park where improvements in forest cover, canopy cover and water availability are observed, forests in Budongo Central Forest Reserve are experiencing minor forest cover loss.

\section{Indicators of forest quality change}

Household perceptions of change in forest quality (see Table 5.4) are consistent with indicators of forest cover change. Data for the Bugoma forest site indicate that forest quality has declined in both private and community forests over the past five years. In particular, the diversity of trees, the number of large trees, and animal diversity have declined significantly. These findings are consistent with reports of high levels of forest degradation on private lands throughout Hoima and Kibaale districts (Nsita, 2005).

Findings for the Budongo forest site are mixed. While tree diversity, the number of large trees and water quality have declined, households indicate that bird and animal diversity has increased. A possible reason for the relatively minor decline or 


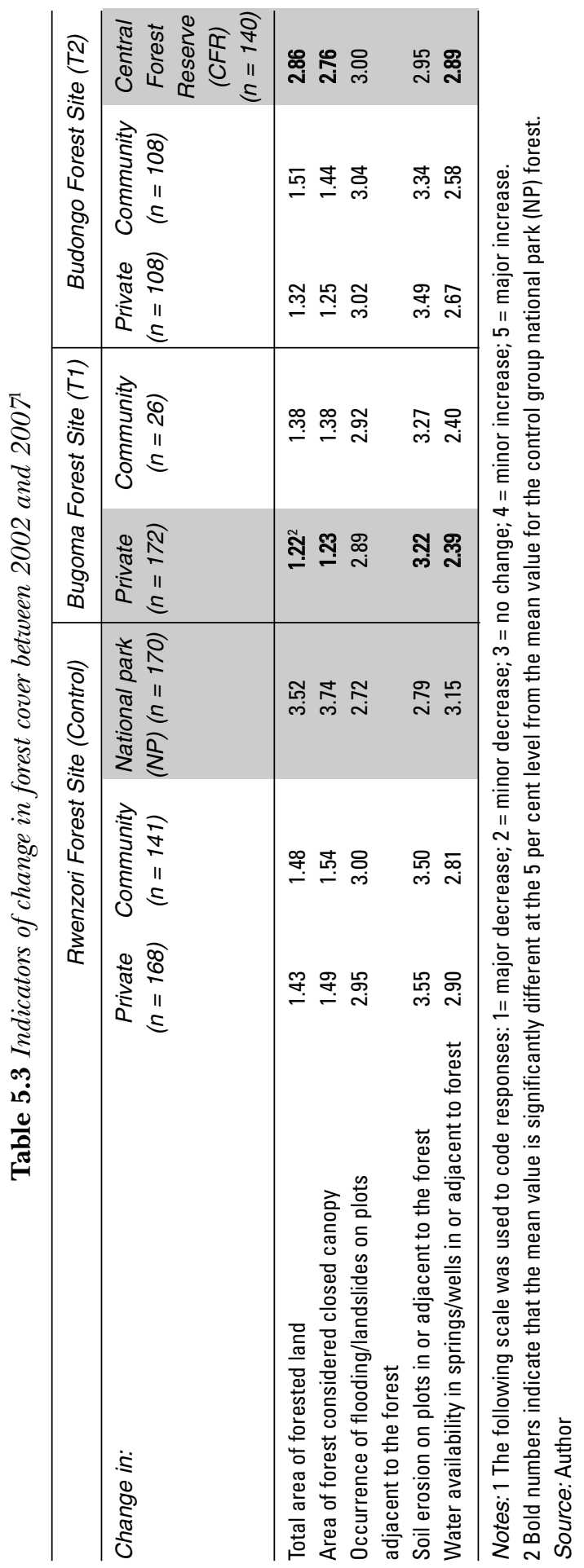




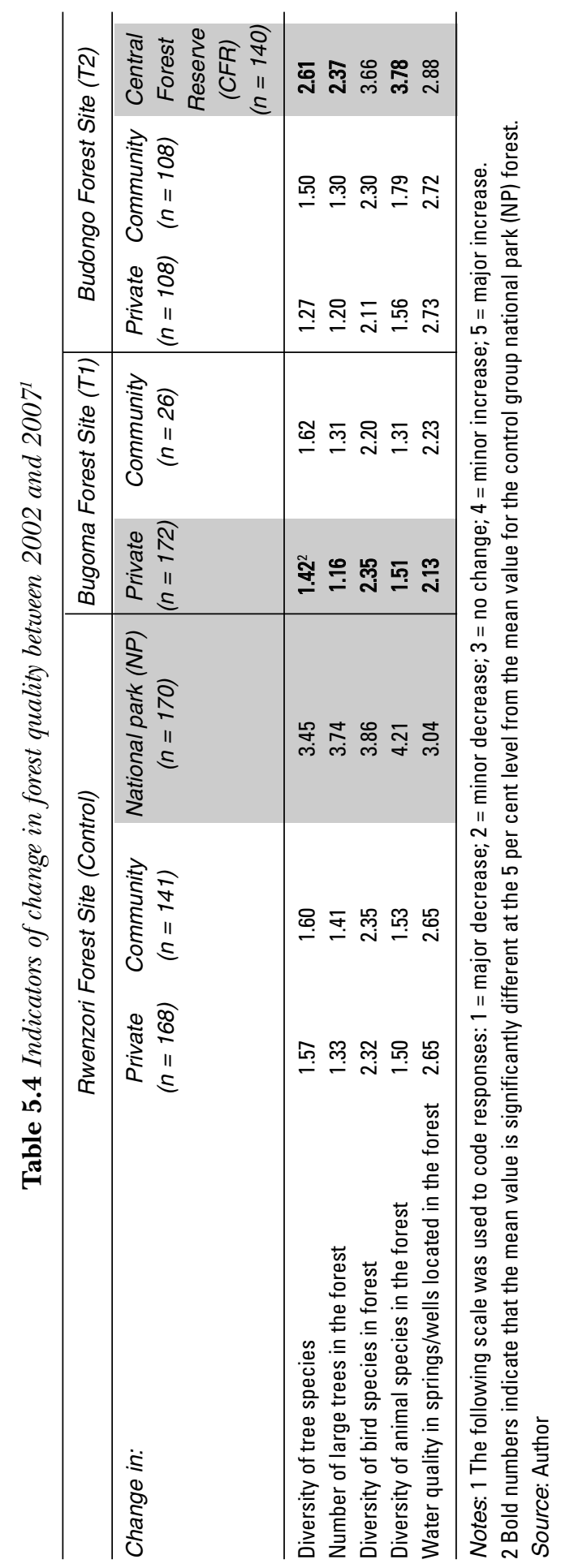


lack of change in some indictors observed in the Budongo forest site is that changes of this nature are medium-term ecological changes that require more significant landuse change before they are easily observed. While clearing of forest in the Budongo site is relatively uncommon, small-scale timber harvesting exists and takes longer to have observable effects.

The shaded columns in Table 5.3 highlight the relevant forest site/tenure comparisons. Comparing findings for privately held land in the Bugoma forest site (T1) and Budongo Central Forest Reserve (T2) with the control group national park forest indicates that centralized management under the Uganda Wildlife Authority is associated with the most favourable forest quality outcomes. Significant differences were observed for all indicators of forest quality when comparing the control group forest with the Bugoma forest site, and for indicators of diversity of tree and animal species and the number of large trees in the Budongo forest site.

Similar responses were recorded for changes in forest cover and quality for private and community forests in all three sites. In general, the data suggest that the total area under forest, and the proportion of forest that is closed canopy are declining significantly under decentralized management, while other indicators of forest cover change including flooding, soil erosion and water availability remain relatively constant. Across all sites there are significant declines in the number of tree species, the number of large trees, and animal species diversity in private and community forest. Minor differences in indicators of forest cover and quality change on private and community forests suggest that forest users face similar incentives for managing private and community forests throughout western Uganda. These findings are consistent with Plumptre (2002), who found that forest cover loss and forest degradation were most significant in western Uganda on private lands. Plumptre (2002) estimates that approximately 80,000ha of forest have been lost in western Uganda since the 1980s, primarily on lands outside of reserves and national parks.

\section{GONGLUSIONS AND POLICY IMPLICATIONS}

While Uganda's forest sector reform is still in the early stages of implementation, the findings point to some striking changes in the role of forests in rural livelihood portfolios and forest condition in western Uganda. The most important finding is that for households and forests affected by the reform there is no evidence that both favourable livelihood and sustainability outcomes have been achieved. In the Bugoma forest site, there has been no significant change in the contribution of forest to household incomes, and forest cover and forest quality have significantly declined. In the Budongo forest site there have been significant gains in the contribution of forest products to the incomes of wealthy households. Livelihood improvements are largely attributed to institutional failures, including selective enforcement that favours the wealthy and an absence of meaningful community engagement in forest management activities. Income gains for wealthy households in this forest site are accompanied by no change or slight declines in forest cover and condition within the Central Forest Reserve. A case study exploring the complex interplay of incentives and roles that must align for favourable outcomes to be 


\section{Box 5.1 Early lessons from the implementation of decentralization reforms in Kenya and Uganda}

\section{Abwoli Banana, Paul Ongugo, Joseph Bahati, Esther Mwangi and Krister Andersson}

Decentralization reforms in Kenya and Uganda are still in their infancy. Both countries are struggling in their search for institutional arrangements and structures that promise to deliver benefits to local communities, while at the same time ensuring forest sustainability. While Kenya's experimentation is in its early stages, the collaborative forest management piloted in a few forests in the country seems to have few lessons to offer - given the profound institutional changes that are required to implement the new Forest Act and the time that it requires for longstanding patterns of behaviour to be transformed. Pilot activities have not changed the nature of interaction between forest authorities and local communities. It remains top down and concentrated in the hands of the Forest Department, means of redress are weak, and community labour is exploited for forest monitoring. It has, nonetheless, served two purposes. First, it has paved the way for the interaction of multiple interests, including the development of community-based organizations and associations for forest management. Much of their involvement to date has been oriented towards activities aimed at deflecting pressure away from forest resources, including tree planting, regeneration of degraded forest patches and ecotourism. These different forms of organization will assume even greater importance as the new Forest Act is implemented since it vests management responsibility and benefits with already organized local actors. Second, even though local communities do not yet have officially recognized roles as rule-makers and cannot engage in the harvesting of forest products for income, they are engaged in nonconsumptive income-generating enterprises. This has served to develop their entrepreneurial capacities in ways that do not threaten forest sustainability. It may well be that a stewardship culture is in the making, which may help to guard against unsustainable behaviour once full management responsibility is ceded to communities. However, the current incentive structure, where the Forest Department draws disproportionate benefits and has a stranglehold on decision-making authority, is insufficient to warrant greater efforts at sustainable use from local communities. If anything, current arrangements are a disincentive for investing in the resource base, with declines in forest cover and quality and increased illegal harvesting important manifestations of this shortcoming.

While Uganda's decentralization reforms are also beset with certain internal contradictions, such as the leasing of forest patches for plantation development at the expense of forest access by local communities, it has a lot of lessons to offer its neighbour. First, because the district council - the official manager of local forests - is subject to an electoral process, there is scope for enforcing some political accountability through electoral rewards or punishment for their performance. Second, local actors have an assortment of options for seeking redress over grievances and/or advisory support for their activities. Third, there is recognition of the importance of 
forests for livelihoods and incomes of communities living adjacent to forests. These elements are fundamental for enhancing community interest in sustainable forest management. The Ugandan experience so far also suggests that it is important to address inconsistencies that can potentially undermine the objectives of decentralization. For example, under-resourcing of local governments requires creative measures for fundraising, which can lead to an increase in forest-related corruption unless accompanied by more substantial flows of revenue from the central government to whom revenue from high-value forests accrues. Mechanisms to pay for and reward local forest management activity should also be fostered. For example, revenues collected from forest product taxation and permits can be ploughed back into communities to pay for or reward community managers involved in patrolling and forest improvement activities. Finally, in order to improve the incentives for individual farmers, instead of leasing forests only to private investors, a given percentage should be leased to farmers for tree planting and management while retaining a portion of the forest reserve in its natural state so that farmers can continue to harvest forest products.

Decentralization can take many different forms, from partial devolution of management responsibility and/or benefits to a more profound devolution of benefits and responsibility to communities or local government. While it is still early to tell the exact implications of these reforms, given the time over which such profound shifts in rules and roles take place, signs indicate that the more profound devolution can engender the incentives necessary for sustainability. More attention should be given to the environmental and livelihood outcomes of transferring power to local communities versus local authorities, and the competencies and conditions under which each may be effective in producing different outcomes.

achieved suggests the fundamental role of institution-building of government agencies and communities for any forest governance reform (see Box 5.1).

Several recommendations emerge from this research. First, policy-makers should be aware of structural inequities within rural societies. The findings from this study document the differential effect of Uganda's forest-sector reform on households within different income categories. For reforms to benefit the poorest households, strategies and incentives should be provided to local governments and managing forestry authorities to facilitate that objective. Second, this research highlights the influence of incentives facing forestry officials working most closely with forestdependent communities. Officials who are poorly facilitated, paid insufficiently or irregularly, or with no capacity to fulfil their mandate are at risk of colluding with illegal resource users and failing to manage forests sustainably. Finally, the pressure for local populations to clear private and community forest for agriculture is tremendous. There is currently very little integration of forestry and agricultural policy in Uganda. Continuing to focus on sustainable forest management, at the expense of addressing the primary cause of land-use change in an integrated fashion, will certainly lead to continued forest loss throughout western Uganda. 


\section{ACKNOWLEDGEMENTS}

I am grateful to the following organizations for funding this research: the Center for International Forestry Research (CIFOR); the Collective Action and Property Rights Initiative (CAPRi) of the Consultative Group on International Agricultural Research; the National Science Foundation (NSF; grant number DDIG 0622392); the Social Sciences and Humanities Research Council of Canada (SSHRC); the Social Science Research Council (SSRC); and the Sustainable Agriculture and Natural Resource Management Collaborative Research Support Programme (SANREM CRSP; grant number EPP-A-00-04-00013-00). This project would not have been possible without the cooperation and advice of Glenn Bush of the University of Stirling and Andy Plumptre of the Wildlife Conservation Society (WCS), Albertine Rift Programme, who shared the baseline data used in this study (Bush et al, 2004). A total of 521 households fully participated in this study between October 2006 and August 2007. Their willingness to share information on the challenging and controversial topic of forests and land, host us for numerous hours in their homes, and stick with us for a full year was critical to project success. The 639 households that participated in the WCS baseline study in 2003 played an equally important role. I am grateful to Arild Angelsen, Laura German, Marty Luckert and Jerry Shively who have given substantive feedback on this chapter, and to three anonymous reviewers. Finally, and most importantly, this research was carried out by an extraordinary team of enthusiastic, hard-working and dedicated research assistants from western Uganda. Arthur Arinaitwe (team leader); Brian Isingoma, Issa Katwesige, Shallon Kihembo, Grace Nyesiga and Samson Tweheyo worked countless hours over the course of 16 months to collect, enter and clean data. Any errors or omissions are my own.

\section{NOTES}

1 The Wildlife Conservation Society (WCS) study included one woodland site dropped in the follow-up study due to budgetary and logistical constraints. The three forest sites with the most similar forest types (Afromontane and tropical high forest) were retained.

2 At the time of the WCS study all of the villages within the Budongo forest site fell within Masindi District. In July 2006, Buliisa District was created. The villages for the Budongo site were not selected proportionally according to the new districting, but rather randomly from among the 12 villages in the Budongo forest site.

3 For a detailed description of the forest sites included in the follow-up study, see Jagger (2009).

4 Polygamous households were listed according to the wife's name; each wife was considered a separate household unless key informants indicated that wives jointly undertook key livelihood activities, such as cooking and cultivating.

5 Incomes are net of costs but do not explicitly take into account the value of labour.

6 Adjusted income is comprised of three components: a time weighting equal to the proportion of the year each household member spends in the household; a nutritional 
weight allocated according to the age and gender of each household member; and an economy of scale weight (Cavendish, 2002). Because the study area does not have a significant proportion of households with migrant labourers, we assumed all individuals to be time weighted at 100 per cent of their time in the household. Each household was assigned a coefficient of adult equivalency based upon nutritional needs, which vary by age and gender. The sum of these values across all members of the household yields the household size measured in adult equivalent units. An economy of scale weight was assigned to each household in accordance with the number of members of the household. The final measure of household size was estimated by multiplying the adult equivalent units by the appropriate weight for household size. Unadjusted estimates of total income were divided by household size in adjusted annual equivalents to produce total household income per adjusted adult equivalent units. Adjusted annual incomes from baseline data were adjusted to real values by multiplying incomes in 2003 by 6.38 per cent, the average inflation rate in Uganda in the 2003 to 2007 period.

7 For a detailed discussion of the difference-in-difference method, presentation of descriptive statistics, including double-difference means, and details of model specifications, see Jagger (2009).

8 See Appendix A in this chapter for descriptive statistics for the variables included in the regression analysis.

9 It is important to note that data on forest cover and forest quality indicate change over the past five years. These data illustrate the capacity of forest management agencies operating in the post-reform period to sustainably manage forests. We did not have data on household perceptions of forest cover and quality change in the pre-reform period to compare with.

10 Closed canopy is defined as crown cover greater than 40 per cent.

\section{REFERENCES}

Agrawal, A. and E. Ostrom (2001) 'Collective action, property rights and decentralization in resource use in India and Nepal', Politics and Society, vol 29, no 4, pp485-514

Andersson, K. and C. C. Gibson (2006) 'Decentralized governance and environmental change: Local institutional moderation of deforestation in Bolivia', Journal of Policy Analysis and Management, vol 26, no 1, pp99-123

Angelsen, A. and S. Wunder (2003) Exploring the Forest-Poverty Link: Key Concepts, Issues and Research Implications, CIFOR Occasional Paper no 40, Center for International Forestry Research, Bogor, Indonesia

Bahiigwa, G., D. Rigby and P. Woodhouse (2005) 'Right target, wrong mechanism? Agricultural modernization and poverty reduction in Uganda', World Development, vol 33, no 3, pp481-496

Banana, A., N. D. Vogt, J. Bahati and W. Gombya-Ssembajjwe (2007) 'Decentralized governance and ecological health: Why local institutions fail to moderate deforestation in Mpigi District of Uganda', Scientific Research and Essay, vol 2, no 10, pp434-445

Bardhan, P. (2002) 'Decentralization of governance and development', Journal of Economic Perspectives, vol 16, no 4, pp185-205 
Bush, G., S. Nampindo, C. Aguti and A. Plumptre (2004) The Value of Uganda's Forests: A Livelihoods and Ecosystems Approach, Wildlife Conservation Society, Kampala, Uganda

Cavendish, W. (2002) 'Quantitative methods for estimating the economic value of resource use to rural households', in B. M. Campbell and M. K. L. Luckert (eds) Uncovering the Hidden Harvest: Valuation Methods for Woodland and Forest Resources, Earthscan, London

Crook, R. C. and A. Sverrisson (2001) Decentralization and Poverty Alleviation in Developing Countries: A Comparative Analysis or is West Bengal Unique?, IDS Working Paper no 120, Institute for Development Studies, Sussex, UK

Deininger, K. (2003) Land Policies for Growth and Poverty Reduction, World Bank, Washington, DC

Fisher, R. J., S. Maginnis, W. J. Jackson, E. Barrow and S. Jeanrenaud (2005) Poverty and Conservation: Landscapes, People and Power, IUCN, Gland, Switzerland, and Cambridge, UK

Gebremedhin, B. and S. Swinton (2002) 'Sustainable management of private and communal lands in northern Ethiopia', in C. B. Barrett, F. Place and A. A. Aboud (eds) Natural Resource Management in African Agriculture, CABI Publishing, New York, NY

GOU (Government of Uganda) (2003) The National Forestry and Tree Planting Act, GOU, Kampala, Uganda

Jagger, P. 2009. Can Forest Sector Devolution Improve Rural Livelihoods? An Analysis of Forest Income and Institutions in Western Uganda. PhD Diss., Indiana University, Bloomington. Jagger, P. (2008) Forest Income after Uganda's Forest Sector Reform: Are the Rural Poor Gaining?, CAPRi Working Paper no 92, International Food Policy Research Institute, Washington, DC Jagger, P., J. Pender and B. Gebremedhin (2005) 'Trading-off environmental sustainability for empowerment and income: Woodlot devolution in northern Ethiopia', World Development, vol 33, no 9, pp1491-1510

Jumbe, C. and A. Angelsen (2006) 'Do the poor benefit from devolution policies? Evidence from Malawi's Forest Co-Management Program', Land Economics, vol 82, no 4, pp562-581

Kerr, J. and J. Pender (2005) 'Farmers' perceptions of soil erosion and its consequences in India's semiarid tropics', Land Degradation and Development, vol 16, no 3, pp257-271

Larson, A. M., P. Pacheco, F. Toni and M. Vallejo (2007) 'The effects of forestry decentralization on access to livelihood assets', Journal of Environment and Development, vol 36, no 3, pp251-268

McCarthy, J. F. (2004) 'Changing to gray: Decentralization and the emergence of volatile sociolegal configurations in central Kalimantan, Indonesia', World Development, vol 32, no 7, pp1199-1223

Meinzen-Dick, R. and A. Knox (2001) 'Collective action, property rights, and devolution of natural resource management: A conceptual framework', in R. Meinzen-Dick, A. Knox and M. Di Gregorio Feldafing (eds) Collective Action, Property Rights and Devolution of Natural Resource Management - Exchange of Knowledge and Implications for Policy, edited Deutsche Stifung für Internationale Entwicklung, Germany

MWLE (Uganda Ministry of Water, Lands and Environment) (2001) The Uganda Forest Policy, Ministry of Water, Lands and Environment, Kampala, Uganda

MWLE (2002) The National Forest Plan, Ministry of Water, Lands and Environment, Kampala, Uganda

MWLE (2003a) The New National Forest Plan: Popular Version (edited by F. I. Division), Ministry of Water, Land and Environment, Kampala, Uganda

MWLE (2003b) Guidelines for Implementing Collaborative Forest Management in Uganda, Ministry of Water, Lands and Environment, Kampala, Uganda 
MWLE (2004) Mapping the NFP Process: An Introduction to the Series, Uganda NFP Process Learning Series Note 1, Kampala: Ministry of Water, Lands and Environment (Forestry Inspection Division), Kampala, Uganda

MWLE (2006) Reform of the Ministry of Water, Lands and Environment: Towards an Enabling Institutional Framework, Uganda NFP Process Learning Note 8, Ministry of Water, Lands and Environment (Forestry Inspection Division), Kampala, Uganda

Ndegwa, S. (2002) Decentralization in Africa: A Stocktaking Survey, Africa Regional Working Paper Series no 40, World Bank, Washington, DC

Nsita, S. A. (2005) 'Decentralization and forest management in Uganda', in C. J. P. Colfer and D. Capistrano (eds) The Politics of Decentralization: Forests, Power and People, Earthscan, London Oyono, P. R. (2005) 'Profiling local-level outcomes of environmental decentralizations: The Case of Cameroon's forests in the Congo Basin', Journal of Environment and Development, vol 14, no 2, pp1-21

Palmer, C. and S. Engel (2007) 'For better or for worse? Local impacts of decentralization of Indonesia's forest sector', World Development, vol 35, no 12, pp2131-2149

Plumptre, A. J. (2002) 'Extent and status of the forests in the Ugandan Albertine Rift', in Report to GEF PDF-b Albertine Rift Project, Wildlife Conservation Society, Kampala, Uganda

Ribot, J. C. (1999) 'Decentralization, participation and accountability in Sahelian forestry: Legal instruments of political-administrative control', Africa, vol 69, no 1, pp23-65

Ribot, J. C. and N. L. Peluso (2003) 'A theory of access', Rural Sociology, vol 68, no 2, pp153-181

Sikor, T. and T. Q. Nguyen (2007) 'Why may forest devolution not benefit the rural poor? Forest entitlements in Vietnam's Central Highlands', World Development, vol 35, no 11, pp2010-2025

Vedeld, T. (2003) 'Democratic decentralisation and poverty reduction: Exploring the linkages', Forum for Development Studies, vol 2, pp159-203

Wooldridge, J. M. (2002) Econometric Analysis of Cross Section and Panel Data, MIT Press, Boston, MA

World Bank (2008) Poverty and the Environment: Understanding Linkages at the Household Level, World Bank, Washington, DC

WRI (World Resources Institute) (2003) 'Decentralization: A local voice', in World Resources 2002-2004: Decisions for the Earth. Balance, Voice and Power, World Resources Institute, Washington, DC

WRI in collaboration with UNDP (United Nations Development Programme), UNEP (United Nations Environment Programme) and World Bank (2005) World Resources 2005: The Wealth of the Poor - Managing Ecosystems to Fight Poverty, World Resources Institute, Washington, DC 


\section{APPENDIX A}

Table 5.A1 Descriptive statistics for variables used in regression analysis

\begin{tabular}{|c|c|c|c|c|c|}
\hline Variable & $\begin{array}{l}\text { umber of } \\
\text { ervations }\end{array}$ & Mean & Standard deviation & Minimum & Maximum \\
\hline \multicolumn{6}{|c|}{ Baseline data (Wildlife Conservation Society Data, 2003) } \\
\hline $\begin{array}{l}\text { Adjusted total income } \\
\text { (Ugandan shillings) }\end{array}$ & 253 & 468,222 & 453,727 & 43,649 & $2,544,500$ \\
\hline $\begin{array}{l}\text { Adjusted forest income } \\
\text { (Ugandan shillings) }\end{array}$ & 253 & 84,747 & 169,884 & 0 & $1,470,238$ \\
\hline Share of income from forests $(\%)$ & 253 & 18.80 & 21.12 & 0 & 90.99 \\
\hline Natural forest owned (ha) & 253 & 0.13 & 0.80 & 0 & 7.80 \\
\hline Arable land owned (ha) & 253 & 1.42 & 1.81 & 0 & 12.00 \\
\hline Female-headed households (\%) & 253 & 8.30 & 27.64 & 0 & 1.0 \\
\hline \multicolumn{6}{|c|}{ Education level of household head (compared to none) } \\
\hline Some or completed primary (\%) & 253 & 64.43 & 48.00 & 0 & 1.0 \\
\hline Secondary or above $(\%)$ & 253 & 19.76 & 39.90 & 0 & 1.0 \\
\hline Dependency ratio & 253 & 151 & 104 & 0 & 600 \\
\hline $\begin{array}{l}\text { Head greater than ten years } \\
\text { in village }(\%)\end{array}$ & 253 & 83.80 & 36.92 & 0 & 1.0 \\
\hline $\begin{array}{l}\text { Value of assets } \\
\text { (Ugandan shillings) }\end{array}$ & 253 & 291,542 & 903,983 & 0 & $7,330,000$ \\
\hline $\begin{array}{l}\text { Value of livestock } \\
\text { (Ugandan shillings) }\end{array}$ & 253 & 172,237 & 215,707 & 0 & $1,162,100$ \\
\hline Minutes to nearest forest & 253 & 62.76 & 56.00 & 0 & 360 \\
\hline
\end{tabular}

\section{Follow-up data (Jagger Dissertation Data, 2007)}

\begin{tabular}{|c|c|c|c|c|c|}
\hline $\begin{array}{l}\text { Adjusted forest income } \\
\text { (Ugandan shillings) }\end{array}$ & 499 & 632,285 & 471,252 & 115,714 & $4,336,662$ \\
\hline $\begin{array}{l}\text { Adjusted total income } \\
\text { (Ugandan shillings) }\end{array}$ & 499 & 91,815 & 148,197 & 0 & $1,919,542$ \\
\hline Share of income from forests $(\%)$ & 499 & 14.33 & 12.54 & 0 & 74.48 \\
\hline Natural forest owned (ha) & 499 & 0.27 & 0.58 & 0 & 4.86 \\
\hline Arable land owned (ha) & 499 & 1.58 & 1.32 & 0 & 9.31 \\
\hline Female-headed households (\%) & 499 & 15.83 & 36.54 & 0 & 1.0 \\
\hline \multicolumn{6}{|c|}{ Education level of household head (compare to none) } \\
\hline Some or completed primary (\%) & 499 & 50.10 & 50.05 & 0 & 1.0 \\
\hline Secondary or above $(\%)$ & 499 & 28.46 & 45.16 & 0 & 1.0 \\
\hline Dependency ratio & 499 & 142 & 112 & 0 & 700 \\
\hline $\begin{array}{l}\text { Head greater than ten years } \\
\text { in village }(\%)\end{array}$ & 499 & 80.76 & 39.45 & 0 & 1.0 \\
\hline $\begin{array}{l}\text { Value of assets } \\
\text { (Ugandan shillings) }\end{array}$ & 499 & 20,925 & 554,392 & 0 & $8,970,000$ \\
\hline $\begin{array}{l}\text { Value of livestock } \\
\text { (Ugandan shillings) }\end{array}$ & 499 & 291,308 & 889,485 & 0 & $9,130,000$ \\
\hline Minutes to nearest forest & 499 & 34.75 & 44.24 & 0 & 240 \\
\hline
\end{tabular}


Table 5.A1 Descriptive statistics for variables used in regression analysis (Cont'd)

\begin{tabular}{lcllll}
\hline Variable & $\begin{array}{c}\text { Number of } \\
\text { observations }\end{array}$ & Mean & Standard deviation & Minimum & Maximum \\
\hline
\end{tabular}

\section{Village-level fixed effects}

\begin{tabular}{|c|c|c|c|c|c|}
\hline Altitude (metres above sea level) & 18 & 1294 & 307 & 963 & 1872 \\
\hline Households per hectare & 18 & 0.36 & 0.17 & 0.10 & 0.73 \\
\hline \multicolumn{6}{|l|}{ Minutes to nearest market for } \\
\hline \multicolumn{6}{|c|}{ Ethnic diversity in village (compared to one ethnic group) } \\
\hline Two or three ethnic groups & 18 & 33.33 & 48.51 & 0 & 1.0 \\
\hline $\begin{array}{l}\text { Between four and ten ethnic } \\
\text { groups }\end{array}$ & 18 & 27.78 & 46.09 & 0 & 1.0 \\
\hline More than ten ethnic groups & 18 & 16.67 & 38.35 & 0 & 1.0 \\
\hline
\end{tabular}

Note: During the follow-up study the average exchange rate was US\$1 = 1817 Ugandan shillings.

Source: Author 


\title{
Hidden Harvest: Unlocking the Economic Potential of Community-Based Forest Management in Tanzania
}

\author{
Tom Blomley, Hadija Ramadhani, Yassin Mkwizu and Andreas Böhringer
}

\section{INTRODUCTION}

Worldwide, approaches to involving people in forest management have multiplied over the past two decades. Adopting a range of names and strategies, and variously called participatory forestry, community forestry, joint forest management or collaborative forest management, all have tended to emphasize the decentralization or devolution of forest management rights in return for mutually enforceable responsibilities, with the aim of producing positive ecological, social and economic outcomes (Ingles et al, 1999; Cater and Grownow, 2005). Decentralization of natural resource management rights and responsibilities revolves around three key themes: accountability, discretionary power and security (Ribot, 2002, 2004). While much of the momentum and impetus for this movement started in Asia, most notably India and Nepal, since the mid 1990s similar changes have been witnessed on the African continent (Wily, 2002). In Africa, the moves towards more devolved forms of forest management have been strongly supported by parallel reforms in both local government legislation and land reforms that have strengthened customary rights, devolved decision-making on land tenure and adjudication, and, in many cases, formalized traditional collective land tenure arrangements (Wily, 2000). Nowhere in Africa has this been stronger than in Tanzania, where a unique blend of political history and bold legislative reforms has created one of the most advanced community forestry jurisdictions in Africa (Wily, 2000).

Over the past 15 years, the Tanzanian government has promoted participatory forest management (PFM) as a major strategy for devolving the management of natural forests for sustainable use and conservation. PFM has been supported by legal and policy reforms as well as significant investments from both the Tanzanian 
government and its development partners. Various forms of PFM are either operational or in the process of being established in over 4.1 million hectares of forestland and in over 2300 villages nationwide.

One of the major policy objectives of PFM is to bring the large areas of unreserved (and poorly protected) forestland under a defined management regime, implemented by local authorities at village level. This form of PFM, known in Tanzania as communitybased forest management (CBFM), has been promoted widely and is spreading rapidly. As many of the largest areas of unreserved woodlands are in some of the poorest and most remote parts of the country, CBFM represents an important strategy in supporting livelihoods in areas where other economic opportunities are severely limited. Prevailing forest legislation provides important incentives to rural communities to manage forests on a sustainable basis by ensuring that almost all forest management benefits are captured at the community or group level. Despite this, there is little evidence that the legal transfer of areas of forest has been accompanied by tangible local economic returns from sustainable forest harvesting and utilization. We investigate this apparent paradox, with regard to wider issues of forest governance, illegal logging, vested interests and incentives within government for economic and ecological inefficiency, manifested in terms of forest degradation and increased poverty. We review, for instance, the progress of decentralizing the management of unreserved forests to mandated village institutions under the overall authority of village government in line with these progressive legal changes. We assess the degree to which the transfer of these forest areas to remote and poor communities has resulted in sustainable and tangible changes in income at the local level and the degree to which income potential has been constrained by failures in governance at village, local government and national levels. We conclude with recommendations to policy-makers, government agencies and development partners on how some of the wider issues of forest governance may be addressed. This chapter draws on our collective and practical experience of working on participatory forestry processes in Tanzania from inside and outside government, as well as a review of literature, both published and grey, that we have been able to compile to date.

\section{CONTEXT: PARTICIPATORY FOREST MANAGEMENT AND DEGENTRALIZATION}

Tanzania has one of the strongest and most devolved frameworks of local governance among the countries in East and Southern Africa (Wily and Dewees, 2001). Communities in rural areas are divided into villages, which are managed by village councils. Village councils are corporate bodies and are, in turn, answerable and accountable to village assemblies, which consist of all the adults living within the village area. This system of local governance dates back to the mid 1970s, when the socialist Ujamaa programme of Tanzania's founding President Julius Nyerere established villages on a legal basis in order to provide a structured means of organizing rural communities for collective agricultural production and service provision (Wily and 
Dewees, 2001). While Nyerere conceived ujamaa villages as largely a means to mould scattered, decentralized and impoverished rural communities into the country's socialist development agenda, the seeds were also being sown for rural empowerment through the structure of village governments (Nelson and Makko, 2005). The Local Government Act of 1982 formalized the powers of village governments by, among other things, enabling villages to make their own bylaws. While these bylaws must not violate any other laws of the country, they are legally binding and fully enforceable in courts of law. The village bylaws enabled by Tanzania's local government legislation provide communities with a powerful tool for creating statutory land and natural resource management rules and procedures at the local level. By-laws passed by communities commonly address such issues as the use of natural resources (trees, hunting and grazing), reinforced by sanctions and fines for those who fail to comply with local rules.

Under the 1999 Village Land Act, village governments were given the legal mandate to exercise decisions relating to land within the 'village area' - an area that encompasses all of the land claimed and used by the village population, which in some cases covers tens of thousands of hectares. Forest within the village area automatically falls under the jurisdiction of the village government. The 2002 Forest Act drew heavily on these key legal provisions and, for the first time, gave the basis in law for communities to own, manage or co-manage forests under a wide range of conditions. The law recognizes two different types of PFM:

1 Community-based forest management (CBFM). This type of PFM enables local communities to declare - and, ultimately, gazette - village, group or private forest reserves on village land. Under this arrangement, communities are both owners and managers of the forest resource.

2 Joint forest management (JFM). This type of PFM allows communities to enter into agreements with government and other forest owners for sharing the costs and benefits of forest management by signing joint management agreements. Under this arrangement, communities are co-managers of forest otherwise owned by the district or central government.

This distinction is extremely important and not widely understood. The first form takes place on village land or private land, and the trees are owned and managed by the village council (through a village natural resource committee), a group or an individual. The second form of PFM, joint forest management, takes place on 'reserved land' - land that is owned and managed by either central or local government (typically the Forestry and Beekeeping Division or district councils). Villagers typically enter into management agreements with government agencies (the 'owner') specifying the sharing of benefits and responsibilities for forest management. Key differences in these two forms of PFM are summarized in Table 6.1.

Table 6.1 illustrates the difference in terms of devolution of both rights and responsibilities under the two PFM approaches adopted in Tanzania. Under CBFM, communities under the law have the full responsibility for forest management and corresponding rights to all the benefits obtained through forest management. JFM, however, transfers management responsibilities to community institutions (typically the 
Table 6.1 A summary of differences in joint forest management (JFM) and community-based forest management (CBFM)

\begin{tabular}{|c|c|c|}
\hline Parameter & Community-based forest management & Joint forest management \\
\hline Who is the forest 'owner'? & Village government or a community group & Central or local government \\
\hline $\begin{array}{l}\text { Who has the primary } \\
\text { responsibility for forest } \\
\text { protection and management? }\end{array}$ & Village government or a community group & Village government \\
\hline $\begin{array}{l}\text { How is the transfer of rights } \\
\text { recognized in law and how } \\
\text { is it endorsed? }\end{array}$ & $\begin{array}{l}\text { Village assembly declares an area } \\
\text { of forest a reserve, and the district } \\
\text { council registers it }\end{array}$ & $\begin{array}{l}\text { Through the signing of a joint } \\
\text { management agreement between } \\
\text { a village council and a higher level } \\
\text { of government }\end{array}$ \\
\hline $\begin{array}{l}\text { Who has rights to forest } \\
\text { products and how are } \\
\text { they shared? }\end{array}$ & $\begin{array}{l}\text { Village government or a } \\
\text { community group }\end{array}$ & $\begin{array}{l}\text { Legal grey area (law recognizes } \\
\text { sharing of forest goods and } \\
\text { services but no legal mechanism } \\
\text { exists for determining in what } \\
\text { relative share) }\end{array}$ \\
\hline $\begin{array}{l}\text { How does the law view } \\
\text { the community and the } \\
\text { benefits obtained? }\end{array}$ & $\begin{array}{l}\text { - Actor, partner } \\
\text { - Forest manager } \\
\text { - Decision-maker } \\
\text { - Rule-maker } \\
\text { - Citizen } \\
\text { (Emphasis: sharing of power) }\end{array}$ & $\begin{array}{l}\text { - Beneficiary } \\
\text { - Forest user } \\
\text { - Consultee } \\
\text { - Rule follower } \\
\text { - Subject } \\
\text { (Emphasis: sharing of benefits - } \\
\text { non-timber forest products } \\
\text { and, at times, revenue) }\end{array}$ \\
\hline $\begin{array}{l}\text { What is the overall } \\
\text { intention of the } \\
\text { management approach? }\end{array}$ & $\begin{array}{l}\text { To decentralize rights and } \\
\text { responsibilities of forest } \\
\text { management }\end{array}$ & $\begin{array}{l}\text { To reduce forest management } \\
\text { costs of government through } \\
\text { benefit-sharing }\end{array}$ \\
\hline
\end{tabular}

Source: adapted from Wily (2002)

patrol of the forest management area), but the mechanism and ratio for sharing the benefits of forest management are a legal grey area. Consequently, a number of authors have criticised JFM for being inherently inequitable and an easy way for the state to shed its responsibilities without transferring any clear rights or benefits (Blomley and Ramadhani, 2006; Lund and Nielsen, 2006; Meshack et al, 2006; Meshack and Raben, 2007). This wide-ranging debate will not be the focus of this chapter as it has been covered extensively elsewhere. Rather, we turn our attention more specifically to the form of PFM that (on paper at least) provides for the greatest transfer of powers, rights and responsibilities - that is, CBFM.

As described in Table 6.1, under CBFM, villagers, being both owners and managers of the forest, are required to assume full management responsibility for the forest, but, in return, have the right to retain all income accrued from its management. The law essentially treats forests on village lands as private forests, and no benefit-sharing with government agencies is required. Village councils can enter into contracts with forest enterprises or can opt to harvest and sell forest products directly. CBFM, under the Forest Act (URT, 2002), allows village governments to 'declare' their own village land 
forest reserves or community forest reserves if they satisfy certain preconditions, such as the election of a village natural resource management committee, the production of a simple management plan and passing of village forest management bylaws. Once the forest is registered by the district council, they can begin active management. The legislation provides specific local incentives for CBFM, which are intended to encourage its rapid adoption and diffusion at local level. These include:

- Waiving state royalties on forest products. This means, in principle, that villages do not have to follow government timber royalty rates but can sell their produce at prices chosen by them.

- Exemption from benefit sharing arrangements. As registered forest managers, village councils may retain all of the income from the sale of forest products.

- Levying and retaining fines and proceeds from confiscated timber and equipment. Fines imposed on village land or community forest reserves are retained by the village. Similarly, any illegally sourced forest produce or equipment used to illegally harvest in a forest reserve on village land may be confiscated and sold by the 'forest reserve manager'.

\section{IMPLEMENTATION PROGRESS TO DATE}

A national survey undertaken in 2008 established that 4.1 million hectares were under some form of PFM, and that over 2300 villages were participating. Of this, more than half is covered by CBFM (see Table 6.2) - the primary focus of this chapter.

CBFM has spread quite rapidly over the past ten years. It was first started in the early 1990s when different models of CBFM were piloted in northern Tanzania. Table 6.3 gives an indication of the spread of CBFM since 1999.

The relatively rapid scaling-up of participatory forestry in Tanzania has been assisted by a number of enabling factors (Blomley and Ramadhani, 2006), but it fundamentally owes its success to a strong forest law and policy that draws heavily on parallel legislation in the local government and land sectors. As a result, legal impediments have been very

Table 6.2 Current coverage of CBFM across mainland Tanzania

\begin{tabular}{lll}
\hline Area of forest under CBFM & 2.34 million hectares & $11.6 \%$ of public land forests \\
\hline Forest types covered by CBFM & Miombo woodlands & $68 \%$ of total area covered \\
& Coastal forests & $15 \%$ of total area covered \\
& Acacia woodlands & $16 \%$ of total area covered \\
Number of declared or gazetted village & Montane forests & $0 \%$ of total area covered \\
land forest reserves & 382 & $1 \%$ of total area covered \\
Number of villages engaged in CBFM & 1102 & \\
Number of districts engaged in CBFM & 51 & $10.4 \%$ of villages in the country \\
\hline
\end{tabular}

Source: URT (2008); Blomley and Ramadhani (2007) 
Table 6.3 Estimates of adoption and spread of CBFM in Tanzania from 1999 to the present

\begin{tabular}{lccl}
\hline Date & $\begin{array}{c}\text { Forest area under } \\
\text { CBFM (hectares) }\end{array}$ & $\begin{array}{c}\text { Number of villages } \\
\text { with CBFM }\end{array}$ & Source \\
\hline 1999 & 323,220 & 544 & Wily and Dewees (2001) \\
2002 & $1,085,300$ & 845 & URT (2001b); FBD records \\
2006 & $2,060,600$ & 1102 & URT (2006) \\
2008 & $2,345,500$ & 1460 & URT (2008) \\
\hline
\end{tabular}

limited. Considerable support from development partners (namely, the governments of Denmark, Finland and Norway, and the World Bank) working increasingly to align and harmonize with and through government structures means that the development of a single, national programme has been possible (Blomley, 2006).

CBFM is a management approach that can be applied to all forest types - whether montane forest with high biodiversity values or lowland miombo woodlands with high levels of use and disturbance. Despite its wide applicability, CBFM tends to be concentrated in the miombo woodlands, much of which is found outside government forest reserves and on village land. Montane evergreen and mangrove forests show a disproportionately small coverage under CBFM, as the total area under these forest types is smaller and the majority are classified as central government forest reserves due to their higher economic or biodiversity values.

Where forests have been transferred to community management, signs from available data are that forest condition is improving. In a study that compared growth characteristics of 13 forest areas under varying management regimes, forest condition appears to be better in those areas managed either wholly or jointly by communities (as evidenced by higher basal areas, mean annual increments and stems per hectare) than areas under exclusive state control (see Figure 6.1). This study, supported by other recent assessments (compare Pfliegner and Moshi, 2007), would suggest that reduced disturbance and uncontrolled activity, supported by community-managed law enforcement efforts, appear to be turning the tide on forest loss and degradation in these areas.

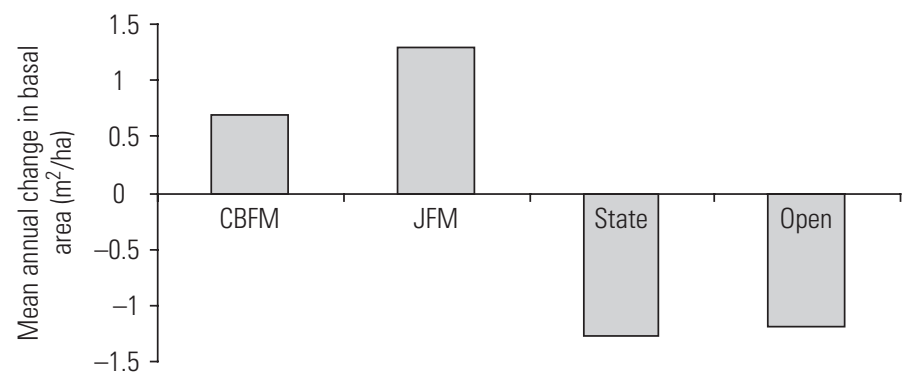

Source: Blomley et al (2008)

Figure 6.1 Mean annual changes in basal area in 13 forests under different management and ownership regimes 


\section{THE CONTRIBUTION OF COMMUNITY-BASED FOREST MANAGEMENT (CBFM) TO VILLAGE-LEVEL INCOME}

There is little empirical data regarding the degree to which CBFM is generating local economic returns at community or household level. Iringa District, one of the areas where CBFM models were piloted in the late 1990s before the passing of the Forest Act, provides an interesting case for assessing its effectiveness and impact. Fourteen villages were assisted to reserve small- to medium-sized areas of miombo woodlands averaging 2600 ha in size, on village land. An assessment of village forest incomes showed annual revenues of around US $\$ 540$ in 2002, but rising to around $\$ 720$ by 2005 (Lund, 2007b).

As illustrated by the above example, forest areas managed by individual communities tend to be rather small (up to a few thousand hectares) and the revenue generation potential from sustainable harvesting remains rather low. There remain, however, vast areas of unreserved woodlands with significant timber values that could be transferred to village management, with the potential to generate important local revenue streams. Although of varying condition, estimates would suggest that up to 20 million hectares of unreserved forests exist that could be brought into CBFM arrangements (Akida and Blomley, 2006). Interestingly, much of the unreserved forest with remaining timber stocks is found in some of the most remote (and consequently underdeveloped) parts of the country, where other economic opportunities are severely limited. Figure 6.2 illustrates this by comparing regional poverty rankings (a) and the area of unreserved forest per square kilometre of land area (b).

Clearly, forest resources on village land, available to local communities through CBFM, represent an exciting investment opportunity with the potential to generate

(a)

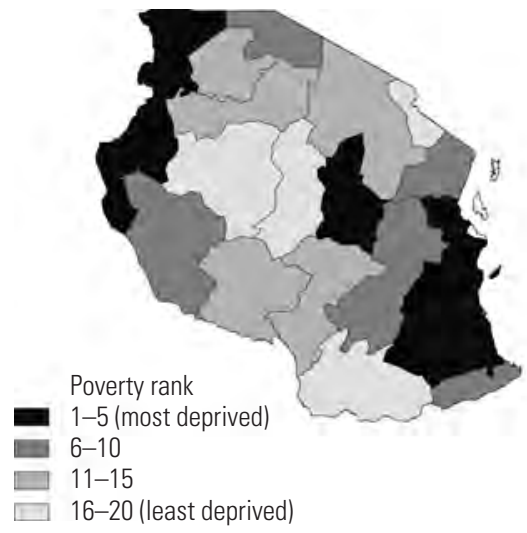

(b)

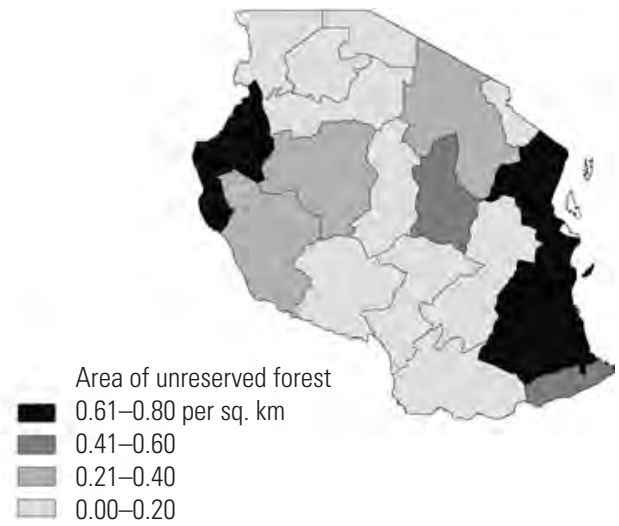

Source: URT (2003a, 2005a)

Figure 6.2 (a) Regional poverty rankings; and (b) area of unreserved forest per square kilometre by region 
sustainable flows of revenue in areas where other forms of economically productive activities may be severely limited. Table 6.4 provides an illustration of a sample of four forest areas currently either under, or in the process of being transferred to, community stewardship with significant potential for local revenue generation from sustainable forest management.

The trade in forest products in Tanzania is thriving, driven by an ever-increasing demand for timber from South Asia. China has rapidly emerged as the fastest growing importer of hardwoods from Tanzania, representing a major shift in trade dynamics when compared to the 1980s, when 82 per cent of sawn hardwood exports were destined for Western Europe (Moyo, 1985). By 2005, 66 per cent of all containers carrying timber products exported from Dar es Salaam were destined for China (Milledge et al, 2007). This increase in demand has coincided with improved road networks - such as the opening of the Mkapa Bridge over the Rufiji River that greatly increased access to the regions of Mtwara and Lindi, both suffering from high levels of poverty and with some of the largest areas of unutilized coastal forests and miombo woodlands in southern Tanzania.

Clearly, there is much to celebrate in Tanzanian CBFM. Increasing areas of forest are coming under direct community management, and when they do, they appear to be recovering and regenerating. A strong and enabling policy and legal environment provides strong incentives for local participation, which, coupled with a thriving timber market, has the potential to generate significant economic benefits at the very lowest levels of government. Why is it, then, that despite this good news, these apparent opportunities have yet to be translated into substantial, secure and widespread economic benefits for forest-dependent communities? We go on to discuss this apparent contradiction in the following section.

Table 6.4 Selected areas of forest under village management and their revenue generation potential

\begin{tabular}{|c|c|c|c|c|c|}
\hline $\begin{array}{l}\text { Forest name } \\
\text { and location }\end{array}$ & $\begin{array}{l}\text { Size } \\
\text { (hectares) }\end{array}$ & Status & $\begin{array}{l}\text { Estimated annual } \\
\text { revenue from } \\
\text { sustainable } \\
\text { harvesting }\end{array}$ & $\begin{array}{l}\text { Number of } \\
\text { villages } \\
\text { managing } \\
\text { forest }\end{array}$ & $\begin{array}{l}\text { Potential } \\
\text { revenue per } \\
\text { village/annum }\end{array}$ \\
\hline $\begin{array}{l}\text { Angai Forest, } \\
\text { Liwale District }\end{array}$ & 141,000 & $\begin{array}{l}\text { Management plan } \\
\text { being developed }\end{array}$ & US\$ 784,000 & 13 & US $\$ 60,300$ \\
\hline $\begin{array}{l}\text { Suledo Forest, } \\
\text { Kiteto District }\end{array}$ & 164,000 & $\begin{array}{l}\text { Village land } \\
\text { forest reserve }\end{array}$ & US $\$ 213,000$ & 9 & US\$23,700 \\
\hline $\begin{array}{l}\text { Mtanza Msona } \\
\text { Forest, Rufiji District }\end{array}$ & 10,713 & $\begin{array}{l}\text { Village land } \\
\text { forest reserve }\end{array}$ & US\$57,900 & 2 & US $\$ 28,950$ \\
\hline $\begin{array}{l}\text { Ipole Wildlife } \\
\text { Management Area, } \\
\text { Sikonge District }\end{array}$ & 247,500 & $\begin{array}{l}\text { Wildlife } \\
\text { Management Area }\end{array}$ & US $\$ 730,000$ & 4 & US\$182,500 \\
\hline
\end{tabular}

Source: Mellenthien (2005); Mustalahti (2007); Nelson and Blomley (2007) 


\section{CHALLENGES TO ENHANCING LOCAL BENEFITS FROM GBFM IN TANZANIA}

\section{Institutional failures, governance shortfalls and illegal logging in the forest sector}

At the national level, a range of factors combine to create a favourable climate for poor governance in the forest sector. First, there are very limited data on the extent and condition of forest resources in the country. Since the mid 1990s, there has been no national assessment despite major changes in forest cover, particularly outside forest reserves. Of over 700 forest reserves in the country, the number with operational management plans is less than 10 per cent (Akida and Blomley, 2006). Under such circumstances, making accurate assessments of sustainable harvest is impossible. Despite this, there is widespread harvesting of timber outside any agreed framework on what may constitute sustainable harvest (Milledge et al, 2007). Second, as in many developing countries, the real contribution of the forest sector to the national economy is significantly undervalued (World Bank, 2007). This means that the general public, decision-makers and politicians are largely unaware of the considerable wealth that exists, and the potential value that this represents in terms of tax revenues and economic opportunities at both national and local levels. Third, the roles of central and local governments with regard to the collection and disbursement of forest revenues is unclear, contested and leads to great inefficiencies (World Bank, 2007). Finally, given the massive growth in demand for timber from Asia in the past five years, remaining forest resources are under significant pressure from harvesting, much of it illegal. This operates with the full support of highly placed staff within local and national government institutions who sustain a patron-client relationship between village leaders, logging operators and politically powerful individuals (Mustalahti, 2007; World Bank, 2007). Due to the relative vacuum of effective controls, the timber trade has become very profitable and many people have entered the business with a view to exporting roundwood to lucrative overseas markets (Milledge et al, 2007). The rapid growth in exports, together with poor capacity of government to regulate the trade, has resulted in an outcry from many quarters such as the press and non-governmental organizations (NGOs) regarding the high levels of uncontrolled harvesting, lost revenues, forest degradation, governance shortfalls and disenfranchised local communities (Mfugale, 2005).

Collectively, these factors result in massive under-collection of forest revenues. Current estimates suggest that between 5 and 15 per cent of actual forest revenues are collected by government, amounting to an annual loss to the treasury of around US $\$ 58$ million (Milledge et al, 2007). In addition to losses to the national revenue base, it is clear that in an environment where illegal logging thrives, the proportion of the final value of harvested timber realized at the community level is negligible and may be less than 1 per cent of the total value of exported timber. 


\section{Limited capacity and incentives at local government levels}

Despite significant decentralization and local government reforms over the past two decades, many districts are still very constrained by human and operational resources, which restrict them from effectively implementing forest laws and policies at the local level. Limited knowledge among district staff regarding the legal reforms in the forest sector further constrains service delivery to local communities. Unfortunately, some of the more remote districts, which ironically have higher levels of forest cover and therefore are highly suited to CBFM, are often even more weakly staffed and attract only poorly qualified employees, or those who have been sent there on 'punishment postings' (Mustalahti, 2007). Misinformation regarding CBFM procedures, legal requirements, steps and delegation of powers, compounded by more conservative views of community involvement in forest management among government foresters, leads to delays and, in some cases, obstruction of policies.

For district councils administering large land areas with significant areas of unreserved forest, forest revenues, levies and taxes constitute an important source of local income that can be used without the sectoral conditionalities attached to much of central government funding (see Box 6.1). The transfer of large areas of unreserved forest to village management may undermine local government goals to boost district-level revenue generation and may be a factor in the reported slow rate of CBFM adoption at the local level.

The conversion and transfer of poorly managed forests on village lands to forests managed by mandated local institutions with clear roles and responsibilities may undermine some of the corrupt networks that perpetuate illegal logging, leading to declining benefit flows to those higher up the chain. CBFM provides a legal framework

\section{Box 6.1 Kilwa District, Eastern Tanzania}

Kilwa is a large district with relatively low population density. It is covered with coastal forests and miombo woodlands covering 1,291,500ha - of which about 80 per cent is unreserved.

Revenue from forestry cess (a local government levy placed on the transport of forest products such as charcoal and timber) is an important source of revenue for the district, and is charged at a rate of 5 per cent of the total royalty payment. In 2003, revenue collected by the district council was 180 million Tanzanian shillings (around US $\$ 150,000$ ), equivalent to around 7 per cent of the total recurrent and development budget of 2.6 billion Tanzanian shillings in 2003. Of the 180 million Tanzanian shillings collected by the district council in local revenue and taxes, 33 million Tanzanian shillings were from forestry cess, which made this item the second most important source of internal revenue for the district after agricultural levies.

Source: Danida (2004) 
for village governments to assume control and management of forest areas, and has been shown to significantly reduce the effectiveness of uncontrolled logging and forest disturbance (Blomley et al, 2008). In such cases, district staff and councillors find that they face a clear conflict of interest - over the continued benefits they enjoy from illegal harvesting in unreserved forests, vis-à-vis their responsibilities to assist communities in securing tenure and forest management rights under CBFM (Persha and Blomley, in press). This conflict of interest often manifests itself through the slowing down (and often halting) of key stages in the legal process of CBFM establishment, such as district council approval of bylaws and management plans (Mustalahti, 2007).

\section{Lack of knowledge among forest-dependent communities on CBFM opportunities}

Over a century of state management of forest resources has left an enduring legacy among communities living close to forests across the country (Wily and Dewees, 2001). Despite the radical changes in policy and law that have been promulgated over the past decade, little impact has trickled down to remote rural communities. Districts with the lowest levels of adult literacy and education often tend to be the same districts that have greatest forest cover, particularly outside reserved forests, due to low population pressure and poor communications (see Figure 6.2). Low levels of education and lack of knowledge of the potential community benefits from sustainable forest management under CBFM make for a fertile environment for illegal forest harvesting. Harvesting of timber represents an important economic activity for men aged between 19 to 45 years' old, with 16 per cent of households living near to forest areas obtaining some economic benefit from the timber trade (Milledge et al, 2007).

Ultimately the challenge facing advocates of CBFM in such an environment is that of incentives, trade-offs and opportunity costs at the local level. While CBFM has the promise to deliver a significantly higher share of the forest value to a significantly greater number of people, poverty drives 'short-termism' and the tendency to cash in on forest extraction benefits today, however small, even though these benefits may constitute a fraction of their potential future value.

Where communities are aware of their rights and returns available under CBFM, evidence suggests that they are ready and able to defend them through active patrolling of forest areas, arresting and fining of illegal forest users and the confiscation and sale of forest produce and equipment. Similarly, attempts by government staff at higher levels to capture and monopolize forest benefits are more strongly resisted in areas with higher levels of legal literacy, as villagers are more able to appreciate and defend their rights (Blomley, 2006).

\section{A focus on conservation and restoration rather than sustainable utilization}

Many of the early pilot sites where CBFM was established were areas that were under threat from uncontrolled and unregulated harvesting. Efforts by local or central 
government foresters to manage the forest sustainably were often unsuccessful due to limited resources and, in some cases, the direct involvement of foresters in the harvesting itself. Consequently, in many of the early CBFM sites, communities were handed over areas where direct-use values of natural resources were, in effect, negative (Blomley and Ramadani, 2006). As a result, considerable time and effort were required to patrol, protect and conserve the forest before any substantive natural capital (in the form of commercially useful timber) could be accumulated and harvested.

Second, experience from other districts where PFM has been introduced more recently is that an important trigger for CBFM, or forest protection in general, occurs when a sufficient number of local residents become sufficiently alarmed by local forest destruction and loss that it prompts some kind of management response (URT, 2003b). In such cases, CBFM is a response triggered by increasing and uncontrollable loss of forest cover and tends to be focused on conservation rather than seen as a tool to capture economic returns from sustainable forest harvesting. Consequently, much of the management actions of community members (as detailed in management plans and bylaws) are focused on protection, conservation and restricted use in order to extend and consolidate control over the resource in question.

This community-level trend is supported by an enduring narrative on the need for conservation and protection of natural forests that permeates many levels of government in Tanzania. This is perpetuated by frequent reports in the national press of uncontrolled and illegal logging in environmentally sensitive forest areas, declining flows in rivers leading to power outages from the reduced capacity of hydroelectric dams, climate change, and continued encroachment on forest reserves by farmers searching for more land. However, much of this is driven by traditional and entrenched views among some foresters regarding forest conservation - namely, that the state is the only effective manager of forests for sustainable use and that 'technical forestry' is beyond the reach of poor rural communities (URT, 2003b). This is reinforced by a continued belief among mid-level forestry staff that the underlying objective of PFM is to reduce forest dependency rather than promote forests as a valuable asset in sustainable livelihoods (Springate-Baginski, 2007). The natural reaction to such fears is to continually emphasize protection over sustainable management, despite the clear provisions provided by law for the latter under the Forest Act.

\section{FROM POLICY TO PRACTICE: PUTTING THE BENEFITS OF SUSTAINABLE FOREST MANAGEMENT IN THE HANDS OF VILLAGERS}

In this section, we propose recommendations to policy-makers, government agencies and donor-supported projects, which, if implemented together, may begin to address some of the constraints identified above. 


\section{Addressing forest governance at the national level}

An entrenched and corrupt system of patronage and clientism exists between village leaders, district council staff, illegal timber operators and highly placed government officials (Milledge et al, 2007). Under such conditions, breaking the web of patronage and reversing the lines of accountability so that elected leaders become downwardly accountable to those whom they represent are long and complex processes. This challenge is clearly not unique to forestry and needs to be tackled at multiple levels. Given that much of the source of this poor governance originates at the national level, it would seem appropriate that any attempt to tackle the problem should start there.

Current discussions, ongoing in Tanzania, on ratification of the Forest Law Enforcement and Governance (FLEG) initiative and the establishment of independent forest monitoring (IFM), backed up with advocacy and communication campaigns within civil society and within the local press, are promising signs that the climate of impunity under which illegal logging has operated to date is beginning to change. The recent report on illegal logging in southern Tanzania (Milledge et al, 2007) has highlighted the extent of lost revenue from illegal logging: revenue that could be used at the national level to support broader development goals and improved forest governance and at the village level to provide invaluable local sources of income for poor and isolated communities. This report has been widely read by government, development partners and civil society alike and may provide sufficient momentum to unlock or, at least, weaken many of the patronage networks that support illegal logging.

\section{Helping communities to claim their rights}

In addition to exploring ways in which government can become more open, transparent and accountable, there is a need to reinforce efforts at the local level directed towards awareness-raising and legal literacy. Forest-dependent communities must be made aware of the potential value of timber on their village land, the opportunities under the law which enable them to realize these rights and how these rights can be claimed from local government institutions. Similarly, it is essential that communities in forest-rich areas are fully aware of the responsibilities placed on elected representatives charged with forest management duties (such as village natural resource management committees) and on district staff and councillors with regard to the devolution of forest management rights. NGOs have an important role to play in helping politically weak community forest management institutions to open and exploit political spaces so that their claims can be articulated at local and national levels. This will require new skills for many of the organizations supporting local forest management initiatives, as most are primarily conservation organizations with limited capacity in advocacy and political empowerment. However, there are rich experiences in the wider development arena that can be drawn upon, particularly with regard to communicating with poor, remote and often illiterate target groups in an accessible format and using a medium that takes account of local realities. Village notice boards, 
using eye-catching graphics and plain language, have been shown to be a useful way in which financial information can be transmitted from financial management institutions (both village and district) to the wider public, and now have been formally endorsed by the government as a communication tool designed to improve local governance (URT, 2005b). Finally, in cases of extreme abuse of power, supporting disenfranchised community groups with legal support may be a controversial but effective way of restoring justice.

\section{Building incentives for local governments}

This chapter has highlighted the important contribution that natural resource taxes and levies make to revenue generation at district council level and the perception that devolving authority for forest revenue collection to villages will result in net losses in income to local governments. Despite this, the efficiency of collection by districts remains rather low and, in some cases, collection efficiency has been found to be as low as 1 to 5 per cent of potential (Lund, 2007a; Milledge et al, 2007). Research from Iringa District has shown a substantial increase in the efficiency of collection when forest revenue collection responsibilities are devolved from district to village level. The total revenue collected by 14 villages implementing CBFM exceeded by several times the amount collected by the district council from forests covering the remaining 153 villages (Lund, 2007b).

In tandem with tackling forest governance at district level through greater transparency and accountability, it will be necessary to build parallel incentives for district councils - who have the primary responsibility for facilitating the handover of unreserved forests to village governments - to engage in CBFM processes. One option may entail facilitating negotiations between village and district councils on the sharing of forest revenues from village forest reserves. Although not a requirement by law, this could lead to a small percentage of the forest revenues collected at village level (perhaps between 5 and 10 per cent) being remitted back to the district councils. A portion of these funds could be allocated to finance forestry extension from the district back to the village. In addition, it would be necessary to demonstrate to district councils that 5 to 10 per cent of forest revenues collected by villages may represent a massive increase in revenue, when compared to current methods where district councils retain revenue collection responsibilities. If such a model was found to work, it could then be translated into more binding guidelines, or even legal regulations for local governments facilitating the establishment of CBFM. Clearly, in order for this to function effectively, it will be important to ensure a wider discussion between the elected and appointed members of the respective district councils and those whom they are mandated to represent and serve. Budgetary incentives at local government levels will only work once perverse incentives described earlier in this section have been broken and staff begin to operate according to their institutional mandates rather than for personal gain.

We have highlighted how governance failures have undermined attempts by local communities to claim their rights regarding the ownership and management of forests 
in accordance with prevailing legislation. However, we have also highlighted how capacity constraints also contribute to weak, ineffective and inefficient service delivery at the local level. While local governments retain the primary responsibility for delivering CBFM at the village level, the presence, capacity and incentives of staff at this level are often severely limited. This is particularly the case in more remote districts where attracting competent and skilled staff is even more challenging, but where the potential benefits of CBFM are greatest. Incentives for local governments (and possibly subsidized through ongoing support to the forest sector) to recruit and retain qualified staff needs urgent attention. Changing mindsets among staff responsible for the delivery of forest policy at the local level takes time, particularly among those who are the product of traditional forestry education. On-the-job training support to address short-term needs must be complemented by longer-term reforms in the curricula of forestry training colleges and universities across the country.

\section{CONCLUSIONS}

CBFM holds the key to sustainable forest management and significant contributions to rural livelihoods in some of the poorest and most marginalized parts of the country. For a variety of reasons, the promise of benefits from the management of these natural resources has yet to materialize in the vast majority of areas under CBFM, despite the growing market for traded timber and a highly enabling legal and policy environment. In this chapter we have attempted to unpack this apparent disconnect between policy and practice. We have found that one of the primary underlying causes of this trend is poor forest governance - namely, the creation of institutional incentives in central and local government that prevent local forest resources from being managed sustainably and returns generated from being captured at the community level. This is reinforced by a very limited awareness of forest management rights, laws and opportunities among forest-dependent communities and weak capacity within local governments. Given this, recommendations common among existing donorsupported projects that emphasize technical solutions (such as the production of guidelines and manuals) or capacity-building (training courses, seminars and skills development) may be necessary, but insufficient, if this problem is to be addressed at its root. Additional, more radical actions are required if these incentives are to be reversed: actions that engage with the 'harsh and brutal realities of the everyday politics of the governed' (Brockington, 2007). We have provided a series of recommendations, which, if implemented together, may begin to address some of the underlying problems facing power, access and control over forest resources in Tanzania. Finally, this chapter has highlighted the need for more substantive and independent research in certain key areas - namely, the contribution of CBFM to local livelihoods in monetary and non-monetary terms, the overall contribution of forest goods and services to the economy as a whole and the impact of various forest management regimes upon forest condition. 


\section{ACKNOWLEDGEMENTS}

Thanks to Fred Nelson, Laura German, Jens Friis Lund, Irmeli Mustalahti, Dan Brockington, Geir Sundet and one anonymous reviewer for their invaluable comments on earlier drafts of this chapter. The authors also wish to thank Simon Milledge for his help in producing the maps in Figure 6.2.

\section{REFERENCES}

Akida, A. and R. Blomley (2006) Trends in Forest Ownership, Forest Resources Tenure and Institutional Arrangements: Are They Contributing to Better Forest Management and Poverty Reduction?, Case Study from Tanzania, Prepared for the FAO, Rome

Blomley, T. (2006) Mainstreaming Participatory Forestry within the Local Government Reform Process in Tanzania, Gatekeeper Series 128, International Institute for Environment and Development, London

Blomley, T. and H. Ramadhani (2006) 'Going to scale with participatory forest management: Early lessons from Tanzania’, International Forestry Review, vol 8, no 1, pp93-100

Blomley, T. and H. Ramadhani (2007) 'Participatory forest management in Tanzania: An overview of status, progress and challenges ahead', The Arc Journal, vol 21, Tanzania Forest Conservation Group, Tanzania

Blomley, T., K. Pfliegner, J. Isango, E. Zahabu, A. Ahrends and N. Burgess (2008) 'Seeing the wood for the trees: Towards an objective assessment of the impact of participatory forest management on forest condition in Tanzania', Oryx, vol 42, no 2, pp1-12

Brockington, D. (2007) 'Forests, community conservation, and local government performance: The village forest reserves of Tanzania', Society and Natural Resources, vol 20, no 9, pp835-848

Carter, J. and J. Gronow (2005) Recent Experience in Collaborative Forest Management, CIFOR Occasional Paper no 43, c, 48p. CIFOR, Bogor, Indonesia

Danida (Danish International Development Agency) (2004) Review of the Present Royalty and Revenue Collection System for Forest Products in Lindi Region, Final Report, PEM Consult Ltd, East Africa

Ingles, A. W., A. Munsch and H. Qwist-Hoffmann (1999) The Participatory Process for Supporting Collaborative Management of Natural Resources: An Overview, FAO, Rome

Lund, J. F. (2007a) 'Is small beautiful? Village level taxation of natural resources in Tanzania', Public Administration and Development, vol 27, pp307-318

Lund, J. F. (2007b) 'Money talks: CBFM and village revenue collection in Iringa District', The Arc Journal, vol 21, Tanzania Forest Conservation Group, Tanzania

Lund, J. F. and $\varnothing$. J. Nielsen (2006) 'The promises of participatory forest management', in H. Charton and C. Médard (eds) Forest Conservation and Poverty Alleviation: The Case of Tanzania, L'Afrique Orientale, Annuaire 2005, L'Harmattan, Paris, pp201-241

Mellenthien, J. (2005) Timber Utilisation in Suledo Village Land Forest Reserve Kiteto District, Unpublished report for ORGUT Consulting AB, Dar es Salaam

Meshack, C. K. and K. Raben (2007) 'Balancing costs and benefits, rights and responsibilities in the management of catchment forests', The Arc Journal, vol 21, Tanzania Forest Conservation Group, Tanzania 
Meshack, C. K., B. Ahdikari, N. Doggart and J. C. Lovett (2006) 'Transaction costs of community-based forest management: Empirical evidence from Tanzania', African Journal of Ecology, vol 44, pp468-477

Mfugale, D. (2005) 'Rufiji forests under threat as traders defy logging ban', The Guardian, http://www.ippmedia.com/ipp/guardian/2005/07/12/44215.html, accessed 1 February 2007

Milledge, S., I. Gelvas and A. Ahrends (2007) Forestry, Governance and National Development: Lessons Learned from a Logging Boom in Southern Tanzania, TRAFFIC, East/Southern Africa

Mniwasa, E. and V. Shauri (2001) Review of the Decentralization Process and Its Impact on Environment and Natural Resources Management in Tanzania, Lawyers Environmental Action Team (LEAT), Dar es Salaam, Tanzania

Mustalahti, I. (2007) 'Msitu wa Angai: Haraka, haraka, haina baraka! Why does handing over the Angai forest to local villages proceed so slowly?', in J. Gould and L. Siitonen (eds) Anomalies of Aid: A Festschrift for Juhani Koponen, Institute of Development Studies, Helsinki, vol 15, pp168-186

Nelson, F. and T. Blomley (2007) 'Eating from the same plate: Integrating community based wildlife and forest management', The Arc Journal, Tanzania Forest Conservation Group, Dar es Salaam, Tanzania, vol 21, pp11-13

Nelson, F. and S. Ole Makko (2005) 'Communities, conservation, and conflict in the Tanzanian Serengeti', in B. Child and M. W. Lyman (eds) Natural Resources as Community Assets: Lessons from Two Continents, Sand County Foundation, Madison, Wisconsin and the Aspen Institute, Washington D.C., pp121-145

Persha, L. and Blomley, T. (in press) 'Evaluating forest policy decentralisation. Local institutions, antropogenic disturbance and montane forest conditions', Conservation Biology

Pfliegner, K. and E. Moshi (2007) 'Is joint forest management viable in protection forest reserves? Experiences from Morogoro Region', The Arc Journal, Tanzania Forest Conservation Group. Dar es Salaam, Tanzania, vol 21, pp17-20

Ribot, J. (2002) Democratic Decentralisation of Natural Resources: Institutionalising Popular Participation, World Resources Institute, Washington, DC

Ribot, J. (2004) Waiting for Democracy: The Politics of Choice in Natural Resource Decentralisation, World Resources Institute, Washington, DC

Springate-Baginski, O., A. Banerjee and K. Sarap (2007) 'Can local forest management help improve forest-based livelihoods? Insights from West Bengal and Orissa', Paper presented at the International Conference on Poverty Reduction and Forests: Tenure, Market and Policy Reforms, Regional Community Forestry Training Centre for Asia and the Pacific (RECOFTC), Bangkok, Thailand

URT (United Republic of Tanzania) (1999) Village Land Act (and Regulations) No 5 of 1999, Ministry of Lands and Human Settlements, Dar es Salaam, Tanzania

URT (2001a) National Forest Programme 2001-2010, Forestry and Beekeeping Division, Ministry of Natural Resources and Tourism, Dar es Salaam, Tanzania

URT (2001b) Project Implementation Manual: Annex 2 - Improving Service Delivery for Participatory Forest Management, Ministry of Natural Resources and Tourism, Forestry and Beekeeping Division, Dar es Salaam, Tanzania

URT (2002) The Forest Act, No 7, Ministry of Natural Resources and Tourism, United Republic of Tanzania, Government Printer, Dar es Salaam, Tanzania 
URT (2003a) The Status of Central and Local Government Forest Reserves, Private Sector, or Others in Tanzania, Ministry of Natural Resources and Tourism, Forestry and Beekeeping Division, Dar es Salaam, Tanzania

URT (2003b) Participatory Forest Management: A Report On Lessons Learnt, Indufor Oy in Association with FTP International Ltd, Dar es Salaam, Tanzania

URT (2005a) Poverty and Human Development Report, The Research and Analysis Group, Dar es Salaam, Tanzania

URT (2005b) Communication Strategy for the National Strategy for Growth and Reduction of Poverty, Vice President's Office, Dar es Salaam, Tanzania

URT (2006) Participatory Forest Management: Facts and Figures, Forestry and Beekeeping Division, Ministry of Natural Resources and Tourism, Dar es Salaam, Tanzania

URT (2008) Participatory Forest Management in Tanzania: Facts and Figures, Forestry and Beekeeping Division, Ministry of Natural Resources and Toursim, Dar es Salaam, Tanzania

Wily, L. A. (2000) Land Tenure Reform and the Balance of Power in Eastern and Southern Africa, Natural Resource Perspectives 58, Overseas Development Institute, London

Wily, L. A. (2002) 'Participatory forest management in Africa: An overview of progress and issues', in Proceedings of the Second International Workshop on Participatory Forestry in Africa, FAO, Rome, pp31-58

Wily, L. A. and P. Dewees (2001) From Users to Custodians: Changing Relations between People and the State in Forest Management in Tanzania, World Bank Policy Research Working Paper no 2569, World Bank, Washington D.C.

World Bank (2007) Putting Tanzania's Hidden Economy to Work: Reform, Management and Protection of its Natural Resource Sector, World Bank, Dar es Salaam, Tanzania 
Chapter 7

\section{Gendered Representation and Participation in Decentralized Forest Management: Case Studies from Cameroon and Senegal}

Solange Bandiaky and Anne-Marie Tiani

\section{INTRODUCTION}

Forest decentralization policy consists of the transfer of some central government powers to local political institutions. Its intended outcomes include greater efficiency, equity and justice in access to resources and service provision at the local level (BakoArifari, 1997), as well as greater democracy, mass participation and proper representation of marginalized groups such as women (Meinzen-Dick and Knox, 1999; Ribot, 2006). Decentralization is expected to give marginalized groups more influence on local policy and forest resource management because open, participatory decision-making works in favour of equity (Ostrom, 1990; Ribot and Larson, 2004) and leads to 'greater responsiveness to citizens, improved decisionmaking, and improved efficiency in service delivery’ (Parry, 1997, p211).

However, the way in which decentralization is practised does not always adhere to the way in which it is theoretically defined and represented in policies and institutional settings. It is very simplistic and misleading to think that the transfer of power by itself will solve the problem (Goetz and Hassim, 2003, pp20-21). 'Development officials need to be cautious about decentralization as a panacea for local development problems. Decentralization facilitates development only if the rules that govern local bodies can produce efficient and effective outcomes' (Patterson, 2003, p49). Studies reveal the poor records of local elected actors in terms of serving women, the poor and marginalized groups, unless it is a requirement from the central government (Crook and Sverisson, 2002; Ribot and Larson, 2004). In Senegal, official processes systematically under-represent or exclude women (Ribot, 1999). Therefore, there is a necessity for practitioners and policy-makers to question gender differences (i.e. what it means to be a man or a woman in a given context) (Cornwall, 2003). 
As an analytical category, gender is an important variable. It is important to address the issue of power relations between men and women and the differences between them in terms of needs, interests and constraints in access to and control of resources (Rocheleau et al, 1996). To what extent have decentralization and forest tenure reform affected women's ability to change the established order and to create a place for themselves in forest management decision-making? In the process, what are the factors that encourage or hamper women's greater involvement in forest resource management? More than a decade after this wave of decentralization measures, what are the results regarding gender equality in access to and control of resources and other benefits from forest management? The answers to these questions lie in the way in which local forest governance institutions operate. The ways in which they determine or affect relations of power and authority are of major importance for understanding gender relations in access to and management of forest resources (Seager, 1993; Robbins, 1998).

In Senegal, under Law 96-06, passed on 22 March 1996 and containing the Local Collectivities Code (Code des Collectivites Locales), the management of wild resources in community forests and areas classified as zone de terroir, ${ }^{1}$ is vested in the decentralized government structures: regions, communes and rural councils. In Cameroon, the 1994 law allows for the creation of council and community forests and communitymanaged hunting areas. In both countries, the decentralized institutions are responsible for forest management and receive a share of forest tax revenues.

This chapter compares the situations in Dialakoto Rural Council in Tambacounda region, south-east Senegal, and the municipal council and community forest management entities of Dja and Mpomo Model Forest (FOMOD), Haut-Nyong Department, East Province, Cameroon. The method used in Senegal was ethnographic and qualitative. Interviews were held with male and female councillors, leaders and members of women's groups, and women who specialize in gathering, processing and selling forest produce. In FOMOD in Cameroon, individual and focus group consultations were held with local elected officials, traditional authorities, leaders of the associations responsible for managing community forests, and non-governmental organizations (NGOs). The issues discussed were opportunities for and limitations on effective participation by men and women in decision-making about resource management, the factors that affect the positioning of women as driving forces in development, and their socio-economic and ecological consequences. Our study analyses the dynamics of men's and women's participation in decision-making regarding forest management, its financial impacts, whether and how gender issues are taken into account in working out the rural councils' programmes and budgets, and the implications of these factors. Recommendations are made for equitable representation and participation with a view to good local governance in forest management.

\section{THE SITES}

\section{Dialakoto rural community, Senegal}

The Tambacounda region, which includes Dialakoto Rural Community (RC), covers 59,602 square kilometres - 30 per cent of Senegal's land area, with three-quarters of 
its mineral and forest resources. Yet it is one of the country's poorest regions. Dialakoto RC covers 6202 square kilometres and has a population of 8722 divided among 34 villages (RdS, 1998). Dialakoto RC lies on the edge of the 913,000ha Niokolo Koba National Park and the Diambour classified forest (127,000ha). Most forest resources of economic value, such as local fruit, honey, gum Arabic, palmyra fibres and dry bamboo, are in protected areas that local people are restricted from entering.

Dialakoto RC also has two community reserves, Malidino (10,059ha) and Mansadala (58,280 ha), set up to conserve biodiversity. The zones de terroir, managed by the rural council and belonging to the local population, are wedged between the protected areas and have few wild resources. Forty per cent of Niokolo Koba Park lies within the RC, as does part of the Diambour classified forest. There are a few villages within the classified forest itself, a situation that has created conflicts.

\section{Dja and Mpomo Model Forest, ${ }^{2}$ Cameroon}

The Dja and Mpomo Model Forest (FOMOD) is located in the East Province of Cameroon and overlaps between four administrative areas: Lomié, Mindoudou, Messok and Ngoyla. At present it covers an area of 700,000ha (MINEF, 2005). The population is estimated at 25,000, mainly Bantu but with some Baka pygmies and immigrants from other parts of the country.

The region is of considerable interest for conservation. It includes the $150,000 \mathrm{ha}$ Dja Wildlife and Biosphere Reserve, one of the largest in the Congo Basin and a world heritage site. It is in this region that pilot experiments in decentralized forest management and devolution have been conducted, with the establishment of the first official community forests, including one managed by the Baka pygmy minority. Several forest management institutions are involved in FOMOD: 4 rural communes; 47 community forests, including 19 actively logged; several forestry concessions, including one, PALLISCO, that has begun the forest certification process; and the mining company Geovic Cameroun. Some dozen NGOs supporting local initiatives and seven international conservation, development or research organizations are also involved.

\section{GENDER, DECENTRALIZATION AND RESOURCE MANAGEMENT: AN OVERVIEW}

In order to understand gender issues in this particular case we must examine different aspects of forest governance and assess how far the gender dimension is being taken into account. Below we examine ongoing forest decentralization policies in Senegal and Cameroon, the organization and functioning of the legal entities responsible for decentralized forest management, and the degree of equity in gendered representation on the decision-making bodies and in their strategic posts. Women's participation in decision-making is analysed in terms of nominal membership and in the processes in which they have voice and influence to put forward their own agenda. 


\section{Senegal}

\section{Decentralized forest resource management policy}

Since 1996, Senegal's forest resource management policies have been drawn up with community participation and decentralization mechanisms in mind. Resulting policy documents were the National Environment Action Plan (NEAP) in 1997, the Forest Code in 1998, and the National Biodiversity Conservation Strategy and Action Plans and the Environment Code in 2001. With the 1996 decentralization and regionalization process, ${ }^{3}$ the state effectively transferred power to local collectivities ${ }^{4}$ consisting of regions, communes and rural communities. These reforms gave rural communities the right to have their own forests and manage them. Local collectivities have autonomy in decision-making and in the management of local affairs, whereas rural councils are the key decision-makers with regard to land allocation and use in rural areas (territorial zones, or zones de terroi $r^{5}$ ). New policies on forest tax collection and distribution were intended to provide resources for community development. Access to wild resources in the zones de terroir were aimed at improving local living standards by creating jobs and income-generating activities. These potential benefits were also intended to encourage sustainable forest management, integrating biodiversity conservation with efforts to combat poverty.

The transfer of powers over natural resource management to local government units with the 1996 decentralization reform brought a new dimension of electoral politics to natural resource management. The rural council, as the last level of local government, is the primary local-level decision-making body. Its main powers with regard to forests are to manage forest land in the zones de terroir, issue woodcutting permits, manage the community's share of fines provided for in the Forest Code, establish and run forest protection committees, and create protected woodlands and protected areas such as community reserves. Taxes and fines collected from the use of forestry resources contribute to rural council budgets. Rural councils, in turn, develop local development plans and give their opinion in all development and environmental projects affecting rural communities.

These new policies emphasized technical aspects and failed to consider gender issues or social and cultural dimensions of forest management. The different environmental policies and action plans redrafted within the decentralization context in Senegal are generally gender blind, gender neutral, or include women's and gender issues in very general terms. Gender is not effectively and adequately taken into account in policies, laws and agendas, undermining women's interests and opportunities regarding forest resource access. No laws prevent women's political participation and representation at the decision-making level; however, no laws have promoted more gender-equitable political participation or representation in decisionmaking (IIED, 2006). While there are no legal constraints to women's political participation in local affairs, gender is still not acknowledged in decentralization policies. The Local Collectivities Code (composed of 372 articles) gives power to local deliberative organs (the councils) to 'ensure good living conditions to all of the population without discrimination'. The code refers to women councillors in only three laws (Articles 28, 98 and 202) about the decision-making bodies (IED, 2006). 


\section{Cameroon}

\section{Decentralized forest resource management policy: What gender policy?}

The forests, wildlife and fisheries Law No 94/01 of 20 January 1994 and its application decree No 95-531-PM of 23 August 1995 represented a significant advance in protecting local communities' right of access to forest resources and giving them responsibility for their management. The concern for protecting village communities' access rights is clear, despite some resistance reflected in restrictions on the rights accorded and the many discretionary exceptions. Decentralization has enabled local people to obtain more direct pecuniary advantage from industrial logging. For example, they receive a share of the annual forest revenues (AFR) and 1000 communauté Financiere Africaine (CFA) francs (US\$2.2) per cubic metre of wood is paid to the villages from sales of standing timber outside concession areas (commonly called the 'village tax'). The law lays down the division of the AFR as follows: 50 per cent for central government, 40 per cent for the commune concerned and 10 per cent for villages adjacent to logging areas. The law also lays down how the funds from these fees are to be used and the bodies that are to manage them, at both commune and village levels.

The community forest management bodies are clearly defined in the manual on allocation procedures and management standards for community forests, published in 1998 by the Community Forests Unit at the Forestry Ministry. While local people's rights of access to resources is mentioned for communal forests (Law 94, Article 30(2)), there is no mention anywhere of the rights of women as a distinct social group. The laws and regulations are silent on this issue. This failure to take specific gender aspects into account would be of no consequence if the rules governing access to and control of forests, forest resources and, indeed, society as a whole were equitable in terms of gender.

\section{Decentralized forest management bodies}

The management of forests and forest revenues involves several decision-making bodies. They are:

- the municipal council for decentralized local authorities (the communes);

- the Forestry Licence Fee Management Committee (CGRF), which serves as the interface between the forest council and communities adjacent to the concessions; and

- the legal entities responsible for managing community forests.

The municipal council was empowered by the administrative decentralization process, while the other two were formed more recently as part of the forest management decentralization process. The municipal council is responsible for managing the council's share of the annual forest licence fees ( 40 per cent of the total). It deliberates on local matters (planning, urban management, local development, etc.) and matters of internal functioning (voting the budget, approving administration and management accounts, etc.). Central government retains the power to sanction or dissolve the municipal council or revoke its decisions. 
The CGRF, set up in 1998, manages village taxes and the 10 per cent of AFR that are the community's share. Its members are the chair, the mayor of the commune, a rapporteur (the local administration officer with responsibility for forests) and six members representing adjacent village communities. The municipal tax officer acts as financial agent. The CGRF is responsible to the nearest administrative authority - the sub-prefect or the district chief. Management of community forests is entrusted to such legal entities as common initiative groups, associations, economic interest groups or co-operatives. These organizations hold internal elections to appoint the members of the community forest management committee or bureau.

\section{GENDER AND DECISION-MAKING IN DECENTRALIZED FOREST MANAGEMENT}

\section{Senegal}

\section{Dialakoto Rural Community: Gender in decision-making \\ Gender representation in the rural council}

The Dialakoto Rural Council, elected for a five-year term in the local elections of 2002, has 28 members representing 4 political parties. ${ }^{6}$ Three of the 28 are women, and 2 of these are from the Senegalese Democratic Party (PDS), the party in power. Being chairman or vice-chairman of the council (board member) or chairing a committee (e.g. the land management, health, education, finance, environment and gender committees) brings decisive prerogatives for decision-making. The chairman of the rural community supervises political, community and environmental activities. The land management, health, education, finance and environment committees are regarded as strategic because they open opportunities for funding, network-building and partnership. For example, the head of the land management committee takes part in all transactions concerning farmland allocation; the chair of the environment committee is involved in collecting forest taxes; the finance committee collects forest licence fees, manages the local community's share of that revenue and takes part in public procurement decisions. None of the three women councillors is on any strategic committee: the woman Socialist Party councillor, despite ten years' experience on the council, is merely a member of the planning and development committee and the two women PDS councillors are confined to the gender committee. The advantages that come with decision-making positions and committee responsibilities give the political parties room for political manoeuvring. Given these political interests, the issues of equity, gender and resource access for local people are not priorities.

\section{The gender committee: Women confined, excluded and domesticated}

The gender committee is the one that the men are least keen to sit on; they consider it the place for managing women's problems and leave its management to women. The 
result is that this committee is a kind of ghetto for women, leaving the field free for men to vie for positions on the strategic committees in all good conscience while complying with the legal requirements for representativeness. Being confined to this committee, women are excluded from those that discuss key problems which women are actually confronted with: access to healthcare, to fresh water, and to forest resources and land. A male councillor stated: 'I don't see what a man could do on the gender committee unless he was really feminist and ready to brush men's interests from his mind.'7 This mistaken view of gender excludes women from decision-making circles on the council. Thus, men do not have to fear competition from women, or consider female leadership on strategic committees as an act of gender compliance. The woman Socialist Party councillor comments that 'The gender committee exists in name only. The council elected in 2002 is at the end of its mandate [2007, a five-year mandate]. Nothing has been done for women and they have received no support from the council to gain access to forest resources and be able to market them.' ${ }^{8}$ Male councillors know that including women in a project is a condition for obtaining funding. So they include them in the project proposals, but not in the budgets. In this way, gender is addressed only formally and opportunistically (Bandiaky, 2007). The gender committee has also been used as an instrument to achieve political and development objectives. The president of the rural council has relegated to the gender committee the role of preparing food and of mobilizing women when government members or partners come to visit. This kind of women's participation in party politics is what Geisler (1995, p547) describes as 'another kind of kitchen'. Women's political participation is, indeed, little more than an extension of their submissive domestic roles.

In Dialakoto, multiparty competition has encouraged factionalism and petty rivalries while suppressing important issues such as gender equity, accountability and responsiveness, and the gendered distribution of voices and decision-making is skewed away from women's interests and concerns. Women have very low representation in the council and do not occupy any key positions; rather, they are relegated to secondary roles.

\section{Cameroon}

\section{The presence of women in the decision-making bodies}

Representation by gender in the decision-making bodies of the four municipal councils in FOMOD and the eight community forest management entities shows disparity in the exercise of power and in the importance of the posts held. In the 8 management entities there are 16 women to 104 men (thus, women make up 13 per cent of the total). Of the 100 councillors on the 4 municipal councils, only 12 are women. Thus, all in all, women make up 12.7 per cent of the different decisionmaking bodies. This is not specific to the locality studied. Nzoyem (2007) made a survey of women's involvement in forest management bodies in the Yokadouma arrondissement; none of the 22 members of those bodies were women.

\section{Assessment of women's decision-making power}

In order to assess the effective power women had in the decision-making bodies, we counted the number of strategic posts they held within them. By strategic posts we 
mean positions of authority with power to take discretionary or policy decisions. These include, for example, the offices of mayor, chair of the finance committee and chair of the management committee for a community forest. Among the four municipal councils there was one female mayor (in Messok) and one chairwoman, of the public procurement committee in Ngoyla.

The FOMOD community forests are managed by legal entities (associations or common initiative groups) headed by elected officers. The members are designated at the consultation meeting or by the entire village in advance of this meeting. As a rule, they are selected, then presented to the village for validation. They are elected for two or three years; unless there are serious problems, their mandates are renewed. Of the 20 functioning community forests in FOMOD, only 1 (RASCOBA) has a woman as chair and 1 has a woman responsible for logging operations (signing contracts and reporting to the ministry). Both women were chosen for their competence or because they already had some influence, having worked for an internationally recognized NGO, the Netherlands Development Organization, in the SDDL project (Soutien an Développement Durable de Lomié) (SDDL/SNV). According to Pa'ah (pers comm, 2006) and as confirmed by the survey, the financial posts (treasurer and accountant) are the only ones frequently entrusted to women. Is this a form of social recognition of their good management qualities, already recognized on the domestic front? Is it because they are supposed to be easier to manipulate, being, in effect, stooges dependent upon those who 'raised' them to this social rank? The question is open for debate. When women are generally so marginalized it is important to understand why, when they are allowed responsible roles, they should be placed in such sensitive posts as treasurer or accountant. This could be a way for other women to enter local power structures.

\section{CAUSES AND IMPLICATIONS OF WOMEN'S MARGINALIZATION}

\section{Causes of women's marginalization}

Women's exclusion from decision-making circles regarding forest management is only one of many examples of their exclusion from political life in general. It results from a combination of political, economic, cultural and social factors. Studies of women's marginalization from forest management decisions highlight the following main causes:

- $\quad$ the feminization of poverty (Kanji and Menon-Sen, 2001);

- perceptions of women's reproductive role in the private sphere (Goetz and Hassim, 2003; Tiani et al, 2005); or

- socio-cultural rules on access to and control of natural resources, which, in most cases, are non-egalitarian (Berry, 1989; Brown and Lapuyade, 2001; Tiani et al, 2007).

Many studies of women's lack of political involvement in Africa mention other reasons, such as feelings of inferiority, vulnerability, lack of transparency, illiteracy and 
rural women's lack of access to training and information. In this comparative study, the reasons for women's marginalization from decision-making bodies are also political, institutional and legal. Electoral systems and political life based on corruption, clientelism and patronage restrict women's access to political decisionmaking circles and, consequently, to the management of forests, which are under the jurisdiction of local elected officials. In Senegal, the list of candidates for a local election is the first factor in women's exclusion. These lists are drawn up by male politicians; women are often added as a complement at the bottom of the list and so have little chance of being elected. In Dialakoto RC, where the few women elected are concentrated in the gender committee, this reinforces their exclusion because they have no powers of decision and no funds. Confined to this committee, the women councillors can no longer, in practice, demand a place on the key committees that deal with forest resources. The political parties are more concerned for their own reelection than for gender issues. The women are regarded as instruments for mobilizing voters and for enlivening political meetings rather than as fully fledged partners with their own interests and constraints where natural resources are concerned.

In Cameroon, the candidate list is usually drawn up by an influential man of the 'elite', a member of the ruling party or the government. A few token women are added to the list for the sake of appearances. The East Province always votes for the party in power, the Cameroon People's Democratic Movement (CPDM), whose lists for local elections are certain to win. These lists are always drawn up in the same way: a man from the 'elite' maintains networks of relations both in government circles and in the village. Sometimes, if he is too busy elsewhere, his wife's name may head the list; but he will exercise political control through her. A study by Tobith and Cony (2006) shows that throughout the process of obtaining and managing community forests, women are involved at the start but are gradually pushed to the sidelines, so that by the time the legal entities are set up to manage the forest they are barely represented, if at all. Either they are no longer invited to these meetings or they are no longer informed of them.

Forest management policies, laws and regulations are generally gender neutral; sometimes women are mentioned in the general remarks. Neither in Senegal nor in Cameroon is there a law that lays down how women should benefit from the local share of collected taxes. There is no quota laid down for women's participation on rural councils. Although the issue of quotas is currently being debated, no law has been passed and ratified and the electoral mechanisms remain discriminatory. In Senegal, the proposition of parity by the Senegalese Council of Women (COSEF), adopted in March 2007 by the Senegalese National Assembly, was rejected and considered unconstitutional by the Constitutional Court.

\section{Social effects of marginalization}

\section{Women's lack of interest and limited involvement in political life}

Women's marginalization from public affairs is reflected in their low level of participation in political life, either for lack of interest or because they are excluded. In 
the 2002 municipal elections in Cameroon, 13.69 per cent of those registered to vote and 3.5 per cent of candidates for the municipal councils were women (125 women out of 3574 invested candidates from all parties) (ALVF, 2006; Tetchiada, 2007). The Organisation for Economic Co-operation and Development (OECD, 2007) mentions that in the 2007 elections there were 118 women out of 1032 candidates; 50 were incumbents and 68 new candidates. After the elections, women held 25 seats out of a total of 180 in the National Assembly. While a general de-motivation for electoral processes is evident in Cameroon (with 40 per cent participation in the combined legislative and municipal elections of 2007), ${ }^{9}$ women are marginalized and even more de-motivated than men from registering to vote and going to the polls.

The situation in Senegal is very different. Women register to vote and do vote en masse (IAD, 2000); but only a minority of candidates are women and few are elected (CAEL, 2005). In the 1996 local elections (communes, arrondissement communes and rural communities), out of a total of 2.6 million registered voters, 1,328,829 were women and 1,290,979 were men (IAD, 2000). Women mobilize equally massively for all types of elections - presidential, legislative and local. But in the 2002 local elections, 89 per cent of those elected were men and only 11 per cent women; the bias was even greater on the boards of the councils, with 91.73 per cent men and 9.37 per cent women (CAEL, 2002). A female mayor or chair of a rural community is a rarity in local government in Senegal. This inequality has consequences for forest management in the rural councils, limiting the extent to which women's interests, constraints and needs are taken into account.

\section{Failure to take account of gender differences and the specific needs of women}

Mbotto et al (2007, p63) note that in the commune of Mbang, a locality adjacent to FOMOD, forest revenues in three villages were invested as follows: 'a shed, repair of chapels, purchase of television sets and generators, although the decisions were not always unanimous. The women preferred purchases of soap and salt; only one village also made a small investment in social services and education'. Bigombe Logo (2008) confirms that those managing community revenues tend to make prestige investments at the expense of economic and social investments: in his report only 20 per cent of forest revenues paid to adjacent communes and village communities were spent on these.

Because of their numerical inferiority in the management bodies, women cannot assert their point of view, thus reinforcing their marginalization. Furthermore, men's priorities are different from women's. In Senegal, women are still under-represented on the rural councils where matters of land allocation and management are decided and the cropping calendar and rural community budget are defined (MFEF, 1993). In Dialakoto RC, most forest resources with economic value are in the national park and the Diambour classified forest. The population, women especially, complain that they have no access to resources in the park; but the CR, which is supposed to defend the community's interests, has not made such access an objective. As a result, the forestry service, which gives primacy to conservation, does not have to address the issue despite its importance for women. 


\section{ECONOMIC AND ECOLOGICAL IMPLICATIONS OF WOMEN'S LOW REPRESENTATION}

The FOMOD forests hold a wealth of non-timber forest products (NTFPs), including wildlife (Betti and Nlengue, 1997). Some of these products have sufficient market value to generate meaningful economic activity for local communities. These are moabi (Baillonnella toxisperma), djansang (Ricinidendron heudelotii), wild mango (Irvingia gabonensis) and caterpillars. ${ }^{10}$ In Cameroon's forest region, management of timber and wildlife is a male preserve (Tiani, 2001). But apart from palm wine, raffia and rattan, NTFPs are managed by women, from harvesting to processing, packaging and sale. However, because the decisions are taken by men, community forest management has, in effect, been reduced to harvesting a few tree species with high commercial value (Mvondo, 2005). The forest is thus underused and economic benefits sacrificed while its biodiversity diminishes as the most valuable species are logged. Gender equity on the councils and management bodies would presumably result in negotiation among different interests and consideration of other forest uses. Management of non-timber forest resources would take its rightful place on the agenda, economic use of the forests would improve, and concern for sustainability would be better expressed with the support of the women.

Around the Niokolo Koba National Park in Senegal, harvesting and craft activities are women's work. Women also process and sell local fruit and vegetables such as jujube, tamarind, nere, wild yam and the fruit and leaves of the baobab. But most of these resources are found in protected areas. Although access to resources within the national park is a major preoccupation for women, it is not a priority for the men, so production and income remain low. Artisanal management of non-timber forest resources in Cameroon, Senegal and many other African countries is ecologically sustainable because it usually involves gathering fallen fruit and other forest products, while the tree itself is preserved.

\section{CONCLUSIONS AND RECOMMENDATIONS}

The decentralization policies adopted in Senegal and Cameroon during the 1990s were innovative in transferring to local authorities legal rights and authority to acquire and manage part of the country's forests and forest revenues. In this chapter we investigated the extent to which decentralization policy as applied in Senegal and Cameroon has the potential to promote gender equity in access to and control over forests, their resources and the profits from them. Our study shows that in both countries women are under-represented in the decentralized institutions and local institutions managing forest taxes and community forests. Few women have attained strategic positions. Men and women have different interests regarding logging, harvesting of NTFPs and economic use of other services that the forest provides. Women have not been able to benefit from the many opportunities that decentralized forest management could provide to develop their capacities or enhance their 
economic and social power. The causes of gender inequality in representation and participation in decentralized forest management decisions in Senegal and Cameroon are political, economic, cultural, social and institutional in nature.

Research results in Senegal and Cameroon indicate that formal democratization does not automatically result in democratic decentralization or direct and fair representation. There are other locally entrenched political and cultural factors that shape the gender distribution of voice and access to natural resources. Assuming that elections will bring democracy masks the very complex issue of electoral politics, which is inherently based on informal power relations, hierarchies and authority. The fact that elections are perceived as a means to achieve electoral votes rather than to achieve democratic representation puts elected officials in an arena of competition, rivalry and pursuit of political interests often detrimental to women's political and environmental interests.

Despite the gloomy picture painted in this chapter, the fact that women have been marginalized from political life is not fatal for them. Several factors are in their favour: the international political environment is more favourable than ever for the integration of gender into national and international institutions; feminist pressure groups are very active; and African girls and women have increasingly more access to formal education. In Senegal as well as in Cameroon, women represent more than 50 per cent of the population, which gives them a numerical majority to better mobilize for their effective political participation and representation.

Several actions could be taken, however, to better support the political and economic aspirations of local women who depend on forests for their and their families' livelihoods:

- Women's needs and interests should be made explicit within the agendas, budgets and development plans of decentralized institutions such as rural councils.

- Conception and implementation of community forest management activities should be differentiated by gender (based on differentiated responsibilities, constraints, needs, interests and opportunities), as should the design of information and communication channels, training and capacity-building programmes. Women's economic needs and interests, as well as men's, should be included in rural councils' budgets and programmes.

- The donors and financial institutions that fund development and environment projects should establish contracts with communities and central governments, which include a requirement for effective, equitable representation of women and answerability in the event of non-compliance with this clause. In this way the notion of gender parity or male-female quotas should be incorporated within all spheres of public management - including forest policy.

- There is a need for the effective implementation of objective 3 of the Millennium Development Goals (MDGs) and the July 2004 African Union Declaration. Principle 21 of Agenda 21 also recognizes that women play a vital role in environmental management and development. Gender-equitable participation and representation in decision-making is essential for sustainable development and good governance, and for achieving MDGT to ensure environmental sustainability. 
- An analytical link should be established between gender issues and decentralization of forest resource management. This would reconcile three approaches that are dialectically connected and complementary, but are often addressed in isolation from each other: gender equity, sustainable resource management and improved rural living conditions. The concept of gender should assume a prominent position in academic and political discourse on decentralized forest resource management in order to clarify in theory, and introduce in practice, a proper consideration of gender issues and their application to good governance and local democracy.

\section{NOTES}

1 This law divided the national domain into four categories: zones urbaines, zones classees, zones de terroir and zones pionnières. It is the areas used mainly for farming that are classed as zones de terroir (translator's note).

2 A model forest is run by a collaborative forest management process based on voluntary inter-sectoral partnership and knowledge-sharing between the local, regional and international levels. In August 2005 the Cameroon government allocated two sites as model forests for a pilot experiment in an African setting: Campo-Ma'an in the South Province and Dja and Mpomo in the East Province. This chapter concerns the Dja and Mpomo Model Forest (FOMOD).

3 The powers and legal and financial autonomy transferred to the rural councils were established by the 1996 Local Authorities Code (RdS, 1996) and the 1998 Forest Code.

4 Local collectivities represent administrative and geographic units. They include the regional council, the municipal council and the rural council.

5 Zone de terroirs are territories that do not fall into the national domain (i.e. classified or forest reserves, national parks and biosphere reserves).

6 Senegalese Democratic Party (PDS), Socialist Party (PS), Democratic League/Movement for Labour (LD/MPT) and And-Jef/African Party for Socialism and Democracy (AJ/PADS).

7 Author interview, Dialakoto, 27 February 2006.

8 Author interview, Dialakoto, 1 March 2006.

9 According to the Justice and Peace Commission, a civil society organization that mobilized 1600 observers countrywide. For further information, see Élections et Leadership, Agence de Presse Africaine (APA), 26 July 2007.

10 According to Ndzomo Abanda (2006), an adult moabi tree produces $327 \mathrm{~kg}$ of fruit a year, from which 104.6 litres of oil, worth 156,900 CFA francs (US\$313) can be produced. One djansang tree produces $35 \mathrm{~kg}$ a year and one andok (wild mango) tree $26 \mathrm{~kg}$.

\section{REFERENCES}

ALVF (Association de Lutte contre la Violence Faite aux Femmes) (2006) Étude sur la participation des Femmes dans la Vie Politique dans les Départements du Diamaré et Chari, Centre Vie de Femmes au Cameroun, Sisyphe Info, 2 January 2006 
Bako-Arifari, N. (1997) Processus de Décentralisation et Pouvoirs Traditionnels: Typologies des Politiques Rencontrées, Décentralisation et Développement Rural 15, Rural Development Division, United Nations Food and Agriculture Organization (FAO), Rome

Bandiaky, S. (2007) Engendering Exclusion in Senegal's Democratic Decentralization: Subordinating Women through Participatory Natural Resource Management, World Resources Institute, Working Paper Series: Representation, Equity, Environment, http://www.wri.org/publication/9393\#

Berry, S. (1989) 'Social institutions and access to resources', Africa, vol 59, no 1, pp41-55

Betti, J. L. et E. Y. NLegue (1997) Etude Ethnobotanique des Plantes Utiles dans le Réserve de Faune du Dja, Cameroun: Les Fruitiers Sauvages, Rapport Technique, Projet ECOFAC AGRECO, Yaoundé, Cameroun

Bigombe Logo, P. (2008) Foresterie Communautaire et Réduction de la Pauvreté Rurale au Cameroun: Bilan et Tendances de la Première Décennie, World RainForest Movement, no 126, January 2008

Bisiliat, J. (1992) 'Introduction', in J. Bisiliat, F. Pinton and M. Lecarme (eds) Relation de Genre et Développement: Femmes et Sociétés, ORSTOM, Paris

Brown, K. and S. Lapuyade (2001) 'Changing gender relationships and forest use: Study from Komassi, Cameroon', in C. J. P. Colfer and Y. Byron (eds) People Managing Forests: The Link between Human Well-Being and Sustainability, Resources for the Future, Washington, DC, and Bogor, Indonesia

CAEL (Cellule d'Appui aux Elus Locaux) (2005) Plaidoyers du dialogue politique: Rapport provisoire sur l'état des lieux Renforcement de la participation des femmes à la vie politique locale, Projet d'Appui aux Elus Locaux (PAEL), Dakar, Senegal

CAEL (2006a) Renforcement de la Participation des Femmes à la vie politique locale: Plan d'Action Stratégique et Opérationnel, PAEL, Dakar, Senegal

CAEL (2006b) Plaidoyer du Dialogue Politique: Rapport provisoire sur l'état des lieux du renforcement de la participation des femmes à la vie politique locale, Union des Associations d'Elus Locaux, Projet d'Appui aux Elus Locaux (PAEL), Dakar Senegal

Cornwall, A. (2003) 'Whose voices? Whose choices? Reflections on gender and participatory development', World Development, vol 31, no 8, pp1325-1342

Crook, R. C. and A. S. Sverrisson (2002) Decentralization and Poverty Alleviation in Developing Countries: A Comparative Analysis or, is West Bengal Unique?, IDS Working Paper no 130, Institute of Development Studies, Brighton, UK

Goetz, A. M. and S. Hassim (eds) (2003) No Shortcuts to Power: African Women in Politics and Policy Making, Zed Book, Cape Town; David Philip, London and New York

IAD (Institut Africain pour la Démocratie) (2000) Femmes, Enjeu électoral: Des Chiffres qui Parlent, IAD, Dakar, Senegal, January

IIED (Institut International pour l'Environnement et le Développement) (2006) Aspects Juridiques liés au Genre et à la Décentralisation au Sénégal: Une Contribution au Projet de Réforme de l'Administration Locale, Study by Moustapha Ngaïndé in collaboration with Rokhaya Chambaz, Programme Réussir la Décentralisation, August

Kanji, N. and K. Menon-Sen (2001) What Does the Feminization of Labour Mean for Sustainable Livelihoods? Opinion: World Summit on Sustainable Development, International Institute for Environment and Development (IIED) in Cooperation with the Regional and International Networking group (RING), London, http://www.iied.org/pdf/gender13.pdf

Mbotto Ndomi, A. A., E. Mandigou et B. Ngonde (2007) 'La contribution de la Redevance Forestière au Développement Local: Les Communes peuvent-elles faire mieux lorsqu'elles 
sont Responsabilisées?', in A. Dongmo Tsobzé, T. Hiehorst et J. M. Mfou'ou (eds) Entre Désespoir et Espoir: Les Défis de la Gouvernance et de la Décentralisation dans les Réalisations des Investissements Publics locaux au Cameroun, Royal Tropical Institute, Amsterdam

Meinzen-Dick, R. and A. Knox (1999) Collective Action, Property Rights, and Devolution of Natural Resource Management: A Conceptual Framework, Project Draft Workshop Paper, Washington DC, 15 July 1999

MFEF (Ministère de la Femme de l'Enfant et de la Famille) (1993) Femmes Senégalaises à l'Horizon 2015, The Population Council, Study coordinated by Fatou Sow and Mamadou Diouf, Dakar, Senegal

MINEF (2005) Note de Proposition des deux Sites: Pilotes de Forêts Modèles pour une Adhésion du Cameroun au Réseau International de Forêts Modèles, Ministère des Forêts et de la Faune, Yaoundé, Cameroon

Mvondo, A. S. (2005) Décentralisation des ressources forestières et justice environnementale: Analyse des évidences empiriques du Sud Cameroun, LEAD Journal (Law, Environment, and Development Journal)

Ndzomo Abanda, G. (2006) 'Utisisation des Produits forestiers non ligneux dans le Dja.28-29', in Home-Grown Plus: Connaissances locales, bien-être des populations, politiques et Sciences: les actes de l'atelier régional sur l'agroforesterie dans le landscape du Dja, Cameroun, World Agroforestry Centre, West and Central Africa, Humid Tropics, Youndé, Cameroon, Lomié, 21-22 June 2006

Nzoyem, D. S. C. (2007) Implication des Femmes dans les Organes de Gestion des Ressources Forestières et Fauniques dans l'Arrondissement de Yokadouma, Rapport de Stage, Appui à l'Autopromotion de la Femme de la Boumba et Ngoko, Organisation Néerlandaise de Développement, Yaoundé, Cameroon

OECD (Organisation for Economic Co-operation and Development) (2007) Elections 2007 in West Africa, Summary Tables, Sahel and West Africa Club (SWAC/OECD) Governance, Conflict Dynamics, Peace and Security unit, Paris

Ostrom, E. (1990) Governing the Commons: The Evolution of Institutions for Collective Action, Cambridge University Press, New York, NY

Parry, T. R. (1997) 'Achieving balance in decentralization: A case study of education in Chile', World Development, vol 25, no 2, pp211-225

Patterson, A. (2003) 'Power inequality and the institutions of Senegalese development organizations', African Studies Review, vol 46, no 3, pp35-54

RdS (République du Sénégal) (1996) Loi Portant Code des Collectivités Locales, RdS, Dakar, Senegal

RdS (1998) Plan Local de Développement de la Communauté Rurale de Dialakoto, Région de Tambacounda, Département de Tambacounda, Arrondissement de Missirah, RdS, Dakar, Senegal

Ribot, J. C. (1999) 'Decentralization, participation and accountability in Sahelian forestry: Legal instruments of political-administrative control', Africa, vol 69, no 1, pp23-65

Ribot, J. (2006) Dans l'Attente de la Démocratie: La Politique des Choix dans la Décentralisation de la Gestion des Ressources Naturelles, World Resources Institute (WRI), Washington, DC

Ribot, J. C. and A. Larson (2004) 'Democratic decentralization through a natural resource lens: An introduction', European Journal of Development Research, vol 16, no 1, pp1-25

Robbins, P. (1998) 'Authority and environment: Institutional landscapes in Rajasthan, India', AAS Annals, vol 88, no 33, pp410-435 
Rocheleau, D., B. Thomas-Slayter and E. Wangari (1996) Feminist Political Ecology: Global Issues and Local Experiences, Routledge, London

Seager, J. (1993) Earth Follies: Feminism, Politics, and the Environment, Earthscan, London

Tetchiada, S. (2007) 'Des femmes veulent être élues', Tribune des Droits Humains, www.humanrights-geneva.info/article.php3, 18 January 2007

Tiani, A. M. (2001) 'The place of rural women in the management of forest resources: The case of Mbalmayo and neighbouring areas in Cameroon', in C. P. Colfer and Y. Byron (eds) People Managing Forest: The Links between Human Well-Being and Sustainability, Resources for the Future, Washington, DC, and Bogor, Indonesia, pp72-89

Tiani, A.M., G. Akwah and J. Nguiebouri (2005) 'Women in Campo-Ma'an National Park: Uncertainties and adaptations in Cameroon', in C. Colfer (ed) The Equitable Forest, Resources for the Future, Washington, DC, pp131-149

Tiani, A. M., M. Zoa and J. Gagoe (2007) Genre et Minorités dans les Forêts Modèles du Cameroun, Rapport de Recherche, Centre de Recherche Forestière Internationale, Secrétariat du Réseau International des Forêts Modèles, Yaoundé, Cameroon

Tobith, C. and P. Cony (2006) 'Gender issues and community forests in Cameroon: Perspectives for women’, Bois et Forêts des Tropiques, no 289, vol 3, pp17-26 


\title{
Forest Revenue Decentralization and Profits Redistribution in the Democratic Republic of Congo
}

\author{
Sébastien Malele Mbala and Alain Karsenty
}

\section{INTRODUCTION}

With over 108 million hectares of forestland, the Democratic Republic of Congo (DRC) has enormous forest resources (Devers and Van de Weghe, 2006). The potential timber production is estimated at over 10 million cubic metres per year (DECNT, 1984). Paradoxically, for many years the annual production rate has barely reached 500,000 cubic metres and forest revenue is relatively low, on average hardly 1 per cent of annual gross domestic product (GDP). In 1997, forest exports brought in close to US $\$ 54$ million, while in 2006 the figure was approximately $\$ 42$ million. This situation is receiving special attention from the Congolese authorities who recognize the many roles that forests can play. Besides their economic role as a source of timber, forests provide food, medicinal plants, household fuel, arable land and non-ligneous forest products. They are therefore essential to the survival of some 40 million Congolese living in poverty-stricken rural areas.

In post-conflict times, timber production should be substantially increased and sustainably managed in order to improve livelihoods in the rural areas by contributing to economic development and poverty alleviation. Tools for sustainable forest management that encompass both social and ecological aspects were produced to meet this need. Hence, in August 2002, the Forest Code, which replaced the colonial forest regime of 1949, was adopted. The code includes innovative measures that encourage new economic activities, forest sustainability, poverty alleviation and forest management decentralization. Furthermore, the government is committed to carrying out a priority reform agenda that, in global terms, seeks to eradicate the mismanagement of the past and lay the grounds for transparent forest management and equitable distribution of profits from forest resources. 
This chapter seeks to assess the recent reforms, especially those related to forest revenue decentralization and the redistribution of revenue accruing from forest resources. Special attention is given to the transfer of management responsibility to local communities as a prerequisite to genuine decentralization. This chapter highlights the limitations of the new forest reforms with regard to prospects for sustainable management, good local forest governance, democratic decentralization and profit redistribution. Progress in transferring forest area fees (FAFs, or redevance de superficie forestière) is carefully considered, and several proposals are made for ensuring payments reach those most in need.

\section{FORESTS IN THE NATIONAL CONTEXT OF THE DRC}

The DRC is among the world's top ten mega-biodiverse countries thanks to its immense size and the multifarious physical and climatic conditions that affect its biological wealth. The ecological role of forestlands is well known; but forests also contribute significantly to meeting people's many basic needs and to creating wealth and jobs at the national level. Forests are known to generate close to one third of the non-agricultural revenue in rural areas. Although the so-called secondary forest products have not been well studied, forest-dwellers are known to derive essential food supplements and medicines from the leaves, bark, fruit and by-products of forest resources.

\section{THE POSITION OF FORESTS IN THE NATIONAL ECONOMY}

The contribution of the forest sector to the national economy is estimated at 1 per cent of GDP. More than 90 per cent of the timber sector is informal, with the output used to fulfill the country's needs for household fuel and services. This sector has been held back not only by war, but also by lack of capital and bank loans and dilapidated transport and handling facilities, among other factors. The forests of the DRC cover a huge area but are not easy to exploit. The Congo River is excellent for navigation between Kisangani and Kinshasa; but the rapids start just downstream of the capital, which means that logs must be unloaded in Kinshasa and placed on trains or lorries to Matadi, a port on the estuary with limited capacity and prone to siltation - causing a serious bottleneck for exports, especially timber. Furthermore, since roads are practically non-existent in the Eastern and Equateur forestland provinces, transportation costs are very high. Transporting 1 cubic metre of wood to Matadi from the Bandundu region and parts of the Equateur province costs in the order of $\$ 50$ to $\$ 70$, while transportation costs from the rest of the Equateur Province run in the $\$ 70$ to $\$ 80$ range. In the east of the country, transporting timber from Béni to the port of Mombassa costs $\$ 120$ to $\$ 160$ (Roda and Erdlenbruch, 2003). The forest is therefore exploited primarily along the navigable parts of the Congo River and its main tributaries. Lastly, except in the eastern part of the 
country, the Congolese forest is not rich in species of the Entandrophragma family (e.g. Sapelli and Sipo), which are abundant in neighbouring countries and prized on international markets. These factors explain why, despite its enormous potential, the country's forest industry has remained very small. Even in peacetime the country never produced more than 500,000 cubic metres per year.

Before 2002, very low revenues from forest taxes $(\$ 0.0014$ per hectare until the end of 2002) led to the establishment of three large concessions of 2 million to 3 million hectares that were hastily mapped (with a difference of 1.38 million hectares between official figures and geographic information system (GIS) readings). These areas covered large areas of non-productive land (30 per cent, on average), especially in the Congolese Basin, where in some areas 40 per cent of the land is considered nonproductive. Yet, a number of companies were shut down because of socio-political unrest and economic crises. The number of operating companies slid from 150 in 1990 to 75 today, with only about 20 of these being economically viable.

\section{THE ECONOMIC AND FISCAL REFORM}

The forest sector was revived at the end of 2002 when several companies, which until that time had been unable to reach their concession areas in the Equateur province, went back to work. The government's efforts to fight fiscal parasitism and abusive logging and to audit the jungle of legal and regulatory texts began bearing fruit in 2003, when a single customs window was installed in the port of Matadi. At the same time, the government started auditing the forest contracts and, in 2002, repealed 163 titles to 25.5 million hectares for breach of contractual obligations. However, the political instability of this 'political transition period' (prior to the June 2006 elections) facilitated the unauthorized allocation of forest titles despite the 2002 official moratorium on new allocations. In October 2008, the Congolese government completed the first phase of the process of converting old forest titles into concessions under the new forest law. Out of over 22 million hectares of forest titles inventoried by a commission with strong representation from the civil society and the indigenous people, only slightly over 7 million hectares were found to be legal. Furthermore, the government announced a new three-year extension of the moratorium on the allocation of new logging concessions.

In 2004, the forest revenue system was revised along the lines of recommendations from an expert mission supported by the World Bank. The experts pointed out that:

Paradoxically, companies have to pay numerous taxes and levies and accept heavy fiscal pressure, but state revenue is small. As for forest taxes, the revenue collected hardly reached $\$ 2$ million in 2002, while the services collecting levies on timber exports (public enterprises and administrative entities) raked in close to $\$ 1.8$ million that same year. The disastrous condition of state accounts makes it very difficult to evaluate the added value of the forestry sector. A very approximate estimate of the added value generated by the formal wood sector, including that derived from the transport sector and that directly traceable to timber, was somewhere between $\$ 14$ and $\$ 15$ million in 2002. (Karsenty et al, 2003) 
The 2003 Economic Review of the Forestry Sector recommended the following principles for the reform:

- Gradually increase the forest area fee in order to discourage speculation on forest concessions; adjust the area allocation to the real capacity of economic operators; and provide for the funding of decentralized administrative entities (DAEs) through the transfer of 40 per cent of the total amount of revenue from the fee, as stipulated in the Forest Code.

- Lower the financial pressure caused by high levels of 'special taxes' on forest enterprises (including illegal financial levies and levies imposed legally by public institutions). ${ }^{1}$

- Provide compensation for interregional differences in transport costs for exports and encourage the diversification of species harvested.

- Make the tax system more rational by systematically applying the ad valorem taxes and applying a tax base that is closer to the free-on-board (FOB $)^{2}$ value and the oscillating prices of the tropical timber market.

- Ensure the collection of payments, thereby increasing revenue and ensuring equitable tax rates for operators.

- Ensure funding for the National Forestry Fund (Fonds Forestier National, ex-FRCF).

The government adopted many of the recommendations in this study in an interministerial order dated 17 March 2004, whose structure is outlined in Table 8.1.

\section{Tax revenue trend}

Revenue from the forest sector has risen since 2002 as a result of this new boost to economic activity and tax reforms. The revenue from forest area fees rose from $\$ 41,100$ in 2000 to over $\$ 5.1$ million in 2006 (see Table 8.2).

Revenue from taxes on logging permits rose from some $\$ 59,000$ in 2002 to $\$ 151,000$ in 2004 . Revenue from taxes on timber exports rose from $\$ 204,000$ in 2002 to $\$ 466,000$ in 2004. Between 2002 and 2004 the value of timber exports rose from $€ 7$ million to $€ 23$ million.

\section{THE STATE OF THE FOREST INDUSTRY}

In the DRC, the forestry industry was established over 75 years ago. Between 1930 and 1949 there was a rush of new forest companies that settled in the Mayombe region, gradually spreading to other provinces during the 1970s. However, levels of industrial timber production never approached the levels of other Congo Basin countries; after the war of the the 1990s, the official figures on timber harvest - while inaccurate have been very low (see Table 8.3).

These figures are lower than the figures on timber exports (see Table 8.4). Thus, considering a product yield of 33 per cent for sawn lumber exports and 50 per cent 
Table 8.1 New forest revenue system relative to the preceding one

\begin{tabular}{|c|c|c|c|c|}
\hline Imports/taxes & Forest area tax & Felling tax & Reforestation tax & Export tax \\
\hline Base & $\begin{array}{l}\text { Land area of concession } \\
\text { (productive area after } \\
\text { approval of land } \\
\text { development plan) }\end{array}$ & $\begin{array}{l}\text { Commercial } \\
\text { volume cut }\end{array}$ & $\begin{array}{l}\text { EXW value, } \\
\text { Matadi and area } \\
\text { covered by annual } \\
\text { felling permit }\end{array}$ & $\begin{array}{l}\text { Free-on-board } \\
\text { (FOB) value, Matadi }\end{array}$ \\
\hline Rate & $\begin{array}{l}\text { Former concessions: } \\
\text { US } \$ 0.10 \text { in } 2004 \\
\text { US } \$ 0.20 \text { in } 2005 \\
\text { US } \$ 0.30 \text { in } 2006 \\
\text { US } \$ 0.50 \text { in } 2007 \\
\text { (forecasts) } \\
\text { New concessions: } \\
\text { Bottom + offer } \\
\text { on tender }\end{array}$ & $\begin{array}{l}1.25 \% \text { of } \\
\text { EXW value } / \mathrm{m}^{3} \\
\text { (EXW }=\text { FOB - } \\
\text { fixed transport } \\
\text { cost) }\end{array}$ & $\begin{array}{l}\text { Log exports: } 4 \% \\
\text { of EXW value } \\
\text { (FOB - fixed } \\
\text { transport } \\
\text { cost); felling } \\
\text { permits: US\$2/ha } \\
\text { in } 2004 \text { and } \\
\text { US\$10/ha in } 2005 \text {. }\end{array}$ & $6 \%$ on FOB value \\
\hline Set by & $\begin{array}{l}\text { Bottom set by } \\
\text { ENV-FIN } \\
\text { Offer determined } \\
\text { through bid submissions }\end{array}$ & $\begin{array}{l}\text { Coordination } \\
\text { Provinciale } \\
\text { Environnement }\end{array}$ & ENV-FIN & ENV-FIN \\
\hline Paid to & $\begin{array}{l}\text { Direction Générale des } \\
\text { Recettes } \\
\text { Administratives, } \\
\text { Domaniales et de } \\
\text { Participation } \\
\text { (DGRAD) (central } \\
\text { services) }\end{array}$ & $\begin{array}{l}\text { DGRAD } \\
\text { (provincial } \\
\text { services) }\end{array}$ & $\begin{array}{l}\text { FFN (ex-FRCF), } \\
\text { but DGRAD since } \\
\text { law on single fund }\end{array}$ & $\begin{array}{l}\text { Customs Service } \\
\text { (OFIDA) }\end{array}$ \\
\hline Allocated to & $\begin{array}{l}\text { Treasury: } 60 \% \\
\text { Provinces: } 25 \% \\
\text { Territories: } 15 \%\end{array}$ & $\begin{array}{l}\text { Treasury: } 50 \% \\
\text { FFN: } 50 \%\end{array}$ & FFN: $100 \%$ & Treasury: $100 \%$ \\
\hline Former tax system & $\begin{array}{l}\text { Land area tax based } \\
\text { on Letter of Intent } \\
\text { and Supply Guarantee }\end{array}$ & $\begin{array}{l}\text { Formerly } \\
\text { proportional } \\
\text { fee }\end{array}$ & $\begin{array}{l}\text { Formerly received } \\
\text { by the Direction } \\
\text { de la Gestion } \\
\text { Forestière (DGF) on } \\
\text { behalf of FRCF }\end{array}$ & No change \\
\hline
\end{tabular}

Table 8.2 Income based on land allocation fee (in US\$)

\begin{tabular}{lllc}
\hline Year & Amount due (US\$) & Amount collected (US\$) & Percentage recovery \\
\hline 2002 & 490,000 & 401,800 & 82 \\
2003 & 745,650 & 553,660 & 74 \\
2004 & $1,959,730$ & $1,249,000$ & 64 \\
2005 & $4,783,000$ & $2,312,800$ & 48 \\
2006 & $4,067,100$ & $2,592,480$ & 64 \\
2007 & $7,353,280$ & $4,661,150$ & 63 \\
\hline
\end{tabular}


Table 8.3 Declared timber harvests between 2002 and 2006

\begin{tabular}{lc}
\hline Year & Logs harvested $\left(m^{3}\right)$ \\
\hline 2002 & 44,000 \\
2003 & 76,000 \\
2004 & 217,000 \\
2005 & 98,000 \\
2006 & 155,000 \\
\hline
\end{tabular}

Source: DGF $(2003,2004,2005,2006,2007)$

Table 8.4 Wood exports and their total values between 2002 and 2006

\begin{tabular}{ccccccc}
\hline Year & $\begin{array}{c}\text { Logs } \\
\left(\mathrm{m}^{3}\right)\end{array}$ & $\begin{array}{c}\text { Sawn } \\
\text { lumber }\left(\mathrm{m}^{3}\right)\end{array}$ & Veneer $\left(\mathrm{m}^{3}\right)$ & Flooring $\left(\mathrm{m}^{3}\right)$ & $\begin{array}{c}\text { Lengths of } \\
\text { wood }\left(\mathrm{m}^{3}\right)\end{array}$ & $\begin{array}{c}\text { Total value } \\
\text { (Euro) }\end{array}$ \\
\hline 2002 & 28,000 & 5800 & 25 & 2530 & 455 & $6,938,092$ \\
2003 & 64,000 & 16,400 & 600 & - & - & - \\
2004 & 94,400 & 17,200 & 760 & 3970 & 510 & $23,047,415$ \\
2005 & 111,200 & 25,700 & 1170 & 5130 & 790 & $30,213,960$ \\
2006 & 151,000 & 26,200 & 2600 & 5500 & 980 & $35,355,872$ \\
\hline
\end{tabular}

Source: DGF $(2003,2004,2005,2006,2007)$

for veneer, the equivalent in roundwood exports for 2006 was about 235,000 cubic metres, which is much higher than the 155,000 cubic metres declared in Table 8.3. Sales of sawn lumber and plywood by the official industries on the local market need to be added. These sales have not been well evaluated and probably amount to about 15,000 cubic metres (sawn), which corresponds to 45,000 to 50,000 cubic metres of roundwood. Lastly, the informal sector, according to 2003 estimates, accounts for between 1.5 million and 2 million cubic metres of timber per year in the form of logs (Djire, 2003).

Most forest companies are foreign financed. The timber industry is dilapidated and rudimentary. As a rule, only sawn lumber and veneer are transformed. Nearly all of the veneer production is exported. The forestry business focuses mainly on a small number of species with very high commercial value. Although the DRC has a tremendous variety of tree species, the industry does little to promote lesser-used tree species. While only 34 species are marketed and developed to meet the wishes of the foreign consumers, some 970 have been inventoried.

Logs are the most common timber export (see Table 8.4); there is little local transformation, with only about 35 per cent of the logs harvested. Yet, the value of Congo's exports is going up, from €6.9 million in 2002 to over €35.3 million in 2006. 


\section{IMPORTANT INNOVATIONS IN THE FOREST CODE}

The decree of April 1949 regulated the forest industry in the DRC for many years. Now regulations come from the Forest Code, set out in Law No 011/2002 of 29 August 2002. This law includes innovative measures that could turn the Congolese forests into a pillar of economic growth and, hence, a tool for poverty alleviation through the following mechanisms:

- transfers of 40 per cent of the revenue received by the public treasury from forest area fees on timber and forestry products to the decentralized administrative entities (DAEs), as follows: 25 per cent for the provinces and 15 per cent for the territoires, and complete allocation of the latter to finance socio-economic infrastructure for local populations;

- introduction of technical specifications for forest concession holders, with certain clauses spelling out their responsibilities to invest in infrastructure for the collective good of people living in areas alongside the concession;

- the possibility for local communities in the forest zones to obtain communal forest concessions in their zones.

This chapter only focuses on the first of these three distinct but complementary measures. It seeks to assess the effects of these monetary transfers on poverty alleviation and socio-economic measures to support local and indigenous populations. It also recommends ways to improve these impacts.

\section{THE FOREST AREA FEE (FAF)}

Until now, the forest area fee (FAF) has been paid by holders of forest titles entitled Letters of Intent or Supply Guarantees for Ligneous Products. In the new Forest Code, this annual fee is called the forest area fee (redevance de superficie forestiere) and is charged to all forest concession holders for the entire concession area.

According to a recent study by the NGO Avocats Vert (Mpoyi, 2006), the forest area fee has become the main source of forest revenue. ${ }^{3}$ Considering past figures, the theoretical global value of the fee across all forest concessions should amount to some $\$ 10$ million per year, as of 2007. But the decision taken in October 2008 to cancel titles that do not meet the legal requirements (i.e. close to 15 million hectares) will bring this potential income down to $\$ 3.5$ million (approximately $\$ 0.50$ per hectare).

\section{ALLOCATION OF THE FOREST AREA FEE AND OTHER FORESTRY TAXES}

Hitherto, the Direction de la Gestion Forestiere (DGF) has been the service empowered to record and effect fee allocations, while the order to pay and the collection was 
handled by the Direction Générale des Recettes Administratives, Domaniales et de Participation (DGRAD), a branch of the Ministry of Finance. The Central Bank of Congo, serving as the state cashier, receives the payment.

Instructions for allocating FAFs are spelled out in the Forest Code. The revenue is supposed to be used for investments in socio-economic infrastructure that benefits the local population. It is not possible to evaluate the effectiveness of these provisions, however, since no FAF transfers have been made since the Forestry Code came into effect in 2002. Yet, it is possible to identify shortcomings in the law itself. First, procedures for drawing up territorial and provincial budgets do not include mechanisms for consulting local communities and populations, nor are there mechanisms for having them participate in setting priorities for provincial and local investment programmes. Local populations also lack the means to monitor provincial and local budgets, or to track the rare investments that have been made (Mpoyi, 2006) increasing the likelihood of mismanagement.

\section{Other forest-sector taxes}

Apart from the forest area fee, the state also receives revenues from taxes on the following:

- $\quad$ logging

- felling

- reforestation

- deforestation tax

- $\quad$ exports of timber and non-ligneous forest products

Percentage allocations to the central government, the National Forest Fund (NFF) and DAEs are summarized in Table 8.5. These data show the critical role of the FAF (relative

Table 8.5 Forest revenue for fiscal years 2005 and 2006

\begin{tabular}{lccccc}
\hline Tax & 2005 & 2006 & & Earmarked to (\%) & \\
\cline { 3 - 6 } & (Euros) & (Euros) & Treasury & $\begin{array}{l}\text { National Forest } \\
\text { Fund (NFF) }\end{array}$ & $\begin{array}{l}\text { Decentralized } \\
\text { administrative } \\
\text { entities (DAEs) }\end{array}$ \\
\hline Forest area fee & $3,863,142$ & $5,147,753$ & $60 \%$ & & $40 \%$ \\
Reforestation tax & 511,100 & 829,131 & & $100 \%$ & \\
Logging permit tax & 382,692 & 262,563 & & $50 \%$ & \\
Felling tax* & - & - & $50 \%$ & $50 \%$ & \\
Timber exports ta*** & & - & $100 \%$ & & \\
Deforestation ta** & - & 2780 & $100 \%$ & & \\
Tax on PFNL[0135] & 2620 & $100 \%$ & & \\
\hline
\end{tabular}

Notes: * Taxes received in province (data not available in Kinshasa).

** Data not available at time of writing. In 2004, customs duties on timber exports amounted to US\$643,000.

Source: DGF $(2006,2007)$ 
to other taxes) for the DAEs, and the potential to link the welfare of local public entities to the area under timber concessions. The potential for these funds to advance local socio-economic development, on the other hand, remains to be seen.

\section{THE POLITICAL STAKES OF TRANSFERS}

The system for collecting resource exploitation taxes (with the exception of corporate taxes) is centralized at the DGRAD, which has provincial branches throughout the country. At the point of exit, the Customs Service (OFIDA) is responsible for collecting export duties and taxes on behalf of DGRAD. OFIDA and other collection bodies, such as the Direction Générale des Impôts, legally retain a certain percentage (5 per cent in the case of OFIDA) for operating expenses and transfer the rest to the Treasury. The Forest Code, like the Mining Code, stipulates that a percentage of certain taxes shall be transferred to the DAEs. In the case of the Forest Area Code, the 40 per cent allocation to DAEs is divided into two, with 25 per cent being paid to the provinces and 15 per cent to the territoires. Despite assurances from the Central Bank (which manages the Treasury) that the transfers will be put in effect, the local populations and most of the territorial administrative authorities are unaware that the DAEs are supposed to receive 40 per cent of the forest area fee (Avocats Verts, 2006).

The Constitution, promulgated in February 2006, applied the transfer rules described in the forest and mining codes to other national tax revenue. Article 175 stipulates that 40 per cent of national tax revenue shall be allocated to the provinces and 50 per cent to the central government. The remaining 10 per cent is to be paid into an equalization fund to compensate for the economic differences among provinces. According to the new Constitution, 40 per cent of these 'other' taxes will be withheld at source, in the provinces. This shift in the direction of transfers is of critical importance: the provinces will withhold their share of revenue from natural resources at source and transfer only the remaining 60 per cent to the Public Treasury. This is a welcome innovation for the provinces that have seen the income from their natural resources consumed by Kinshasa. The provinces will no longer have to transfer national taxes to the Treasury and then wait for a payment order from the Minister of Finance to receive their due share.

The question of at-source revenue withholdings versus revenue transfers for forestry and mining was sharply debated in the National Assembly when the 2007 budget was being voted on, and should be listed among the issues requiring urgent agreement among the new national and provincial institutions. The central government has asked the Minister of the Budget to postpone the implementation of the at-source revenue withholding while thinking about how to introduce it in the future. Three reasons can be given for this:

1 As yet, there is no decentralization law ${ }^{4}$ to govern this arrangement.

2 The central government still has to defray costs for the provinces, ${ }^{5}$ especially the wages of government employees and health costs, down to the local level.

3 Only scanty contributions (less than 1 per cent in some cases) are made by certain provinces to the state budget. 
The DRC is composed of 11 provinces. Only three make substantial contributions to the central budget: 38 per cent for Kinshasa city and province, 33 per cent for BasCongo and 19 per cent for Katanga. This disparity can be explained by the DRC fiscal system:
A substantial part of fiscal revenue comes from merchandise in transit and exploitation rights, which explains why it is collected at obligatory passage points (e.g. the port of Matadi and the Kasumbalesa border post in Katanga). Kinshasa, as the national capital, can tax natural resources (oil from Bas-Congo, diamonds from the two Kasaïs, and wood from Equateur Province, etc.)... Without some corrective measure, the 40 per cent rule will mean that over 80 per cent of the resources allocated to the provinces will be paid to only three entities, with the other provinces having to share the remaining 20 per cent, some receiving less than 1 per cent. (Liégois, 2008)

The 10 per cent withheld for the equalization fund is far too little to make up for these large inequalities. Ultimately, the system for revenue generation and distribution will have to be revised to make it more coherent and fair towards provinces that feel cheated by the present system. In the meantime, provinces set up to benefit from these transfers are constantly pressuring the central government to speed up the implementation process.

\section{Transfer of the forest area fee and at-source withholdings}

There are two types of revenue that revert to the provinces and the territories: revenue from the forest area fee provided for in Articles 121 and 122 of the Forest Code, and all the royalties or taxes (including mining) collected by the provinces and the other DAEs through application of Article 175 of the Constitution. The Forest Code speaks of transfers and gives details on the method to be used, while the Constitution adopts the 'withhold at source' principle for all other national revenue. Considering the hierarchy of legal texts, the forest area fee, which is a form of national revenue, should be paid according to the same mechanisms and under the same conditions as those adopted for all other national revenue allocated to the provinces - namely, via the Constitution's 'withhold at source' principle. It is important to note the following:

- Although the breakdown of amounts due to the Public Treasury and the DAEs as of 2003 has been worked out by DGRAD, no forest area fees have yet to be transferred to the DAEs.

- The new Constitution spells out the share of the national revenue to be transferred to the provinces but says nothing about the share that the provinces are to pay to DAEs out of provincial revenue.

- The detailed and computerized expenditure chain is not yet operational in the provinces, and has an even longer way to go in the territoires. 


\section{RECOMMENDATIONS}

Based on an analysis of the structural features of public finance management under the new DRC Constitution, a number of simple, realistic recommendations can be made for improving the administration of the FAF in terms of fee collection, transfer and allocation.

\section{Collection of the forest area fee}

Clearly define the conditions for fiscal revenue allocation between the central government, the provinces and the decentralized administrative entities. The Constitution sets the respective share of proceeds for the central government and the provinces. It is also important to enforce the constitutionally sanctioned breakdown of fiscal revenue among the different levels of government. Enforement decrees have yet to be prepared.

\section{Transfer of the forest area fee}

Apply the same mechanism for governing FAFs and other national revenue. Without contravening the decentralization law and the principle of equalization, it should be agreed that the 40 per cent of the FAF should be handled in a similar way to the 40 per cent of national revenue allocated to DAEs - namely, by applying the "withhold at source' principle. The 'withhold at source' principle needs to be further reconciled with the principle of a single state account.

Work out equitable revenue allocation rates between the provinces and the other DAEs to be applied nationally. Relations between the provinces and the territoires are characterized by serious injustice due to power imbalances and the lack of law enforcement. Allocation rates between the provinces and the territories should be agreed upon and means for the effective transfer of amounts due to the territories defined. The best mechanism would be to apply the same 'withhold at source' principle as is stipulated for provincial-level withholdings.

\section{Allocation of the forest area fee}

Strengthen the budgetary and financial management capacity of provincial and local institutions. An efficient 'withhold at source' system will considerably increase the revenue of at least some of the provinces and local entities. If the budget and financial management of provincial and local institutions is not improved, risks of misuse and waste will continue to be enormous, especially the risk of excessive increases in wages, fees and other benefits, to the detriment of collective interests. Training should be provided and rules and procedures established for financial management and for the awarding of public contracts in order to enhance transparency and minimize corruption and favouritism. Systems of checks and balances and performance monitoring should also be established.

Create mechanisms for information access and public participation. The best way to ensure the public's effective participation in defining socio-economic programmes for provincial and local levels is to facilitate their access to information on revenue flows, 
economic planning and local investment monitoring. This is where the active involvement of civil society organizations is needed most, not only to train and inform village populations of the stakes and challenges connected to the use of public funds by their representatives, but also to teach them to demand explanations and justifications.

Support institutional strengthening at provincial and local levels. It is important to create meaningful interfaces between provincial and local-level institutions in order to provide feedback on local needs and concerns about economic and social plans, and to assist in the monitoring of provincial and local public contracts and investment projects.

\section{CONGLUSIONS}

This chapter seeks to assess progress in implementing the decentralization and redistribution of forest revenue, a very important instrument in poverty alleviation in the rural forest areas, and to propose guidelines to improve the way in which it is operationalized, ensuring that the intended benefits reach local populations. At present, five years after adopting the principle of forest area fee transfers, many questions are still being asked about the practical implementation of this decision. Even before its application, the 2006 constitution sanctioned the recommendation of Forest Code legislators to increase the share of national forest-related revenue that is to be allocated to the provinces from 15 to 40 per cent. The terms and conditions laid down in the constitution for transferring the 40 per cent to decentralized administrative entities were also innovative: the principle of annual retrocession through a payment order from the Minister of Finance is replaced by a "withhold at source' policy.

A major challenge is for the central authorities and the provinces to reach an agreement on the 'withhold at source' option. Another major challenge relates to the capacity of the provincial entities to manage funds withheld and transferred, and to implement a revenue allocation system that secures the interests of the local populations in investment programmes and public contracts. There is a burning need for institutional support and technical capacity-building. The reforms in decentralization and public finances currently under way should also address the question of the share that the provinces are to pay to the territories and should describe the payment transfer method in full. The central government institutions need to establish means of guaranteeing that the provinces keep their promises to local entities.

The Democratic Republic of Congo is not the only country where the fiscal decentralization of natural resources has created problems and triggered strong political debates between central government and local governments. In Bolivia, all of 2008 was marked by an acute political crisis focused on the reallocation of revenue from natural resources, pitting resource-rich provinces against the central government - which has its own redistribution goals and constraints. Decentralization and especially fiscal decentralization in countries where natural resources are not 
evenly distributed and where income and corporate taxes are very low always creates major challenges for equality. Compensatory mechanisms are needed; but operationalizing them often stokes strong political opposition from local governments in resource-rich areas. In the DRC the problem is made worse by a system that collects fiscal revenue at the national exit point or in the capital city, rather than in the provinces where resources originate. In the case of forest revenue, the rules do not seem to favour the main forest areas. Finding an equitable, politically acceptable solution will prove to be a challenge, and will require a good dose of hard work, public participation and political will for it to be achieved.

\section{NOTES}

1 Many of these 'special taxes' contribute to supporting administrative services or public companies whose services to the forest sector are either non-existent or grossly overpriced (Karsenty et al, 2003).

2 Free-on-board refers to the market price of timber sold at national points of export.

3 The rate of this fee has been established in interministerial orders 005/CAB/MIN/ENV/2005 and 107/CAB/MIN/FINANCES/2005 of 25 July 2005 at 0.20 French francs per hectare for 2005, 0.30 French francs per hectare for 2006 and US $\$ 0.50$ per hectare for 2007.

4 An organic law on decentralization that explains the composition, organization and functioning of decentralized territorial entities and their relations with the state and the provinces.

5 According to Article 171, the finances of the central authority and the provincial authority are kept separate. Article 204 lists issues that fall exclusively within the powers of the provinces (e.g. the provincial debt, loans internal to the provinces and the purchase of goods to meet the needs of the province).

\section{REFERENCES}

DECNT (Direction de l'Environnement, de la Conservation de la Nature et du Tourisme) (1984) Rapport du Premier Symposium National sur les Forêts, CCIC, Kinshasa

Devers, D. and J. P.Van de Weghe (eds) (2006) Les Forêts du Bassin du Congo: État des Forêts 2006, Partenariat des Forêts pour le Bassin du Congo, COMIFAC/EC/USAid/Coopération Française, Kinshsa

DGF (2004) Rapports Annuels D’activités Exercices 2004, DGF, Kinshasa

DGF (2005) Rapports Annuels D'activités Exercices 2005, DGF, Kinshasa

DGF (2006) Rapports Annuels D'activités Exercices 2006, DGF, Kinshasa

DGF (2007) Rapports Annuels D’activités Exercices 2007, DGF, Kinshasa

Djire, A. (2003) Rapport Final de L'Étude sur le Secteur Informel du Bois d'œuvre en RDC, Rapport d'Appui à la Revue Économique du Secteur Forestier, World Bank and Ministère de 
l'Environnement, des Affaires Foncières et du Tourisme and Ministère des Finances, Kinshasa

Karsenty, A., E. Pousse, J. M. Roda, E. Chezeaux, A. Djire, K. Erdlenbruch, B. Molele, S. Liotet, N. Yambayamba Shuku and F. Amsini (2003) Revue économique du secteur forestier, Ministère de l'Environnement, des Affaires Foncières et du Tourisme and Ministère des Finances, Kinshasa

Liégeois, M. (2008) La Décentralisation en RD Congo - Enjeux et Défis, Groupe de Recherche et d'Information sur la Paix et la Sécurité (GRIP), Brussels

Mpoyi, M. A. (2006) Analyse de l'impact de la réforme forestière sur la pauvreté et le social (AIPS/Forêts): La redevance de superficie en matière forestière, Perception, rétrocession aux EAD et affectation des sommes rétrocédées: États des lieux, Avocats Verts/Réseau REPEC, Kinshasa

RDC (2006) Document de stratégie de réduction de la pauvreté, Adopté par le gouvernement de la RDC en juin 2006, Kinshasa.

Roda, J. M. and K. Erdlenbruch (2003) Analyse des Conditions de Reprise Économique du Secteur Forestier en République Démocratique du Congo, Rapport d'Appui à la Revue Économique du Secteur Forestier, World Bank and Ministère de l'Environnement de la RDC, Kinshasa 
Chapter 9

\title{
Governance of Decentralized Forest Revenue in Central Africa: For Better or for Worse?
}

\author{
Patrice Bigombé Logo
}

\section{INTRODUCTION}

Decentralized management of forest resources has become the benchmark for sustainable development doctrines and practices. Since centralized forestry policies have proven ineffective in enhancing the well-being of local populations, a new model based on the transfer of certain powers to local government (collectivités territoriales décentralisées) and local communities - has gradually become the norm, with provisions for the allocation of a percentage of forestry and wildlife revenue to the local level. This is included in new forestry policies and legislation throughout Central Africa (Compagnon and Constantin, 2000).

A reform of this nature should lead to more rational use of forest resources and the attendant revenue. At the outset, these measures were viewed as a simple administrative/technical reform to make public services more efficient; but it is increasingly recognized that the implications of these reforms are more far reaching. This has led, among other things, to new ways of thinking about the configuration and exercise of authority within complex societies, and even to questioning the nature of the state - in other words, to questions about the political processes that buttress an evolution of this type when also rooted in the historical, social and cultural contexts of the societies concerned. It calls for an analysis of "the manner in which authority is exercised in the management of economic and social resources in a developing country' (Campbell, 2001, p119) or, more globally, the manner in which the central state and local government structures carry out their responsibilities in managing revenue generated from the exploitation of natural resources.

The Congo Basin, the second largest forest in the world, is located in Central Africa - where forests cover close to 204 million hectares and are home to 45 per cent of the world's biodiversity. Forests have an undeniable importance for the livelihoods of resident populations, for government and for the international community 
(Boukongou, 2005). Close to 30 million people belonging to over 150 ethnic groups currently live in the region and have occupied these forests for a very long time. Vestiges of human occupation can be traced back to several hundreds of thousands of years in several parts of these forest areas. ${ }^{1}$ Forests have important social and cultural functions for all these populations, especially the pygmies, whose survival depends largely upon forest resources (Oyono, 2006). Forest exploitation generates income for the central government, and is therefore expected to have additional poverty alleviation functions.

In most countries with a timber industry, the forest sector is the second most important for the economy, second only to oil, agriculture or mining (Karsenty, 2002; Perez, 2005). During the last few decades, ever larger areas of forest have been opened to logging. For the region as a whole, the figure was 49,400,000ha in 2004 , and accounted for 36 per cent of the total area designated as production forests and 27 per cent of the total area of dense humid forests. In Equatorial Guinea, Gabon, Central African Republic (CAR) and the Republic of Congo (Congo-Brazzaville), between 77 and 93 per cent of forestlands have been allocated (COMIFAC, 2007). In the Democratic Republic of Congo (DRC), permits cover only 18 per cent of areas designated as production forests because many logging permits were cancelled in 2003. Production figures rose with the end of the war, reaching 8.5 million cubic metres for the region as a whole in 2004. Gabon is at the top of the list, followed by Cameroon and Congo-Brazzaville.

Besides economy-wide taxes, the forest sector is also liable for special forestry taxes. Logging operations are charged a forest area fee (FAF) that differs from country to country. The fee is applied to the entire concession area, even portions that are not exploited during the fiscal year, as well as to areas considered 'non-productive'. There is also a volume tax (or felling tax) that is usually based on the value of the species. Export taxes are also leveraged as an incentive for local value-added processing. Log exports are usually taxed heavily, while exports of processed timber may be tax exempt, as in Gabon.

Sector reforms of the forest taxation system were adopted during the 1990s in Cameroon, CAR, Congo-Brazzaville, Gabon and the DRC. A decentralized forest taxation system was established and aimed, among other things, to ensure sustainable management of forest resources and to increase the sector's contribution to poverty alleviation (Nguiffo et al, 2007). The idea was to make up for the injustices that forest populations had suffered for so many years when they did not benefit from forest revenue.

The decentralized forest taxation system involves payment of a percentage of the revenue derived from timber and wildlife exploitation to local government and local communities. This system has been given pride of place in forest governance in Central Africa, and is a major innovation in forest management (Odd-Helge Fjelstad, 2001; Lund, 2007).

Six countries (Burundi, Cameroon, CAR, Congo-Brazzaville, Gabon and the DRC) have introduced local retrocession mechanisms for forest revenue. Based on experiences in Cameroon and Gabon, countries which appear to be most advanced in putting these reforms into practice, this study poses a number of questions. How will states ensure the effective implementation of the reforms? What governance logic 
presides over the utilization of revenue derived from fiscal decentralization for development schemes in the concerned regions? Beyond technical and ethical dimensions, how do local communities assimilate these reforms?

The answers to these questions are given in two sections. The first gives a general overview of the norms employed in configuring state reforms in Central Africa. The other provides an analysis of the direction of governance of decentralized revenue and stakes associated with the use of these mechanisms in supporting local development.

\section{THE CONFIGURATION OF SYSTEMS FOR TRANSFERRING REVENUE FROM TIMBER AND WILDLIFE OPERATIONS TO LOCAL GOVERNMENT AND COMMUNITIES}

The structure of fiscal decentralization systems in Central Africa is not uniform. These systems may be characterized by a diversity of mechanisms that are by nature dynamic. The mechanisms for implementing fiscal decentralization vary from one country to another, as do their basic dynamics. Two types of mechanisms may be identified:

1 the 'parafiscal' type; and

2 systems for sharing forest revenue between the central government, local government and local communities.

\section{Emergence and consolidation of the parafiscal system}

The parafiscal system covers all taxes that are not included as a legislative requirement, but, instead are established through ministerial regulations and paid regularly by logging companies. This system is applied in Cameroon, CongoBrazzaville and, to a certain extent, Gabon.

In Cameroon, parafiscal taxes primarily consist of contributions by logging companies to the construction of infrastructure defined in their cahier des charges (formal agreement with specifications on services or products to be delivered) and payment of 1000 CFA francs per cubic metre of timber for small forest concessions (ventes de coupe), in accordance with Circular No 370/LC/MINEF/CAB of the Ministry of Environment and Forests, dated 22 February 1996. This obligatory contribution, now suspended, was written into the cahier des charges with the aim of benefiting neighbouring communities.

Ventes de coupe are logging permits for areas outside the 'permanent forest domain'. They are valid for three years and cannot be used on areas over $2500 \mathrm{ha} .^{2}$ These permits are awarded through an order of the Minister of Forests following a public call for tender and following the advice of an inter-ministerial commission. Introduced at the end of the 1996/1997 fiscal year, this 1000 CFA francs contribution - referred to locally as a 'tax' - generated considerable revenue during the 1997/1998 and 1998/1999 fiscal years. It is still operational, since ventes de coupe logging permits are still being awarded. ${ }^{3}$ 
The tax thus appears to be a formal contribution by logging companies to local infrastructure as laid out in formal agreements (the cahiers de charge).

In Congo-Brazzaville, the parafiscal system is being implemented through development funds established by logging companies. The system emerged through a voluntary initiative of a concession holder, the Congolaise Industrielle du Bois (CIB), within a broader set of social measures put into place to obtain Forest Stewardship Council (FSC) certification within CIB concessions. It consists of the establishment of a local development fund to 'contribute to local development and poverty alleviation'. The management plan of the forest management units states that:

... this fund, shared by FMUs [forest management units], will receive 200 CFA francs per cubic meter of commercial timber felled within these units. This fund is to finance projects for the general welfare of the local population... It will be administered by a voluntary management committee composed of representatives of the forest administration, the Prefecture, the local government, the CIB, local NGOs and local populations. A tripartite agreement will be prepared to spell out modalities for fund management, selection and eligibility criteria for projects to be funded, the roles of each member of the management committee, etc. These development funds will complement public funds derived from forest area taxes paid by logging companies, part of which are to be utilized to finance local development. (CIB, 2005)

The development fund of the Kabo Forest Management Unit (FMU), FSC certified in May 2006, is operational. The inaugural session of the advisory board, which is in charge of management, was held on 25 September 2007 in Pokola, and the second ordinary session on 27 December 2007. Two of the six micro-projects submitted by villages bordering the FMU were approved.

The most interesting parafiscal system is the one being developed in Gabon. In the beginning, Gabonese forest laws did not include a parafiscal system for the benefit of local communities. However, Article 251 of Law 16/01 of 31 December, 2001 establishing the Forest Code provides for the transfer of forestry fees to local communities. In 2000, before the law was adopted and pending the application decree, the logging company Compagnie Equatoriale des Bois (CEB), of its own accord, drew up an innovative tripartite agreement covering 15 villages with their 4919 inhabitants in the Sébé-Brikolo and Léconi-Lékori regions. This agreement provides for the payment of 1000 CFA francs per cubic metre of timber exported by CEB. The money is distributed on the basis of finages (village territories), managed by village associations and is to be used for the construction of schools, community centres, houses for families and teachers, local ceremonies and to purchase diesel local generators.

The sector's different stakeholders have not reached an agreement on whether to institutionalize this parafiscal system. Industry feels that this is 'one tax too many'. The state has adopted a laissez-faire attitude or does its best to reap maximum benefits. Local communities fight to gain control over the mechanism seen to be best suited for accessing benefits from forest resource exploitation. The dominance of administrative authorities in the process indicates that unless preventive measures are taken, the state may seize opportunities offered by this parafiscal system that were originally intended 
for local development schemes. At the end of the day, this may be yet another means to reproduce the predatory logic that has predominated in the local management of fiscal decentralization.

\section{Systems for sharing taxes and forestry fees between the central state, local governments and local communities}

In Cameroon, fiscal decentralization, introduced through the 1994 Forestry Law, is linked to the annual FAF. It has since been taken up in various finance laws and applies to all felling permits awarded through calls for tender (concessions and ventes de coupe) according to the area covered by the permits. ${ }^{4}$

Forest concessions are subject to the provisions of the 1994 law and its implementing decree 95/531/PM of 23 August 1995, other more recent texts and the finance laws in force at the time. The 1994 law states: 'considering the development of village communities bordering certain national forests under exploitation, part of the revenue from the sale of forest products shall be paid to these communities... Contributions from social welfare funds shall be paid in totality to the concerned communities, and shall not be allocated elsewhere' (unofficial translation). ${ }^{5}$

Annual forestry fees (AFFs) are calculated on the basis of the financial offer chosen during the call for tender. These fees are divided between the central state (50 per cent), local government (40 per cent) and neighbouring communities (10 per cent). Sums obtained that are due to local communities are paid to the authorized local tax officer. ${ }^{6}$ If the area being logged covers more than one village, the share due to each village is prorated based on the land area covered by the permit. ${ }^{7}$ Forest concessions pay three annual instalments, starting from the first year of the provisional agreement. Funds due to villages are incorporated into village budgets. Funds are managed by forest fee management committees composed of mayors (or representatives with the rank of local advisor), local tax officers (treasurers), district forest officers (rapporteurs), an auditor appointed by neighbouring communities and six community representatives.

The same system is used for transferring revenue from wildlife activities. A 1999 ministerial decree stipulates that taxes paid from hunting activities within hunting zones (zones d'intérêt cynégétique or ZICs) shall be reallocated according to the same distribution scheme as the AFF. If community-managed hunting zones (zones d'intérêt cynégétique à gestion communautaire, or ZICGC) are leased to hunting guides, direct compensation is to be paid to communities that own the area, together with a 10 per cent leasing tax.

In the Central African Republic, felling and reforestation taxes are worth mention. The felling tax amounts to 7 per cent of the value of the timber being felled. It is divided as follows: the state (40 per cent, destined for the Public Treasury), the Forestry Fund (30 per cent) and local communities (30 per cent). The reforestation tax (11 per cent of the value) is divided between the state (50 per cent for the Public Treasury and 25 per cent for the Forestry Fund) and the concerned villages (25 per cent). A presidential order dated 16 May 2007 forbids direct payment of forest taxes to community authorities and obliges the beneficiary village to open a bank account where funds are deposited. The utilization of the funds is conditional on the 
development of an annual communal programme of activities. The mayor and the payment officer (receveur-payeur), or another specifically appointed officer, are jointly responsible for any financial misappropriations. ${ }^{8}$

In Congo-Brazzaville, the concerned fees include forest area taxes and tourism revenue. The forest area tax is to be used for development activities in the regions, as explained in Article 91 of the 2000 Forest Code. Its terms and conditions are defined in the 2002 decree establishing the method for allocating the 50 per cent of the forest area tax set aside for regional development. Article 91 of the law stipulates that 'the forestry tax is to be paid once a year by the licence holder to the Ministry of Water and Forests. This tax is in turn allocated as follows: 50 per cent to the forestry fund and 50 per cent to a special account held by the National Treasury and earmarked for regional development.' Articles 2 and 3 of the decree indicate that 'the 50 per cent of the forest area tax earmarked for development at the level of the départements and deposited in a special account at the Treasury shall be distributed in an equal manner to all the départements' and that 'if a specific national or local programme is developed, the intended distribution may be subject to special measures by the Council of Ministers'. The Treasury officer shall allocate the funds, and these funds are to be booked in the budgets of the various départements as state subsidies for development activities. No percentages have been earmarked for direct transfer to local or indigenous communities.

Although the funds are deposited in the National Treasury, their actual transfer to the départements remains a problem. Even when the funds are earmarked for regional development activities, there is no way of distinguishing funds generated by forestry operations from other state funds. A 2006 World Bank study reports that implementation of this policy 'is non-existent because since 2000, no mechanism has been put into place to transfer funds from the Ministry of Economics, Finance and Budget to local government. ${ }^{9}$ It is also important to note that this transfer does not ensure redistribution to local and semi-nomadic populations, and that there is risk that the majority of funds will be captured by urban areas. In short, transfers to local communities should be based on the principle of equity - or, in other words, people in the most underprivileged zones (landlocked, resource-poor) should benefit just as much as those living in areas of more intense economic activity and with more consistent forest revenue' (World Bank, 2006, p80).

The perception and management of revenue from tourism is also unclear. However, interesting models are being tested in pilot projects operating near certain protected areas, such as the Lésio Louna and the Southwest Léfini reserves. Between 2003 and 2005, tourism in these two reserves generated a total of 6.3 million CFA francs. For the Nouabale-Ndoki National Park, revenue generated for the neighbouring population, most notably for Bomassa, was estimated at 1.9 million CFA francs for this same period, and 1.86 million francs for the year prior. ${ }^{10}$ Funds from tourism earmarked for local communities were utilized for infrastructure in Bomassa: construction of a school, a healthcare centre and a community centre. These facilities are open to both the Bantu population and the Bangombé pygmies.

In the DRC, the 2002 Forest Code stipulates that 40 per cent of the FAF should be allocated to decentralized administrative units in the logging area proper, 25 per cent to the province and 15 per cent to rural communities (Diaw and Milo, 2006). This regulation has not yet been applied. 
The push to institutionalize fiscal decentralization must be seen in the context of forestry reforms of the 1990s (Diaw et al, 2006). The governance trajectories that made these reforms possible cause one to reflect on the linkage between the powers delegated to local communities for forest revenue management and the quest for well-being.

\section{THE GOVERNANGE LOGIC OF DEGENTRALIZED FOREST REVENUE}

While the establishment of systems for transferring revenue from timber and wildlife exploitation to decentralized local governments and communities is taking time, support for the approach in Central Africa is more or less widespread. The implementation of institutionalized mechanisms and management practices can serve as a reference for a qualitative evaluation of experiences at the vanguard of democratic forest governance, based on profitability and governance criteria. These include availability of transferred revenue; relevance and effectiveness of management institutions; liability and accountability; and the significance of socio-economic outcomes and impacts.

\section{Availability of transferred revenue}

Does the revenue really reach its destination? The answer is 'yes' for two countries: Cameroon and Gabon. The other countries are still creating formal mechanisms for managing decentralized revenue. In Gabon, the pioneer experience of CEB (Massoukou, 2007; Nguimbi et al, 2007) functions well due to its simple procedures. In each of the villages, management committees have been replaced by an association responsible for managing the revenue after transfer. Territorial redistribution based on finages (village territories) was preferred to prorated figures based on the number of inhabitants, as envisaged in the original agreement (la convention). The funds generated from this system and distributed to finages are administered by village associations. By 15 August 2007, a total of 779,479,247 CFA francs were available and distributed among 12 neighbouring villages.

In Cameroon, payments due to the local government (commune) and to local communities are being effectively transferred. Payments were initiated at the end of the 1996/1997 fiscal year and increased the following year. In the absence of a formal framework for managing this revenue, especially that earmarked for neighbouring villages, the local administration (divisional officers, or prefets and sub-prefets) and the logging companies developed their own method for the payment and redistribution of funds. This system works on the basis of direct payments in cash and kind to neighbouring villages, or partial payment in cash to the local councils (communes) and in-kind contributions to local communities. The money earmarked for neighbouring villages was once turned over in a solemn manner to the village chief or the chairman of the management committee by local authorities at meetings attended by the village, the logging company, local authorities, village elders and local development partners. 
The joint MINEFI-MINAT order of 29 April 1998 changed this method. Community funds are now managed by a management committee chaired by the local mayor. Between 2000 and the end of 2006, 40.5 million CFA francs ${ }^{11}$ were transferred to the local governments and local communities.

In addition to funds from the timber industry, local communities also receive revenue from hunting zones used for safaris. The regulations governing these activities are already being applied in the south-eastern and northern parts of Cameroon (Noupa, 2003). Well before this ministerial decision, the Mambélé agreement of 8 June 1999 had already defined a system for dividing revenue from wildlife between the state, local governments and neighbouring villages. The sums generated are significant, although lower than the revenue from timber. Revenue generated from community-managed hunting zones (ZICGCs) in eastern Cameroon was evaluated at 42,815,094 CFA francs for the 2000 to 2004 period.

\section{Effectiveness of local forestry revenue management institutions}

To date, impacts of fiscal decentralization on local development have been marginal. In Cameroon, for instance, slightly under 20 per cent of the forest revenue earmarked for local governments and neighbouring villages is actually invested in local development (Milol and Pierre, 2000). The effectiveness of local management institutions remains a major concern.

Decentralized government authorities - namely, junior divisional officers (souspréfets) and district heads - are responsible for creating forestry fee management committees. Placed under their tutorage, these committees are responsible for adopting work programmes and plans and related budgets, allocating resources to projects on the basis of priorities and available funding, and monitoring and controlling the implementation of projects financed by revenue earmarked for local communities. The committee meets at least once every three months and invites resource persons and representatives of technical services based on their specialized knowledge. The committee cannot deliberate unless at least half of the members are present, and decisions are taken by a simple majority. The committee is therefore supposed to be run like a joint assembly with equal representation, as a platform for information sharing and body for collective decision-making. In reality, however, these management committees are taken over by mayors, counsellors and the municipal collection officers who influence and control most of their activities.

In the CEB case in Gabon, responsibilities for managing development funds were at the outset to be given to a management committee composed of representatives of the Ministry of Water and Forests, the Ministry of the Interior, the local council, CEB and neighbouring villages (one person from each village). This committee also had administrative, financial and accounting responsibilities; in other words, it was to analyse and select projects submitted by villages, agree on budgets, authorize payments, and monitor and control project implementation. Project eligibility was based on the following criteria: the project's alignment to the needs and priorities of the beneficiary population; the relation between project cost and availability of funds earmarked for the village; and the likelihood of eventual job creation. A tripartite agreement was drawn up and included in the cahier des charges (Article 7) signed on 
3 March 2000 by the Minister of Forests, giving it the weight of law. Parties to the agreement include the Forest Department (responsible for ensuring application of the law and verifying the payment of fees pledged by CEB), CEB, concerned villages and other local groups represented by an elected association accountable to village chiefs, the association itself and the canton.

Despite a number of information and awareness-building sessions, local residents felt that the management committee was too complex and thus rejected it. The CEB suggested that the money be paid on the basis of 'village zones', with the officers of each village association to be responsible for managing the funds. The draft agreement was modified on the basis of this proposal and the management committees were replaced by village associations (Ondo, 2000; Massoukou, 2007). In the main, the revised institutional arrangements for managing forest revenue have favoured elected local officials and more literate inhabitants, particularly retired civil servants, jobless diploma holders and a handful of local notables. They are often made hastily, without proper perspective and without widespread participation to ensure the downward accountability of newly created committees. As a result, these committees are not well accepted at the local level and have not established any social legitimacy. Instead, they have helped to consolidate the emergence of a 'forestry elite' and, in most cases, marginalize traditional authorities. These mechanisms raise the question of legitimate democratic representation in the decentralized management of forest revenue, and privilege mechanisms of self-selection and cooptation in place of free and fair elections. Self-selection is being promoted by village chiefs, notables and elites, who are forcing their way into forest revenue management institutions. Cooptation is rife in the selection of committee members. Mayors, who serve as presidents of management committees, coopt dependents, people indebted to them, relatives and clients to these committees to ensure their allegiance (Oyono and Efoua, 2006), undermining the accountability of these committees. Committees, as established, are mainly accountable to the administrative authorities and the political elite at the central level, rather than to local communities. At the local level, those with responsibility and authority over forest revenue management report neither to local communities nor to the state on how they exercise their authority. Present-day processes of accountability and decision-making related to local forest revenue management are weak and often non-existent (Nguiffo and Djeukam, 2002).

The same problems exist for wildlife fees and community-managed hunting zones. When creating these zones, too little attention was given to the complexity of local social structures and dynamics, and the considerable time needed for certain social groups - such as the Baka 'pygmies' - to understand, accept and be integrated into the process of creating norms and procedures for managing forest areas and biodiversity. Women, Baka 'pygmies' and the so-called 'temporary' immigrants are not adequately represented in wildlife resource development committees (COVAREFs) (Njounan Tegomo, 2003; Madingou, 2004; Sayer, 2004), although they carry out important activities in the local forest areas. The seeming indifference they exhibit towards community-managed hunting zones may be seen as a form of protest and rejection of the socio-ethnic representation mechanisms established by technical officers and village leaders (Madingou, 2004). 
Governance problems have not, however, totally impeded tangible socioeconomic achievements in certain regions. Local management of forest revenue has brought about certain socio-economic outcomes that would not have existed in the absence of these reforms. For example, the CEB experience has contributed to improved living conditions in beneficiary villages and to improvements in social infrastructure and services. These include construction of a school in Otoundou, a dispensary in Ondzeye and meeting houses in Otoundou and Ossélé; purchase of chainsaws, satellite dishes, subscriptions to Canal+France and uniforms for football teams; and repairs to power units. Other benefits included sanitation, assistance in the event of death, cemetery rehabilitation and interest-free loans for certain community members. Houses are being built and renovated either by contractors or by the villagers themselves, organized into teams of contracted labourers (Massoukou, 2007). Most of the achievements in communities receiving forest revenue involve social infrastructure, and the acquisition and management of communal forests - a tendency confirmed by a recent study on the management of annual forestry fees in eastern Cameroon (Mbetoumou et al, 2006).

Funds from wildlife management in Cameroon seem to be less well invested. Bureaucracy plays a significant role in the allocation and management of COVAREF funds. Figure 9.1 shows that over 50 per cent of COVAREF funds are used for the building and running of offices, with the balance used for local infrastructure.

Despite these tangible achievements, outcomes related to societal transformation and local development remain weak in many villages. Strategies used by some individuals to monopolize benefits and governance problems have led to poor revenue management. In Cameroon, only 20 per cent of the funds earmarked for communes and local communities are actually invested in local development (Milol and Pierre, 2000). Old and new 'big men' use these funds to consolidate and build up their personal fortunes (Laurent, 2000), while poor local planning accounts for the other losses. Local managers seem to be reproducing the predatory state model characterized by frequent misappropriations (Karsenty, 1999). The current model for local revenue management in Cameroon is fostering a predatory clientelist alliance between the central state, local governments (collectivités territoriales) and forestry fee management committees, and between the authorities and local political elites. Financial resources derived from forestry fees, intended for local use, are being appropriated by private sources (Nguiffo, 2001) through the assimilation of village accounts (10 per cent of AFFs) into local government accounts, overbilling, undue withholdings, imaginary taxes and simple embezzlement.

Feelings of frustration, discouragement and helplessness characterize Cameroonian forest regions that are the intended beneficiaries of fiscal decentralization policies. The possibility of financing local development out of forest resources must be seen in relative terms. At present, the economic, cultural, social and material losses to local people engendered by industrial logging operations are not justified by the scale of collective benefits. Numerous pygmy families, for instance, located in regions that are supposed to receive local forest revenue, are living in misery and destitution. In Gabon, there are short- and long-term problems of redistribution and fair access to benefits within and between villages. The management model based on village territories (finage) is proving to be a factor that 


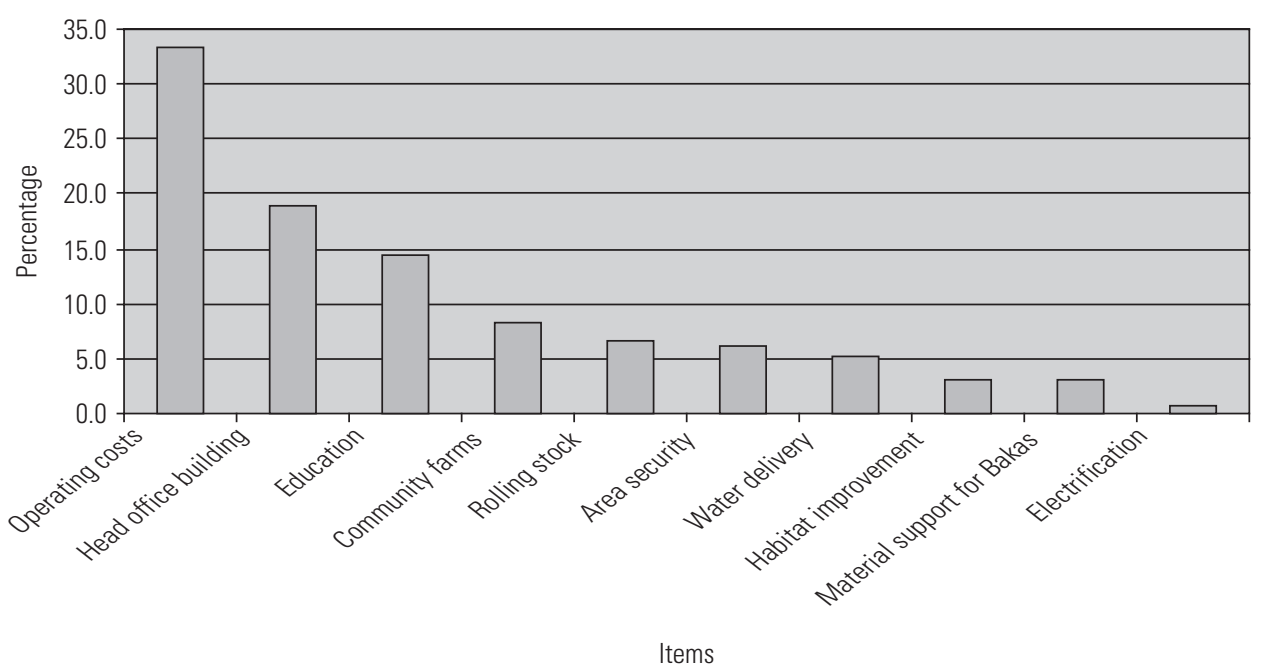

Source: Bigombe and Nguetti (2006), p13

Figure 9.1 Distribution of wildlife resource development committee (COVAREF) funds in eastern Cameroon

restricts the choice of development projects. Villages where finages are not being adequately exploited cannot undertake major construction works. Disparities in the size of logged areas lead to differences in the allocation of funds and the ability to make social investments. In all villages studied by Massoukou (2007), house construction was an unanimous priority due to its importance to local identity. Houses were allocated not on an individual basis, but based on the number of families living in the village and family size. The usual practice is to give one house to each family; but a decision was then taken by the association to give a second house to large families. Massoukou (2007, p33) noted that:

... the distribution [of houses] within villages was not always fair. As the Secretary General of the Otoundou Association stated: 'The distribution was not equal because some families felt they were disadvantaged. This led to rumours in the village. For things to be fair, each family has to have at least two houses, regardless of the number of household members. We needed 40 houses, not 30.' Since forests are communal property, villagers felt that everyone should have the same rights to profit from forestry operations and therefore, if the decision was to build two houses per family, all families regardless of size - should benefit.

Favouritism, clientelism and lack of transparency in benefits-sharing are compromising the equitable management of investments. Dissatisfaction and frustration trigger conflicts within communities. These conflicts, in turn, highlight the 
problem of insufficient representation of the various village groups on committees, and also, for certain groups, the desire to have a free hand in management decisions: 'As long as I have been living here, I did not know that the village of Mbomo-Nkomo existed, but as soon as the subject of money from the forests came up, Mbomo-Nkomo appeared... Nearly all committee members are from the same family and the financial disputes that arise among members divides the family.' Lack of transparency in financial management by the associations' officers and delays in house construction are often perceived as the result of misappropriation.

\section{CONCLUSIONS}

Fiscal decentralization of forestry revenue to local communities is gradually being implemented in Central Africa. The process has taken on different trajectories and modalities as a function of the political and social realities of each context. Not all countries have made the same choice concerning payment transfer mechanisms, although there are some similarities in practices, results and constraints. The process of using public funds for private matters and interests compromises the logic of local forestry revenue management and the downstream 'needs of the state' (effectiveness, legitimacy and security). These elements are felt both in the relationship between the centre and the periphery, and in the way in which benefits from the reforms are received at the local level. The pace of implementation is slow and the results are unsatisfactory. The problem is not that the principles are poorly adapted or that the managers are intrinsically unproductive. Rather, the politics which accompany reforms are more complex and imperceptible than anticipated.

Furthermore, reforms are being carried out in a context of multifaceted, difficult and sometimes chaotic transitions from state monopolies of natural resource management towards the involvement and gradual shift of responsibility to local communities and civil societies. The fast pace of change is taking place alongside a rather cumbersome inertia of public actors. Changes in the modes of management and governance are far from radical. It will take time to change mindsets and move away from the exclusive and clientelist management regime that has characterized the forest sector in Central Africa in years past, to one oriented towards local development and the participation of empowered village communities. This is due to the fact that the expected changes do not fall solely under the domain of forest management and local stakes (Pierre, 2006). Rather, they are part of complex relations and politics between the local, national and international levels whose dimensions grow smaller as decentralization reforms are strengthened and advanced. The types of exchanges, transactions and social relations that are being forged and reflected in the management of decentralized forestry revenue raise a fundamental issue regarding the social relations connected to natural resources, and the authoritarianism of Central African states. The power relations that link the centres of power to the local level with regard to forest management trigger strategic behaviour that jeopardizes the ability of reforms to produce positive outcomes. 
Reforms should be adapted to the social context of Central Africa, especially to the complex political relations and powerful networks that connect local societies to the political decision-making centres in times of decentralization (Karsenty, 1999). The role of 'democratic decentralization' (Manor, 1999) in accompanying these reforms is critical. We already know, as Dele Olowu (2001, p1) has stressed, that:

... decentralisation has to cope with two major political problems. The first stems from the fact that the political and administrative leaders are not ready to share the monopoly of power they inherited from the colonial period... The second political dilemma is the confiscation of power by local elites. In many cases, the local elite, rather than the most vulnerable groups, capture decentralized powers... In the absence of more ambitious institutional, political and economic reforms, democratic decentralization will be a contradiction because improvements in financial allocation can only take place if the local government is accountable to its citizens and has the capacity to carry out its functions.

Taking advantage of the potentials and opportunities presented by the decentralization process that is taking hold in Central Africa (Sawadogo, 2001), which promises to ensure the development of local public spaces, generate new approaches for managing collective goods and invent new forms of citizenship, may pave the way for positive transformations in the management of local affairs and, thus, local forestry revenue. This could occur by revising institutional mechanisms for fiscal decentralization to anchor management institutions in the sociological realities of local societies and to ensure that the revenues earmarked for local communities indeed reach the intended beneficiaries. This would occur through a divided management system in which local government institutions manage the local government share and villages manage their share (Mbarga, 2005). Legitimate democratic representation should be mainstreamed within financial management institutions to guarantee the accountability of managers to the state and local communities and to enable the sanctioning of dishonest managers (Oyono and Efoua, 2006; Ribot, 2007). Making this happen requires the widespread application of the rule of law. This must start with major reforms in citizenship, which itself requires a redefinition of the rights and responsibilities of citizens in their political relations among themselves, and in their relations with the central state and decentralized government bodies.

\section{NOTES}

1 Hewn stone tools, at least 480,000 years' old, have been found near the Lopé National Park in Gabon (Oslisly, 1994).

2 Article 55(1) of the Law of 20 January 1994 on Forestry, Wildlife and Fisheries.

3 The last vente de coupe was supposed to be awarded in 2002 so that this logging system would no longer exist following 2004. But from September to October 2003, another public call 
for tender for the allocation of vente de coupes was launched. To this date, the decision to dissolve the system has not yet been fully implemented.

4 Forest concessions are given provisional permits during the first three years, during which the forestry fee is based exclusively on the floor price set out in the finance law in force at the time (Nguiffo, 2001). If the concession holder meets the sustainable management criteria and requirements, he receives a permanent 15-year permit that can be renewed once. The fee, at that time, is calculated on the basis of the floor price plus the financial offer, as reported by the permit holder.

5 Article 68(1) and 68(2) of Law No 94/01 of 20 January 1994 on Forestry, Wildlife and Fisheries.

6 Law of 20 January 1994, Article 68, para 1; Decree No 98/009 of 23 January 1998, Article 10, para 3 , establishing the dutiable base and collection modalities for royalties and taxes on forestry activities.

7 Finance Law, fiscal 1999-2000, Article 11.

8 A presidential order of 16 May 2007 on the use of forestry taxes allocated to villages in the Central African Republic, Bangui.

9 The local councils at departmental level and the districts have authority over local development issues, including forests.

10 Discussion with Marc Gately, director of the WCS/PNNN project, Bomassa, 10 June 2006.

11 Figures obtained from data compiled by the Programme de Sécurisation des Recettes Forestières du Cameroun in December 2007.

\section{REFERENCES}

Assembe, S. (2006) 'Decentralized forest resources and access of minorities to environmental justice: An analysis of the case of Baka in Southern Cameroon', International Journal of Environmental Studies, vol 1, pp1-9

Bigombe Logo, P. (2000) (ed) La décentralisation de la gestion forestière au Cameroun: Situation actuelle et perspectives, FTPP-CERAD, Yaoundé

Bigombe Logo, P. (2003) The Decentralized Forestry Taxation System in Cameroon: Local Management and State Logic, Environmental Governance in Africa Working Paper no 10, World Resources Institute, Washington, DC

Bigombé Logo, P. (2004a) Le retournement de l'État forestier: L'endroit et l'envers des processus de gestion forestière au Cameroun, Presses de l'UCAC, Yaoundé

Bigombé Logo, P. (2004b) 'La fiscalité forestière décentralisée dans la réforme Camerounaise', Revue Africaine de Sciences Sociales et d'Études Culturelles, vol 1-2, pp203-233

Bigombe Logo, P. and J. Nguetti (2006) 'Les zones d'intérêt cynégétique à gestion communautaire au sud est Cameroun', Rapport GEPAC, Yaoundé, CERAD, 18pp

Boukongou, J. D. (2005) 'La protection du bassin du Congo: Un enjeu multilatéral', Géopolitique Africaine, vol 17, pp141-154

Campbell, B. (2001) 'La gouvernance: Une notion éminemment politique', in Haut Conseil de la Coopération Internationale (ed) Les non-dits de la bonne gouvernance: Pour un débat politique sur la pauvreté et la gouvernance, Karthala, Paris, pp119-148

CIB (2005) Kabo Forest Management, CIB, Pokola 
COMIFAC and Ministère de l'Environnement de la RDC (2007) Rapport de l'atelier régional sur la contribution des redevances forestières au développement socio-économique des populations $d u$ Bassin du Congo, Kinshasa

Compagnon, D. and F. Constantin (2000) (ed) Administrer l'environnement en Afrique: Gestion communautaire, conservation et développement durable, Karthala-IFRA, Paris

Diaw, C. D. and A. Milol (2006) Analyse des moyens techniques et légaux de mise en cuvre d'accords incitatifs et de gestion durable en République du Congo, CIFOR, Kinshasa.

Diaw, M. C., P. R. Oyono and F. Sangkwa (2006) 'Les réformes forestières et les nouvelles frontières de la gestion locale au Cameroun', in R. Nasi, J. C. Nguinguiri and D. E. de Blas (eds) Exploitation et gestion durable des forêts en Afrique centrale: La quête de la durabilité, L'Harmattan, Paris, pp317-367

Karsenty, A. (1999) 'Vers la fin de l'Etat forestier? Appropriation des espaces et partage de la rente forestière au Cameroun', Politique Africaine, vol 75, pp147-161

Karsenty, A. (2002) 'Le rôle controversé de la fiscalité forestière dans la gestion des forêts tropicales: L'état du débat et les perspectives en Afrique centrale', Cahiers d'Economie et Sociologie Rurales, vol 64, pp6-36

Kombi Etame, M. N. (2006) 'Les Pygmées Baka et la gestion des espaces forestiers au sud-est Cameroun: Cas des ZIC et des concessions forestières', in S. C. Abéga and P. Bigombe Logo (eds) La Marginalisation des Pygmées d'Afrique Centrale, Maisonneuve et Larose and Afrédit, Paris

Koulbout, D. and B. Tchikangwa Nkanje (2001) 'La gestion et l'exploitation de la faune dans les zones d'intérêt cynégétique à gestion communautaire au Sud-Est', Paper presented at the Workshop on Community Wildlife Management, Garoua, Cameroon, 13-15 March 2001

Laurent, P. J. (2000) 'Le big man local ou la gestion d'un coup d'Etat de l'espace public', Politique Africaine, vol 80, pp169-181

Lescuyer, G. (2007) 'Les impacts sociaux de la fiscalité forestière décentralisée dans le Bassin du Congo', Paper presented at a workshop of RFC-WWF, Yaoundé, Cameroon, 27 October 2007

Lund, J. F. (2007) 'Is small beautiful? Village level taxation of natural resources in Tanzania', Public Administration and Development, vol 15, pp1-12

Madingou, E. (2004) 'Les Pygmées Baka et la gestion décentralisée des ressources fauniques au Sud-Est-Cameroun', Paper presented at the 5th meeting of CEFDHAC, Yaoundé, Cameroon, 24-26 May 2004

Manor, J. (1999) The Political Economy of Democratic Decentralization, World Bank, Washington, DC

Mbetoumou, M. et al (2006) 'Elites et redevances forestières à Djolenpoum (Est Cameroun)', Contribution à une meilleure gouvernance des ressources naturelles en Afrique centrale', Rapport GEPAC, Yaoundé, IRSA-CERAD, 30pp

Massoukou, L. (2007) La rétrocession d'une partie des revenus de l'exploitation forestière aux populations locales gabonaises: Efficacité, équités et pérennité, MSc thesis, ENGREF, Montpellier

Mbarga, N. H. (2005) 'Etude empirique de la fiscalité forestière décentralisée au Cameroun: Un levier de développement local?', Paper completed as part of the requirements for a Masters of Science in Agronomy and Agro-Food Science, Ecole Nationale du Génie Rural des Eaux et des Forêts (ENGREF), Montpellier

Mbetoumou, M., P. Bigombe Logo, S. C. Abéga and V. Daou Joiris (2006) Elites et redevances forestières à Djolempoum (Est-Cameroun): Contribution à une meilleure gouvernance des ressources naturelles en Afrique centrale, Report from the Participatory Management Programme in Central Africa, IRSA-CERAD, Yaoundé, Cameroon

Médard, J. F. (1990) 'L'Etat patrimonialisé', Politique Africaine, vol 39, pp25-36

Milol, A. and J. M. Pierre (2000) Impact de la fiscalité forestière décentralisée sur le développement local, DFID, Yaoundé 
Nguiffo, S. A. (2001) 'La chèvre broute où elle est attachée: Propos sur la gestion néopatrimoniale du secteur forestier au Cameroun', in S. Lapuyade (ed) The Forest Taken Hostage: The Need to Control Transnational Corporations - a European Study, Forests Monitor, Cambridge, pp14-15

Nguiffo, S. A. and R. Djeukam (2002) Le droit pour ou contre la foresterie communautaire? Analyse de contraintes juridiques à la mise en cuvre de la foresterie communautaire au Cameroun, SNV-WWFCED, Yaoundé, Senegal

Nguiffo, S. A., T. Fomete, D. Abouem a Tchoyi and P. Bigombe Logo (2007) Aperçu de la législation forestière en Afrique centrale, World Bank Report, First International Conference of Members of Parliament on the Sustainable Management of Ecosystems of Dense and Humid forests in Central Africa, 24-27 October 2007, Yaoundé, Cameroon

Nguimbi, L. and C. Nzang Oyono (2007) La prise en compte des aspirations des populations locales dans l'exploitation du bois: Cas de la Compagnie Équatoriale de Bois (Gabon), Report to the 6th CEFDHAC meeting, 20-22 November 2007, Libreville, Gabon

Nguimbi, L., P. A. Roulet and R. C. Oyono (2007) La question sociale dans les exploitations industrielles du bois: Cas de la CEB (Gabon), GEPAC, Libreville: GEPAC

Njounan Tegomo, O. (2003) Les Pygmées Baka et la gestion participative des aires protégées au Sud-Est-Cameroun: Une étude des zones d'intérêt cynégétique à gestion communautaire à la périphérie du parc de Lobeke, MSc thesis, University of Yaoundé, Cameroon

Noupa, P. (2003) Impact de l'exploitation forestière sur les sites transfrontaliers prioritaires pour la conservation de la biodiversité: Cas de la tri nationale de la Sangha, IUCN, Yokadouma

Odd-Helge, F. (2001) 'La décentralisation fiscale en Tanzanie: Pour le meilleur ou pour le pire?', Afrique Contemporaine, numéro special, 3ème trimester, pp128-141

Olowu, D. (2001) 'Structures et processus politiques et institutions locaux', Communication présentée à la Conférence sur la Décentralisation et la Gouvernance Locale en Afrique, Cape Town, 26-30 March 2001

Ondo, R. and CEB (2000) Activités de terrain pour la mise en place de la convention tripartite, CEB, Lastourville

Oslisly (1994) 'The Middle Ogooue Valley: Cultural changes and palaeoclimatic implications for the last millennia', Azania, vol 29, pp324-331

Oyono, P. R. (2006) 'Acteurs locaux, représentation et "politics" des éco-pouvoirs dans le Cameroun rural post-1994', Canadian Journal of Development Studies, vol XXVII, no 2, pp63-185

Oyono, P. R. and S. Efoua (2006) 'Qui représente qui? Choix organisationnels, identités sociales et formation d'une élite forestière au Cameroun', Afrique et Développement, vol XXXI, no 2, pp147-182

Perez, M. (2005) 'Logging in the Congo Basin: A multi-country characterization of timber companies', Forest Ecology and Management, vol 214, pp221-236

Pierre, J. M. (2006) 'Le risque social de l'aménagement durable des forêts en Afrique centrale', in A. Bertrand, P. Montagne and A. Karsenty (eds) Forêts Tropicales et Mondialisation: Les Mutations des Politiques Forestières en Afrique et à Madagascar, Cirad and L'Harmattan, Paris, pp95-104

Poissonnet, T. M. (2005) Mise en cuvre de la gestion forestière décentralisée au Cameroun: Impacts politiques, socio-économique et environnementaux d'un processus en apprentissage, BSc thesis, Engref, Montpellier 
Ribot, J. C. (2007) Dans l'attente de la démocratie: La politique des choix dans la décentralisation de la gestion des ressources naturelles, WRI, Washington, DC

Sawadogo, A. R. (2001) L'Etat africain face à la décentralisation: La chaussure sur la tête, Karthala, Paris

Sayer, J. (2004) 'Hunting for conservation? The experience of village hunting zones in southeast Cameroon', Carpo-Focus, vol 1, pp13-14

Smouts, M. C. (2006) 'Les politiques forestières rattrapées par la mondialisation: Contraintes et opportunités', in A. Bertrand, P. Montagne and A. Karsenty (eds) Forêts Tropicales et Mondialisation: Les Mutations des Politiques Forestières en Afrique et à Madagascar, Cirad and L'Harmattan, Paris, pp35-52

Usongo, L. and B. Tchikangwa Nkanje (2001) Natural Resources Management as Tool for Poverty Alleviation: The Case of Lobeke, Yokadouma, WWF, Gland, Switzerland

World Bank (2006) Revue du secteur forestier au Congo: Les aspects économiques des forêts de production, World Bank, Washington, DC 


\section{Local Government and Forest Resource Governance in Mali: Taxation and Decentralized Management of Forest Resources in Siby Rural Commune}

Bréhima Kassibo

\section{INTRODUCTION}

The 1990s saw a tidal wave of liberal democracy and decentralization across the world. Africa was no exception. These reforms envisaged a shift towards democratic decentralization, or the transfer of power and resources to local democratically elected representatives who are, in turn, accountable to their constituents (Crook and Manor, 1998; Agrawal and Ribot, 1999). But these reforms, carried out in response to economic, political, administrative and social imperatives, were not always successful. A number of African countries - pressured by donors to undertake such reforms continue to resist the transfer of the powers and resources required to enable local stakeholders to manage their affairs and natural resources (Manor, 1999; Kassibo, 2004; Ribot, 2004, 2007). The tendency is to take back with one hand the advantages they have been obliged to grant with the other.

The Malian government, with strong encouragement from foreign donors including the World Bank, undertook a thorough overhaul of legislation on forest resource management. The aim was to delegate powers and resources for forest management to decentralized elected authorities or local communities, given the purported efficiency associated with bringing decision-making closer to the forest and forest users (Rochette, 1988; ARD, 1989; CILSS, 1989). This made villages responsible for commercial exploitation of village forests by creating nearly 300 rural fuelwood markets around the country. The experiment, termed participatory decentralized forest resource management, was conducted without the involvement of communes ${ }^{1}$ - which were not taken into consideration by promoters of the Domestic Energy Strategy (Stratégie Energie Domestique, or SED). Contrary to the law's provisions, the experiment 
has actually excluded local communities from receiving forestry revenues. It has also caused the decentralized authorities considerable loss of income by reducing their share of tax revenues, and undermined their legitimacy in the management of the resource.

This chapter shows that the experiment amounts to a simple privatization of resource management and a de-concentration of tax collection. Based on a study of rural wood markets in the rural commune of Siby, we analyse four aspects:

1 the political, economic and social background to the reform;

2 the legal and institutional framework in which donors' strategies and government policies are played out;

3 the behaviour and interactions of stakeholders in the context of the reform, and the issues it has raised; and

4 consequences of the reform's failure for democratic governance, civil society and local development.

\section{BACKGROUND: DECENTRALIZATION IN MALI}

The seeds of decentralization were planted in the political reforms of March 1991, when a multiparty democracy was established. Initiated by the Decentralization Mission in 1993, it reached fruition in 1996 with the creation of elected local government entities: 703 communes, 58 circles and 8 regions falling under federal district of Bamako. The executive bodies associated with these decentralized entities were not set up until 1999. The event most eagerly awaited by leaders of the new decentralized authorities was the transfer of jurisdiction and financial resources for forest management. So far, the Malian government has made no such transfer. This severely constrains the decentralization process, particularly decentralized environmental management. The decentralized authorities had not yet been established when the first fuelwood markets were created; they are still not involved in managing them, and receive only a minor share of tax revenue derived from them. Our analysis shows that this is due to the political interference of key decision-makers, who sought to recover for themselves the advantages that had been earlier conceded by the forest legislation reforms.

\section{SIBY RURAL COMMUNE}

Siby rural commune was created in 1996, and the commune council is now in its second term. As in other rural communes in Mali, local political life is strongly marked by the struggle between political parties. Traditional authorities have a strong influence on the selection of candidates and their election to the council and its executive committee. The commune lies some $50 \mathrm{~km}$ west of Bamako, in the Kati cercle - which is part of the Koulikoro administrative region. The majority of the population are Malinke, but 
there are several minority ethnic groups. The commune includes 21 villages, 4 of which have populations over 1000. Siby town itself has a population of 5094, one quarter of the commune's overall population of 20,287.

\section{The commune's forests}

There are two large forests within the commune: Wanda Forest, which is classified as a World Heritage Site, and Keniébaoulé Forest, part of which falls within the Néguéla Commune. The forests consist of ligneous and herbaceous woodland and shrub savanna formations. Gallery forests occupy many of the riparian zones.

\section{Forest exploitation dynamics}

Commercial wood harvesting in Mali's forests - which began with logging concessions and a coupe system ${ }^{2}$ installed under French colonial rule, and has evolved more recently to include rural wood markets - has increased the market value of timber and fuelwood and changed the way in which local people use and perceive the forest. At least 80 per cent of the commune's villages have a thriving business in wood and bamboo. The forests have been intensively harvested for decades.

Malian forests are classified according to various levels of control. ${ }^{3}$ Forests with two levels of control exist in Siby Commune: uncontrolled and guided. Uncontrolled forests are areas that are neither demarcated nor managed, yet where harvesting requires a user's permit from the Nature Conservation Service. With the creation of rural wood markets, some forest areas were also demarcated and classified as 'guided' harvesting areas. Starting in 1997, the Fuelwood Unit (Cellule Combustible Ligneux, or CCL), an executive body established under the Domestic Energy Strategy, established rural fuelwood markets in seven villages in the commune to supply Bamako with charcoal. Of the seven markets created, only two were still operational at the time of our study. Three were selected as study sites: Kaka and Konkani (the two functioning markets) and Dogoro (no longer functioning).

\section{DONOR STRATEGIES AND GOVERNMENT POLICY}

Prior to the political reforms of 1991, the legal and regulatory framework was characterized by a central government monopoly on natural resource management. The highly repressive Forest Code of 1986 excluded rural communities from all commercial exploitation of forests; to harvest wood, an official wood-cutting permit had to be purchased. This policy failed and led to severe damage to forest resources, amidst a generalized indifference by rural communities.

\section{An exogenous reform}

After Moussa Traoré's fall from power in 1991, Mali’s development partners took advantage of the new political climate to guide forest policy. Niger's experiment in 
decentralized resource management based on rural fuelwood markets was considered a success, prompting donors to duplicate this approach in Mali (Noppen et al, 2004). For the World Bank, it was a matter of integrating the private sector into forest exploitation through community management. The World Bank pressured the Malian government to undertake reforms to involve rural communities more closely in forest resource exploitation through community-based commercial wood harvesting. 'Fiscal decentralization', under which forest taxes were to be collected and redistributed at the local level, was presented by the World Bank as an indispensable instrument for the new policy. Official forest managers at the time, unwilling to let go of their privileges, resisted the reforms.

\section{Unsuitable legal and institutional framework}

The reform process, initiated in 1991, was completed with the adoption of the 1995 laws on decentralization and the launching of the Domestic Energy Strategy (SED) in 1997 - which sought to stimulate rural wood markets. Although the political climate was favourable and decentralization was being gradually implemented, the attempted reform was vigorously resisted by the Ministry of Environment, the Directorate of the National Forestry Service, officials of the Domestic Energy Strategy and private merchants. The reform was seen as a threat to past privileges and interests. For the merchants, it meant an end to free access to village forestlands, which were now to be controlled by the rural fuelwood markets. For forestry officials, it meant losing their monopoly on technical matters associated with forest management (demarcation, forest inventories) and an end to their policing role (long characterized by repression and abuses against local people). Moving the SED's management bodies to the Ministry of Energy and Mines and making the project financially autonomous created a jurisdictional conflict for the administration of forest resources. For SED officials mainly foresters - the idea of giving rural communities a share in tax revenue was synonymous with moral corruption (see below).

\section{The donors' philosophy}

Of the donors funding the SED, the largest contributor was the Dutch overseas development agency FMO, along with the World Bank and several other bilateral and multilateral organizations. These donors recommended a project approach, considering the village as the most appropriate social entity for achieving mass participation. This was in line with a 'participatory' ideology in which villages are considered the legitimate managers of natural resources and favoured over democratically elected local authorities. This reflects donor mistrust of elected commune officials, given their reluctance to support government responsibilities for environmental management both at commune and national levels. The envisioned result was a collective privatization of forest resources for the benefit of local communities. It is this that explains the failure to integrate decentralized forest management within the broader devolution of environmental management responsibilities to local authorities. 


\section{IMPLEMENTATION OF THE REFORM: THE DOMESTIC ENERGY STRATEGY}

According to its promoters, the SED philosophy is based on the following principles: ensuring sustainable development by conserving standing timber assets for future generations; transforming rural communities into guardians of the resource; and to integrate fuelwood taxation into public law. It marks a notable change in the way in which the state perceives rural populations, with recognition of their merits and reestablishment of their forest management rights. The strategy is based on four main instruments:

1 master plans for territorial development planning and forest exploitation;

2 establishment of rural wood markets by private operators responsible for establishing forest management systems;

3 environmental monitoring; and

4 a new regulatory and fiscal system.

The structures of the SED, overlapping between two government ministries, include the Strategy Management Unit (UPS) at the apex, and two second-level structures: the Domestic Energy Unit (CED), responsible for applying the strategy with regard to fuelwood demand, and the Fuelwood Unit (CCL), responsible for applying the strategy with regard to fuelwood supply. The CCL defines and implements fuelwood supply master plans for Mali's major cities. This is the unit responsible for environmental monitoring and for supervising and monitoring rural fuelwood markets.

\section{RURAL FUELWOOD MARKETS}

The rural management structures (structures rurales de gestion, or SRG) are organizations of rural wood producers registered with the authorities to supply rural fuelwood markets. A rural fuelwood market is a place designated for the sale of fuelwood; it is created by an authorized fuelwood management structure. These markets are designed to improve rural living conditions by providing a regular, substantial income. They have three purposes: to provide urban populations with regular, sustainable fuelwood supplies; to ensure sustainable technical and commercial management of forests by SRG members; and to strengthen the SRGs' ability to negotiate with merchants.

The rural markets' decision bodies include:

- The general assembly, which is the primary decision-making body. It should meet annually and ad hoc general meetings can also be called on an as-needed basis. 
- The executive committee, which has responsibility for governing rural markets. It consists of a number of officers, whose executive functions include control, representation, SRG accounts and financial control, wood harvesting oversight, and integrating women and livestock herders into the process. In practice, they have taken over these markets, relegating the general assembly to a subsidiary role.

In principle, the executive committee should only execute decisions taken by the general assembly, to which it is theoretically subordinate. This system was outlined by the SED, but has not withstood the pressures exerted by political realities on the ground. In the first place, annual general meetings rarely take place and this body's existence remains theoretical. The executive committee is elected for one year; but these term limits have never been applied and, in practice, committee membership is permanent. The executive committee is a visible presence in day-to-day activities, and its chairman serves as liaison with outside actors: the SED, CCL, private operators, commune authorities, forestry officials, technical officers and visitors. This has accentuated its apparent legitimacy and representativeness in the eyes of outsiders. Although the village council (the chief and councillors) have relatives and allies on the executive committee, they are unable to control it completely. This monopoly is detrimental to the village council's position vis-à-vis the village assembly.

In Siby, the introduction of rural fuelwood markets met a real demand by the local community to play a part in commercial wood harvesting. While this is justified in principle, the way in which it has been applied is questionable. In our view, the approach taken centres on a technical rather than sociological logic. The project has privileged a group of individuals, the SRG, over the village community as a whole. As a result, the SRG lacks legitimacy and is not representative, tending to defend its own interests (those of the woodcutters), rather than those of the community. Prior to colonization, village forests were for the community's use, and all members of the community had free access to them. Members of the SRG's executive committee are far from representative of the majority of the population; but the SRG has emerged as the real manager of forests, which other villagers regard as common property. After the markets were established, villagers, notables and chiefs - who once considered woodcutting low-grade work - realized the financial stakes involved. They sought to control the activity by placing close relatives on the committee and by claiming ownership rights to the forest in the name of 'the community' but otherwise acting in their own interests.

\section{STAKEHOLDER DYNAMICS: THE STRATEGIC GROUPS}

Law No 95-003 of January 1995, which instituted the new wood harvesting and management structures, changed the status of the resource and engendered significant changes in systems and practices of popular representation. The rural markets are a key element in this policy and have major implications because they involve a multitude of competing stakeholders who are all users of the resource, 
whether or not they possess legal or legitimate powers. In this respect, the markets are a political arena. However, the stakeholders do not form static homogeneous groups. Strategic groups form and dissolve according to circumstances. These groups are the state, represented by the Nature Conservation Service (Service de la Conservation de la Nature, or SCN), the CCL (representing the Domestic Energy Strategy), the commune council, traditional authorities, rural management structures (village assembly and SRGs), private merchants, non-resident charcoal burners, and youth groups.

\section{Groups opposing the reform}

\section{The merchant-SCN-CCL lobby at work}

Stronger powers for rural communities with regard to village forests put an end to the privileges of some members of this group, such as merchants and forestry officials (see above). Villagers no longer had to suffer harassment over forest use and began to grasp the meaning of their new powers in forest management. The lobby's first action was tenacious opposition to the new forest reform, including attempts to prevent Laws 95-003 and 95-004 from being passed. Thanks to donor intervention, the lobby was unable to prevent the passing of the 1995 laws.

\section{Exclusion of SRGs from forest tax redistribution and marginalization of the commune}

In decree No 95-422/P-RM, which set the rates and distribution of forest exploitation taxes, Article 6, Chapter III, included rural management structures (SRGs) in the distribution of tax revenues. They were to receive 40 per cent of the revenues from guided forests and 60 per cent of the revenues from controlled forests. The communes were also to receive a share: 50 per cent in uncontrolled areas, 40 per cent in guided areas and 30 per cent in controlled areas (see Table 10.1).

When decree No 95-422/P-RM was issued, the merchant-SCN-CCL lobby set out to make it inoperable and to deprive the SRG of their legal rights to a share of tax revenue. During an awareness campaign conducted in preparation for the establishment of rural markets, local communities were informed of the allocation of a share of tax revenue to SRGs; however, this provision then disappeared from later documents. Before decentralized authorities were properly operational and before the

Table 10.1 Decree No 95-422/P-RM Setting Tax Rates on Wood Harvesting and Distribution of Revenues

\begin{tabular}{lccc}
\hline Exploitation & Uncontrolled & Guided & Controlled \\
\hline Rural management & - & $40 \%$ & $60 \%$ \\
structures (SRG) & & & \\
Rural commune & $50 \%$ & $40 \%$ & $30 \%$ \\
Central government & $50 \%$ & $20 \%$ & $10 \%$ \\
\hline
\end{tabular}

Source: République du Mali, Sécrétariat Général du Gouvernement (1995) 
decreed SRG rights could be put into practice, another decree, No 98-402/P-RM of 17 December 1998 repealed the earlier decree and definitively excluded SRGs from any share of tax revenue. The communes' share was also greatly reduced: from 50 to 0 per cent in uncontrolled areas, 40 to 5 per cent in guided areas and 30 to 10 per cent in controlled areas. Central government bodies now received the lion's share, including 100 per cent of taxes from uncontrolled areas (see Table 10.2). Wood harvesting taxes for state forests are now distributed according to the guidelines in Table 10.2. ${ }^{4}$

By repealing the first decree and replacing it with a more restrictive one, representatives of the Malian state in effect took back with one hand what they had theoretically given with the other. The CCL deprived SRGs of a major source of income. Astonishingly, although the CCL had set up the rural markets in 1996 to 1997 when decree No 95-422/P-RM was still in force, that decree was never applied. A further disturbing fact is that the financial component of the rural market experiment in Niger (from which the donors had drawn much of their inspiration for creating the markets in Mali) was intentionally excluded from the SED. In Niger, the local management structures receive 50 per cent of forest tax revenue for controlled markets and 30 per cent for guided markets (Noppen et al, 2004).

The CCL explains its about-face with unconvincing arguments and justifies the exclusion of rural communities from a share of tax revenues by arguing that it is a form of moral corruption: 'Too many environmental programmes tend to buy the ecological conscience of rural populations by offering them subsidies or infrastructures in exchange for management of the resources - an unsustainable procedure and a fool's bargain once the money is spent' (SED, 1998). They argue, rather, that the aim is to give these populations rights and responsibilities in two respects: taking charge of village lands and receiving a larger share of proceeds from the fuelwood trade.

In this way the state, through its services and agencies, took back its control over forests through a new division of tax revenues heavily in its favour. Through the forest management fund, a large share of forestry profits was appropriated and became subject to the discretionary powers of the Nature Conservation Service (SCN) and the Ministry of Environment. It is clear that CCL officials responsible for establishing and

Table 10.2 Decree No 98-402/P-RM of 17 December 1998 Setting the Distribution of Revenues from Taxes on Wood Harvesting ${ }^{5}$

\begin{tabular}{lccc}
\hline Allocation & \multicolumn{3}{c}{ Percentage by forest status } \\
\cline { 2 - 4 } & Uncontrolled & Guided & Controlled \\
\hline Central government budget & $60 \%$ & $35 \%$ & $15 \%$ \\
Forest maintenance and & & & \\
management works & - & $30 \%$ & $45 \%$ \\
Forest supervision & $-5 \%$ & $5 \%$ & $10 \%$ \\
Rural communes & - & $5 \%$ & $10 \%$ \\
Regional chambers of agriculture & $5 \%$ & $10 \%$ & $10 \%$ \\
Forestry officers & & $5 \%$ & $10 \%$ \\
\hline
\end{tabular}

Source: République du Mali, Sécrétariat Général du Gouvernement (1998) 
supervising rural fuelwood markets actively colluded in excluding the SRGs from receiving a share of the tax revenue. This is not surprising since most of these officials were foresters who had been negatively affected by the decree. In whose interest was it to obstruct the process? The lobby opposing the reform finally achieved its aims; but these actions were to affect the viability of the project and change the behaviours of all concerned.

\section{CONSEQUENGES OF THE CHANGES TO THE REFORM}

\section{Conflict and alliances in rural markets}

The exclusion of SRGs and, hence, the rural markets from any share of forest tax revenues discredited members of the executive committee in the eyes of local residents. Their purely voluntary status has demotivated committee members, while the local population sees them as working for themselves and defending only their own interests. Executive committees have become increasingly unrepresentative of the local population because 'they do not care about the general interest'. Traditional authorities, who see the powers of SRG executive committees as undermining their own authority, have taken advantage of this loss of popular legitimacy and used the village assemblies to regain their position on the pretext of defending community interests. To compensate for the loss of their share of tax revenues, they imposed an informal tax on non-resident woodcutters in their areas, using the revenue for publicinterest uses such as repair of village pumps and salaries for teachers at village schools thus restoring their legitimacy in the eyes of the local population. SRG Executive Committee members, in turn, had to ally with these traditional authorities or lose their credibility.

Meanwhile, the central government created the Malian Agency for the Development of Household Energy and Rural Electrification (AMADER) to replace the defunct SED project. When AMADER set up co-operatives in place of SRGs, the traditional authorities took advantage of the elections of co-operative managers to place their henchmen in positions of responsibility. This gave them de facto control over rural fuelwood markets.

\section{Intergenerational conflicts}

Traditional authorities sometimes put their own interests before those of the community, and this can generate internal conflicts. One example of this was in the village of Saguélé, where the youth observed the village chief and council using the money derived from the tax on non-resident woodcutters for their own benefit. In protest, they set fire to all of their charcoal stocks and forced them out of the village. It took the combined effort of all commune authorities - the sub-prefect, the commune council and the Siby Village Council - to settle the dispute. 


\section{Identity-based claims}

Most of the non-resident woodcutters came from the Sikasso region and belonged to a different ethnic group than the Malinke. They worked as protégés to the merchants, but were sidelined when the rural market management system was being established. Ostracized by the villagers and accused of every ill, they had to pay informal taxes to the village for the wood they harvested (Mbodj, 2005).

In introducing the informal tax system with the help of the SRG leadership, the traditional authorities proclaimed to all outsiders, the commune and, indeed, the state, their authority over village lands and resources over which they claimed ownership (Gautier et al, 2006). Furthermore, the change in harvesting status of the village forest to guided harvesting and its allocation to the village through the rural markets enabled rural communities to transform priority harvesting rights to exclusive rights. They claimed ownership rights and excluded outsiders in the name of the principle of local citizenship, ${ }^{6}$ chasing them from the village.

\section{Institutional legality and custom-based legitimacy: Commune versus village}

Who, in principle, should manage the forests? In Mali, the lowest level of decentralization is the commune, consisting of a number of villages, districts and pastoralist fractions that are not legal entities in their own right. Village lands make up a commune's territory; but because land tenure has not been devolved, the commune council has no control over village lands and resources. The rural communes were therefore not involved in the creation of rural markets and were marginalized from the management of forests designated for guided harvesting. Forests designated for uncontrolled harvesting are managed unilaterally by forest officials, who continue to police the forests and issue wood-cutting permits. In principle, the Domestic Energy Strategy gave the commune powers to manage rural fuelwood markets and delegated certain prerogatives to it; but these have remained fictional and have never completely materialized. Having been excluded from a share of forest tax revenue without any valid justification, the SRGs turned to the prefecture to claim their rights. The prefecture, in turn, referred them to the commune, which was still receiving a share under the decree in force, albeit a very small one. The SRGs accused the communes of grabbing their share. Thus, the administration (the prefecture) used the commune as a scapegoat, undermining its credibility. The frustration engendered by these actions was one of the factors prompting traditional authorities to impose illegal taxes on the non-resident woodcutters and claim ownership rights to the forest.

The meagre revenues drawn from forest taxes and inefficiency in collecting municipal taxes give commune authorities little opportunity to carry out development work in the villages. Unable to meet community needs, they have suffered a loss of legitimacy. Similarly, the prevailing clientelism in the choice of commune managers and the tendency of political parties to tamper with election candidate lists - rob the parties of much of their legitimacy in the eyes of local people, most of whom are marginalized through these manoeuvres. In their eyes, only the traditional authorities are legitimate. 


\section{Conflicts of jurisdiction between nature conservation and SED officials}

Before the SED was developed, nature conservation officials had full control over forest resource exploitation, issuing wood-cutting permits, policing forests and enforcing regulations. With the new policy, the monopoly that the Nature Conservation Service (SCN) had long enjoyed over forest revenues was handed over to the SED. The donors delegated project management responsibilities to the ministry responsible for energy and water rather than the Ministry of Environment. This led to a muted rivalry between the two ministries, which seriously harmed the lobby opposing the reform. During the time that rural markets were being established, the CCL sidelined foresters from technical operations, such as inventorying resources and demarcating forest areas, over which they had previously held a monopoly. These tasks were allocated to purpose-made NGOs and consultancies. Forest authorities could no longer issue permits to forest users, who were now obliged to buy forest products from village markets. The SCN thus lost the absolute power that it had possessed over the administration of forest resources. Forest officials were relegated to a support role under project staff, who were better paid and had vast material and financial means at their disposal. Forestry officials felt frustrated and became indifferent to their advisory role and to forest supervision, which now fell to the rural markets. There was no longer anyone to oversee tree felling and replanting or to ensure proper rotation of plots in the forest areas allocated to SRGs. As one forestry official in Siby states:

We pay for the engine fuel. We have to pay for the vehicles and machines ourselves, and to maintain them. We have no operating budget at all. We get only 5 per cent of tax revenues from controlled and uncontrolled areas. Last November [2005], we received only 17,000 francs to divide among all foresters... We live from hand to mouth. In Bamako, they just tell us to get on with it.

Many of the forestry officials we met in SED project areas expressed similar sentiments. One forester in a classified forest ${ }^{7}$ in the Mandingo Mountains, in the neighbouring commune of Mandé, spoke in more radical terms:

Our work is a mission; but we must have the means to carry it out. We have to pay for our means of transport, including fuel and maintenance. We have to pay 10,000 francs for our uniforms. I still have my old beret that dates back to 1977, while the young graduates in training get new uniforms and enjoy better conditions than us experienced, faithful field workers. Phase 1 of the project has failed. Why not adopt new strategies?'

According to Nature Conservation Service officials, the work of supervising forests and overseeing rural markets, which is theoretically their job, has not been properly carried out for lack of the necessary material and logistical means. According to project evaluators, this is one of the main reasons for the failure of the SED (Kerkhof et al, 2002). 


\section{The laundering of fuelwood money}

The merchants' lobby took advantage of the disorganized state of rural markets to seal alliances with various other stakeholders. Its aim was to fraudulently bypass the regulations and re-establish control over fuelwood marketing. They forged alliances with other disenfranchised groups: the non-resident woodcutters, Nature Conservation Service officials and the managers of markets that were still functional (Kaka and Konkani). Sidelined from the process at the start, they took control of village markets with the complicity of the very people who had been their adversaries prior to the reforms.

The merchants obtain wood and charcoal more cheaply from non-resident woodcutters working for them in uncontrolled areas. They transport their spoils to the rural markets that are still functioning. The market managers supply them with valid vouchers for transport from the guided harvesting areas, which reduces the official rate of tax on the wood. They may also obtain transport vouchers from private individuals prepared to sell vouchers in their possession. Armed with these transport vouchers, they pass through forest checkpoints, where they enjoy some degree of complicity from forestry officials. If the records of the two abovementioned SRGs were to be checked, it would certainly be revealed that quotas had been abnormally overshot. However, the SED project never carried out any such check before it was closed down.

\section{The malfunctioning of rural markets: From guided to uncontrolled}

The withholding of the SRG share of forest revenue discouraged their leaders, who found themselves working for no gain while being unjustly accused by their fellow citizens of working for their own interests. For a number of reasons, most of the SRGs have ceased to function. The entire population cuts wood with no concern for forest plot rotations or for methods that encourage regeneration. Forest use is becoming anarchic, the quotas disregarded, with neither SRG brigades nor forestry officials supervising or monitoring. Village woodcutters sell their outputs to the merchants, who process them fraudulently through the Kaka and Konkani markets. Fraud is now widespread in the commune. Given the small number of forestry officials and the limited resources they have at their disposal for forest supervision, whole lorry loads slip though the net, heading for Bamako by circumventing checkpoints.

The failure of the rural markets was a severe blow to the credibility of the SED, which closed down when its funding was not renewed. Although a number of evaluations have revealed the shortcomings and errors of the SED, the donors and the Malian government have recently replaced it with a new structure: AMADER. AMADER has simply turned all the SRGs into co-operatives, without making any of the necessary adjustments to allow the commune to manage its forest assets properly or the village communities to benefit from a share of the revenues. 


\section{CONGLUSIONS AND RECOMMENDATIONS}

The 1995 laws demonstrated the Malian government's political will to devolve responsibilities and powers to local communities in forest resource management and in the sharing of forest revenue. Local populations, long deprived of their legitimate rights to forests, considered these laws and Decree 422 as a form of social justice that restored age-old ownership rights. Yet by failing to consider power dynamics between various stakeholders within the government, and between government and project managers, and by ignoring local social dynamics and land tenure at council and community levels, this law induced a savage resistance from actors whose former privileges were threatened. Since most of its opponents were powerful government agents, Decree 422 was quickly repealed and replaced by another that stripped local communities of their share of forest taxes.

Fairly well conceived in theory but ill applied, the Malian decentralization process has had a negative impact upon local governance and economic development within the commune, altered power relations between stakeholder groups and caused numerous local conflicts as well as resource degradation. The withdrawal of powers and benefits that this law had conceded to forest users and local people brought frustration among actors directly involved in forest management, de-motivated local management entities and exacerbated behaviours such as corruption, illegal logging, identity-based withdrawals and mismanagement of forest resources.

Given the high stakes involved in land and natural resource control, shifts in discretionary powers over natural resources can be highly charged. The transfer of forest estates to decentralized authorities must be accompanied by the exercise of grassroots democracy. Under current law, commune councils are supposed to involve rural communities in exploiting wood and other resources. Agreements between the two parties should lay down the responsibilities of each party (Article 22 of Law No 96-050). It is not the role of the decentralized authorities to exploit forest resources directly or to assume technical responsibilities for forest management; rather, they should become the nexus of policy-making and organization of activities taking place within their territory, as laid down in decentralization laws and decrees. Effective involvement of the communes in forest resource management could be a fitting way to make forest resource management democratic. However, even in the absence of 'push-back' from higher authorities, this may not be an easy goal to achieve. For example, the Malian experience of urban land division by the communes has been disastrous, giving rise to all kinds of abuses: land speculation, illicit enrichment of elected officials, corruption, abuse of power, etc. (Kassibo, 1998). These are simply the same ills that daily undermine state governance at all levels to Mali, illustrating the critical importance of the broader governance context to the effectiveness of forest decentralization. Could elected commune councillors be an exception to the rule if given discretionary powers over forest resource management, considering the high stakes involved? It seems doubtful, for corruption would bring great rewards and temptations would be strong. Only the future will tell, once the delayed transfer of 
powers over forest resources, long demanded by commune councils, takes place. However, a new revision of the legislation could help to re-establish equitable distribution of tax revenues among all stakeholders. This might help to lay the basis for the emergence of genuine local democracy.

\section{Lessons learned}

From this unsuccessful experience of decentralized forest management, one can derive several lessons. First, an exogenous reform imposed by funding agencies has little chance of succeeding if there is no buy-in by the main actors who can guarantee its success and in the absence of an appropriate legal and institutional environment recognized by all. Second, implementation can generate conflicts between opposing groups because of the high stakes, leading to bad governance and mismanagement of forest resources. A truly democratic decentralization must take into account the interests of all actors and ensure a fair distribution of benefits. The role of the state will be to reconcile the interests of various stakeholders in order to safeguard social peace, a prerequisite for the sustainable management of forest resources. The Government of Mali should launch adequate reforms in this respect in order to reinforce the decentralization process through the promotion of local democracy.

\section{Recommendations}

In order to establish sustainable participatory management of forest resources and to improve local governance, the Malian government should meet the following conditions:

- Involve local communities and decentralized authorities in a more equitable distribution of forest tax revenues to enable genuine endogenous development. In doing so, it would be best to take into account and improve upon the original advantages granted under Decree No 95-422/P-RM, which was later deliberately repealed.

- Create a framework for consultation and collaboration between rural communities and decentralized authorities in order to involve them more in decision-making and provide the foundations for genuine local governance.

- Promote the active participation of decentralized authorities in the management of forest resources within their territory through the decisive and effective transfer of power and allocation of the accompanying revenues, while also introducing a system for proper accounting of revenues received and their utilization.

\section{ACKNOWLEDGEMENTS}

This chapter is based on anthropological research on rural fuelwood markets in Siby Rural Commune. We are grateful to the French Agricultural Research Centre for International Development (CIRAD), who funded the research for three years 
(2004-2006) under a comparative research programme entitled Thematic Action Programme/Natural Resources and Populations (ATP/RN-POP) for the 'study of transfers of natural resource management from central to local government in West Africa: Niger, Mali, Senegal'. Over these three years, I spent several periods in the field to supervise my doctoral student Seydou Kéita, to whom I am grateful for the considerable additional information he provided me. I would also like to thank Jesse Ribot of the World Resources Institute (WRI), who initiated and supervised the Decentralization and Environment research programme and whose institution provided funding to finalize the research.

\section{NOTES}

1 In Mali, a commune is a third-level decentralized administrative unit, below the cercle and above the village level.

2 This is a regulated timber exploitation system where felling permits are issued by area.

3 Wood harvesting in Mali is variously classified as controlled (in demarcated, managed forest areas), guided (in sections of the demarcated forests that are not managed) and uncontrolled (in forests that are neither demarcated nor managed).

4 Figures taken from Article 8 of decree No 98-402/P-RM of 17 December 1998.

5 This decree, which revoked decree No 95-422 (see above) was, in turn, revoked by Decree No 04-137 (BIS) of 27 April 2004 - authorizing the distribution of taxes on wood harvesting from state forests and wildlife reserves between Forest and Wildlife Protection and Management Funds and the territorial authorities. In its Article 3 it allocates 80 per cent of tax revenue to forest planning and protection and 20 per cent to territorial collectivity budgets. Of the 80 per cent allocated to forest funds, 5 per cent theoretically belongs to the territorial collectivities to undertake action plans and forest protection plans, but they are not paid directly to them. The SRGs and Regional Chambers of Agriculture remain excluded from revenue flows.

6 Gautier et al (2004) report the same practice in the commune of Zan Coulibaly. We also observed it in other communes and it has spread to most rural markets found within guided harvesting areas. The government has decided to close its eyes to the practice, perhaps to make up for villagers' frustration over their exclusion from the distribution of official forest revenue.

7 Unlike Niger and Senegal, in Mali several classified forests are regarded as controlled harvesting areas and are under SRG management.

\section{REFERENCES}

Agrawal, A. and J. C. Ribot (1999) 'Accountability in decentralization: A framework with South Asian and African cases', Journal of Developing Areas, vol 33, summer, pp473-502

ARD (Association for Rural Development) (1989) 'Option pour promouvoir le contrôle et la gestion par les usagers des ressources naturelles renouvelables au Sahel', Paper presented at 
the Rencontre Régionale pour un Nouvel Équilibre Socio-écologique en Milieu Sahélien, CILSS, Club du Sahel, Ségou, May 1989

CIC International (2006) Potential for Afforestation in South Africa: Analysis and Correlation of Estimates of the Potential for New Afforestation, Department of Public Enterprise, Pretoria

CILSS and PRECONS (1997) Décentralisation et approche participative pour l'application des mesures de CE/DRS au Sahel, Actes de l'atelier régional d'échanges, Sao dos organas, Commission Européenne, Deutsche Forstservice Gmbh, Cap Vert

Crook, R. C. and J. Manor (1998) Democracy and Decentralization in Southeast Asia and West Africa: Participation, Accountability, and Performance, Cambridge University Press, Cambridge

FENU (2000) 'Développement local et gestion décentralisée des ressources naturelles', Paper presented at a workshop in Cotonou, New York, NY, pp1-96

Ferrar, A. A. and M. C. Lötter (2007) Mpumalanga Biodiversity Conservation Plan Handbook, Mpumalanga Tourism and Parks Agency, Nelspruit

Gautier, D., L. Boutinot and B. Hautdidier. (2004) 'La mise en place des marchés ruraux au Mali: Un évènement social et territorial', L'Espace Géographique, vol 4, pp289-305

Kassibo, B. (1998) La Décentralisation au Mali: État des lieux, Bulletin no 14, Euro-African Association for the Anthropology of Social Change and Development (l'APAD), Hamburg, http:/ /apad.revues.org/document579.html, accessed 10 January 2009

Kassibo, B. (2004) Historical and Political Foundations for Participatory Management and Democratic Decentralization in Mali: A Synthesis of Two Case Studies, Environmental Governance in Africa Working Papers no16, WRI, Washington, DC

Kerkhof, P., B. Béridogo and M. Tamboura (2002) Evaluation Finale, Stratégie Energie Domestique: Phase transitoire, Coopération Néerlandaise au Mali, Bamako

Kruger, F., J. Crafford and A. Ginsburg (2008) 'The regulation of water-use impacts in forestry in South Africa: Appraisal of the development of policy and governance', Paper presented to the Workshop on Forest Governance and Decentralization in Africa, Durban, S. Africa, 6-9 April 2008, CD-Rom

Manor, J. (1999) The Political Economy of Democratic Decentralization, World Bank, Washington, DC

Mbodj, F. B. (2005) Gestion décentralisée des ressources forestières: Enjeux économiques et socio spatiaux, L'exemple de la Commune Rurale de Siby, MSc Thesis, Paris University, Paris

Noppen, D., P. Kerkhof and C. Hesse (2004) Les marchés ruraux de bois au Niger: Bilan de l'appui danois à la Stratégie Energie Domestique du Niger 1989-2003, IIED/DANIDA, London

République du Mali, Sécrétariat Général du Gouvernement (1995). Décret no 95-422/P-RM fixant le taux et la répartition des taxes perçues à l'occasion de l'exploitation du bois.

République du Mali, Sécrétariat Général du Gouvernement (1998). Décret no 98-402/P-RM du 17 décembre 1998 fixant le taux et la répartition des taxes perçues à l'occasion de l'exploitation du bois.

Ribot, J. C. (2004) Waiting for Democracy: The Politics of Choice in Natural Resource Decentralization, WRI, Washington, DC

Ribot, J. C. (2007) Dans l'attente de la Démocratie: La Politique des Choix dans la Décentralisation de la Gestion des Ressources Naturelles, WRI, Washington DC

Rochette, R. M. (ed) (1988) Le Sahel en lutte contre la désertification: Leçons d'expériences, CILSS, PAC/GTZ, Weikershein, Margaf

Stratégie Energie Domestique (1998) Statuts et règlement intérieur de la Structure Rurale De Gestion: Module de formation, Unpublished report, SED, Bamako 


\section{Box C Governance of multi-stakeholder forest landscapes and ecosystem services: The case of tree-water interactions in South Africa}

\section{Laura A. German}

With a long history of industrial pulp, paper and timber production and hydrological research related to tree-water interactions, South Africa provides a unique opportunity to learn about cross-sectoral governance of critical ecosystem services. In response to stakeholder concerns and research indicating that plantation forests reduce water flow in streams, South Africa has embarked on a comprehensive governance reform process to regulate expansion of 'stream-flow reduction activities' - particularly plantation forestry. Building upon good governance practices - environmental impact assessments, multisectoral review (in the form of Licence Assessment Advisory Committees, or LAACs), and strong support for research to guide policy formulation - South Africa provides a model for other countries struggling to govern trade-offs of industrial expansion. However, government agencies and industry struggle with complex regulations and their effects on new investment. As investors turn to neighbouring countries with more lax environmental standards and without a strong research tradition to support policy, many of South Africa's lessons may be of use to its neighbours in the region.

These three boxes profile South Africa's experience from the perspective of independent consultants in hydrological research on tree-water interactions (see Box C.1) and those involved in resource economics, policy and governance (see Box C.2). The diverse views presented in these boxes suggest that evidence-based research, multi-stakeholder dialogue, and flexible policy design and evaluation are critical elements in governing complex trade-offs in contemporary landscapes characterized by multiple and often divergent interests. It also suggests the need to harmonize policies across neighbouring countries to avoid the 'Delaware effect' - where tight regulation in one country causes businesses to flee to other countries with weaker (social and environmental) standards.

It is also important to reflect on the lessons that may be derived from this case on how the principles of democratic decentralization and subsidiarity (namely, that matters ought to be handled by the smallest, lowest or least centralized competent authority) might apply to the governance of forest ecosystem services. For an ecosystem service such as water, which cuts across both sectoral and divisional (state and national) boundaries, there are a number of functions that can and should not be devolved to the lowest state or customary authority. For the case of water resource allocation, these include research, decisions on resource allocation at regional or national level, and incentive or regulatory functions to ensure sustainable provision of the ecosystem service. Research, particularly hydrological research, can be costly, and drawing on public funding sources as well as labour pools may be required both to cover costs and to ensure research quality. Decisions on resource allocation require multiple levels of nested decision-making, from the transnational to the local, to ensure equitable allocation for stakeholders at each scale. And regulatory functions - while often enhanced through active stakeholder participation at each level of decision-making by 
enhancing buy-in and reconciling diverse interests and needs - also require some cross-scale governance. For example, decisions in upper catchments with abundant water resources may affect stakeholders far downstream - requiring a means of communicating externalities (off-site effects) associated with upstream management practices to those responsible for them, whether through regulation, compensation or conditional payments for ecosystem services delivered.

\section{Box C.1 Policy-oriented research for forests and water in South Africa}

\section{Mark B. Gush}

South Africa has never had abundant resources of indigenous timber-producing forests. In terms of naturally occurring trees the country is more often characterized by open woodland than closed-canopy forest. Remnant patches of indigenous evergreen forest do remain; however, they are carefully conserved and sustainably managed through selective harvesting. Their protection was necessitated by heavy and uncontrolled exploitation between the 17th and early 20th centuries. The promulgation of the 1913 Forest Act eventually stemmed the destruction of the country's natural forests. However, a subsequent series of historical events (world wars, the 'Great Depression', industrial development, etc.) resulted in the demand for timber exceeding supply, and forced South Africa to accelerate the expansion of its own exotic plantation forest industry. Plantation forests of fast-growing exotic species were established in the high-rainfall regions of the country, which largely constituted mountain catchments (i.e. important water-yielding areas).

\section{Past research on tree-water interactions}

Exotic plantations are characterized by tall, dense evergreen canopies and deep-rooted systems. Their physiology contrasts strongly with the typically short, seasonally dormant vegetation with shallow root systems (e.g. grassland) that they usually replace during afforestation activities in South Africa. Consequently, as the area under exotic plantations grew, so did concerns about their impacts upon water resources. These water-use concerns led to the initiation of South African forest hydrological research in 1935, and the establishment of long-term paired catchment research stations (e.g. Cathedral Peak). Research initially focused on water use by pines and eucalypts, but has expanded to include a wider range of indigenous and exotic (alien invasive) species. Numerous local and international studies have now indicated conclusively that forest plantations consume more water than grasslands or shrublands and thus reduce water yield (stream flow) from afforested catchments (see Figures C.1 and C.2).

\section{Policy}

The findings and recommendations emanating from the above research led to the 1972 introduction of an Afforestation Permit System requiring timber growers to apply for permits to establish exotic plantation forests. Applications became mandatory, and 


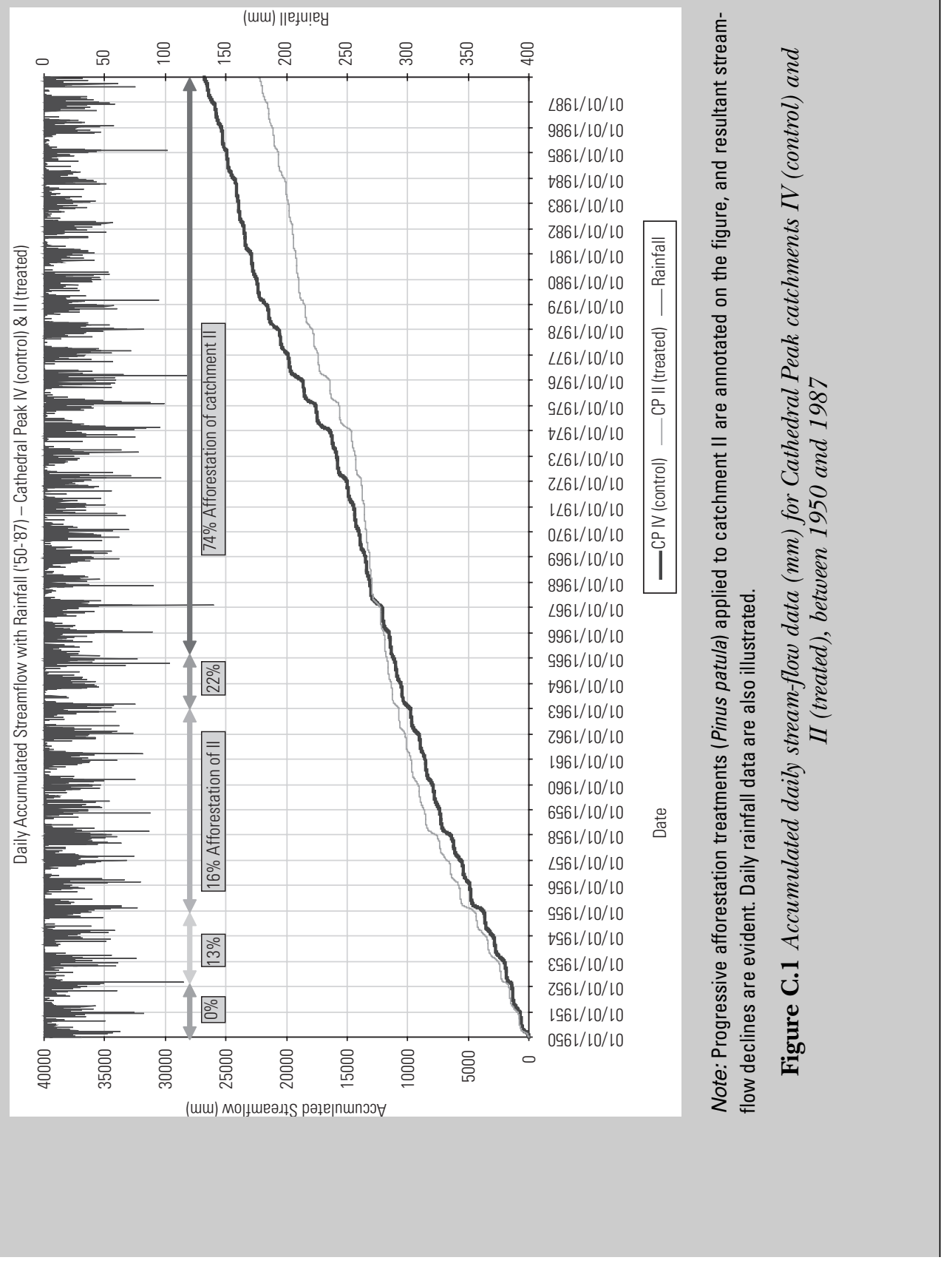


plantations were rejected if it was deemed that the afforestation would use an unacceptably high proportion of water in a catchment. The policy has undergone a series of refinements since then, notably the declaration in the National Water Act of commercial afforestation as a stream-flow reduction activity (SFRA) or land use that may reduce the amount of water in rivers and thus available to downstream users. To date, plantation forestry remains the only declared SFRA, although plantation bamboo and dryland sugarcane have been recommended for declaration as SFRAs. The key reason for the declaration of water-using activities as SFRAs was the need for appropriate control over the use of water resources, preventing uncontrolled dwindling of the resource, and allowing sufficient water to meet the human and ecological reserve (water required for basic human consumption and ecological functioning).

The current afforestation licensing and regulation system is based on research which extrapolates results from the paired catchment studies to all potential forestry areas in South Africa through a modelling exercise. Simulations on the experimental catchments themselves afforded opportunities for thorough verification of an appropriate model. Thereafter, stream-flow reduction estimates at a national scale were calculated using a simplified water balance equation (precipitation = evapotranspiration (Et) + stream flow), where an increase in Et (caused by a change from the natural vegetation to commercial forestry) constituted a stream-flow reduction. These streamflow reductions were individually simulated for the three principal exotic plantation tree genera at a national scale, and results were represented in the form of tables. The results are utilized by regional offices of the Department of Water Affairs and Forestry (DWAF) in water resource management decision processes. Water-use authorizations and forestry licence allocations are currently overseen by regional Licence Assessment Advisory Committees (LAACs). These are cooperative governance committees, which

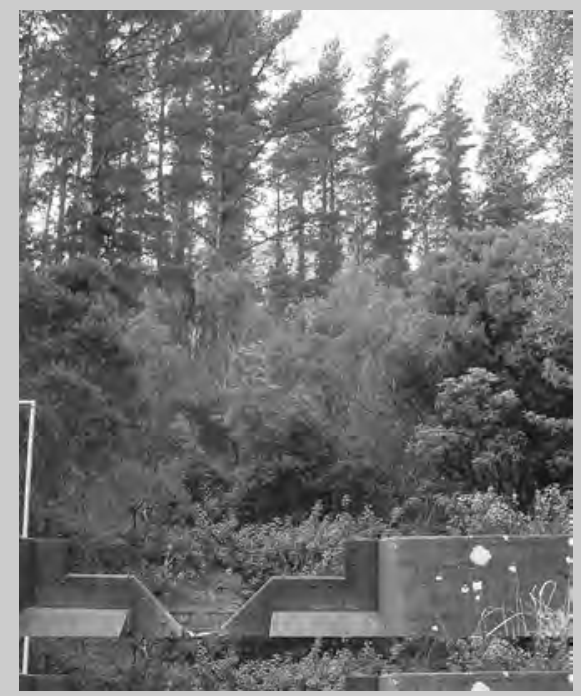

Figure C.2 Stream-flow gauging weir used to assess the impacts of catchment afforestation with Pinus radiata on stream flow 
include representatives from the forest industry, environmental and civil society groups, and regulators from departments implementing relevant legislation.

Research is still needed to inform a number of policies on tree-water interactions in South Africa:

- The National Water Act aims to devolve water management to local catchment management agencies (CMAs). While CMAs are still being established, management of much of the country's water resources nevertheless takes place at regional level. As water demands increase, water resource managers will be under increasing pressure to assess the impacts of different land uses and management practices upon catchment water yield as a whole. To meet the water resource objectives defined in the act, methods are needed to predict and monitor the impacts of a mosaic of land uses upon water.

- The Working for Water programme, funded by DWAF, is a national project aimed at clearing invasive alien plants from South African river courses to help restore the water balance and biological diversity in South Africa's most important wateryielding catchments. The effects of clearing different invasive species need to be better quantified to ensure clearing operations are optimized and stream-flow gains substantiated.

- Commercial forestry companies are required by law to leave riparian areas unplanted to reduce negative impacts of trees on stream flow, resulting in the loss of thousands of hectares of productive forestry land. Keeping riparian areas clear of weeds is also costly to landowners, and they need to know what return in water is achieved for their efforts.

\section{Box C.2 The regulation of water-use impacts of forestry in South Africa: Appraisal of the development of policy and governance}

\section{Adapted from Kruger et al (2008)}

Plantation forestry is controversial and conflict ridden due to its perceived or observed social and environmental costs. Yet, by international standards plantation forests are well managed in South Africa, with over 80 per cent of the plantation forest estate certified by the Forest Stewardship Council (FSC) as being sustainably managed. In 1998, new provisions for the licensing of stream-flow reduction activities (in effect, only commercial plantation forestry) took effect through the National Water Act. The government has used a cooperative governance framework to institute these new requirements, as required in the Constitution. As a result, the procedure for administering applications involves 50 steps or activities and 3 government agencies who collectively form Licence Assessment Advisory Committees at provincial level. Several of these steps are time consuming and onerous. The transaction and financial 
costs associated with these new governance arrangements, and the resulting designation of some catchments as excluded from further afforestation, have contributed to a decline in annual afforestation rates in South Africa, with expansion since 1990 amounting to a mere 6000ha. This outcome conflicts with the government's stated intent of supporting economic and social development. Reconciling forestry and water policy is an urgent matter for South Africa's attainment of its development goals.

\section{Economic importance of plantation forestry}

South Africa has approximately 1.4 million hectares of plantation forest, delivering about 18 million cubic metres of timber per year. Most of this is for domestic consumption, though a substantial fraction is currently exported as wood chips, pulp and paper. Government forestry policy aims 'to promote a thriving forest sector, to be utilized for the lasting benefit of the nation, and developed and managed to protect the environment'. The development strategy of the Government of South Africa (Asgi-SA) has the principal, overarching goal of halving poverty between 2004 and 2014 through twin strategies of economic growth and improving the quality of life. Forestry is included in the Asgi-SA and industrial sector strategies as a contributor to this overall development strategy. In addition, the 'binding constraints' identified in these strategies include infrastructure development and housing - each of which is dependent upon the provision of forest products. Plantation forests provide the only significant renewable resource for lumber, paper and board products required to satisfy development needs yet South Africa's consumption levels fall well under the International Institute for Environment and Development's (IIED's) recommended $60 \mathrm{~kg}$ per person per year to satisfy basic education, communication and hygiene needs. In the face of the sector's relevance to the country's development, a substantial shortfall in the domestic supply of forest products has emerged and is set to intensify. Estimates of the area of new afforestation in South Africa that would be required to satisfy the growth of demand by the year 2030 are around 700,000 ha. A recent appraisal of land suitable and readily available for afforestation suggests that 200,000 ha are suitable and available, with availability of an additional 575,000 ha of suitable land undermined by policy, regulatory and institutional factors (CIC International, 2006). Costly and burdensome procedures have diverted investors from forestry.

\section{Environmental performance of plantation forestry}

Water-use efficiency. The assumption underlying water policy is that South Africa is a water-scarce country. While much of the policy is derived from research on plantation impacts upon stream flow reduction (see Box C.1), it is also important to consider a sector's water-use efficiency (e.g. amount of water consumed per biological yield or economic output) and relative consumption. Of South Africa's 'available' water - or the fraction of runoff that may reliably be allocated for use, 62 per cent (about 13,227 million cubic metres per year) is used in irrigated agriculture. Of this, much is lost in leakage or 
wasteful use, with estimates of loss reaching up to 40 per cent. The water use attributed to plantation forests is 3 per cent of yield. The attributable water use in these forests is thus a small fraction of that wasted in irrigation.

Biodiversity. South Africa has highly biodiverse ecosystems, many of which are also ideal for plantation forestry. Afforestation impacts biodiversity by replacing natural grasslands and other indigenous vegetation. In a recent biodiversity assessment conducted for the biodiversity conservation plan for Mpumalanga Province, Ferrar and Lötter (2007) classified plantation forests with dryland crop cultivation, intensive animal farming and irrigated crop cultivation as being land uses "that have moderate to high impact upon biodiversity'. They recommended that these land uses be restricted to areas with low biodiversity.

\section{Conclusions and recommendations}

Plantation forestry is an important contributor to the South African economy, yet involves economic and environmental trade-offs. To reconcile divergent interests and harness the industry's contribution to national development, we recommend the following:

- Water policy should not be about preventing water use, but about promoting equitable and efficient use. Cross-sectoral and public debate over the criteria and procedures for equitable and efficient use should be fostered, ensuring symmetry in interests and institutions present.

- Support an understanding of the reasons behind contentious and divergent perceptions around plantation forestry, evaluating alternative land uses not only according to their impacts upon stream flow, but also according to their water-use efficiency and contributions to achieving national development goals. Support governance reforms encouraging water-use efficiency and allocations according to development priorities.

- Evaluate the respective contributions of domestic and export-oriented plantation forestry to the country's economic development (in terms of the provision of forest products and taxation and funding of social programmes), and prioritize sector developments accordingly.

- Move towards arms-length regulation through a combination of statutory minimum standards and market-based and co-regulatory measures, as captured in sustainability certification and the National Forests Act - with clear and consistent leadership from government, and the consent of the environmental advocacy coalition.

\section{REFERENCES}

CIC International (2006) Potential for afforestation in South Africa: Analysis and correlation of estimates of the potential for new afforestation. Pretoria: Department of Public Enterprise. 
Ferrar, A. A. and M. C. Lötter (2007) Mpumalanga Biodiversity Conservation Plan Handbook. Nelspruit: Mpumalanga Tourism and Parks Agency.

Kruger, F., J. Crafford and A. Ginsburg (2008) The regulation of water-use impacts in forestry in S. Africa: Appraisal of the development of policy and governance. Workshop on Forest Governance and Decentralization in Africa, Durban, S. Africa, April 6-9, 2008. CD-Rom. 


\section{Decentralization Outcomes in the Context of Political Uncertainty in Zimbabwe: A Comparative Assessment of Co-Management and CAMPFIRE and Implications for Policy}

Everisto Mapedza

\section{INTRODUCTION}

For many years Zimbabwe was one of the leading countries in Africa in terms of its innovative community-based natural resource management (CBNRM) initiatives, with the Communal Areas Management Programme for Indigenous Resources (CAMPFIRE) being one of the most well-known. But the growing political upheavals in the country have changed many aspects of life dramatically. Although forest and wildlife governance reforms through decentralization have aimed at giving rural citizens rights to benefit from natural resources within their areas of jurisdiction, political uncertainty has affected this decentralizaton Zimbabwe in numerous ways. This chapter uses a detailed case study approach to distil lessons from experience for policy-makers and practitioners on devolution of natural resource management. It assesses the impact of political uncertainty in the new millennium and its social, institutional and ecological effects on community-level natural resource management.

The study was carried out in Gokwe South and North districts, where two wellknown and well-established community-based natural resource management programmes have been operational: co-management (Mafungautsi area) and CAMPFIRE (Nenyunga area). The two districts are both in the Midlands Province of Zimbabwe. The study used key informant interviews, participant observation, focus group discussions and literature reviews. The chapter shows how political uncertainty in Zimbabwe has resulted in increased centralization of power and erosion of earlier successes in decentralized natural resource management. One of the conclusions of the case study is that there is a need to enable more democratic and accountable local governance in order to be able to implement devolved responsibilities. 
Partnerships between the state and non-governmental organizations (NGOs) are important; but they should be aimed at strengthening local management units. Partnerships between decentralized units and the private sector need the support of NGOs to help tilt the balance of benefits in favour of poor rural communities who pay the 'real price' of sustainably managing and living with natural resources such as forests and wildlife.

\section{BACKGROUND}

\section{Recent political history of Zimbabwe}

Zimbabwe became independent from Britain in 1980 after an anti-colonial struggle spanning more than two decades. Land ownership was a key motivation in the struggle for independence. The early 1980s were characterized by economic growth and the delivery of social services and infrastructure to the previously disadvantaged sectors of society (Hammar et al, 2003). Significantly, many farmers from communal land ${ }^{1}$ seized these opportunities and shifted from subsistence to commercial production in what has been dubbed Zimbabwe's agricultural revolution (Rukuni and Eicher, 1994). By the late 1980s, economic growth faltered, largely due to the over-regulation and price controls inherited and maintained from the previous regime (Bond and Manyanya 2002). An Economic Structural Adjustment Programme (ESAP) supported by the World Bank and the International Monetary Fund (IMF) aimed to liberalize the economy and bolster economic growth. ESAP had many positive impacts across the economy; however, these were mostly confined to the private sector and middle- and upper-income earners. A critical weakness of ESAP was the failure to provide safety nets to cushion those who lost out (Raftopoulos, 2001).

ESAP triggered a number of processes in the mid to late 1990s. These included a trend towards increased corruption, a decline in economic growth and an increase in the rate of inflation. Economic liberalization, which resulted in the decline in employment opportunites while opening up the media, also resulted in greater political aspirations and the Zimbabwe African National Union-Patriotic Front (ZANUPF) government was defeated in its aim of establishing a one-party state. This gradually led to the emergence of the first credible opposition to the ruling ZANU-PF party.

In 2000, the government lost the February referendum for a new national constitution, representing the first defeat of the ruling ZANU-PF party in 20 years. The opposition Movement for Democratic Change (MDC) and the National Constitutional Assembly (NCA) had campaigned against the government's proposed constitution, which made provisions for large-scale appropriation of white-owned farmland. Immediately, the government backed invasions of commercial farms as an alternative approach to redressing the land issue, as retribution against those who were perceived to have supported the opposition and to divert attention away from the declining economic situation. The farm invasions significantly cut agricultural output and exports, worsening the fiscal pressures on the government. Importantly, they also resulted in the loss of foreign capital, skills and new foreign investment. The World 
Bank and the IMF withdrew their support for the government. The cumulative effect was that Zimbabwe entered a period of sustained hyper-inflation and economic contraction (Bond and Manyanya, 2002). ${ }^{2}$

The declining national economy has resulted in a gatekeeper state, with Zimbabwean politicians acting as middlemen ${ }^{3}$ rather than regulators for local and (limited) foreign capital (Logan, 2005). It is easier for authoritarian regimes to "maintain the loyalty of the core group during economic crisis than it is for democracies. With fewer favours, they can achieve far greater loyalty among the reduced number of actors that support them' (Corrales, 2004, p37). ${ }^{4}$ This gatekeeper role is playing out across all sectors of the economy, including forestry and wildlife management. Under the decentralization rubric, rule-making, decision-making and rule enforcement powers are being usurped by the elite from the majority previously managing forestry and wildlife resources. Law enforcement is selectively applied to reward government supporters and punish their opponents, as is demonstrated within CAMPFIRE in Nenyunga.

\section{COMMUNITY-BASED NATURAL RESOURCE MANAGEMENT (CBNRM) IN ZIMBABWE}

Community-based natural resource management (CBNRM) emerged as a response to the failure of centralized natural resource management strategies worldwide. CBNRM also became part of the broader structural adjustment programmes within Africa and developing countries at large. These include financial austerity measures that were meant to reduce central government spending. In Southern Africa, donor organizations also played a key role in channelling resources towards CBNRM initiatives in countries such as Zimbabwe.

Zimbabwe had two well-known and well-established CBNRM approaches: comanagement and CAMPFIRE. The philosophy of both initiatives is that local communities need to realize commercial benefits in order for them to sustainably manage local natural resources. This philosophy attempts to link the costs of managing the resource with the benefits derived from the natural resource. In both co-management and CAMPFIRE, a nested institutional structure from national to local level helps to operationalize decentralization - including responsibilities for natural resource management and governance of the financial benefits of the same. They include five levels of government (national, provincial, district, ward and local) and village-level resource management committees (RMCs) composed of seven elected villagers - namely, chairperson, vice chairperson, secretary, treasurer and three committee members. Ward-level bodies are called ward development committees and ward wildlife management committees (WWMC), and are composed of the ward councillor, who automatically becomes the chairperson, and other elected office bearers (vice chairperson, secretary, treasurer and two committee members).

Decentralization is further viewed as providing a framework for enabling lower levels of governance to perform duties and derive benefits from natural resources in line with 
the subsidiarity principle - which states that duties should be devolved to the lowest feasible level. Higher-level institutions should only have an oversight role as a mechanism to ensure reinforcement of decisions made at the local level and also as a check on excesses at the local level (Chitsike, 2000). For an understanding of how Zimbabwe's forest governance reforms compare with other countries in the region, see Box 11.1.

\section{Box 11.1 Forest decentralization experiences from Southern Africa}

\section{Frank Matose}

A review of forest management reforms across Southern Africa reveals the relationship between forest governance reforms and their impacts upon local livelihoods. Findings, derived from three cases (Mafungautsi Forest Reserve in Zimbabwe, Chipange Chetu in Mozambique and Tsitsikama-Covie Forest in South Africa), are summarized according to a number of key institutional parameters and associated outcomes, as follows.

Tenure arrangements. Only in Mozambique has the state passed on land rights to communities through land certificates or Direito de Uso e Aproveitamento da Terra (DUAT). However, timber and wildlife are still vested in the state. Divesting some rights to forests and forest resources to communities as a means of enhancing economic benefits and restituting resources alienated from them is an issue which governments still need to address.

Organizational structure. The Mozambique case presents a mixture of informal customary organizations and local elected systems under district councils working in tandem. The other two cases promote community participation through user groups/committees (sensu Manor, 2005). Depending upon the size of the forest area, local organizations can enhance local participation, but often require outside support for organizational strengthening.

Accountability. In all three cases, decision-making over key forest resources remains with the state, even in the case of Mozambique where land is 'owned' by communities. Decisions over timber and wildlife resources within the forest still lie with the state; only in Mozambique have negotiations been initiated as a means of fostering downward accountability to communities. Local RMCs (e.g. Mafungautsi) were found to be upwardly accountable until a Center for International Forestry Research (CIFOR)-led project explored ways of democratizing these structures. Officials around Tsitsikama are still accountable to the state for day-to-day management; but there is some limited consultation of communities. Across the entire region, the state needs to become more accountable to forest communities with whom they have joint management arrangements.

Transfer of power. For Zimbabwe and Mozambique, adaptive management experiments were initiated in order to provide lessons for devolved management for other forests or protected areas by the respective governments. In the Mozambican case, at least some financial resources from sport hunting and timber harvesting are passed on to communities; but decision-making powers over these same resources are 
retained by the state - as in the case of Zimbabwe. For the South African case, power has barely moved at all, as SANParks remains a statutory body and no resources have been transferred. Governments therefore need to transfer discretionary power to communities and to equitably share the revenues derived from forests.

Livelihood outcomes. The insights from the cases are mixed and show limited progress, with the exception of Mozambique, where as much as a 40 per cent increase in household incomes were witnessed (Anstey, 2005). For the other two cases small revenues are generated from minor activities that communities engage in under the joint management schemes; but these do not contribute substantially to community livelihoods. Thus, there is a need to make benefits from forests more tangible for communities involved, through sharing of high-value resources such as timber and wildlife.

Research findings are summarized in Table 11.1.

Table 11.1 Decentralization arrangements and outcomes in Southern Africa: Case studies

\begin{tabular}{|c|c|c|c|}
\hline Parameters & Zimbabwe & Mozambique & South Africa \\
\hline Tenure & $\begin{array}{l}\text { State forest, with } \\
\text { communities given } \\
\text { co-management rights } \\
\text { over minor forest products }\end{array}$ & $\begin{array}{l}\text { Community forest } \\
\text { land through DUAT; } \\
\text { the state retains } \\
\text { rights to dispose of } \\
\text { timber and wildlife } \\
\text { resources, and } \\
\text { allocates a percentage } \\
\text { to communities }\end{array}$ & $\begin{array}{l}\text { State forest - with } \\
\text { neighbouring communities } \\
\text { having limited rights due } \\
\text { to a preservationist } \\
\text { approach by the state }\end{array}$ \\
\hline $\begin{array}{l}\text { Organizational } \\
\text { structures }\end{array}$ & $\begin{array}{l}\text { Resource management } \\
\text { committees (RMCs) }\end{array}$ & $\begin{array}{l}\text { Mixture of informal } \\
\text { customary and local } \\
\text { elected representatives } \\
\text { from local councils }\end{array}$ & $\begin{array}{l}\text { Participatory forums } \\
\text { involving the state and } \\
\text { local communities }\end{array}$ \\
\hline Accountability & $\begin{array}{l}\text { An 'adaptive } \\
\text { co-management' } \\
\text { project has enabled a shift } \\
\text { of RMC accountability } \\
\text { from the state to users }\end{array}$ & $\begin{array}{l}\text { Local administrative } \\
\text { bureaucracy poses } \\
\text { challenges for } \\
\text { democratized } \\
\text { governance }\end{array}$ & $\begin{array}{l}\text { An arm of state is } \\
\text { still in control of forest } \\
\text { management, with } \\
\text { strong upward } \\
\text { accountability }\end{array}$ \\
\hline $\begin{array}{l}\text { Transfer } \\
\text { of powers }\end{array}$ & $\begin{array}{l}\text { Officially still limited; } \\
\text { for minor resources, } \\
\text { decisions have been } \\
\text { devolved to RMCs }\end{array}$ & $\begin{array}{l}\text { Still in a transition } \\
\text { to handing over } \\
\text { decision authority } \\
\text { to local institutions }\end{array}$ & Very limited \\
\hline $\begin{array}{l}\text { Livelihood } \\
\text { outcomes }\end{array}$ & $\begin{array}{l}\text { Grasses (thatch and } \\
\text { broom) are contributing } \\
\text { to livelihood changes } \\
\text { for resource users - with } \\
\text { net incomes between } \\
\text { US\$190 to } \$ 429 \text { per } \\
\text { year (2002-2004) }\end{array}$ & $\begin{array}{l}\text { Sport hunting and } \\
\text { resource license fees } \\
\text { are increasing household } \\
\text { incomes by as much } \\
\text { as } 40 \text { per cent (from } \\
\text { US } \$ 6190 \text { to } \$ 31,000 \\
\text { for } 2001 \text { to } 2004 \text { ) }\end{array}$ & $\begin{array}{l}\text { Employment from } \\
\text { tourism and conservation } \\
\text { were the only perceived } \\
\text { positive outcomes from } \\
\text { governance reforms }\end{array}$ \\
\hline
\end{tabular}

Source: Matose and Watts, 2008 
It can be concluded that experiments in devolved forest management in the region have been initiated but are incomplete. The degree of transfer of power and resources is an issue that still requires attention in order for communities to enjoy rights and accrue meaningful benefits. The Mozambican case appears to offer some hope through the sharing of rights and responsibility between local customary institutions and local elected officials and transferring a percentage of revenue from forest resources. One would hope that these are complex adaptive systems that are only in their infancy, and as such more investment by the state is still needed in transferring power and resources for devolution to take hold.

\section{Co-management}

Co-management, in theory, seeks to decentralize forest management powers to local communities living next to state-protected (gazetted) forests in order to prevent resource-use conflicts. It involves the creation of environmental or resource regimes featuring partnerships between local communities or resource users and agencies of (sub)national governments. These state agencies (e.g. the Forestry Commission) normally possess the legal mandate for forest management. In Zimbabwe, comanagement began in 1993 in villages surrounding the Mafungautsi Forest Reserve. These villages formed 15 resource management committees that were institutions through which benefits such as harvesting broom grass, thatching grass, reeds and firewood were to be administered. Previously this role was performed by the Forestry Commission's district office. The proceeds from these minor forest products were then supposed to be used for community development projects such as schools, or a revolving fund for providing loans to projects such as beekeeping. In the Mafungautsi area, comanagement received funding from the Canadian International Development Agency (CIDA). Initially, it performed well as CIDA and other stakeholders, such as the Center for International Forestry Research (CIFOR) and the Centre for Applied Social Sciences (CASS), played a mediating role between the community and the Forestry Commission.

In co-management, RMCs were formed as sub-committees of the village. Their main role is to issue non-timber resource exploitation permits and to help enforce forest protection rules. The RMCs, it was hoped, would be able to collect revenue from minor forest products which would then be invested in community projects.

\section{CAMPFIRE}

CAMPFIRE has been operating in Zimbabwe since 1989, largely restricted to buffer zones adjacent to national parks. CAMPFIRE is a government initiative that decentralizes the management of and benefits from wildlife resources to local communities in the communal areas (Murphree, 1991). Previously, only private (largely white) farmers were able to manage and benefit from wildlife on their land. Most rural district councils have entered into contractual arrangements with safari operators who bring hunting clients into CAMPFIRE areas. The safari operator pays the hunting fees to rural district councils (RDCs), and the RDCs then pass on a portion of the revenue to communities in CAMPFIRE wards. 
Initial plans for CAMPFIRE envisaged the formation of natural resource management co-operatives at village level (Martin, 1986), but this was not acceptable to politicians who felt threatened by financially independent villages. A compromise was to devolve appropriate authority for the management of wildlife to district councils (Murphree, 1991). Such deconcentration of authority meant that powers would be given to the RDCs - rather than to CAMPFIRE wards or villages. In return, district councils nominally agreed to devolve the responsibility for wildlife management and related financial benefits to sub-district levels - namely, the ward, administered by the ward wildlife management committee (WWMC). The WWMC is chaired by an elected councillor who represents the ward at rural district level. The rural district council then links with the national government via the provincial government.

The development of CAMPFIRE and its implementation were guided by a loose consortium of governmental organizations, NGOs and university departments known as the CAMPFIRE Collaborative Group (CCG). ${ }^{5}$ The programme was funded by numerous international donors. The US Agency for International Development (USAID) was the largest single donor, providing approximately US $\$ 20$ million between 1989 and 2003 (Child et al, 2003). Prior to 2000, the programme was largely hailed as a successful example of communities deriving benefits from wildlife resources.

\section{RESEARCH METHODS}

This chapter is the result of participatory research studies that were largely conducted by the Centre for Applied Social Sciences (in Mafungautsi) and the World Wide Fund for Nature (WWF) (in Nenyunga). The research period stretched from the early 1990s to 2004. Field interviews were carried out with members of local communities, and current and former committee members of resource management committees (in the co-management case study) and ward wildlife management committees (CAMPFIRE case study). Key informant interviews were conducted with the Forestry Commission of Zimbabwe (FCZ), the Gokwe rural district councils (both north and south), WWF, CASS and Zimbabwe Trust (ZimTrust). Interviews with the CAMPFIRE Association (CA) were conducted later, in March 2005. Some former CAMPFIRE Collaborative Group employees and researchers also carried out key informant interviews. A literature review and focus group discussions with RMCs, women, men and youths were conducted in 2005 and were also important tools for data collection.

\section{Case study selection}

CAMPFIRE research was conducted in the Nenyunga ward of Gokwe North District. The ward wildlife management committee in the research area consists of three villages. The co-management case study focused on Mafungautsi Forest Reserve and on two RMCs: Batanai and Chemwiro-Masawi.

Both research areas are in the same agro-ecological region, which means that their biophysical environments are fairly similar. Both areas are largely communal areas with no large-scale commercial farming. Nenyunga is one of the prime 
CAMPFIRE wards as its habitat can support a resident wildlife population rather than being an area through which wildlife passes en route to more suitable habitats. Both areas also have a similar socio-political and economic history. This is a frontier region with a number of residents having migrated from other parts of Zimbabwe in search of land. Immigrants are largely from Masvingo and belong to the Karanga ethnic group. Most of the Karangas viewed the less-educated resident Tonga as 'backward'. The Gokwe area was seriously affected by political turmoil in the post-2000 era. The political turmoil provided an opportunity for the ethnic contests to be manifest within the broader political struggles and contestation.

\section{Assessing the social, institutional and ecological effects of political uncertainty}

A number of key variables were used to assess the impact of the February 2000 watershed on the two initiatives, facilitating the comparison of the pre- and post-2000 periods. One needs to appreciate the multi-dimensional roots of decline in natural resource management in Zimbabwe. The variables assessed include the following:

- Integrity of the resource area. This analyses what has happened to the resource through assessing fire trends and the wildlife corridor's integrity. The role of institutions in enforcing resource integrity was also assessed.

- Non-quota use ${ }^{6}$. These are illegal resource extraction activities, an important proxy for sustainability.

- Financial management and benefits. Incentives are key for local-level resource management. A decline in incentives will result in reduced interest as the cost will be higher than the benefits. This was assessed by looking at the financial benefits accruing to both the co-management and CAMPFIRE communities.

- Financial accountability. Accountability in the management of benefits (financial) is key in building trust and promoting collective decision-making and enforcement of rules. This was assessed through looking at what accountability mechanisms were in place for both the RMCs and the CAMPFIRE committees.

\section{RESEARCH FINDINGS}

This section presents the main findings based on selected variables. These variables are compared using the pre- and post-2000 periods, with key findings summarized in Table 11.2.

\section{Integrity of the protected area}

Co-management case study

Pre-2000. One of the main management challenges facing gazetted areas in Zimbabwe has always been illegal forest fires, which in most instances are blamed on the disgruntled neighbouring village residents. Before the June 2000 parliamentary 


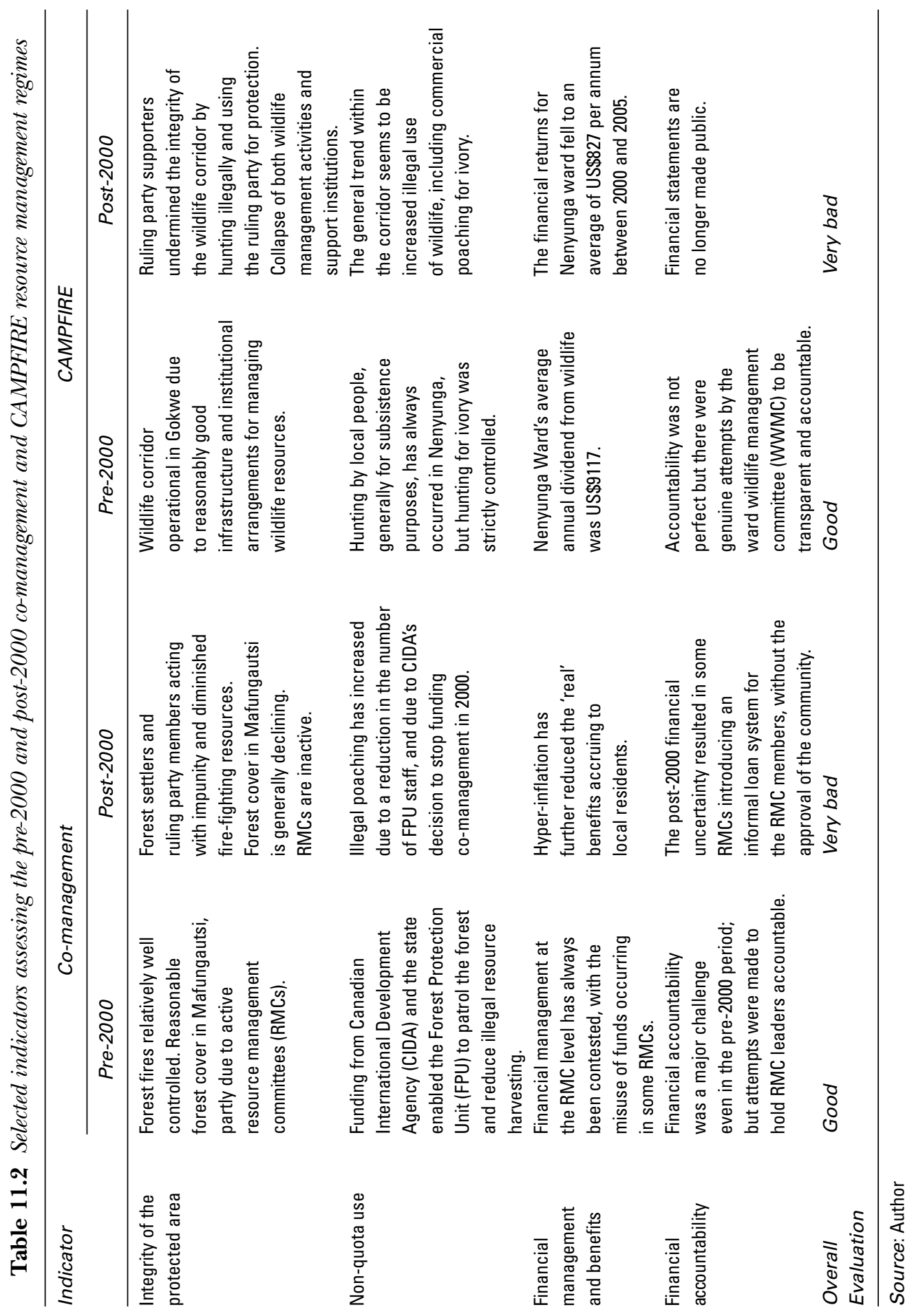


elections, forest fires were relatively controlled - although fires have been a major issue dating back to the colonial period. However, the science of fire burning within the semi-arid savannas has always been controversial, with some researchers arguing that controlled burning is beneficial to the ecosystem (Mapaure, 2002). Forest cover in Mafungautsi was also good in the pre-2000 period.

Post-2000. Since 2000, forest fires have increased, according to both RMC officials and the Forestry Commission officer in Gokwe, for a number of reasons. After June 2000 there were fewer resources for fire fighting and a culture of acting with impunity was quickly developing among villagers. About 180 households invaded the reserved forest arguing that they were reclaiming their ancestral land stolen when the forest reserve was gazetted. The new settlers began using fire to open up fields for cultivation in the Mafungautsi forest area. Due to the political clout surrounding land invasions in Zimbabwe, both the Forest Protection Unit (FPU) and the RMCs were powerless to stop them. In the neighbouring RMC in the Bomba area, people opened up fields within the forest. In the forest adjacent to Lutope FPU Camp, people went as far as to build huts within the forest. To safeguard themselves against eviction, they have formed cells and branches ${ }^{7}$ of the ruling party. The practice has spread to a number of villages, who are assuming that the regulations have been relaxed and that they can also use the name of the ruling party to make them immune from prosecution. Some RMC members, in areas such as Chemusonde, have also moved into the Mafungautsi Forest. ${ }^{8}$

Forest cover in Mafungautsi is generally declining since 2000, as demonstrated in aerial photo studies (Mapedza et al, 2003) and from field interviews. Mapedza et al (2003) identified clear trends of increased forest cover loss after the year 2000 in surrounding villages; but the image is less clear for the forest reserve area itself (compare Vermeulen, 1996; Mapedza et al, 2003). Although figures were not available, the general impression of both the FCZ and RMCs is that poaching has significantly gone up since people started living within the forest area in 2000.

\section{CAMPFIRE case study}

Pre-2000. When CAMPFIRE was still vibrant a wildlife corridor was established in Gokwe within the context of very high levels of immigration, settlement and conversion of land from wildlife habitat to agro-pastoral uses. There was a significant influx of settlers from all over Zimbabwe after the eradication of tsetse fly and the construction of a new tarred road after independence in 1980. It is estimated that wildlife habitat lost to new settlements in the Gokwe North area increased from 27 to 57 per cent of the total district land area between 1985 and 1999 (Dunham et al, 2003).

There were better infrastructure and institutional arrangements for managing both forestry and wildlife resources in the area prior to 2000. For example, since the 1990s many low-cost electric fences had been constructed to separate people and their crops from areas of wildlife habitat. ${ }^{9}$ Soon after the formation of the game corridor, ${ }^{10}$ a 'problem animal reporting system' was established in Nenyunga with the support of the WWF.

Post-2000. The integrity of the wildlife area was further undermined after 2000 due to the ability of ruling party supporters to act with impunity. Aerial surveys carried out in 2001, one year after the start of political uncertainty in 2000, indicated that there 
was an expansion in agricultural activities in the Nenyunga area and the broader Sebungwe region (Dunham et al, 2003). When the land invasions began in 2000 people also increased livestock grazing within the wildlife corridor area. In 2004, the RDC once again resorted to using the police to clear the corridor of cattle. While there were no human settlements within the corridor, expansion of agricultural activities and cattle grazing has often been blamed for reducing the wildlife habitat. Home ranges for elephants in CAMPFIRE wards had been compressed due to the expansion of agricultural activities (compare Hoare, cited in Dunham et al, 2003). A former member of parliament for the area argued that local residents wanted to see rural development in the form of agricultural expansion - not the wildlife model of development, which offers fewer individual financial incentives. ${ }^{11}$

Measures to reduce the human-wildlife conflict in Nenyunga ward have largely been discontinued. Gokwe North RDC no longer has a functional CAMPFIRE vehicle and is therefore unable to support the rapid deployment of the wildlife unit to handle incidents involving wildlife. At the ward level, the problem animal reporters (PAR) have not been working for over a year because they have not received their allowances. In addition, the district board of management (DBM) has been unable to buy ammunition for the shotguns that were used to scare elephants out of the fields. The electric fence on the northern border of the game corridor has been completely vandalized.

\section{Non-quota use}

\section{Co-management case study}

Pre-2000. Since the introduction of co-management there had been no commercial logging inside Mafungautsi. Commercial logging did take place in 1999 in villages surrounding the gazetted forest. In this instance, the FCZ made it clear that co-management was mainly based on non-timber forest products (NTFPs), with the exception of deadwood - whose collection was strictly regulated. There were a few cases of illegal harvesting of poles and small animals. With funding from the Canadian International Development Agency, the Forest Protection Unit managed to patrol the forest and reduce illegal resource harvesting.

Post-2000. Another round of salvage logging, which entailed logging remaining timber in an area which had been recently logged, was being carried out by Mockdale Company in the villages surrounding Mafungautsi in 2005. This seems to be a desperate move by the Gokwe South RDC to secure revenue. The local community contested this through their traditional leader. The logging company was owned by a former employee of the president's office, who was said to be under-reporting his timber harvests. Illegal poaching increased due to a reduction in the number of FPU staff, and to CIDA's decision to stop funding co-management in 2000. The political crisis was now offering opportunities for those politically connected to exploit forest resources at the expense of local farmers.

\section{CAMPFIRE case study}

Pre-2000. Hunting by local people, generally for subsistence protein needs, has always been practised in both Mafungautsi and Nenyunga. It has been estimated that in some 
of the 'wildlife-rich' wards, locally hunted wildlife accounted for 40 per cent of the protein in the residents' diets (Murindagomo, 1997). The Tonga people, the 'original' residents of the Zambezi Valley, have a long history of hunting, fishing and use of NTFPs. The loss of wildlife habitat, however, has always been considered the primary threat for wildlife populations in the communal lands, rather than local hunting. Evidence from aerial surveys shows that settlement in the Sebungwe region dramatically changed the distribution of large mammals in the pre-2000 period. Studies from within Gokwe and the neighbouring Nyaminyami District showed that herds of elephants are reluctant to venture within $2 \mathrm{~km}$ of human settlement (Hoare, 2002).

Despite the fragmentation of habitat and the compression of the range, it was estimated that there were over $900^{12}$ elephants in 1999 within Gokwe North District, most of which were either resident or used the habitat created by the corridor (Khumalo, 2003). Between the establishment of the corridor in 1991 and 2000, there were low levels of illegal hunting within its boundaries. Importantly, levels of illegal offtake were never considered serious enough to affect commercial hunting quotas which remained relatively stable during the same period (Khumalo, 2003).

Post-2000. The general trend within the corridor seems to be of increasing illegal use of wildlife. Commercial poaching for ivory was not a major feature before 2000 . After 2000, it appears to have developed and may involve representatives from the military and senior politicians. ${ }^{13}$ Informants estimate that between January and August 2004, at least 14 elephants were illegally killed in the wildlife game area. Informants claim that the elephants are now being killed for their ivory and not their meat suggesting that illegal hunting has moved from subsistence to commercial levels. The safari operator also noticed an increase in the use of licensed and unlicensed weapons in the area. Within the Nenyunga community, there were unconfirmed sightings of poachers in army uniforms. Poachers with strong political connections were not being arrested. In 2001 it was estimated that the resident population of elephant in Gokwe North had declined to just under 800 from 900 animals in 1999. More importantly, the proportion of elephants in the communal lands of the Sebungwe had fallen from 37 to 29 per cent, ${ }^{14}$ an indication of habitat loss through settlement (Dunham and Mackie, 2002). Furthermore, the 2001 national aerial survey showed that the carcass ratio, which is the ratio of dead to live elephants, within Gokwe had increased from 3.9 per cent in 1999 to 5.8 per cent in 2001 (Mackie, 2002). The political crisis created an environment conducive to rent-seeking practices by those who are politically connected.

\section{Financial management and benefits}

\section{Co-management case study}

Pre-2000. Funds generated by co-management have always been limited. Financial management at the RMC level has always been contested, with the misuse of funds occurring in some RMCs. Interviewees also cited attempts to bring some of those who had misappropriated RMC funds before traditional leaders in the Batanai RMC.

Post-2000. The revenue generated by RMCs is limited. One of the reasons given by the RMC members for the low revenue collected is low permit fee for broom grass 
collection. The daily permit fee at the time of fieldwork was 500 Zimbabwean dollars (about US\$0.08). In 2004 the RMCs asked for all payments to be made in cash rather than in kind, which increased revenues. Timber can generate significant amounts of revenue, but RMCs had no access to this revenue because the Forest Act of 1996 says such revenue has to accrue to the rural district council as the land authority. The Forestry Commission also receives a 15 per cent commission for carrying out forestry inventories and verifying quantities logged by concessionaires.

\section{CAMPFIRE case study}

Pre-2000. Gokwe RDC allocated revenue to wards on a producer-per-ward principle. Nenyunga ward, with the highest proportion of land in the corridor, received substantial dividends between 1991 and 1999. The highest recorded disbursement, in 1996 , was $\$ 19,488$. It is important to point out that while the situation was not ideal pre-2000, information was available on the proportion devolved to the rural communities at ward level. At Gokwe North RDC level, 53 per cent of CAMPFIRE revenue was disbursed to communities in 1991, although by 1999 this percentage had fallen to 18 per cent (Khumalo, 2003).

Post-2000. The dividends received by Nenyunga ward have dramatically fallen over the years due to high levels of inflation and withdrawal of external donor support. Of the total revenue received from 1991 to the present $(\$ 86,165), 95$ per cent was received in the nine years between 1991 and 1999 (with an average annual ward dividend of $\$ 9117$ ). Between 2000 and 2005 the ward received a total of just $\$ 4134$, an average dividend of $\$ 827$ per annum. The worst year was 2003 , when Nenyunga was entitled to only $\$ 117$ and the councillor took the cheque and allegedly failed to cash it.

\section{Financial accountability}

\section{Co-management case study}

Pre-2000. Financial accountability was a major challenge even in the pre-2000 period; but while accountability mechanisms were not effective, there were at least attempts to do something about it. There was even an attempt to incorporate educated people within the RMCs who were capable of carrying out internal audits. Through CIDA's support, basic record-keeping courses were given. In Batanai some of the RMC members were arraigned before the traditional leaders for misappropriating RMC funds. In both Chemwiro-Masawi and Batanai RMCs, the FCZ helped by auditing RMC accounts, and named and shamed those who had misappropriated funds.

Post-2000. The post-2000 financial uncertainty resulted in some RMCs introducing an informal loan system for RMC members without prior approval of the community. Any committee member who faced financial hardship could borrow money from the RMC fund. When the FCZ discovered that RMCs could not account for all of their income, RMC members argued that they had decided to loan out the money to needy RMC members. Since there were no records of these transactions, it was difficult to assess how much had been diverted in this manner. The harsh economic climate was also partly to blame, as office bearers were barely coping with the ever-escalating cost of living. 


\section{CAMPFIRE case study}

Pre-2000. Although accountability in the pre-2000 period was not perfect, there were genuine attempts by the WWMC to be transparent and accountable. Support from a variety of organizations, particularly the Danish Association for International Cooperation (Zimbabwe) and the WWF, assisted in developing financial management systems and skills. Financial records were presented at all WWMC meetings and annual general meetings, allowing interested residents to critique allocations and spending. Another technique used by the WWMC was to display financial statements in public places, such as shops and community centres. In Nenyunga, those who misused CAMPFIRE funds were removed from the WWMC, including the incumbent councillor.

Post-2000. In the CAMPFIRE area the RDC still maintains some oversight of the WWMC's financial affairs and countersigns all financial transactions carried out by the WWMC. However, the constraints on resources at RDC level mean that there are limited efforts to monitor the role of the WWMC. More importantly, the WWMC is no longer perceived as being accountable to the residents of the ward. Financial statements are no longer made public. A longstanding problem animal reporter pointed out that if you ask for a detailed explanation of CAMPFIRE funds, you will 'end up in hot soup'. This has created the conditions for elite capture, as the CAMPFIRE programme in Nenyunga has been hijacked for personal benefits by some committee members, councillors and traditional leaders. Political arguments are used to justify the exclusion and disempowerment of villagers, and even to threaten RDC officials (see Mapedza and Bond, 2006).

\section{ANALYSIS AND DISCUSSION}

The post-2000 period has brought uncertainty politically, economically and socially, all of which has affected the management of natural resources in the Gokwe area. High inflation has seriously eroded the benefits that most resource managers derive from the communal areas of Zimbabwe (the annual inflation rate reaching 1,694,000 per cent at the time of writing). ${ }^{15}$ In the forest sector, proceeds from NTFPs, which have always been low, have been further eroded, making them even less significant for community development projects. One of the main weaknesses of co-management as practised in Mafungautsi is the exclusion of proceeds from timber, leaving the RMCs access to only low-value forestry resources. Allowing local communities access to lowvalue minor products acts as a disincentive in co-management. Meaningful resources need to be devolved for local communities to invest their time and effort in partnering for sustainable management of forests and wildlife. In Zimbabwe, the partnership was tilted in favour of the state, with co-management largely viewed as a cheaper form of maintaining reserved forests.

In Nenyunga, revenue has also been eroded by inflation and the withdrawal of donor support in the form of transport, PAR allowances and the purchase of bullets, all of which now have to be paid for from diminishing CAMPFIRE dividends. Financial difficulties have also led the RDC to reduce the proportion of revenue it can plough 
back into the wards. The weakened WWMC has become subject to the whims of a councillor who was more interested in advancing his interests in the name of the ruling party, at the expense of the initial intended beneficiaries of CAMPFIRE. Previous gains in local resource management capacity and knowledge are now being eroded. In both co-management and CAMPFIRE, the withdrawal of external support from CIDA and USAID, which was largely viewed by the Zimbabwean government as punishment for embarking on the controversial land reform programme in 2000, has also had a detrimental effect. There is an increasing erosion of most of the pre-2000 achievements, despite their shortcomings.

The fact that the institutions for resource management in both co-management and CAMPFIRE still exist, though very weak, is some cause for hope. However, the mere presence of institutions without meaningful powers will not positively contribute to CBNRM. Both co-management and CAMPFIRE institutions lacked the powers to make their own rules. Most of the legislative powers lay with higher-level institutions. In both instances, the local institutions were reduced to enforcing externally derived rules and regulations. These tendencies cannot be interpreted in isolation from the increasingly dictatorial policies in Zimbabwe. It is, indeed, true that some upward accountability is required to ensure the protection of critical ecosystem services; however, oversight of local institutions by higher-level authorities does not need to be dictatorial. Local-level institutions need to be accompanied by a more democratic dispensation, and long-term solutions are needed which can be resilient in the face of continued and significant political uncertainty.

\section{CONCLUSIONS AND POLICY RECOMMENDATIONS}

The following policy recommendations are offered on the basis of two underlying goals:

1 to promote more sustainable livelihoods for people who rely on the two resource regimes; and

2 to sustainably manage the resource base (forests and wildlife) for local and global benefits.

These recommendations are directed at policy-makers and funding agencies within the environmental sector:

- Increase the direct incentives flowing from sustainable resource management to local communities. In the CAMPFIRE case this implies decentralizing the relationship between the safari operator and the local community. A direct link between these two actors will help local communities to derive benefits directly, rather than indirectly through the local authority, as is the case at present. This arrangement was denied by politicians right at the conception of the CAMPFIRE programme. This more direct arrangement will give local communities stronger incentives for managing their 
natural resources and promote local-level accountability. In the Nenyunga case study, revenue was no longer being passed to the ward wildlife management committee on time and the proportion received continues to fall as central government reduces spending on service provision. This means that the local-level institutions are being deprived of the necessary resources to monitor environmental management and outcomes. In the co-management area, there is a need to change legislation to allow RMCs to access proceeds from commercial timber concessionaires so that incentives for local communities are increased.

- Give local communities greater powers to deal with problem animals and related local issues. The effective management of problem animals could reduce the disincentives for sustainable wildlife management among local communities. Effective problem animal control (PAC) requires rapid response. With local government facing transport constraints, local communities are better placed to carry out this activity and reduce human-wildlife conflicts. The state should devolve this role and the requisite resources to the local communities, while maintaining an oversight role. PAC can be effectively handled by the ward wildlife committee with the support of locally recruited animal reporters and former fence minders. Support would be needed to further train them in order to ensure that minimum hunting licensing requirements are met and to effectively deal with problem animals. Other locallevel decisions should be made locally in line with the subsidiarity principle.

- Reassess the balance between livestock and wildlife in light of the difficulties of maintaining wildlife corridors, the need for tsetse control and the lack of prior research on the real risks of livestock grazing to wildlife. Some of the Nenyunga community members were of the view that agricultural production and livestock rearing would bring more benefits than wildlife. In the forestry area, grazing and agricultural activities were also perceived as bringing more benefits to the local communities than protected forests. More rigorous cost-benefit assessments and ecological assessments of grazing impacts need to be carried out within the two case study contexts to help strike a reasonable balance between agricultural activities and conservation.

- Create mechanisms to add value to both wildlife and forestry resources. Such initiatives might include eco-tourism, which has the potential to generate more income and offer employment opportunities. It is, however, important to note that ventures such as eco-tourism are capital intensive and might require public support or partnerships with outside investors. Training would also be needed for the local communities to be able to manage such ventures as a profitable business.

- Increase donor support to the areas of local community representation and accountability within existing institutions. Institutional support for resource management committees and ward wildlife management committees will enhance local capacity not only to manage wildlife and forests, but also to manage other natural resources. Donor support should be tailored in such a way that it results in resilient institutions capable of managing their natural resources after external support is withdrawn. This would be similar to the support previously provided by USAID, the WWF, Zimbabwe Trust and other CAMPFIRE Collaborative Group (CCG) members, and by the Canadian International Development Agency in the co-management area (who provided resources for building the capacity of RMCs). 
These policy recommendations have to be assessed in the context of the current unstable political context in Zimbabwe, which makes it difficult to affect central and local government functions. This makes it even more essential that local communities have the resources - financial, technical and effective governance systems - to manage resources sustainably in the face of instability. This chapter and the broader literature show that this requires democratic decentralization which empowers the local community, rather than administrative decentralization which increases central government monitoring at the local level. With increasing threats to the state, there is now an increased tendency to centralize power and undermine moves towards democratic decentralization - perceived as providing a forum for local-level dissent. However, even within such an oppressive context there are indications that increasingly undemocratic practices will not be sustainable for long; local and international condemnation should eventually bring more democratic governance to Zimbabwe.

\section{NOTES}

1 Communal areas are where most black Zimbabweans live.

2 As of 16 July 2008, the Zimbabwean dollar was worth 600 billion Zimbabwean dollars against US\$1. Inflation was 2.2 million per cent in June 2008 (The Mail and Guardian, www.mg.co.ac.za, accessed 16 July 2008).

3 These are people who facilitate business for a profit. In the wildlife sector, for instance, politicians who are supposed to regulate the sector might facilitate hunters' access to wildlife for a fee.

4 While Corrales (2004) was analysing the Cuban crisis and how the Castro regime seemed to have weathered the economic crisis, this explanation has resonance with what is happening in Zimbabwe.

5 The CCG members included the CAMPFIRE Association (CA), World Wide Fund for Nature (WWF), the Centre for Applied Social Sciences (CASS), Zimbabwe Trust (ZimTrust), the Forestry Commission (FCZ) and the Department of National Parks and Wildlife Management (DNPWM).

6 Illegal resource utilization. Legal hunting is based on annual quotas that are calculated on the basis of the annual wildlife population.

7 These are structures of the ruling Zimbabwe African Nationalist Union (ZANU) Patriotic Front (PF) party.

8 One should also note that this is the third wave of invasions into Mafungautsi. The first wave was around 1979/1980, the second in 1984/1985 and the current one began in 2000 alongside the 'fast-track land reform'.

9 The funds for the electric fence came from the Rio-Tinto Foundation. Rio Tinto (Zimbabwe) was at the time developing the Sengwa Coalfield in the adjacent Simchembu ward.

10 This is land set aside to allow free movement of wildlife usually connecting two ecological zones.

11 The people of Zhomba feel that cattle and crops are more important than wildlife (former fence supervisor interviewed on 2 September 2004). 
12 Precise estimates of wildlife populations are extremely difficult, if not impossible, to obtain. Aerial surveys rely on a sample technique from which the total population is estimated within given confidence intervals.

13 Recently two Chinese nationals were arrested in Harare with 74 elephant tusks (See The Daily Mirror, www.dailymirror.co.zw, accessed 6 July 2005).

14 The Sebungwe communal area comprises Gokwe North and Nyaminyami rural district councils. The logic behind a combined survey is to assess if wildlife has not just relocated within the same broader agro-ecological region.

15 As of May 2008 inflation was above 1.6 million per cent.

\section{REFERENCES}

Anstey, S. (2005) 'Governance, natural resources and complex adaptive systems: A CBNRM case study of communities and natural resources in Northern Mozambique', in U. Dzingirai and C. Breen (eds) Confronting the Crisis in Community Conservation: Case Studies from Southern Africa, University of KwaZulu- Natal Press, Pietermaritzburg, pp138-193

Bond, P. and M. Manyanya (2002) Zimbabwe's Plunge: Exhausted Nationalism, Neoliberalism and the Struggle for Social Justice, Weaver Press, Harare

Child, B., H. Moinuddin, B. Jones, A. Mlalazi and D. Mazambani (2003) Communal Areas Management Programme for Indigenous Resources Final Evaluation Report: Zimbabwe Natural Resources Management Program - USAID/Zimbabwe Strategic Objective No 1, USAID, Harare

Chitsike, L. T. (2000) Decentralization and Devolution of Campfire in Zimbabwe, CASS, University of Zimbabwe, Harare

Corrales, J. (2004) 'The gatekeeper state: Limited economic reforms and regime survival in Cuba, 1989-2002', Latin American Research Review vol 39, no 2, pp36-65

Dunham, K. M. and C. S. Mackie (2002) National Summary of Aerial Census Results for Elephant in Zimbabwe: 2001, WWF-SARPO, Harare

Dunham, K. M., C. Davies and K. Muhwandagara (2003) Area and Quality of Wildlife Habitat in Selected CAMPFIRE Districts, Report prepared for WWF-SARPO, WWF, Harare

Hammar, A., B. Raftopoulos and S. Jensen (2003) Zimbabwe's Unfinished Business: Rethinking Land, State and Nation in the Context of Crisis, Weaver Press, Harare

Logan, O. (2005) The Age of Consent: A Manifesto for a New World Order, http://72.14.207.104/ search?q=cache:VyWXpnj8yxwJ:www.redflag.org.uk/frontline $/ 17 / 17$ monbiot.html+gate keeper+state $\& h \mathrm{l}=\mathrm{en} \& \mathrm{gl}=\mathrm{uk} \& \mathrm{ct}=\mathrm{clnk} \& \mathrm{~cd}=10$, accessed 8 January 2006

Mackie, C. S. (2002) Aerial Census of Elephants and Other Large Herbivores in the Sebungwe Region, Zimbabwe: 2001, WWF-SARPO, Harare

Manor, J. (2005) 'User committees: A potentially damaging second wave of decentralization?', in J. C. Ribot and A. M. Larson (eds) Decentralization of Natural Resources: Experiences in Africa, Asia and Latin America, Frank Cass, London

Mapaure, I. (2001) The Influence of Elephants and Fire on the Structure and Dynamics of Miombo Woodland in Sengwa Wildlife Research Area, Zimbabwe, DPhil thesis, Tropical Resource Ecology Programme, University of Zimbabwe, Harare 
Mapedza, E. and I. Bond (2006) 'Political deadlock and devolved wildlife management in Zimbabwe: The case of Nenyunga Ward', Journal of Environment and Development, vol 15, pp407-427

Mapedza, E., J. Wright and R. Fawcett (2003) 'An investigation of land cover change in Mafungautsi Forest, Zimbabwe, using GIS and participatory mapping', Journal of Applied Geography, vol 23, pp1-21

Martin, R. B. (1986) Communal Area Management Programme for Indigenous Resources (CAMPFIRE), Branch of Terrestrial Ecology, Department of National Parks, Harare

Matose, F. and S. Watts (2008) 'Towards Community-Based Forest Management in Southern Africa: Do Reforms Lead to Improved Livelihoods for the Poor?', paper presented at the Durban, CIFOR/DWAF workshop.

Murindagomo, F. (1997) Wildlife, Cattle and Comparative Advantage in Semi-Arid Communal Lands and Implications for Agropastoral Options and Government Policy: A Case Study in the Sebungwe Region, Zimbabwe, M.Phil thesis, University of Zimbabwe, Harare

Murphree, M. W. (1991) Communities as Institutions for Resource Management, CASS, University of Zimbabwe, Harare

Raftopoulos, B. (2001) 'The labour movement and the emergence of opposition politics in Zimbabwe', in B. Raftopoulos and L. Sachikonye (eds) Striking Back: The Labour Movement and the Post-Colonial State in Zimbabwe, 1980-2000, Weaver Press, Harare, pp1-24

Rukuni, M. and C. K. Eicher (1994) Zimbabwe's Agricultural Revolution, University of Zimbabwe, Harare

Vermeulen, S. J. (1996) 'Cutting of trees by local residents in a communal area and an adjacent state forest in Zimbabwe', Forest Ecology and Management, vol 81, pp101-111 


\title{
Bridging the Gap between Environmental Decision-Makers in Madagascar
}

\author{
Nadia Rabesahala Horning
}

\section{INTRODUCTION}

Madagascar is recognized as one of the countries richest in biodiversity. Because of its exceptional biological wealth, the country has enjoyed significant foreign and national support for biodiversity conservation since the 1980s. Yet, deforestation and the environmental degradation (including biodiversity loss) that it causes continue to vex donors, national policy-makers and farmers alike. To explain this paradox this chapter argues that conservation results are not commensurate with conservation efforts because conservation models and policies overlook the specific and limited conditions under which conservation behaviour can occur. To do this, I employ an analytical framework that singles out key actors, their interests in supporting conservation (or not), the institutional and financial means mobilized for conservation, and the conservation outcomes that institutions ultimately produce at local and national levels.

Following a brief introduction to conservation theory and history in Madagascar, the chapter analyses findings from the two levels of analysis. It first focuses on the community level and examines the causal links between rules and resource users' conservation behaviour (measured in terms of forest cover change). It draws on a 1998 to 1999 study conducted in southern Madagascar with five communities living on the periphery of various types of protected forests. Employing the same analytical framework, the second part of the chapter moves to the national level to evaluate the link between foreign assistance and conservation policy outcomes (measured in terms of the government's commitment to adopt conservation policies) since the implementation of the country's National Environmental Plan (1991 to present). The chapter then proceeds to combine the two levels of analysis to show that conservation is likely only under specific and limited conditions. 


\section{BACKGROUND: HISTORICAL ANTEGEDENTS TO MALAGASY BIODIVERSITY CONSERVATION}

Four political economic periods mark Madagascar's post-colonial history. The first is the immediate post-colonial period (1960 to 1971), followed by a period of scientific socialism (1972 to 1981); the third is the liberal reforms and structural adjustment period (1982 to 2001). The final and current period (2002 to present) has been a period of democratic and free-market experimentation. Although successive governments enacted distinct economic policies throughout these periods, the injection of foreign aid into the economy constitutes a common thread: Madagascar has never suffered a shortage of bilateral and multilateral development assistance. The reasons for steady aid inflows are beyond the scope of this chapter, but attracting foreign aid has been an important task of the executive since 1960.

In the first two periods France, the former colonizer, was Madagascar's main source of foreign aid, given its substantial economic and political interests in this former colony. With the advent of neoliberal reforms during the 1980s, multilateral assistance via the International Monetary Fund (IMF) and the World Bank began to weaken France's influence by introducing new development assistance partners for the Malagasy state. The post-Cold War international environment was particularly propitious for the imposition of neoliberal policies, of which structural adjustment programmes (SAPs) are the best example. Additionally, as was the case with many African countries, Madagascar faced tremendous economic problems at that particular time. As the presence of international institutions grew, Anglo-Saxon (as opposed to French) interests began to influence the country's policy agenda and the environment emerged as a critical policy issue. ${ }^{1}$ Consequently, environmental protection occupied a central role in the country's policy agenda during the last two political economic periods.

Partly because environmental protection was a brand new policy goal in the neoliberal era, no environmental protection institutions per se were formerly in place. ${ }^{2}$ The Waters and Forests Division of the Ministry of Agriculture (DEF), the Land Division of the Ministry of Agriculture (DD), and the National Geographic Institute (FTM) had management rather than protection mandates. These state institutions, like many of their counterparts in sub-Saharan Africa, were notoriously inefficient, corrupt, understaffed (particularly the first two) and underfunded. Foreign donors took it upon themselves to address this institutional gap.

\section{Madagascar's National Environmental Action Plan (NEAP)}

The first programme of its kind in Africa, Madagascar's National Environmental Action Plan (NEAP) was set up in 1988 with strong support from the World Bank. It was given legal status when the National Assembly passed Law 90-033 in December 1990. This programme was to support the Malagasy government to develop policies and carry out projects aimed at alleviating the island's environmental problems. Designed as a three-phase, 15-year programme, the NEAP's implementation began in 1991. The NEAP contained six components, of which 'protecting and managing the national heritage of biodiversity' was one. ${ }^{3}$ 
This policy was to be carried out in three five-year phases known as EP1 (1991 to 1995), EP2 (1996 to 2002), and EP3 (2003 to 2008). The main objective in EP1 was to create the regulatory and institutional framework necessary to carry out the country's new environmental policy. Existing institutions were strengthened (FTM's spatial data and analytical capabilities were updated), while new institutions for environmental protection were established. The latter - and perhaps the most noteworthy - NEAP innovations (Gezon, 2000) include the Agence Nationale d'Actions Environmentales (ANAE) (for soil conservation), Agence Nationale pour la Gestion des Aires Protégées (now Madagascar National Parks) (ANGAP) (for protected area management and biodiversity conservation), and Office Nationale pour l'Environnement (ONE) (for policy formulation, improvement in the regulatory framework and environmental awareness). A new Ministry of the Environment was also created. In addition, enabling legislation was introduced for the creation of foundations and trust funds as mechanisms for sustainable funding; for forest protection and management; and for decentralized resource management. The proliferation of environmental actors in this initial phase called for the creation of a multi-donor secretariat to facilitate communications among executing agencies.

In EP2, activities supported under EP1 were to be consolidated, with particular emphasis on integrating local resource users within the country's environmental management schemes. EP3, the final phase, sought to mainstream environmental considerations into the country's overall macro-economic management and sectoral programmes (Gaylord, pers comm, 6 July 2005). As a result of both the state and donors' commitments to protect the environment, much foreign aid has poured into biodiversity conservation since the NEAP's inception. Funding increased steadily, from around US $\$ 100$ million to US $\$ 170$ million, throughout the three phases of the NEAP. For EP2 and EP3, 30 per cent of the total budget was to be internally generated (by the Government of Madagascar), which was not the case for EP1. However, unlike EP2, in EP3 the 70 per cent of externally generated funds were granted, not loaned, to Madagascar.

\section{BIODIVERSITY AS A GLOBAL COMMONS}

Because biodiversity is a global commons - or a shared resource in which countless global stakeholders have an interest (with or without a responsibility to protect) - this chapter builds on the scholarship of commons management. In particular, it concerns itself with the issues of scale inherent in common-pool resource conservation (Herring, 2001; Young, 2002; Sayer and Campbell 2004; Berkes, 2006). Largely inspired by the work of Ostrom (1990), students of commons management have explored commons governance by studying single-level phenomena. Many scholars have focused on the local or community level (Bromley, 1992; Uphoff, 1992; Gibson et al, 2000; Agrawal and Gibson, 2001). Some have worked at the national (Ascher, 1999) and international levels (Breitmeier et al, 2006), sometimes linking these two levels (Ostrom, 1995). Yet others have explored linkages between local and global 
commons governance (Keohane and Ostrom, 1995; Young, 2002) and between national and local commons governance (Agrawal, 2005).

While focusing on one or the other level has generated many important lessons, the existing body of scholarship has yet to recognize and demonstrate that these lessons carry across levels. This chapter addresses this gap by exploring the extent to which the logic and dynamics of resource conservation that prevail at the community level also apply to the national level in Madagascar. Among scholars interested in cross-level linkages in commons management, Young (2002) warns against the possible pitfalls of 'scaling up' from (or, in other words, applying the principles known to work among) local institutions to solve global environmental problems due to differences in problem structure, agency and social context. This chapter challenges this position, not by linking local-level phenomena to global ones per se, but by showing that community dynamics 'scale up' or apply to the national level in the context of Madagascar. This analysis is different from what has thus far been written on Madagascar to the extent that existing analyses have focused on the interplay between foreign stakeholders (donors, NGOs, etc.) and Malagasy decision-makers (Kull, 1996; Duffy, 2006). Recognizing that similar principles exist at both the national and local levels of environmental decision-making is important, partly because it helps to understand the extent to which (and reasons why) conservation outcomes are possible only under specific and limited conditions. By logical extension, when such conditions do not exist, the challenges of biodiversity conservation persist.

The most common explanations for deforestation and biodiversity loss in Madagascar relate to high population growth, poverty and the resulting pressures on the environment (energy needs, access to agricultural land, illicit exploitation of natural resources such as wildlife and timber, mining, etc.). If it were true that poverty, broadly defined, causes deforestation, one would expect patterns of deforestation to vary with levels of economic well-being. Yet patterns of deforestation vary across and within the island's various regions in ways that are largely independent from socio-economic indices: some forests are severely degraded in some parts, whereas others are largely undisturbed. Economic (market infrastructures) and natural (soil erosion and climate change) factors have also been identified as causing or exacerbating deforestation; but most analyses emphasize agricultural systems such as tavy (slash-and-burn agriculture) as major culprits. While it is undeniable that slash-and-burn agriculture as well as wild fires, coupled with population growth, exacerbate pressures on forests in the eastern and southern parts of the island, one must not overlook the fact that state-sanctioned mining and timber operations have caused great damage to forest habitats as well - that is, explanations blaming farmers' practices are, at best, incomplete.

In addition to anthropogenic factors, institutional explanations have been identified at two principal levels. At the national level, existing institutions' low management capacity has been pointed out, while, at the local level, limited tenure security is seen as a hindrance to agricultural intensification - hence, destructive practices. Institutional causes of deforestation put forth in Madagascar, while filling an explanatory gap, similarly do not offer a complete picture because they do not pay due attention to how key actors' interests shape institutions at multiple levels of decision-making. This chapter explores ways in which these institutional explanations can be supplemented to identify solutions thus far underexplored. 


\section{METHODS}

Data for this research were collected at various administrative levels in Madagascar from 1998 to 2005. For the community level, five communities located in Bara country, southern Madagascar, were selected. These communities are adjacent to four forests with different protection status (Zombitse National Park, Ihera and Iarindrano Classified Forests and Analavelona Sacred Forest), and all depend upon forest access for their livelihood. ${ }^{4}$ They were relatively similar in population size (with the exception of the one neighbouring the national park), but varied in terms of distance to markets and to the forest. Table 12.1 summarizes the demographic and geographic characteristics of these communities.

At each site, five sets of variables were considered:

1 state and community actors, of whom forest users are subsets;

2 forest resources;

3 rules in use;

4 compliance with rules; and

5 conservation outcomes.

A cross-sectional survey design was used to collect data on the dependent variable (changes in forest cover) and a host of independent variables. The latter included different attributes of the rules governing resource use and access, attributes of the resource, and the proximity of villages to forests and markets (for forest product harvest and sale) and to courts (for dispute resolution). The attributes of rules included whether or not rule regimes balanced prescriptions (must), proscriptions

Table 12.1 Characteristics of surveyed communities: Demographics and isolation

\begin{tabular}{|c|c|c|c|c|c|}
\hline $\begin{array}{l}\text { Community } \\
\text { (population size) }\end{array}$ & Forest & $\begin{array}{c}\text { Number of } \\
\text { households* }\end{array}$ & $\begin{array}{c}\text { Household } \\
\text { size }^{*}\end{array}$ & $\begin{array}{c}\text { Time to } \\
\text { market (hours)* }\end{array}$ & $\begin{array}{l}\text { Time to forest } \\
\text { (hours on foot) }\end{array}$ \\
\hline Andranoheza (357) & Analavelona & 76 & 5.1 & 2.5 & 3.5 \\
\hline Fanjakana (249) & Sacred Forest & 52 & 4.8 & 12.3 & 1 \\
\hline $\begin{array}{l}\text { Andranomaitso } \\
\text { (814) }\end{array}$ & $\begin{array}{l}\text { Zombitse } \\
\text { National Park }\end{array}$ & 148 & 5.5 & 2 & 0.3 \\
\hline Mitia (422) & $\begin{array}{l}\text { Ihera } \\
\text { Classified Forest }\end{array}$ & 111 & 4.7 & 3 & $<1$ \\
\hline larindrano (298) & $\begin{array}{l}\text { larindrano } \\
\text { Classified Forest }\end{array}$ & 85 & 3.5 & 3.5 & $<1$ \\
\hline
\end{tabular}

Notes: Population figures are approximate for 1999.

* Indicates average figures.

Source: Rabesahala Horning (2004, p110) 
(must not) and permissions (may), and whether or not sanctions (or else) were commensurate with infractions. Another attribute concerned the consistency and predictability of monitoring and sanctioning. Data on the particular contexts in which these rules were devised and implemented were also collected.

The survey relied on several instruments, which included a survey questionnaire (170 individuals, representing 30 to 58 per cent of all households), rapid appraisal exercises, semi-structured interviews, focus group interviews, and visual analysis of remotely sensed data. The main purpose of interviewing individuals was to gain forest users' perspectives on their livelihood strategies, resource needs and isolation; their knowledge and understanding of rules governing resource access and uses; their assessment of the legitimacy of rules and rule enforcement authorities, and of the effectiveness of existing institutions in inducing compliance; and their outlook on the future of their environment. Changes in forest cover over a 51-year period (1949 to 2000) for each of the study sites were determined comparing topographic maps from 1957 (generated from 1949 aerial photographs) and Landsat Thematic Mapper satellite imagery (path 160, row 76) acquired in 1989 (11 April), 1994 (3 November) and 2000 (23 August).

For levels of analysis beyond local communities, individual interviews were conducted at the commune (township), provincial and national levels between 1998 and 2005. Informants included forest agents, conservation project personnel, mayors, national and foreign NGO representatives, university students and professors; representatives of the World Bank, the United Nations Development Programme (UNDP) and the US Agency for International Development (USAID); and foreign and national consultants.

\section{COMMUNITY-LEVEL DYNAMICS: THE LINK BETWEEN RULES AND CONSERVATION OUTCOMES}

\section{State rationale and conservation models}

Madagascar's conservation models are predicated upon two principal assumptions. The first - addressed in this section - is that successful conservation requires rules to provide incentives for resource users to be good stewards of natural resources, specifically, state-devised rules such as forest legislation or the Environmental Charter. In other words, legislation is a precondition for resource and biodiversity conservation. This belief in the conservation power of state rules largely explains why conservation strategies have favoured the establishment and, more recently, the expansion of protected areas. In September 2003, for instance, an executive decision was made to more than triple the total area under (state) protection, going from 1.7 million hectares to 6 million hectares, effective immediately. ${ }^{5}$ Although the decision came to some as a surprise, it was a mere confirmation of state officials' belief that forests under official state protection stand a better chance of being protected. 
Historically the establishment and maintenance of protected areas represents the most explicit attempt at keeping farmers out of forests. State legislation enacted in the 1930 s, when these protected areas were created, governs forest access and use to this day. As long as the colonial state was willing and able to enforce its laws, forest legislation effectively induced farmers' compliance. Upon independence, the Malagasy state preserved the system of protected areas that the French had developed and the forest legislation that governed their protection. It did not, however, maintain the apparatus necessary to enforce its own laws, thereby rendering them relatively ineffective.

\section{Challenging the state rationale: Evidence from the ground}

Not surprisingly, President Ravalomanana's ambitious plan to triple the island's network of protected areas received praise from conservation enthusiasts. Yet, at least in the case of forest habitats where 90 per cent of the island's biodiversity is found, the notion that resources are better protected when placed under the formal protection of the state is, at best, questionable. As an example, the study conducted in Bara country shows that the existence of state rules does not necessarily guarantee that forests will be conserved (Rabesahala Horning, 2004). In fact, deforestation was most severe in and around Zombitse National Park, which is governed by the most restrictive form of conservation. By contrast, the community-managed sacred forest of Analavelona was remarkably well preserved. As for the two classified forests (in principle under state management), deforestation occurred in one and not in the other. Table 12.2 summarizes the rates of deforestation for the period 1989 to 2000 in this area, showing that for the two periods surveyed (1989 to 1994 and 1994 to 2000) the government-managed national park is the most severely deforested. One is thus hard-pressed to claim that stricter rules automatically produce conservation behaviour.

Table 12.2 Extent of deforestation around southern forests

\begin{tabular}{lcccc}
\hline Forest & \multicolumn{3}{c}{ Deforestation (forest to non-forest cover) } \\
\cline { 2 - 5 } & \multicolumn{2}{c}{$1989-1994$} & \multicolumn{2}{c}{$1994-2000$} \\
\cline { 2 - 5 } & Percentage & Hectares & Percentage & Hectares \\
\hline Analavelona Sacred Forest & 0 (ND) & 0 (ND) & 0 (ND) & 0 (ND) \\
Zombitse National Park & 24 & 1646 & 9 & 489 \\
lhera Classified Forest & 0.13 & 4 & 0.07 & 2 \\
larindrano Classified Forest & 0 (ND) & 0 (ND) & 0 (ND) & 0 (ND)
\end{tabular}

Note: ND = none detectable.

Source: Rabesahala Horning (2004, p119) 


\section{Community-level dynamics}

The study also revealed that the rules that influence behaviour at the community level are rules in use, or rules as applied. ${ }^{6}$ These rules in use are hybrids of state legislation and community-devised rules and norms (for examples of community-devised rules, see Rabesahala Horning, 2005). They result from dynamic relationships that involve key actors who operate according to particular interests in specific dynamic contexts. These key actors come from two traditionally interacting camps: the state and rural communities, of which forest users are subsets. The nature of the relationship among key actors varies, depending upon their purposes vis-à-vis forests. Sometimes, key actors from both camps agree on exploiting the forest (e.g. for logging or mining). At other times, they derive more benefit from keeping the forest standing (e.g. for pasture or protected areas such as nature reserves and national parks). In both cases, they cooperate in order to achieve their shared goal of monopoly over resource access. When key actors' purposes vis-à-vis the forest diverge, they compete - using rules as tools of exclusion, but with the goal of prevailing over one another. Cooperation, competition and mutual ignorance thus occur, depending upon the specific context in which rules are interposed and applied - that is, rules are dynamic and contested, not static. Furthermore, the conservation outcomes that ensue influence the dynamics of local-level negotiations, thereby creating a feedback loop. The Bara study reveals that key players' ability to devise and diffuse rules in use that are compatible with local production systems; monitor compliance and enforce rules; and legitimize their authority and the rules that they enforce in the eyes of forest users determine whether and to what extent they succeed in achieving and maintaining a power of exclusion through users' compliance with state rules.

\section{Theoretical implications}

To determine the conditions under which rules are most likely to produce conservation outcomes, one needs to frame the relationship between rules and conservation behaviour within the larger context of interactions among key actors (resource users and others with designated authority); their purposes vis-à-vis the forest (actors' interests); the rules that actors' interactions produce (institutions); resource users' reactions to the rules (legitimacy and compliance); and the conservation behaviour that the enforcement of these rules produces (resource conservation versus degradation). ${ }^{7}$

Findings suggest that conservation behaviour is likely in two out of four conservation outcome scenarios. First, resource conservation can result when key actors' interests converge towards protecting the resource (against potential users) and rules of exclusion are enforced effectively. This was the case of Analavelona Sacred Forest. Resource conservation is also likely when key actors interested in conservation have strong rule-enforcement capabilities (e.g. to monitor users' behaviour and consistently sanction non-conformance). This was the case for one of the classified forests (Iarindrano). If both sets of actors are interested in exploiting the forest or if the party who wants to conserve lacks the rule-enforcement capabilities, then resource degradation is the likely outcome. Empirically, therefore, 
rules can produce resource conservation as much as they can resource degradation, challenging the assumption that legislation automatically produces conservation behaviour.

While community-level dynamics are critical to understand, it remains necessary to examine the policy context in which these dynamics are produced. The following section examines whether and to what extent local-level dynamics related to interests and institutional design apply where conservation policies are articulated (i.e. at the national level).

\section{NATIONAL-LEVEL DYNAMICS: THE LINK BETWEEN AID AND POLICY OUTCOMES}

The second working assumption behind the predominant conservation model is that biodiversity conservation necessitates state and parastatal organizations to create and implement conservation policies. The creation and maintenance of these organizations, in turn, require considerable financial means. Implicitly, the more money that is invested into the environment, the better the chances of achieving biodiversity conservation. ${ }^{8}$ Since Madagascar is one of the poorest countries in the world and because successive governments have been particularly receptive to donors' calls for environmental protection, the state has relied on foreign aid to finance conservation institutions and programmes. The implicit assumption is that aid (financial and technical) is a precondition for conservation policies to produce conservation behaviour on the part of resource users.

The following sub-section describes national-level dynamics, again exploring the conditions (actors' interests and financial flows to institution-building) under which biodiversity conservation outcomes may be achieved.

\section{National-level dynamics}

At the national level, the two main camps are the Malagasy state, represented by a series of government agencies, and foreign donors. Donors entrust operators such as conservation NGOs with implementing their visions of what constitutes proper conservation (sometimes subsumed under 'development') strategies. These key actors interact in a dynamic environment susceptible to changes in both domestic and international political and economic contexts. At this level, key actors negotiate the state's policy priorities. Sometimes they agree to give conservation the highest priority, in which case conservation institutions are created and maintained. These require considerable financial and human resources that the state can ill afford. For the Government of Madagascar, this means that the success of conservation is contingent upon securing foreign aid in exchange for compliance with donors' conservation/development vision(s). As discussed above, such negotiations have resulted in a plethora of conservation institutions and the creation of a multi-donor secretariat to coordinate environmental activities. ${ }^{9}$ In turn, key individuals from these 
conservation institutions influence negotiations between donors and the government to ensure their own sustainability. In the end, the degree to which the government commits to strong conservation policies is the result of these dynamic negotiations. These dynamics are detailed below.

\section{Madagascar's environmental pledge}

In January 2005 (i.e. less than two years after announcing his government's intention to triple the size of Madagascar's protected areas at the Durban congress), the president announced his Madagascar, Naturellement $!^{10}$ initiative at a Paris-based conference. The idea, he explained, was to integrate environmental protection within Madagascar's overall political and economic strategies and actions. This vision, he went on to say, was a strong message to the Malagasy people (largely absent) and to his government (with key ministries represented). Of course, this was mostly a strong signal to the international community. ${ }^{11}$ On this occasion the president also publicly stated that fostering economic growth without destroying the country's natural heritage is 'a difficult challenge for which we (Madagascar) need the support of the international community', given the resources such a goal demands (République Française, 2005). Ten years of efforts and international support, he declared, helped but did not control environmental degradation. In reality, foreign support had been forthcoming for more than ten years.

\section{Key actors involved in NEAP}

Judging from the respective financial contributions to EP1, the key actors for the first phase of the NEAP at the national level were multilateral (mainly the World Bank/International Development Association (IDA) and the United Nations Development Programme) and bilateral (Norway, Switzerland, France, Germany and the US) donors, on the one hand, and the Government of Madagascar, on the other. Donors funded US $\$ 67.9$ million (80 per cent of EP1 costs) and the Government of Madagascar was responsible for the remaining \$17.1 million (20 per cent). Under EP2, relative contributions remained the same, with the government's contributions nearly doubling due to the increased costs of the programme.

In the final phase, not only did the government's contribution drop to less than 9 per cent, but according to World Bank reports, 70 per cent of the aid that the country received was in the form of grants rather than loans (Rakotoarijaona, pers comm, 28 June 2005). This, one can argue, is an indication of the government's increased ability to get donors to foot its environmental bill. It also suggests that the government's ability to act as a sovereign state is severely compromised: the more donors contribute financially, the better their ability to determine Madagascar's environmental policy. Most likely, it is also an indication that donors were willing to pay a higher price to achieve conservation goals. In fact, the contributions of the World Bank and bilateral donors increased steadily throughout NEAP, while the government's peaked from EP1 to EP2 and dropped thereafter (see Figure 12.1). This begs the question: what interests have donors had in funding biodiversity conservation in Madagascar? 


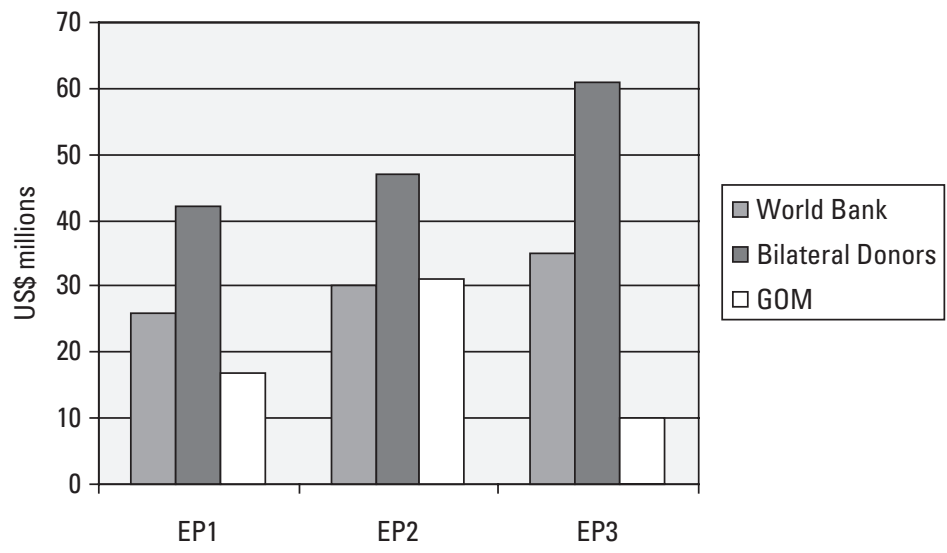

Source: World Bank (1996, 1998)

Figure 12.1 Evolution of financial contributions to the National Environmental Action Plan (NEAP)

\section{Interests}

As mentioned previously, unlike other natural resources such as diamonds, oil or timber, biodiversity is a global common: potentially all humanity can benefit from conserving it (and likewise lose by destroying it). Given the island's high number of endemic plant and animal species, its higher levels of genetic information per unit area (possibly the highest on Earth), the number of discoveries still being made and the severity of environmental degradation, conservation organizations consider Madagascar to be a top priority conservation site or biodiversity hotspot.

As shown earlier, environmental and biodiversity conservation in Madagascar has been donor-driven, fuelled by Western environmental ethics from the Anglo-Saxon tradition (Gaylord, pers comm, 6 July 2005). This is not to suggest that the Malagasy state has not been preoccupied with protecting its natural heritage. Notwithstanding a decade of socialist policies that encouraged open-access behaviour in the rural areas beginning in the mid 1970s, deforestation has preoccupied the state since the 18th century. Since King Andrianampoinimerina united the kingdoms and societies of Madagascar into a relatively unified political system in the late $1700 \mathrm{~s}$, the state has presented itself as a fierce guardian of forests (Harper, 2002). To this day, all forests are considered the sole property of the state (domaine de l'Etat), which in principle gives the state the authority to decide how best to exploit and protect them. As the ultimate guarantor of sustainable forest management, the state has long exercised tremendous power over forest users, ranging from forest-dependent communities to exploitants forestiers. ${ }^{12}$ Yet, the state has generated too few resources (human and financial) to carry out this formidable task, especially since independence. In the absence of state capacity to devise, carry out and finance its own environmental 
policies, foreign donors have been able to dictate how conservation should be carried out. Donors' power to influence conservation policies is evident in the emergence and evolution of the country's environmental sector. ${ }^{13}$

\section{National-level environmental performance}

How effective have conservation efforts been? Assessing a country's environmental performance is no easy task, although reports that discuss the major achievements under the first two phases of the environmental action plan offer indicators (Lindemann, 2004). ${ }^{14}$ Deforestation is a critical indicator of environmental performance because it is central to environmental degradation and because close to 90 per cent of Madagascar's remaining biodiversity occurs in forest habitats. Because the task here is to appreciate the extent to which state policies have supported (or hampered) biodiversity conservation since 1960, one must move beyond the spatial confines of protected areas and consider forest cover, in general.

Harper et al (undated) recently conducted a study of deforestation and forest fragmentation in Madagascar over a 50-year period (1950s to 2000). Setting aside areas obscured by cloud cover, they found that forest extent was 160,000 square kilometres in 1952 and 89,800 square kilometres in 2000. For the 1950 to 1970 period, 6.2 per cent of forests were cut down; for the 1970 to 1990 period, the figure increased to 28.4 per cent; and for 1990 to 2000 it decreased to 8.5 per cent. ${ }^{15}$ Overall, forests covered 27 per cent of the island in the 1950s and 16 per cent in 2000. The decrease in deforestation since the 1990s, the authors point out, is deceiving and remains troubling considering the increased forest fragmentation - with ever smaller portions of forest remaining intact. The combination of deforestation and forest fragmentation leads Ganzhorn et al (2001, p374) to conclude that 'many of Madagascar's ecosystems have been reduced in size and degraded beyond the point of recovery and will suffer further losses in biodiversity'.

\section{Theoretical implications}

Similar to the local level, policy commitment to conservation is likely under a set of specific and limited conditions. Two possible scenarios exist which will lead to strong conservation policy commitments. In one of them, donors and the government agree on making conservation a policy priority. When this is the case, pending foreign assistance, environmental institutions are necessary and relevant. In the other scenario, donor and government interests diverge: donors push for environmental conservation while the government wants to give other sectors (such as agriculture, health or industry) policy priority. Here, policy commitments and meaningful institutional support are not likely without donor funding for conservation. Even then, government support to implementation (and related institutional reforms) can determine the relative effectiveness of outcomes.

The other two scenarios are likely to produce weak to no conservation commitment on the part of the state. If and when each actor's interests in conservation are second to other policy areas, only limited political will can go into conservation. In 
the final scenario the government wants to prioritize conservation while donors do not share this policy interest, in which case environmental institutions are not likely to ensure conservation outcomes mainly due to the state's low financial capabilities (scenario 4).

Since NEAP's inception, Madagascar's scenario has been in the first category. However, conservation policies have been donor driven given foreign actors' impressive financial means and their eagerness to conserve the island's biodiversity. National policies have reflected a commitment to conserve the country's natural wealth, but the government's failure to build local capacities to implement these policies is indicative of feigned compliance rather than a true commitment to conservation. This is because the benefits of institutional investments have stayed in the capital city to finance Madagascar's conservation sector - to the detriment of lower-level environmental institutions (Rabesahala Horning, 2008). As predicted under this scenario, some conservation has been achieved; but outcomes have not been commensurate with efforts put into protecting Madagascar's natural wealth because the benefits of national-level institutional investments did not trickle down to the local level.

\section{WHAT WE LEARN FROM THE TWO-LEVEL ANALYSIS}

The case of Madagascar suggests that the dual conservation models are founded upon a questionable causal link between rules and conservation behaviour at the community level, and aid and conservation policies at the national level. In reality, this study finds that to view rules and foreign-supported conservation institutions as panaceas for conservation ignores the dynamic contexts in which key actors negotiate institutions at both levels. ${ }^{16}$ It also ignores the disconnect that exists between national and community levels in terms of the ability or willingness to reconcile different interests. Instead, it assumes erroneously that more foreign aid will produce strong conservation institutions, which, in turn, will produce strong conservation policies that will translate into effective rules capable of producing conservation behaviour on the part of forest users.

A closer examination of the dynamics at play strongly suggests that understanding conservation outcomes requires one to identify key actors and their purposes vis-à-vis the resources, as well as the institutions that these actors devise to protect their interests. It also requires realizing that these two levels of conservation politics are connected only sporadically through development or conservation projects. More often than not, they evolve in a parallel, not interdependent, fashion because so much energy winds up invested in the creation and maintenance of environmental institutions at the national level. Meanwhile, at community level, the primary manifestation of such an investment is in the form of conservation and development project experiments rather than widespread institutional strengthening, given the shortcomings mentioned above. ${ }^{17}$ These projects have had limited time spans due to donors' budget cycles and changes in the approaches en vogue in the conservation and development worlds (Kull, 1996). It has also taken the form of occasional visits from state officials (the gendarmes and forest guards) touring villages with the main purpose of extortion, at least in the minds of villagers (Rabesahala Horning, 2005). 
At the community level, key actors' success in monopolizing access to resources depends upon one crucial factor: their willingness and ability to enforce rules in use. In turn, key actors' enforcement capabilities partly rely on their ability to legitimize their own authority and to devise rules that are compatible with local production systems. Thus, rules are not best understood as tools of administration, but as tools of exclusion that key players use to exclude other potential forest users from appropriating forest resources. At the national level negotiations revolve around making conservation a policy priority (or not). At this level the government depends upon donors' financial contributions to build and maintain environmental institutions to carry out its policy objectives (through conservation programmes). Donors, for their part, depend upon the government's cooperation and capacity to implement conservation policies to achieve their goals. So long as the state's administrative capacities or political support remain weak, conservation outcomes may be achieved but are likely to be suboptimal.

Ultimately, understanding the dynamics of conservation at both levels, instead of one or the other, makes it clearer why conservation achievements are not commensurate with institutional investments. Figure 12.2 depicts the specific and limited conditions under which conservation has a chance of succeeding at the national and local levels. It shows that out of four possible local-level scenarios, conservation is likely only under two - namely, where rules are in place and where enforcement capacities are strong should actors' interests diverge. Likewise, out of four possible national-level scenarios, conservation is also likely where institutions are in place and where strong financial capabilities can counterbalance the limited commitment by one of the key actors (in this case, government). The case of Madagascar strongly suggests, however, that financial commitments to conservation are not a sufficient condition if the government fails to put in place institutional mechanisms that allow interests or institutions to effectively align at both levels of decision making (symbolized by the lower arrow).

National Level

Local Level

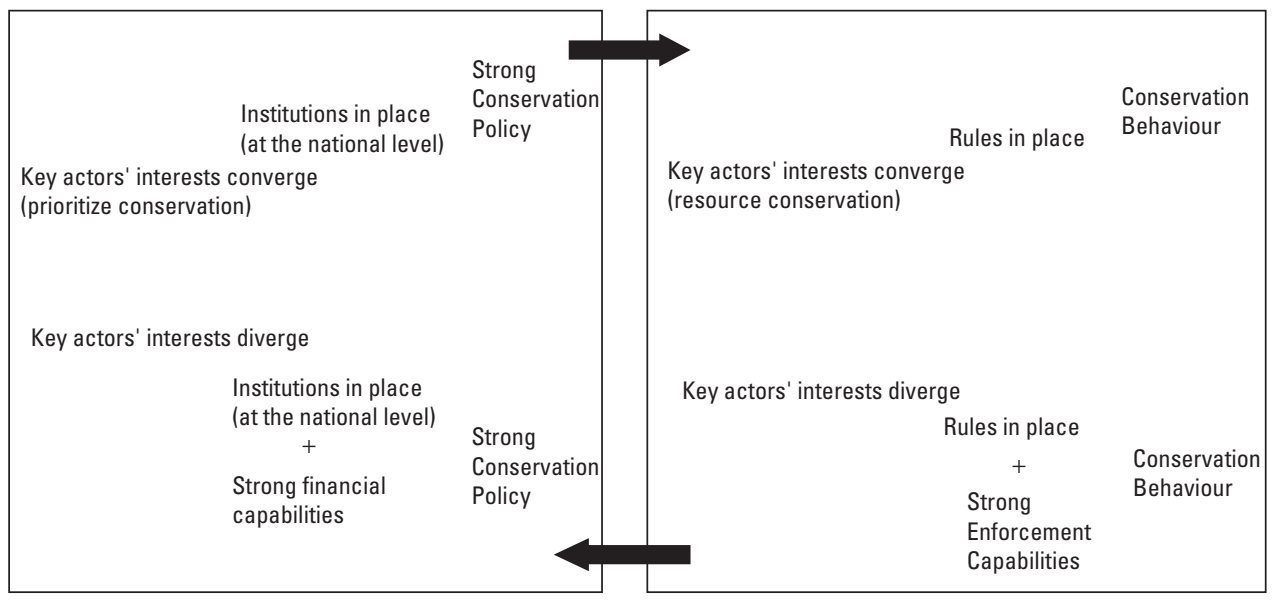

Figure 12.2 National and local conditions for resource conservation 


\section{THE GELOSE EXPERIMENT (1999-PRESENT)}

Having the minimum and specific conditions in place at each level alone may be insufficient for producing conservation outcomes if the functional linkages between the two levels are weak. These include linkages of communication and awareness (e.g. actors' awareness of their rights and responsibilities under co-management), trust (actors' willingness to trust each other, which is, in turn, an outcome of the historical relationship between state and community actors) and interests (whether aligned or opposed to interests at other levels and to conservation outcomes). The challenge of effectively linking decision-makers at multiple levels is well illustrated in Madagascar's GELOSE (gestion locale sécurisée, or secured local management) experiments. Randrianarisoa et al (2008) (see also Box 12.1) report that some of these GELOSE contracts have had positive effects on local livelihoods and the environment in select communities by increasing the economic value of the resource under management (silk worms, in the cases described). While the potential benefits of these contracts have been identified, studies conducted to ascertain the effectiveness and future feasibility of GELOSE contracts as a whole clearly show that the relationship between different levels of decision-making remain tenuous in the absence of strong elements of institution-building, which are often unique to shortterm projects (as in the quality of external facilitation enabling the positive outcomes reported in Box 12.1). Local- and national-level key actors have difficulty integrating each other's interests within their respective management decisions - hence the disconnect between the two levels of decision making (Montagne and Cooke, 2007, pp175-188). This has compromised the capacity of GELOSE to achieve its main goals of effective (rather than nominal) decentralized and sustainable natural resource management.

\section{POLICY IMPLICATIONS}

Achieving better conservation outcomes requires that specific steps be taken. First, policies should be sensitive to the fact that not all situations are conducive to achieving conservation outcomes. Accordingly, projects should target those situations where the minimal conditions discussed in this chapter are met at both levels of decision-making or where they can easily be put into place.

In order to evaluate the extent to which the minimum set of conditions exists at the local level, it is important to evaluate the status of both rules and interests. Rules may be evaluated on the basis of whether rules exist, and the extent to which these rules are enforced. Where rules are not enforced, it is also important to assess the extent to which the rules and those in charge of enforcing them are seen as legitimate by both forest-dependent communities and local government actors responsible for conservation or forest management. Interests in forest management can also be gauged by what these actors say and do, the latter being the best indicator. Where 


\section{Box 12.1 Decentralized forest resource management in the highlands of Madagascar: The cases of Arivonimamo and Merikanjaka}

\section{Aimee Randrianarisoa, Estelle Raharinaivosoa and Annette Kolff}

In 1996, Madagascar adopted the GELOSE (gestion locale sécurisée, or secured local management) policy for the transfer of natural resource management responsibilities to local communities. One year later, the GCF Decree (Gestion Contractualisée des Forets) was passed to elaborate upon the modalities for contracted forest management for the benefit of local communities. These two policy instruments demonstrate the political readiness of the country to decentralize the management of its natural resources.

Under these policies, responsibility for managing decentralized forests was devolved to legally established community forest associations or Communautés Locales de Base (COBAs). In 2000, two successive Swiss-funded rural development programmes (FDP and SAHA) - implemented by Intercooperation, a Swiss NGO supported the transfer of forest resource management. Merikanjaka and Arivonimamo are two of the rural municipalities in the highlands of central Madgascar where the new decentralized forest management policies were put into practice.

In keeping with requests from COBAs, programme support focused on:

- assisting communities in drawing up contracts to transfer and implement land development plans;

- implementing forestry management plans; and

- building local capacity to develop income-generating activities and socio-economic infrastructure.

The positive effects of these management transfer activities can already be seen in the following fields:

- preservation and good management of the Tapia forest;

- control of bush fires;

- regeneration of the declining silkworm population and revival of the silk industry;

- improvement of water supply systems for lowland rice cultivation;

- reduced poaching of medicinal and orchid plants;

- improved living conditions for the most vulnerable households;

- emergence of local leadership;

- strengthening of social capital through stronger relations among COBAs and between COBAs and the communes;

- access to foreign funding. 
Success factors common to the two sites included:

- mobilization of the communal and regional authorities;

- the sense of ownership among COBAs;

- the integrated approach to local development;

- the quality of technical backstopping;

- support to local governance.

At Arivonimamo, the effects of these factors were more tangible thanks to:

- economic valorization of the resource;

- the (pre-)existence of structured business chains;

- regular and immediate benefits perceived by the poorest households.

As for Merikanjaka, cultural motivations made communities favour the transfer of management; however, conflicts between various COBA slowed down the process and undermined the potential benefits, in comparison with Arivonimamo.

Thanks to the spill-over effects from these activities, 19 COBAs in the Arivonimamo rural commune and about 10 in the Merikanjaka commune formed a union which has since received financial support from local authorities. This decentralized management experience was disseminated into neighbouring communes. The experiment ran into the following problems:

- differences in the approaches used by technical and financial partners, which led to problems in internal uptake of the process;

- exclusion of vulnerable groups;

- conflicts of interest between COBAs and within the unions;

- scarcity of available resources;

- retarded implementation of decentralized natural resource management.

In both experiences of community management of forestry resources, the transfer of management to local communities produced encouraging results as long as it included:

- concrete economic development gains;

- proactive efforts to meet the needs of various social categories within local communities; and

- effective cooperation between local communities, community authorities and decentralized forest services. 
actors' actual behaviour vis-à-vis the resource promoted degradation (e.g. through excessive use by local communities or the corrupt behaviour of government agents), reasons for this behaviour must be sought out in order to identify the main motivational barriers to sustainable use. As suggested in Chapters 1 and 4 in this volume, these barriers may be found in the inadequate resourcing of local forest management operations, the market price of the resource, or in the strength of local tenure and institutions to regulate access. ${ }^{18}$

At the national level, baseline conditions are easier to assess: governments are committed to conservation to various degrees; but those strongly committed to conservation are more likely to establish and adequately resource institutions to carry out conservation policies. The situation varies across time. For instance, President Ravalomanana president of Madagascar has worked closely with conservation organizations (via donors), while his predecessor did not. ${ }^{19}$ Recent national conditions were therefore more favourable than they were prior to 2002.

Yet, the minimum set of conditions can also in some cases be put into place where absent in order to enhance the likelihood of success of future conservation initiatives. One possibility is to shift local incentives towards sustainable forest management through supporting local marketing and value addition; grounding efforts in local conservation priorities; and/or strengthening forest tenure. The case study in Box 12.1 highlights how good facilitation can enhance local ownership of decentralized forest management efforts, enhancing local conservation interests through the incorporation of income-generating activities and thus widespread buy-in to the initiative. Increasing the perceived legitimacy of local rules may also be possible through devolving rule-making authority to local communities. Successful experiments with such 'local bylaw' reforms have been reported for Eastern Africa (Sanginga et al, 2004; German et al, 2008).

While this first step of ensuring the minimum conditions are in place is necessary, it is still not sufficient to produce conservation outcomes. Given the context under which decision-makers operate, it is critical to envisage channels of communication among influential actors (i.e. actors whose decisions can potentially affect each other's decisions and, thus, resource use and conservation) across levels. The main purpose of this second step is to help these actors identify areas of common interest, thereby encouraging cooperation around issues of resource management.

In some ways this is a difficult challenge because of the negative perceptions that state and local actors have developed about each other historically. These actors routinely blame each other for the degradation of forest and other resources such as pasture and agricultural lands (Rabesahala Horning, 2005, p152). In other ways this challenge is not impossible to overcome, precisely (and paradoxically) because these two sets of actors have been in touch for a long time. Historically, the state has been effective in reaching out to, and making demands on, local communities. Examples of state-mandated initiatives abound, ranging from tax collection during colonial times to organizing elections or road repairs at the lowest administrative levels since independence (Rabesahala et al, 1994). Undeniably, a state apparatus has been in place which has allowed state actors to make demands and monitor compliance with state-sanctioned rules. ${ }^{20}$ Communities, for their part, have also been invited to make requests of the state. More often than not, especially during electoral campaigns and 
when targeted by some participatory development projects, community members have been asked to prioritize their needs and interests. As discussed above, some have even been invited to co-manage resources with a state counterpart (GELOSE). Seldom, however, have communities been consulted as good stewards of the environment, much less guiding experts in resource management. This should be the first thing to change so that state agencies and communities may enter into a real partnership for sustainable resource management with local economic benefits.

New channels of communication would complement (not replace) a top-down approach with a bottom-up one to make negotiations among equal partners possible. This does not require new channels of communication as much as defining new roles and responsibilities for local and state actors. It also requires developing mechanisms for benefit-sharing. The cases of Merimanjaka and Arivonimamo mentioned in Box 12.1 suggest that sharing the financial benefits derived from resource co-management provides realistic incentives for long-term partnerships among equals. ${ }^{21}$ This can help to align local interests with national and international conservation interests, or to strengthen the enforcement potential of rules by enhancing local buy-in to these rules along with the necessary conditions argument mentioned above.

Ultimately, those who make decisions at the national level must understand that their own success depends heavily upon what local communities decide to do with the environment. A first step in this direction would be to allow resource management plans to originate at the local level. Such management plans would be collected at one administrative level and evaluated at the next level, eventually giving the state the opportunity to gather a series of regional management plans (or designs) that would then inform policy decisions at the national level. This would allow national-level policy-makers to assess what is realistic to expect of communities in terms of resource management. A second step would consist of devising policies sensitive to variations across regions, or even across communities, in management capacities and constraints. The current top-down approach can only preclude such possibilities.

\section{CONCLUSIONS}

Considering the dynamics of environmental decision-making at the national and local levels, it becomes evident that conservation can only happen under limited and specific conditions relating to key actors' interests, the institutions that they negotiate and put in place to protect these interests, and resource users' reactions to these institutions (i.e. the rules of conduct that they specify and the roles that they assign). The evidence from Madagascar complements similar evidence from South-East Asia (Lebel, 2006) and supports theoretical claims that multilevel analyses should complement single-level analyses to improve our understanding of why forest and natural resource conservation is difficult to achieve.

It is costly to devise and adapt conservation institutions, not only materially but in terms of time. Therefore, to posit that formal legislation and foreign aid are panaceas for curtailing deforestation (and the biodiversity losses that come with it) is, at best, 
misleading. This does not mean that it is impossible to achieve conservation. On the contrary, the Madagascar case strongly suggests that there are opportunities to utilize existing institutions in ways that are deliberate, focused and effective. Such opportunities arise where local institutions are in place to protect the interests of those community members who want to conserve forests. Analavelona Sacred Forest, in Bara country, is a clear example of this (Rabesahala Horning, 2005).

The Madagascar case also suggests that governments facing environmental crises have the tools to devise means of utilizing resources at their disposal in ways beneficial to the environment and their polities. What these governments need to do is to understand the particular contexts in which power relations are negotiated for the purpose of controlling resource access at various levels of decision-making.

\section{ACKNOWLEDGEMENTS}

The author wishes to thank Ned Horning of the American Museum of Natural History's Center for Biodiversity Conservation (CBC) for his assistance with the collection and analysis of remotely sensed data and two anonymous reviewers for their comments on previous versions of this chapter. Their input is much appreciated.

\section{NOTES}

1 Researchers and environmentalists found new opportunities to explore Madagascar's biological wealth when the country opened up as the result of liberal reforms. Subsequently, a strong Washington-based environmental lobby pressured the US government to steer development aid in the direction of biodiversity conservation.

2 One exception, arguably, is COMODE (Conseil Malgache des ONG pour le Développement et l'Environnement), a consortium of national development and environmental NGOs formed in the mid to late 1980 s.

3 The other five components were:

1 improving the living conditions of the population by improving the protection and management of natural resources;

2 promoting environmental education, training and communication;

3 developing mapping and remote sensing tools;

4 developing environmental research on territorial, coastal and marine ecosystems; and

5 establishing mechanisms for managing and monitoring the environment).

4 Under Malagasy law all forests fall under the jurisdiction of the state. Strict nature reserves, special reserves and national parks are three types of protected areas (i.e. with their protection mandated by the state). Classified forests are set aside as potential conservation or exploitation sites. Because of their indeterminate status, they are not classified as protected areas. Forests that communities manage, de facto, are called alam-pokonolona (community forests), of which some hold the status of sacred when they are believed to shelter ancestors' spirits, as in the case of Analavelona. 
5 This decision was announced at the Fifth World Parks Congress in Durban, South Africa. At the time of writing, the conservation community was still struggling to implement this ambitious plan.

6 The term rules in use is borrowed from Ostrom (1990).

7 This theoretical framework is an adaptation of the Institutional Analysis and Development (IAD) framework presented, among others, in Ostrom (1995).

8 This is evident in the various World Bank reports on Madagascar's NEAP.

9 More recently a Comité Conjoint was also set up to ensure communication among key actors in the donor and NGO communities, all of whom come to the environmental table with compatible or competing agendas.

10 Madagascar naturally!

11 There was nothing new about this concept, since Madagascar's 1990 Environmental Charter specifically states that environmental protection is a means to development goals. The above historical background also helps suggest that Ravalomanana's 'new' vision amounts to little more than history repeating itself.

12 This French term is used to refer to logging companies of all sizes.

13 Although some question the accuracy of the term 'environmental sector', the author uses it to the extent that environmental protection has attracted donor funds and generated economic activities for foreign contractors and Malagasy professionals alike.

14 These include rates of deforestation, critical habitat conservation/degradation, quality of biodiversity, rural households benefiting from conservation-related projects, tourism revenues and changes in mentalities with regards to the environment.

15 These periods correspond roughly with the first three political economic periods identified earlier. Please note that the last period is only 10 years in duration, thus underestimating deforestation rates relative to the other two periods.

16 In order to understand institutions in a meaningful way for conservation, they should be distinguished from organizations by regarding them comprehensively as 'complexes of norms and behaviours that persist over time by serving collectively valued purposes' (Uphoff, 1986, p9). There are thus some institutions that are organizations (structures of recognized and accepted roles) and some that are not. In Governing the Commons, Ostrom (1990, p51) defines institutions in a more restrictive way as:

... sets of working rules that are used to determine who is eligible to make decisions in some arena, what actions are allowed or constrained, what aggregation rules will be used, what procedures must be followed, what information must or must not be provided, and what payoffs will be assigned to individuals dependent on their actions.

Institutions in this narrower sense involve standards of behaviour, defined according to rules and norms, which are statements - written or not - specifying what is forbidden (proscriptions), what is permitted (permissions) and what is obligatory (prescriptions). Unlike norms, rules must specify what sanctions (... or else) are operative in case of non-compliance (Crawford and Ostrom, 1995). 
17 Man and the Biosphere Reserves during the late 1970s; integrated conservation and development projects during the 1990s; corridor approaches in the late 1990s to early 2000s; and, most recently, sustainable forest management sites (sites de gestion forestière durable).

18 In the past two decades, countless studies have been conducted with extensive consultation of local actors on various aspects of natural resource use. The results of these studies have seldom been put to use beyond the project or task for which the research was done. A wise step would be to capitalize on the information presented in research reports to identify potential target sites. In addition, organizations interested in supporting conservation interventions should solicit the input of local authorities (mayors, forest agents, agricultural extension agents, church leaders, etc. at the commune level) and locally respected community members on the communities under their jurisdiction. Many such individuals possess reliable knowledge about the various communities with whom they interact on a regular basis, as well as of the likelihood that the necessary conditions for producing conservation outcomes are in place.

19 The two leaders were operating in very different international contexts (Cold War versus neoliberal era).

20 This is not to imply that state actors have been consistent in monitoring and sanctioning deviant behaviour. Rather, the representatives of the state have developed ways to effectively reach out to rural communities when it was in state actors' best interests to do so.

21 The benefits of such financial incentives have been documented in other parts of the world, such as Guatemala's Tikal National Park (see Dietz et al, 2003, pp10-11).

\section{REFERENCES}

Agrawal, A. (2005) Environmentality: Technologies of Government and the Making of Subjects (New Ecologies for the Twenty-First Century, Duke University Press, Durham

Agrawal, A. and C. Gibson (eds) (2001) Communities and the Environment: Ethnicity, Gender, and the State in Community-Based Conservation, Rutgers University Press, New Brunwick

Ascher, W. (1999) Why Governments Waste Natural Resources: Policy Failures in Developing Countries, Johns Hopkins, Baltimore

Berkes, F. (2006) 'From community-based resource management to complex systems: The scale issue and marine commons', Ecology and Society, vol 11, no 1, p45

Breitmeier, H., O. Young and M. Zürn (2006) Analyzing International Environmental Regimes: From Case Study to Database, MIT Press Cambridge

Bromley, D. W. (ed) (1992) Making the Commons Work: Theory, Practice, and Policy, ICS Press, San Francisco, CA

Crawford, S. and E. Ostrom (1995) 'A grammar of institutions', American Political Science Review, vol 89, no 3, pp582-600

Dietz, T., E. Ostrom and P. C. Stern (2003) 'The struggle to govern the commons', Science, vol 302, pp1907-1912

Duffy, R. (2006) 'Non-governmental organisations and governance states: The impact of transnational environmental management networks in Madagascar', Environmental Politics, vol 15, no 5, pp731-749 
Ganzhorn, J., P. P. Lowry II, G. Schatz and S. Sommer (2001) 'The biodiversity of Madagascar: One of the world's hottest hotspots on its way out', Oryx, vol 35, no 4, pp346-348

German, L., W. Mazengia, W. Tirwomwe, S. Ayele, J. Tanui, S. Nyangas, L. Begashaw, H. Taye, Z. Admassu, M. Tsegaye, F. Alinyo, A. Mekonnen, K. Aberra, A. Chemangeni, W. Cheptegei, T. Tolera, Z. Jotte and K. Bedane (2008) Enabling Equitable Collective Action and Policy Change for Poverty Reduction and Improved Natural Resource Management in the Eastern African Highlands, CAPRi Working Paper 86., IFPRI, Washington, DC

Gezon, L. (2000) 'The changing face of NGOs: Structure and communitas in conservation and development in Madagascar', Urban Anthropology and Studies of Cultural Systems and World Economic Development, vol 29, no 2, pp181-190

Gibson, C., M. McKean and E. Ostrom (eds) (2000) People and Forests: Communities, Institutions, and Governance, MIT Press, Cambridge

Harper, G., M. K. Steininger, J. Compton, D. J. Tucker and F. Hawkins (undated) Fifty Years of Deforestation and Forest Fragmentation in Madagascar, Unpublished report

Harper, J. (2002) Endangered Species: Health, Illness, and Death among the Madagascar's People of the Forest, Carolina Academic Press, Durham

Herring, R. (2001) 'Authority and scale in political ecology: Some cautions on localism', in L. Buck, C. Geisler, J. Schelhas and E. Wollenberg (eds) Biological Diversity: Balancing Interests through Adaptive Collaborative Management, CRC Press, Boca Raton, FL

Keohane, R. and E. Ostrom (eds) (1995) Local Commons and Global Interdependence: Heterogeneity and Cooperation in Two Domains, Sage, London and New Delhi

Kull, C. (1996) 'The evolution of conservation efforts in Madagascar', International Environmental Affairs, vol 8, no 1, pp50-86

Lebel, L. (2006) 'The state, the firm and the farmer: Community conservation and the use of land and water in upper tributary watersheds', Paper prepared for the International Association for the Study of Common Property, Ubud, Bali, 19-23 June 2006

Lindemann, S. (2004) Madagascar Case Study: Analysis of National Strategies for Sustainable Development, Unpublished working paper

Montagne, P., Z. Razanamaharo and A. Cooke (2007) Le Transfert de Gestion à Madagascar: Dix Ans d'Efforts, CIRAD, Montpelier

Ostrom, E. (1990) Governing the Commons: the Evolution of Institutions for Collective Action, Cambridge University Press, Cambridge

Ostrom, E. (1995) 'A framework relating human "driving forces" and their impact on biodiversity', in Workshop on Political Theory and Policy Analysis, Bloomington

Rabesahala Horning, N. (2004) The Limits of Rules: When Rules Promote Forest Conservation and When They Do Not - Insights from Bara Country, Madagascar, PhD thesis, Department of Government, Cornell University, NY

Rabesahala Horning, N. (2005) 'The cost of ignoring rules: Forest conservation and rural livelihood outcomes in Madagascar', Forests, Trees and Livelihoods, vol 15, pp149-166

Randrianarisoa, A., E. Raharinaivosoa and A. Kolpff (2008) 'Transfer of forest management responsibilities: The case of Merikanjaka and Arivonimamo in the highlands of Madagascar', Paper presented at the Workshop on Forest Governance and Decentralization in Africa, Durban, South Africa, 8-11 April 2008 
République Française (2005) Conférence Internationale: Biodiversité Science et Governance, http:/ / www.enseignementsup-recherche.gouv.fr/cid20285/archives-videos-de-2003-a2007.html\#2005, accessed 5 January 2006

Sanginga, P. C., R. Kamugisha, A. Martin, A. Kakuru and A. Stroud (2004) 'Facilitating participatory processes for policy change in natural resource management: Lessons from the highlands of southwestern Uganda', Uganda Journal of Agricultural Sciences, vol 9, pp958-970

Sayer, J. and B. Campbell (2004) The Science of Sustainable Development: Local Livelihoods and the Global Environment (Biological Conservation, Restoration, and Sustainability), Cambridge University Press, Cambridge

Uphoff, N. (1986) Local Institutional Development: An Analytical Sourcebook with Cases, Kumarian Press, West Hartford

Uphoff, N. (1992) Learning from Gal Oya: Possibilities for Participatory Development and PostNewtonian Social Science, Cornell University Press, Ithaca and London

World Bank (1996) Madagascar: Second Environment Program, Report No 16133-MAG: 25, modified (November), World Bank, Washington, DC

World Bank (1998) Implementation Completion Report: Republic of Madagascar Environment Program, Report No 17297 (January), World Bank, Washington, DC

Young, O. R. (2002) The Institutional Dimensions of Environmental Change: Fit, Interplay, and Scale, MIT Press, Cambridge and London 



\title{
PART III
}

\author{
International Trade, Finance and \\ Forest-Sector Governance Reforms
}



Chapter 13

\section{Trends in Ghana's International Timber Trade: Implications for Local Livelihoods and Sustainable Forest Management}

J. Henry Owusu

\section{INTRODUCTION}

Like most sub-Saharan African countries, Ghana adopted a structural adjustment programme (SAP) - a set of free market-based economic policies dubbed the Economic Recovery Programme (ERP) - in April 1983 under the auspices of the World Bank and the International Monetary Fund (IMF). These reforms aimed to resuscitate the country's ailing economy and to foster development in an 'accelerated' and 'sustainable' manner (World Bank, 1981, 1989). Along with the general economy, the decade prior to the adjustment programme (1973 to 1982) saw a rapid decline in timber exports comprising logs, lumber and other wood products such as veneer and plywood, reaching its lowest ebb in 1982, the year prior to structural adjustment. As a watershed in Ghana's timber trade, the adoption of the ERP in early 1983 engendered a dramatic upturn and expansion in the volume of Ghana's timber exports which lasted for the next decade and beyond (1983 to 2006), as shown in Figure 13.1.

This chapter examines the implications of this swing in the volume, content and direction of the timber trade. In particular, it explores the impact upon traditional interdependent relationships between the formal and informal sectors of the wood industry, the livelihoods of forest communities and forest management. At the domestic level, the analysis shows how Ghana's quest to sustain the volume and content of its wood exports has, inter alia, constricted the traditional forward linkage between sawmills and downstream processors - creating an acute lumber shortage on the domestic market. This, in turn, has generated what is largely perceived to be illicit activities by chainsaw operators to meet the domestic demand, and further marginalized forest communities. The analysis shows how, at the international level, Ghanaian wood processing firms now operate largely as subcontractors of convenience for firms overseas via an expanded forward linkage, in the process 


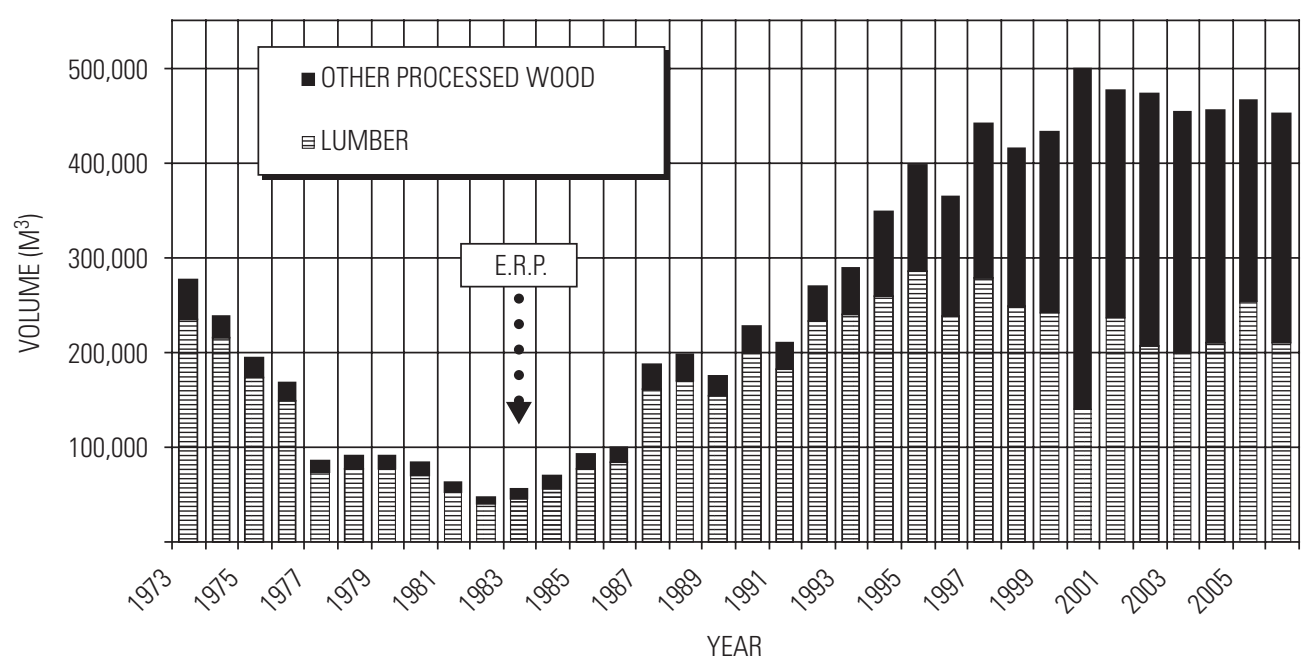

Source: CBS (1983, 1984, 1985); TEDB (1990); FPIB (1991); Coleman and Amankwah (1998); TIDD Wood Export Reports (2002-2006)

Figure 13.1 Volume of lumber and other wood products exported, 1973-2006

exporting potential Ghanaian wood-processing jobs overseas. The chapter is divided into several sections, beginning with a brief overview of the methodology used. This is followed by a discussion of the broader economic and political context - namely, the nature of the adjustment programme, the reasons for and perspectives on its adoption, and the importance of the forest sector and the timber trade within the broader programme. The next section focuses on the implications of the new trends resulting from the programme for local livelihoods and sustainable forest management. This section also discusses issues relating to the marginalization of forest communities and the informal sector - reflecting on the centralization of forest governance functions aimed at keeping tabs on timber exports under the ERP, but leading to the constriction of traditional linkages between the formal and informal sectors in the wood processing sector and an associated loss of jobs. Concluding remarks along with policy recommendations conclude the chapter.

\section{METHODOLOGY}

The analysis draws on the author's ongoing research on the timber sector, which began in 1990, and utilizes a combination of qualitative and quantitative research methods. These methods were designed to identify not only the causal mechanisms behind trends in the production and export of processed wood, but also the effects of these trends. Primary and secondary data on Ghana's timber industry, including material from relevant government policy documents and statistical data on the 
timber trade, were collected in Ghana during annual summer research trips between 1991 and 2007. Access to primary data tended to be very difficult and limited, particularly due to anticipated self-exposure or vulnerabilities to sanctioning or regulatory authorities. Nevertheless, a lot of the information has been made available through other researchers such as Donkor (2003), Sarfo-Mensah 2005), Domson and Vlosky (2007) and Birikorang et al (2001). Where feasible, primary data were collected using a qualitative corporate interview technique appropriate for studies in periods of economic change because of its sensitivity to historical, institutional and strategic complexities (Schoenberger, 1991). Key personnel in wood-processing firms and leaders of related umbrella organizations such as the Ghana Timber Millers Organization were interviewed. Statistical data were obtained from both governmental and non-governmental sources to explore the general patterns in export-oriented output of firms and the underlying determinants. The sources included relevant bodies such as the Ghana Statistical Service and the Ministry of Land and Mineral Resources. These data were supplemented with information from international organizations such as the International Tropical Timber Organization (ITTO). The chapter also benefited from work conducted by non-governmental organizations (NGOs) such as Forest Watch Ghana and the UK Department for International Development (DfID) Forestry Research Programme.

\section{STRUCTURAL ADJUSTMENT, THE FOREST SEGTOR AND THE TIMBER TRADE}

Ghana's pattern of trade since the colonial period - both domestic and international - and livelihoods supported by this trade have been characterized as structurally problematic in the sense that they constitute economic and social imbalances that constrain the country's development (see UN/ECA, 1986). This problem, largely seen as the consequence of sub-Saharan Africa's integration into the global market system (Mabogunje, 1981; Sawyerr, 1990) is reflected in the pervasive primary and semi-processed commodity export bias of the economy and the high level of poverty that characterizes most of the population, of whom forest communities represent a very significant part. For Ghana (formerly the Gold Coast under the British), the structural problems were initiated during the colonial period, when Britain organized the colony as a tributary economy to expand her own wealth. Regarding the issue of decentralization of forest governance and management, Sasu (2004) points out that Britain implemented a decentralization exercise at the time to solicit the support of traditional authorities in enforcing colonial policies. This was done by providing them with a legal basis to carry out some limited local government functions such as resource management. Regarding the livelihoods of forest communities, a Forests and European Union Resource Network (FERN) report (2006, p19) points out that the colonial state, as'a creation of the European merchant houses, discouraged traditional subsistence economic activities in a bid to force communities into the cash economy and to cut off their links with their 
resources'. After independence in 1957, there was a shift to centralization as state control over local governance and natural resources increased (Sasu, 2004, p3). In this shift, 'the state continues to ensure cheap access to communities' assets on behalf of the corporate sector (especially the transnational corporate sector). The state continues to abuse community rights. The international commodity markets continue to undervalue natural resources and transfer wealth to big businesses in the North' (FERN, 2006, p20). At the time of independence in 1957, therefore, the economy was 'warped', characterized by a one-sided orientation towards the export of raw materials such as timber, and external dependence (see Sawyerr, 1990) - a trend which marginalized forest communities.

From the perspective of the World Bank and the IMF (the primary promoters and sponsors of Ghana's ERP) however, market distortion resulting primarily from perceived unnecessary state intervention in the economy as reflected in the timber industry and the related patterns of trade in the 1970s and 1980s. Consequently, Ghana's ailing economy needed to 'structurally adjust' to 'get the prices right' (Younger, 1989), and to forge an accelerated and sustainable development in the country. This is where the forest sector, particularly the production and export of timber to enhance international trade, became significant within the context of the structural adjustment programme.

\section{THE GHANAIAN ECONOMY AND THE FOREST SECTOR}

Ghana's economy, which was one of the most promising in terms of development in SSA at the time of independence in 1957, took a downturn during the 1970s, reaching its lowest ebb in the early 1980s with serious political repercussions (see World Bank, 1984; Ninsin, 1990). By the beginning of 1983, the economy was heavily in debt. At the beginning of the 1983 adjustment year, her outstanding external debt was US $\$ 1,120,638,000$ (disbursed) and $\$ 1,499,479,000$ (undisbursed), with a total interest payment of $\$ 38,705,000$ and a total service payment of $\$ 99,746,000$ (World Bank, 1985, p33). The country's ability to meet her debt servicing obligations was in jeopardy. Consequently, during the early 1980s, Ghana's Provisional National Defence Council (PNDC) government, like many others in the heavily indebted developing world, began to lose the option of doing business with foreign lenders on an exclusively bilateral basis. The promotion of SAPs became a concerted effort on the part of lender countries and institutions to deal with borrower countries on a case-bycase basis rather than as a group. The programmes were implemented with a strategy of providing loans to the indebted developing countries and dictating policies. Ghana, like other indebted developing countries, was simultaneously seduced by the foreign loans, frightened by its fiscal crises and balance of payments deficit, and haunted by the possibility of being declared insolvent by the IMF and the World Bank (Ould-Mey, 1996). In relation to the economic crisis, the prospect of insolvency and the government's political survival, Ninsin (1990) shows that the Ghanaian government's 
adoption of the ERP was essentially metonymical ${ }^{1}$ rather than a genuine measure for catalysing and sustaining economic development. According to Ninsin (1990), the programme was adopted as a convenient measure to defuse a domestic political and economic crisis that the government itself helped to fashion and to stave off its own imminent collapse as a consequence of its initial failure to 'accommodate international capital,' which, as Sawyerr notes (1990, p28):

...takes the form of rendering ... labour and resources open to exploitation in situ; supplying raw materials and other inputs needed by the Western industrialized economies; and providing markets for their products. For this purpose, it is necessary to ensure unimpeded access to the raw materials and markets of Third World countries, as well as uninterrupted movement of capital into, and profits and rent out of, their economies.

It was within the context of this metonym that this World Bank (1984) pointed out to the PNDC government that 'the forestry sector offers the greatest immediate potential for growth and foreign exchange earnings' at its inception. The significance of the programme's metonymical basis is that it enabled the government to display a deep sense of purpose and urgency - an unflinching commitment to mobilize the forest sector, along with other raw material production sectors such as mining and cocoa, to achieve its goal. In this regard, a centralized approach was thought to be most effective. Thus, the livelihoods and interests of forest communities were not part of the calculus of the government and international capital at all - at least initially (see Ryan, 2001). To simultaneously meet the immediate needs of both international capital and the PNDC government, the forest sector needed an immediate rehabilitation. At the beginning of the ERP in 1983, therefore, the sector was infused with the second highest sector adjustment loan (SECAL) of $\$ 157$ million, out of the initial loans advanced by the World Bank to the PNDC government (Ofei-Nkansah, 1991, p229). For international financiers, rehabilitating the forest sector was a priority because a large proportion of the processed lumber was exported for international consumption prior to the deterioration of the sector. Between 1963 and 1969, for example, the sector exported a minimum of 50 per cent of its total output (CBS, 1969), and the years preceding adjustment reflected a similar pattern.

\section{The importance of changes in the forest sector}

As a renewable resource-based sector with immense potential for upstream and downstream linkages, and which 'offered the greatest immediate potential for growth and foreign exchange earnings', as noted by the World Bank, prior to the ERP the forest sector had historically accounted for 5 to 6 per cent of Ghana's total gross domestic product (GDP) and 11 per cent of total commodity export earnings. Wood from this sector was the third most important item after cocoa and minerals among commodity exports. In terms of volume, the post-ERP years have witnessed an impressive upturn and expansion in timber exports, particularly in processed wood, 
and more so with the phasing out of log exports beginning in 1987. By June, 1990, the PNDC government had been able to pay off all outstanding external payments arrears. The PNDC government had thus been 'successful' in getting back into the 'good books' of international creditors, with whom normal relations were restored, particularly for trade financing in 1990 (World Bank, 1991) - to the extent that Ghana was even touted subsequently as a 'star pupil of adjustment' in international financial circles based on her 'successes'. All of these trends have implications not only for the environment and deforestation, ${ }^{2}$ but also for the traditional interdependent relationships that existed between the formal and informal sectors of the wood industry, the livelihoods of forest communities and forest management in Ghana. We focus on how Ghana's quest to sustain its wood exports has:

- further marginalized forest communities;

- created a domestic lumber shortage; and

- constricted the traditional local forward linkage between sawmills and downstream processors.

\section{IMPLICATIONS OF THE REFORMS}

\section{Marginalization of forest communities}

In 1992, the proprietor of The Makers, one of the small-scale wood processing firms, remarked to me that 'the government has been exploiting and exporting timber as if we are the last generation of Ghanaians'. Yet this process of unprecedented exports involved an increased marginalization and neglect of the very peoples whose livelihood depended upon the source of the timber - forest communities (Bamfo, 2003). These 'forest-owning and dependent communities receive negligible returns from the destruction of their resources' (FERN, 2006). Forest Watch members in Ghana believe that community representatives receive less than 5 per cent of their royalty entitlements and none of their entitlement to timber rights fees (FERN, 2006, p11). Regarding this rather 'unfair benefits-sharing' with the forest communities, the report points to three areas where the unfairness is largely reflected (see FERN, 2006, pp11-13). First are the terms of international trade, in which the market prices for exported wood do not reflect the real economic, environmental and social value of the forests destroyed to supply the wood product. While the distorted prices constitute a direct transfer of rents to the buyers or international consumers, the transfer tends to be directly enjoyed by the formal sector of the industry. The second involves state collection of revenue in the form of timber rights fees, stumpage fees, income tax and export levies at the expense of the forest communities. The third involves elite capture of forestry-related revenues collected by the state. According to Article 267(6) of Ghana's Constitution, 10 per cent of the revenue or royalties accruing from stool lands should be paid to the administrator of stool lands to meet administrative expenses. Of the remainder, 25 per cent should go to the stool for its maintenance in keeping with its status; 20 per cent to the traditional authority and 55 per cent to the district 
assembly of the area in which the stool lands are situated. This centralized approach to benefits-sharing is problematic because, as noted in the FERN report (2006, pp14-15), "none of these institutions accounts to forest-owning communities for royalties they receive; and none of these institutions has deployed these resources in development projects that could create long-term economic opportunities to compensate communities for resource destruction'.

The elite capture of royalties, the FERN report notes, is expressed even by the chiefs, who tend to appropriate royalties for their personal or household use. They rationalize this appropriation with a claim that the constitutional stipulation 'maintenance of the stool in keeping with its status' refers to that royal perk, and that it is only the royalties allocated to district assemblies that belong to the community. This view disregards the fact that the chiefs are mere formal custodians of stool lands; consequently, compensations to landowners in the form of royalties belong to the community as a whole. This is clearly stated in Ghana's Constitution that such 'lands are vested in the appropriate stool on behalf of, and in trust for, the subjects ... in accordance with customary law and usage' (Article 267(1)). As pointed out by the FERN report (2006), since stools symbolize the social unit, and not the person who occupies it, the status of the stool can therefore only refer to the well-being of the community whom it symbolizes.

Despite the deforestation associated with the expanded timber exports, and the community exclusion from the benefits generated, it is, rather, the members of the community - the struggling farmers and the desperate chainsaw operators (along with bush fires) - who are actually blamed for the deforestation by the Forestry Commission and the forest industry. In defence of the marginalized forest communities, the FERN report argues that it:

... is a gross distortion of the truth. While there have, for example, been bush fires (especially in the mid 1980s), these can be purposefully set by the unscrupulous as a tactic to destroy the evidence of over-logging. There is also illegal clearance for farming; but this, too, often occurs in the wake of industrial devastation ... there is, indeed, a chainsaw problem, but the evidence suggests that chainsaw operators are increasingly funded and answerable to persons close to the established timber (export) companies. (FERN, 2006, p9)

Despite the fact that the 'ownership rights of pre-colonial communities and the applicability of their customary laws to surface land are not in dispute', the report notes that:

... in practice, state management rights have meant expropriation of communities. The only incidences of ownership that these communities still enjoy are the right to receive a share of royalties from forest exploitation and to participate in inventorytaking prior to the award of timber utilization contracts. The state takes most important decisions without reference to communities, and discriminates against communities with respect to resource access. Laws dating back to 1927 have criminalized community use of forest resources. (FERN, 2006, p10) 
Even though the Forest and Wildlife Policy (FWP) of 1994 sought to involve all stakeholders for the efficient management of forest resources, the concept of participation was later ignored under the Timber Resources Management Act (TRMA) of 1998. As noted by Odoom (2005, p7), despite the fact that the TRMA required farmers' consent for the felling of trees on their farms as well as payment of compensation for any damage to crops, 'the assessment of such compensation payments is not fully transparent and the rights of appeal unclear'.

Bamfo (2003) sums it up this way: 'In the past 50 years, Ghanaian farmers have lost many of their traditional rights to timber trees on farms, and their access and rights to land and trees in reserves have been severely curtailed'. This has coincided with the growth of industrial wood processing. Issues relating to state management and decisions, and the criminalization of communities, link our discussion with the third implication of the new trends - namely, the shortage of lumber on the domestic market; the informal sector as a survival strategy for some members of the community; and the relationship between the formal and informal sector in the domestic and international timber trade.

\section{Domestic lumber shortage, the informal sector and constricted traditional linkages}

In order to appreciate the implications of the new trends, it is important to put the dualistic (formal and informal) structure of the forest sector in perspective, with a particular focus on the informal sector, which accommodates a large part of forest communities. In general, colonial and post-colonial government attitudes towards, and treatment of, the informal sector have been based on the perception of that sector as a 'diversion of economic transaction beyond the reach of the state' and, hence, 'unregulated and non-legal rather than legal' (Hutchful, 2000, cited in SarfoMensah, 2005; Domson and Vlosky, 2007). Regarding forest governance and centralization, Sasu (2004, p2) argues that as a reflection of this perception, 'not much has been done to promote collaborative resource management due to the reluctance of the state to devolve management authority to local communities', much of which is informal. In this regard, he notes that since the early 20th century, succeeding colonial and post-colonial governments have attempted to shift control or supervision over the disposition of lands from traditional rulers to this state, and that one of the key reasons for this continued centralization is the 'perceived notorious traditions of misuse of land by the traditional authorities'. The role of traditional authorities is rooted in the nature of the informal sector, and this makes it imperative for a fundamental understanding of the sector to put it in a historical perspective. As noted earlier by Mabogunje (1981) and Sawyerr (1990), the historical structure of relations between Europe and Africa is rooted in the diffusion of international capital during the colonial era as part of the space creation process of capitalism. This structure was expressed in the form of unequal exchange in the area of trade, economic dependence, external control and unequal social arrangements. These were all new to Africa. It is in this respect that the FERN report (2006, p16) points out that: 
For centuries before colonialism, these cultures depended on forest resources. Economic production, social organization, religious belief and identity all depended on this relationship. Destruction of the forests and community exclusion from access to them have massively disrupted these communities.

As illustrated in Figure 13.2, the process of incorporating the colonies into the international capitalist system led to the emergence of hybrid developing economies comprising a mixture of capitalist and pre-capitalist elements. Unlike capitalist economies, characterized by an impersonal marketplace of economic transactions, in the pre-capitalist economy, exchanges were/are largely defined by personal relationships. Economic activity in the pre-capitalist economy thus tended not to be motivated by individual profit alone, but was embedded in a range of social considerations that allowed for redistribution of opportunities and benefits. This is impossible in modern capitalism where formalized state action dominates the process of redistribution (Hyden, 1980). African economies are therefore segmented into a continuum of these two relational spaces - namely, the formal and informal sectors. The formal sector is relatively more advanced economically and involves all activities that are considered part of a country's official production (with strong state control), measured by GDP. The informal sector, on the other hand, encapsulates all other economic activities - production of goods and services outside the formal sector. Thus, it operates largely outside the mainstream of government activity, regulation (weak state control) and benefit flows. Work in this sector is often done for no cash payment

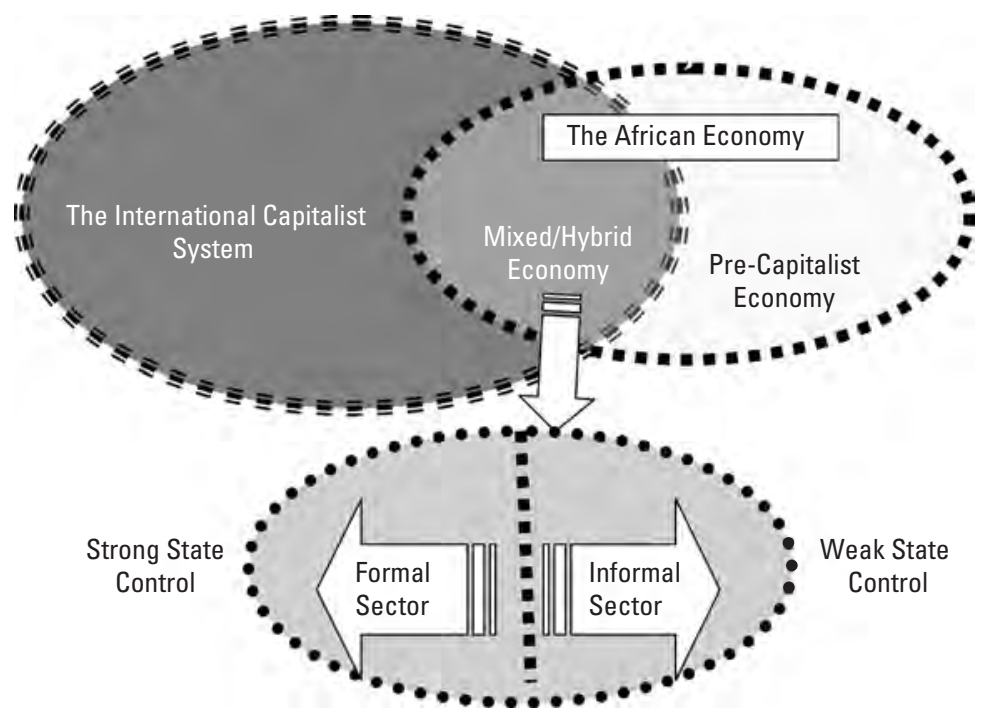

Figure 13.2 Formal and informal sectors of the African economy 
or not reported to the government as taxable income. Actors in the formal sector therefore tend to perceive informal sector activities as illegal.

But, as shown in Figure 13.2, the segmentation of the African economy into two relational spatial categories, formal and informal, indicates that the latter sector meshes into the former at the low end of a continuum, the highest end of which is advanced capitalism, and the lowest end being the pristine pre-capitalist economy. Within national economies in Africa and, for that matter, the forest sector, intersegmental movements of factors of production and output are possible - in fact, frequent in the case of labour and goods, hence the broken line used in the diagram between the formal and the informal sectors (see Ninsin, 1991; Meagher, 1995). The key aspect here is that informal sector constitutes a socio-economic space within which capitalist and pre-capitalist elements struggle for control. In essence, the state is 'suspended' to a degree over the informal sector (see Hyden, 1980) - hence, people, including some government officials, are able to move in and out of the informal sector to operate whenever deemed necessary for survival (e.g. among the poor and unemployed), convenient or personally profitable, as in the case of some corrupt government officials (see Sarfo-Mensah, 2005). Unlike the informal sector in developed economies, where it is largely 'underground' or illegal because it falls outside the remit of government control and regulation, it is openly acknowledged in SSA as an integral component of the overall economy because it "plays a significant role in economic activity, particularly in production, distribution ... and employment creation' (UN/ECA 1986, p3). African policy-makers need to bear this in mind in policy formulation for the timber industry. In fact, as part of the struggle and control process, formal-sector firms tend to exploit the informal sector at times as a survival measure to control their own periodic crisis (see Weiss, 1987; Meagher, 1995). This is because under free market conditions, contractual relations prevail to bind informal sector operators to formal sector firms, for the supply of either raw materials or semifinished goods to the latter (Ninsin, 1991, p4).

African policy-makers need to realize that although the informal sector renders useful and productive functions in African economies without formal controls and compensation, it is essentially a creation of the formal sector and, in fact, in relational terms, represents the failure of capitalism to transform African economies into successful industrial ones (Ninsin, 1991). Operations in the informal sector, as in the case of the large number of poor and otherwise unemployed chainsaw operators, are therefore largely for survival in a new and harsh capitalist economic environment. So also are members of the forest community, whose traditional access to resources is severely restricted or blocked through official policy as the state appropriates such resources in the interest of the urban elites, as reflected in Lipton's urban-bias thesis (see Lipton, 1982). It is in this regard that Potter et al (1999, p33) suggest, regarding the internal processes associated with colonialism in Africa, that 'the acceleration and intensification of European capitalism brought about a breakdown of existing relationships between traders and African societies into reaction'. Reflections of this reaction to the breakdown of relations within the pre-capitalist economy include the inequalities and asymmetrical relationships that have emerged between the formal and informal sectors at the sub-national level. Thus, the customary symbiotic 
relationships among forest communities have not been adequately factored into policy-making. Rather, they have been jettisoned as backward and diversionary, thereby undermining the potentially healthy and symbiotic relationship between the formal and informal wood sectors in the economy and with forest communities, which is critical for the sustainability of the timber industry, as a whole, and its associated domestic and international trade. The informal sector is, in fact, a dependent and subordinate part of the formal. Such a holistic re-conceptualizing of the dualistic structure of the forest sector by policy-makers would enable them to appreciate the real nature and dynamics of the informal sector, and, for that matter, forest communities. In fact, it would shed more light on why it is very difficult to ban illegal chainsaw operations in Ghana and elsewhere (see Sarfo-Mensah, 2005, p14; TBIGhana, 2003), given the convenient parasitic relationship the government has with them, especially as they meet the demand-supply gap of lumber on the domestic market, as well as serving as a source of livelihood for a good number of Ghanaians (see TBI-Ghana, 2003). Let us now put the domestic lumber shortage, the informal sector and the constricted traditional linkages resulting from the ERP in context.

\section{Pre-ERP production and market structure of the wood-processing sector}

As shown in Figure 13.3, the pre-adjustment timber exports were largely dominated by logs. In the downstream processing of timber, firms were 'seldom integrated into the national economy in a manner calculated to set off chains of growth in any significant direction ... backward and forward linkages (had) only a limited role ... and (had) been confined mainly to simple backward linkages' (Darkoh, 1973, p9). According to Combé (1972, pp4-5), production costs were so high for extraction and processing that benefits for formal wood-based firms could only be realized through sales on the international market. As with unprocessed logs a large proportion of the lumber was therefore exported for international consumption. High-quality wood became available on the domestic market only on special order and at exorbitant prices. What the sawmills, all of which are formal-sector firms, sold as 'local grade' were simply those wood products that did not meet the quality or aesthetic standards of the international market. This rejected timber nevertheless commanded fairly high prices due to an artificial price structure resulting from dependence on the lucrative export trade. In addition, the supply of lumber for construction on the domestic market was irregular because it represented only the surplus from the export trade, small quantities of lumber generated by a few small-scale sawmills that produced exclusively for the local market, and by the informal sector (see Combé, 1972, p47).

Based on the dualistic structure of the forest sector, Figure 13.3 illustrates the preadjustment intra-sectoral linkage structures of the wood processing industry and their associated markets. The sector and the domestic markets, as per Figure 13.2, are segmented into two categories, formal and informal, to indicate that the informal sector meshes into the formal at the low end of a continuum that constitutes the national economy. A broken line is used to reflect the fact that inter-segmental movements of factors of production and outputs are possible $\grave{a}$ la Ninsin (1991) and Meagher (1995). Two types of arrows are used to represent the production and 
distribution flows within the sector as a whole - namely, the large arrows (for linkages) and the thin arrows (for product destination or market). It must be noted that official data for the actual volumes are generally unavailable; hence, the arrow types are for purposes of differentiation and their respective sizes do not indicate the volume of flow. The large arrows represent the three types of sectoral linkages identifiable within the industry: the intra-formal, the formal-informal and the intra-informal. The intraformal sectoral linkage system shows the established traditional system of forward linkages from the primary processing stage through the tertiary stage in the preadjustment era. Residual lumber from the export-oriented sawmills, and regular lumber from the small-scale sawmills oriented towards domestic consumption, served as inputs for secondary processing such as furniture manufacturing. Further downstream, a small proportion of products from secondary processing, excluding the leakage into the domestic and international markets, was used as inputs for tertiary processing (e.g. floorings) in vertically integrated and non-integrated firms.

The formal-informal sectoral linkage system (arrow 2) shows that the relations between the two sectors were via the direct sale of local (low-)grade or unwanted

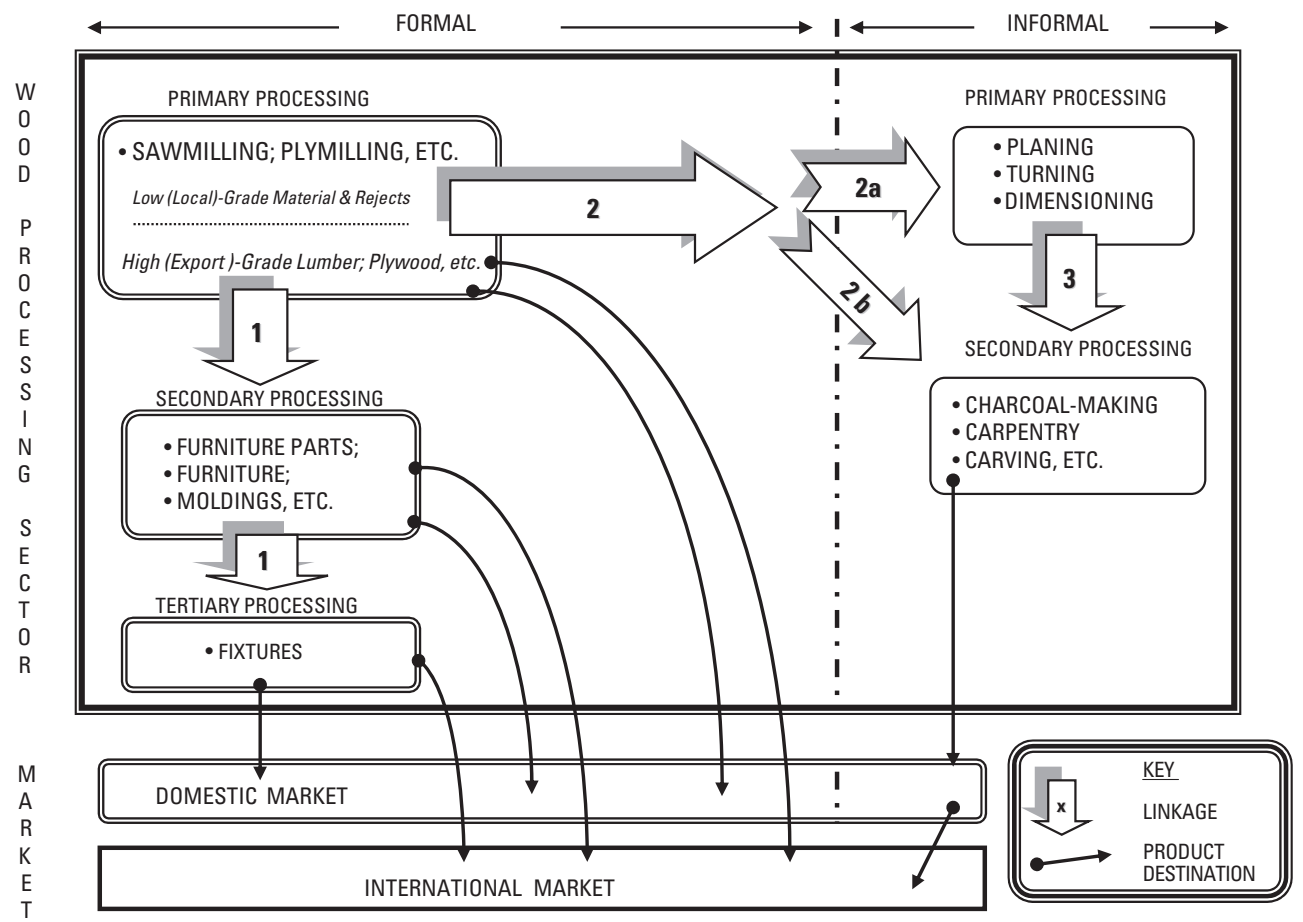

Source: Owusu (2001b)

Figure 13.3 Pre-Economic Recovery Programme (ERP) linkages between Ghana's formal and informal wood-processing sectors and associated markets 
materials as inputs from the formal sector to the informal. As shown by arrows $2 \mathrm{a}$ and 2b, the sawmills sold their 'off-cuts' from logs, 'rejects' from export parcels and other low-grade material to the informal sector. Some of these were then planed and resized for sale, or used by small-scale artisans such as carpenters and traditional woodcarvers as inputs for small-scale construction, 'roadside furniture' (for low-income groups) and items such as traditional handicrafts. Some of the 'rejects' were used as fuelwood or charcoal for household and other uses. These activities straddle the formal and informal sectors. The major markets of the informal sector are found in Accra, Kumasi and Takoradi, the top three cities in the country's urban hierarchy. Products from these markets are also found throughout Ghana, and some of them find their way to other West African countries such as Burkina Faso, Niger, Mali, Togo and Senegal (Boateng 1991, p14). The production activities described above also show a traditional intrainformal forward linkage system (arrow 3), between primary and secondary processing in that sector. Formal wood processing had substantial inter-sectoral linkages with the construction and transport sectors, but the linkage with the energy sector was rather limited (see Combé, 1972, pp111-112). On the whole, therefore, in the pre-adjustment era, while sub-national linkages to the wood-processing industry were generally weak (see Darkoh, 1973, pp9-11; Huq, 1989, p128) and the formal sector of the industry produced mainly for the external market (see Mabogunje, 1981) while relying mainly on the informal sector to meet the demands of the domestic market, there had developed a degree of forward linkage between sawmills and downstream processors in the formal sector. This is a basic feature in a production network, and a critical element in any regional development equation (Fik, 1999, pp20-21). This is because the stronger and more numerous the linkages in an economy, the more likely the economy is to experience and sustain growth.

\section{Post-ERP production and market structure of the wood-processing sector}

Between the pre-adjustment and post-adjustment eras, as illustrated in Figure 13.4, the most important and significant change involved the intra-formal sectoral linkage system: the traditional forward linkage (now represented by arrow 1a) between sawmills and downstream processors in the formal sector was largely destroyed - with expansion implications for the informal sector. This unprecedented change is largely due to the dramatic expansion in lumber exports to the international market to generate foreign exchange (illustrated by the left-most product destination (thin black) arrow labelled 'expanded exports' in Figure 13.4), generating a major shortfall on the domestic market. This expansion in lumber exports has, in the process, constrained lumber sales on the domestic market. As observed by Barker et al. $(1991,1)$, 'the millers are not supplying local manufacturers, and the manufacturers are not able to produce the quality or quantity of goods the export market demands.' This situation led to an emergence of an intensive formal-informal sectoral linkage system (the arrow 2 group). Arrow 2c illustrates the associated general shift of lumber sourcing for formal sector secondary-stage processing from the formal sector to the informal sector, where prices for the reprocessed 'off-cuts' and rejected lumber previously purchased from the sawmills were lower. Thus, some formal-sector firms such as producers of furniture, furniture parts and fixtures, generally procured 
low-grade material from the informal market (largely supplied by chainsaw operators) as inputs instead of the high-cost lumber from sawmills in the formal sector. As a result of the expansion in lumber exports, therefore, the informal sector has become dominant in meeting the needs of the local market (Birikorang et al, 2001). This is noteworthy because the informal sector is a 'struggling' entity, generally neglected and discriminated against by the government (see UN/ECA, 1986, p3; World Bank, 1989, p135), and thus excluded from ERP-related production incentives. It must be noted that as part of the creation of an enabling environment for investment by local and foreign capital under the programme, wood-processing firms were given incentive packages under the investment code (PNDC Law 116, $1985)$ to encourage exports. This added to the problem by discouraging sale of lumber on the domestic market. The sawmill owners and managers enjoyed tax rebates based on volumes exported. Additionally, they could retain at least 35 per cent of export earnings in an external account (for safekeeping), as well as an extra portion of the earnings, ostensibly for the purchase of machinery, equipment and spare parts. Because it was convenient for the government to have the informal sector - through the chainsaw operators - meet the local demand as it (the government) concentrated

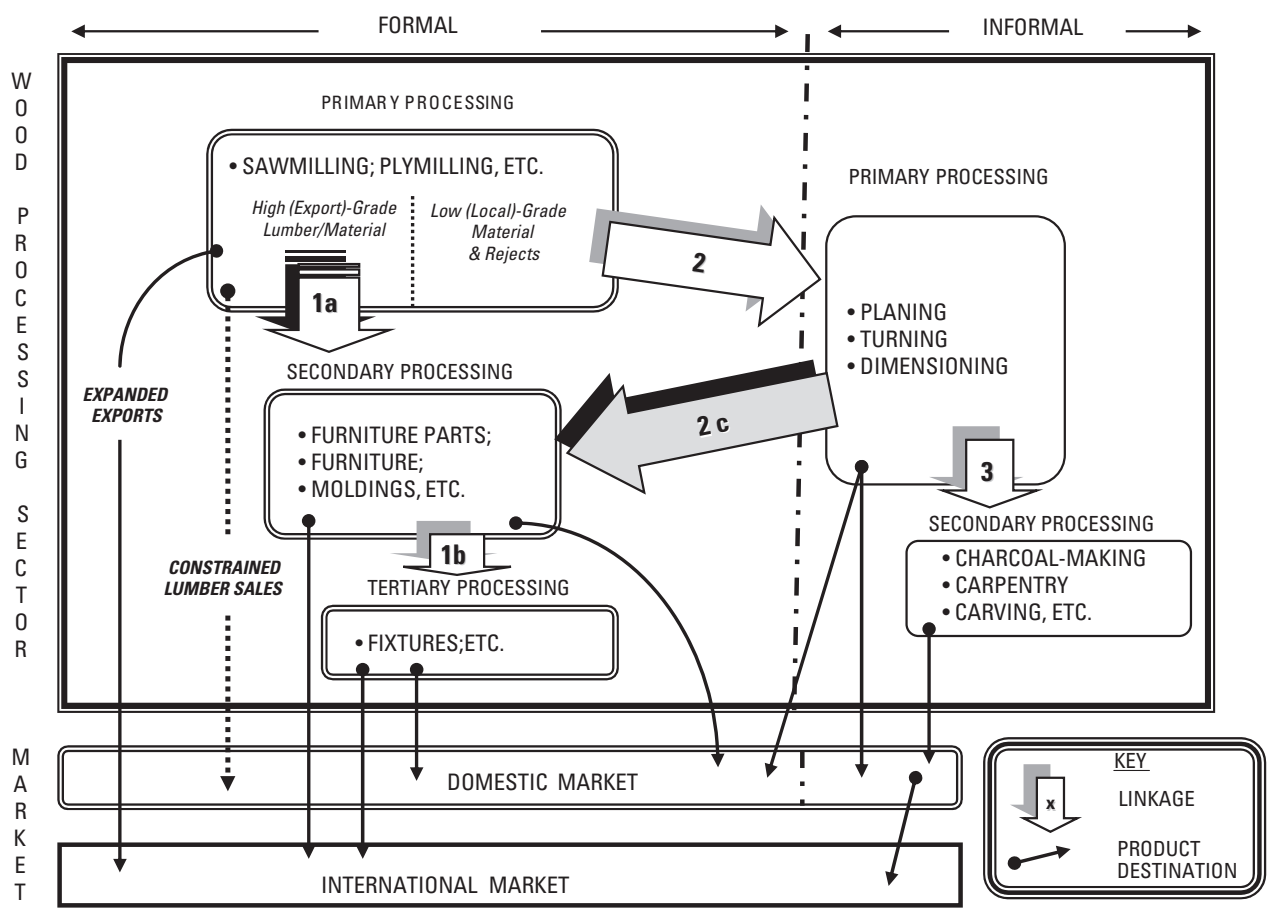

Source: Owusu (2001b)

Figure 13.4 Post-ERP linkages between Ghana's formal and informal wood-processing sectors and associated markets 
on exports to accommodate international capital, it deemed it proper to issue the 'now illegal' chainsaw operators permits to operate. As Odoom (2005, p15) puts it: 'The ERP led to the legalization of chain-sawing as a result of increased demand for lumber to support the dramatic growth in construction activities.'

It is therefore the informal sector through the chainsaw operations that stepped in to bail out the government's own formal sector by providing the 70 to 85 per cent of the lumber needs of the domestic market (TBI-Ghana, 2003). According to a Forestry Research Programme (FRP) country report on Ghana (R 8509), the formal sector or the 'traditional mills by law (Section 36 of L. I. 1649) are obliged to supply not less than 20 per cent of their mill output to the local market. If this law is complied with, the mills will deliver just about 120,000 cubic metres to the local market - only 24 per cent of the estimated local consumption of 500,000 cubic metres. It is the 'difference between the legal supply and estimated demand [that] is filled by illegal chainsaw lumber' (Coleman, 2004, cited in FRP, 2006). In fact, the domestic demand is likely to rise or to keep pace with Ghana's expanding construction industry and the growth of the economy (Domson et al, 2007). This must be viewed against the fact that the sawmills are characterized by an overcapacity of outdated and inefficient equipment (ITTO, 2005). Such processing overcapacities contribute to illegal logging and other predatory forestry-related behaviour (IUCN, 2006), and there is evidence that 'this overcapacity is increasing due largely to new investments to take advantage of the relatively cheap raw material and the existing loopholes in investment incentive provisions', as noted by Domson et al (2007, p10). It is in this regard that Ninsin (1991) points out that under free market conditions, contractual relations emerge to bind informal sector operators to the formal sector, for the supply of either raw materials or semi-finished goods to the latter. That aside, it is unrealistic to expect poor farmers and other rural poor from villages and small towns in the forest region the forest community - to travel to timber markets or sawmills in the big cities or district centres to buy lumber from the formal sector for their own private construction needs at formal-sector prices, when chainsaw operators are more easily accessible and can deliver their needs at a much lower and affordable price. As a matter of fact, as noted in the FRP report (2006), formal-sector sawmills cannot even sell their products on the domestic market at prices commensurate with their production costs; consequently, they are compelled to export their products to enable them to stay in business, thus intensifying the international forward linkage with overseas -ers who further process the wood.

\section{CONCLUSIONS AND POLICY RECOMMENDATIONS}

Since Ghana's adoption and implementation of ERP in 1983, the economy has witnessed a dramatic turnaround in its timber trade, with a remarkable expansion in the volume of timber exported; some diversification in terms of content; and new and diversified markets outside of Europe. In addition to leading to deforestation, the quest to sustain and increase Ghana's share of the international trade in timber has 
further marginalized forest communities, thus jeopardizing their livelihoods. This quest has also created a serious domestic lumber shortage, which has pushed the informal sector to step in to meet domestic demand, and constricted the traditional local forward linkage between sawmills and downstream processors. This destruction of the traditional forward linkage between sawmills and downstream processors in the formal sector has been detrimental to the forest sector and, for that matter, the Ghanaian economy as a whole. It has also constrained the crucial integration of the informal sector with the formal. This is because as a production network of any industry takes shape over time, jobs are created as linkages are established intra- and inter-sectorally - jobs that could benefit some members of the forest community to reduce high rates of unemployment. Instead, potential Ghanaian jobs are exported overseas via an expanded forward linkage with downstream processing firms abroad.

In terms of policy, one cannot look at Ghana's international timber trade without due regard to the material source of the trade and its socio-economic framework namely, the forest, its peoples and their livelihoods. In this respect, it can be said that at the root of all these trends in Ghana's international timber trade is the issue of centralization of forest-sector governance. This has created a basic disconnect between formal sector-based policy-makers, on the one hand, and poor forest communities on the other, who straddle the formal and informal sectors for purposes of survival. Currently, because of the rather centralized approach (despite the decentralization law, concretely expressed in the 1993 Local Government Act), forest communities generally do not have a meaningful stake in the process; hence, some of their farming practices tend to be inimical to the environment and the industry. As noted by Boni (2006, p2), 'precious timber that could have been logged and exported' is felled 'by farmers and simply left to rot, or more simply killed on the spot by setting fire to the base of the tree', with immense financial waste. It is therefore important for the actors involved in policy formulation and implementation to remember that for centuries prior to the colonial era, these stakeholders have depended upon forest resources for their livelihoods - their economic production, social organization, religious beliefs, and identity have all depended upon this relationship. Consequently, the formal and regulated exploitation of forests by the government, and the exclusion of communities from access to these forests through centralized decision-making and control are very disconcerting. A question by an elderly man, of the forest community Sagyimase, is quite instructive in this regard. In his frustration with the formal sector the government and the timber industry, he asked a researcher: 'Why do we need permits to enter the forest reserves to fell trees for the construction of homes? And why does the government not do the same to our brothers who live by the sea? We do not understand this' (Sarfo-Mensah, 2005, p16).

Generally, progress has been made in the government's effort to address the disconnect between diverse actors with new decentralization and forest management measures (ITTO, 2000; Sasu, 2004), and measures are being taken to complement forest policy reforms (see Bamfo, 2003); but there is need to ensure further progress. In this regard, there has been an increased recognition by policy-makers that a healthy symbiotic relationship between the formal and informal wood sectors in the economy as a whole, as well as in forest communities, is critical - not only for the sustainability 
of the timber industry, but also for the associated domestic and international trade. In terms of policy recommendations, therefore:

- There must be a dedicated effort on behalf of government to involve and cooperate with forest communities to combat deforestation and forest degradation, in the mutual interest of both actors. Bolstered with formal and informal environmental education, forest communities should be encouraged to engage in tree replanting and forest management. Decentralization via such community participation contributes to formalization of the informal sector.

- Forest communities must be given formal access to timber for home construction and other basic needs. This can be worked out through agreements among traditional authorities, district assemblies and other stakeholders. This should be coupled with a review of revenue-sharing to ensure an equitable distribution of royalties and other benefits.

- Given the expanding markets and increasing volumes of processed wood sales, a significant proportion of revenue should be expressly set aside to help forest communities exclusively in the form of social and economic infrastructure, and scholarships or financial aid for education for the youth. This would give them a vested interest in the proper management of forests. Efforts in this respect should be akin to the intensity of the PNDC government's unflinching commitment in mobilizing the forest sector under the ERP to diffuse the domestic political and economic crisis that it faced. Such rural poverty alleviation arrangements could be supported with agreements with the US, major consuming countries in Europe and emerging ones such as China (which strategically needs African timber), Saudi Arabia, Kuwait and the United Arab Emirates through special funds to help the forest communities and forest management.

- Efforts to develop a well-integrated production network in terms of forward and backward linkages should be explored to address processing overcapacities and to provide more jobs. This can be done by providing tax and levy incentives to encourage new investments in downstream processing and recovery rates. This way, rural peoples should be integrated within wood-processing activities to provide the youth, in particular, with jobs. Struggling sawmills could also be financially supported to voluntarily leave the industry and thus reduce the level of processing capacity.

Ghana's pursuit of a Validation of Legal Timber Programme aimed at improving the monitoring of tree harvesting; a timber utilization contract system for social responsibility of concessionaires; other social responsibility arrangements; and its commitment to a voluntary partnership agreement with the European Union to improve trade and production of legal timber are all laudable. However, without addressing the partnership with the informal sector and constituent forest communities in a decentralized fashion, success in these areas will be difficult, if not impossible, to achieve. Fostering such a healthy symbiotic relationship, inter alia, requires a new, pragmatic and sympathetic look by African governments and policymakers at the true nature and dynamics of the informal sector and forest 
communities. In fact, the difficulties encountered by the government in banning the operations of chainsaw operators in Ghana are testament to this need. As Sasu (2004, p14) puts it, the decentralization process should be 'community driven, flexible and transparent' and 'conscious efforts should be made to empower communities and guarantee their rights to equitable benefit-sharing'. In this way, policies formulated and implemented would be based on partnership, a necessary ingredient for the sustainability of the forest sector as a whole.

\section{NOTES}

1 Development policies are said to be metonymical when they are used by a government, policy-makers or a group of political actors in tandem with their development objectives to achieve hidden policy objectives or to promote a hidden interest or agenda (see Gore, 1984, p258).

2 Deforestation was exacerbated by other factors in addition to timber exports, such as farming, an 'irrational land tenure policy' documented by Boni (2006, p3, undated) and processing overcapacities (IUCN, 2006).

\section{REFERENCES}

Bamfo, R. K. (2003) 'Policy and institutional reform for forestry: The Ghanaian experience', Paper presented at the Africa Forest Law Conference, Yaoundé, Republic of Cameroon, 13-16 October 2003, http://lnweb18.worldbank.org/.../Ghana+-+Policy+\&+Institutional+ Reform+for+Forestry+-+Support+Document.pdf, accessed 29 November 2007

Barker, K., P. Boateng and A. Moreno (1991) Timber and Wood Products Section of Export Diversification in Ghana, Report prepared for the US Agency for International Development, Development Associates Inc, Bethesda, Maryland

Birikorang, G., R. Okai, K. Asenso-Okyere, S. Afrane and G. Robinson (2001) Ghana Wood Industry and Export Ban Study, DFID, London

Boateng, P. (1991) 'Report from Consultant Boateng', in K. Barker, P. Boateng and A. Moreno (eds) Timber and Wood Products Section of Export Diversification in Ghana, Report prepared for the US Agency for International Development, Development Associates Inc (Annex B: 1-33), Bethesda, Maryland

Boni, S. (2006) 'Ghanaian farmers' lukewarm reforestation: Environmental degradation, the timber option and ambiguous legislation', Paper presented at the Colloque International Les Frontières de la Question Foncière, Montpellier, France, http://www.mpl.ird.fr/ colloque_foncier/Communications/PDF/Boni.pdf, accessed 16 October 2008

CBS (Central Bureau of Statistics) (1969) Statistical Handbook 1969, 3rd edition, CBS, Accra

CBS (1983) Industrial Statistics 1977-1979, CBS, Accra

CBS (1984) Industrial Statistics 1980-1982, CBS, Accra

CBS (1985) Industrial Statistics 1981-1983, CBS, Accra 
Coleman, H. G. and G. Amankwah (1998) 'The current status and future challenges of the development and marketing of timber products: The Ghana example', Paper presented at the 26th International Forestry Students Symposium, 13-27 September, mimeo, TEDB, Takoradi

Combé, J. (1972) Forest Exploitation and Woodworking Industries in a Developing Country: Case Study of Ghana, Memoire presented for the Diploma of the Institute, Geneva/FPRI, UST, Kumasi, Ghana

Darkoh, M. B. K. (1973) 'Industrial strategy and rural development in Africa, with special reference to Ghana', Geoforum, vol 16, pp7-24

Dicken, P. and P. Lloyd. (1990) Location in Space: Theoretical Perspectives in Economic Geography, 3rd edition, Harper Collins, New York, NY

Domson, O. and R. P. Vlosky (2007) A Strategic Overview of the Forest Sector in Ghana, Louisiana Forest Products Development Center Working Paper no 81, Louisiana State University Agricultural Center, Baton Rouge, LA, www.lfpdc.lsu.edu/publication/papers/WP\%2081\%20SWOT\% 20Analysis\%20of\%20Ghana\%20Forestry\%20Sector.pdf, accessed 29 November 2007

Donkor, B. N. (2003) Evaluation of Government Interventions in Ghana's Forest Product Trade: A Post Intervention Impact Assessment and Perceptions of Market Implications, Louisiana State University, Baton Rouge, LA

FERN (Forests and European Union Resource Network) (2006) Forest Governance in Ghana: An NGO Perspective, Report produced for FERN by Forest Watch, Ghana, www.fern.org/media/ documents/document_3643_3644.pdf, accessed 29 November 2007

Fik, T. (2000) The Geography of Economic Development: Regional Changes, Global Challenges, 2nd edition, McGraw Hill, New York, NY

FPIB (Forest Products Inspection Bureau) (1991) Export Permit for the Year 1991, FPIB, Takoradi, Ghana

FRP (Forestry Research Programme) (2006) Chainsaw Logging and Milling in Ghana: Background Study Report, www.illegal-logging.info/uploads/FRP_Chainsaw_Logging_Ghana.pdf, accessed 29 November 2007

Gore, C. (1984) Regions in Question: Space, Development Theory and Regional Policy, Methuen, London

Huq, M. M. (1989) The Economy of Ghana, Macmillan Press, London

Hutchful, E. (1996) 'Ghana', in P. Engberg-Pederson, P. Gibbon, P. Raikes and L. Udshot (eds) Limits of Adjustment in Africa, Heinemann, Portsmouth, NH, pp143-214

Hyden, G. (1980) Beyond Ujamaa: Underdevelopment and an Uncaptured Peasantry, University of California Press, Berkeley and Los Angeles

ITTO (2002) 'Year 2000 objective: The progress made', Tropical Forest Update, vol 10, no 2, p6

ITTO (2005) Status of Tropical Forest Management: Ghana, Technical Series no 24, pp98-104

IUCN (2006) Strengthening Voices for Better Choices, World Conservation Union, Bangkok, Thailand, http://cmsdata.iucn.org/downloads/strengtheningvoicesbrochure.pdf, accessed 16 October 2008

Lipton, M. (1982) 'Why poor people stay poor', in J. Harriss (ed) Rural Development: Theories of Peasant Economy and Agrarian Change, Hutchinson, London, pp66-81

Mabogunje, A. L. (1981) The Development Process: A Spatial Perspective, Holmes and Meier, New York, NY 
Meagher, K. (1995) 'Crisis, informalization and the urban informal sector in sub-Saharan Africa', Development and Change, vol 23, no 26, pp259-284

Ninsin, K. A. (1990) 'Ghana under the PNDC: Delinking or structural adjustment?', in A. Mahjoub (ed) Adjustment or Delinking?: The African Experience, UN University/Third World Forum: Studies in African Political Economy, United Nations University Press and Zed Books, Tokyo and London, pp131-156

Odoom, F. K. (2005) Chainsawing in the Natural Forests of Ghana: An Assessment of the Socio-economic Impacts of this Practice, Case study report, FAO, Rome

Ofei-Nkansah, K. (1991) 'Ghana's timber boom', West Africa, vol 3833, 18-24 February, p229

Ould-Mey, M. (1996) Global Restructuring and Peripheral States: The Carrot and the Stick in Mauritania, Rowman and Littlefield, Lanham, MD

Owusu, J. H. (2001a) 'Determinants of export-oriented industrial output in Ghana: The case of formal wood processing in an era of economic recovery', The Journal of Modern African Studies, vol 39, no 1, pp51-80

Owusu, J. H. (2001b) 'Spatial integration, adjustment and structural transformation in Africa: Some linkage pattern changes in Ghana', The Professional Geographer, vol 53, no 2, pp230-247

Potter, R. B., T. Binns, J. A. Elliot and D. Smith (1999) Geographies of Development, Addison Wesley Longman, Singapore

Ryan, P. A. (2006) Notes on High Forest Management: Mid-Term Review Report, Ghana National Resources Programme, Accra

Sasu, O. (2004) 'Decentralization of federal systems in forests and National Forestry Programme: The case of Ghana', Paper presented at the Interlaken Workshop on Decentralization in Forestry, Interlaken, Switzerland, 27-31 April 2004, http://www.cifor.cgiar.org/publications/ pdf_files/interlaken/Oppon_Sasu.pdf, accessed 16 October 2008

Sarfo-Mensah, P. (2005) Exportation of Timber in Ghana: The Menace of Illegal Logging Operations, Fondozione Eni Enrico Mattei, Milan, Italy, www.feem.it/NR/rdonlyres/7B28B8FB-0D284FFC-9527-B966B2A54C02/1462/2905.pdf, accessed 29 November 2007

Sawyerr, A. (1990) The Political Dimension of Structural Adjustment Programmes in Sub-Saharan Africa, Ghana Universities Press, Accra

Schoenberger, E. (1991) 'The corporate interview as a research method in economic geography', The Professional Geographer, vol 43, no 2, pp180-189

TBI-Ghana (2003) Chainsaw Lumber Production: A Necessary Evil, Tropenbos International, Wageningen, www.tropenbos.nl/publications/FactSheets/ChainsawInfosheetstuur.pdf, accessed 29 November 2007

TEDB (Timber Export Development Board) (1990) The Ghana Timber Industry: Basic Information, Facts and Figures, TEDB, Takoradi

TIDD (Timber Industry Development Division) (2002) Report on Export of Wood Products, Ghana Forest Division, Takoradi

TIDD (2003) Report on Export of Wood Products, Ghana Forest Division, Takoradi TIDD (2004) Report on Export of Wood Products, Ghana Forest Division, Takoradi TIDD (2005) Report on Export of Wood Products, Ghana Forest Division, Takoradi TIDD (2006) Report on Export of Wood Products, Ghana Forest Division, Takoradi UN/ECA (United Nations Economic Commission for Africa) (1986) African Alternative Framework to Structural Adjustment Programmes for Socio-Economic Recovery and Transformation (AAF-SAP), United Nations, New York, NY, E/ECA/CM.15/6/Rev.3 
Weiss, L. (1987) 'Explaining the underground economy, state and social structure', Journal of British Sociology, vol 32, no 2, pp216-234

World Bank (1981) Accelerated Development in Sub-Saharan Africa, World Bank, Washington, DC

World Bank (1984) Ghana: Policies and Program for Adjustment, World Bank, Washington, DC

World Bank (1985) Ghana: Towards Structural Adjustment, Vol. II: Statistical Appendix, 7 October, Report No 5854-GH, World Bank, Washington, DC

World Bank (1989) Sub-Saharan Africa: From Crisis to Sustainable Growth, World Bank, Washington, DC

World Bank (1991) Ghana: Progress on Adjustment, Report No 9475-GH, World Bank, Washington, DC

Younger, S. D. (1989) 'Economic recovery program: A case study of stabilization and structural adjustment in sub-Saharan Africa', in Successful Development in Africa: Case Studies of Projects, Programs and Policies, Economic Development Institute of the World Bank, Analytical Case Studies No 1, World Bank, Washington, DC 


\section{Forestry Governance and Trade Transformations: Experiences from Tanzania and Implications for Sustainable Development}

Simon Milledge

\section{INTRODUCTION}

Forestry investment and timber trade in the United Republic of Tanzania, as with many other African nations, arguably offers greater potential to stimulate economic growth and reduce rural poverty now than at any period in recent history. In the case of indigenous hardwood exports, a supportive legal framework and transformations in the 'three Rs' (resources, routing and retailing) have substantially boosted trade opportunities. Rich in resources, Tanzania has recently become potentially wealthier as the country was found to be supporting wide tracts of timber species, highly prized in the international marketplace. The routing of timber from forest to sawmill to port and beyond has been greatly facilitated by improved road and port infrastructure. Dramatic growth in market demand and purchasing power from China (and other markets such as the European Union and the US) has transformed global timber trade dynamics and provided the framework for retailing Tanzania's valuable hardwoods to external markets. Despite this golden opportunity for the timber trade to generate equitable and broad-based benefits, expectations have not been met.

This chapter summarizes lessons learned from southern Tanzania. It quantifies the decline in forestry governance during a period when global market forces have stimulated unprecedented levels of harvesting and export. This situation arose over barely a decade, alongside various reforms in the political system, economic management and government administration. This chapter explains how perverse incentives, both institutional and individual in nature, have created barriers to good ethical forestry governance. At the institutional level, challenges with implementing rural-based social models of forest management during a period of market liberalization, privatization and decentralization are presented. Competing interests 
around this lucrative revenue source is discussed in light of the rural transformation arising from political devolvement and the growing public appreciation of such natural assets. The chapter examines how the opportunity and inclination for corrupt behaviour have flourished in these circumstances, and quantifies the extent and impact of different types of forestry-related corruption. Lastly, the chapter recommends how Tanzania might restructure and strengthen its forest governance and better harness the potential provided by the continuing large-scale transformations at rural and global levels.

\section{OPPORTUNITIES ABOUND: TANZANIA, TRANSFORMATIONS AND TIMBER TRADE}

\section{Natural resources: A mixed blessing}

Natural resources are among the most valued national assets of any country, and Tanzania is no exception. Natural resources are the main source of people's livelihoods and the backbone of the country's main productive sectors: agriculture, tourism and mining. The last quarter of a century has witnessed remarkable growth in numerous extractive industries, ranging from oil, gas and minerals to renewable resources such as timber. ${ }^{1}$ The predominantly rural location of these natural resources, together with seemingly insatiable national and global markets, sounds like the ideal recipe for making rural poverty history and stimulating national economic growth.

As will be elaborated upon later in this chapter, it is not an exaggeration to state that natural resources have had, and continue to have, one of the greatest influences in shaping societal relationships, the political economy and governance. Central to this influence is the potential revenues sourced from natural resources, such as tropical timber. A key question, therefore, is whether these influential developments have been in line with national development goals, and, in particular, the interests of the poor majority? If so, sustainable natural resource exploitation could be catalytic in terms of ensuring broad-based and equitable development outcomes. If not, a growing dependency and monopolization of the capture of natural resource revenues by entrenched political and economic elites could act as a debilitating inhibitor to the realization of pro-poor reforms.

In the context of tropical timber trade in Tanzania, it is first instructive to understand some of the opportunities for sustainable development which have arisen as a result of biogeographic factors, socio-economic and political developments.

\section{RECIPE FOR OPPORTUNITY}

The United Republic of Tanzania is located in East Africa, covering an area of 945,090 square kilometres and with a population ${ }^{2}$ of 38.5 million in 2005 (UNDP, 2007). 
Bordering eight countries and the Indian Ocean, Tanzania continues to mark an important transit point along centuries-old trade routes to the Near and Far East.

Opportunities for trade and investment have greatly increased since the mid 1980s following various reforms in the political system, economic management and government administration. Key structural adjustment programmes have targeted economic recovery, trade liberalization, public-sector privatization, local government decentralization and reforms to the civil service, agricultural and other priority sectors. With respect to natural resources, including forests, these reforms have aimed to provide new opportunities for the rural majority and incentives to attract foreign investment. In 2005, 85 per cent of merchandise exports were primary exports (UNDP, 2007).

The net result of these reforms has been variable. On the one hand, Tanzania has one of Africa's fastest growing economies and highest inflows of direct foreign investment. On the other hand, Tanzania was classified with 21 other countries (all African) as having low human development, with 90 per cent of the population having an income of less than US $\$ 2$ a day and 36 per cent of the population falling below the national basic needs poverty line (UNDP, 2007).

Tanzania is endowed with a relatively large and valuable forest resource base. Despite the loss of around 10 million hectares of forest between 1970 and 1998, forests collectively cover 40 per cent of the mainland. These forests are diverse in composition, ranging from mangrove to montane forests. Both BrachystegiaJulbernardia miombo woodlands, which comprise almost two-thirds of the forested land, and coastal forests, notable for their high biodiversity, contain valuable hardwoods. The majority of forests are unreserved and under a common property regime; they recently covered an estimated 14.5 million hectares (or 61 per cent of all Tanzania's woodlands and forests) according to the National Forest Policy of 1998. Reserved forest is primarily in the form of forest reserves managed by central or local government authorities (12.5 million hectares). In terms of forest use, over 70 per cent of the entire forest area - reserved and unreserved - is classified as 'production forest', where the harvesting of forest products is permitted.

Various legal and policy instruments provide a framework ${ }^{3}$ to support the sustainable utilization of forest resources. Extensive regulations cover harvesting, transport, processing, trade and export of forest products, with forest royalties stipulated for harvesting and export. In addition, local authorities are permitted to establish bylaws to levy additional taxes. In the past decade, significant policy and legislative revision have taken place to promote decentralized forest management. This includes the promotion of participatory forest management (PFM), involving the active role of rural communities. As with many African countries, rural communities in Tanzania are highly dependent upon forest resources, with over 80 per cent of the population living in rural areas. Thus, the provision of various incentives for PFM can help to fill the gap in state forest management capacity, and also ensure that forests contribute towards national poverty alleviation goals. Given the fact that almost twothirds of Tanzania's woodlands and forests are unreserved, PFM clearly provides significant rural development opportunities through an enabling environment for forest resource ownership, user rights and benefit flows. In 2006, over 2 million hectares of forest was under community-based forest management (see Chapter 6 in this volume), closely matching the area of forest found in national parks. 
Favourable biogeographic factors, structural adjustment reforms and participatory forestry frameworks are not the only ingredients in this recipe for opportunity. Since the beginning of the millennium, three key transformations have occurred that have directly influenced timber trade: the 'three Rs' (resources, routing and retailing).

\section{A TRIO OF TIMBER TRADE TRANSFORMATIONS}

\section{Resources}

In addition to their high diversity and geographic extent, Tanzania's forest wealth has potentially increased in recent years. This was catalysed following the realization that wide tracts in southern Tanzania contain timber species highly prized in the international market place (e.g. Baphia kirkii, Millettia stuhlmannii and Combretum imberbe). Several factors then combined to ensure high profit margins (Milledge et al, 2007). First, most timber was sourced from unreserved land where purchase prices remained low due to undervaluation by rural communities (see Figure 14.1). Second, a perceived high abundance prevented price increases that normally transpire as a product becomes scarcer. Third, Tanzanian freight-on-board (FOB) log values continued to increase and remained highly competitive compared to other African producers. Lastly, low levels of enforcement effort meant that unscrupulous traders commonly avoided paying government royalties.

Southern Tanzania was characterized by having low capacity to add value to timber products, and the majority of harvested hardwood was shipped as roundwood up until the mid 2000s. While legislation was enacted in mid 2004 to ban raw log exports, this was often undermined by the low risks and high potential profits by trading to China; not only was there a high demand, but fiscal incentives in China promoted the import of roundwood. Insufficient incentives persist in Tanzania to promote the processing of hardwood prior to export.

\section{Routing}

A second recent transformation in timber trade has concerned the routing from forests to sawmills and ports. Transport infrastructure development is a key ingredient to secure economic growth; but for many years the lack of a permanent crossing across

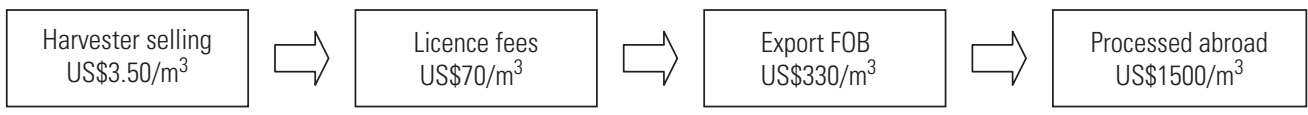

Figure 14.1 Diagram illustrating the gross value chain for hardwood logs from Tanzania (2005) 
the Rufiji River, particularly during the rainy season, seriously limited development prospects in southern Tanzania (Milledge and Kaale, 2005). Completion of the Mkapa Bridge in August 2003 provided a more reliable river crossing throughout the year and facilitated road improvements. As a result, accessibility was enhanced and the travel time to Dar es Salaam, the main domestic timber market and exit point by seaport, shortened considerably. An overall increase in timber volumes was recorded following the opening of the bridge, due to reduced transport seasonality, a rise in the number of traders and the use of larger logging trucks (Millege and Elibariki, 2005).

\section{Retailing}

A third transformation concerns global timber markets. In particular, dramatic economic growth in China, coupled with high resource demands, has transformed global timber trade dynamics. In 2004, China was the world's largest importer of round logs, and Africa's share of this market is growing (Adams, 2004; Thornton, 2005).

This transformation has provided the means for retailing Tanzania's valuable hardwoods to external markets, and China has emerged as the leading importer of timber from Tanzania. Furthermore, Tanzania became Africa's sixth largest timber exporter to China in 2005, showing a 1386 per cent increase by value since 1997 (Milledge et al, 2007). This statistic is even more remarkable when one considers that timber in Tanzania has originated predominantly from miombo woodlands that naturally contain relatively low densities of hardwood, quite unlike the tropical forests of many other African timber producers.

The timber trade chain does not stop at China, of course, and a large proportion of the imported wood is re-exported in the form of manufactured products. In 2005, approximately 70 per cent of China's wood imports were used in exported wood products (White et al, 2006). It is therefore quite likely that much of Tanzania's timber ultimately ends up in major markets such as the US and the European Union (EU), whose huge demand for Chinese manufactured wood products increased by 700 to 900 per cent between 1997 and 2005 (ITTO, 2005).

\section{REALITIES REVERBERATE: FOREST GOVERNANGE AND SUSTAINABLE DEVELOPMENT}

As is to be expected from such a combination of transformative developments, the period from 2000 to 2005 witnessed unprecedented levels of timber harvesting and trade from southern Tanzania. An estimated 500,000 cubic metres of timber were harvested for commercial purposes from southern Tanzania during 2003, and forest revenue to the central government more than doubled between 2003 and 2005 (Milledge et al, 2007). Associated with this rise in timber trade activity, a growing number of stakeholders voiced their concerns regarding levels of legality, sustainability and governance. Fieldwork conducted by TRAFFIC during the same period attempted to clarify the scale, patterns, causes and impact of governance shortfalls. 


\section{MEASURES OF TIMBER TRADE GOVERNANCE}

While several definitions of governance exist, a useful one is the "capacity of the state to turn taxes into equitable social and economic services and the maintenance of law and order' (Cooksey, 2005). This definition allows two measures of forestry governance, the level of $\operatorname{tax}$ compliance (i.e. revenue collected as timber royalties) and the level of legal compliance (i.e. legality of timber harvesting and trade).

\section{Legal and tax compliance of timber trade}

Various comparisons of officially mandated timber harvest volumes (i.e. derived from legal documentation such as harvest licences and transit passes) and actual harvest volumes (i.e. independent physical counting methods) provide a measure of timber harvest legality. During mid 2004, at the peak of timber trade activity in southern Tanzania, official records of timber harvest volumes were equivalent to just 4 per cent of the actual harvested volumes (Milledge and Elibariki, 2005). In other words, 96 per cent of potential government revenue from royalties was being lost due to unreported or under-reported harvest volumes.

The implications of such low tax compliance were considerable. At the national level, and based on relative revenue projections and collections across the country, it was estimated that the central government (Forest and Beekeeping Division, or FBD) lost some US\$58 million during 2003/2004 (Milledge et al, 2007). This estimate was double the potential annual revenue collections of forest royalty claimed by the National Forest Programme (NFP). At the level of local government, the total budgets of some districts would have increased fourfold if all the potential forest revenue had been realized. If all the revenues were collected in accordance with legal frameworks, the forest sector would be completely self-supporting without the need for foreign assistance.

\section{Spatial and temporal patterns}

Moreover, ongoing monitoring of timber trade revealed a downward trend in legal compliance, from 23 per cent in 2001/2002 (also prior to completion of the Mkapa Bridge) to 4 per cent in 2004/2005 (Milledge and Elibariki, 2005). In support of this finding was a qualitative assessment of illegality along the timber trade chain, which revealed a perceived increase in illegal activities affecting several types of severe infractions. In particular, logging without documentation, logging in unauthorized areas, logging undersized trees and the use of invalid export documentation were reported to be increasing in severity (Milledge et al, 2007).

Spatial patterns in legal compliance also gave rise to concern. It was found that levels of illegality at the point of export (e.g. Dar es Salaam seaport) were surprisingly high. For example, a large mismatch was evident between official export and import statistics to the main destination country: China (see Table 14.1). During a three-year period, 2003 to 2005, Tanzanian export statistics to all destinations worldwide amounted to only 11 per cent of the volume of timber imports reported by China as 
Table 14.1 Comparison of timber export volumes $\left(\mathrm{m}^{3}\right)$ from Tanzania (2003-2005)

\begin{tabular}{lclc}
\hline \multicolumn{2}{l}{ Tanzania total exports $\left(\mathrm{m}^{3}\right)$} & \multicolumn{2}{l}{ China imports from Tanzania } \\
\hline $2002 / 2003$ & 4920 & 2003 & 45,432 \\
$2003 / 2004$ & 8529 & 2004 & 41,699 \\
$2004 / 2005$ & 5867 & 2005 & 21,374 \\
\hline
\end{tabular}

coming from Tanzania (Milledge et al, 2007). It is normally expected that measurements of legal compliance rise considerably at the point of exit through the fraudulent acquisition of official documentation that effectively renders the timber legal on overseas markets. In the case of Tanzania, however, relatively little change had occurred from point of harvest (4 per cent legal compliance) to export (11 per cent legal compliance), indicating chronic levels of illegality and corruption.

\section{IMPEDIMENTS TO GOOD GOVERNANGE}

\section{Perverse incentives: Asset competition and dependence}

Public appreciation of the value of natural assets (including timber trade) is growing, and has led to competing interests over access, ownership and benefit flows. This asset value has increased markedly in recent years given the favourable changes to the 'three Rs' of resources, routes and retailers. As a result, competition exists between at least five different players: central government, local government, rural communities, the private sector and political entities.

Decentralization has further increased competition over forestry assets as it can lead to greater dependence upon locally generated natural resource revenues. For example, ongoing administrative decentralization places pressures on raising revenues locally, and many districts in southern Tanzania now exhibit a high dependence upon securing forest-related revenues. At the same time, gradual political devolution as a result of increased demands for electoral accountability has placed greater pressures on maintaining both individual and party power relations. Forest-related revenues can be a primary source of accumulating the necessary wealth and status.

This scenario unfortunately acts as a multipronged fork! High dependence upon natural resource revenues (especially by economic and political elites) can reduce the incentives to 'share the pie', resulting in resource-access and benefit-sharing conflicts. This is particularly pertinent in the case of expediting PFM implementation in southern Tanzania, which has seen resistance from some local government authorities. In addition, if majority control of resource revenues is in the hands of regulators, then due processes and controls may be undermined or open to corruption. High dependence upon lucrative forest resources can act as an inhibitor to change, especially in the absence of alternative sources of income. 


\section{Accountability: Weak fiduciary contracts}

In recent years, the greatest demands for accountability in the forest sector have originated from the development community, media and, occasionally, academic institutions, parliament or civil society organizations. However, the demand for accountability by rural communities in southern Tanzania is noticeably weak, an irony considering the fact that forests are predominantly unreserved ( $>85$ per cent of forests are on open, public land in this part of the country).

An important limiting factor is the weak 'fiduciary contract', a reciprocal relationship of accountability between citizens and the state in which services are provided by the state in exchange for financial contributions from citizens (Rutashobya, 2004). From the perspective of rural communities, a lack of perceived direct benefits from state-owned forests reduces incentives to demand accountability from the state. At the same time, however, incentives for holding the state to account can also dwindle in cases where devolution of forest ownership to communities has resulted in zero taxation.

From the perspective of the state, low levels of accountability demanded by rural citizens acts as a further disincentive to change the status quo in forest governance, especially considering the high degree of budgetary dependence, low levels of investment and high rates of return. At the national level, evidence suggests that the current structure of government income (large proportion of budget support from donors), revenue (increasing proportion of revenues from natural resources) and taxation (narrow tax base) provide insufficient incentives for developing higher levels of state-citizen accountability (Maal, 2007).

\section{Pervasive corruption}

An impressive list of interventions has been tried and tested to reduce unregulated and illegal timber harvests and trade in Tanzania (Milledge et al, 2007). The success of these interventions has been highly variable, however, since the majority has either focused on 'quick fixes' or failed to address key influencing factors and drivers. More specifically, a major focus has been improving trade regulatory measures (as a means to control trade levels), while significant resources were also mobilized to strengthen management capacity (as a means of making the controls more effective). Examples of such measures include nationwide forest inventories, sawmill assessments, numerous trade restrictions, and the establishment of district harvest committees and zonal forest surveillance units.

Unfortunately, insufficient attention was directed at understanding and addressing factors that were undermining or negatively influencing the effectiveness of such controls. Corruption (as opposed to capacity constraints) was the primary factor causing governance shortfalls in the forest sector; yet it remains poorly addressed in a holistic manner. Corruption in the forest sector ranges from petty corruption to highly organized patronage and personal involvement. Petty corruption (mostly bribery) was found to be widespread, but most severe at the stages of log hammering, transport and export (see Figure 14.2). A linked concern was the likelihood of trade restrictions failing since they tend to be applied at the very same 


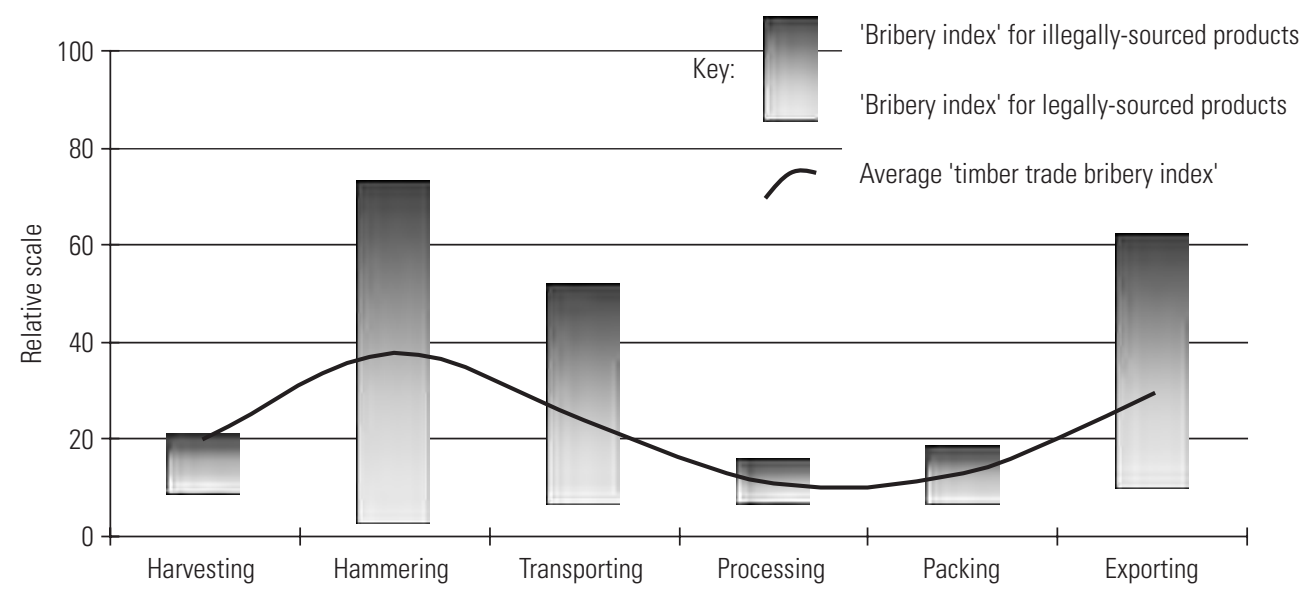

Note: 'Relative scale' takes into account perceived frequency and size of bribery.

Figure 14.2 'Timber trade bribery index' (ranging from 0-100) during the main stages of the timber trade chain for both legally and illegally sourced products

trade 'bottlenecks' most influenced by bribery. Results further indicated more chronic forms of petty corruption, since even traders in legally harvested timber products were, by predicament, unfortunately affected by bribery (see Figure 14.2).

From a development perspective, favouritism and patronage are far more significant than petty corruption. Amongst the greatest concerns with respect to governance and accountability was the influence that direct involvement in timber trade by senior public officials, collusive networks and an overwhelming private sector may have on decisions relating to relaxing timber trade restrictions, financial management and the effectiveness of enforcement. An account of the occurrence of favouritism in timber trade (including self-dealing, nepotism and cronyism) is given in Milledge et al (2007).

The presence of direct interests in timber trade at executive and ministerial levels arguably presented the most concern with respect to ensuring integrity in decisionmaking, fairness, impartiality, transparency and justice (see Table 14.2). At the village level, the personal involvement of village leaders in the timber trade has led to an unfair distribution of revenue.

Table 14.2 Some reported examples of self-dealing, nepotism and cronyism in the timber trade

\begin{tabular}{ll}
\hline Level of government & Examples of positions with personal involvement in the timber trade \\
\hline Executive & Cabinet minister, regional commissioner, district commissioner \\
Parliament & Member of parliament \\
Central government & Minister, assistant director, principal/senior forest officer \\
Local administration & District executive director, forest/game officer, village executive officer \\
Security & Army officer, police officer
\end{tabular}




\section{DISCUSSION AND RECOMMENDATIONS}

Forests, through the timber trade, could contribute in a significant way towards sustainable development in Tanzania. After all, opportunities abound. The current scenario of un-captured opportunity has become particularly prominent in recent years. While benefits have accrued at various levels, the true potential from socioeconomic and political perspectives has not been realized. Indeed, current dynamics have led to several detrimental impacts inhibiting the achievement of national poverty reduction goals ${ }^{4}$ and, therefore, the Millennium Development Goals (MDGs) (Milledge et al, 2007). Perverse incentives and other impediments, both institutional and individual in nature, have created barriers to good forestry governance.

The following discussion therefore revolves around four key questions arising from the previous section. These questions cover the three major short- to mid-term impediments - asset competition, pervasive corruption and accountability deficiencies as well as the longer-term goal of maximizing opportunities for sustainable development.

\section{Is it possible to reconcile competing interests over appreciating forest assets?}

\section{Clear policy outcomes a precursor to reducing forestry asset domination}

A root cause of forestry governance shortfalls in Tanzania is the competition over valuable timber assets. Competition can also act as a key impediment to change. In particular, beneficiaries of the current patterns of access to the country's forestry assets (such as economic and political elites) will likely resist change in the absence of economic incentives such as alternative income sources.

Experience in southern Tanzania has also shown how the lack of demand for accountability further reduces the likelihood that beneficiaries, who are highly reliant on forest-related income, will take action that could disrupt the status quo. The steadily increasing forest asset values and relatively low maintenance costs for timber income (given the generally low levels of reinvestment into forestry management) further reinforce this situation. The lack of incentives for change can also inhibit efforts to deal with corruption.

So what is the real issue with competition, which normally provides healthy conditions for maximizing financial returns? The challenge lies in policy outcomes. Under the current scenario, it is inevitably the powerful economic and political elites, both individual and institutional, which benefit from the greatest proportion of forestry revenue flows in southern Tanzania. Unfortunately, the poor majority has arguably the least bargaining power with respect to forestry asset competition, making pro-poor change an uphill struggle. After the poor majority, local government is a close second in terms of weak bargaining power.

This chapter argues for the need to develop clearer policy-driven goals for forest product trade based on priority longer-term national development needs. In light of the importance placed on realising improved indices of human development in rural 
areas, policy interventions are required to promote rural community development opportunities (as a means towards poverty reduction) and the generation of state revenues (as a means towards self-sufficient decentralized government administration). This will help to prevent reinforcement of the above-mentioned domination of forestry assets and revenue flows by economic and political elites.

\section{Identifying alternative income sources to reduce reliance on forestry assets}

The absence of economic incentives such as alternative sources of income is a key impediment in reducing inhibitors of change. The identification of suitable alternatives is fundamental, therefore, in moving from policy thinking to successful practice. This imperative is made all the more important considering clear indicators of unsustainable timber harvests in the south of the country (Milledge et al, 2007).

In southern Tanzania, a relatively common scenario is where local (and sometimes central) government is reluctant to relinquish control over forestry revenues to communities (PFM) in the absence of alternative revenue sources. It is important for local governments to actively demonstrate a broadening of the income basket, rather than continued heavy reliance on natural resources. A well-monitored stepwise approach is recommended, with a special focus on broadening the tax base.

This is probably not an unreasonable task considering the increase in economic activity in southern Tanzania following completion of the Mkapa Bridge and associated infrastructure developments. Indeed, a move away from the state's heavy reliance on forest-related revenues, alongside the devolution of forest management to rural communities, might genuinely produce a win-win scenario in terms of development and conservation outcomes from such a major development project.

Another positive economic (and social) incentive for the devolution of forest management and ownership to rural communities is the reduced financial burden to local government in the longer term. While some government income is, indeed, forfeited, such devolution provides building blocks for self-sufficiency at rural levels. In the longer term, therefore, improvements in rural social conditions should reduce the normal development costs carried by local government. It is important for existing successful PFM initiatives to demonstrate these types of economic and empowerment arguments to promote its expansion.

\section{How can demands for accountability be established?}

Ironically, most forests are found on public land; yet there persists a low vertical societal demand for accountability. In addition, forest-related incomes can be substantial; yet there is little scrutiny of returns on investment for forest management. Overall, improved forestry governance requires strengthened fiduciary contracts, which, in turn, needs sufficient incentives to raise demands for accountability.

PFM is an available tool that can strengthen fiduciary contracts through a reciprocal relationship between citizens (who gain tangible advantages from ownership, access and benefits from forest-related revenues) and the state (who benefit from resource taxation and fiscal savings by devolving management). This potential can only be realized through faster PFM and associated land entitlement. Since 
taxation is likely to be at the centre of fiduciary contracts, alternative tax arrangements need to be sought in cases where devolution of ownership is accompanied by 100 per cent revenue retention rights. It is also recommended that PFM efforts be linked to other parts of rural society where demands for accountability do exist (e.g. within religious institutions and education, agriculture and health sectors).

The opportunity for corruption generally arises from insufficient oversight and other institutional arrangements which provide means of accountability, transparency and coherent organization. The opportunity for forestry corruption in Tanzania has been aided by low levels of horizontal accountability (intra-government relationships). At the same time, government ability to manage the timber trade is compromised by insufficient capacity (see Figure 14.3). It is recommended that stronger linkages be made between relevant government departments. For example, revenue collection would be enhanced through better linkages (or outsourcing) with the Tanzania Revenue Authority. Timber trade compliance would be made more effective through further engagement with police, customs and other law enforcement institutions. Several bodies could play stronger roles in strengthening accountability and reducing forestry corruption, such as the Public Ethics Commission, parliamentary oversight committees and the Prevention and Combating Corruption Bureau. In addition to strengthening horizontal accountability, efforts to engage multiple actors can help to address capacity constraints.

Horizontal accountability has suffered for many years from conflicts of interest, competition over forestry-related revenues between the two ministries involved with forestry management at central (Ministry of Natural Resources and Tourism, or MNRT) and local government PO-RALG levels, and a lack of clear mandates and roles. This scenario has affected the efficiency of planning, revenue collection, compliance and disciplinary action, among other issues (Milledge et al, 2007). Decentralized forest management requires the establishment and communication of clearer responsibilities and operational linkages between MNRT and PO-RALG.

Another dimension of accountability is external, including relationships between governments and international entities. Forestry products are exported worldwide; yet there are relatively low demands for accountability with respect to legality of origin.

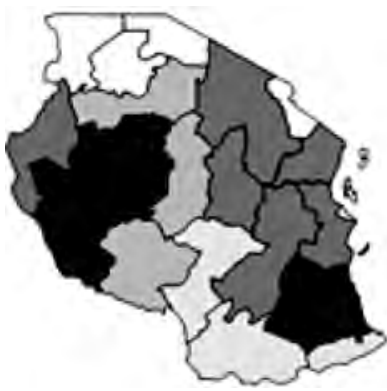

Total forest area

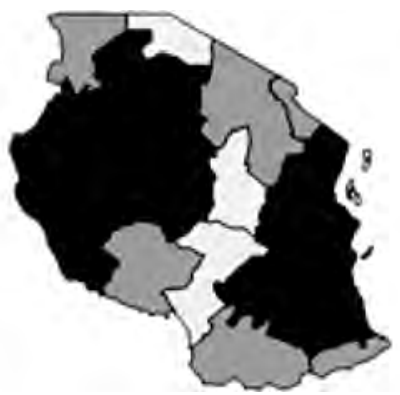

Forestry revenue targets, FY04

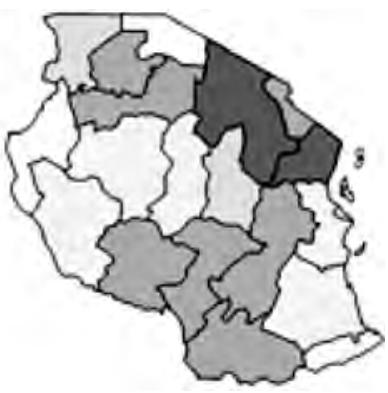

Local government staffing capacity

Source: Milledge et al (2007)

Figure 14.3 Geographic variation in forest area, revenue targets and staffing capacity 
Tightening importing nations' legislature (e.g. EU, US and China) could assist in verifying the legality of tropical hardwood supplied from Tanzania. The Convention on International Trade in Endangered Species of Wild Fauna and Flora (CITES) holds the potential to strengthen international timber trade controls and monitoring. It is recommended that species in trade from Tanzania are assessed for their potential listing under CITES as a tool for sustainable trade.

Furthermore, timber trade is an area of growing foreign investment; yet there are relatively low demands for social and environmental responsibility. It is recommended that Tanzanian authorities collaborate with key timber importing nations in the development of industry standards, voluntary codes of conduct and other bilateral initiatives to ensure legality, sustainability and social ethics.

\section{How can pervasive corruption be effectively addressed?}

\section{Shift in emphasis from technical solutions to people-centred approaches}

As just discussed, reducing the opportunities for corruption is one important strategy. As important, but frequently neglected, is reducing the inclination for corruption, which is usually caused by low moral values and motivation. Improved human resource management is required to reduce multi-tasking and deficits in forest officers (e.g. reviewing staff responsibilities, outsourcing options and staffing levels), and to enhance motivation (e.g. revised remuneration packages and working conditions).

The role of leadership in raising motivation and moral values cannot be understated; good leadership may be more influential than other human resource management solutions given the social context. For example, it is not uncommon in Tanzania for nepotism to be viewed as natural, while patronage may not be viewed as a form of corruption, even where conflicts of interest are apparent. Furthermore, the involvement in illegal timber trade activities, or forest-related corruption, is not considered particularly serious by many Tanzanians in the south of the country. These factors, when combined with strong respect for seniority and social standing, can easily combine to become a serious hindrance to good forestry governance. Strong leadership at all levels can help to modify perceptions, moral values and motivation. Indeed, public statements at presidential and ministerial levels during 2007 helped to raise the profile of forestry-related corruption.

\section{Holistic measures to address forestry corruption}

Khan et al (2005) argued that one major reason why many anti-corruption strategies have failed in Tanzania is that 'they ignore the interdependence of different types of corruption'. Within the forest sector, evidence suggests that most efforts to address corruption have focused on bribery and other forms of bureaucratic corruption, the most obvious and easiest forms of corruption to combat in the short term. It is apparent that such polarized interventions can cause shifts in emphasis to more damaging forms of corruption. The emergence of the organized involvement of senior public officials in timber-related businesses, including members of the executive, raises the spectre of the forest sector becoming more influenced by political corruption. It is therefore important to develop holistic approaches and, thus, prevent a worst case scenario where control over forestry resources becomes heavily linked to 
developing political factions, leading to shorter-term decision-making and forms of corruption that are very difficult to reverse.

In light of the ongoing process of decentralization, the increasing value of forest resources, and some evidence of factionalism within the MNRT, it is important that anti-corruption efforts in the forest sector ensure that those involved in corruption are not the ones leading anti-corruption strategies. Otherwise, short-term decisionmaking by factions in control of resource ministries are unlikely to match national interests. At the same time, there is sufficient evidence (see Table 14.2) that forestry corruption extends well beyond the line ministry; yet public scrutiny and focus remains on the MNRT. For example, the entire senior management of FBD was reformed in December 2007 (the fourth significant management change in as many years). Finger-pointing remains common, while accepting joint responsibility and a team approach seems elusive. This scenario does little to build confidence, and reduced morale even increases the inclination to engage in corrupt activities. A holistic approach to addressing forestry corruption requires efforts by, and addressed to, many different stakeholders (and not purely by, and to, the line ministry).

\section{How can the sustainable development opportunities of timber trade be maximized?}

\section{Long-term national vision for forest product trade and investment}

Progress towards realizing larger development goals for the sector could be enhanced greatly through the articulation of a specific overarching long-term (30- to 50-year) vision for forest product trade. Such a long-term vision would include targets covering the composition of different forest management, ownership and investment arrangements, the levels of log production to satisfy projected market demands, and required levels of investment.

Developing such a long-term vision is particularly important to ensure that proactive planning and responses to powerful global timber market transformations truly contribute to the betterment of society. As more countries compete to enter into bilateral trade and investment agreements with African nations, it is becoming more of an imperative to have a domestic vision with which such bilateral agreements can be aligned. Otherwise, a country such as Tanzania will continue to be at the mercy of powerful importing countries or other vested interests. The same almost certainly applies to all natural resource extractive industries.

Development of such a long-term vision will require improved national coordination between sectors responsible for natural resource management, economic planning and empowerment. Forests are not a union matter; yet differing policies between the mainland and Zanzibar can undermine forest product trade controls. Nationwide policy harmonization is therefore required to reach consensus on a long-term vision for timber trade and investment.

\section{Preparing rural communities for liberalized markets}

Ensuring adequate national capacity to cope with dynamic natural resource markets is imperative; but what about ensuring rural capacity to adapt? Given the promotion of PFM 
and the importance of ensuring that rural communities benefit from trade opportunities, a linked question is how can social models of forest management really work in a liberalized and globalized market environment that works on economic principles?

The globalized nature of timber trade has not only arisen from transformations in key markets and trade routes. Within Tanzania, ongoing decentralization, privatization and market liberalization have opened opportunities for investment and trade in the forest sector. These developments have also broadened administrative and management options, one of which is PFM involving rural communities (under the leadership of local authorities).

Unfortunately, PFM has not lived up to expectations or its potential in southern Tanzania. Most experience demonstrates how PFM has suffered from serious inhibitors such as competing interests and insufficient business acumen. At the same time, it is recognized that PFM holds the potential to strengthen local-level governance (Mkwizu and Milledge, 2007). Key issues to be addressed at rural levels include the low levels of awareness of roles, responsibilities and opportunities for empowerment in a potentially global marketplace, and communication gaps between different role players, leading to compromised vertical (societal) accountability.

In general, PFM has proceeded at a relatively slow (and costly) pace in southern Tanzania. Indeed, it is clear that in some villages where the trustee stewardship PFM partnership has been delayed for long periods, villagers have acted in defiance to make quick profits from short-term timber trade opportunities. It is therefore important for all stakeholders working on PFM development projects to expedite forest management devolution. Only then will village communities gain formal ownership of, and control over, their forest resources. Attention should then focus on developing rural microenterprise and sustainable forest management skills.

\section{CONCLUSIONS}

Despite the opportunities for timber trade to generate equitable and broad-based benefits, expectations have not been met in recent years, especially in southern Tanzania. High levels of illegality in timber trade have posed serious financial implications in terms of lost government revenues. Timber harvesting is conducted at unsustainable levels, resulting in considerable forest degradation and undermining long-term sustainable use options.

At the same time, there is insufficient evidence of significant human development in many areas where trees have been harvested and sold for export. An overlap between human demographics and forest cover is particularly evident in southern Tanzania, where some of the poorest people live in forest-rich areas (see Chapter 6 in this volume). In most cases, it is not necessarily the forests acting as a poverty trap, but the poor trapped by circumstances outside their control.

Perverse incentives generated by asset competition, weak fiduciary contracts and pervasive corruption have served as major barriers to improved forestry governance. This situation has been further influenced by market liberalization, government decentralization, political devolution and transformations in global markets and transport infrastructure. 
National and regional processes such as Africa Forest Law Enforcement and Governance (AFLEG) have developed an Indicative List of Actions that serve to strengthen forestry governance. While efforts are ultimately required across the spectrum of indicative actions, this chapter recommends areas for emphasis.

While enforcement-related strategies remain core to improving forestry governance, experience has shown that greater emphasis is required on non-regulatory measures. Incentive-orientated approaches are central to removing impediments to good forestry governance. Holistic approaches are required to address complex issues such as forestry corruption, both in terms of scope and stakeholder participation.

At a higher level, longer-term planning and outlooks for forestry trade and investment are required not only for timber exports, but other extractive industries. These visions need to encompass political, economic and social aspirations as well as take best advantage of global opportunities. In the absence of such long-term planning and setting of milestones, the course of timber trade investment and trade may not meet sustainable development goals.

\section{NOTES}

1 Mining is the fastest growing sector, accounting for 60 per cent of total exports and replacing agriculture in terms of export value (Khan and Gray, 2005).

2 According to the Human Development Report 2007/2008, Tanzania's population increased from 16 million in 1975 to 38.5 million in 2005, growing at an average rate of 2.7 per cent per annum (UNDP, 2007).

3 The forest sector is guided by the National Forest Policy of 1998, which is implemented through the National Forest Programme, 2001-2010 (NFP). Within the Ministry of Natural Resources and Tourism (MNRT), the Forest and Beekeeping Division (FBD) is responsible for execution of the NFP and primary legislation, the Forest Act of 2002. Decentralized forest management involves the Prime Minister's Office - regional administration and local government - and has linkages with a number of other policies and legislation (Milledge et al, 2007).

4 The primary framework document for poverty reduction in Tanzania is called the National Strategy for Growth and Reduction of Poverty, a five-year plan (2005-2010) abbreviated as MKUKUTA in Swahili.

\section{REFERENCES}

Adams, M. (2004) State of Play for Tropical Timber, ITTO Tropical Forest Update 14/4

ITTO (International Tropical Timber Organization) (2005) Annual Review and Assessment of the World Timber Situation 2004, Document GI-7/04, ITTO, Yokohama, Japan

Khan, M. H. and H. Gray (2005) State Weaknesses in Developing Countries and Strategies of Institutional Reform - Operational Implications for Anti-Corruption Policy and A Case Study of Tanzania, Report for DfID, London 
Maal, S. J. (2007) Tax and Governance in Tanzania, MSc thesis, Economic Theory and Econometrics, Department of Economics, University of Oslo, Oslo, Norway

Milledge, S. A. H. and B. Kaale (2005a) Bridging the Gap: Linking Timber Trade with Infrastructural Development in Southern Tanzania - Baseline Data before Completion of the Mkapa Bridge, TRAFFIC East/Southern Africa, Dar es Salaam, Tanzania

Milledge, S. A. H. and R. Elibariki (2005b) The Status of Logging in Southern Tanzania, TRAFFIC East/Southern Africa, Dar es Salaam, Tanzania

Milledge, S. A. H., I. K. Gelvas and A. Ahrends (2007) Forestry, Governance and National Development: Lessons Learned from a Logging Boom in Southern Tanzania, TRAFFIC East/Southern Africa, Tanzania Development Partners Group and Ministry of Natural Resources and Tourism, Dar es Salaam, Tanzania

Mkwizu, Y. and S. Milledge (2007) 'Can participatory forest management assist with local-level forest governance?’, The Arc Journal, vol 21, pp28-30

Rutashobya, L. (2004) Fiduciary Risk Assessment for the Provision of Direct Budgetary Support in Tanzania, DfID, Dar es Salaam, Tanzania

Thornton, A. (2005) 'Chinese involvement in African illegal logging and timber trade', Paper presented to the US House of Representatives, Committee on International Relations, Subcommittee on Africa, Global Human Rights and International Operations, Environmental Investigation Agency, US

UNDP (United Nations Development Programme) (2007) Human Development Report 2007/2008, UNDP, New York

White, A., X. Sun, K. Canby, J. Xu, C. Barr, E. Katsigris, G. Bull, C. Cossalter and S. Nilsson (2006) China and the Global Market for Forest Products: Transforming Trade to Benefit Forests and Livelihoods, Forest Trends, Washington, DC 


\title{
The Africa Forest Law Enforcement and Governance (AFLEG) and Forest Law Enforcement, Governance and Trade (FLEGT) Processes and the Challenges of Forest Governance in African Tropical Timber-Exporting Countries
}

\author{
James K. Gasana and Jean-Marie Samyn
}

\section{INTRODUCTION}

Since the Group of Eight (G8) industrialized nations launched an action programme on forests in 1998, the issue of illegal logging and the role of timber consumers in world markets in ensuring that traded timber comes from sustainable sources have been attracting increasing attention. Several processes and initiatives were launched at global, regional and sub-regional levels to foster international dialogue and cooperation to fight illegal logging and illegal timber trade, and to improve governance in the forest sector. These processes and initiatives include the World Bank-supported Forest Law Enforcement and Governance (FLEG) processes and the European Union's Forest Law Enforcement, Governance and Trade (FLEGT) process. In Africa, cooperation in promoting forest law enforcement and governance, which is the focus of this overview, has developed as a result of these processes and initiatives. This cooperation led to the initiation of the Africa Forest Law Enforcement and Governance (AFLEG) process in 2003, and to a dynamic in which the public sector, civil society and the private sector are cooperating to enhance forest law enforcement and forest governance. This chapter presents a summary of the progress made so far in this cooperation as well as the challenges, at regional level and in bilateral programmes. 


\section{BACKGROUND}

One of the most important drivers of tropical deforestation is poor governance of forest resources, which leads to illegal practices, including conversion of forests to agricultural land. In May 1998, the G8 launched an action programme on forests, which prioritizes the elimination of illegal logging and timber trade, and seeks to complement actions undertaken at the regional and international levels. Since then, the issue of illegal logging and the role of timber consumers in world markets have been attracting renewed attention. Several programmes and initiatives have been promoted at global, regional and sub-regional levels to foster international dialogue and cooperation to fight illegal logging and illegal timber trade, and to improve governance in the forest sector. They include the World Bank-supported FLEG programme, which emerged in 2001 as a first response by the international community to the issue of illegal activities in the forest sector; the EU's FLEGT process, which materialized in 2003 through a Plan on Forest Law Enforcement, Governance and Trade that includes support of and coordination with FLEG processes, the Asian Forest Partnership, the Congo Basin Forest Partnership, and the United Nations Food and Agriculture Organization (FAO); and the International Tropical Timber Organization (ITTO) regional forest law enforcement and governance-related activities.

The Africa Forest Law Enforcement and Governance process developed as one of the FLEG processes that are supported by the World Bank, governments of the UK and the US, and other partners. It aims to foster international dialogue and cooperation to fight illegal logging and illegal timber trade, and to improve governance in the forest sector. It seeks to create the political 'space' and technical means to address illegal logging and trade in illegal timber and timber products. It is implemented by governments in partnership with major stakeholders from civil society and the private sector to catalyse joint action. It seeks alignment with existing sub-regional institutions and processes to ensure continuity, sustainability and mainstreaming within existing mechanisms and programmes.

In recognition of the increasing public concern with the social, economic and environmental consequences of illegal logging and related trade worldwide, the European Commission adopted the EU Forest Law Enforcement, Governance and Trade process, which became the main coordinated mechanism through which EU member countries address forestry problems in timber-producing developing countries. FLEGT came in support of FLEG, for which the European Commission had committed itself to developing an action plan in order to combat illegal logging. In April 2002 it hosted an international workshop to discuss how the EU should combat illegal logging. At the World Summit on Sustainable Development (WSSD) in Johannesburg during the same year, the commission expressed a commitment to combat illegal logging and the associated trade in illegally harvested timber. 


\section{AFLEG AND FLEGT PROCESSES: A BRIEF INTRODUCTION}

\section{AFLEG}

The first Africa Forest Law Enforcement and Governance (AFLEG) Ministerial Conference took place in Yaoundé, Cameroon, from 13 to 16 October 2003. It was cohosted by the Government of Cameroon and the World Bank. The objectives of the conference were to share and explore ideas on forest governance, to consider priority issues, including illegal forest exploitation and associated trade in Africa, and to identify ways in which various stakeholders can address these issues, including partnerships between producers and consumers, donors, civil society and the private sector. The conference produced a Ministerial Declaration and an AFLEG Action Plan, emphasizing the need for institutional and policy reforms; capacity-building; law enforcement and monitoring of wildlife resources and forest management practices; mobilization of financial resources for communities dependent upon forest resources to reduce illegal activities; promotion of cooperation between law enforcement agencies within and among countries (creation of sub-regional taskforces); involvement of local communities in decision-making; awareness-raising regarding the impact of illegal logging and associated trade; and advancement of the implementation of AFLEG objectives within the New Partnership for Africa's Development (NEPAD) and other processes.

In order to reactivate the process, which was dormant for several months after the Ministerial Conference, the World Conservation Union (IUCN), the Facilitating Agency of the Conference on Central African Moist Forest Ecosystems (CEFDHAC), organized with the UK Department for International Development (DfID) in January 2005, a series of national awareness and consultation workshops in Libreville (Gabon), Yaoundé (Cameroon), Kinshasa (Democratic Republic of Congo) and Brazzaville (Congo). These workshops paved the way for the Congo Basin-wide tripartite consultation meeting that took place in Brazzaville on 29 January 2005, with the aim of integrating AFLEG issues into the agenda of the February 2005 Summit of the Central African Heads of State. The objective was to mobilize stakeholders at different levels in order to prepare action plans with concrete prioritized actions.

Taking into account the new developments, the World Bank, in cooperation with the Government of Gabon and the Central African Forest Commission (COMIFAC), supported Intercooperation in July 2005 in organizing a sub-regional meeting in Libreville, with the following objectives:

- to help change the perception that AFLEG is a top-down and a donor-imposed effort; and

- to adopt practical immediate and medium-term actions at national and regional levels. 
Six countries present at the AFLEG Ministerial Conference and members of COMIFAC participated in this pilot sub-regional initiative to reactivate the AFLEG programme: Burundi, Cameroon, Central African Republic, the Democratic Republic of Congo, Gabon and the Republic of Congo. The meeting recommended the creation of a sub-regional taskforce within the CEFDHAC. Another workshop was organized in December 2005 by IUCN and the German Technical Cooperation (GTZ) to review the initial terms of reference of the task force, develop a plan of action and secure the integration of the COMIFAC Plan de Convergence with the FLEG process.

In November 2006, the first meeting of the taskforce took place in Bangui (Central African Republic) on the initiative of the executive secretariat of COMIFAC to establish an AFLEG/FLEGT taskforce geared towards the development of an action plan for implementing the COMIFAC convergence plan. The outcome was an AFLEG/FLEGT work plan that includes the following elements (COMIFAC, 2006):

- $\quad$ support to the Regional Network of Parliamentarians (REPAR) in Congo Basin countries;

- $\quad$ piloting third-party independent forest monitoring in Gabon and the Democratic Republic of Congo;

- support to local non-governmental organizations (NGOs) to monitor social benefits derived from the 'social-benefits contracts' included in the concession contracts in several Congo Basin countries.

In January 2007, a Regional Workshop on Forest Law Enforcement in Central Africa took place in Libreville, Gabon. It was jointly organized by COMIFAC, FAO and ITTO and hosted by the Government of Gabon. The meeting was attended by more than 60 participants representing forestry and wildlife administrations, NGOs and the private forest sector of the ten member countries of COMIFAC (Burundi, Cameroon, Central African Republic, Congo, Democratic Republic of Congo, Equatorial Guinea, Gabon, Rwanda, Sao Tomé et Principe, and Chad) as well as representatives of regional organizations and development partners. The objective of the workshop was to promote a multi-actor dialogue and the exchange of experiences among COMIFAC member countries on best practices for improving law compliance in the forest sector. The main outcomes included a stronger ownership of the forest law enforcement process in the Central Africa sub-region; the deepening of the commitment of public and private sectors and civil society to collaborate; and awareness of the need for concrete actions. Priority actions identified include revising and harmonizing national policies and legislation related to forests through the involvement of all stakeholders. It should be mentioned here that the World Bank has not yet supported similar AFLEG-related activities in West Africa.

\section{The European Union FLEGT}

In recognition of the increasing public concern with the social, economic and environmental consequences of illegal logging and related trade worldwide, the European Commission adopted the EU Forest Law Enforcement, Governance and 
Trade process, which became the primary coordination mechanism through which EU member countries address forestry problems in timber-producing developing countries. FLEGT came in support of the FLEG process, for which the European Commission committed itself to developing an action plan to combat illegal logging. In April 2002 it hosted an international workshop to discuss how the EU should combat illegal logging. At the WSSD in Johannesburg during the same year, the European Commission expressed a commitment to combat illegal logging and the associated trade in illegally harvested timber.

To build on the commitment taken at the WSSD summit, the commission published, in May 2003, the European Union Action Plan for FLEGT (Commission of the European Communities, 2003). The action plan sets out a new approach to tackling illegal logging, which links the push for good governance in developing countries with the legal instruments and leverage offered by the EU's own internal market. The core components of the action plan are support for improved governance in timberproducing countries and a licensing scheme to ensure only legal timber enters the EU. The licensing scheme is to be implemented on a voluntary but binding basis through a series of partnerships with timber producing countries. The European Commission also proposes action for cooperating with other major consumer markets, such as the US and Japan, to stop the trade in illegally harvested timber. The plan sets out a range of proposals on issues that include:

- development cooperation focused on addressing illegal logging in producer countries;

- political measures to control imports of illegally harvested timber into the EU;

- public procurement measures that ensure procurement of legally sourced timber;

- $\quad$ private-sector initiatives;

- financing and investment safeguards; and

- conflict timber.

The plan also sets out a range of measures that include:

- $\quad$ support for improved governance and capacity-building in timber-producing countries;

- development of voluntary partnership agreements (VPAs) with timber-producing countries to prevent illegally produced timber from entering the EU market; and

- efforts to reduce the EU's consumption of illegally harvested timber and discourage investments by EU institutions that may encourage illegal logging.

Of these measures, the most instrumental element the action plan is the VPA. These are negotiated bilaterally between the European Community and interested timberproducing countries. Their aim is to ensure that only legally sourced timber products are imported into the EU from partner timber-producing countries, under the conditions of the licensing system. At the same time, there is an attempt to exclude from EU markets all illegally logged and traded timber products. The licensing scheme was adopted by the Council Regulation in December 2005. 
In the VPA, the parties should outline key factors in implementing the licensing system. These may include:

- laws and regulations to be considered in deciding the status of legality to be applied in awarding the licence;

- the institutional arrangements behind the system; and/or

- the degree of independent verification of legal behaviour at every stage of the chain of custody of forest products.

In addition, the EU adopted a new timber licensing system that should enable the identification of legally produced and legally imported forest products. Timber products imported from VPA partner countries must possess a validly issued licence of legality in order to be allowed access into the EU.

VPAs are currently under negotiation between the EU and interested timberproducing and timber-exporting countries. At the forefront of these countries as far as negotiations are concerned are Cameroon, Ghana, Indonesia and Malaysia. Indeed, the European Commission has started formal negotiations on VPAs with Ghana and Cameroon, and substantial dialogue with Malaysia and Indonesia. Initial discussions have taken place with the Democratic Republic of Congo (DRC), the Republic of Congo and Gabon.

In December 2006, the EU published a consultation document exploring options with regard to specific legislation to outlaw the import of illegal timber and wood products into the EU. This consultation, which closed in March 2007, proposed four additional options for combatting illegal logging and related trade. ${ }^{1}$

The First Central African Forum on FLEGT took place from 3 to 4 July 2007 in Brazzaville, Congo, with the following objectives:

- inform stakeholders (administrations, NGOs, the private sector) about the FLEGT process;

- $\quad$ share experiences gained by those countries that are already engaged in FLEGT; and

- identify next steps towards the development of VPAs.

About 100 government delegates attended the forum from COMIFAC member countries, representatives of international organizations, NGOs and the private sector. The forum noted a number of points. First, it was clear that Cameroon had made more progress than other central African countries. It has an adequate chain-ofcustody system and had enhanced information access on national laws and regulations. The negotiation process of the VPA with the EU was on track to start in August 2007. Gabon, Congo and the Central African Republic (CAR) had shown their commitment to FLEGT by sending letters of intent to the EU. The DRG had not yet declared its commitment. 


\section{DIFFERENGES AND POSSIBLE SYNERGIES BETWEEN AFLEG AND FLEGT}

As already mentioned, AFLEG is one of the FLEG processes supported by the World Bank and other governments and stakeholders. As with the other FLEG processes, it covers both legal compliance or legality and governance. Addressing legality implies defining illegal activities, and understanding the root causes of illegality and its consequences. Dealing with forest governance means considering the set of rules and institutions that control and determine what happens to a nation's forests and who gains and who loses as a consequence. 'Good' forest governance is governance that best meets, in a transparent, equitable and sustainable manner, the forest-related needs and goals of a society and its constituent parts. Forest governance is about who in government holds power, who is responsible and how accountable decision-makers are to citizens and to each other.

The main difference between FLEG and FLEGT is that FLEG processes are largely supply-side approaches to reduce illegal logging at source, while the FLEGT Action Plan is both supply side, by providing assistance to producer countries, and demand side, by curtailing the trade of illegally logged timber to the EU. The FLEGT Action Plan sets out a new and innovative approach to tackling illegal logging, linking good governance in developing countries with the legal trade instruments and leverage offered by the EU's internal market. The FLEGT process focuses on using demand instruments mixed with activities in exporting countries in order to discourage exports of illegally sourced timber and to favour legal ones. It is recognized that the FLEG programme contributed to creating the enabling conditions for the EU initiative to materialize.

According to Contreras (2007), there are also opportunities for taking advantage of synergies between FLEG and FLEGT. FLEG initiatives have so far largely focused on producer countries affected by illegal logging. The FLEG emphasis has thus been on strengthening governance on the supply side of logging and trade. The FLEGT programme emphasizes managing demand in the EU market, although it also considers actions in exporter countries to improve legal systems and institutional capacity in order to satisfy the legality requirements of the European market. As FLEG will in the future increasingly shift its focus towards greater efforts in individual countries, opportunities for better collaboration and synergies between processes that embrace supply as well as demand might increase.

Proof of the political commitment to integrate AFLEG and FLEGT is found in the organization of a sub-regional workshop of the AFLEG/FLEGT Taskforce in Brazzaville, Congo, from 5 to 10 July 2007, organized with the financial support of GTZ and French Cooperation. The workshop aimed to improve the understanding of AFLEG and FLEGT concepts among members of the Central African AFLEG/FLEGT Task Force. During the five-day workshop, emphasis was placed on: 
- concepts and tools concerning AFLEG, FLEGT and governance;

- the link between the COMIFAC Convergence Plan and AFLEG; and

- an appropriate organizational learning process to operationalize the Sub-Regional Task Force.

\section{MAIN ACHIEVEMENTS OF AFLEG AND FLEGT}

\section{Awareness-raising, knowledge creation and capacity-building}

General concern about illegal activities in the forest sector has been raised in many African countries with the organization of the Ministerial Conference and with the signing of the declaration by different countries. This could be considered a first important political commitment and a good basis for further action. It has paved the way for combating illegal logging and improving governance in the forest sector. Mobilization has reached governments, international organizations, and organizations of civil society and the private sector, both in producing and consuming countries. As such it could be considered a success because today the issue of illegal logging has been brought to light and become a subject of concern for producer as well as consumer countries.

FLEG processes have also raised awareness among government officials and key stakeholders about the magnitude of the problem and the dire economic, social and environmental consequences that it has for timber exporting countries. In October 2006, the first international Conference on the Sustainable Management of Central African Forest Ecosystems brought together 400 African parliamentarians and experts from governmental and non-governmental organizations in Yaoundé, Cameroon to focus on good forest governance and poverty alleviation. One of its objectives was further defining the role of sub-regional parliamentarians in sustainable forest management (SFM).

Through FLEG processes, much information has been collected and disseminated, studies have been conducted, figures have been produced and debate at regional and country level has started. There has been considerable improvement in knowledge concerning the causes and effects of illegal activities in the forest sector. It is generally recognized today that various actors and stakeholders are responsible for illegal activity and the complexity of the issue has been highlighted. The analytical work carried out and the state of knowledge achieved are valuable inputs into the dialogue and resulting strategies. Through the different meetings, workshops and fora, and through the different working groups and task forces mentioned above, stakeholder capacity has also been enhanced.

\section{Sub-regional coordination and cooperation}

Since its inception, AFLEG has placed priority on collaborating with other relevant regional and sub-regional processes and institutions. Mechanisms for consultation and coordination have been developed at international and regional levels. In addition to 
NEPAD, links have also been established between AFLEG and COMIFAC and the Congo Basin Forest Partnership (CBFP). ${ }^{2}$ The first link was established with the Central African Forest Commission (COMIFAC), which was legally established in September 2004 in Libreville as the entity responsible for forests in the region. COMIFAC is the political and technical commission in charge of orienting, coordinating, monitoring and harmonizing different strategies and initiatives pertaining to the forest sector in the Congo Basin. It is therefore the sole regional level decision-making body on forests of the region. Its members include Burundi, Central African Republic, Cameroon, Congo, Chad, Democratic Republic of Congo, Equatorial Guinea, Gabon, Sao Tomé et Principe, and Rwanda. The commission has an executive secretariat, which coordinates the implementation of the Convergence Plan. The commission has developed a common vision of forest governance in the Central African region and a technical action plan. It plays a key role in the implementation of the AFLEG Ministerial Declaration.

Agreements for transboundary cooperation in central African countries were also established. At the Central African Heads of States Summit that created COMIFAC, a trilateral agreement (TRIDOM Agreement) was signed between Cameroon, Gabon and Congo to protect 14.6 million hectares of forest. Also signed at the summit was a trilateral agreement between Cameroon, the Central African Republic and the Republic of Congo concerning the Sangha Tri-National Conservation Area. Central Africa hopes to offer a model in transboundary cooperation that demonstrates how to reach across borders to enforce law when forests, wildlife and the livelihoods of local communities are threatened.

\section{INITIATIVES AT THE NATIONAL LEVEL}

The Libreville workshop in 2007 summarized the advances made by many countries. These are summarized in Annex 1 at the end of this chapter. The FAO and ITTO were requested to continue supporting countries in their efforts to strengthen capacities for forest policy and law enforcement, particularly in relation to the AFLEG/FLEGT processes and to support the translation, dissemination and extension of forest laws and regulations. Next steps include the establishment of national technical committees for the elaboration and validation of forest regulations in each country, the development of a road map for the AFLEG/FLEGT process, and the adoption of an inter-state convention for forest control.

\section{THE CHALLENGES AHEAD}

As already mentioned, FLEG processes, as a whole, can be considered positive initiatives that have raised awareness. The different ministerial conferences in Asia, Africa and Eastern Europe have mobilized governments, international organizations, 


\section{Box 15.1 Lessons learned from the Africa Forest Law Enforcement and Governance (AFLEG) process}

Through the AFLEG Ministerial Declaration made in Yaoundé, Cameroon in October 2003, several African governments committed themselves to the elimination of illegal logging and associated corruption practices in the forest sector. Since then, lessons learned in the process leading to the declaration and after its adoption include the following:

- It is necessary to encourage tripartite exchange by the inclusion of governments, the private sector and civil society at all stages of the consultation processes in order to avoid suspicion, particularly regarding the discussion of sensitive issues such as good environmental governance and illegality.

- The AFLEG Ministerial Declaration, as a result of not being binding, is considered a weak tool for the implementation of its goals.

- The AFLEG Ministerial Declaration rightly underlines gaps in forest law enforcement and governance, but does not sufficiently highlight the efforts and progress that countries are making in implementing sustainable forest management policies.

- Many stakeholders feel there is a lack of implementable action plans compared with the attention given to workshops and meetings with no connection to concrete actions under implementation.

- In the eyes of some stakeholders, there is insufficient coordination between different forest governance processes, such as AFLEG, FLEGT and the Congo Basin Forest Partnership (CBFP).

and organizations of civil society and the private sector, both in producing and consuming countries.

In view of what is presented in the previous sections, it appears that substantial effort has been made and that many initiatives have been taken. At the international level, the World Bank, the EU, the FAO, the ITTO, as well as individual European countries have joined efforts to support the AFLEG process. The process has opened dialogue between government, the private sector and civil society. At a sub-regional level, different structures have been put in place such as COMIFAC, CBFP and FORCOMS, and government, civil society and private-sector actors at different levels have been involved. A task force was created in 2006 and prepared an AFLEG/FLEGT work plan. Workshops have been organized and numerous initiatives have been taken at national level (in Burundi, Cameroon, Congo, Gabon, DRC, CAR and Rwanda). Six countries have initiated negotiations or expressed their interest in starting negotiations with the EU to reach a VPA. But the ultimate impact of all of these efforts still seems to be limited, if not insignificant. Forest law enforcement and governance remain weak. What are the principal reasons for such poor performance? There are several, some of them country specific. Reasons common to a majority of countries are discussed below. 


\section{The complexity of the issues to be addressed}

One of the main reasons for limited success is the complexity of the issues to be addressed. FLEG is not only about illegal logging and law enforcement; the root causes of illegal logging and poor law enforcement are found in the broader 'governance' context. Tackling these causes would generally imply bringing farreaching changes at institutional, organizational and individual levels. Such changes are complex, and will need the long-term commitment of countries and donors alike, as well as strong political support at the highest level.

Raising awareness through international meetings, workshops and political declarations is important. But organizing workshops and formulating recommendations is not enough to incur change. Workshops have limited scope. People make declarations, make some commitments or formulate recommendations; but without a clear roadmap and concrete goals, very little takes place. Supporting reforms at institutional, organizational and individual levels is quite another thing. It is a long-term process that requires direct support at the country level. Illegal logging has to do with governance, and combating illegal logging will need profound changes, which will take time to achieve. Coordination with existing bilateral support or with other international initiatives at the country level (such as the National Forest Programme Facility) is necessary in order to translate political commitment into concrete measures and actions. Governance challenges in the forest sector are frequently related to a lack of vision or policy for the sector, inadequate mechanisms, lack of means and capacity, corruption, etc. Experience has shown that changes at this level are slow and that resistance to change can be very strong. So far, these international initiatives have not achieved much in terms of creating the appropriate conditions for required policy, legal and institutional reforms.

The definition of 'illegality' is itself a matter of controversy between some NGOs, governments, the private sector and analysts. Very often the tendency is to focus on illegal logging or illegal harvesting of timber. In reality, illegal activities are manifest in the establishment of rights to land, corrupt activities to acquire forest concessions, and activities at all stages of forest management and the forest goods production chain - from the planning stages, to harvesting and transport of raw material and finished products, to financial management (CIFOR, 2003). The list of 'violations' is long, illustrating the complexity of solutions. Definitions of 'illegality' may vary from one country to another; even within a country, opinions may vary widely.

\section{Risk of undesirable impacts}

Reforms, control of legality and improved law enforcement are all measures that could have negative or undesirable impacts upon some sections of the population, especially the poorest and the marginalized. Restricting international market access to legal timber could penalize small- and medium-sized enterprises, which cannot comply easily with the requirements imposed by 'legality' standards or complex certification schemes. 
Many people, including the poor and unemployed, may derive an income from illegal forest activities. Most of the illegal timber is also supplying the local market and meeting national needs for energy (firewood) or construction materials. The informal sector, which can be seen as a consequence of low incomes and widespread poverty, is providing jobs for thousands of people along the whole chain of custody, and illegal forest activities generate substantial 'informal' revenue. Any change aimed at reinforcing law enforcement or governance should pay greater attention to the informal sector in order to better understand the magnitude and distribution of benefits derived from the sector, the human resources involved, the level of exploitation of natural resources required to support it, and the sector's contribution to livelihoods and the economy at national, regional and local levels.

So far, very limited work has been carried out to understand the complex relationships between different violations, or the impacts upon various stakeholders. If measures are taken without a good analysis and understanding of the local context, there is a high risk that it will negatively affect the most vulnerable segment of the population.

The Rights and Resources Initiative (RRI) has been engaged in a body of work at global, regional and national levels on alternative tenure and enterprise models (ATEMs), which aim to provide guidance and lessons for decision-makers engaged in forest tenure and governance reforms. These models aim to strengthen tenure and access rights of local forest actors, and level the playing field for small- and mediumsized forest enterprises, including community-based forest enterprises so that these can be more competitive in the marketplace and better complement large industry, including those managing public concessions and commercial plantations and related processing industries. Is this a possible alternative solution to the problem? It is probably too early to answer the question; but studies are ongoing in a few pilot countries and the results will provide us with concrete elements for further analysis and action.

\section{Lack of concrete actions and funding}

Funding and technical assistance should be made available to countries in order to adopt FLEG strategies and action plans, and to implement concrete actions. Once the causes and consequences of illegal activities are understood, the FLEG process should identify strategies to combat them and propose measures to improve governance. The list of initiatives taken at country level might give the impression that substantial progress has been made in reinforcing governance in the sector and in tackling the root causes of illegal activities. In fact, some countries have made genuine efforts to enhance levels of forest governance. Cameroon is one of them. But despite years of effort and numerous reforms, the first concrete results materialized only recently. Today Cameroon has adopted a Forest and Environment Sector Development Programme supported by a consortium of donors as a comprehensive answer to the sector's problem. Ghana has also multiplied efforts to address illegality in the forest sector and the main donors have also agreed to start 
a sector budget support (SBS) covering forests, environment and mining. This support, combined with the country's initiative to sign a VPA with the EU, is bringing new hopes for reorganizing the forest sector and managing forests in a sustainable way.

But this is far from sufficient. New ways to support concrete actions must be explored. One of them is the initiative taken by the World Bank to produce guidelines for the preparation of FLEG national strategies. It has been limited so far to the ENAFLEG process and the initiative is still in its pilot phase. If successful, these guidelines could be applied with slight modifications for African countries. On the other hand, the FLEGT process offers a chance for countries which have expressed their interest to enter a VPA to improve governance in the forest sector or to address fundamental institutional reform processes. Countries should take the initiative themselves or with the support of bilateral donors to identify the root causes of illegality and to integrate actions to tackle them within their Forest National Master Plans. In the countries ${ }^{3}$ where the Forest Governance Learning Group is active, it could help to develop ideas on forest governance and to make them work for practical, just and sustainable forest use.

\section{Decentralized forestry}

In most countries, the quality of decentralized governance in the forest sector appears to be strongly associated with and dependent upon the quality of governance of the whole government apparatus, which is also true in Africa. In countries where the state is weak, where a certain degree of political stability is absent, where institutions and legal frameworks are dysfunctional, and where corrupt abuse of public office is common, it is highly improbable that a satisfactory level of governance in the forest sector can be achieved.

Decentralization is a gradual process. Coming from a point where decisions and control over resource management were highly centralized to a new situation in which several actors at different levels (national, provincial, district and local) will find their place and know their roles and responsibilities implies a complex process of institutional, organizational and individual change for which many people are not prepared. Three key factors internal to the sector appear to set the conditions for good decentralized forest governance, as earlier defined:

- $\quad$ effective and balanced distribution of responsibilities and authority among levels of government, respecting the subsidiarity principle, which means appropriate responsibilities and power for each level of government;

- adequate resources and institutional effectiveness at each level of government;

- $\quad$ sufficient participation of civil society and the private sector at all levels of forest governance.

Today, despite all the efforts made and the energy spent by different countries, the successes are still quite limited. True decentralization in forestry remains the 
exception. In most of the cases, forests are state owned and forest departments continue to manage them in a very centralized way. Some efforts of 'deconcentration'4 have been undertaken; but decentralization in the form of 'devolution of power' ${ }^{5}$ is still rare. Therefore, FLEG processes should focus on promoting decentralized forestry and increased participation of different stakeholders in decision-making at various levels.

Decentralization will not solve all of the problems related to the forest sector and approaches need to be adapted to regional and local contexts. To bring change, one should not wait for a clean and effective legal system to be in place; forests will have disappeared long before. The tenure issue (including aspects of clarity and stability) is probably one of the most crucial and will require special attention. According to Karsenty (pers comm), there is room and need for diversification of forest tenure models, which might be seen as complementary rather than alternatives competing with the current system. Second in importance is capacity-building, which needs to take place at all levels, but with a special focus on weak links. It should emphasize progressive changes in the attitude and behaviour of people, as well as in institutional norms. A broad range of innovations already exists on the ground and could serve as models for further progress.

\section{Low level of coordination between the different actors}

Another reason for slow progress is the low level of (and even sometimes the lack of) coordination between the main international agencies involved in the process. So far, concrete results in individual countries have been obtained by bilateral aid and support. Progress was made with regard to 'legality', mainly in the framework of the FLEGT initiative. AFLEG, led by the World Bank, should increase and reinforce its collaboration with other multilateral and bilateral agencies active in the forest sector and identify synergies. As already mentioned, the AFLEG process could benefit from experiences and ideas developed by the FGLG process where it is active.

Coordination should also be fostered between AFLEG, the ITTO and the FAO, who have initiatives to address illegal activities. It is worth mentioning that The Netherlands has recently signed a US $\$ 3$ million contribution to the ITTO to support a programme on tropical forest law enforcement and trade (TFLET). The programme, which will also be supported by other donors to make up a total budget of $\$ 4.3$ million, seeks to enhance civil society's capacity to contribute to forest law enforcement; enhance the capacity of small- and medium-sized enterprises to produce and trade timber from legal and sustainable sources; support and increase international trade in legally/sustainably produced tropical timber; and enable forest-dependent communities to sustainably manage their forests for poverty alleviation.

FAO with the National Forest Programme (NFP) Facility is also strongly embedded in many African countries (41 in total) through its Focal Points. NFPs provide a global framework for addressing forestry issues within the context of 
sustainable development. The NFP Facility is a funding mechanism and information unit created in response to recent intergovernmental meetings, which recognized the essential role of NFPs in addressing forest-sector issues. Again, the AFLEG could establish links and mechanisms of collaboration with the Facility on governance and law enforcement issues.

\section{CONCLUSIONS}

Since the late 1990s, there has been a new spirit of international cooperation in combating forest crimes, and a shift to considering illegal logging and related timber trade as international issues. The FLEG and FLEGT processes raised the profile of illegal logging both in Asia and in the rest of the world, and international concern over illegal logging and the associated trade in illegal timber has grown fast. The overall outcome is that many countries have been engaged in one or more forest law enforcement and governance processes. At a regional level in Africa, countries have defined or are defining priority issues and actions in forest law enforcement and governance under the framework of the AFLEG Ministerial Declaration. Governments, the private sector, civil society and international organizations are collaborating to target the improvement of governance in the forest sector and the promotion of SFM. In particular COMIFAC and CBFP in Central Africa have been active in setting the agenda in improved forest governance with a focus on SFM.

Overall, achievements resulting from cooperation and exchange at regional level and through bilateral cooperation in the framework of the AFLEG, FLEGT and the CBFP include:

- increased awareness of the causes and impacts of forest crime;

- a shared sense of responsibility among both producer and consumer countries;

- understanding of the distinct roles of various stakeholders;

- identification of priority actions;

- $\quad$ exchange of experiences and best practices among countries;

- generation of basic data on forest crime as a basis for multi-stakeholder discussions and as a means for establishing baselines to monitor progress;

- networks of information-sharing; and

- the inclusion of illegal logging and forest crime within several regional processes.

With regard to bilateral cooperation, the EU FLEGT has demonstrated the potential to promote the development of operational regional and national forest law enforcement mechanisms. Clear examples of this are the bilateral agreement on VPAs in preparation in Cameroon and Ghana. Bilateral approaches, such as the VPAs under FLEGT, are promising as far as concrete results are concerned in the fight against illegal logging. Their negotiations are bringing together all interested parties in producer and consumer countries to develop solutions and promote responsible 
forest management. There is clearly an interest by many countries in the AFLEG and FLEGT processes, as well as in forest partnerships and programmes relating to forest law enforcement. However, the AFLEG process needs to be revitalized to sustain this interest. More resources should be allocated for national analytical work in order to determine priority actions at policy and enforcement levels. More support should also be given to regional workshops for the dissemination of experiences and FLEG instruments.

\section{NOTES}

1 These include: (i) Strengthening Voluntary Partnership Agreements; (ii) Strengthening Voluntary Private Initiatives (certification, codes of conduct, etc.); (iii) Implementation of an import ban; and (iv) Adoption of a law that either prohibits the trading and possession of timber and timber products produced illegally in foreign countries (comparable to the proposal for a US 'Combat Illegal Logging Act', 2007 - Amendments to the existing US Lacey Act, 1981), or requires documentary proof of legality for all timber and timber products placed on the EU market, imposed at the border and/or at point of sale.

2 The Congo Basin Forest Partnership was launched at the WSSD in 2002 with the aim of encouraging donors to commit resources to the management and conservation of forests in Central Africa. CBFP consists of 29 members, including 3 international organizations and 10 non-governmental groups. It aims at improving communication among its members and coordinating investments to promote sustainable management of Congo Basin forest ecosystems and their wildlife, to ensure good governance, and to raise the living standards of people in the region. It works closely with COMIFAC.

3 Niger, Ghana, Cameroon, Uganda, Malawi, Mozambique, South Africa.

4 Redistribution of decision-making authority and financial and management responsibility among levels of government.

5 Transfer of specific decision-making powers from one level of government to another, or transfer of decision-making powers by the government to entities of civil society.

\section{REFERENCES}

Brack, D. (2007) The EU FLEGT Initiative: Improving Governance, Excluding Illegal Products, Chattam House, First Update Meeting on Illegal Logging and Associated Trade, Forest Trends, Washington, DC

Chattam House (2006) Illegal Logging Update and Stakeholder Consultation, Meeting Notes Update No 8-1, Royal Institute of International Affairs, London

Christy, L. C., C. E. Di Leva, J. M. Lindsay and P. T. Takoukam (2007) Forest Law and Sustainable Development: Addressing Contemporary Challenges through Legal Reform, World Bank, Washington, DC CIFOR (2003) National and International Policies to Control Illegal Forest Activities, CIFOR, Bogar, Indonesia 
COMIFAC (2006) Report to the Regional AFLEG/FLEGT Task Force, Réunion Constitutive de la Task Force Sous-régionale AFLEG/FLEGT, Bangui, Central African Republic, 14-16 November 2006

Commission of the European Communities (2003) Forest Law Enforcement, Governance and Trade (FLEGT): Proposal for an EU Action Plan, Commission of the European Communities, Brussels Contreras-Hermosilla, A. (2007) Forest Law Enforcement and Governance Program: Review of Implementation, World Bank, Washington, DC

Contreras-Hermosilla, A., H. M. Gregersen and A. White (2007) Decentralized Forest Governance with Federal Systems of Government: What Works and Why, CIFOR and Rights and Resources Group, Bogor and Washington, DC

Edmunds, D. and E. Wollenberg (2003) Local Forest Management: The Impacts of Devolution Policies, Earthscan, London

European Commission (2004) Impact Assessment of the EU Action Plan for Forest Law Enforcement, Governance and Trade, FLEGT, Commission of the European Community, Brussels

FAO in collaboration with ITTO (2006) Best Practices for Improving Law Compliance in the Forest Sector, FAO, Rome

Gasana, J. K. (2007) Report to FAO/OIBT/COMIFAC, Atelier Régional FAO/OIBT/COMIFAC sur l'Application des Législations Forestières en Afrique, Libreville, Gabon, 9-11 January 2007

Gasana, J. K. and J. M. Samyn (2005) Réunion sous-régionale sur le suivi du processus de l'application des législations forestières et la gouvernance en Afrique (AFLEG), Meeting Report prepared for the World Bank, Libreville, 13-14 July 2005, Intercooperatio, Bern

Ghana Ministry of Lands, Forestry and Mines (2007) Ghana's Entry into a Voluntary Partnership Agreement with the EU, VPA Briefing Paper no 1, February 2007, Ministry of Lands, Forestry and Mines, Accra

Global Witness (2002) Forest Law Enforcement in Cameroon: First Summary Report of the Independent Observer, May-November 2001, Global Witness, Yaoundé

Global Witness (2005) Forest Law Enforcement in Cameroon, 3rd Summary Report of the Observer, July 2003-February 2005, Global Witness, Yaoundé

Global Witness (2006) Progress in Tackling Illegal Logging in Cameroon, Annual Report, March 2005-February 2006, Global Witness, Yaoundé

Global Witness (2007) Evolution du contrôle et des sanctions de l'exploitation forestière illégale au Cameroun, Annual Report, March 2006-February 2007, Global Witness, Yaoundé

Gulbrandsen, L. H. and D. Humphreys (2006) International Initiatives to Address Tropical Timber Logging and Trade, Report for the Norwegian Ministry of the Environment, FNI Report 4/2006, Fridtjof Nansen Institute, Oslo

Hakizumwami, E. and C. Ndikumagenge (2003) Initiatives et processus sous-régionaux de conservation et de gestion forestière en Afrique Centrale: Cohérence ou concurrence?, Proceedings of the 12th World Forestry Congress, Québec, Canada

Hembery, R., A. Jenkins, G. White and R. Richards (2007) Illegal Logging: Cut It Out! The UK's Role in the Trade in Illegal Timber and Wood Products, Illegal Logging Report, WWF-UK, Surrey, UK

IISD Reporting Services (2006) 'Summary of the First Parliamentarians Conference on SFM in Central African Forest Ecosystems', Conference Bulletin, vol 129, no 4, pp30

INDUFOR (2004) Impact Assessment of the EU Action Plan for Forest Law Enforcement, Governance and Trade (FLEGT), European Commission, Brussels

Karsenty, A. (2007) Overview of Forest Industrial Concessions and Concession-Based Industry in Central and West Africa and Considerations of Alternatives, CIRAD, Montpellier 
Kishor, N. (2007) 'Overview of the progress of existing regional and bilateral cooperation on improving forest law enforcement', Presentation to the Chatham House Meeting Illegal Logging Update and Stakeholder Consultation, London, 9-10 July 2007

Koyo, J. P. (2004) 'Coordinating forest sector development in Central Africa', Unasylva, vol 218, no 55, pp34-38

MINEF (Ministry of the Environment and Forestry of Cameroon) (2004) Project of Independent Observer in Support of Forest Law Enforcement in Cameroon, MINEF, Yaoundé, www.minef.cm, accessed April 2008

PFBC (2007) Facilitation pour le Partenariat du Bassin des Forêts du Congo - Bilan et Perspectives 2007, Atelier CARPE 2007, Yaoundé

Piñeiro, M., J. K. Gasana, K. Muir-Laresche and R. Moore (2007) Independent Evaluation of FAONetherlands Partnership Programme (Phase II) 2004-2007, Final Report, FAO, Rome

Ribot, J. C. (2002) Democratic Decentralization of Natural Resources: Institutionalizing Popular Participation, World Resources Institute, Washington, DC

Rights and Resources Initiative (2007) Transitions in Forest Tenure and Governance: Drivers, Projected Patterns and Implications, RRI, Washington, DC

Rights and Resources Initiative (2008) RRI Strategic Analysis: Alternate Tenure and Enterprise Models (ATEMs), Revised Concept Note, RRI, Washington, DC

Samyn, J. M. and T. Stadtmüller (2006) Report on the Yogyakarta Workshop on Forest Governance and Decentralisation in Asia and the Pacific, Intercooperation, Bern

Tacconi, L., M. Boscolo and D. Brack (2003) National and International Policies to Control Illegal Forest Activities, Report prepared for the Ministry of Foreign Affairs of the Government of Japan, Japan

Visseren-Hamakers, I. J. and P. Glasbergen (2006) 'Partnerships in forest governance', Global Environmental Change, vol 17, no 3-4, pp408-419

World Bank (2006a) Strengthening Forest Law Enforcement and Governance: Addressing a Systemic Constraint to Sustainable Development, Report no 36638-GLB, World Bank, Washington, DC

World Bank (2006b) Guidelines: Formulation and Implementation of National Action Plans to Combat Illegal Logging and Other Forest Crime, Draft for discussion, World Bank, Washington, DC 


\section{Annex 1}

\section{Initiatives at National Level}

\section{BURUNDI}

- Creation of an environmental police in charge of law enforcement.

- Training of environmental police.

\section{CAMEROON}

- Strengthening of independent monitoring.

- Adoption and dissemination of forest and wildlife control strategies.

- Commitment to voluntary partnership agreement (VPA) negotiations under the framework of the Forest Law Enforcement, Governance and Trade (FLEGT) process.

- Creation of local committees to ensure local monitoring of forest law enforcement.

\section{CONGO}

- Launching of independent monitoring activities.

- Establishment of control strategies.

- Preparations to enter the FLEGT/VPA process.

- Organization in July 2006 of a forum on Africa Forest Law Enforcement and Governance (AFLEG)/FLEGT, in collaboration with the European Union (EU).

\section{GABON}

- Preparations to enter the FLEGT/VPA process.

- Strategy for forest and wildlife control. 


\section{DEMOCRATIC REPUBLIC OF CONGO}

- Commitment to forest reform with the financial support of the World Bank and the EU.

- Adoption of a new forest law.

- Launching of a forest law enforcement and governance project, with funding from the EU and execution by the World Conservation Union (IUCN).

- Establishment of a national consultative group on forest law enforcement.

- Involvement of the senate and parliament in anti-illegal logging processes.

- Training of journalists in law enforcement.

\section{RCA}

- Designation of a focal point for AFLEG/FLEGT/FORCOMS.

- Involvement in the AFLEG/FLEGT process.

\section{RWANDA}

- Adoption of laws against illegal felling.

- Establishment of local committees for forest protection. 


\title{
Free, Prior and Informed Consent: Implications for Sustainable Forest Management in the Congo Basin
}

\author{
Luke Freeman, Jerome Lewis and Sophie Borreill-Freeman with Christoph \\ Wiedmer, Jane Carter, Nicole Clot and Belmond Tchoumba
}

\section{INTRODUCTION}

This chapter examines changes that are occurring in the way in which local forest populations, particularly Pygmy hunter-gatherers, are consulted and involved in the management of forest concessions in the Congo Basin. Demand for timber certified by the Forest Stewardship Council (FSC) is growing and some forest companies operating in the Congo Basin wish to achieve the high standards of FSC forest management to benefit from the market opportunities opened up to FSC-certified timber. Through this process, forest companies are becoming answerable not just to individual states' code forestier, but to supra-national bodies with international standards of sustainable forest management (which generally encapsulate and surpass national ones). Principles 2 and 3 of the FSC standard demand the gaining of free, prior and informed consent (FPIC) for exploitation. Theoretically, FPIC means that communities living in the concessions should be fully informed about intended forestry activities and freely give their consent before any of these activities begin. The aim is to leave the local population room to refuse the company's exploitation or to negotiate with it on the management of forest resources. While this may seem clear on paper, in practice a lot of problems may arise, many of which are specific to the local social context. How do you achieve equal participation and free consent from indigenous hunter-gatherers who are politically marginalized by their farmer neighbours? Can it be said that consent is freely given when for local populations agreeing to logging activities is their only means of obtaining education, healthcare and basic infrastructure? How do you ensure complete consultation among a mobile hunter-gatherer population? Moreover, can FSC auditors prove this has been 
achieved? This chapter summarizes preliminary results from a feasibility study conducted in five major forest concessions in the Democratic Republic of Congo (DRC), the Republic of Congo and Gabon. By looking at the possibilities offered by FPIC and the difficulties surrounding its implementation, this chapter will evaluate if and under which conditions these FSC criteria could give local populations control over forest use and improve their living conditions. This chapter seeks to provoke debate on whether the universal theoretical concept of FPIC can respond to specific local human needs and situations.

\section{BACKGROUND}

The area of the Congo Basin, comprising most notably Democratic Republic of Congo (DRC), the Republic of Congo (RC), Angola, Equatorial Guinea, Central African Republic (CAR), Cameroon and Gabon, is the second largest block of tropical forest in the world. The total forest area is estimated to be between 187 and 207 million hectares, with the DRC covering between 128 and 135 million hectares (ITTO, 2006). This forest is of critical value for the global environment and for millions of local people (Debroux et al, 2007). While the Congo Basin has enormous wealth in minerals and timber, it has, paradoxically, high levels of human poverty. Over recent decades the DRC, in particular, has faced violent armed conflicts, human rights violations, internal displacement of peoples, uncontrolled economic exploitation (particularly in the mining sector), and overall poor law enforcement and governance. The comparative peace and stability since 2006 represents both a huge opportunity for the more equitable development of the region and a potential threat - in that powerful interest groups could use peace-time opportunities to harvest forest resources for personal gain at a previously unseen level of exploitation. For governments and international agencies, it is a challenging task to focus on long-term issues such as forest management or nature conservation when there are such pressing concerns, including humanitarian crises.

\section{THE INDIGENOUS FOREST PEOPLES}

The forest peoples of the Congo Basin can be broadly divided into two different groups: the Bantu and Ubangian farmers and fishers who live in sedentary settlements, and a wide range of semi-nomadic Pygmy $^{1}$ hunter-gathers and former hunter-gatherers living in forests. While the Pygmies are generally recognized as the aboriginal inhabitants, the Bantu have lived in the area for many generations, perhaps as long as 2000 to 3000 years in some places (Bahuchet and Guillaume, 1982; Vansina, 1990; Kleiman, 2003). While we take 'indigenous forest peoples' to refer to Pygmies, we recognize the complexity behind this definition ${ }^{2}$ - with well over 26 different Pygmy ethnic groups with differing customs and languages (Köhler and Lewis, 2002). There 
are no reliable census data on their population and definitions are often blurred by mixed marriages with Bantu and other groups (World Bank, 2007), but estimates of their number range from 70,000 to 600,000 in the DRC alone (Debroux et al, 2007).

The relationship between farmer and hunter-gatherer groups is today characterized by discrimination. Farming groups politically and economically marginalize Pygmy peoples through negative stereotyping, exclusion and a denial of their basic rights (Woodburn, 1997), and seek to dominate them through a variety of means (Köhler and Lewis, 2002). Where Pygmy peoples have access to good forest they can resist these attempts. However, expanding commercial forest exploitation has created increasing freedom of movement and livelihoods. In this context, the definition of local forest rights becomes very important. Generally, sedentary villagers are in a better position to defend their rights than Pygmy groups (World Bank, 2007). Debroux et al (2007) note: 'from a legal point of view the indigenous peoples are citizens equal to other Congolese. In most cases, however, they have neither the same access to land and resources as other groups, nor the same recognition of rights, nor the same influence, and organizational, technical or economic capacities.'.

\section{FOREST EXPLOITATION}

Pygmy groups use a huge range of different forest species for timber (to a limited extent), fuelwood, bushmeat, other forest foods, medicines, materials and implements. The interest of the Bantu and Ubangian groups focuses on the clearing of areas for agriculture, although they also use a wide variety of forest products for subsistence purposes and occasional sale (e.g. bushmeat).

It is very difficult to find accurate figures on the commercial exploitation of the forest of the Congo Basin; but it is true to say that vast areas of forest in the DRC remain unexploited. The International Tropical Timber Organization (ITTO) figures listed in Table 16.1 provide an official indication; but in reality there is substantial informal activity. The value of informal timber used in the DRC today is tentatively estimated at about US $\$ 100$ million in terms of market value in comparison to the value of industrial timber of about $\$ 60$ million (Debroux et al, 2007).

Table 16.1 Forest estate in the Congo Basin

\begin{tabular}{lccc}
\hline Congo Basin country & $\begin{array}{l}\text { Estimated total } \\
\text { forest area } \\
\text { (million hectares) }\end{array}$ & $\begin{array}{l}\text { Total area of } \\
\text { closed natural forest } \\
\text { (thousand hectares) }\end{array}$ & $\begin{array}{l}\text { Total area of production } \\
\text { forest (natural forest) } \\
\text { (thousand hectares) }\end{array}$ \\
\hline Democratic Republic of Congo & $128-135$ & 126,236 & 20,500 \\
Republic of Congo & $20.3-22.1$ & 22,000 & 18,400 \\
Gabon & 25.8 & 21,800 & 10,600 \\
Cameroon & $13.3-23.8$ & 19,985 & 8840 \\
\hline
\end{tabular}

Source: ITTO (2006) 
With the end of the civil war in the DRC, forest companies are seeking to intensify exploitation of these massive forest resources. Commercial forestry is often the only significant economic activity in large areas, and given the widespread lack of infrastructure it is often the companies that invest in the construction of roads and ports - as well as, occasionally, schools and health centres. This places them in a strong bargaining position with the government, and reports of corruption with regard to obtaining concessions are frequent (Greenpeace, 2007). At the same time, some companies are actively seeking to distance themselves from such a negative reputation.

Given the substantial commercial opportunities from current forest activities, there are increasing calls - locally and internationally - that forest-derived revenue should be used to the benefit of all Congolese people, and that the rights of indigenous peoples, who have seen so few development benefits, should be particularly respected. Such calls are generally linked to arguments for sustainable forest management - good governance and equitable local participation being seen as an integral part of sustainability (Carter, 2005). New forest legislation (brought in at least, in part, through the support of international agencies) in Cameroon, the DRC and RC emphasizes the greater participation of local people. The participation and consent of local people in forest management is a requirement of FSC certification. Of the ten principles on which management is assessed, two specifically focus on social issues: ${ }^{3}$ tenure and use rights and responsibilities (principle 2) and indigenous people's rights (principle 3).

Forest companies operating in the Congo Basin are well aware of the above trends. A number are interested in gaining FSC certification; some already have. Certification improves forest management, creates positive publicity and allows a premium to be charged on certified timber. However, in the complex situation of the Congo Basin, negotiations with local communities can easily be ignored; thus, the concept of FPIC is an important guiding principle (see Box 16.1).

\section{Box 16.1 The definition of free, prior and informed consent (FPIC)}

Free, prior and informed consent recognizes indigenous peoples' inherent and prior rights to their lands and resources and respects their legitimate authority to require that third parties enter into an equal and respectful relationship with them, based on the principle of informed consent. (Commission on Human Rights, 2004)

\section{FREE, PRIOR AND INFORMED CONSENT (FPIC)}

The concept of free, prior and informed consent is a key element in the respect of the rights of indigenous peoples and concerns all kinds of development activities affecting their lands and resources. FPIC means that the local communities are given prior access to all relevant information, and then consulted freely, without pressure or 
manipulation. After consultation and negotiations, they decide whether or not to give their consent; there is a clear right to say 'no', if this is felt appropriate.

\section{THE RIGHTS OF INDIGENOUS PEOPLES}

FPIC is a useful instrument for resolving conflicts created by the different legal systems applying to forests - international and national laws, and local concepts of ownership. Through consultation, negotiation and, finally, through giving consent, possible conflicts between the different levels of legislation and between the different parties can be resolved.

At the international level, there is increasing recognition that certain rights of indigenous peoples should have the status of international customary rights (Nobirabo, 2007). The FPIC concept is thus not only a concept for voluntary agreements; states are increasingly obliged to implement the concept in all activities in their territory. Sometimes called the indigenous peoples' convention, ${ }^{4}$ Convention 169 of the International Labour Organization states in Article 7.1 that 'the peoples concerned shall have the right to decide their own priorities for the process of development as it affects their lives, beliefs, institutions and spiritual well-being' and 'to exercise control, to the extent possible, over their own economic, social and cultural development' (ILO, 1991). Article 16 states that 'relocation shall take place only with their free and informed consent' . The Convention on Biological Diversity (CBD) also requires the respect of the rights of the indigenous people, while the United Nations Declaration on the Rights of Indigenous Peoples (13 September 2007) explicitly recognizes free, prior and informed consent in many of its articles. However, no Congo Basin countries have signed ILO 169, and the implementation of CBD, to date, remains without positive results for indigenous peoples.

At a local level there has been only limited progress on getting issues of consent onto the national agenda and making it a requirement of exploitation on lands inhabited by indigenous forest peoples. This is partly because the governments of the Congo Basin only recently signed the United Nations Declaration on the Rights of Indigenous Peoples (UNDRIP) and have not yet incorporated it into national law. Additionally, the lobby groups purporting to represent such peoples are mostly urban based and so have little connection with their lives, needs and interests (see Lewis, 2001).

\section{METHODOLOGY}

The purpose of the investigation was to see to what extent the rather vague concept of FPIC could be refined in order to create a model that corresponds to the realities of life in the Congo Basin. The study was conceived by the Society for Threatened Peoples and Intercooperation, which managed it; the field research carried out by Anthroscape Ltd (the main authors of this chapter). The study was supported financially by the Swiss Department for Economic Affairs (SECO), by the foundation 


\section{Box 16.2 Forest Stewardship Council (FSC) criteria 2 and 3}

\section{FSC principle 2: Tenure and use rights and responsibilities}

Long-term tenure and use rights to the land and forest resources shall be clearly defined, documented and legally established.

2.1 Clear evidence of long-term forest use rights to the land (e.g. land title, customary rights, or lease agreements) shall be demonstrated.

2.2 Local communities with legal or customary tenure or use rights shall maintain control, to the extent necessary to protect their rights and resources, over forest operations unless they delegate control with free and informed consent to other agencies.

2.3. Appropriate mechanisms shall be employed to resolve disputes over tenure claims and use rights. The circumstances and status of any outstanding disputes will be explicitly considered in the certification evaluation. Disputes of substantial magnitude involving a significant number of interests will normally disqualify an operation from being certified.

\section{FSC principle 3: Indigenous people's rights}

The legal and customary rights of indigenous peoples to own, use and manage their lands, territories, and resources shall be recognized and respected.

3.1 Indigenous peoples shall control forest management on their lands and territories unless they delegate control with free and informed consent to other agencies.

3.2 Forest management shall not threaten or diminish, either directly or indirectly, the resources or tenure rights of indigenous peoples.

3.3 Sites of special cultural, ecological, economic or religious significance to indigenous peoples shall be clearly identified in cooperation with such peoples, and recognized and protected by forest managers.

3.4 Indigenous peoples shall be compensated for the application of their traditional knowledge regarding the use of forest species or management systems in forest operations. This compensation shall be formally agreed upon with their free and informed consent before forest operations commence.

Source: http://www.fsc.org/en/about/policy_standards/princ_criteria

Art for Tropical Forests and by the Federal Department of Foreign Affairs. Anthroscape researched current practice for the gaining of consent in five concessions in the region, ${ }^{5}$ of which one had already gained FSC certification and was therefore considered by its auditors to have successfully negotiated their interpretation of FPIC. Each concession visit lasted about five days. Anthroscape held extensive conversations with managers and with specialists in the social aspects of the companies' management plans. An equal amount of time was spent visiting local people living in the concessions and listening to their accounts of the processes by which the company had negotiated the right to exploit.

The criteria of FSC principles 2 and 3 (see Box 16.2) were used to guide the investigations in all five concessions visited while bearing in mind that FSC criteria are 
not the only definitions of FPIC. Although four of the companies visited were not yet FSC certified, we nevertheless used the FSC criteria as a working definition to uncover the problems and constraints in the companies' practice should they wish to apply a FPIC approach. This was not to judge or condemn those companies but to test FPIC critically on the ground in order to generate some guidelines for practical implementation. The notions of 'free' and 'informed' become concrete only when applied to specific contexts. Within the constraints of each particular situation we attempted to identify procedures that could maximize the potential for a population to be fully informed about the implications of their giving consent and to choose freely whether to do so.

In the Congo Basin, criteria included under principle 2 - regarding land tenure and use rights and responsibilities - apply to both farmers and Pygmy hunter-gatherers. Issues particular to indigenous hunter-gatherers are dealt with in principle 3.

\section{PRELIMINARY FINDINGS}

Since this chapter reports on very recently conducted research, we outline below only some of our immediate findings.

\section{Institutional constraints: The law of the state and Forest Stewardship Council principles}

\section{The need for consent}

The relationship between FSC principles and state law creates a measure of controversy around the question of consent and whether, indeed, forest companies need to obtain it at all from local communities. The controversy stems from the fact that both parties share use rights granted by the state, the legal owner of the land. FSC principles 2.2 and 3.1 require that forest communities 'shall maintain control, to the extent necessary to protect their rights and resources, over forest operations unless they delegate control with free and informed consent to other agencies'.

However, one forest company in Congo-Brazzaville interprets national laws to mean that they do not require the consent of local people in order to exploit their concessions. They claim that since the land is the property of the state and since the state has granted them use rights, they have as much right to exploit the forest as local people (whose use rights the state also recognizes), regardless of how long they have been there. In their view, the fact that FSC principle 1 requires them to obey state laws renders FSC principles 2.2 and 3.1 irrelevant. There are two problems with this position. First, the procedures by which regional states originally established concessions frequently failed to ensure consultation with local people; and in some cases they may have been compromised by corruption. Second, principle 1 states that as well as obeying state laws, companies must conform to all FSC principles in order to obtain certification. The debate then centres on whether FSC principles contradict state laws or simply supplement them. In fact, many of the FSC principles make 
requirements not required by state laws. For example, reduced impact logging (RIL) is not required by law in every country; but all companies seeking FSC make great efforts to demonstrate that they are doing it. Exceeding the law's demands is not the same as breaking the law.

The problem remains, nevertheless, that a company that follows FSC principles 2.1 and 3.2 and requests consent runs the risk of a large number of local communities not giving it. The company would then be prevented from felling trees that they have bought the right to fell. It would then have a choice. It could either persist in its negotiations with the local population until consent was reached. Or, it could abandon its attempt at FSC certification and exploit without the population's consent, having been granted use rights by the state. Certification is not compulsory, but consent is a requirement of certification.

\section{Conservation, the environment and consent}

Another way in which the relationship between FSC principles and state laws has consequences for the issue of consent is in matters governing the protection of nature and access to hunting. The opening up of roads increases pressure on local flora and fauna, particularly as roads facilitate commercial hunting. FSC principle 6.2 requires foresters to protect threatened species and their habitats. At the same time, state laws closely regulate hunting activities, dictating where, how, when and for which purposes (i.e. not commercial) hunting may occur.

For example, in Congo-Brazzaville foresters act in partnership with the state over the protection of natural resources through the use of conservation zoning and the employment of eco-guards to police hunting activities on their concession. Even if this policing were to be well regulated (and there is evidence that it is not), foresters that take this approach to comply with state laws and FSC principle 6.2 find themselves in contravention of FSC principle 3.2, which states that forest management shall not threaten or diminish the resources of indigenous peoples.

Although 'traditional' hunting is permitted all year round, the interpretation of what constitutes 'traditional' hunting is variably interpreted. Many local and indigenous people claimed that the fear of eco-guard persecution caused them to abandon hunting. Some other reasons given were that their traditional hunting grounds have been reduced, they cannot afford hunting permits, and they fear victimization by eco-guards acting outside of their remit. It is likely that hunting skills and associated religious activities are being lost.

In short, forest operations increase pressure on fauna while limiting local people's access to it as a resource. While FSC principles 6.2 and 3.2 might seem reasonable, in northern Republic of Congo the combination of a predominantly 'eco-guard' approach to wildlife management and growing human pressure created by forestry roads and workers' towns has created a situation where the two principles can easily conflict with one another. The implications for negotiating FPIC from indigenous people are serious. Would people consent to exploitation if they were fully aware that operations could diminish their access to hunting resources and erode their cultural knowledge? Indigenous people's current acceptance of such activities is less consent than a resignation to powers beyond their control. 
The apparent conflict between the two FSC principles means that certifiers have to use their own discretion to assess whether the measures of control aimed at protecting wildlife respect the human rights of forest dwellers. This means that these measures should neither deny people access to a sustainable livelihood nor threaten their safety through heavy-handed and discriminatory enforcement. Creative solutions must be sought that respond to the particularities of each situation. For example, localized scientific studies to establish levels of sustainable off-take of game would provide parameters for negotiating equitable forest use.

\section{Constraints on communication: Informing in the local context}

One of the most difficult facets of the notion of FPIC is the question of information. Obviously, local people cannot give their consent to forest operations unless informed about the exploitation. But this begs the important question of exactly how wellinformed people need to be in order to come to a free decision about consent. This entails several subsidiary questions. How is the community defined, and does everyone need to be informed to the same degree? What level of detail and sophistication is it reasonable to expect? How can the population ever know if they have enough information to make an informed decision? Who should arbitrate in these matters? Who should check that understanding has been achieved to the agreed level?

Underlying these questions is the obvious point that giving out information does not guarantee understanding. Our research shows that although forest companies across the region consider that they have carried out thorough awareness-raising (sensibilization) the population shows little or no comprehension of the content. The barriers to effective communication in this context are political, social, cultural and pedagogical. They are easier to diagnose than they are to overcome. But until this is done, free and informed consent can rarely be achieved.

\section{Informing and social structure}

One major constraint on communication is the social structure of many villages in concessions in the Congo Basin. Many local populations comprise Bantu and Ubangian speaking farmers and Pygmy hunter-gatherers and former huntergatherers. If living in the same village, the latter are invariably under the political authority of the former. Farmer and farmer-Pygmy villages tend to be patriarchal, with a customary and/or elected/designated chief dominating decision-making and relations with outsiders. Our investigations revealed how often the consultation and negotiation process had only involved local political leaders such as the chef de secteur or préco. This may be due to such powerful local individuals claiming to speak on behalf of the community; of course, it is also easier for the company to deal with only one person. The result is that it sidelines populations with rights to forest use but with little voice in local politics, such as women and Pygmies. Consultation or negotiation strategies which focus on a single individual effectively remove control over resource management from large sections of the community. This contravenes FSC principles.

If consent is being given by local chiefs without such populations being informed, consulted or listened to then FPIC has not been achieved. In such cases, it is necessary 
to grasp the local political realities in order that sensibilization should reach the widest possible range of the population. For example, in one concession le chef de secteur explicitly rejected the right of women to participate in consultation and negotiation processes, thus excluding 51 per cent of his sector's large adult population. It is not uncommon for some groups or individuals to be effectively excluded from village politics (being constrained by traditional power relations); even if present at meetings, such persons do not speak and may also not pay much attention, as they know they have no influence.

The question is to what extent effective strategies can be devised that circumvent such (self-) exclusionary practices in the context of existing structures of power. One forest company in Congo-Brazzaville refused categorically to engage in such manoeuvring, claiming it was not in their remit 'to meddle with social structure'. However, this need not be a question of interfering with social structure, but of recognizing the existence and rights of significant sections of the community such as women and indigenous ethnic groups. Of course, this dilemma is not confined to the Congo, but is found in many parts of the world in which participatory natural resource management is implemented. Usual practice is to seek to facilitate the formation of a representative community structure - a committee that includes representatives of all stakeholder groups, without alienating the traditional leadership. Much could be learned in this respect (both 'how to' and 'how not to') from experience in participatory forestry in Cameroon (see, for example, Oyono, 2005). Although the investment of time required to ensure fully representative discussions may seem heavy, it can pre-empt conflicts and save much potential delay and recrimination in the future.

\section{Methods of communication}

Another major consideration is the means and media through which sensibilization is carried out. A high percentage of the forest population is non- or poorly literate, and it is not unusual for there only to be one literate person in a village. We visited one village in Congo-Brazzaville where the population was unable to give us any information about the terms of consent because the chief was away and all the documents were with him, the only person who could read. In a nearby village we found a case where the signature on the consent form was clearly the scrawl of an illiterate person. The form was in French and included legal terms alien to local cultural understandings. When we checked with the company's interpreters we found that they had misunderstood these terms and therefore mistranslated them. Two forest companies we visited had attempted to bridge the illiteracy gap using flash cards with pictures relating to forest operations, protection of wildlife and so forth. This is a worthy attempt to diversify the media of information transfer. Nevertheless, it is based upon the informers' ideas about how information should be conveyed (and the implicit assumption that sensibilization is a one-way process). It seems likely that local people targeted here have minimal (if any) experience of the use of pictures to convey messages; certainly, pictures do not form part of their own communicative repertoire. Effective sensibilization depends upon finding precisely what does.

Unfortunately, the forest companies' social teams, who are responsible for sensibilization, are constrained by their limited expertise in participatory approaches. 
They use a top-down mode of informing, based on school pedagogy, in which information is passed from the active, knowledgeable speaker to the passive, ignorant listener. This is not necessarily how people learn best, least of all people without formal education. Research (Lewis, 2002, 2008) shows that Pygmies acquire knowledge through active interaction within relevant social contexts and that it is rude to lecture others or to publicly claim to know more than others. This factor may account for low comprehension and/or retention rates among Pygmies.

\section{Information, mapping and consent}

One element of sensibilization that seems to be more widely understood is the process of mapping the key subsistence and cultural resources that communities wish to protect from exploitation. Forest companies refer to this process as "participatory mapping'. Given that participatory mapping has been successfully used in a wide variety of contexts of natural resource planning and management - often in the context of indigenous communities establishing their tenure or use rights (Carter 1996) - it can be reasonably expected to work in the Congo. In practice, our research indicated that community participation is limited, the mapping usually being carried out by between one and six community members in association with the companies' social relations teams. There is no mechanism to involve the whole community either in the process or in discussing the results. Thus, many people are ignorant of which resources have been safeguarded. Being map illiterate, they cannot use the maps to monitor that the resources marked on them are, indeed, protected. These problems could be overcome by a more intensive consultation process that actively seeks the participation of different stakeholders within the community (including women, young and old, and those using the forest for different purposes). The teaching of basic map literacy, and making the maps simpler, would also help. It is important to recognize that as $2 \mathrm{D}$ images of a $3 \mathrm{D}$ reality, maps take little account of how local people orient themselves in the forest. Thus, their use requires careful facilitation.

\section{The challenge of communication}

The task facing forest companies in ensuring effective sensibilization varies enormously. Some concessions contain hundreds of villages and few of them have schools; in Gabon most villages have functioning schools and the majority are literate. Most companies visited do not take responsibility for schooling, arguing that this is the state's job. Those visited in DRC sometimes build or repair schools, but rely on the state to provide teachers. Increased schooling is one means to bridge the communication gap in the long term; but forest companies also need short-term answers. The community radio station being built in one concession in Congo-Brazzaville could provide an interesting model to address this. Insights, tools and support provided by experts in cross-cultural communication and non-literate populations will be invaluable in supporting such efforts, although they require an investment in money and especially time. However, if ill thought out or financially burdensome, solutions to address this might become a disincentive from genuinely seeking FPIC as part of an FSC certificate. 


\section{The concept of consent}

As consent is a contract between two parties, it follows that the parties should share a mutual understanding of what it means. Our field research indicates that this is generally not the case, thus resulting in conflict and mutual recrimination.

\section{Different models of consent}

We began our investigation into local ideas of consent by asking our interpreters how they would translate consent into local languages. There was a range of possibilities, ranging from 'I accept of my own will' to 'I accept because I am tired of this debate'. Consent is not an autonomous concept, but one which mutates depending upon the circumstances and context of the negotiations.

When we asked local people to expand upon the contextual aspect of the consent they had given to forest operations we often found that it had not been given as part of a negotiation, but as one man said: 'We accepted because we were obliged to. If the state has already decided that the company can exploit then we have no influence over this.' Others claimed that they had given their consent freely but that the company had not provided the material benefits (sawn timber, etc.) that the community had claimed in return for its consent. In only one case, in Gabon, did the consent process seem to be satisfactory to the communities we visited, despite extreme difficulties in the early stages of their relations.

While the first example points to the differential in power between the two parties, the others indicate how consent is conceived of as fundamentally contractual. These points are related. Contrary to European notions of consent as something that is achieved and marked at a moment in time, that is finite, definite and definitive, the Central African notion describes a transactional social relationship based on ongoing verbal and material exchange. The difference is not absolute and incommensurable, more one of emphasis. Whereas in European consent the emphasis is on finalizing the boundaries of mutual responsibility, in the Central African case consent opens them up to ongoing negotiation.

The differences in power need to be recognized and carefully managed. The weaker party, feeling that they are 'obliged' to give consent under constraint, will realize that it is not in their interests to give it definitively, for this would weaken their claim to share in the forest company's profits. Instead, they keep the channels of negotiation permanently open through renewed demands for compensation. In turn, the stronger party hopes to foreclose the negotiation process as a means of finalizing the terms of consent to its permanent advantage. Unless the parties recognize and acknowledge that they are operating under essentially different concepts of consent, they will struggle to achieve a mutually satisfactory outcome.

\section{Is mutual understanding possible?}

The different concepts of consent can be reconciled. The concession we visited in Gabon has achieved this through anthropologically informed research that has raised both parties' awareness of the other's concept of consent. This has enabled them both to negotiate strategically through the issues of resource mapping, rights, laws, 
traditional concepts and local associations to the point where consent to forest operations was agreed. This achievement was then marked by a celebration. After that the company was able to channel its relations with villages into an ongoing transaction of information, pecuniary compensation and material items based on timber production in their forest areas. It is worth noting that this company paid its communities a significantly higher sum per cubic metre of timber removed than other regional companies. The outcome of a mutually satisfactory and sustainable relationship can be put down to a combination of sound research, continual dialogue over many years, a level of benefit-sharing deemed fair by both parties, and a constant effort on the part of the company to improve their practice.

Two companies visited are concerned that their exploitation would be jeopardized if they were required to continually renegotiate terms of consent with every single village. What is more, they maintain that different deals struck with different villages would lead to claims that some villages were being better compensated than others. The resultant conflicts could cost them a lot of time, effort and good will. However, even if every company's context is specific (the number of communities, the social profile etc), there are, nevertheless, lessons to be learned from the Gabonese example.

To summarize, any sustainable notion of consent has to be rigid enough to stand as legal proof of an agreement, but flexible enough to contain means of redress.

\section{FPIC AND SUSTAINABLE FOREST MANAGEMENT}

If free and informed consent is to make an important contribution to sustainable forest management, it should be based on establishing certain basic processes and actions. These include ascertaining communities' customary rights; developing effective communication and information-sharing strategies; ensuring that a share of the profits and taxes derived from forest exploitation are invested locally; protecting people's important forest resources against the negative impacts of timber exploitation and wildlife management; and giving them a clearly defined role in decision-making processes that concern forest they use. Forestry companies could benefit from outside support in this until clear examples of best practice have been developed.

We recommend that the following steps be taken by forest companies:

- Hire staff with the appropriate skills to work with the local populations (language skills, research skills, appropriate cultural knowledge and social skills) and to provide them with adequate resources and institutional support.

- Ensure that discussions with the community are proactive in seeking to include all major stakeholder groups (not just the most powerful and vocal), and that negotiations are conducted with a body that represents them.

- Identify, together with local community representatives and external specialists, the traditional rights of local people and their way of using the forests, and analyse 
the impacts that logging activities might have upon them and their way of life in order to co-develop mutually acceptable mitigation strategies. Seek to ensure that this is widely communicated and discussed within the community.

- Elaborate and make public a policy demonstrating that the forest company recognizes and respects the traditional rights of the local population, that it guarantees their use of, and free access to, the forest and its resources and that the company is sharing benefits with the local communities.

- Develop an ongoing dialogue between local communities and forest companies, using appropriate communication mechanisms, to ensure a regular exchange of information and goods/benefits. Consent should be understood as an ongoing relationship between forest companies and fully represented local communities. Consent can be marked at certain key stages of this relationship by appropriate ceremonies to provide evidence that the community consents to the company's activities.

- Develop appropriate conflict resolution mechanisms and a complaint procedure together with local communities and forest companies that enables them to contact, discuss and resolve all problems that are directly or indirectly linked to the activities of the companies.

- Engage with and, if necessary, employ local and/or international expertise to ensure continued development of FPIC.

- Publish the processes and agreements elaborated with and accepted by the local communities and the forest companies.

Following these guidelines should result in an agreement in which the granting of FPIC marks progress in an ongoing relationship between a company and the local community, based on exchanging information and material goods during the entire time that the forest area is harvested. A number of forest companies have achieved significant progress in this direction. ${ }^{6}$

Furthermore, it is not only forest companies that can determine the use of FPIC in forest management. It could be fuelled by greater awareness and demand amongst timber consumers, and state support in the countries concerned; if the implementation of FPIC became a requirement for the awarding of forest concessions, or was at least a factor in decision-making, this would clearly have an impact upon company activities (and would put those already having experience at a competitive advantage). Corporate social responsibility should, ideally, go hand in hand with state responsibility.

\section{ACKNOWLEDGEMENTS}

Intercooperation, the Society of Threatened Peoples and Anthroscape Ltd are grateful to the Swiss Department for Economic Affairs (SECO), the foundation Art for Tropical Forests and the Federal Department of Foreign Affairs for their financial support for this study. Nevertheless, the views expressed are those of the authors alone 
and do not necessarily represent those of the donors. We are also grateful to the forest companies who collaborated in this study, taking time to respond to many questions, and to all the peoples of the DRC, RC and Gabon who contributed in one way or another to the research.

\section{NOTES}

1 'Pygmy' is an academic term referring to the diverse groups of forest hunter-gatherers in the Congo Basin. It translates the local concept of 'forest people' (Lewis, 2001; Koehler and Lewis, 2002). Despite sometimes being used negatively, it is increasingly used by Pygmies themselves to express solidarity with other Pygmy groups.

2 For several definitions of indigenous peoples, see Nobirabo Musafiri (2007, p61). In relation to Pygmy hunter-gatherers, see Klieman (2003, Chapter 4).

3 For more information, see http://www.fsc.org/en/about/policy_standards/princ_criteria.

4 The official name is Convention (No 169) Concerning Indigenous and Tribal Peoples in Independent Countries.

5 Two concessions in Congo-Brazzaville, two in the DRC and one in Gabon.

6 Admittedly, these are mostly those large companies with the means to make the significant investment required for FSC certification. However, smaller companies are able to benefit from the new environmental and social methods and technologies developed by these large companies. This lowers the cost of meeting certification standards.

\section{REFERENCES}

Bahuchet, S. and H. Guillaume (1982) 'Aka-farmer relations in the Northwest Congo Basin', in E. Leacock and R. B. Lee (eds) Politics and History in Band Societies, Cambridge University Press, Cambridge, pp189-211

Carter, J. (1996) Recent Approaches to Participatory Forest Resource Assessment, Rural Development Forestry Study Guide 2, Overseas Development Institute, London

Carter, J. with J. Gronow (2005) Recent Experience in Collaborative Forest Management: A Review Paper, CIFOR Occasional Paper no 43, CIFOR, Jakarta, Indonesia

Commission on Human Rights (2003) Economic, Social and Cultural Rights: Commentary on the Norms on the Responsibilities of Transnational Corporations and Other Business Enterprises with Regard to Human Rights, E/CN.4/Sub.2/2003/38/Rev.2, http://www.unhchr.ch/Huridocda/ Huridoca.nsf/0/29378ff2003ceb0c1256d7900310d90/\$FILE/G0316018.doc, accessed 4 February 2008

Commission on Human Rights (2005) Standard Setting: Legal Commentary on the Concept of Free, Prior and Informed Consent, E/CN.4/Sub.2/AC.4/2005/WP.1, www2.ohchr.org/English/ issues/indigenous/docs/wgip23/WP1.doc, accessed 4 February 2008

Debroux, L., T. Hart, D. Kaimowitz, A. Karsenty and G. Topa (eds) (2007) Forests in Post-conflict Democratic Republic of Congo: Analysis of a Priority Agenda, CIFOR, Jakarta, Indonesia 
Greenpeace (2007) Carving up the Congo, Greenpeace, Amsterdam

ILO (International Labour Organization) (1991) Convention No 169 Concerning Indigenous and Tribal Peoples in Independent Countries, http://www.unhchr.ch/htm/menu3/b/62.htm, accessed 4 February 2008

ITTO (International Tropical Timber Organization) (2006) Status of Tropical Forest Management 2005, ITTO, Yokohama

Klieman, K. (2003) The Pygmies Were Our Compass: Bantu and Batwa in the History of West Central Africa, Early Times to circa 1900 C. E., Heinemann, Portsmouth, New Hampshire

Köhler, A. and J. Lewis (2002) 'Putting hunter-gatherer and farmer relations in perspective: A commentary from Central Africa', in S. Kent (ed) Ethnicity, Hunter-Gatherers, and the 'Other': Association or Assimilation in Southern Africa?, Smithsonian Institute, Washington, DC, pp276-305

Lewis, J. (2001) 'Forest people or village people: Whose voice will be heard?', in A. Barnard and J. Kenrick (eds) Africa's Indigenous Peoples: 'First Peoples' or 'Marginalized Minorities'?, CAS, Edinburgh, pp61-78

Lewis, J. (2002) Forest Hunter-Gatherers and their World: A Study of the Mbendjele Yaka Pygmies and their Secular and Religious Activities and Representations, $\mathrm{PhD}$ thesis, London School of Economics, London

Lewis, J. (2008) 'Ekila: Blood, bodies and egalitarian societies', Journal of the Royal Anthropological Institute, vol 14, no 2, pp297-315

Nobirabo Musafiri, P. (2007) Droit Foncier des Peoples Autochtones et le Droit International : Cas des Peuples de la Forêt Pygmées de la République Démocratique de Congo, Stämpfli Editions, Bern

Oyono, P. R. (2005) 'Profiling local-level outcomes of environmental decentralisations: The case of Cameroon's forests in the Congo Basin', Journal of Environment and Development, vol 14, no 3, pp317-337

Vansina, J. (1990) Paths in the Rainforests: Towards a History of Political Tradition in Equatorial Africa, University of Wisconsin Press, Madison, WI

Woodburn, J. (1997) 'Indigenous discrimination: The ideological basis for local discrimination against hunter-gatherer minorities in sub-Saharan Africa', Ethnic and Racial Studies, vol 20, no 2, pp345-361

World Bank Inspection Panel (2007) Investigation Report: Democratic Republic of Congo, http://siteresources.worldbank.org/EXTINSPECTIONPANEL/Resources/FINALINVREP whole.pdf, accessed 4 February 2008 


\section{On the Nature of Intergenerational and Social Networks in the African Forest Sector: The Case of Chinese, Lebanese, Indian and Italian Business Networks}

Jean-Marc Roda

\section{INTRODUCTION}

One classical form of industrial organization dominated the production and trade of tropical rainforest timber until the 1990s. Heavy investments, lack of flexibility, harvesting policies showing a clear preference for high-value hardwoods, and a low level of specialization in marketing strategies among operators form the footprint of this organization. Since the mid 1990s, a more flexible form of industrial organization has developed in the sector by communities of overseas Chinese, Indians, Lebanese and Italians. Based on responsive and mobile inter-firms networks, this form of industrial organization has enabled a high degree of specialization in marketing strategies. These networks, diverse in origin, are nevertheless very similar in their structure. Involved firms are simultaneously in cooperation and in competition ('coopetition'), with information exchange and low transaction costs the source of their competitiveness.

This chapter aims to characterize and contribute to a better understanding of the actions and functions of this new form of industrial organization within the African forest sector. It is part of ongoing research of a wider scope, which analyses how traditional as well as new forms of transnational industrial networks are taking advantage of the opportunities associated with globalization, models the networked and flexible systems of production, and seeks to understand the relative opportunities for development and threats to natural resources that each creates. At the crossroads of economics, geography, regional studies and business science, the chapter theorizes and generalizes network production into a single model capable of simultaneously explaining these different networks. In this model, trust and reputation are 
institutionalized. Middlemen and brokers have a key role. Firms optimize their location through a hierarchy of relations between actors and a pseudo-ethnocentric business orientation. Finally, in addition to these properties, the model explains network dynamics, the resilience of network properties and the multi-scale nature of their structure.

\section{BACKGROUND}

Since the 1960s, the global timber trade has gradually evolved from a South-North orientation to South-South trade, a phenomenon that has accelerated from the mid 1990s. Asia consumes more than 70 per cent (in roundwood equivalents) of the forest products originating from the tropics, and Africa has become the new frontier for the supply of wood to the expanding Asian economies, as is illustrated by the evolution of the international trade of tropical logs between 1997 (see Figure 17.1) and 2003 (see Figure 17.2). As a manifestation of this Asian demand, Asian industrial actors become an important, if not a defining, feature of the timber trade on the African continent. One distinctive feature of these actors, compared to conventional forms of industrial organization, is their propensity to display collective efficiency under the form of informal and intergenerational social networks organized across the globe. While most of the Asian actors are ethnic Chinese, other networks of industrial actors also display a similar ethnocentrism and collective efficiency within the forest sector - including Lebanese, Indian and Italian networks (Roda and N'Sitou, 2005).

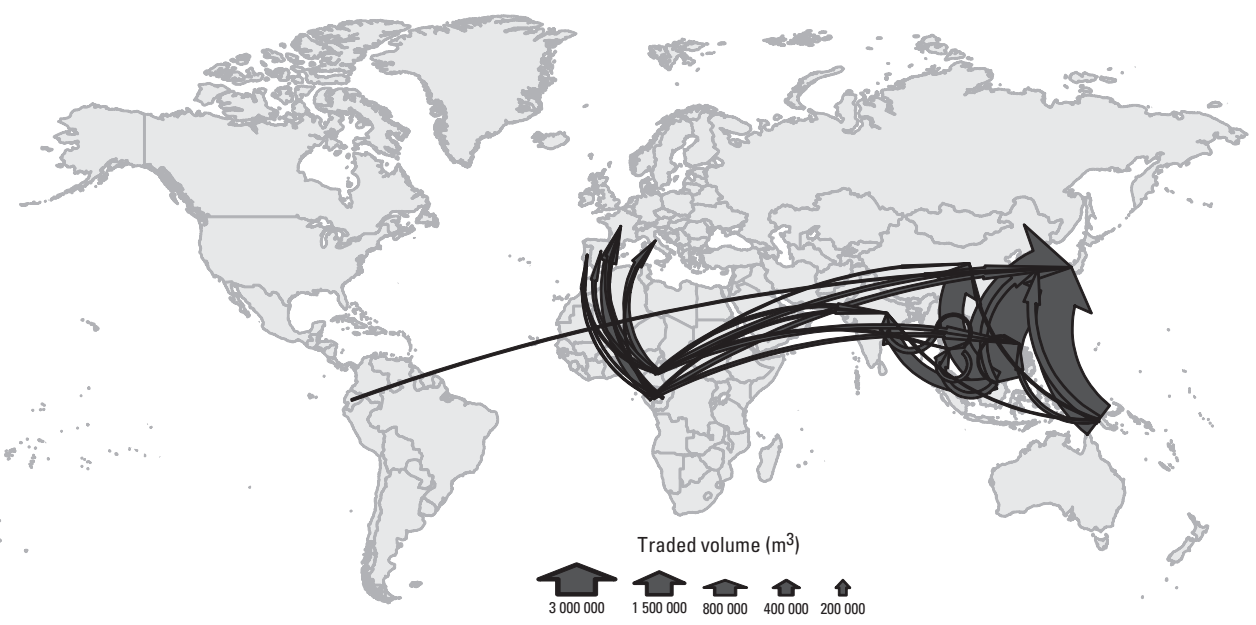

Source: FAO (2008)

Note: Volume of trade is represented by the width of arrows.

Figure 17.1 International trade of tropical logs in 1997: Major fluxes 


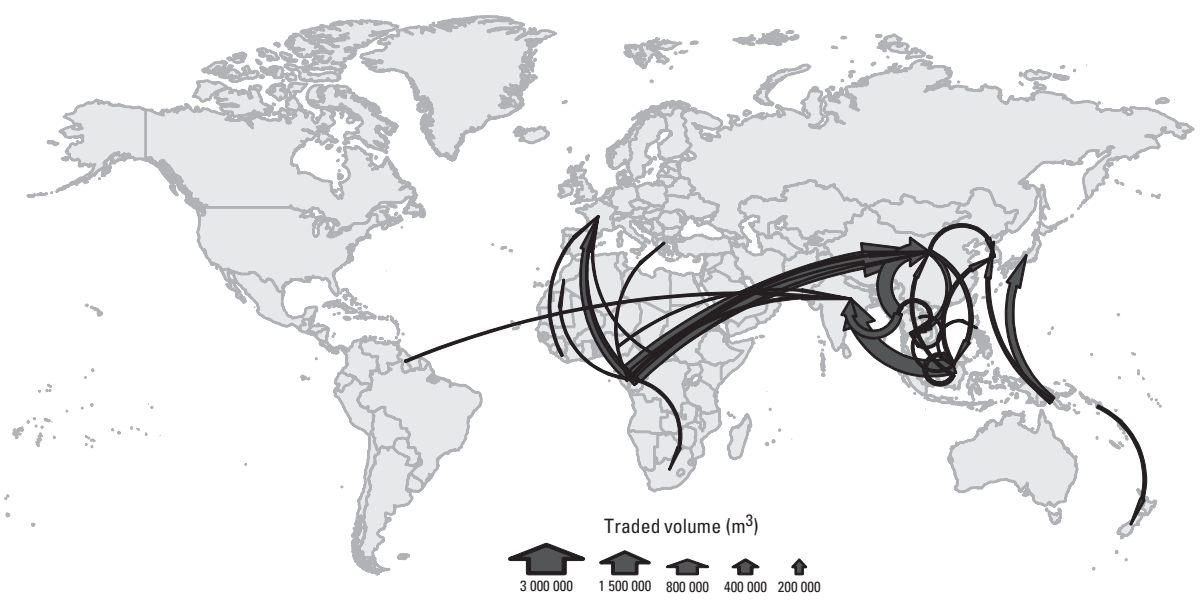

Source: FAO (2008)

Figure 17.2 International trade of tropical logs in 2003: Major fluxes

\section{QUESTIONS AND APPROACH}

\section{Research questions and hypotheses}

The initial aim of the model presented in this chapter was to establish the positive and negative impacts of these networks upon the environment, and upon the socioeconomic development of the region. Based on the literature dealing with activities of Asian and other social networks within the African forest sector (Karsenty, 1996; Guilguy, 1997; Karsenty and Debroux, 1997; Debroux, 1998; Sizer and Plouvier, 2000; Roda, 2005; Roda and N'Sitou, 2005), we formulate two major hypotheses. First, we explore the widespread perception that compared to traditional industrial actors of the African forest sector, these networks behave like 'predators' of natural resources and undermine the sustainability of forests where they have a direct or indirect influence. The second hypothesis is that these networks are able to continue their economic and finance activities under the worst economic conditions and where instability makes it difficult for other commercial actors to operate. In the absence of any environmental assessments truly independent of markets conditions, we approach these hypotheses through indirect data and inference. ${ }^{1}$

The following set of research questions helped to frame this research: What are the forest harvest and exploitation strategies of these networks? What is their modus operandi? What do these networks contribute to local development in Africa? What is the extent and limitations of their economic efficiency? Purported to be ethnically homogeneous, are these networks able to integrate themselves within the local society, and what features characterize their socio-economic interactions with it? What regulates these networks, and what are opportunities for heightened regulation - where needed? What are the strategic and policy implications for forest governance in Africa? 


\section{METHODOLOGY AND CONGEPTUAL FRAMEWORK}

Interviews and surveys conducted within the African tropical forest sector throughout the 2000 to 2006 period form the basis for the analysis in this chapter and other works. ${ }^{2}$ Anthropological semi-structured interviews, firm economics and industrial organization analysis have been used in order to link social analysis with the economic and market realities faced by business networks and their subsequent strategies. Classical methods for researching social business networks have been used (Cadène and Vidal, 1997), as well as specific methods for opaque and sensitive timber networks (Roda, 2004). Variables used in field research to study industrial actors and their behaviour are summarized in Table17.1. Data collection was followed by analysis and conceptualization of these networks in order to formulate an appropriate economic model to represent them.

The conceptual framework was inspired by three major streams of theory - first, within the new economy ${ }^{3}$ and the neoclassical approach of industrial clustering (Porter, 1990), the theories of collective efficiency for small- and medium-scale enterprises (rooted in Marshall, 1890, and popularized by Brusco, 1982, and Becattini, 1987); post-Fordism and flexible specialization (Piore and Sabel, 1984); and the school of regulation (Boyer, 1986; Salais and Storper, 1993)..$^{4,5}$ The second falls within the regional science tradition, and explores how industrial actors tend to cluster according to various factors of cost, competition and network externalities (Bernard and Vicente 2004). ${ }^{6,7}$ The final theoretical contribution lies on the interface between sociology and industrial organization (Castells, 1998), which theorizes a continuum of networks in which business networks optimize their strategies according to the links that they can establish for local, national, and international up-scaling (Rallet, 2000) (Veltz, 1996; Braudel and Wallerstein, 2000). ${ }^{8}$ Our own approach integrates these theories to tackle the analysis of social business networks operating in the African forest sector using concepts from industrial organization and sociology.

Table 17.1 Variables used in field research to study industrial actors and their behaviour

\begin{tabular}{|c|c|c|c|}
\hline Questions & $\begin{array}{l}\text { Life/business } \\
\text { histories }\end{array}$ & $\begin{array}{l}\text { Descriptive, structural and } \\
\text { contrast enquiries }\end{array}$ & $\begin{array}{l}\text { Marketing and technical } \\
\text { cross-checking }\end{array}$ \\
\hline Firm level & $\sqrt{ }$ & $\begin{array}{l}\text { - Activities, sister companies, } \\
\text { ownership and shareholding } \\
\text { - Structure and organization } \\
\text { - Workforce and contractors } \\
\text { - Logistics, inputs and outputs }\end{array}$ & $\begin{array}{l}\text { - Machinery and equipment } \\
\text { - Vehicles and transport strategy }\end{array}$ \\
\hline & & $\begin{array}{l}\text { - Nature of products, their qualities } \\
\text { and quantities }\end{array}$ & $\begin{array}{l}\text { - Visits to units, log/timber parks, } \\
\text { showrooms, etc. }\end{array}$ \\
\hline $\begin{array}{l}\text { Product } \\
\text { level }\end{array}$ & $\sqrt{ }$ & $\begin{array}{l}\text { - Supply and sales } \\
\text { - Technical and commercial specifications }\end{array}$ & \\
\hline $\begin{array}{l}\text { Social } \\
\text { level }\end{array}$ & $\sqrt{ }$ & $\begin{array}{l}\text { - Personal details } \\
\text { - Ethnicity, family, religion, etc. } \\
\text { - Business and social relationships }\end{array}$ & $\begin{array}{l}\text { - Discussions with other actors, } \\
\text { side information }\end{array}$ \\
\hline
\end{tabular}

Source: from personal communications (Alain Bertrand, 1993; Philippe Cadène, 1993; Roland Jaffré, 2001) 


\section{FINDINGS AND DISCUSSION: A NEW ECONOMY FOR AFRICAN TIMBER?}

\section{Specificities of social-business networks operating in the African forest sector}

Major industrial reorganization in the timber industry began 10 to 15 years ago. Most of the industries traditionally operating in the African forest sector have seen their influence decrease since that time. Industries falling under this conventional model of industrial organization tend to share the following attributes:

- dependence upon a relatively narrow base of private capital, within one family;

- $\quad$ specific small market niches;

- $\quad$ specialization in the harvesting and processing of a limited number of timber species;

- when operating in countries with weak governance and/or high economic uncertainty, they tend to limit themselves to activities with the highest possible gross margins; ${ }^{9}$

- high rates of bankruptcy, with few proving capable of surviving over the long term;

- when operating in uncertain economies where traditional banking services do not exist or are extremely costly, they can internally finance their subsidiaries and help to bear risk.

In order to contrast with the Asian newcomers, this chapter refers to all companies exhibiting these properties as 'traditional Western companies'. A significant number of actors defined by this model have simply disappeared, or have been purchased by newcomers belonging to a range of social-business networks whose organization and mode of operation is radically different from the previous owners. While the literature on social-business networks operating in the African forest sector is rather limited, the media and non-governmental organizations (NGOs) have begun - particularly following the end of the war in Liberia - to raise the issue of a so-called breakthrough of Asian interests in Africa. Since the mid 1990s, these business networks are visible in all of the world's tropical forests, not only in Africa. They are not formed by multinationals, but by a web of transnationals - which may be defined as networks whose relationships are not defined by formalized direct or legal relationships (e.g. subsidiaries), but rather by close or extended kinship between owners of the companies and informal transactions (e.g. personal loans). ${ }^{10}$

\section{Chinese networks}

The 'breakthrough' of Asian social-business networks in the African forest sector has stimulated the imagination of the media and professional associations. Indeed, these new actors - mainly ethnic Chinese from South-East Asia (particularly from Malaysia and the Philippines, but more recently from mainland China) - are now firmly settled in Africa, transferring the huge demand from China and the rest of Asia for primary resources. For example, the Chinese groups WTK, Rimbunan Hijau and M. ${ }^{11}$ (Malaysia), Vicwood (from China, but with connections to the Philippines), and 
Integrated Timber International and Timber World (Singapore) operate in Liberia, Cameroon, the Central African Republic (CAR), Congo-Brazzaville, South Africa and Mozambique. They are all associated with sister companies, which are themselves associated with other sectors in order to optimize transport costs (such as trading domestic appliances from Asia to Africa, and timber from Africa to Asia). They first tried to strictly duplicate their Asian logging methods in Africa. Some continue to operate using Asian labourers. Others, after a series of spectacular failures, ${ }^{12}$ adapted themselves more deeply and now tend to buy former Western-owned companies, and to hire Western managers proven more capable of relating well with African authorities and societies than the ethnic Chinese themselves. ${ }^{13}$ All of these networks, contrary to the traditional Western companies, have segmented production into several subcontracting and legally independent companies. They also rely heavily on local middlemen and subcontractors. This subcontracting structure is not always obvious, and it is not rare to see a company which on its surface appears to be integrated but for which various components of its workforce, in fact, belong to various subcontractors. ${ }^{14}$ Mainly through Asian partners specialized in logistics, these companies engage in triangular trade between Asia, Africa and the Middle East or even Europe, importing manufactured products from Asia and exporting raw timber to Asia. Instead of specializing in a few timber species of a particular quality, as is standard practice by traditional Western companies, they harvest a larger range of species and accept a wider range of qualities. Sorting is not done in Africa prior to export, as Western companies typically do, but is carried out by intermediate buyers and brokers in Asia.

\section{Indian networks}

Similarly, Indian business networks (mainly run by Indians originating from Gujarat) ${ }^{15}$ source a wide range of timber products and qualities from Africa, largely to supply India. Perhaps more eclectic than Chinese networks, Indian networks source all kind of timbers, from the large and beautiful humid tropical forest species to the small semi-deciduous species from East Africa and plantation species. ${ }^{16}$ They also transfer sorting to intermediate buyers and brokers in India. Originally established in East Africa, these networks are now extending their business activities into West and Central Africa, but in a very discreet manner - even when mobilizing large volumes of timber. Indeed, except for a fistful of Indian companies directly operating in forests, they prefer to trade with and buy directly from producers or work through African agents in these regions. Their propensity to work through brokers and agents explains their low visibility. Their strategy of sourcing is quite similar to the ethnic Chinese, with the possible exception of companies or buyers willing to simultaneously handle a range of non-timber forest products (NTFPs), precious ores and other minerals. ${ }^{17}$

\section{Syro-Lebanese networks}

Syro-Lebanese networks are long established in Africa and already belong to the typical African ethnic mosaic - some having acquired the nationality of the African country where they are settled. These groups almost always trace their origins to the region bordering Lebanon and Syria. Their strategies usually depend upon the 
development of a local and regional transport business, often as transport subcontractors. They then diversify into various agribusiness sectors, as well as into the forest sector and others (i.e. fuel transport and distribution), optimizing their core logistic activities. ${ }^{18}$ Once they are operating in the forest sector, they export various timber products to countries of the Mediterranean basin and the Middle East. Unlike Chinese and Indian business networks, they do not hesitate to expand industrial activities into downstream processing of furniture and other finished products. As in the agribusiness sector, in the forest sector they increase their economies of scale by supplying the large (and often ignored) domestic demands of Africa. In order to do so, they lower costs and quality standards to match African purchasing power. At the same time, they are able to make use of wood material which is usually rejected by other industrial operators focused on export markets. For example, Syro-Lebanese sawmills are the only ones to reach 60 per cent material recovery for tropical hardwoods; ${ }^{19}$ traditional Western sawmills barely reach 35 to 45 per cent recovery rates due to the specificity and selectiveness of their customers.

\section{Italian networks}

Finally, Italian business networks have carved a very unique niche for themselves. Different from the other three types of business networks, they avoid investing in forest logging activities as much as possible, preferring instead to purchase logs. They focus on what they claim to be their core competency: the processing of highly transformed finished and semi-finished products, with innovative and highly mechanized and automated industries. In doing so, they serve as the sourcing branch for the industrial districts of northern Italy, ${ }^{20}$ famous for their machinery and design innovations and in the literature on 'post-Fordism' and flexible specialization (Rabelotti, 1995; Roda, 2005). With their high degree of specialization, ${ }^{21}$ they are usually more resilient to the shocks, shortages and other hazards affecting other Western actors in the African forest sector. They work as firm networks, ${ }^{22}$ usually diversifying around machinery, automation and public-works sectors. Their distinctive strategy is to carefully prepare semi-finished or finished products in order to transfer them at relatively low prices to their sister companies in Italy and Europe, who specialize in marketing and are able to capture most of the added value in Europe instead of Africa. The capture of added value is not done through the degree of product transformation per se, but through their detailed knowledge of the market and the management of a 'marketing mix' seeking designs, innovations and constant flexibility.

\section{STRUCTURAL SIMILARITIES AMONG CHINESE, SYRO- LEBANESE, INDIAN AND ITALIAN BUSINESS NETWORKS}

\section{Predator or efficient relay of foreign demand?}

In terms of various legal irregularities, we observed no differences between the companies surveyed and traditional Western companies. When occurring, they were 
observed in both forms of industrial organization. In this regard, Africa seems to be like everywhere else in the world: private companies operate to balance the various costs of their activities, including organizational and 'image' costs. That is to say, they balance the costs of paying penalties for legal irregularities with the other costs of doing business (including those associated with compliance), not seeking moral perfection but an optimum between profit and reputation within the relevant market niches.

Regarding forest management plans, differences observed between companies derived from the nature of forest concessions - including the presence of compulsory management plans, the nature of the forest class ${ }^{23}$ and host country regulations (Karsenty, 2007). The only significant difference between categories of companies was the high proportion of Italian and Indian groups buying logs exclusively through third parties within the domestic market, thus avoiding any association with or interest in forest operations and removing themselves from concern for, and accountability to, forest management.

While eco-certification is still limited in the natural forests of Africa, it seems that only companies with a significant share of their traditional markets in Western countries (relatively eco-sensitive markets) have undertaken the costly process of becoming certified. We have observed only one Asian company in the very preliminary stages of eco-certification, a formerly Western company recently purchased by a Chinese company with a very large share of its markets in Europe.

These business networks are able to maintain economic activities in the most unstable and difficult conditions, thus bringing at least a minimal form of economic development to places where other traditional companies fail. ${ }^{24}$ Our research suggests that these networks are not more predatory than traditional Western companies, but rather display better marketing capabilities, thus allowing them to harvest a wider range of tree species which are not harvested by traditional Western companies limited by their narrow market niches. This leads to improved productivity above the 3 to 10 cubic metres per hectare commonly observed among traditional Western companies (Karsenty and Debroux, 1997), but may also lead to more far-reaching ecological impacts. Typically, they also work with greater speed and efficiency on tasks already carried out by other companies. In this regard, they might have 'predatory' characteristics, but seem to be doing the same, only faster and more efficiently than others. ${ }^{25}$

The comparison between the same networks operating in various African countries as well as outside Africa shows that the same groups and networks can behave very differently from one place to another (Roda, 2005). They seem to closely fit their behaviour to local governance conditions, strictly applying regulations only where they exist and are enforced. In some countries, groups of companies very closely linked operate in an exemplary fashion, following long-term sustainable management plans. In other countries, due to the extremely high level of economic uncertainty and weak governance, the same groups practice 'hit and run' models of exploitation. They may even pay fees for securing access to forest resources through barter, which can involve infrastructure development, provision of vehicles, etc. In extreme cases, it can involve goods as disparate as gold ingots and arms, if requested 
by local governments, local African businessmen or warlords - a feature which does tend to distinguish them ethically from their traditional Western counterparts with stronger reputational concerns. In fact, these networks have proven to be highly versatile, their flexible organization allowing them to adapt to almost any economic environment. They act as 'go-betweens', connecting African forest resources with demand linked to the growth of urban centres of emerging economies, specifically the Gulf countries, India and China. In African forests, they have begun to supplant more classical industries that dominated the forest sector until the mid 1990s.

\section{'Coo-petition', trust, intergenerational reputation and finance}

The main common feature of all of these business networks is a form of "coopetition' ${ }^{26}$ - that is, a mix of fierce competition as well as cooperation between actors in the network. In this coo-petition process, transnational companies maintain their cross-borders relationships not through ownership or subsidiaries, but through acquaintances based on extended kinship and cultural proximity. They use calculated cooperation within the framework of general cut-throat competition. More specifically, even if a particular company specializes in one specific sector, the broader business network enables multi-sector cooperation through the linkages established between the forest sector and other sectors (e.g. agribusiness, mechanics and machinery, logistics, public works and media). This often enables some form of negotiation with local authorities under a form of barter trade. For example, a contract made with a public works company can be paid in the form of logging rights to another company specialized in the forest sector. In Gabon, this was seen in the case of a public building built by a Chinese company for the Government of Gabon, which was paid in kind by an authorization to another Chinese company to harvest a state plantation - with an agreement between the two companies enabling each to benefit from the situation (Roda, 2005). Even if the two companies do not belong to the same owner, they can cooperate, contracting a debt within their network. The debt can be paid as a service to other companies in a different country, through international monetary exchanges, or can be transferred over generations. In a nutshell, the relationships within the network are characterized by calculated cooperation, resilient over several generations, ${ }^{27}$ but where competition and opportunism are the rule.

Decision-making as well as production are segmented and decentralized, and one can witness very fast life cycles where companies are constantly being created or closed, following what comes across as some sort of 'entrepreneurial Darwinism': only those companies which are created at the right time in the right niche survive and form bonds with other enterprises in the network. ${ }^{28}$ Information flow within the network is the key to its competitiveness. In fact, the entire network can be seen as an organization designed to optimize transaction costs instead of production costs. This is a critical advantage in places or times where information is opaque, economic uncertainty high or when adaptations need to be quick.

Trust and reputation within the network are the essential elements federating the business networks. On the basis of common cultural values, which are a form of social capital, the economic actors show a certain degree of innate trust, with further degrees 
of acquired trust built after repeated economic exchanges. The unconditional trust associated with kinship does exist; but its limits are very quickly reached when the financial sums at stake are substantial. Actually, it is less trust than reputation which shapes the business network. Reputation is attached to a name, and can be transmitted from one generation to another. Thus, reputation forms a very operational entrepreneurial capital of an intergenerational nature. It provides the means to start new activities, or to obtain loans proportionate to the strength of the reputation.

In each of the four groups of business networks, the mix of competition and cooperation is regulated by a strong hierarchy of business relationships, even if only implicit. This hierarchy is structured according to priorities given to kinship, followed by community, elective relationships, occasional business partnership and outsiders. The levels of this hierarchy correspond to levels of leveraging power associated with reputation.

\section{Intermediation and transaction costs}

All of the four types of business networks studied here share another structural trait: they present a continuum of organization linking certain industrial districts (or localized systems of production) where business networks originate in non-localized clusters spread all over the globe. The localized systems of production are still operational in Gujarat, Malaysia (Sarawak), the Philippines, northern Italy and at the border of Lebanon and Syria. With this structure, embedded scales of actors connect the demands of large urban centres in emerging economies to the African forest resource.

In all of these networks, a key function is that of intermediation - the act of serving as an intermediary or mediating, in this case the process of linking economic actors from different groups or different locations. Specialists and generalists, overt or covert actors, middlemen and brokers have pivotal roles for the operational aspects of the systems of production and trade by enabling the transfer of trust and engaging their own reputation for others. Some intermediaries, with whom certain actors of the network have established acquaintances throughout their business life, also have a pivotal function by facilitating transactions with other actors who do not belong to the network. An example of this is the French managers with professional experience in Asia and Africa who manage Vicwood's African operations.

Despite cultural differences among the four networks, each of them forms a social institution with the same major functions:

- relatively endogenous regulation of the network;

- a mechanism ensuring the resilience of reputation (thus, of trust and distrust); and

- a set of rules of reciprocity and redistribution of services, and even for profit-sharing.

Finally, in all of these networks there is a hierarchy of relationships shaped by kinship, cultural ties and acquaintances, in which the transaction costs of doing business are proportionate to the 'distance' between actors. 


\section{IMPLICATIONS FOR FOREST GOVERNANGE IN AFRICA}

\section{Forest governance and business networks: Perceptions and reality}

The notion of forest governance has evolved from strict definitions centred on public administration at the national level to a broader conceptualization, where governments are "not the only actors in governance, but a wide range of other societal interest groups and actors [also] have an important role to play in decision-making structures' at various scales (FAO, 2004). Our work does not consider exhaustively all of the dimensions of forest governance associated with the studied business networks. Here the focus will rather be on two aspects that can be substantiated from our field work and analysis:

1 the strict legal dimension (public-sector management, accountability, law enforcement, information and transparency); and

2 environmental performance and control.

Considering the strict legal dimension of forest governance, it is widely believed that the studied business networks (particularly the relative newcomers, the Asian networks) actively bypass the law through corruption or political influence, and that they are also active (through corruption) in the dysfunctional nature of public administration. However, a survey conducted in Cameroon (Roda, 2006) failed to show any significant difference between these business networks and other traditional Western companies in this regard. The differences observed were greater between different companies in each group than between the groups themselves. In all groups, there were cases of 'services' such as fuel gifts to local administrations, per diems paid to various agents, etc., forming what have been theorized as 'practical norms', but are, in fact, everyday forms of corruption (Nguinguiri, 2007). For 23 audited companies studied in Cameroon, only 4 were found to be very strict and refusing to engage in this kind of activity (one Italian, one French, one Lebanese, one Chinese); the others were more or less deeply involved. The factors explaining these differences have to be studied further, but our surveys seem to highlight the complex interplay of factors, such as how many years the company has operated in Africa (the longer, the more 'corrupt'), distance of their primary activity from the forest (companies with forest concessions, compared to companies just transforming the wood), etc. This same survey (Roda, 2006) did not highlight any significant difference between business networks and traditional Western companies. Forest governance in Cameroon is relatively more evolved than in other neighbouring countries, however, suggesting that these findings should be verified elsewhere.

Considering environmental performance and sustainability, there is a common perception that there are noticeable differences between large Western companies who implement management plans and the limited sustainability of Asian operations. But again, the Cameroonian surveys failed to show any significant difference between the two forms of industrial organization. ${ }^{29}$ We did a complete audit of the forest sector in 
Cameroon (Roda, 2006), and again the differences observed were greater between the companies in each group than between the groups themselves (see Table 17.2). Based on our observations, the implementation of management plans was only influenced by the status of forest concessions, which determined whether management plans were compulsory or not. For all companies observed, Western or otherwise, the choice of wood supply system (i.e. concession, licensing or subcontracting system, or direct purchase on the local market) was typically driven by the market orientation and industrial strategy ${ }^{30}$ of the company, rather than by any specific commitment to environmental performance. This was true irrespective of whether the choice of system was legally binding in the management plan.

We observed that, apart from the politically correct marketing discourse, the economic actors - irrespective of their origins - do not exhibit any particular inclination towards a certain type of environmental performance. Rather, they act according to regulations and their effective enforcement, much in the way that they act vis-à-vis any other external factor influencing their costs and competitiveness. Clearly, with the exception of companies whose primary markets are in Europe, their actions are more influenced by factors such the cost of environmental efforts, transport costs, political uncertainty, infrastructure costs, costs associated with administrative dysfunctionality and other financial costs, than by environmental responsibility. This does not mean that these private actors lack awareness of the environmental consequences of their actions, but that, for them, the actual costs and benefits of environmental responsibility are limited compared to other industrial risks.

\section{Policy lessons}

As a first major policy lesson, it seems that with this new type of economic actor (yet with some ancient organizational features), all the market-based instruments for promoting sustainable management of African forests (i.e. eco-certification and boycotts $^{31}$ ), as well as law enforcement processes (i.e. FLEGT ${ }^{32}$ ) are likely to be limited

Table 17.2 Attributes of environmental behaviour for the 23 largest companies with forest concessions in Cameroon (February 2006)

\begin{tabular}{lcccc}
\hline & \multicolumn{4}{c}{ Number of companies } \\
\cline { 2 - 5 } & $\begin{array}{l}\text { Large forest } \\
\text { companies }\end{array}$ & $\begin{array}{l}\text { With a } \\
\text { management plan }\end{array}$ & $\begin{array}{l}\text { With a pre-audit } \\
\text { of certification }\end{array}$ & $\begin{array}{l}\text { With Forest Stewardship } \\
\text { Council certification }\end{array}$ \\
\hline Traditional Western & 12 & 7 & 4 & 1 \\
Networked business & 8 & 6 & 1 & - \\
Chinese & 1 & 1 & 1 & - \\
Italian & 5 & 3 & - & - \\
Lebanese & 2 & 2 & - & - \\
Other (African) & 3 & 3 & - & 1 \\
Total & 23 & 16 & 5 & \\
\hline Source: Roda & & & & - \\
\hline
\end{tabular}

Source: Roda (2006) 
in terms of their impact upon the new form of industrial organization studied here which represents an ever-increasing market share. This is because the leverage for these policies lies within Western markets and societies. With the exception of Italian networks, these business networks have their primary markets in transition countries of Asia and the Middle East, where scores of other factors such as price, availability of the material, etc. are the essential drivers of demand. Environmental criteria so far have little or no effect on these markets. In the specific case of Italian networks, marketbased instruments might also be quite ineffective - but for different reasons. This is because they deal with semi-finished and finished products, which are not within the scope of the Forest Law Enforcement, Governance and Trade (FLEGT) process. While eco-certification tools may still have potential, they would apply to market niches where the wood material is not as important as technological innovation, design and other attributes of the product, limiting the impact of these tools.

These networks could also be seen as an entry point for local government and actors who would like to derive income from timber exports and value-added processing (sustainable or otherwise), despite the increasing international pressure on environment and legality issues. Given the fact that South-South trade of primary sources is now well established and supported by the geopolitical will of China, and that these flexible networks are assuming increasing importance in African economies, a total disconnect between Western policies and patterns of forest resource exploitation becomes possible. Even with new institutional mechanisms such as the fiscal instruments being tested in the Congo Basin, the flexibility of these networks facilitates an infinite array of ways to circumvent environmental regulations, if national governance and law enforcement are not improved.

This leads to a second major policy lesson: it becomes more urgent than ever that actions and policies focus on structural problems within African societies, prior to or simultaneously with any other forest governance strategy. By their very nature - namely, the ability to adapt to and take advantage of all available degrees of freedom - flexible networks can be seen, rather than as predators, as a manifestation of the governance and entrepreneurial environment of a specific country. This underlines the critical dependence of forest governance and sustainability on the underlying nature of economic development and the rule of law in African countries.

Traditional North-South axes are challenged, as the massive rush of African leaders to Beijing in 2006 highlighted. The fact that today the global and geopolitical chess game has made the giant transition economies more attractive than ever for African states implies that these flexible networks will continue to gain in importance on the ground. This fact, added to the growing demand for African timber in Asia, subordinates the question of forest governance to the broader problems of chronic instability, civil unrest, chronic corruption, or simply poverty and inequality. Without addressing these structural problems adequately through appropriate development policies, focusing on the question of impacts of flexible inter-firm networks on natural resources is probably off track. These networks may help to bring economic development to African countries, but at the cost of forest sustainability. Reducing these problems would, on the contrary, help to regulate the behaviour of these networks towards improved forest governance, while leveraging their potential in capturing the value of undervalued timber resources on the global market. 
These flexible networks raise two problems typical of global trade more broadly. First, they are much less sensitive to the classical tools of regulation. The second is the organization of African governance systems, and the extent to which they can be made more effective in practice. It seems that both African governance and new systems of global regulation face significant challenges in implementation. This leads to the third policy lesson: it is urgent to invent new governance instruments or industrial policies to regulate the forest sector. This is a challenge for research on industrial policies. Negotiation and regulatory instruments among entities such as the Association of Southeast Asian Nations (ASEAN), the European Union and the African Economic Community (AEC) may be the most pragmatic way to tackle this challenge.

\section{CONCLUSIONS}

Since the mid 1990s, the dynamics of the tropical timber trade have been increasingly powered by the demand from large transition countries, among which China plays a major role. Before this time, a classical 'Fordist' organization was the rule for harvesting, processing and trading operations of African hardwoods. This organization typically involved large investments and small gross margins, if one considers the economic risk. ${ }^{33}$ Typical strategies focused on a few species of high value, with a limited base of customers, thus characterized by some rigidity of functions.

In recent years, the traditional form of industrial organization has been challenged in Africa, as in the rest of the world, by the development of new systems of production based on very mobile and dynamic social-business networks. Each of these networks involves a specific cultural or ethnic group, the most active in the African forest sector being overseas and mainland Chinese, Indian, Syro-Lebanese and Italian networking cultures. Despite the apparent cultural differences among them, the four types of business networks are actually very similar in their structure. The companies are simultaneously cooperating and competing ('coo-peting'), and their competitiveness is based on a flow of information and a minimization of transaction costs rather than production costs.

Beyond the forest sector, this unprecedented development of flexible firm networks illustrates the deep industrial reorganization which is now taking place in the global economy and in developing economies. Traditional North-South axes are challenged as the very basis for competitiveness is redefined. In our globalized world, now more interconnected than ever, the global economic transactions and the local enterprises manifested by them are pulled into a global arena of cut-throat competition. Mirroring ancient modes of production, today's competitive production based on networks of enterprises seems to have a common set of features and determinants - irrespective of cultural background. Reputation and trust are institutionalized within the network, and transactions become essential - with enterprises optimizing their position through a hierarchy of relationships between actors and a somewhat ethnocentric business orientation. 


\section{NOTES}

1 See the sub-section 'Forest governance and business networks: From perceptions to reality'.

2 Roda (2000, 2001, 2005, 2006); Roda and Gérard (2003); Roda and Erdlenbruch (2003).

3 The New Economy refers to an evolution of developed countries from an industrial and manufacturing-based, wealth-producing economy into a service-sector, asset-based economy as a result of globalization and currency manipulation by governments and their central banks.

4 This stream of theory belongs to the subfield of industrial economics that studies the behaviour of firms, the structure of markets and their interactions, particularly the clustering and networking of firms. This stream has been influenced by the multilayer concept, among others, of social capital (Weber, 1968; Bourdieu, 1980; Coleman, 1988; Putnam, 1995). Its definitions have been influential in the analysis of production systems.

5 This theoretical corpus defines very precisely the concepts of flexibility, efficiency and networked production, which are useful in analysing and understanding diverse types of business networks. In particular, post-Fordism flexible specialization and regulation theories explore the flexibility of production (and trade) systems and their economic efficiency. In these theories, the terms 'flexible' and 'flexibility' refer to both functional and numerical flexibilities, which can be categorized into:

- flexibility in output volume;

- product flexibility, allowing the firm to change its product configuration over the short run without marked losses of efficiency;

- flexible employment;

- flexible work practices;

- flexible machinery;

- flexibility in restructuring; and

- flexible organizational forms (e.g. networks of specialized producers).

6 Network externality may be defined as a change in the advantages or disadvantages that an agent derives from a good or service when the number of networked agents consuming the same kind of good or service changes.

7 The second stream of theory goes beyond spatial economics and locational theories, trying to integrate in a multidisciplinary approach geography, economics, sociology, anthropology and political science in order to study specific economic dynamics with their human and natural constraints.

8 The third stream of theory is a field of sociology that studies economic activity and industrial networks through the various social networks which constitute them.

9 For example, in West and Central Africa, one of the activities offering the highest profit margins has been the export of 'red timbers' in the form of high-grade logs and standardized sawn wood.

10 This transformation often applies to companies that have retained their original name (i.e. WTK or Vicwood groups).

11 Confidentiality requested during the interviews.

12 These resulted from differences in African inter-personal relationships and context, as compared to Asia. 
13 For example, Vicwood operations typically follow this pattern, buying formerly Westernowned companies and using Western managers who have worked for years in Africa.

14 The subcontracting structure, which can also be observed in the Italian and Syro-Lebanese networks, and in Africa as well as overseas, minimizes risk by spreading economic activities across sectors. For example, in one Syro-Lebanese forest company operating in Central Africa, timber transport operations are subcontracted to another company, which is also a subcontractor for an agro-industry and a fuel dealer belonging to the same Syro-Lebanese network. Thus, transport costs are optimized, with trucks never travelling empty. When the need for timber transport seasonally decreases, transport activities do not slow down thanks to the needs of other sectors.

15 We met Gujarati agents in Côte d'Ivoire, Cameroon, Gabon, the DRC, South Africa and Mozambique. We also met a few agents of Tamil origin and from Mauritius in Mozambique who are using their acquaintances through religious Hindu sects to establish business ties with India.

16 In the case of plantation species, Indians have become one of the main buyers of young plantation teaks from Côte d'Ivoire.

17 According to the Deputy Minister of the Environment in the DRC (2004), many Indian agents from East Africa have approached his office seeking contracts for various minerals such as coltan and gold, with timber being only of secondary interest at that time.

18 These logistical activities range from fuel transport (Kamach Group) to frigorific transport in Gabon and multipurpose lorries, including timber transport in Cameroon, the DRC, CAR and Côte d'Ivoire.

19 In CAR the Kamach Group reached this recovery rate by selling low-quality sawn timber to North Africa and West Africa as far as Mauritania. In the DRC, the group owned by Mr Sabbagh reuses small and poor-quality sawn timber to build school furniture for the domestic market. In Côte d'Ivoire, another Lebanese group is using small wood remains to produce joints for 'all purpose' furniture for the local market.

20 All of the Italian companies of Central Africa trace their origins to Milan and the surrounding areas.

21 Ranging from Italian mosaic floorings produced by nearly all Italian companies of Central Africa to the reconstituted timber of Alpicam in Cameroon.

22 A firm or inter-firm network is a group of companies within the same production sector or value chain, which cooperate to some extent through repeated interactions and information exchanges, thus creating various positive dynamics for the group, such as better competitiveness or improved flexibility (Piore and Sabel, 1984).

23 The countries with compulsory management plans in one category of forest also have other forest classifications where harvest is allowed under certain conditions and licensing procedures, but without a management plan. These classifications include non-permanent forests, community forests (in Cameroon) and other country-specific denominations.

24 We observed that in very unpredictable situations - such as CAR during the 2002 to 2003 coup d'état, the DRC in 2003 to 2004 and Mozambique in 2001 - Lebanese, Italian and Chinese companies seemed to run most smoothly with a significant proportion of local staff, despite the troubled events.

25 Conversely, this efficiency does not prevent them from facing difficulties, especially in the case of Chinese companies that face cultural challenges in 'dealing with the African 
mentality', as described by the manager of Vicwood, or which fail to make the anticipated profits (Karsenty and Debroux, 1997).

26 Coo-petition is a neologism coined by Cawthorne (1995) in order to express the paradoxical mix of fierce competition between the actors of such business networks and the cooperation required to compete with actors which do not belong to the network.

27 During fieldwork, we observed the case of an Indian family business reimbursing a debt in the third generation.

28 Cawthorne (1995) uses the metaphor of 'amoebaean capitalism' in order to capture the phenomenon of companies budding into other companies when employees break off to create their own company, while keeping privileged bonds with the mother company.

29 The only available environmental criterion allowing a sound comparison throughout Africa would be the number of eco-certified or eco-labelled companies. However, this criterion is dependent upon market conditions. Companies with markets that show no sensitivity to sustainability, and which do not demand a green label, have no reason to cover the costs of obtaining such a label, irrespective of their environmental impacts. A concern voiced by business networks with primary markets in Asia or the Middle East, which are not eco-sensitive markets, is that absence of such a label is not proof of low environmental performance.

30 For example, creation of new industrial facilities versus purchase of a formerly existing mill.

31 Such market tools have a different intrinsic nature: eco-certification is a tool inciting a producer to have certain behaviour according to the preference of some consumers (for certain labels) and the eventual associated price premium, while a boycott is a sanction operationalized through the suppression of market access.

32 Forest Law Enforcement, Governance and Trade is a process consisting of bilateral negotiations between the EU and select countries in order to ensure the legality of forest products imported into Europe.

33 We observed gross margins of less than 15 per cent for classic integrated Western forest companies. This is very low, considering the investments, machinery costs and risks, compared to gross margins of around 25 per cent for companies operating in Europe with similar equipment and investments (Roda, 2006).

\section{REFERENCES}

Baroncelli, A. and C. Assens (2002) 'Marché-Réseau-Hiérarchie: Une Réflexion sur les Idéaux Types Organisationnels, ESCP-EAP', in Les Actes de la XIème Conférence de l'AIMS, AIMS, Paris Becattini, G. (1987) Mercato e Forze Locali: Il Distreto Industriale, Il Mulino, Bologna

Bernard, P. and J. Vicente (2004) Modèles Décentralisés D’interactions et Coexistence Spatiale des Modes de Coordination, http://www.univ-tlse1.fr/lereps/publi/teleload/bvrei.pdf

Bourdieu, P. (1980) 'Le Capital Social: Notes provisoires', Actes De La Recherche En Sciences Sociales, vol 31, pp2-3

Boyer, R. (1986) La Théorie de la Tégulation: Une Analyse Critique, Editions de la Découverte, Paris Braudel, F. and E. Wallerstein (1985) 'L'économie Monde Selon Braudel et Wallerstein: Civilisation Matérielle, Économie et Capitalisme, XVe-XVIIe Siècle (1979) et La Dynamique 
du Capitalisme (1985)', in I. Géneau de Lamarlière and J. F. Staszak (eds) Principes de Géographie Économique, Lerozier editions, Bréal, p55

Brusco, S. (1982) 'The Emilian Model: Productive decentralization and social integration', Cambridge Journal of Economics, vol 6, no 2, pp167-184

Cadène, P. and D. Vidal (1997) Webs of Trade: Dynamics of Business Communities in Western India, Manohar, Delhi

Castells, M. (1998) La Société en Réseaux: L'ère de L'information, Fayard, Paris

Cawthorne, P. M. (1995) 'Of the networks and markets: The rise of a South Indian town - the example of Tiruppur's cotton knitwear industry', World Development, vol 23, no 1, pp43-56

Coase, R. (1937) The Nature of the Firm, http://www.economie2000.com

Coase, R. (1988) The Firm, the Market and the Law, http://www.economie2000.com

Coleman, J. S. (1988) 'Social capital in the creation of human capital', American Journal of Sociology, vol 94 (supplement), pp95-120

Debroux, L. (1998) 'Vent d'Est sur le Bassin du Congo: La Forêt Africaine Face à une Réalité Mondiale', APFT News, 5 April

FAO (United Nations Food and Agriculture Organization) (2004) Trade and Sustainable Forest Management: Impacts and Interactions (Impact Assessment of Forest Products Trade in the Promotion of Sustainable Forest Management), FAO, Rome

FAO (2008) FAOSTAT Online Database, http://faostat.fao.org/, accessed 1 July 2008

Guilguy, C. (1997) 'Les Filières Forestières Africaines Face aux Défis D’une Industrialisation Durable: Faut-il Avoir peur des Investisseurs Malaisiens?', Marchés Tropicaux, vol 2687, pp1012-1015

Humphrey, J. and H. Schmitz (1996) 'The triple C approach to local industrial policy', World Development, vol 24, no 12, pp1859-1877

Karsenty, A. (1996) 'Les Ambitions Asiatiques en Afrique Centrale', Bois et Forêts Des Tropiques, vol 248, p78

Karsenty, A. (2007) Overview of Industrial Forest Concessions and Concession-Based Industry in Central and West Africa and Considerations of Alternatives, Report for the Rights and Resources Initiative, http://www.cbfp.org/tl_files/archive/thematique/Forest_Concessions_and_ Concession_Industry_Central.pdf, accessed 10 January 2009

Karsenty, A. and L. Debroux (1997) 'L'implantation des Sociétés Forestières Asiatiques en Afrique Centrale: Rimbunan Hijau au Cameroun', Bois et Forêts Des Tropiques, vol 254, pp80-85

Marshall, A. (2004) Principles of Economics: An Introductory Volume, http://www.economie2000.com

Nadvi, K. and H. Schmitz (1998) 'Industrial clusters in less developed countries: Review of experiences and research agenda', in P. Cadène and M. Holmström (eds) Decentralized Production in India: Industrial Districts, Flexible Specialization, and Employment, Sage, Delhi, pp60-138

Nguinguiri, J.-C. (2007) 'Gouvernance des Aires Protégées: L’importance des "Normes Pratiques" de Régulation de la Gestion Locale pour la Faisabilité des Réformes dans le Bassin du Congo', Le Bulletin De L'APAD, vol 26, pp1-8

Olivier de Sardan, J.-P. (2005) Anthropology and Development, Zed Books, London

Piore, M. J. and C. F. Sabel (1984) The Second Industrial Divide: Possibilities for Prosperity, Basic Books, Washington, DC

Porter, M. E. (1990) The Competitive Advantage of Nations, The Free Press, New York, NY

Putnam, R. D. (1995) 'Bowling alone: America's declining social capital', Journal of Democracy, vol 6, no 1, pp65-78 
Rabelotti, R. (1995) 'Is there an "industrial district model"? Footwear districts in Italy and Mexico compared', World Development, vol 23, no 1, pp29-41

Rallet, A. (2000) 'Local globalisation ou "glocalisation" Sellon Rallet', in I. Géneau de Lamarlière and J. F. Staszak (eds) Principes de Géographie Économique, Lerozier, Bréal

Roda, J.-M. (2000) 'Peut-on Confondre la Qualité et L'excellence des Produits Forestiers?', Bois et Forêts Des Tropiques, vol 264, p69, http://72.14.235.104/search?q=cache: MUU5LllDRsoJ:bft.cirad.fr/cd/BFT_264_69.pdf

Roda, J.-M. (2001) Feasibility Study for a New Marketing Strategy for the Timber Production of Grupo Madal, Including Ecocertification, CIRAD, Montpellier, France, http:/ /agritrop.cirad.fr/.

Roda, J.-M. (2004) Forest Products Network Analysis: A Methodology Guide, CIRAD, Montpellier, France, http://agritrop.cirad.fr/

Roda, J.-M. (2005) Réseaux D'entreprises et Stratégies Industrielles dans les Forêts Tropicales, Phd thesis, University Paris VII - Diderot/Jussieu, Paris, http://tel.archives-ouvertes.fr/tel$00011300 / \mathrm{en} /$

Roda, J.-M. (2006) 'Diagnostic Économique et Fiscal de la Filière Bois au Cameroun', in A. Karsenty, J.-M. Roda, E. Fochivé, A. Milol and M. Kuetche (eds) Audit Economique et Financier du Secteur Forestier au Cameroun, Ministere de L'economie et des Finances, Yaoundé, http://agritrop.cirad.fr/

Roda, J.-M. and K. Erdlenbruch (2003) Analyse des Conditions de Reprise Économique du Secteur Forestier en République Démocratique du Congo, CIRAD-World Bank, Montpellier, http:/ /agritrop.cirad.fr/

Roda, J.-M. and J. Gérard (2003) Etude de Faisabilité de L'extension des Activités Industrielles de SBL/TRB dans le Cadre de L'élaboration d'un Plan D'aménagement Forestier, Libreville/Lastourville, Gabon, CIRAD, Montpellier, http://agritrop.cirad.fr/

Roda, J.-M. and M. N'Sitou (2005) 'The breakthrough of Asian networks', African Geopolitics, vol 17, winter, pp117-126, http://econpapers.repec.org/paper/epfwpaper/40400.htm

Roda, J.-M. and S. Rathi (2005) Expertise 'Investissement pour la Production D'énergie à Partir de Déchets d'une Scierie au Gabon, CIRAD, Montpellier, http:/ /agritrop.cirad.fr/

Salais, R. and M. Storper (1993) Le Monde de Production, Ecole des Hautes Etudes en Sciences Sociales, Paris

Schmitz, H. and B. Musyck (1994) 'Industrial districts in Europe: Policy lessons for developing countries?', World Development, vol 22, no 6, pp889-910

Sizer, N. and D. Plouvier (2000) Increased Investment and Trade by Transnational Logging Companies in Africa, the Caribbean, and the Pacific: Implications for the Sustainable Management and Conservation of Tropical Forests, WWF, WRI, European Commission, Brussels

Veltz, P. (1996) Mondialisation, Villes et Territoires: L'économie D'archipel, Presses Universitaires de France, Paris

Vicente, J. (2004) Economie Régionale et Urbaine, http://www.univ-tlse1.fr/lereps/present/ vicente.html

Weber, M. (1968 [1947]) The Theory of Social and Economic Organisation (original title: Wirtschaftt und Gesellschaft), Parsons, Talcot, The Free Press, New York, NY

Williamson, O. E. (1985) The Economic Institutions of Capitalism, Free Press, New York, NY 


\title{
Climate Change: What Are Its Implications for Forest Governance?
}

\author{
Carmenza Robledo, Jürgen Blaser and Sarah Byrne
}

\section{INTRODUCTION}

Forests play a central role in climate change. The effects of climate change are having a strong impact upon forest ecosystems and will affect the livelihoods of forestdwelling communities. Greenhouse gas (GHG) emissions from forests also account for up to 25 per cent of the current yearly greenhouse gas emissions worldwide. However, through conserving and responsibly managing all types of forests, there is an important potential to substantially contribute to reducing greenhouse gas emissions and enhancing carbon sinks. Thus, creating enabling conditions for forests to play a role in helping to adapt to and mitigate the effects of climate change will be an important task in forestry in the coming years. At present, the use of forest mitigation options in developing countries is very restricted and implies high burdens for local communities. The inclusion of a wider range of forestry options in a post-2012 climate regime with a more accessible set of modalities and procedures can have considerable potential to benefit local communities and mitigate climate change. Using forest options for addressing climate change requires a serious improvement in the governance of forest resources, including legal clarity, establishing clear legitimate land and/or carbon tenure, establishing national and local consensus on aims and implications through stakeholder participation, and setting up functioning monitoring systems and incentive mechanisms. Unless robust and proactive steps are taken to clarify and strengthen the property rights of rural and forest peoples, future climate change initiatives will benefit only a few, primarily wealthy elites, and reinforce existing social and economic disparities. 


\section{THE ROLE OF FORESTS AND FORESTRY IN CLIMATE CHANGE}

Climate change is considered to be one of the major threats to sustainable development as a result of its impacts upon health, infrastructure, settlements, agriculture and food security, and forest ecosystems. Land-use change, primarily tropical deforestation, forest degradation and forest fires, are the second principal source of GHG emissions. Additionally, deforestation is one of the most critical environmental problems facing developing countries today in terms of its long-term negative impact upon biodiversity, loss of economic opportunities and increased social inequality. Four main questions need to be answered in order to understand the role of the forest sector in climate change:

1 How does climate change affect the forest sector?

2 How can the forest sector contribute to reducing vulnerability to climate change?

3 To what extent does the forest sector contribute to human-induced climate change?

4 How can the forest sector contribute to mitigating climate change?

\section{How does climate change affect the forest sector?}

\section{Impacts upon forest ecosystems}

Climate change is likely to affect all forest landscapes. With rising temperatures, changes in water availability and the expected increase in carbon dioxide levels, it is anticipated that forests will change at two levels: physiology and metabolism; and ecosystem functioning. These changes will have significant impacts upon the availability and quality of forest goods and services, including the capacity of forests to sequester carbon from the atmosphere.

\section{Impacts upon forestry and forest-dependent people}

The socio-economic impacts of climate-induced changes in forests have not yet been quantified. However, it is clear that they affect all forestry activities, including those within the formal and the informal sector of the economy, as well as forest-related livelihoods. Some of the most important impacts of climate change in forestry are impacts upon timber quality and quantity, changes in the availability of non-timber forest products (NTFPs) and ecosystem services, changes in species diversity, and changes in land-use patterns.

Impacts upon forest-dependent livelihoods cover a wide range of possibilities, including direct impacts from extreme events (e.g. loss of housing), impacts upon health and welfare, loss or reduction of income, loss of employment or changes in working conditions, reduction in the availability of food, impacts upon health and loss of or changes in cultural habitat (Robledo and Forner, 2005; Robledo et al, 2005, IPCC, 2007b, 2007c; Klein et al, 2007). These will increase the already existing 
vulnerability of forest-dependent people. Decreases in living conditions and increases in conflicts are some of the possible consequences.

Climate change can also open opportunities for forest-dependent people. Some potential opportunities are improving recognition of local knowledge in coping with climate variability; promoting native species that cope better with climate variability; promoting diversification in forest use so that the impact of each activity is reduced and therefore also the overall vulnerability; promoting sustainable forest management as a means of reducing vulnerability while reducing GHG emissions, and enhancing carbon sinks; or developing new market opportunities for traditional forest products that are highly resilient to climate change.

\section{How can the forest sector contribute to reducing vulnerability to climate change?}

Sustainable management of forests can increase adaptive capacity while providing benefits beyond the sector. The function of forests in adaptation needs to be highlighted as those communities responsible for managing the forest are hardly recognized for their role in reducing the vulnerability of other sectors. Thus, there is a twofold challenge: the first is to clearly quantify the potential of forests and sustainable forest management in reducing climate change vulnerabilities; the second challenge is to ensure that poor communities involved in such management are recognized and compensated for their efforts so that such contributions are sustained.

\section{To what extent does the forest sector contribute to human-induced climate change?}

Forests account for almost half of the global terrestrial carbon pool (reservoir) and, if vegetation alone is considered (excluding soils), they hold about 75 per cent of the living terrestrial carbon. Forests play an important role in the global carbon budget because they can be either sources or sinks of atmospheric carbon. Emissions depend upon both the rate of deforestation and changes in carbon stocks per hectare after deforestation, with changes in carbon stocks varying with land use, region, ecosystem, and use of the removed forest biomass. In addition, forest fires contribute to the release of GHGs. Annual emissions from land-use change (mainly through deforestation and degradation in tropical developing countries) account for approximately 20 to 25 per cent of the total anthropogenic emissions of greenhouse gases; net emissions are at 17 per cent (Houghton, 2005; IPCC, 2007c).

Estimates of the future rate of deforestation vary widely among different authors. Sathaye et al (2007) estimate that deforestation will continue in all regions, at particularly high rates in Africa and South America, for a total of just under 600 million hectares lost cumulatively by 2050 .

There are some signs that in the immediate future commercial use of biomass for bioenergy will become increasingly important and might be a new and additional threat of deforestation. Areas under biofuel plantations have increased dramatically 
around the world, particularly for soybeans and oil palm. Globally, the area planted with oil palm and soybean increased from about 11 million hectares to 77 million hectares between 1990 and 2002. Because plantations are often established after natural forests have been logged and then burned to clear the land for planting, the increasing area under such plantations may seriously threaten the remaining tropical forest, particularly in South-East Asia and the Amazon.

Poor communities' contribution to increased forest-related GHG emissions is a highly relevant issue. According to a recent report presented to the secretariat of the United Nations Framework Convention on Climate Change (UNFCCC), povertydriven activities, especially forest conversion for subsistence farming, are responsible for up to 45 per cent of deforestation and forest degradation worldwide (Blaser and Robledo, 2007). The social, economic and ecological impacts of these emissions are not yet completely understood. However, it is obvious that a policy framework and corresponding funds need to be guaranteed for promoting poverty alleviation programmes aimed at solving the direct and underlying causes of deforestation and forest degradation in any post-2012 mitigation agreement.

\section{How can the forest sector contribute to mitigating climate change?}

According to the Intergovernmental Panel on Climate Change (IPCC), ${ }^{1}$ a sustainable forest management strategy aimed at maintaining or increasing forest carbon stocks in the long term, while producing an annual sustained yield of timber, fibre or energy from the forest, will generate the largest sustained mitigation benefit (IPCC, 2007c, Chapter 9). In its Fourth Assessment Report (AR4) the IPCC considers four groups of activities as available options to reduce emissions by sources and/or to increase removals by sinks in the forest sector (IPCC, 2007c):

- maintaining or increasing the forest area through reduction of deforestation and degradation and through afforestation/reforestation; ${ }^{2}$

- maintaining or increasing the stand-level carbon density (tonnes of carbon per hectare);

- maintaining or increasing the landscape-level carbon density; and

- increasing off-site carbon stocks in wood products and enhancing product and fuel substitution.

There are five management practices associated with these groups of mitigation activities:

1 afforestation and reforestation;

2 biofuel plantations and substitution through wood products;

3 reducing emissions from deforestation and forest degradation (including conservation);

4 improving management; and

5 forest restoration (see Table 18.1). 
Table 18.1 Mitigation options and forest management practices

\begin{tabular}{ll}
\hline Mitigation options & Forest management practices \\
\hline Maintaining or increasing forest area & $\begin{array}{l}\text { Afforestation and reforestation (plantations including agroforestry) } \\
\text { Reducing emissions from deforestation and forest degradation } \\
\text { through sustainable management and conservation }\end{array}$ \\
Maintaining or increasing stand-level & $\begin{array}{l}\text { Reduction of forest degradation } \\
\text { Forest restoration }\end{array}$ \\
carbon density & $\begin{array}{l}\text { Improving management (e.g. reduced impact logging) } \\
\text { Improving forest management }\end{array}$ \\
Maintaining or increasing & Fire control \\
landscape-carbon density & Sustainable biofuel plantations \\
wood products and enhancing substitution & Substitution through wood products \\
\hline
\end{tabular}

\section{Afforestation and reforestation ${ }^{3}$}

Afforestation and reforestation are the direct human-induced conversion of nonforested land into forested land through planting, seeding, and/or the human induced promotion of natural seed sources. The two terms are distinguished by how long the non-forest condition has prevailed. Afforestation and reforestation activities lead to increases in carbon pools and are currently the only forest management practice eligible for the Clean Development Mechanism until 2012.

\section{Biofuel plantations and substitution through wood products}

Substitution of products with high upstream emissions levels with products with lower upstream emissions is an interesting possibility for mitigating climate change. In the forest sector it includes mainly three options:

1 substituting high energy consuming materials with wood in the building industry;

2 using wood for heating; and

3 promoting forest-based biofuels.

These activities have a positive carbon balance when wood is produced sustainably (i.e. carbon stocks are renewed in the forest); and emissions from producing wood materials or biofuels are equal to or less than the products they substitute (allowing the annual harvest to be set equal to or below the annual forest increment, thus allowing carbons stocks to be maintained or to increase while providing an annual carbon flow to meet society's needs for fibre, timber and energy) (IPCC, 2007c).

In addition to biofuels derived from wood and NTFPs, some agricultural products are used in producing biofuels (e.g. maize, sugar cane and palm oil). In terms of their potential to contribute to climate change mitigation, there are two main considerations:

1 In some cases the establishment of these agricultural activities follows a deforestation event. The corresponding GHG emissions must be included in the carbon balance of the biofuel to determine whether there is a net positive or negative effect. 
2 Other emissions must also be included in the carbon balance, especially upstream emissions (e.g. due to the production of fertilizers), as well as all the GHG emissions during the biofuels production.

\section{Reducing emissions from deforestation and forest degradation (REDD)}

Deforestation in the tropics is a major source of GHG emissions. In some circumstances, deforestation and degradation can be delayed or reduced through proper management (Soares-Filho et al, 2006). Reducing deforestation and degradation is the forest mitigation option with the largest and most immediate carbon stock impact in the short term per hectare and per year globally because large carbon stocks are not emitted when deforestation is prevented. The mitigation costs of reduced deforestation depend inter alia on the causes of deforestation (commercial agriculture, subsistence farming or wood extraction), the associated returns from the non-forest land use, the returns from potential alternative forest uses, and any compensation paid to the individual or institutional landowner.

\section{Improving forest management}

Forest management activities include silvicultural interventions that promote a greater proportion of the desired species, tree population and size structure, which, in terms of timber, means promoting the maximum volume of usable growing stock and therefore of carbon which may not be released to the atmosphere. They also include harvesting systems that maintain partial forest cover, minimize losses of dead organic matter or soil carbon by reducing soil erosion, and avoid burning and other highemission activities. Replanting or natural regeneration promotion after harvest or natural disturbances accelerates tree growth and reduces carbon losses. The use of fertilizers or drainage of forest soil (especially in peat lands) can have a negative effect in the overall carbon balance and should therefore be minimized. Moderate drainage, however, can lead to increased peat carbon accumulation (Minkkinen et al, 2002). Economic considerations are typically the main constraint because retaining additional carbon on site delays revenues from harvest (IPCC 2007c).

\section{Forest restoration}

Forest restoration is probably the most promising option in forestry for restoring carbon stocks (Blaser and Robledo, 2007). Restoration is a combination of planting trees and human-induced natural regeneration within a degraded forest $\operatorname{~area}^{4}$ that has lost most of its carbon stock. Forest restoration is thus a strategy applied in degraded forest areas. Forest restoration aims to enhance and accelerate natural processes of forest regeneration (including carbon stocks) in order to regain the desired species composition and growing capacity of the forest ecosystem. In terms of mitigating climate change, forest restoration becomes complementary to reducing emissions from forest degradation. Under current conditions there is a huge area of degraded forest that could be restored while improving overall livelihood conditions (including biodiversity, long-term income and health). Forest restoration is an important issue in all developing countries. 
In general, promoting sustainable forest management, including all of the activities mentioned above, will contribute to permanently reducing emissions from the forest sector. Furthermore, sustainable forest management can be considered in many cases an appropriate and cost-effective adaptation measure, reducing not only climaterelated risks but also overall ecological and human vulnerability to stress. Such activities will certainly have many collateral environmental and socio-economic benefits. In the following sections we concentrate our attention on the mitigation options in the forest sector. However, one should bear in mind that adaptation to, and mitigation of, climate change are complementary strategies that should be pursued jointly in any forestry activity aimed at addressing climate change.

\section{FORESTRY ACTIVITIES IN THE KYOTO PROTOCOL UNTIL 2012}

In the Kyoto Protocol, forestry activities fall under 'land use, land-use change and forestry' (LULUCF). LULUCF activities under the Kyoto Protocol are governed by Articles 3.3 and 3.4. Under the Clean Development Mechanism (CDM), forestry activities have been included under afforestation and reforestation (A/R CDM). A/R activities under the CDM were only clarified by the end of 2003. This caused a delay in the regulation and methodologies in $\mathrm{A} / \mathrm{R} \mathrm{CDM}$ in comparison to the $\mathrm{CDM}$ in other sectors (e.g. energy). Additionally, A/R CDM methodologies are confronted with a higher level of complexity and scrutiny than others. Even if it is too early to make a detailed assessment, some observations are worth mentioning:

- The CDM is a heavily regulated system in which the main investments are to be made up front. Consequently, poor communities either need to establish partnerships with investors or obtain some kind of subsidy in order to be able to participate.

- Designing an A/R CDM project requires a high level of knowledge of internationally agreed procedures and methodologies. In many countries, as this knowledge is not present, this means the need to engage international expertise, which further increases project costs.

- A/R CDM has stimulated new interest for planting trees, especially in heavily degraded areas. This is, indeed, a new opportunity for the forest sector. Unfortunately, the sector is reacting very slowly to the opportunities provided by the CDM. As a consequence, many A/R CDM activities are proposed without consideration of the forest strategy; even worse, in many cases national strategies for promoting forestry are lacking any consideration of $A / R$ CDM as new mechanisms for forestry promotion.

- A/R CDM, especially through small-scale projects, offers a possibility for poor people to get involved, especially through the promotion of community forestry. There are some very interesting projects in the pipeline (e.g. in Uganda, Colombia and Madagascar) that promote participation and the empowerment of 
local communities and/or indigenous peoples and which are aimed at improving not only the carbon balance, but also communities' overall livelihoods. However, the so-called simplified modalities for small-scale reforestation/afforestation projects under the CDM that have been developed to allow communities to participate in the CDM have proven largely out of reach, given the high installation and transaction costs of project preparation. These high costs, and the requirements for clear property rights for investment, have resulted in the current situation where almost all projects to date have targeted either publicly owned reforestation areas or private plantations - and where most community involvement has occurred in the voluntary market (e.g. outside of the CDM).

These experiences illustrate that, as currently structured, carbon markets have been inequitable, posing the risk of aggravating the growing economic gap between forest dwellers and the rest of society. A lot needs to be done to make a post-2012 carbon sequestration approach accessible to poor communities in the tropics.

\section{KEY ISSUES RELATED TO GOVERNANCE AND CLIMATE CHANGE IN THE FOREST SECTOR}

In the broader context of linking climate change and forests described in this chapter, governance is understood as institutions and process that form 'a complex tapestry of competing authority claims' (Mehta, 1999). A governance analysis implies unravelling the threads that are knotted together to make the tapestry. We consider issues related specifically to the three spheres of governance: the public sector, the private sector and civil society. Why is climate chage important to all three spheres? The arguments are as follows:

- Climate change is a global concern that needs to be addressed by society as a whole. If only one or two spheres set and implement agreements for governing forest resources in a manner that contributes to addressing climate change, then many stresses, needs, challenges and opportunities will not be properly considered. Consequently, such agreements could increase the vulnerabilities of forest livelihoods and/or enhance GHG emissions from the forest sector. This scenario is to be avoided.

- Climate change has impacts upon forest resources without differentiation if these are publicly or privately owned, or under another form of tenure. Moreover, climate change can increase existing or potential conflicts with regards to land tenure and rights. A legal framework on forest tenure and rights that recognizes customary rights and also corresponds to the legitimate interests of all stakeholders is required for addressing climate change in the forest sector.

- Addressing climate change requires huge investments, which are beyond public budgets. It also brings new business opportunities. In both cases, the appropriate participation of both the private sector and civil society is required. Such 
participation can only be promoted if governance agreements are in place that reflect the priorities of all sectors.

- The UNFCCC has created market mechanisms, such as the CDM. The three spheres of governance have roles to play in ensuring the equal participation of all stakeholders.

- Neglecting to consider any one sector can increase existing social conflicts or create new ones.

Consequently, in this analysis we include the issues in each sphere (public, private and civil society) that are key for governing forest resources in the context of climate change. Clearly, forest tenure and rights is a primordial issue in governing forests. As such, this issue, as well as the rights to environmental services of forest ecosystems, are considered. Measures aimed at using forestry as a mitigation or adaptation option need to include transparent and equal participation of all affected social groups. Thus, a more integrative framework is presented here.

\section{Issues related to the public sector}

Good governance of forest resources, and participation and empowerment of the forest-dependent poor, will substantially rely on the consideration of their priorities when institutional frameworks are defined.

\section{International agreements on climate change, especially in the UNFCCC context}

The 191 signatory countries (so-called parties) of the UNFCCC design the international institutional framework and clarify the global priorities for adapting to and mitigating climate change. Decisions in the UNFCCC take place in a closed space where only parties have a vote. Other actors, such as non-governmental organizations (NGOs) or representatives of the private sector, participate as observers.

Since the agreement on the Millennium Development Goals (MDGs) in 2000, poverty alleviation and environmental sustainability, as well as good governance, are of high importance on the international agenda - hence also in the negotiations within the UNFCCC. However, there is still a lot to do to ensure that the institutional framework for addressing climate change is designed in a way that facilitates pro-poor initiatives and good governance in the forest sector.

With regard to mitigation, the picture includes the current agreements in the Kyoto Protocol, where forestry activities in developing countries are restricted to afforestation and reforestation (and bioenergy) under the Clean Development Mechanism (A/R CDM). For small-scale A/R CDM projects, the participation of 'low-income communities or individuals' is required. The definition of 'low-income communities or individuals' and the degree of participation (in planning, implementing and owning) is to be established by each developing country. Smallscale A/R CDM projects have simplified modalities and procedures and a simplified methodology for carbon accounting. Such simplifications are aimed at reducing the transaction costs of these projects while maintaining accuracy in carbon accounting. 
Currently there are three major negotiation processes under the UNFCCC: the Ad Hoc Working Group on Further Commitments for Annex I Parties under the Kyoto Protocol (AWG-KP); the Ad Hoc Working Group on Long-Term Cooperative Action under the Convention (AWG-LCA); and the ongoing discussions under the Subsidiary Body for Scientific and Technical Advice under the UNFCCC (SBSTA). At the 15th Conference of the Parties (COP 15) to be held in Copenhagen in 2009 these discussions should converge on a consistent agreement for a post-2012 mitigation regime (see Winkler, 2008). All mitigation options in forestry are considered in these processes and have to convert into a post-2012 mitigation regime. The Bali Action Plan agreed in December 2007 (AWG-LCA) is a comprehensive two-year process aimed at enabling the full, effective and sustained implementation through long-term cooperative action, now up and beyond 2012 (see Dec. 1/CP.13'Bali Action Plan') that channels the negotiation processes mentioned above. It will have a major impact upon how and by whom the forest will be used in the future. It is therefore of prime importance to ensure that good governance considerations are taken into account when defining a post-2012 regime on mitigation.

\section{National Frameworks on Climate Change and their relation to the forest sector and other natural resources}

Each country that participates in the UNFCCC defines its own institutional framework for addressing climate change. This national framework constitutes the coordination mechanism between international decisions and the implementation of climate change programmes and projects at the national and local levels. This governance space should be a very flexible one where a multitude of actors can participate. Because of its cross-cutting character, addressing climate change at the national level requires a high level of coordination between the different governance spaces that are to participate in adapting to or mitigating climate change. The role of the forest sector in mitigating climate change during the first commitment period (2008 to 2012) needs to include the following elements:

- Non-Annex I countries (developing countries) need to fulfil some requirements to be able to participate in the CDM during the first commitment period. These requirements involve:

- creating a designated national authority at the level of public services;

- defining forest criteria thresholds within the range provided in the official definition of forest (Dec. 11/CP.7) for the country during the first commitment period (high area and minimum cover);

- defining the meaning of 'low-income communities and individuals' who are to participate in the planning or implementing of small scale A/R CDM projects.

- All projects in the A/R CDM will take place in areas that have been non-forested since at least 1990. In the majority of cases, these areas are under a different land use than forest and/or the A/R CDM projects take place on land outside of the influence of the forest authority. In such cases, coordination between forestry and other sectors is necessary. 
- If A/R CDM projects are expected to have significant negative environmental or socio-economic impacts, a corresponding impact assessment needs to be done based on national legislation.

- Bioenergy projects are considered to be part of the energy projects of the CDM. Socio-economic impacts are not required to be analysed in these projects, which can jeopardize the sustainability of these projects. Therefore, a wider understanding of the impacts of bioenergy projects needs to be carefully considered.

For a post-2012 regime, how countries define the national framework for participating in REDD and other forest mitigation options will be especially important. In this context, committing forests as carbon reservoirs will require clarity on which forest areas are to be used for development purposes (forests that might be converted through a planned process into other land uses in a foreseeable future), as well as which areas are to be considered as a permanent forest estate ${ }^{5}$ (Forner et al, 2006). A national framework on REDD will need to consider all social groups who claim forest tenure and use rights. Besides the state and private owners, this also includes indigenous peoples, settlers, concessionaires and many other groups carrying out forestry activities (legal and illegal). Activities in REDD, which will be related to one or another form of payment, need a clear institutional framework that promotes the equal participation of these social groups, with special consideration for poor people.

A great challenge is to ensure consistency between mitigation plans and programmes in developing countries and ongoing decentralization processes. Experience in this regard is very limited. Generally speaking, sub-national entities are not well informed or aware of existing mechanisms aimed at addressing climate change. Relations are established directly between project participants at the local level and the regulatory climate focal points at the national level. This situation is a clear gap in governance that needs to be addressed.

\section{Land tenure and land-use rights}

There is a vast literature on forest land tenure and use rights (RRI, 2007). It can be stated that hundreds of millions of people living in or near forests and making use of forest lands and resources have no or few secure rights and tenure over these lands and resources. In many cases, the lack of rights and tenure is directly related to poverty and to the absence of incentives to avoid degradation of those resources.

Lack of clarity on land tenure and use rights considerably affects the possibility of promoting mitigation activities in the forest sector. In this context the main question is who owns the carbon credits, certificates and/or other benefits when reducing GHG emissions or enhancing carbon sequestration through forestry activities. To understand the question, we need to again differentiate between the agreements that are valid for the first commitment period and the possibilities in a post-2012 regime, currently under negotiation:

- For the first commitment period until 2012, the regulations on A/R CDM require that 'changes in circumstances within the project boundary that affect legal title to the land or rights of access to the carbon pools' are to be clarified and are 
subject to monitoring and verification (Dec. 19. CP.9). In cases where the ownership of the pools is not clear or when different carbon pools have different owners, it is extremely difficult to determine who owns the carbon credits or certified emission reductions (CERs). If there is no clarity on the ownership of the CERs, any market transaction can be questioned, bringing many difficulties for both credit sellers and buyers. This difficulty can be solved at the level of national legislation, or by using specific and clear agreements and contracts between the owners of carbon pools in a given project. It must be said that solving the ownership of carbon credits can become a major burden for any mitigation scheme in the forest sector that is based on a market mechanism.

- For a post-2012 regime, the concerns on 'carbon ownership' will gain importance as more forestry mitigation options are considered.

As mentioned earlier, over 40 per cent of the deforestation and forest degradation worldwide is a consequence of poverty. What is necessary is to reduce emissions and, when possible, increase sequestration capacity from forest conversion and degradation while promoting an improvement in the living conditions of forest-dependent communities. The negotiators on REDD need a clear position in order to promote an international scheme that does not encourage further inequalities in the forest sector.

\section{Rights associated with services from forest ecosystems}

There are only a few countries where the ownership of forest ecosystem services is included in the corresponding legislation (e.g. forest legislation, territorial legislation, etc). With increasing interest in various payments for environmental services (PES) schemes, the question of ownership of these services remains open. Who receives the benefits of a scheme that recognizes the role of forest ecosystem services in reducing vulnerability? With regards to mitigation, this question is crucial and remains challenging as long as forest owners and local forest users are not the same. The A/R CDM scheme pays for the service of sequestering carbon from the atmosphere and retaining it in the biosphere. In the case of REDD, the idea is to promote emissions reductions, supporting the capacity of the forest to sink and maintain carbon in the five carbon pools. Additionally, maintaining forests through REDD has a direct impact upon forest capacity to provide other ecosystem services, such as water flow regulation and conservation of biological diversity and cultural habitat. If the direct beneficiaries of these services own or have secure access rights to the forest and its ecosystem services, they will become the best allies in conserving the forest and in reducing emissions from deforestation and forest degradation. Potential conflicts between different stakeholders due to their various interests regarding forest use will need to be carefully considered when discussing any governance mechanism for forest resources in the context of climate change.

\section{Issues related to the private sector}

The private sector includes all sectors of the economy, including formal and informal segments. ${ }^{6}$ Forestry activities required for promoting mitigation of climate change are 
often linked to the informal sector of the economy. An authoritarian treatment of the informal segment of the economy will cause an increase in social conflicts, reduce the permanence of carbon in the forest and increase the vulnerability to climate change of many forest-dependent people. ${ }^{7}$ Therefore, we argue that any climate change mitigation strategy has to be based on dialogue with all forest users and must create business schemes for all forest-dependent people that promote an equal distribution of benefits. For the purpose of this chapter, this type of business is called 'participatory business'.

It must be said that until now the role of the private sector in the context of forests and climate change has not always been positive. Over 40 per cent of the emissions from deforestation and forest degradation are completely or partially related to extractive activities funded by private companies. Moreover, conflicts of interest between large companies and local communities regarding forest-use rights have been widely documented. In many cases, these conflicts have reduced the adaptive capacity of forest ecosystems as well as of forest-dependent people. A private sector oriented only by short-term profit needs to be reoriented towards a more participatory business practice if forest resources are to be used in addressing climate change. For designing participatory business schemes, a number of issues should be considered.

\section{Sharing of benefits ${ }^{8}$}

In the case of mitigation, countries with reduction commitments are already paying for carbon sequestration through the CDM, and market mechanisms are under discussion for REDD. In both cases, forest activities can bring many collateral benefits, including income improvement. The question here is: who will get this income? What is necessary to ensure that forest-dependent people participate as beneficiaries in the payment mechanisms resulting from the UNFCCC? We foresee at least five requirements:

1 recognition of the role of forestry activities in adaptation to, and mitigation of, climate change;

2 recognition of the key role of forest-dependent people in undertaking these activities;

3 understanding new business opportunities and the role of forest-dependent people in making these opportunities possible;

4 creation of a legal framework that reflects the first three points; and

5 creation and application of business mechanisms that facilitate the participation of all forest users in business activities aimed at adapting to or mitigating climate change.

It is also important to note that weak local institutional capacity can be a key constraint to equitable management of forest revenue and ability to translate income into concrete development gains at the local level (see Box 18.1). Institution-building must be part and parcel of any effort to engage communities in achieving - and benefiting from - REDD. 


\title{
Box 18.1 Governance of forest income from community forest exploitation in Cameroon
}

\author{
Joseph Tsana Enama and Anicet Minsoum'a Bodo
}

\section{The institutional framework and organizational model for community forestry}

The institution of community forests represents one of the greatest innovations in forest legislation in Cameroon. The evolution of legal texts is evidence of the will of the Cameroonian government to improve local communities' participation in forest resource management, and to make community forestry an economic development option for the rural population. These texts establish a process of progressive devolution of management power to communities through the establishment and empowerment of local organizations. According to the legislation, the exploitation of community forests by local populations can be done through known legal entities - associations, common initiative groups (CIGs), cooperatives or economic interest groups (EIGs).

An association is formed by a group of individuals designated by their respective communities to act on their behalf. The association has a number of advantages: it is relatively easy to establish and manage, it is exonerated from taxes, and benefits derived from its activities are invested in social infrastructures. However, an association is not entitled to subsidies, gifts and legacies. ${ }^{9,10} \mathrm{~A} \mathrm{CIG}$ is an economically based grouping of individuals, with the same advantages as an association. In addition to the authorization/freedom to redistribute benefits to members, a CIG can receive subsidies, gifts and legacies. A co-operative is seen as a large CIG. This form of organization offers more guarantees of financial transparency because of the legal requirements; but its management structure is complex, demanding and bureaucratic - consisting of a general meeting, board of directors, inspection committee, director and auditor of accounts. An EIG has the same characteristics as the CIG but its lifespan is limited and it is subject to taxation. Associations and CIGs are the most common organizational forms since both are easy to establish and govern. A key difference, however, is that in associations, benefits tend to be held and used collectively, but are divided up and utilized individually in CIGs - depending upon the internal forest tenure arrangement. At the end of 2007, among the 124 community forests under management agreements, 87 (70 per cent) were managed by CIGs and 37 (30 per cent) by associations.

\section{Forest income management}

The revenue generated by community forests derives mainly from the marketing of timber products. Sawn wood products from 86 per cent of community forests are exported through indirect routes. These products are either sold to logging companies holding timber exportation permits or to processing industries with which they have established partnership contracts, sometimes exclusive, but seldom to the advantage of local communities. 
The use of this income tends to be oriented towards communal works such as habitat improvement, construction and rehabilitation of community buildings (parishes, meeting houses, classrooms), the establishment of village palm groves, the digging of wells, and salary payments for temporary teachers. In some cases, people invest in income-generating activities such as the establishment of sawmills, carpentry or joiners' shops, non-timber forest product (NTFP) processing activities or environmental activities (e.g. ecotourism). Projects that generate income, such as savings-and-credit systems or village bursar shops, are largely absent.

The financial management practices of local institutions are often characterized by lack of transparency, non-rigorous financial practices and embezzlement of funds. Poor management of forest revenue creates conflicts and renders the actions of local management organizations ineffective, at times leading to the cessation of forest management activities. Constraints on the economic viability of community forest management entities include:

- corruption among some forest administrators;

- low levels of professionalism;

- under-valuation of forest resources identified during the elaboration of management plans; and

- limited economic returns and difficulty in accessing capital to finance activities.

These factors deeply weaken local forest management organizations, increasing their vulnerability in the face of illegal practices.

\section{Recommendations}

Considering the aforementioned constraints, improving the economic returns and livelihood outcomes from community forestry requires systematic efforts to strengthen the management and organizational capacities of local organizations responsible for community forest management. Key recommendations in this regard include the following:

- Support the development of strategic and beneficial alliances between local community forest organizations and large forestry companies, fostering synergies in terms of service provision, and more efficient processing and economic use of forest resources.

- Assist local organizations to improve the marketing of forest products by providing pertinent information and training.

- Facilitate the association of local forest management organizations into unions or federations as a means of minimizing transaction costs, more easily accessing new opportunities and international markets, and influencing political decisions.

- Encourage local community forestry organizations to facilitate implementation of income-generating activities for the benefit of communities.

- Contribute to strengthening the institutional capacities of existing community forestry organizations. 
- Assist local organizations to develop effective norms and entrepreneurial capacities, and to establish a stronger social foundation.

While the above functions can be supported by NGOs and local technical services, the government should also support the revision of rules in order to create a legal framework that favours the development of small-scale rural forest enterprises.

\section{Sharing of responsibilities}

One characteristic of activities aimed at mitigating climate change is the need for longterm effects. Forestry aimed at addressing climate change needs to ensure the permanence of forests for a determined period of time. If a forest is lost, due, for example, to a forest fire, who is liable for the GHG emissions or for the reduction in forest goods and services aimed at reducing vulnerability? Clarification concerning liabilities is therefore extremely important when considering any mitigation activity. Not only do benefits need to be shared among different forest users, but also responsibilities if they want to participate in the mechanisms defined within the UNFCCC. The following issues should be considered:

- clarification and, whenever possible, quantification of existing and future risk of forest loss and reduction of ecosystem services;

- participation and roles of different forest users in increasing/reducing these risks;

- definition of legal instruments for equitable sharing of responsibilities which are likely to be linked to mechanisms for benefits sharing.

\section{Access to new business opportunities}

The issues explained before clarify how, by addressing climate change, the participation of new actors in the private sector is essential. Since much of the business related to climate change, such as carbon trading, happens in international markets, there are many constraints that make it impossible for most forest users to participate in this new business. Mechanisms for addressing these constraints are regularly forgotten in international negotiations. However, for people in the field, these constraints remain a major barrier to accessing international markets and therefore having an impact in governing the sector.

\section{Issues related to civil society}

The participation of civil society is the third sphere that we consider in the analysis. According to our understanding, there are different levels in civil society. At the base are individuals who, according to different characteristics, can be grouped in social groups (e.g. farmers and settlers). The local community covers all of these different social groups acting in a given landscape. Participation implies that all social groups who depend upon forests should be involved in planning and implementing measures for adapting to and mitigating climate change. 
Participation goes far beyond simply being informed, and requires that social groups are able to make their priorities and expectations clear, are included in decision-making, obtain benefits, assume responsibilities and are fully recognized for their involvement. The participation of civil society is more likely to be strong if their forest rights and tenure are solid. In addressing climate change, participation becomes a key issue since social groups who have been involved in using the forest will need to change their behaviour and the relationships between them. Addressing climate change requires, on the one hand, innovation in terms of legislation, science and technology, and, on the other, a better understanding of and respect for traditional knowledge and civic mechanisms. These two elements (need for change in behaviour and capacity to absorb innovation and to combine it with traditional knowledge) bring many challenges and opportunities for civil society and state institutions. The following issues are essential for tackling these challenges and opportunities:

\section{Empowerment}

Empowerment is a complex process that starts with awareness of a lack of (decisionmaking) power and of the right to access this power. Through empowerment, new social groups can actively participate in a decision-making process (i.e. accessing new governance spaces). If empowerment is not based on dialogue and mutual respect, social conflicts can arise and chances to increase equity can be jeopardized. Empowering social groups so that they can participate in activities to address climate change includes the clarification of land tenure and land-use rights, access to capacitybuilding, valuation of local knowledge and access to other knowledge, and access to business and markets.

\section{Knowledge-sharing}

Ideally, knowledge-sharing should consist of at least two processes - valuing local and traditional knowledge and disseminating scientific knowledge:

1 Valuing local and traditional knowledge. In terms of addressing climate change, it is important to value local knowledge. The role of local knowledge in mitigating climate change, especially in promoting REDD, is highly relevant. However, since climate change is having an impact upon forest ecosystems, the extent to which this knowledge can be helpful for mitigating climate change will depend upon specific circumstances.

2 Disseminating scientific knowledge. A lot has been said on the importance of research in understanding the role of the forest sector in addressing climate change. Both the IPCC and the UNFCCC have frequently highlighted the need for promoting scientific research on climate change and have requested their parties to ensure more funds. However, if the results of scientific research are not available to forestdependent people, it will not be possible for them to understand the type of innovations that addressing climate change will require. Thus, knowledge transfer needs to take place from science to communities and vice versa. 


\section{Forming associations}

Many measures for mitigating climate change are to be taken on a large geographical scale. Social groups interested in participating in planning and implementing these measures often can only benefit from creating associations that help them to bring their priorities onto the agenda. Interest groups can be created focused on similarities (e.g. belonging to a cultural group or to a type of user) or on complementarities (e.g. private investors and small farmers). Ongoing experience has demonstrated the advantages of promoting associations based on complementarities (e.g. public-private-civil society partnerships, company-community partnerships, civil society-private-sector partnerships, etc.), provided efforts are made to level the playing field between more and less powerful actors.

\section{Cross-cutting issues}

\section{Capacity-building}

Improving capacities is a key issue in making progress in governance and should be considered for the public sector as well as for the private sector and civil society. Capacity-building should increase the skills of different actors to participate in different governance spaces, use or modify existing mechanisms or propose new ones when required. With regards to climate change, only through an improvement of capacities are forest-dependent people able to use new opportunities, realize what risks are involved and assume responsibilities for adapting to and mitigating climate change. New knowledge on climate change mitigation should be an integrated part of capacity-building in sustainable forest management. In this field, support organizations, such as NGOs, have an important role to play.

\section{Mechanisms for decision-making}

Addressing climate change is very much a global issue for which international mechanisms for decision-making have been established. On the other hand, activities in the forest sector are implemented at the local level, where other decision-making mechanisms are in place. The first challenge is therefore to ensure that mechanisms for decision-making on forest resources and climate change are integrated across local, national and international levels; or make it possible for actors from a given governance space (e.g. local) to have access to decision mechanisms from other governance spaces (e.g. national, global). It is essential to highlight the importance of using participatory mechanisms for decision-making and to promote understanding of the priorities and decisions at all levels when addressing climate change in the forest sector.

\section{CONCLUSIONS}

It is clear that effective and legitimate governance in forestry in the wider sense will be a central challenge to achieving a meaningful role for forestry and forest-dependent 
people in climate change adaptation and mitigation strategies. Legal aspects and governance have been the focus of a number of international and national initiatives, such as the present workshop, the global workshop on governance and decentralization in Interlaken, Switzerland, as well as the various forest law enforcement and governance (FLEG) processes in Asia, Africa, Europe and northern Asia. With the increased attention to forests, particularly through the expected inclusion of REDD and other forest mitigation options in a post-2012 regime, it is expected that countries that improve their forest governance, clarify forest and carbon tenure and address illegality effectively are more likely to immediately benefit from future forest mitigation incentives, as well as investments in forest-based adaptation.

Some general conclusions can be made based on the experiences cited above:

- Due to the long-term character of mitigation projects at the field level, new challenges in terms of planning, implementing and monitoring have arisen. Of particular importance is the fact that these projects need to include more socioeconomic, environmental and institutional aspects, including traditional activities, in the sector.

- The forest sector is slowly starting to consider climate change mitigation opportunities and challenges. However, due to the complexity of the issue and the intricate requirements, efforts to improve the capacities of local and national actors to capture such opportunities are required.

- The active participation of local users in mitigating climate change is required for ensuring long-term permanence of these measures. Excluding social groups from sharing the benefits and responsibilities increases social conflicts and is therefore against the strategic goal of any mitigation measure.

- The agreement on an international framework for addressing climate change through the UNFCCC has promoted global interest for the potential participation of the forest sector in mitigating climate change. Nevertheless, the main disadvantage of these international processes is that local specificities are not taken into account. This creates difficulties when implementing mitigation activities at field level.

- The A/R CDM is a highly overregulated system. This has two main impacts: a high level of expertise is required in developing $\mathrm{A} / \mathrm{R}$ CDM projects; and high up-front investments are required when initiating an $\mathrm{A} / \mathrm{R} \mathrm{CDM}$ project. These two impacts make the design and establishment of an A/R CDM project unfeasible for forestdependent communities.

- Climate change-relevant investment in the forest sector is a long-term undertaking. It needs security with respect to land-use and long-term commitment of involved parties. Secured rights and tenure are, thus, a prerequisite so that such investment can happen and be an effective measure in mitigating climate change.

Improving governance in the forest sector is a crucial requirement if measures aimed at adapting to or mitigating climate change are to succeed. The benefits will extend beyond the forest sector, providing positive benefits to the agricultural and energy sectors, and possibly also to water resource management. By contrast, if governance, rights and tenure 
challenges in the forest sector are not addressed, the possibility of using forest mitigation options to promote sustainable development are extremely limited.

Those seeking to enhance the governance of forest resources to facilitate forestry options that contribute to adaptation to, and mitigation of, climate change must consider that:

- Governance goes beyond state-centred notions and includes issues related to the public sector, as well as the private sector and civil society. This implies the need to create and support governance spaces among representatives of these spheres so that agreements, norms, legislation and other mechanisms for managing forest resources for addressing climate change can be designed considering the priorities, possibilities and constraints of all stakeholders (governance actors). The dialogue in such governance spaces should be aimed at ensuring a better balance in the UNFCCC negotiations so that all three spheres are equally represented in decision-making.

- Any activity in the forest sector aimed at mitigating climate change has clear and accountable forest tenure and forest use rights as a starting point. Therefore forest (and carbon) tenure and use rights need to be in favour of local stakeholders if forest resources are to be effectively harnessed to address climate change. Many countries will need support for improving and enforcing their legislation on forest tenure and use rights.

- Parties negotiating in the UNFCCC need to better understand the potential role of, and multiple constraints facing, the forest sector so that decisions at the international level can be applied at the local level at an affordable cost. More flexibility needs to be integrated within the UNFCCC's existing mechanisms and in those to be agreed in a post-2012 mitigation regime. Furthermore, parties in the negotiation need to increase their understanding of forest-related issues and of the priorities for forest users so that any international agreement can be effectively and realistically implemented. Advocating local forest users' priorities is thus important to the design of any future strategy that includes the role of forests in climate change adaptation and mitigation.

- In order to achieve good governance, clarification of forest and carbon tenure and use rights in favour of local stakeholders is a priority. Due to the nature of the sector, climate change options in forestry will always require high standards with regards to implementation, monitoring and evaluation. Thus, high governance standards are an ultimate requirement. Unless robust and proactive steps are taken to clarify and strengthen the property rights and interests of rural and forest peoples, future climate change initiatives will benefit only a few, primarily wealthy elites, and reinforce existing economic and social disparities.

\section{NOTES}

1 The role of the IPCC is to assess on a comprehensive, objective, open and transparent basis the scientific, technical and socio-economic information relevant to understanding the 
risk of human-induced climate change, its potential impacts and options for adaptation and mitigation.

2 Afforestation and reforestation are understood in this chapter according to their definitions under the Kyoto Protocol in Dec. 11/CP:7.

3 Ibid.

4 Forest degradation is the reduction of the capacity of a forest to produce goods and services. 'Capacity' includes the maintenance of ecosystem structure, functions and carbon stocks.

5 The term 'permanent forest estate' is used for land, whether public or private, secured by law and kept under permanent forest cover. This includes land for the production of timber and other forest products, for the protection of soil and water, and for the conservation of biological diversity, as well as land intended to fulfil a combination of these functions.

6 The formal segment of the economy is the one regulated by the state, while activities in the informal sector do not follow these regulations or only partially (Esser, 1983).

7 Permanence relates to the period of time that carbon can stay in the biosphere. Due to different risks, including fires and pests, carbon can be released into the atmosphere, thereby reducing the climate change mitigation effect of a project.

8 There are many potential benefits of forestry activities aimed at adapting to and mitigating climate change. For this section, however, we focus on business-related benefits, especially payments.

9 During the 1980 and 1990s, these types of externally driven groupings have been presented to local people as the only means of accessing funding in the form of subsidies, gifts and legacies from politicians, the state or from international agencies. Numerous organizations have emerged with the sole purpose of capturing these external funds.

10 Unless it is recognized as something of public utility by presidential decree.

\section{REFERENCES}

Achard, F., A. S. Belward, H. D. Eva, S. Federici, D. Mollicone and F. Raes (2005) Accounting for Avoided Conversion of Intact and Non-Intact Forest; Technical Options and a Proposal for a Policy Tool, EU Joint Research Council, presented at COP11, Montreal, 1 December

Basnet-Parasai, R. (2007) 'Who owns carbon in community managed forest?', Paper presented to the Amsterdam Summer School, The Netherlands

Batterbury, S. P. J. and J. L. Fernando (2006) 'Rescaling governance and the impacts of political and environmental decentralization: An introduction', World Development, vol 34, pp1851-1863

Blaser, J. and C. Robledo (2007) Initial Analysis on the Mitigation Potential in the Forestry Sector, Report prepared for the Secretariat of the UNFCCC, August, http://unfccc.int/files/ cooperation_and_support/financial_mechanism/application/pdf/blaser.pdf

Chomitz, K., P. Buys, G. de Luca, T. S. Thomas and S. Wertz-Kanounnikoff (2007) At Loggerheads? Agricultural Expansion, Poverty Reduction, and Environment in the Tropical Forests, World Bank Publications, Washington, DC

Cogan, D. (2006) Corporate Governance and Climate Change: Making the Connection, Ceres Inc, Boston 
Esser, J. (1983) Migration und informeller Sektor am Beispiel Indonesien, Konstanz, Flagge, lngeborg Gaventa, J. (2005) Reflections on the Use of the Power Cube Approach for Analyzing the Spaces, Places and Dynamics of Civil Society Participation and Engagement, CFP Evaluation Series 2003-2006, no 4, MB Netwerk, The Hague.

FAO (United Nations Food and Agriculture Organization) (2007) Forest Tenure Assessment, http://www.fao.org/forestry/site/33848/en, accessed 1 October 2007

Forner, C., J. Blaser, F. Jotzo and C. Robledo (2006) 'Keeping the forest for the climate's sake: Avoiding deforestation in developing countries under the UNFCCC', Climate Policy, vol 6, no 3, pp275-294

Houghton, R. A. (2005) 'Aboveground forest biomass and the global carbon balance', Global Change Biology, vol 11, no 6, pp945-958

IPCC (Intergovernmental Panel on Climate Change) (2007a) Climate Change 2007: The Physical Science Basis, Contribution of Working Group I to the Fourth Assessment Report of the Intergovernmental Panel on Climate Change. Summary for Policymakers, Cambridge University Press, Cambridge

IPCC (2007b) Climate Change 2007: Climate Change Impacts, Adaptation and Vulnerability, Contribution of Working Group II to the Fourth Assessment Report of the Intergovernmental Panel on Climate Change. Summary for Policymakers, Cambridge University Press, Cambridge

IPCC (2007c) Climate Change 2007: Mitigation Options. Contribution of Working Group III to the Fourth Assessment Report of the Intergovernmental Panel on Climate Change. Chapter 9, Forestry, Cambridge University Press, Cambridge

Minkkinen K., R. Korhonen, I. Savolainen and J. Laine (2002) 'Carbon balance and radiative forcing of Finnish peatlands 1900-2100: The impact of forestry drainage', Global Change Biology, vol 8, no 8, pp785-799

Robledo, C. and J. Blaser (2008) Key Issues on Land Use, Land Use Change and Forestry (LULUCF) with an Emphasis on Developing Country Perspectives, United Nations Development Programme, Bureau for Development Policy, Environment and Energy Group, New York, NY

Robledo, C. and C. Forner (2005) Adaptation of Forest Ecosystems and the Forest Sector to Climate Change, Forest and Climate Change Working Paper 2, FAO, Rome

Robledo, C., M. Kanninen and L. Pedroni (2005) Tropical Forests and Adaptation to Climate Change: In Search of Synergies, CIFOR, Bogor, Indonesia

Robledo, C., J. Blaser, S. Byrne and K. Schmidt (2008). Climate Change and Governance in the Forest Sector: An Overview of the Issues on Forests and Climate Change with Specific Consideration of Sector Governance, Tenure and Access for Local Stakeholders, Rights and Resources Initiatives, RRI Publication, www.rightsandresources.org/publication_details.php?publicationID $=857$

RRI (2007) 'Transitions in forest tenure and governance: Drivers, Projected patterns and implications', www.rightsandresources.org/publication_details.php?publicationID=133

Sachs, W. (2007) Climate Change and Human Rights, WDEV Special Report 1/2007, European Briefings on Globalisation, North-South Relations and International Ecology, World Economy and Development, http://www.globalpolicy.org/socecon/envronmt/climate/ 2007/07climatehumanrights.pdf

Sathaye, J. A., W. Makundi, L. Dale, P. Chan and K. Andraskos (2007) 'GHG mitigation potential, costs and benefits in global forests: A dynamic partial equilibrium approach', The Energy Journal: Multi-Greenhouse Gas Mitigation and Climate Policy Special Issue, pp95-124

Soares-Filho, B. S., D. C. Nepstad, L. M. Curran, G. C. Cerqueira, R. A. Garcia, C. A. Ramos, E. Voll, A. McDonald, P. Lefebvre and P. Schlesinger (2006) 'Modelling conservation in the Amazon basin', Nature, vol 440, pp520-523 
Sohngen B. and R. Beach (2008) 'Avoided deforestation as a greenhouse gas mitigation tool: Economics issues for consideration', Journal of Environmental Quality, vol 37, pp1368-1375

Stern, N. (2006) The Economics of Climate Change: Stern Report, Cambridge University Press, Cambridge, UK, and New York, NY

Tavoni, M., B. Sohngen and V. Bosseti (2006) Forestry and the Carbon Market Response to Stabilize Climate, http://ideas.repec.org/p/fem/femwpa/2007.15.html

UNDP (United Nations Development Programme) (1997) Governance for Sustainable Development: A UNDP Policy Document, UNDP, New York

Winkler, H. (2008) Climate Change Mitigation Negotiations, with an Emphasis on Options for Developing Countries, United Nations Development Programme, Bureau for Development Policy, Environment and Energy Group, New York, NY 


\section{PART IV}

Conclusions 



\section{Forest Governance and Decentralization in Africa: Issues and Emerging Trendls}

Doris Capistrano

\section{DECENTRALIZATION, DEMOCRATIZATION AND GOVERNANCE REFORM}

There is broad consensus in international development and policy circles that decentralization and good governance are an inherent component of environmentally sustainable, pro-poor development. The trend since the 1980s and 1990s towards decentralization in many regions, including Africa, is in line with this thinking. The chapters in this volume provide insights and lessons from African countries on how decentralization and governance reform processes are unfolding and their impacts upon actors and stakeholders at different levels.

In its broad sense, decentralization involves the transfer of roles, responsibilities and power from a central authority or government to actors and institutions at lower levels in a political-administrative and territorial hierarchy. Most countries in the African region embarked on the path of decentralization in the late 1980s and early 1990s as part of structural adjustment programmes - largely under pressure from international donors and multilateral agencies, notably the World Bank and the International Monetary Fund (IMF). Decentralization was initially conceived of primarily as a means to downsize the state, particularly at the central/national level, in order to reduce budget deficits. Increased political space and a larger share in the benefits were to be provided to local governments and citizens, who were expected to take on expanded responsibilities and fill roles previously performed by central governments. This was accompanied by a discourse of participation and power-sharing with sub-national institutions and local communities. While this discourse has become increasingly nuanced (Colfer and Capistrano, 2005; Gluck et al, 2005; Ribot and Larson, 2005), it remains strongly instrumental in its approach to participation despite increased use of the language of empowerment and heightened appeals to principles of social justice and equity. 
By the late 1990s, discussions on decentralization were being framed largely in the context of a paradigm shift 'from government to governance' in which different stakeholders have rights, roles and responsibilities and together negotiate and define policy directions. Governance encompasses mechanisms, processes and institutions through which citizens and stakeholders articulate their interests, exercise their rights and obligations, and resolve conflicts. Framed in the context of governance, decentralization became increasingly associated with democratization; multistakeholder processes came to be viewed as manifestations of democracy in action. In decentralized forest and natural resources governance, citizenship and residency-based forms of belonging constitute the bases for democratic participation. Citizenship, whether based on blood rights or civil or territorial rights, is central to the exercise of democratic decision-making and resource allocation. In many African societies, the lineage or the clan (a group of lineages descending from a common and putative ancestor) is often the (de facto or invisible) decision-making unit on matters of land and natural resources, and thus important in determining rights to property and in realizing the benefits of citizenship (see Chapter 3 in this volume; Diaw, 2005).

Decentralization was advocated and promoted on the premise that if local authorities who have discretionary power over public resources represent and are accountable to the local population, their decisions will lead to more efficient and equitable outcomes than if central authorities make those decisions (Ribot, 2004). In theory, decentralized policy decisions and political processes grounded at the local level are expected to bring government closer to its constituents and give citizens more opportunities to participate in the day to day business of governance.

As rights holders, citizens have the right and the responsibility to participate while governments, as duty bearers, have an obligation to provide a basis for the fulfilment of civic rights and human rights, more generally, and to be responsive to citizens' concerns. These reciprocal rights and obligations, in turn, are expected to foster greater transparency, increased citizens' demand for accountability and increased responsiveness of governments to local needs, resulting in better public service delivery, more efficient and sustainable resource use, and improved governance overall. The enhanced collaboration among key stakeholders - local government, civil society and the private sector - anticipated to develop in due course, is also expected to be a driving force for development, innovation and further improvements in governance at different levels.

Where ties of blood and social obligation link rights holders and duty bearers, however, this pathway is not as straightforward and can be complicated. In the forest sector, citizens' and communities' incentives to demand accountability from the state may be low if direct benefits from state-owned forests are perceived to be low and if devolution of forest ownership to communities has not led to increased taxation. Low levels of accountability demanded by communities can serve as further disincentive for the state to pursue necessary governance reforms - especially if state budgetary dependence upon forests is high, levels of investment low and rates of return high (see Chapter 14, this volume). Moreover, in many countries, states do not serve as neutral arbiters among stakeholders, but are instead allied with powerful interest groups and thus are disinclined to respond to demands for accountability if it would hurt allied interests. 
Over the years the goal posts for decentralization have constantly shifted along with changes in development thinking and evolving ideals for the governance of environmental resources (Capistrano, 2008). Pre-existing complex social networks and customary institutions have also proven to be resilient and persistent in their influence. Not surprisingly, in practice, decentralization in Africa as in other regions has fallen far short of expectations. Indeed, to be effective, the process of decentralization requires time, persistent effort, consistent monitoring and course correction along the way.

Analyses of cases around the globe indicate that certain forms of decentralization have led to some improvements in livelihoods, resource use and the quality of decision-making under certain conditions. In many contexts, however, the effectiveness of decentralization and accompanying governance policy reforms has been undermined by a variety of factors. The most notable factors include conflicts between customary and formal law; inconsistencies within formal law and discrepancies between policy and practice; weaknesses in institutional capacity at different levels; lack of political commitment to implement decentralization and governance reforms despite enabling laws and policies; inadequate provision of needed financial and other resources; uncertainty due to the tendency of governments to recentralize control; unclear and insecure property rights to forest land and resources; rent-seeking, corruption and illegalities; and capture of the major share of benefits by dominant groups at the expense of other stakeholders (Manor, 1999; Ribot, 2004; Capistrano and Colfer, 2005; Colfer et al, 2008).

How decentralization and governance processes unfold in Africa and how they ultimately impact upon different stakeholder groups in society depend in no small measure on the nature of societal institutions and the historical antecedents that shaped them. The multiple scales and frames through which governance institutions operate, including customary forms of representation, authority and property rights, are important defining elements. Inevitably, similar reforms undertaken in different countries and contexts can have different trajectories, even while they may share some similar patterns and evolutionary pathways.

\section{DEGENTRALIZATION: DIVERSE FORMS, CONTESTED MEANINGS}

While there is broad agreement on the concept of decentralization in the abstract, what constitutes decentralization in practice remains a contentious issue. A number of authors have elaborated upon the nature of decentralization (e.g., political, administrative or financial) and upon distinctions between devolution, delegation and de-concentration (Edmunds and Wollenberg, 2003; Ferguson and Chandrasekharan, 2005; Larson, 2005; Ribot and Larson, 2005; Chapter 2, this volume).

Ribot (2004) argues in favour of democratic decentralization and distinguishes between democratic decentralization and community-based natural resource management (CBNRM). He defines democratic decentralization as the transfer of 
powers from central governments to elected (presumably representative and accountable) local governments in the name of local citizens. CBNRM is much broader and can take the form of decentralization. It pertains to interventions that engage 'communities' in projects through participatory processes. This distinction may be applied as well to community-based forest management (CBFM) and forms of community forestry (CF), a general term used to refer to a variety of models of community management of forest resources. In practice, implementers of CBNRM/CBFM/CF define the 'community' (e.g. as user groups, stakeholders, etc.) and their mode of representation in project implementation (e.g. through elected or appointed committees, stakeholder fora, etc.). In democratic decentralization, the 'community' is made up of all citizens under the jurisdiction of the local government and is arguably more inclusive. But the concept of 'local community' does not stand out as a readily identifiable entity with well-defined contours and stable internal regulations (see Chapter 4, this volume). It can also mask structural inequities in which certain groups dominate decision-making and capture a major share of benefits at the expense of other groups.

Diaw (in Chapter 3) points to numerous cases of de facto decentralization, 'space taking' or 'decentralization by default' through self-initiated efforts (as opposed to externally sponsored projects) of local communities to protect, restore and manage local forest resources. Unlike the relatively few celebrated cases of largely externally driven CF and CBFM, the many self-initiated cases of community forest management have been rendered invisible by dominant paradigms of decentralization and conservation that focus on power, territories and external forces as agents of change. The role, legitimacy and innovative potential of communities and local actors and their web of embedded institutions and informal networks to shape outcomes have been largely ignored. These cases, argues Diaw, demonstrate the capacity of local societies to conserve and manage their resources without employing the discourse and instrumental rationality of decentralization, conservation or democracy.

Conflict, especially violent resource-related conflict characterized by state absence or weakness, can also create conditions of de facto decentralization in which 'might is right' (de Koning et al, 2008). Post-conflict situations can be major opportunities for far-reaching governance reforms. For example, following the war in Liberia, the newly installed government initiated wide-ranging reforms to decentralize forest management through local community management and to address the systemic corruption, illegality and rent-seeking in the forest sector. The influx of international assistance for reconstruction and rehabilitation that often comes in the aftermath of conflict and return to peace can provide fragile, post-conflict states the needed funds and technical assistance to push through with reforms they could not otherwise undertake on their own (Kaimowitz, 2006; de Koning et al, 2008). For previously marginalized communities and stakeholders, this presents opportunities to access new resources and mobilize potential new allies to advocate for governance reforms in their favour. Diaw (Chapter 3) argues that in post-conflict societies, decentralization will be better off granting space for local agency rather than trying to over-define how local actors should organize.

Regardless of the understanding and practice of decentralization, there is a sense in the literature and at the Durban workshop that the participation of local 
communities in forest management is a positive trend and an important element of forest governance reform. Indeed, in Africa as in other regions, though policy and governance interventions may not necessarily be decentralized or democratic, there is a marked trend towards greater community engagement in forest management (see Chapter 2). A number of country cases presented in this volume illustrate this trend (Chapters 5, 6, 11 and 12 for Madagascar, Tanzania, Uganda and Zimbabwe). Whether and to what extent community participation provides benefits over the long term and whether it can be sustained still remains to be seen. Long-term improvement in governance and realization of sustained benefits require sufficient time and significant efforts to strengthen institutions and develop capacities at different levels. Some authors have noted, however, that some forms of CBNRM/CBFM/CF can end up circumventing the state, stalling state reforms and/or undermining local government institutions (see Chapters 4 and 10; Larson and Ribot, 2005). Externally supported decentralization projects tend to favour models based on voluntary community-based committees over elected local government authorities. Such models can create competing institutions for resource management at the local level, undermining progress towards legitimate forms of political representation and/or providing excuses for local government to evade its responsibilities and forestall needed reforms.

Alongside the trend towards greater community forest management is a trend towards further privatization of forest resources. The pressure for privatization has been especially pronounced during the past 15 years as environmental policy around the globe has relied increasingly on market mechanisms over regulations to influence the behaviour of key actors and stakeholders (Anderson et al, 2001). Both regulation and privatization are premised on the law enforcement ability of governments to uphold and enforce property rights (see Chapter 4). But while regulation depends upon the coercive influence of the state for enforcement, privatization relies on respect and enforcement of property rights by the state and society at large, and uses incentives to encourage sustainable resource use and management.

Authors differ on whether privatization can be considered a form of decentralization (Ferguson and Chandrasekharan, 2005; Ribot and Larson, 2005). Nevertheless, in some countries in Africa decentralization, in practice, has meant privatization of state-owned forest resources (see Chapter 10; Ribot and Larson, 2005). State-owned forest resources turned over to local governments or communities are often captured by powerful actors, essentially privatizing benefit flows intended for the collective. In Mali, for example, merchants and public servants sidelined by the move towards forest management by communities and local government effectively sabotaged policies to decentralize taxation of commercial fuelwood harvest and trade that could have increased communities' share of revenues. The merchants and their allies successfully lobbied to repeal the decree. This has led to the re-centralization of resource rents before any concrete benefits could be realized, re-established the dominance of allied merchants and public servants, and undermined local incentives for sustainable harvest (see Chapter 10).

Forest concessions awarded to private companies for logging and management remain the most common form of privatization in African forestry. The concession system is a legacy of the region's colonial history. The system has continued even after 
Table 19.1 Forest area under concessions (A) and under management by communities and indigenous groups $(B)$ in heavily forested countries of Africa (million hectares)

\begin{tabular}{lccc}
\hline Country & $\begin{array}{c}\text { Under concession } \\
\text { (million hectares) }\end{array}$ & $\begin{array}{c}\text { Under communities } \\
\text { (million hectares) }\end{array}$ & $\begin{array}{c}\text { Proportion of total under } \\
\text { community management }(B /(A+B))\end{array}$ \\
\hline Cameroon & 6.4 & 1.1 & 14.7 \\
CAR & 5.4 & 0.0 & 0.0 \\
Congo & 8.7 & 0.5 & 5.4 \\
DRC & 33.5 & 0.0 & 0.0 \\
Gabon & 18.9 & 0.0 & 0.0 \\
Mozambique & 4.6 & 2.0 & 30.3 \\
Tanzania & 0.6 & 3.6 & 857.1 \\
\hline
\end{tabular}

Source: calculated using data from Sunderlin et al (2008)

ex-colonies became independent, with more or less the same features, but with central governments assuming the role of their former colonizers. Significant areas of Africa's forests remain under concessions of various types (Karsenty, 2007; Sunderlin et al, 2008). Forest area under community and indigenous peoples' management is increasing, albeit slowly, especially in countries with policies supportive of community and joint forest management. But despite policies for decentralized forest governance, concessions rather than local communities continue to manage a major portion of the forest estate - particularly in the heavily forested countries in Central Africa (see Table 19.1). The rapid pace of expansion of industrial relative to community models of forest management suggests a bias towards land uses that maximize state revenue (German and Cerutti, 2009).

\section{LIVELIHOOD AND SUSTAINABILITY IMPACTS, REVENUE AND BENEFIT-SHARING}

The impacts of decentralization on livelihoods have been mixed. Under certain conditions, decentralization and devolution of rights can lead to improved livelihoods, particularly if it includes sharing of high-value resources, taxes/revenues and commercial opportunities; proactive efforts to meet the needs of different social groups; and effective cooperation among communities, local government, forest services and other key stakeholders (see Chapters 2 and 11; Randrianarisoa et al, 2008). However, the hoped-for impacts of decentralization and forest governance reforms on poverty alleviation have yet to materialize. Livelihood improvements also tend to accrue to relatively better-off communities and households. Jagger's (Chapter 5) systematic comparison of income changes before and after Uganda's 2003 forest-sector governance reform shows that wealthy rural households living in the Central Forest Reserve experienced large gains in income from forests, total household income and share of household income derived from forests. On the other 
hand, households in the lowest-income quartiles suffered moderate losses in forestderived income and significant losses in their share of household income from forests. Indeed, without the necessary institutional safeguards, livelihood improvements for some groups and households tend to be at the expense of other less endowed or powerful actors - or occur at the expense of long-term sustainability.

Decentralization can create perverse incentives and encourage corruption and rentseeking by forest law enforcement authorities, especially in areas with high-value resources. For example, decentralization of forest management responsibilities to local government and communities typically has not been accompanied by financial and other resources needed to support their expanded roles, leading to increased reliance on revenues generated from forest resources to finance operations. The incentive for local actors to intensify exploitation of forest resources runs counter to the expectation that decentralization will improve forest management and reduce deforestation. In the absence of strong governance mechanisms, especially for financial accountability and recourse to justice, and where power is concentrated within elite networks bound by relations of patronage, this can fuel competition, further entrench the pre-reform status quo and encourage corruption. Increases in community and household income can come about through illicit harvest and sale of forest products and rent capture (see Chapters 6 and 15). In Jagger's (Chapter 5) case study sites in Uganda, for example, the major portion of forest income came from sawn wood harvested and sold illegally. In these sites, law enforcement authorities also tended to focus disproportionately on the poorest households.

In Tanzania, village councils have management responsibility over land and natural resources and the power to make legally binding bylaws. Legal mechanisms also exist for villagers to become owners, managers or co-managers of forest resources. Despite these provisions to help ensure that almost all forest management benefits are captured at the community or group level, there is little evidence that the legal transfer of forests has been accompanied by significant economic returns at the local level. Available data in southern Tanzania suggest that CBFM, the form of participatory management with greatest potential for economic empowerment, yielded only modest incomes of between US $\$ 540$ to $\$ 720$ per village per year (see Chapter 6 ).

The availability of large areas of forests in Tanzania that could be brought under community management offers the potential for generating higher incomes and revenue streams. However, the propensity to transfer degraded forest and low-value resources to communities coupled with generalized institutional failures and weaknesses constrain the realization of this potential. The key constraints are similar to those faced by many other countries in Africa and around the globe. These include limited information and basic data needed for management (on forest condition, extent and sustainable harvest, etc.); lack of awareness of and appreciation for the economic value and revenue generation potential of forests; conflicting roles in forest management and revenue collection between central and local government authorities; widespread graft and corruption; illegal logging and trade; poorly resourced and uninformed local government staff; lack of awareness of rights and laws among forest-dependent communities; and communication gaps between actors, which undermine accountability (see Chapters 2, 3, 4, 5, 11, 13 and 14). 
Local and intermediate levels of government need adequate resources and a strong degree of financial autonomy to achieve effective decision-making and policy implementation. Likewise, decentralized units need to have the capacity to generate sufficient financial resources. As in other regions, initial decentralization initiatives in Africa have been strongly criticized for devolving responsibilities without transferring adequate power and resources with which to undertake devolved functions. The pressure on local governments to raise revenues for their operations can encourage overharvesting of forest resources (Larson, 2005; Barr et al, 2006; see Chapter 14).

While there is evidence of improvements in forest quality from community forest protection, fire control and regeneration following decentralized management in many places (see Chapters 5,6 and 11), there are also instances of increased deforestation and unsustainable forest exploitation following decentralization (Chapters 12 and 14). Decentralized forest management is not necessarily better than centralized management in terms of sustainability outcomes, especially if benefits and revenues from forests are not as attractive as alternative land-use options and local institutional capacity to regulate use is weak.

Fiscal reforms initiated in a number of countries in recent years have tended to incorporate provisions for improved forest revenue and benefit-sharing between central and lower levels of government and with communities. Apart from providing local governments and communities incentives for sustainable management and enhanced investment in forestry activities, such fiscal reforms are expected to increase efficiency and transparency in revenue and tax collection under decentralized forest governance (see Chapter 14; Oyono, 2006).

There are indications of some positive results from these tax and revenue sharing provisions. For example, efficiency of forest revenue collection increased substantially following the devolution of responsibility for revenue collection from district to village level in Tanzania's Iringa District (see Chapter 14). In many countries, using forestderived revenue, communities are increasingly investing in social infrastructure and services and venturing into community enterprises. The multiplier effects on the local economy of such investments tend to be significantly higher compared with investments of equal amounts by external actors (ITTO/RRI/Forest Trends, 2007). With devolution of revenue collection to the community or village level, however, questions about financial transparency and accountability of local actors and institutions are increasingly being raised. There are also concerns about leakages and increased corruption at the local level (see Box 18.1 in Chapter 18; Oyono, 2006). Evidence suggests that efforts to strengthen local governance must accompany fiscal decentralization for it to be effective.

Despite the trend towards greater benefit and revenue-sharing across Africa, serious impediments to communities realizing their due share remain. Burdensome bureaucratic procedures imposed on communities (e.g. approved management plans, permit requirements, etc.) generally entail high transaction costs with uncertain benefits. Forests transferred to communities for management still tend to be concentrated in degraded, low-value areas which require considerable effort to restore to a productive status, while states retain control of the most productive and valuable forests and forest resources. 
Insecure and unclear property rights over land and forest resources are a major source of uncertainty of benefit streams from decentralized forest management (Chapter 1; Sunderlin et al, 2008). Uncertain benefits can also be due to conflicts and political turmoil that grip parts of Africa from time to time (de Koning et al, 2008). In Zimbabwe, for example, the political crisis that has engulfed the country since 2000 has eroded institutional capacities and gains already achieved under programmes for CBNRM and co-management (see Chapter 11). Yet greater devolution is suggested as a means to enhance the resilience of forest management institutions, and thus forests, in times of political instability.

The reaction of powerful interest groups to decentralization and governance reforms can make the realization of potential benefits uncertain. Groups with entrenched interests often attempt to recapture devolved powers and push for a return to the pre-reform status quo. They also tend to develop new mechanisms and form alliances to maintain or enhance their positional advantage under the new regime. Under pressure from powerful vested interest groups who stand to lose from reforms, governments can suddenly reverse policies and wipe out potential benefits literally with the stroke of a pen. In Mali, for example, a decree on decentralization and revenue-sharing granted village communities between a 30 and 50 per cent share of revenues from different types of forest under their management. Before the decentralized units were operational and their rights established, a subsequent decree reduced their share to between 0 and 10 per cent (see Chapter 10).

Women and marginalized groups tend to be particularly disadvantaged in benefit sharing in Africa, as in other regions. Comparisons between Senegal and Cameroon show that women's access to resource management-related decision-making is very marginal (see Chapter 7). As a consequence, women's unique interests and concerns are not considered, restricting their access to forest resources and control over cash incomes. Ethnic minorities and marginalized populations such as the Pygmies of Central Africa also experience similar types of exclusion (see Chapter 16).

\section{TRADE AND INTERNATIONAL INFLUENGES ON LOCAL GOVERNANCE}

The changing pattern of forest products trade in Africa is transforming the landscape and reshaping the forest sector architecture in many countries (see Chapters 4, 13 and 17). At the same time that it introduces new ways of doing business and raises standards of behaviour expected of state and corporate actors, it threatens to undermine progress already achieved.

Africa's expanded trade and engagement in international and regional fora for international environmental governance also serve to promote increasing alignment of norms and standards in individual countries with those of the international community. Demand for greater transparency and changes in norms of behaviour from the international community - particularly Western donor countries but also, increasingly 
from neighbouring countries in Africa - are pressing governments to reform governance standards. The development of a multi-tiered, transnational civil society movement over the past two decades and its mobilization around forest-related issues has also brought new ideas and innovative approaches to the governance of forests within and beyond national boundaries. Civil society, often referred to as nongovernmental organizations (NGOs), involves citizens acting collectively in a public sphere to express their interests, achieve mutual goals and demand accountability from the state. The active involvement of indigenous peoples and grassroots-based federations in this increasingly global movement has focused attention on local people's rights as a critical element in sustainable forest use and management. Combined with pressure from below exerted by organized local communities and grassroots organizations, these pressures from the international community are pushing some governments in Africa to follow through on decentralization and to further improve their governance record. Governments are beginning to respond, albeit often reluctantly, to the challenges associated with climate change and forest-related corporate investment and trade, and to align with international norms of governance (see Chapters 15, 16 and 18).

Initiatives spearheaded by civil society organizations, donor governments and the private sector are not only evolving industry standards, but also contributing new tools, voluntary codes of conduct and more ethical principles for doing business. These initiatives have been spurred on both by progress in the development of concepts/principles in international environmental conventions and by frustration with the slow pace of negotiation and action in international forest forums and processes (Gluck et al, 2005).

Innovative instruments, including certification, have been designed to improve forest and forest-related governance in ways that complement regulatory approaches - in what has been described as 'governance without government'. These instruments generally rely instead on market incentives, voluntary self-regulation and third-party monitoring and verification, rather than on government regulation (Nussbaum and Simula, 1995; Gluck et al, 2005). They also build on progressive language from international treaties and conventions - such as Human Rights, the Convention on International Trade in Endangered Species of Wild Fauna and Flora (CITES), the Convention on Biological Diversity (CBD), the United Nations Framework Convention on Climate Change (UNFCCC), etc.; legally binding international agreements on special subjects (e.g. trade of tropical timber); and on non-legally binding instruments ('soft law') on forests to push for behavioural change among state and corporate entities.

Legislation and behavioural norms developing around the concept of free and prior informed consent (FPIC) is one example of such an instrument that could strengthen indigenous peoples' rights and control over local forest resources. Enshrined in the CBD, International Labour Organization (ILO) Convention 169 and the 2007 United Nations Declaration on the Rights of Indigenous Peoples (UNDRIP), FPIC pertains to all kinds of development activities affecting indigenous peoples' land and resources. In operational terms, FPIC means that local communities are given prior access to all relevant information pertaining to development activities affecting their land and resources and then consulted freely, without pressure or manipulation. After consultation and negotiations, they decide whether or not to give consent with a clear right to say 'no' (see Chapter 16). FPIC is a requirement for voluntary 
certification under the Forest Stewardship Council (FSC) label, and is obligatory for states that ratify CBD and ILO conventions.

Making FPIC a requirement for awarding forest concessions and other land-based investments on customary land can potentially improve corporate practices and reduce incidents of conflict and abuses commonly associated with the concession system and large-scale investment. Widespread application of the FPIC concept can strengthen the hand of indigenous peoples in their negotiations with state and corporate entities and help to promote more just and equitable outcomes from their dealings with more powerful stakeholders. But for it to be effective, it needs to be implemented in a manner that recognizes and deals with asymmetries in power between often marginalized indigenous peoples and those who seek their consent, and that treats consent as an active process rather than a decision taken at one point in time (in which the decision to 'opt out' remains a possibility as experience is acquired). Freeman et al (Chapter 16) recommend processes and actions that include ascertaining local customary rights; developing effective communication and information-sharing strategies; ensuring that a share of profits and taxes derived from forest exploitation are invested locally; protecting locally important forest resources against the negative impacts of timber exploitation and wildlife management; and giving customary rightsholders a clearly defined role in decision-making processes that concern the forests that they use. They also recommend specific steps that companies need to take to establish basic processes and mechanisms for FPIC to contribute to more sustainable and equitable forest management. These include hiring staff with appropriate skills, articulating and publicizing company policies, recognizing and respecting traditional rights of local populations, and developing an ongoing dialogue between local residents and timber companies based on mutual respect.

A mix of voluntary and regulatory instruments has also emerged to address pervasive corruption, illegal activity and criminality in the forest sector. With a great deal of encouragement from donors and international agencies, African countries are also increasingly cooperating to address common transboundary governance challenges, such as illegal logging and forest products trade, to promote more sustainable forest management in the region. Within the framework of Africa Forest Law Enforcement and Governance (AFLEG), countries have agreed on an action plan that emphasizes capacity-building; law enforcement and monitoring; attention to wildlife resources; forest management practices; mobilization of financial resources for forest-dependent communities to reduce illegal activities; promotion of cooperation between law enforcement agencies within and among countries; involvement of local communities in decision-making; and awareness-raising regarding the impact of illegal logging and associated trade. The action plan also calls for the implementation of AFLEG in harmony with the New Partnership for Africa's Development (NEPAD) and other regional processes (see Chapter 15).

These regionally focused initiatives are complemented by actions agreed by donor countries and trading partners, notably the European Union (EU). The EU Action Plan adopted by the European Council in 2005 sets out a range of measures to support improved governance and capacity-building in timber-producing countries; reduce the EU's consumption of illegally harvested timber; and discourage investments by EU institutions that contribute to illegal logging. The action plan also includes provisions 
for the development of voluntary partnership agreements (VPAs) with timberproducing countries to prevent illegally sourced timber from entering the EU market (see Chapter 15). These complementary initiatives are notable in their efforts to address both the supply and demand sides of illegal logging, trade and corruption and in their recognition of the intricate links between illegal forest products harvesting and trade, on one hand, and the subsistence and livelihoods of forest dependent communities and households, on the other.

Indeed, what constitutes 'legal' and 'illegal' remains a grey area, especially when laws and regulations are inconsistent, and when formal law is at odds with customary law and traditional practice. Onerous bureaucratic requirements and the high transaction costs associated with legal compliance often induce communities to operate outside the law, making customary forest uses technically illegal. In such contexts, more vigorous law enforcement can end up unfairly targeting and unjustly penalizing forestdependent communities, even while laws and regulations are applied more selectively and benignly in favour of logging companies and large forestry enterprises (Colchester et al, 2006). There is also a tendency to equate informal economic activities (i.e. those operating outside formal markets and, thus, outside formal regulatory authority) with illegality. Government economic policies can also be a major factor driving segments of the economy towards informality (see Chapter 13). Restricting international market access to 'legally' harvested timber can also discriminate against small- and mediumsized enterprises and poor timber-exporting countries that cannot afford or easily comply with the requirements imposed by legality and certification schemes (see Chapter 15; ITTO, 2002; ITTO/RRI/Forest Trends, 2007). In Ghana, for example, policies adopted in 1983 as part of the country's structural adjustment market liberalization reforms promoted an aggressive export-oriented expansion in forest products trade. This led to increased dualism in the forest sector, with a formal sector producing high-quality timber for export to generate foreign exchange revenues, and an informal sector producing largely for the domestic market, but also serving (illegally) as sub-contractors for the formal sector (see Chapter 13) - further marginalizing forest communities and leading to domestic lumber shortages.

Alongside the regional and international initiatives to address systemic weaknesses in forest-related governance, dynamic changes in the pattern of trade in Africa are creating new opportunities as well as threats to the progress already made towards decentralization and governance reforms. The threats are especially pronounced in the resource-rich countries of Central Africa. The emergence of China and India as economic and geopolitical power figures is manifest in Africa in the form of increased exports of raw materials and natural resources, particularly to China, and increased inflows of foreign direct investment in raw material-producing sectors. The 2006 China-Africa Summit attended by representatives of 48 African countries was accompanied by the signing of new commercial contracts worth US $\$ 1.9$ billion. By 2009, Chinese aid to Africa is expected to double and Chinese credit and grants to Africa are expected to grow to US $\$ 5$ billion. The Chinese offer African countries direct, condition-free financial assistance in exchange for guaranteed access to strategic resources (see Chapter 4). These flows of trade and investment are providing timber and natural resource-rich countries significant sources of finance outside of the traditional donors and multilateral development banks, which have been pushing 
for governance reforms and the adoption of Western standards of business practice as conditions for assistance. There are concerns that this would encourage countries to backtrack on governance reform commitments and unravel voluntary agreements already in place or under negotiation (Chapter 4). The costs and impacts of illegal logging and trade can be significant. In Tanzania, up to 96 per cent of potential revenue from forest royalties was found to be lost due to unreported and underreported harvest volumes. In 2003/2004 alone, this amounted to US\$58 million (see Chapter 14).

The mode of operation of (typically ethnically based) trading networks gaining ascendancy in Africa also raises questions about the effectiveness of new governance tools and even of conventional regulatory measures. These trading networks combine the efficiency and organizational capacities of Western corporate operations with flexible and adaptive strategies negotiated and coordinated 'within the family' of companies in the network, employing cooperation and competition as needed. Entities within the trading networks can be selective in their compliance with voluntary and regulatory requirements, depending upon the local context (see Chapter 17). The same company or family of companies operated by allied groups in a trading network can behave as exemplary corporate citizens in one context and flagrantly violate social and environmental standards in another. The nature of the competition, the strength or weakness of a host country's overall regulatory and governance instruments, and the capacity of local citizens to demand accountability and defend their rights all figure in the choice of strategy in a particular arena of operation.

Market-based incentives may have limited effectiveness in influencing corporate practices of companies within the network, particularly when they are integrated vertically and/or horizontally with other members of the network, when they monopolize specific markets, or when they rely on the network rather than on regular credit and capital markets to finance their operations. These business networks have demonstrated the ability to operate even in the most unstable and difficult conditions due to their flexibility and economic efficiency. While capitalizing on opportunities to minimize their costs or maximize profits, and thereby capable of inducing negative social and environmental costs in contexts of weak governance, this does not necessarily make them more predatory than traditional Western companies (see Chapter 17).

International initiatives for climate change mitigation and adaptation are also creating opportunities and challenges for African decentralization and governance reforms. With deforestation, forest degradation and other land-use changes accounting for approximately 20 per cent of annual greenhouse gas emissions worldwide, forests and how they are managed would have to be among the key elements of a comprehensive global response to climate change. Africa can potentially benefit from the evolving carbon market for afforestation/reforestation, while heavy initial investment, high levels of expertise needed and the requirement of clear property rights for investment make it very difficult for decentralized government bodies, smaller forest owners and forest communities to participate and realize the potential benefits from the evolving Clean Development Mechanism (CDM) market (see Chapter 18), the benefits of voluntary carbon markets are reaching local communities in some countries. A new financial instrument (the Forest Carbon 
Partnership Facility, or FCPF), launched by the World Bank with contributions from Norway and other countries, is also making available new resources (US\$500 million over a five-year period) for new public policies and deforestation reduction programmes in forest-rich developing countries.

Whether and to what extent this infusion of funds will benefit Africa, and how these will impact upon local communities, remains to be seen. What is clear, however, is that a reputation of poor governance and corruption can inhibit carbon sequestration finance and climate change-related investments from flowing into a country. It is also clear that secure and unambiguous property rights and tenure are essential for any market-based compensation mechanism, whether for carbon sequestration or other environmental services provision, to function (see Chapter 18). The necessity of large-scale geographic coverage, possibly spanning a number of districts or provinces, can be challenging if forest management is decentralized. There is concern that climate change mitigation initiatives could be used by governments to recentralize forest management and reconsider their commitments to decentralization, further marginalizing communities from resources upon which they depend (see Chapter 4). On the other hand, communities are well situated to deliver carbon sequestration and environmental services under payments for environmental services schemes if the contracts are negotiated with communities responsible for the protection and maintenance of these services.

\section{CONCLUSIONS}

The trajectory of decentralization and governance reform in Africa is similar in many respects to those unfolding in other developing regions. Decentralization still needs to be implemented fully as real sharing of power, authority and benefits have yet to happen in most countries. So far, the outcomes of this incomplete decentralization and associated governance reforms have been mixed and their impacts uneven. As a work in progress, it will require more time for the results to be apparent and fully understood. Effective monitoring systems to proactively identify barriers to success and to identify lessons and 'good practice' are essential in realizing the potential benefits of decentralization and other forest governance reforms.

As in other regions, there are many constraints and impediments to effective and equitable decentralization and forest governance reform in Africa. Recommendations for action formulated by participants in the Durban workshop to address some of the key issues are summarized in Box 19.1. Perhaps more so than in other regions, however, Africa has to grapple with more difficult challenges associated with widespread poverty, fragility of states and vulnerability to violent conflict, generalized weakness of state institutions, and lack of information and technical capacity. But Africa has a tremendous reserve of capacity not only to deal with difficult issues but also to innovate in the face of new challenges and unfolding opportunities. Much of this capacity resides in local institutions, social networks and in the hitherto invisible local actors generally sidelined in discussions of decentralization and governance reforms. It will be important to enable this capacity to be expressed, to flourish and to become integral to decision- and policy-making going forward. 


\section{Box 19.1 General recommendations from the Durban Workshop on Forest Governance and Decentralization in Africa}

Theme I: Decentralized forest management and livelihoods:

- Improve forest governance through the establishment of clear and enforceable rules on forest management and transfer of powers and responsibilities; third-party and self-monitoring systems; enhanced public debate over privatization; and strengthening of networks capable of influencing policy.

- Strengthen democracy by enhancing downward accountability of local authorities; mechanisms to counter-balance existing inequities; establishing mechanisms for managing conflict among stakeholders; and implementation of national and international policies on gender, minorities and indigenous groups.

- Strengthen capacity through civic education on rights and responsibilities of different actors; forestry research in social and natural sciences; enhanced public access to research findings; support to local technical, organizational and revenuegeneration skills; and mechanisms for regular communication between local communities and government.

- Ensure economic benefits to local people by enhancing incentives for sustainable management through stronger rights over lucrative resources (along with responsibilities to ensure that a minimum set of rules and standards for forest management and use are met); identification and removal of barriers to marketing and value addition; and through meaningful fiscal decentralization.

Theme II: Conservation, sustainable forest management and forest governance:

- Support democratic forest conservation and management initiatives by allocating meaningful resources for capacity-building of all actors; encouraging open fora for deliberation over natural resource management; and fostering an incremental shift by forest agencies from a regulatory to a support function.

- Allocate decision-making roles and responsibilities to the lowest appropriate level through improved support to a more strategically chosen set of priority conservation functions (and devolving others to customary forms of management); interpreting policy as a framework for action rather than as a detailed set of management prescriptions; and ensuring that decentralized functions receive adequate financial and human resources.

- Ensure that comprehensive monitoring and evaluation systems accompany governance innovations to monitor livelihood and environmental outcomes of these reforms and foster adaptive learning among concerned stakeholders.

- Consider the true value of forest and landscape goods and services in decisionmaking through adequate consideration of the full range of forest ecosystem goods and services and the interests and values attached to these by different stakeholders; explore innovative means to leverage science and multi-stakeholder cooperation to identify and govern trade-offs in multi-stakeholder forest landscapes; and support cross-sectoral checks and balances in the governance of environmental services. 
- Support and develop regional cooperation on shared resources and challenges to enable improved management of transboundary resources and support harmonization of policies so that governance successes in one country do not contribute to governance challenges in neighbouring countries.

\section{Theme III: International trade, finance and forest-sector governance reform}

- Improve outcomes of trade, investment and marketing by rethinking approaches to regulatory and incentive-based mechanisms for corporate behavioural reform; leveraging the potential of market-based instruments (certification, voluntary partnership agreements and Forest Law Enforcement, Governance and Trade processes) to support public policies; and the pursuit of holistic anti-corruption efforts with greater attention to high-level corruption and improved checks and balances (e.g. audit and accountability mechanisms).

- Improve equity in finance by supporting reinvestment of forest revenues into enhanced productive capacity and social welfare infrastructure; strengthening mechanisms for distributional equity associated with private-sector investments and market-based payments for forest ecosystem services; enhancing financial incentives for certification and corporate social and environmental responsibility; and improving upon national accounting systems so that the full value of forest goods and services is recognized.

- Support local communities' efforts to reduce capture of resources by local and external elites by clarifying and securing rights and tenure over forest land and resources; addressing the barriers to value capture by local communities; and ensuring that restrictions on rights associated with private-sector investments and environmental service provision are equitable (e.g. similar rules applied to all; customary rights honoured).

- Promote appropriate responses to climate change by fostering national-level dialogue among government agencies, the private sector and civil society in the development and adaptation of norms and standards that support concrete returns from carbon offsets to sustainable forest management and poverty alleviation; and supporting active participation of forest-sector actors in the development of the post2012 United Nations Framework Convention on Climate Change agenda to enhance benefits to local stakeholders directly involved in land use change and forest use.

\section{REFERENCES}

Anderson, T. L. and D. R. Leal (2001) Free Market Environmentalism, St. Martin's Press, New York, NY

Barr, C., I. A. P. Resosudarmo, A. Dermawan, J. F. McCarthy, M. Moeliono and B. Setiono (eds) (2006) Decentralization of Forest Administration in Indonesia: Implications for Forest Sustainability, Economic Development and Community Livelihoods, CIFOR, Bogor 
Capistrano, D. (2008) 'Decentralization and forest governance in Asia and the Pacific: Trends, lessons and continuing challenges', in C. J. P. Colfer, R. D. Dahal and D. Capistrano (eds) Lessons from Forest Decentralization: Money, Justice and the Quest for Good Governance in Asia-Pacific, Earthscan, London

Capistrano, D. and C. J. P. Colfer (2005) 'Decentralization: Issues, lessons and reflections', in C. J. P. Colfer and D. Capistrano (eds) The Politics of Decentralization: Forests, Power and People, Earthscan, London

Colchester, M. with M. Boscolo, A. Contreras-Hermosilla, F. Del Gato, J. Dempsey, G. Lescuyer, K. Obidzinski, D. Pommier, M. Richards, S. N. Sembiring, L. Tacconi, M. T. Vargas Rios and A. Wells (2006) Justice in the Forest: Rural Livelihoods and Forest Law Enforcement, CIFOR, Bogor Colfer, C. J. P. and D. Capistrano (eds) (2005) The Politics of Decentralization: Forests, Power and People, Earthscan, London

Colfer, C. J. P., R. D. Dahal and D. Capistrano (eds) (2008) Lessons from Forest Decentralization: Money, Justice and the Quest for Good Governance in Asia-Pacific, Earthscan, London

de Koning, R., D. Capistrano, Y. Yasmi and P. Cerrutti (2008) Forest-Related Conflict: Impacts, Links and Measures to Mitigate, Rights and Resources Initiative, Washington, DC

Diaw, M. C. (2005) 'Modern economic theory and the challenge of embedded tenure institutions: African attempts to reform local forest policies', in S. Kant and A. Berry (eds) Sustainability, Institutions and Natural Resources: Institutions for Sustainable Forest Management, Springer Verlag, The Netherlands

Edmunds, D. and E. Wollenberg (2003) Local Forest Management: The Impacts of Devolution Policies, Earthscan, London

Ferguson, I. and C. Chandrasekharan (2005) 'Paths and pitfalls of decentralization for sustainable management: experiences of the Asia Pacific region', in C. J. P. Colfer and D. Capistrano (eds) The Politics of Decentralization: Forests, Power and People, Earthscan, London German, L. and P. Cerutti (2009) 'A framework for evaluating the impacts of expanded trade and investment on forests: Customary rights and societal stakes', Paper presented at the Africa regional meeting of the International Association for the Study of the Commons, Cape Town, South Africa, 20-22 January 2009

Gluck, P., J. Rayner, B. Cashore, A. Agarwal, S. Bernstein, D. Capistrano, K. Hogl, B. M. Liss, C. McDermott, J. S. Maini, T. Oksanen, P. Ollonqvist, H. Pulzl, E. Rametsteiner and W. Pleschberger (2005) 'Changes in the governance of forests resources', in G. Mery, R. Alfaro, M. Kanninen and M. Lobovikov (eds) Forests in the Global Balance: Changing Paradigms, IUFRO World Series, vol 17, International Union of Forest Research Organizations, Helsinki

ITTO (International Tropical Timber Organization) (2002) Forest Certification: Pending Challenges for Tropical Timber, ITTO Technical Series no 19, ITTO, Yokohama

ITTO, RRI (Rights and Resources Initiative) and Forest Trends (2007) Community-Based Forest Enterprises: Their Status and Potential in Tropical Countries, ITTO Technical Series no 28, ITTO, Yokohama

Karsenty, A. (2007) Overview of Industrial Forest Concessions and Concession-Based Industry in Central and West Africa and Considerations of Alternatives, CIRAD and RRI, Montpellier and Washington, DC

Larson, A. (2005) 'Democratic decentralization in the forestry sector: Lessons learned from Africa, Asia and Latin America', in C. J. P. Colfer and D. Capistrano (eds) The Politics of Decentralization: Forests, Power and People, Earthscan, London 
Larson, A. and J. Ribot (2005) 'Democratic decentralization through a natural resource lens: An introduction', in J. C. Ribot and A. M. Larson (eds) Democratic Decentralisation through a Natural Resource Lens, Routledge, London and New York

Manor, J. (1999) 'User committees: A potentially damaging second wave of decentralization?', in J. C. Ribot and A. M. Larson (eds) Democratic Decentralisation through a Natural Resource Lens, Routledge, London and New York

Ribot, J. C. (2004) Waiting for Democracy: The Politics of Choice in Natural Resource Decentralization, World Resources Institute, Washington, DC

Ribot, J. C. and A. M. Larson (eds) (2005) Democratic Decentralisation through a Natural Resource Lens, Routledge, London and New York

Sunderlin, W., J. Hatcher and M. Liddle (2008) From Exclusion to Ownership? Challenges and Opportunities in Advancing Forest Tenure Reform, Rights and Resources Initiative, Washington, DC 
A/R CDM 360-5, 372-3

access rights $37,43,104,148$

see also rights to resources

accountability

committees 182-3

decentralization $7-8,10$

obstacles 35

outcomes 46, 222-3, 228

Southern Africa 218-19

democracy and 29, 49

financial 222-3, 227

governance reforms 380

Tanzanian trade 289, 292-4

actors, powers and accountability

framework 10

Ad Hoc Working Groups, UNFCCC 363

additionalities, PES programme 95

administrations and private interests $86-8$

administrative decentralization $\quad 8-9,30-1$, 34,58

advisory bodies 63

afforestation $\quad 208-11,358,360-5,372-3$

afforestation and reforestation $\mathrm{CDM}$

(A/R CDM) 360-5, 372-3

AFFs (annual forestry fees) 178

AFLEG (Africa Forest Law Enforcement and

Governance) 299-318, 389

AFR (annual forest revenues) 148

Africa Forest Law Enforcement and

Governance (AFLEG) 299-318, 389

agency concept 71

Agency for the Development of Household Energy and Rural Electrification

(AMADER) 199, 202

aid organisations $\quad 242-5$

alternate tenure and enterprise models (ATEMs) 310

AMADER (Agency for the Development of Household Energy and Rural

Electrification) 199, 202

annual forest revenues (AFR) 148

annual forestry fees (AFFs) 178

appreciation of assets 291-2
Arivonimamo, Madagascar 249-50, 252

articulation 32,41

Asia

'breakthrough' of interests 339

decentralization $3,6,61-2,65-7,126$

foreign direct investments $83-4$

market-based instruments 347

see also China; India

Asia Forest Partnership 4

Asia-Pacific region 6

assets

competition over 288, 291-2

governance reforms 104

association formation 367,371

assurance concept 11

at-source withholdings $\quad 168-70$

ATEMs (alternate tenure and enterprise models) $\quad 310$

Aubréville, A. 40

Australia 63-4, 66

authority of state 174,244

autonomy $80,90-1$

'avoided deforestation' 91-4

awareness-raising $\quad 138,306,309,327-9$

Bali Action Plan 363

Bali Declaration 81, 91, 93

Bantu peoples 320-1

Bara country, Madagascar 238-41, 253

Barrow, Edmund 12-13

barter system 342-3

baseline data for research 108

Bayart, J.-F. 89

benefit-sharing arrangements

biodiversity conservation 252

climate change and $\quad 366-9$

community marginalization $\quad 266-7$

decentralization impacts $\quad 384-7$

participatory forest management 129-30

biodiversity $\quad 60,213,234-58$

bioenergy projects $357-9,364$

biofuel plantations $\quad 357-9$ 
blood rights $57,67-9$

bottom-up approaches 253

'breakthrough' of Asian interests 339

bribery 289-90

budgetary allocation effects 106

Budongo Central Forest Reserve 104, 113-17

Bugoma forest site, Uganda 104, 110, 113-17

'bundle of rights' concept 11

'business-as-usual' deforestation scenario 91

business networks 335-53, 391

business participation 366,369

bylaws, Tanzania 128

\section{Cameroon}

business networks $345-6$

community forests $\quad 88-91,367-9$

decentralized forest management bodies 148-9

democratic decentralization 44

Dja and Mpomo Model Forest 145-6, 148-51, 153-4

environmental decentralizations 62

FLEGT processes 304, 311

free, prior and informed consent 322

marginalization of women 152-3, 155

park conservation 64

public administration 86

revenue decentralization $175-6,178$, $180-1,183-5$

tenure system 12

CAMPFIRE initiative, Zimbabwe $\quad 215,217$, 220-5, 225-31

capacity-building $\quad 306,312,371,392-3$

capacity limitations, Tanzania 135-6, 140, 293

Capistrano, D. 5-7

capitalism 269-71

CAR see Central African Republic

carbon balance, bioenergy 358

carbon credits $91,93,365$

carbon sinks 354

carbon trading 20

catchment management agencies

(CMAs) 209

causal mechanisms, trade 262-3

CBD (Convention on Biological

Diversity) 323
CBFM see community-based forest

management

CBFP see Congo Basin Forest Partnership

CBNRM see community-based natural

resource management

CCL see Fuelwood Unit

CDM see Clean Development Mechanism

CEB see Compagnie Equatoriale des Bois

Central Africa

'Great Games' 81, 93

law enforcement 390

revenue decentralization $\quad 174-90$

transboundary cooperation 307

see also individual countries

Central African Forest Commission

(COMIFAC) 301-2, 304, 307, 313

Central African Republic (CAR) 175, 178-9

Central America, PES programmes 95

centralism

Ghana 265, 268, 276

'Great Games' 96-7

historical context $\quad 57-8$

Zimbabwe 215-16

see also decentralization; government control

Center for International Forestry Research (CIFOR) 4

certification systems

business networks 342,347

FSC 20, 83-5, 322, 324

certified emission reductions (CERs) 365

CF (community forestry) 382-3

CFMAs (collaborative forest management agreements) $\quad 107-8$

CGRF (Forestry Licence Fee Management Committee) 149

chainsaw operators $271,275,278$

checks and balances, public institutions $86-7,96$

China

business networks 335-6, 339-48

devolution approach 3

economic growth 16

'Great Games' 80-3

local governance influence 390-1

Tanzanian trade $133,285-6$

CIFOR (Center for International Forestry

Research) 4 
CITES (Convention on International Trade in Endangered Species of Wild Fauna and Flora) 294

citizenship $31,68,187,200,380$

civil rights $57,67-9$

civil society $13,29,361-2,370-1,388$

see also non-governmental organizations clans 380

Clean Development Mechanism (CDM) 360-6, 372-3, 391

climate change $\quad 2,20,354-76,391-2,394$

clustering research methods 338

CMAs (catchment management agencies) 209

co-management programme, Zimbabwe

$215,217,220,222-30$

Colfer, C.J.P. $\quad 5,7$

collaborative forest management agreements (CFMAs) 107-8

colonial Africa

decentralization $\quad 33-4,37,58,263$

informal sector $\quad 268-9$

structural problems 263-4

COMIFAC see Central African Forest

Commission

commercial forestry $\quad 321-2$

see also business...

commitment

REDD mechanism 91

requirement for 96

committees

forestry fee management $\quad 181-3$

rural fuelwood markets 196,199

village-level RMCs 217, 220-1, 224, 227

ward-level 217, 221, 228

common initiative groups (GICs) 367

commons management, biodiversity 236-7

Communal Areas Management Programme

for Indigenous Resources see CAMPFIRE initiative

communal property $\quad 11-12$

communes

Madagascar 239

Mali 191-214

communication channels

FPIC concept $327-9$

Madagascar 251-2 communities

concept of $\quad 89-90$

definition 382

financial equity 394

governance reforms and $85-6$

Malagasy environment 234, 236-42, 247-8

marginalization 261-2, 266-8

participatory mapping 329

Tanzanian trade 284, 289, 295-6

transfer of revenue to $176-81,183$

types of $\quad 88-90$

wood-processing sector 277

Zimbabwean policy 229

community-based forest management

(CBFM) 126-43, 382-4, 385

community-based logic 89

community-based natural resource management (CBNRM) 14-15, 30, 32, 60

definitions 381-3

environmental decentralizations $\quad 61-3,66$

insights from 38-41

timber concessions 37

Zimbabwe 217-21, 229

community-based organizations 9

community forests

Cameroon $\quad 88-91,146,148-51$

climate change and $\quad 367-9$

cover/quality change indicators 117

community forestry (CF) 382-3

community rights $\quad 12-13$

community wildlife management (CWM)

$$
\text { 63-4 }
$$

Compagnie Equatoriale des Bois (CEB), Gabon $177,180,182-3$

comparative assessments, decentralization outcomes 215-33

competition

business networks $\quad 335,343-4,348,391$

Tanzanian trade $282-3,288,291-2$

complementarity-based interest groups 371

concession system $\quad 37,90,105,383-4,389$

configuration of transfer systems $\quad 176-80$

conflicts

de facto decentralization 382

of private sector interests 366

rural fuelwood markets 199,201 
Congo Basin 93, 96, 174-5, 319-34 see also Congo-Brazzaville; Democratic Republic of Congo

Congo Basin Forest Partnership (CBFP) 306-7, 313

Congo-Brazzaville

FPIC concept $\quad 320,322,325-6,328-9$ revenue decentralization 175,177 , 179

Congo River 161

consent concept 330-1

free, prior and informed 319-34, 388-9

models of consent $\quad 330$

need for consent $\quad 325-6$

conservation $14-15,56-78$

consent and 326-7

decentralization $32,43,45,56,60-1$

democratization of 393

historical context $57-60$

Madagascar 234-58

modern movement $\quad 58-60$

outcomes 239-40, 248-9

protected areas 2, 59, 239-40

Tanzanian CBFM 136-7

'conservation rents' $16,79-80,94-6$

control, levels of 193, 200, 202

see also centralism; government control

Convention on Biological Diversity (CBD) 323

Convention on International Trade in

Endangered Species of Wild Fauna and

Flora (CITES) 294

'conversational thread' see dialogues

cooperation

business networks $335,343-4,348,391$

community forests 367

regional 306-7, 394

coo-petition, networks $335,343-4,348$

cooptation 182

coordination, AFLEG process $306-7$, 312-13

corruption

business networks 345

decentralization impacts 385

moral corruption argument 198

Tanzanian trade 283, 289-90, 293-7

coupe system, Mali 193

COVAREF revenue $183-4$ cronyism 290

cross-cutting themes

climate change $363,371-2$

decentralization $7-17$

customary authorities 9

customary rights 12-13

Customs Service (OFIDA), DRC 168

CWM (community wildlife management) 63-4

DAEs (decentralized administrative entities) 163, 166-70

de facto decentralization 382

de facto rights 11

de jure rights 11

de-concentration $\quad 30-1,34$

see also administrative decentralization

decentralization $\quad 56-78,379-81$

asset competition 288

conservation and 56, 60-1

corruption opportunities 295

cross-cutting themes $7-17$

definitions $8,31-2,381-4$

devolution comparison 3

FLEG processes 311-12

forms of 101-258, 381-4

gender representation $\quad 144-59$

'Great Games' 96-7

historical context $33-4,57-60$

implementation

obstacles 35-40

principles/guidelines 5

Kenyan reforms 118-19

livelihoods impact 384-7,393

local/regional/global dialogues 1-26

monitoring systems $\quad 392-3$

outcomes and 38-47, 101-258

participatory forest management 126-30

revenue from forests $160-73,174-90$,

191-214, 230

structural problems 263

sub-Saharan Africa 1, 29-55

sustainability impacts $\quad 384-7$

wood-processing sector 277

decentralized administrative entities (DAEs)

163, 166-70

decision-making

climate change issues $\quad 370-2$

decentralization and 8,30 
democratization of 393

environmental 234-58

gendered participation $145-6$, 149-51

Interlaken workshop 1

Decree 422, Mali 197-8, 203-4

deforestation

budgetary allocation effects 106

climate change $355-7$

Congo Basin 93, 96

environmental performance indicators 245

FERN report 267

funding to reduce 91-4

poverty and 237

state rules 240

see also reducing emissions from deforestation and degradation

degradation of forests $81,91-4$

see also reducing emissions from deforestation and degradation

deliberative democracy 71

democracy

blood/civil rights and 67-9

conservation and 57,69-70

governance reforms and 379-81, 393

politics and $69-70$

democratic decentralization $\quad 1-2,17-18$

definitions $8,31,381-2$

gender and 155

local democracy $\quad 56-78$

revenue management $186-7,191,204$

sub-Saharan Africa 1, 29-55

democratic representation 31

Democratic Republic of Congo (DRC)

160-73, 175, 320-2

see also Congo Basin

demographics, Madagascar 238

dependence on forests $288,292,355-6$

development-conservation separation 65

devolution 3

definition 8

historical context 58

natural resource management 7

participatory forest management 126-9

tenure system 12-13

see also decentralization

DFOs (district forest officers) 113

DFS (District Forestry Service), Uganda 106-7
DGRAD see Direction Générale des Recettes Administratives, Domaniales et de Participation

Dialakoto rural community, Senegal 145-6, $149,152-4$

dialogues

framing $27-100$

local/regional/global 1-26

difference-in-difference (DID) method 110-12

Direction Générale des Recettes

Administratives, Domaniales et de

Participation (DGRAD), DRC 167-8

discretionary powers 49, 203

district councils

Tanzania 135-6

Zimbabwe 220-1, 228

district forest officers (DFOs) 113

District Forestry Service (DFS), Uganda 106-7

Dja and Mpomo Model Forest (FOMOD), Cameroon 145-6, 148-51, 153-4

Domestic Energy Strategy (SED), Mali 194-8, 201-2

domestic trade, Ghana 268-76

domestication of women $\quad 149-50$

donor strategies

Madagascar 242-6

Mali 193-4

downward accountability $7,10,46$

DRC see Democratic Republic of Congo

duration concept, 'bundle of rights' 11

Durban Vision, Madagascar 243

Durban workshop 2, 7, 392-4

dynamic relationships, Madagascar 234, 236-7, 239, 242-52

eco-certification 342,347

eco-guard approach, Congo Basin 326

eco-tourism 230

ecology

decentralization outcomes 44-6

minimum standards approach 48

political uncertainty and 222

economic growth effects 16-17

economic implications

biodiversity conservation 235, 237

blood/civil rights 68

capitalism 269-71

Central African forests 175 
climate change $\quad 355-6$

community-based forest management 126-43

decentralization $\quad 183,393$

DRC forestry position $161-2,166-8$, $170-1$

gendered representation 154

Ghana's forest sector 264-6

market liberalization $\quad 295-6$

plantation forestry $208-9$

social-business networks 339-42

see also finance

economic incentives see incentives

economic instruments 79-100

economic interest groups (GIEs) 367

Economic Recovery Programmes (ERPs) 261-2, 264-6, 271-7

economic reforms, DRC 162-3

see also fiscal reforms

Economic Structural Adjustment

Programmes (ESAPs) 216

ecosystem services $355,365-6$

'efficient relay' trade hypothesis 341-3

electoral democracy $61,70,155$

see also democracy

elephant poaching 226

elite groups

community marginalization 267

decentralization benefits 9

economic growth effects 16

governance reforms and 19, 61-2

'Great Games' 97

empowerment $\quad 370-1$

enfranchisement 37

environmental decentralizations $\quad 61-3,65-7$

environmental decision-making, Madagascar 234-58

environmental governance

consent and 326-7

'Great Games' 82-5, 96

infrastructure assessments 49

environmental performance

business networks $345-7$

decentralized NRM 215

national-level conservation $\quad 245-6$

plantation forestry 212

equity $19,30,394$

ERPs see Economic Recovery Programmes

ESAPs (Economic Structural Adjustment

Programmes) 216
EU (European Union) 299-318, 389-90

Europe-Africa capitalist relations 269

European Union (EU)

Action Plan 389-90

FLEGT process 299-318

exchange system, Ghana 269-70

executive committee, fuelwood markets 196, 199

exploitation dynamics

Cameroon 367-9

Congo Basin 321-2

Malian forests 193

export trade

Central Africa 175

Democratic Republic of Congo 163, 165

Ghana 261-2, 265-6, 271-6

Tanzania 288

tropical Africa 299-318, 336-7

see also trade

external accountability $\quad 293-4$

FAFs see forest area fees

FAO see Food and Agriculture Organization

farming groups, Congo Basin 321, 324, 327

favouritism in trade 290

FCPF (Forest Carbon Partnership Facility) 93, 391-2

FDIs (foreign direct investments) 83-4

felling taxes 178-9

FERN (Forests and European Union

Resource Network) 264, 266-7, 269

FID (Forestry Inspection Division), Uganda 106

fiduciary contracts $\quad 289,292-3$

field research, networks 338

finance

CAMPFIRE benefits 222-3, 227

FLEG processes $\quad 310-11$

governance reform $\quad 16-17$

management (Zimbabwe) 222-3, 227

REDD mechanism $79,81,91-4,97$

trade and 259-378, 394

see also economic...

financial accountability 222-3, 228

fines, PFM 130

firm networks 338,341

fiscal decentralization 8,18

fiscal reforms

benefit-sharing 386

Central Africa $176-80$ 
Democratic Republic of Congo 162-3 see also economic reforms

FLEG see Forest Law Enforcement and Governance

FLEGT see Forest Law Enforcement, Governance and Trade

flexible networks $347-8$

flexible specialization research 338, 341

FOB (free-on-board value) 163

follow-up data for research 108-10

FOMOD see Dja and Mpomo Model Forest

Food and Agriculture Organization (FAO) $12,300,308,312-13$

Fordism 348

see also post-Fordism

'foreign demand relay' hypothesis 341-3

foreign direct investments (FDIs) 83-4

forest area fees (FAFs) 166, 175

allocation of $166-8,170-1,184$

collection of 170

revenue from $163-4$

systems for sharing $178-80$

transfers 161, 163, 166, 169-70

Forest Carbon Partnership Facility (FCPF) 93, 391-2

Forest Code

Democratic Republic of Congo 160, 166, 168-9

Mali, 1986193

forest cover change indicators $114-15,117$

forest-dependent people $\quad 288,292,355-6$

forest industry

Democratic Republic of Congo 163-5

Ghana 263-6

Forest Law Enforcement and Governance (FLEG) 19, 138, 299-300, 305-6, 308-14

Forest Law Enforcement, Governance and Trade (FLEGT) 299-318, 347

forest management see decentralization

forest quality change indicators 114 , 116-17

Forest Sector Umbrella Programme (FSUP) 106

Forest Stewardship Council (FSC) certification system $\quad 20,83-5$, 322,324

free, prior and informed consent 319-20, $322,324-7$

forest tenure see tenure system foresters

historical context 33

local democracy role 48

rent-seeking 37

Forestry Inspection Division (FID), Uganda 106

Forestry Licence Fee Management

Committee (CGRF) 149

Forests and European Union Resource

Network (FERN) 264, 266-7, 269

formal sector 269-75, 277, 390

free-on-board (FOB) value 163

free, prior and informed consent (FPIC) 319-34, 388-9

French-influenced Madagascar 235

FSC see Forest Stewardship Council

FSUP (Forest Sector Umbrella Programme) 106

fuelwood markets 191-214

Fuelwood Unit (CCL), Mali 193, 195, 197-9, 201-2

fugitive power 67,70

funding see economic...; finance

G8 (Group of Eight) nations 299-300

Gabon

business networks 343

FPIC concept 320, 329-30

revenue decentralization $175,177,180$, 182-3, 185

Gambia 66

GELOSE experiments, Madagascar 250, 252

gender

benefit-sharing and 387

representation $42,144-59$

gender committee, Dialakoto 149-50, 152

general meetings, fuelwood markets 195-6

geographic factors, autonomy $90-1$

geopolitical trade flows $81-2$

Ghana 261-81, 311, 390

GHG (greenhouse gas emissions) 354-7, 359

GICs (common initiative groups) 367

GIEs (economic interest groups) 367

global commons, biodiversity as 236-7

global dialogues $1-26$

governance concept

AFLEG process 305, 309, 311-12

climate change and 361-2, 373

democratization/decentralization 380 
governance reforms $\quad 16-17$

Central Africa 174-90

decentralization and $1-2,10,61-3$, 379-81, 392-3

Democratic Republic of Congo 160-73

democratization $\quad 379-81,393$

elite groups 18

environmental decentralizations 61-3

finance and 259-378, 394

flexible networks 348

future of $79-100$

Mali 191-214

process/implementation $106-8$

Tanzanian trade $284,287-90$

Uganda 103-25

governance shortfalls, Tanzania $134,138-40$

government control

benefit-sharing 387

business networks versus 345

decentralized forest management 9,34 , $42-4$

environmental decision-making 253

informal sector and 270

privatization and 383-4

revenue decentralization $178-80,193-4$, 198

sustainable forest management 14

Tanzanian forests 131

see also centralism; state...

grassroots organizations 388

'Great Games' 18, 79-100

greenhouse gas (GHG) emissions $\quad 354-7,359$

Group of Eight (G8) nations 299-300

Guatemala 44

guided forests, Mali 193, 200, 202

hardwood trade, Tanzania $\quad 282-98$

harvesting activities

gender and 154

revenue from $163,165,200$

Tanzania $134,136-8,290,296$

'heartland' of conservation $\quad 58-60$

Heavily Indebted Poor Countries (HIPC)

Initiative 82

historical context

biodiversity conservation $\quad 235-6$

conservation $57-60$

decentralization $\quad 33-4,57-60$

'Great Games' 80

Zimbabwean politics 216-17
Hoima district, western Uganda 104, 113

holistic anti-corruption measures 294-5, 297

holistic societies 89

horizontal accountability 293

house allocation, Gabon 184

household studies, Uganda 108-17

hunter-gatherer groups, Congo Basin 321, 324,327

hunting zones $181,183,326$

ICDPs see integrated conservation and development projects

identity-based claims, fuelwood markets 200

IFIA (Inter-African Forest Industry Association) 84

IFIs see international financial institutions

IFM (independent forest monitoring) 138

IIED see International Institute for Environment and Development

illegal forest activities

decentralization and 385-6

definitions 309

law enforcement processes 299-318

regulatory tools $389-90$

Tanzania 134, 136-8, 290, 296

Zimbabwe 225-6

IMF see International Monetary Fund

incentives

CAMPFIRE initiative $\quad$ 222-3, 227, 229

community-based forest management 135-6, 139-40

decentralization impacts 42,385

sustainable forest management 19

Tanzanian trade 282, 288, 296-7

tenure system 11-12, 14

income

alternative sources 292

community forests $367-9$

management of 368

measures 110-13

village-level $\quad 132-3$

see also livelihoods; revenue from forests

incorporation 37

independent forest monitoring (IFM) 138

independent observation (IO) 86-7

India

business networks $335-6,340-4,348$

devolution approach 3

environmental governance 66-7 
'Great Games' 81-3

local governance influence 390

space-making case 71

indigenous forest peoples

Congo Basin 320-1, 323-6

privatization and 384

rights of $323-5,388-9$

see also pygmy groups

indigenous protected areas (IPAs) 66

Indonesia 3-4

industrial concessions $\quad 90$

industrial organization $\quad 335-53$

informal sector $268-78,310,366,390$

information access mechanisms $170-1$

information flow, networks 343

informed consent $\quad 322,324,327-9$

see also free, prior and informed consent

infrastructure

assessments 49

conservation and $69-70$

institutional choice, definition 31

institutions

biodiversity conservation $\quad 235,237,246-8$, 252-3

checks and balances $86-7,96$

community forests 88,367

consent principles $325-7$

democratic decentralization $29-30,41-3$

environmental governance 83

governance reforms 381

political uncertainty 222,228

revenue decentralization $181-5,194,200$

Tanzania 134

integrated conservation and development projects (ICDPs) 61, 63-5

integrated rural development (IRD) 47

integrity of resource areas 222-5

Inter-African Forest Industry Association (IFIA) 84

interest groups $367,371,387$

interests, conservation $\quad 244-5,248-9$

intergenerational conflicts 199

intergenerational networks 335-53

Intergovernmental Panel on Climate Change (IPCC) 357-8

Interlaken workshop $1,4-7$

intermediation, networks 344

international agreements

climate change $362-3$ trade 388

see also individual agreements

international financial institutions (IFIs)

81,87

International Institute for Environment and

Development (IIED) 212

International Model Forest Network 71

International Monetary Fund (IMF)

216-17, 261, 264-5

international politics $81-2$

international trade 259-378

Ghana 261-81

governance reforms 16-17, 394

local governance influence $387-92$

tropical logs 336-7

International Tropical Timber Organization (ITTO) 300, 308, 312

interviews, research 239, 338

investment arrangements 295

see also trade

IO (independent observation) $\quad 86-7$

IPAs (indigenous protected areas) 66

IPCC (Intergovernmental Panel on Climate Change) $\quad 357-8$

IRD (integrated rural development) 47

Italian networks $335-6,341-8$

ITTO see International Tropical Timber Organization

joint forest management (JFM) 63, 66, $128-9,384$

Kenya 118-19

Kibaale district, western Uganda 104, 113

Kilwa district, eastern Tanzania 135

kinship reputation 344

knowledge creation, FLEG 306

knowledge-sharing 370-1

Kyoto Protocol 360-1

LAACs (Licence Assessment Advisory

Committees) 209

land tenure see tenure system

land-use changes $\quad 355-6,360$

land use, land-use change and forestry

(LULUCF) 360

land-use rights $364-5$

see also property rights; tenure system

landscape management 2 
Latin America $\quad 44,57-8,61-6$

law enforcement, trade 299-318, 346-7, 389-90

see also legislation

leadership role, corruption 294

Lebanese networks $\quad 335-6,340-8$

legal compliance, Tanzania 287-8

legality concept $305,309-10,390$

legislation

consent principles $325-7$

FPIC concept 388

gender and 147, 152

Madagascar 239-40

Mali 191-2, 194, 203-4

Tanzania 128, 131, 284, 287-8

see also individual laws; law enforcement

legislative democracy 46

legitimacy

commune authorities 200

power and 67,70

liberal reforms 191

see also governance reforms

liberalized markets $\quad 295-6$

Libreville workshop 301-2, 307

Licence Assessment Advisory Committees

(LAACs) 209

licensing systems $\quad 303-4$

line ministries' role $30,32,34-5$

lineages 380

literacy levels, consent and 328

literature review 104-6

livelihoods

climate change impacts $\quad 355-6$

decentralization and $8-10,18-19,40-1$, 44-5, 384-7, 393

international trade and 261-81

outcomes 110-13, 219

Uganda 103-25

wage levels 48

livestock rearing 230

loan programmes, Ghana 264-5

local agency

space-making 71

space-taking 17

local benefits, CBFM 134-6

local collectivities 147

local communities

definition problems 89,382

Zimbabwean policy 229

see also communities local democracy $\quad 46-9,56-78$

local dialogues 1-26

local governance concept $60-1$, 387-92

local government

community-based forest management 383

decentralization and $61,385-6$

incentive systems $\quad 139-40$

revenue management $174,176-80$, 191-214

Tanzania 135-6, 292-3

see also democratic decentralization

local institutions 29-30, 42-3

see also institutions

local knowledge value $\quad 370$

local livelihoods see livelihoods

local-level conservation 236-7, 247-52

see also communities

$\log$ exports

business networks 336-7

Central Africa 175

Democratic Republic of Congo 165

Ghana 261, 266, 271

logging permits $175-7$

long-term vision, Tanzania 295, 297

low-income communities/individuals, definition 363

LULUCF (land use, land-use change and forestry) 360

lumber

exports 261-2, 265, 271, 274-5

shortages 268-76

Madagascar 234-58

Malagasy state $\quad$ 235-6, 240, 242

Mali

democratic decentralization $\quad 35-6$

environmental decentralizations 62

privatized resources 383

revenue-sharing 387

Siby rural commune 191-214

management plans

biodiversity conservation 252

business networks 342,346

decentralization obstacles $35-6$

REDD mechanism 93-4

management practices, climate change and 358-9

mapping process, consent 329 
marginalization

forest communities $\quad 261-2,266-8$

Siby rural commune $197-200$

women $144,149-53,155,387$

market-based instruments $346-7,391$

market forces, decentralization 37,42

market liberalization $\quad 295-6$

market structure

fuelwood markets 191-214

wood-processing sector 271-6

merchant-SCN-CCL lobby, Mali 197, 202

Merikanjaka, Madagascar 249-50, 252

metonymical programmes 265

minimum standards approach 48

Ministry of Natural Resources and Tourism

(MNRT), Tanzania 293, 295

miombo woodlands, Tanzania 131-2

mitigation of climate change $354,357-60$, 372-3, 391-2

international agreements $\quad 362-3$

private sector 366

public sector 364

MNRT see Ministry of Natural Resources and Tourism

money laundering activities 202

monitoring systems, decentralization $\quad 392-3$

montane forests, Tanzania 131

moral corruption argument 198

Mozambique 44, 218-19

Muir, John 59

multi-stakeholder forests $\quad 207-8$

municipal councils $\quad 150-1$

see also local government

mutual understanding, consent 330-1

nation states 68

national economy, DRC 161-2

National Environmental Action Plan (NEAP), Madagascar 235-6, 243-4, 246

National Forest Programme (NFP) 313

National Forestry Authority (NFA), Uganda 106-8, 113

National Forestry and Tree Planting Act 106-7

national-level governance, Tanzania 138

see also governance...; government control; state...

national-level initiatives

climate change $363-4$
Madagascar 234, 236-7, 239, 242-8, 251-2

Tanzanian trade 295

trade law enforcement $\quad 307-8$

national parks 58-9

see also park conservation

natural resource management (NRM)

decentralization $30,126,215-18$

devolution of 7

gender and 146-50

local governance 61

see also community-based natural resource management

natural resources, Tanzania 283

natural wilderness conservation $\quad 58-60$

Nature Conservation Service (SCN), Mali 197-8, 201-2

NEAP see National Environmental Action Plan

negotiation process

access rights 37,43

consent and 330

nepotism 290

The Netherlands 312-13

networks 335-53, 381, 391

New Partnership for Africa's Development (NEPAD) 389

NFA see National Forestry Authority, Uganda

NFP (National Forest Programme) 313

NGOs see non-governmental organizations

Niger 193-4, 198

Niokolo Koba Park, Senegal 146, 154

non-equivalent comparison groups

108-10

non-governmental organizations (NGOs) $82,138,216,388$

see also civil society

non-quota use, Zimbabwe $\quad$ 222-3, 225-7

non-timber forest products (NTFPs) 225, 228

North-South trade $336,347-8$

NRM see natural resource management

NTFPs see non-timber forest products

obfuscation 37

OFIDA (Customs Service), DRC 168

open-access tenure 12

opportunity creation, Tanzania 283-5, 291, 293-6 
organizational structures

community forests 367

Southern Africa 218-19

outcomes

conservation 239-40, 248-9

decentralization and $38-47,101-258$

livelihoods $110-13,219$

policies 242-5

sustainability $113-17$

overcapacity, sawmills 275

ownership claims, fuelwood markets 200

PAC (problem animal control) 230

parafiscal system $176-8$

park conservation $\quad 58-9,63-5$

participatory approaches $\quad 36-7$

business matters 366,369

civil society 370

Democratic Republic of Congo 170-1

gendered 144-59

historical context 34

mapping consent $\quad 329$

rural fuelwood markets 191-2, 194

participatory forest management (PFM)

126-30, 137, 284, 292-3, 296

see also community-based forest

management

partnerships

Congo Basin Forest Partnership 306-7

decentralization outcomes 216

voluntary agreements $303-4,309,311$, 314,390

patronage system 134, 138

payment mechanism, REDD 93

payments for environmental services (PES) $85,94-5$

people-centred corruption solutions 294

permits

community forests 88

logging operations $\quad 175-7$

perverse incentives 282, 288, 296, 385

PES (payments for environmental services) $85,94-5$

petty corruption $\quad 289-90$

PFM see participatory forest management

Philippines workshop 3

plantation forestry

biofuels 357-9

South Africa 208-10
PNDC (Provisional National Defence

Council), Ghana 264-6

poaching activities, Zimbabwe $\quad 225-6$

policy implications

business networks $346-8$

environmental decision-making 234, 242-6, 248-52

rural fuelwood markets 193-4

Tanzanian CBFM 137-9

Ugandan governance reforms $\quad 117-18$

water use 208-14

Zimbabwean politics 215-33

policy recommendations

Ghana 275-8

Tanzania 291-6

Zimbabwe 230-1

political connectedness 105

political decentralization see democratic decentralization

political parties, Mali 192,200

political systems

blood/civil rights $\quad 67-9$

conservation/democracy $\quad 69-70$

democratic decentralization 47

international influences 81-2

Latin America $57-8$

tax transfers $\quad 168-9$

women's marginalization $\quad 151-3,155$

Zimbabwe 215-33

post-Fordism 338, 341

see also Fordism

poverty

climate change and 357,362

deforestation and 237

Tanzania 132, 296

powers

actors/accountability and 10

civil society $\quad 370-1$

consent and 330

democratic decentralization $34-5,41,46$, $67-70$

discretionary 49, 203

gender differences 144-5, 147, 149-51

local communities 230

participatory forest management 129

revenue decentralization $191,203-4$

transfer of 218-19

'predator' hypothesis, business networks

337, 341-3

primary data research 263 
prior consent 322

see also free, prior and informed consent private property

definition 11

open-access situations 12

private sector

climate change issues $\quad 361-2,366-9$

institutional decentralization 29

interests, administrations and $86-8$

Zimbabwean partnerships 216

privatization $36-7,383-4$

public control functions $87-8$

rural fuelwood markets 192, 194

problem animal control (PAC) 230

production structure, wood-processing 271-7

profits redistribution, DRC $\quad 160-73$

project eligibility, revenue allocation 182

property rights $10-13,63,104-5,387$

see also tenure system

protected area conservation $2,59,239-40$

Provisional National Defence Council

(PNDC), Ghana 264-6

public control privatization $87-8$

public domain definition 31

public institutions

'conservation rents' 96

democratic decentralization 29

private interests and $86-8$

see also public sector

public property

definition 10-11

open-access situations 12

public sector

climate change issues $\quad 361-6$

environmental governance 83

see also public institutions

pygmy groups $175,183-4,319-22,327$

quality of forests indicators $114,116-17$

quasi-experimental research designs 104, 108-10

random sampling methods $\quad 108-9$

RC see Republic of Congo

RDCs see rural district councils

recognition, definition 31

REDD see reducing emissions from

deforestation and degradation redistribution, tax revenue $\quad 197-9$

reducing emissions from deforestation and degradation (REDD) 2, 359, 364, 372

ecosystem services $365-6$

funding $79,81,91-4,97$

institution-building 367

negative effects 17,85

reforestation

climate change and 358

taxes 178-9

reforms see governance reforms

regional cooperation 306-7, 394

regional dialogues $1-26$

regression results, livelihood outcomes

110-13

regulatory tools

flexible networks 348

illegal forest activities $\quad 389-90$

rent-seeking 37

representation

decentralization obstacles 35

definition 31

democratic decentralization $30,42,46$, 49

gendered 144-59

Republic of Congo (RC)

FPIC concept $320,322,325-6,328-9$

revenue decentralization $175,177,179$

see also Congo Basin

reputation, business networks 343-4, 348

research context, DRC 161

research methods

biodiversity conservation 238-9

business networks $337-9,341$

CAMPFIRE initiative 221-3

free, prior and informed consent 323-31

governance reforms $\quad 108-10$

international trade $262-3$

water-use impacts 211-14

resource management committees (RMCs)

217, 220-1, 224, 227

resource transformations, Tanzania 282, 285

responsibilities

climate change mitigation 369

FSC tenure criteria 324

participatory forest management 129

social responsibility 277

responsiveness, local democracy $\quad 46,49$ 
restoration of forests $\quad 136-7,359-60$ retail operations, Tanzania 282, 286 revenue from forests community marginalization 267 decentralization 160-73, 174-90, 191-214, 231, 384-7

Tanzanian trade 287, 293 see also income

Rights and Resources Initiative (RRI) 310 rights to resources blood/civil rights $57,67-9$ climate change and $362,364-6,373-4$ community-based forest management $129,136,138-9$

ecosystem services $365-6$ environmental decentralizations 63 gender and 149 governance reforms 104-5 indigenous forest peoples $323-5,388-9$ international trade and $387-9$ local dialogues 3 tenure system $\quad 10-13$

RMCs see resource management committees RMNP (Rwenzori Mountains National Park) 104, 114-16

routing operations, Tanzania $\quad 282,285-6$ royalties 130,267

see also revenue from forests

RRI (Rights and Resources Initiative) 310 rule attributes, Madagascar 238-42, 247, 248-52

rural communes, Mali 191-214

rural communities, Tanzania 284, 289, 295-6

rural councils

Senegal $147-8,153$

Zimbabwe 220-1, 228-9

rural district councils (RDCs) 220-1, 228-9

rural fuelwood markets 191-214

Rwenzori Mountains National Park (RMNP) 104, 114-16

SAPs see structural adjustment programmes sawmills 271-7, 341 sawn lumber products 163,165 scalability, democratic decentralization 30 scientific knowledge dissemination 371 SCN see Nature Conservation Service secondary forest products, DRC 161 sectoral governance $82-5$

sectoral linkages, wood-processing 272-4

SED see Domestic Energy Strategy

self-dealing 290

self-management, community forests 90

self-selection, committee members 182

Senegal

democratic decentralization $36-7$

Dialakoto rural community $145-6$, $149-50,152-4$

environmental decentralizations 62

forest resource management policy 147

women's marginalization $\quad 152-3,155$

sensibilisation, consent concept $327-9$

services see ecosystem services

SFM see sustainable forest management

SFRA (stream-flow reduction activity) 209

Siby rural commune, Mali 191-214

similarity-based interest groups 371

slash-and-burn agriculture 237

social effects

political uncertainty 222

women's marginalization $\quad 152-3$

social fencing, parks 63,65

social movement theory 71

social networks $335-53,381$

social projects 60,67

social responsibility, Ghana 277

social structures, Congo Basin 327-8

socio-economic factors $166-8,170-1,183$, 355-6

see also livelihoods

socio-political context

conservation/democracy 69

democratic decentralization 47

South Africa 15, 207-14

South-South trade 81-2, 336, 347

Southern Africa

decentralization outcomes 218-20

devolution approach 3

tenure system 12-13

see also individual countries

space-granting 70-1

space-making $70-1$

space-taking $18,70-1$

spatial patterns, Tanzanian trade $287-8$

SRGs (structures rurales de gestions) 195-202

SSA see sub-Saharan Africa 
stakeholder dynamics

historical context 34

multi-stakeholder forests $\quad 207-8$

rural fuelwood markets $196-9$

standards-based regulations $\quad 82-3$

the state

authority of 174,244

laws/consent $325-7$

power and 67-9

reform movement $\quad 61-3,85-6,91$

rules of 239-40, 251

tenure rights $12-13$

see also governance...; government control; legislation

state property see public property

statistical data research 263

statutory tenure rights 12-13

stool lands, Ghana 267

strategic groups, fuelwood markets 196-9

strategic posts, gender and 149-51

stream-flow reduction activity (SFRA) 209

structural adjustment programmes (SAPs) 261-4

see also Economic Recovery Programmes

structures rurales de gestions (SRGs) 195-202

sub-regional coordination/cooperation 306-7

sub-Saharan Africa (SSA) 1, 29-55, 84

see also individual countries

subcontracting structures 340

subsidiarity $15,31,218$

subsidiary bodies 63

substituted wood products $358-9$

superstructure, conservation and 69

survey questionnaires 238-9

sustainability

decentralization impacts $\quad 384-7$

local government 30

outcomes 113-17

western Uganda 103-25

sustainable development 282-98, 355

sustainable forest management (SFM)

$$
14-15
$$

business networks $345-6$

climate change $356-7,360$

Congo Basin 319-34

democratization 393

FLEG processes 306,313

FPIC principles $\quad 331-2$
Ghana 261-81

incentive-based systems 18

Tanzania 134, 136-9

Zimbabwe 230

Syro-Lebanese networks $\quad 340-4,348$

Tambacounda region, Senegal $145-6$

Tanzania

benefit-sharing $\quad 385-6$

community-based forest management 126-43

decentralized forest management 34

environmental decentralizations 62

trade transformations $\quad 282-98$

tax revenue

Central Africa $175-80$

decentralization impacts 386

DRC 162-3, 166-9

Mali 191-214

Tanzania 287

see also forest area fees

technical solutions to corruption 294

temporal patterns, Tanzanian trade 287-8

tenure system $\quad 10-13$

alternate models $\quad 310$

blood/civil rights $\quad 67-9$

CBNRM 39

climate change and $362,364-5,373-4$

decentralization $\quad 63,67,312,392$

environmental decentralizations $\quad 63,67$

FSC criteria 324

Southern Africa 218-19

theoretical implications

environmental performance 245-6

rules/conservation relationship 241-2

timber concessions $\quad 37,105$

Timber Resources Management Act (TRMA), Ghana 268

timber trade

Ghana 261-81

social-business networks 339-41

Tanzania 282-98

tropical Africa $\quad 299-318,336-7$

see also trade

top-down approaches 253, 329

tourism revenue $179-80,230$

trade 259-378, 394

geopolitics 81-2

Ghana 261-81 
governance reforms 16

law enforcement and 299-318, 389-90

local governance influence 387-92

networks 335-53, 391

Tanzania 133, 282-98

trends 19

traditional hunting methods 326

traditional knowledge value $\quad 370$

traditional linkages, Ghana 267-76

see also elite groups

transaction costs, networks 344

transboundary cooperation 307

transcendentalism $\quad 58-9$

transfers

availability of revenue $\quad 180-1$

community marginalization 266

forest area fees 161, 163, 166, 169-70

GELOSE experiments 250

political stakes of $168-9$

of power 218-19

systems configuration $\quad 176-80$

transport vouchers 202

transportation $161,282,285-6$

tree-water interactions 207-9

TRMA (Timber Resources Management Act), Ghana 268

tropical African trade 299-318, 336-7

trust, business networks $\quad 343-4,348$

two-level analysis, conservation $\quad 234,246-8$

Ubangian peoples $320-1$

Uganda 35-6, 103-25

Ujamaa programme $127-8$

uncontrolled forests, Mali 193, 200, 202

UNDRIP (United Nations Declaration on the Rights of Indigenous Peoples) 323

UNFCCG see United Nations Framework Convention on Climate Change

UNFF see United Nations Forum on Forests

United Nations Declaration on the Rights of Indigenous Peoples (UNDRIP) 323

United Nations Food and Agriculture Organization 300, 308, 312-13

United Nations Forum on Forests (UNFF) $2,4,7$

United Nations Framework Convention on Climate Change (UNFCCC) 357, 362-3, 366, 369, 372-3

United Republic of Tanzania see Tanzania

United States of America (USA), parks 58-9 unreserved forests, Tanzania $\quad 132,136$

upward accountability 7,10

USA (United States of America), parks 58-9

use rights see land-use rights

values, democratic decentralization $\quad 32-3$

veneer production 165

ventes de coupe permits $176-7$

verification function privatization $87-8$

vertical accountability 292

village associations, Gabon 182, 184

village communities, definition 89

see also communities

village councils

Mali 196-7, 199

Tanzania 127-30, 385

village lands versus communes 200

village-level income benefits $\quad 132-3$

village management

Tanzania 127-30, 132-3, 137-9

Zimbabwe 217, 220, 224, 227-8

voluntary partnership agreements (VPAs) 303-4, 309, 311, 314, 390

vulnerability to climate change $\quad 356-60$

wage level minimum standards 48

ward-level bodies, Zimbabwe 217, 221, 227-9

ward wildlife management committees

(WWMC) 217, 221, 228

water-use impacts $15,207-14$

WCS (Wildlife Conservation Society) 108

West Africa 62-3

see also individual countries

Western companies versus business network 345-6

wilderness conservation $\quad 58-60$

Wildlife Conservation Society (WCS) study 108

wildlife operations

CAMPFIRE initiative 229-1

Congo Basin 326-7

revenue transfers $176-81,183-4$

Wily, Alden 34

'withhold at source' policies $168-70$

women

marginalization of $144,151-3,155,387$

representation/participation 144-59

wood-processing sector, Ghana 261-3, 271-8 
Workshop on Decentralization and the Environment 3

Workshop on Forest Governance and

Decentralization in Africa 2, 6, 392-4

workshops, limitations of 309

World Bank

FLEG processes $\quad 299-300,305-6$, 308-14

Ghana's ERP 261, 264-5

'Great Games' 79-80, 82, 85

Madagascan NEAP 243-4

Mali fuelwood markets 194

Zimbabwean politics 216-17
World Resources Institute (WRI) 35

World Summit on Sustainable Development (WSSD) 300, 303

WRI (World Resources Institute) 35

WSSD (World Summit on Sustainable

Development) 300, 303

WWMC see ward wildlife management committees

Yogyakarta workshop 6

youth activism 199

Zimbabwe 42, 64, 215-33 
